\title{
ІНЖИНІРИНГ КРИЗ ТА РИЗИКІВ ТРАНСПОРТНИХ ПОСЛУГ
}

Колективна монографія

За ред. В.М. Самсонкіна та І.В. Ніколаєнко

Київ

Талком

2021 


\section{УДК 656.073:005.334](02) \\ I-62}

Монографію рекомендовано до друку ріменням Вченої ради Держсавного університету інфраструктури та технологій МОН Украӥни, протокол № 1 від 30.09.2021 p.

Авторський колектив: В.М.Самсонкін, І.В. Ніколаєнко, Ю.В. Булгакова, Р.В. Вернигора, О.В. Галан, О.М. Гненний, О.А. Горецький, В.Л.Горобець, С.Б. Демченко, А.С. Дорош, В.К. Мироненко, А.М. Окороков, О.І. Саблін, М.В. Хара, Н.С. Чернова, Р.С. Щербина, О.Г. Юрченко.

\section{Наукові редактори:}

В.М. Самсонкін, доктор технічних наук, професор кафедри технологій транспорту та управління процесами перевезень Державного університету інфраструктури та технологій (м. Київ);

I.B. Ніколаєнко, кандидат технічних наук, доцент кафедри технологій міжнародних перевезень і логістики ДВНЗ «Приазовський державний технічний університет» (м. Маріуполь).

\section{Рещензенти:}

А.Б. Бойнік, доктор технічних наук, професор, завідувач кафедрою автоматики та комп’ютерних систем керування рухом поїздів Українського державного університету залізничного транспорту (м. Харків);

С.С. Селіванов, доктор технічних наук, професор, завідувач кафедри судноводіння та безпеки життєдіяльності на морі Морського інституту імені контр-адмірала Ф.Ф. Ушакова (м. Херсон).

І-62 Інжиніринг криз та ризиків транспортних послуг: кол. моногр. сонкіна та І.В. Ніколаєнко. — Київ : Талком, 2021. - 312 с.

ISBN 978-617-8016-10-4

У монографії представлені матеріали науково-практичних досліджень в рамках міжнародного проєкту програми Свропейського союзу Erasmus+ «Інжиніринг криз та ризиків у сфері транспортних послуг» (CRENG).

Розглядаються питання впливу кризових ситуацій на роботу транспортних підприємств та шляхи підвищення ефективності функціонування транспортнологістичних систем в умовах криз та ризиків.

Видання призначене для науково-педагогічних працівників, аспірантів і здобувачів вищої освіти, а також керівників та фахівців промислових підприємств та бізнес-структур, які цікавляться сучасним станом і перспективою розвитку наукових досліджень.

УДК 656.073:005.334](02) 


\section{АВТОРСЬКИЙ КОЛЕКТИВ}

В.М. Самсонкін, доктор техн. наук, професор кафедри «Транспортних технологій та управління процесами перевезень» Державного університету інфраструктури та технологій, Київ;

I.В. Ніколаєнко, канд. техн. наук, доцент кафедри «Технології міжнародних перевезень і логістика» ДВНЗ «Приазовський державний технічний університет», Маріуполь;

Ю.В. Булгакова, канд. техн. наук, доцент, начальник відділу міжнародних зв'язків Національного авіаційного університету, Київ;

P.B. Вернигора, Декан факультету «Управління процесами перевезень», канд. техн. наук, доцент кафедри «Транспортні вузли» Дніпровського національного університету залізничного транспорту імені В. Лазаряна, Дніпро;

О.В. Галан, канд. техн. наук, доцент кафедри «Інформаційні технології та дизайн» Державного університету інфраструктури та технологій, Київ;

О.М. Гненний, доктор економ. наук, доцент, завідувач кафедри «Економіка та менеджмент» Дніпровського національного університету залізничного транспорту імені В. Лазаряна, Дніпро;

О.А. Горецький, канд. істор. наук, доцент кафедри «Технологій транспорту та управління процесами перевезень» Державного університету інфраструктури та технологій, Київ;

В.Л. Горобець, докт. техн. наук, професор кафедри «Безпека життєдіяльності» Дніпровського національного університету залізничного транспорту імені академіка В. Лазаряна, Дніпро;

Є.Б. Демченко, канд. техн. наук, доцент кафедри «Транспортні вузли» Дніпровського національного університету залізничного транспорту імені В. Лазаряна, Дніпро;

А.C. Дорош, канд. техн. наук, доцент кафедри «Транспортні вузли» Дніпровського національного університету залізничного транспорту імені В. Лазаряна, Дніпро;

В.К. Мироненко, докт. техн. наук, професор, завідувач кафедри «Управління комерційною діяльністю залізниць» Державного університету інфраструктури та технологій, Київ;

А.М. Окороков, завідувач кафедри «Управління експлуатаційною роботою», канд. техн. наук, доцент кафедри «Управління експлуатаційною роботою» Дніпровського національного університету залізничного транспорту імені В. Лазаряна, Дніпро;

O.I. Саблін, докт. техн. наук, завідувач кафедри «Безпека життєдіяльності» Дніпровського національного університету залізничного транспорту імені академіка В. Лазаряна, Дніпро;

М.B. Хара, канд. техн. наук, доцент кафедри «Транспортні технології підприємств» ДВНЗ «Приазовський державний технічний університет», Маріуполь;

Н.С. Чернова, канд. економ. наук, доцент кафедри «Економіка та менеджмент» Дніпровського національного університету залізничного транспорту імені В. Лазаряна, Дніпро;

P.C. Щербина, канд. техн. наук, доцент кафедри «Транспортних технологій та управління процесами перевезень» Державного університету інфраструктури та технологій, Київ;

О.Г. Юрченко, канд. техн. наук, доцент кафедри «Управління комерційною діяльністю залізниць» Державного університету інфраструктури та технологій, Київ. 


\section{MICT}

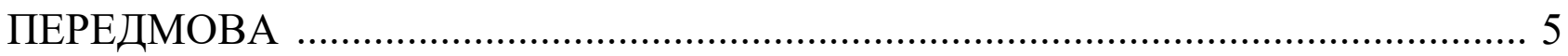

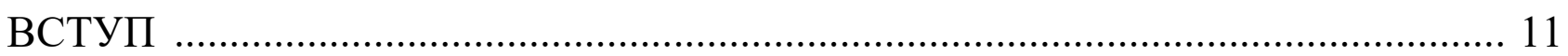

РОЗДІЛ 1. Дослідження впливу людського фактору на функціонування

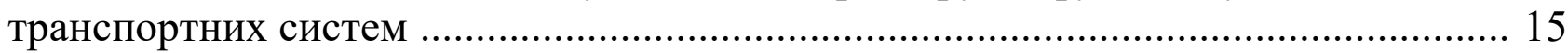

Саблін О.І., Горобещьь В.Л.

РОЗДІЛ 2. Дослідження соціо-технічних систем .................................................... 45 Юрченко О.Г., Булгакова Ю.В.

РОЗДІЛ 3. Управління ланцюгами поставок та мережами .................................... 74 Хара М.В., Ніколаєнко І.В.

РОЗДІЛ 4. Оцінка ризиків перевізного процесу засобами імітаційного моделювання

Вернигора Р.В., Окороков А.М., Демченко С.Б.

РОЗДІЛ 5. Інноваційні технології Big Data та інформаційної безпеки

в управлінні транспортними системами

Галан O.B.

РОЗДІЛ 6. Управління ризиками та засоби прогнозу та зменшення впливу в транспортних системах 166

Горецький О.А.

РОЗДІЛ 7. Основи гуманітарної логістики та транспортного обслуговування в надзвичайних ситуаціях 203

Мироненко В.K.

РОЗДІЛ 8. Системи управління безпекою та навколишнім середовищем у транспортних процесах 226

Самсонкін В.М., Щербина Р.С.

РОЗДІЛ 9. Нові виклики в управлінні кризами і ризиками в логістичних системах 253

Ніколаєнко І.В., Хара М.В.

РОЗДІЛ 10. Управління проектною командою і особиста ефективність 282

Гненний О.М., Чернова Н.С., Дорош А.С. 


\section{ПЕРЕДМОВА}

Монографія $є$ результатом співпраці освітян України з іноземними партнерами в рамках реалізації проєкту програми Європейського союзу Erasmus + «Інжиніринг криз та ризиків у сфері транспортних послуг/ Crisis and Risks Engineering for Transport Services» (CRENG) № 598218-EPP-1-2018-1-PL-EPPKA2-CBHE-JP.

Розвиток інжинірингу ризиків та криз на транспорті зараз $є$ дуже актуальним напрямком не тільки в Україні, але й в Європі та світі. В умовах глобалізації спостерігається постійне зростання обсягів перевезень вантажів та пасажирів. Розвиток технологій диктує зміни в структурі ланцюгів постачання та їх технічному оснащенні. Такі зміни призводять до того, що транспортною системою важко керувати, зростають ризик помилок та ціна подолання криз.

Практика показала, що навіть в СС недостатньо спеціалістів із інжинірингу ризиків та криз. Одним із прикладів $є$ недавні події в ЄС в 2014 р., пов'язані із воєнним конфліктом в Сирії. Не було оптимальних рішень, достатнього інформаційного забезпечення для організації транспортування біженців. Європейські університети проаналізували цей досвід та почали розробку програм підготовки магістрів за напрямком ризик- і кризис інжинірінгу на транспорті та в логістиці.

В Україні актуальність навчання майбутніх спеціалістів інжинірингу ризиків та криз продиктована зростанням попиту на відповідні компетентності, який виник на фоні складної політико-економічної ситуації в країні та станом невизначеності ключових процесів. Провідні підприємства України відправляють працівників на підвищення кваліфікації за кордон за великі кошти. Водночас, в Україні $\epsilon$ більш ніж достатній науковий потенціал для того, щоб виховувати таких спеціалістів самостійно.

Проєкт CRENG є міжрегіональним, оскільки об'єднує країни ЄC, країни Східного Партнерства (Україна, Азербайджан) та Центральну Азію (Туркменістан). Актуальність саме міжрегіонального партнерства полягає в тому, що транспортні системи всіх країн-партнерів грають ключову роль у розвитку транспортного шляху TRACECA (Transport Corridor Europe-Caucasus-Asia), та мають великі перспективи бути частиною Нового шовкового шляху. В таких умовах постає питання гармонійного розвитку транспортних систем цих країн та досягнення їх повної інтероперабельності. Саме розвиток знання та освіти, заснований на трансфері досвіду та найкращих практик має стати підгрунтям для гармонізації транспортних систем країн-партнерів.

Глобальна мета проєкту полягає в підтримці розвитку інжинірингу криз та ризиків у сфері транспортних послуг для забезпечення стійкості транспортних систем України, Азербайджану та Туркменістану для їх інтеграції до світової 
транспортної мережі. Для внеску в розвиток інжинірингу криз та ризиків у сфері транспортних послуг в країнах-партнерах буде створене середовище для навчання висококваліфікованих спеціалістів, які затребувані на ринку праці, на засадах Європейських найкращих практик та Болонського процесу.

Для досягнення глобальної мети в проєкті поставлені наступні завдання:

- розробити, впровадити та акредитувати нову практично-орієнтовану магістерську програму «Інжиніринг криз та ризиків у сфері транспортних послуг» в Україні, Азербайджані та Туркменістані;

- наблизити вищі навчальні заклади України, Азербайджану та Туркменістану до ринку праці в галузі інжинірингу криз та ризиків для транспортних послуг;

- стимулювати взаємодію між вищими навчальними закладами СС та України, Азербайджану, Туркменістану в галузі інжинірингу криз та ризиків для транспортних послуг.

Консорціум проєкту CRENG складається із організацій країн $\mathrm{CC}-$ Польщі, Німеччини та Франції та організацій країн-партнерів СС - України, Азербайджану та Туркменістану. Європейська частина консорціуму представлена передовими організації та університети $\mathrm{CC}$, які передали науковий та практичний досвід в сфері управління ризиками та кризами у сфері транспортних послуг та найкращі практик із управління масштабними міжнародними проектами. Консорціум країн-партнерів включає найкращі вищі навчальні заклади, транспортні компанії, Міністерства освіти, спільна сумлінна праця та взаємодія котрих дозволили здійснити трансфер досвіду ЄС та забезпечити достатній вплив результатів проєкту на розвиток транспортної галузі в Україні, Азербайджані та Туркменістані.

Партнерами проєкту CRENG з $\mathbf{E C ~ є : ~ В а р ш а в с ь к а ~ П о л і т е х н і к а , ~ П о л ь щ а ~ ( к о о р - ~}$ динатор проекту); Берлінський технічний університет, Німеччина; Політехнічний університет О-де-Франс, Франція; Exolaunch GmbH, Німеччина.

Україна в консорціумі представлена: Приазовським державним технічним університетом, Дніпропетровським національним університетом залізничного транспорту імені академіка В. Лазаряна, Державним університетом інфраструктури та технологій, АТ «Укрзалізниця».

Від Азербайджану в проекті приймають участь: Бакинський інженерний університет, Азербайджанський технічний університет, Азербайджанський технологічний університет, Бакинське транспорте агентство, Міністерство освіти Азербайджанської Республіки.

Партнерами з Туркменістану є: Інститут телекомунікацій та інформаційних технологій Туркменістану, Міжнародний університет гуманітарних наук та розвитку, Туркменський державний архітектурно-будівничий інститут, Міністерство освіти Туркменістану. 
Для досягнення цілей проєкту поставлені та виконані наступні завдання:

1. Підвищена кваліфікація викладачів університетів країн-партнерів із новітніх підходів інжинірингу криз та ризиків у сфері транспортних послуг в університетах $\mathrm{EC.}$

Викладачі країн-партнерів пройшли двотижневе стажування в передових університетах СС. Впродовж стажування викладачі:

- опанували новітній академічний контент та новітні методики його викладання, ознайомились 3 лабораторною базою та актуальними напрямки наукових досліджень в області інжинірингу криз та ризиків у сфері транспортних послуг;

- відвідали майстер класи із різних аспектів проектного менеджменту;

- прийняли участь у круглих столах із обговорення та остаточного формування контенту нових дисциплін та концепції магістерської CRENG.

2. Створено середовище для викладання та вивчення нових дисциплін із інжинірингу криз та ризиків у сфері транспортних послуг, яке включає методичне забезпечення викладання дисциплін, електронні курси на базі платформи MOODLE, навчально-дослідницькі лабораторії.

Нову магістерську програми формують дисципліни, назви яких співзвучні із назвами розділів монографії.

CRENG Лабораторія представляє собою потужний комплекс для моделювання та представлення результатів моделювання складних транспортних процесів, а саме потужні робочі станції та спеціалізоване програмне забезпечення Any Logic. Лабораторії є унікальною та наявні тільки в університетах-партнерах проекту CRENG.

3. Впроваджена в дев'яти університетах країн-партнерів нова магістерська програма «Інжиніринг криз та ризиків у сфері транспортних послуг».

4. Впроваджений новий інструмент взаємодії університетів та роботодавців «Гаманець компетенцій» (Skills Wallet), який полягає в організації в університеті набуття окремих компетентностей студентами виключно на замовлення певного роботодавця, зарахування таких результатів навчання та адекватне їх представлення роботодавцю для прийняття рішення про працевлаштування студента.

5. Впроваджений метод проектного навчання в міжнародному середовищі (International Project Based Learning, IPBL). Метод IPBL $є$ міцним засобом формування у студентів soft skills, який заснований на організації тривалої роботи студентів у групах, в тому числі з іноземними студентами, над актуальним для галузі проектом.

6. Проведено пілотне навчання студентів за новою магістерською програмою «Інжиніринг криз та ризиків у сфері транспортних послуг».

На етапах розробки магістерської програми, контенту навчальних дисциплін, пілотного навчання проведено моніторинг якості результатів із залученням груп зовнішніх та внутрішніх стейкхолдерів: викладачів, студентів, роботодавців. 
Такий підхід гарантує забезпечення потреб студентів у отриманні якісного навчання, роботодавців - у отриманні спеціаліста 3 необхідними компетентностями, всебічний розвиток та удосконалення освіти та новій магістерській програмі відповідно до змін економічного середовища.

7. Розроблено та розпочато реалізацію стратегії забезпечення сталості та розповсюдження результатів проєкту, включаючи створення CRENG Мережі (рис. 1) та CRENG веб-платформи.

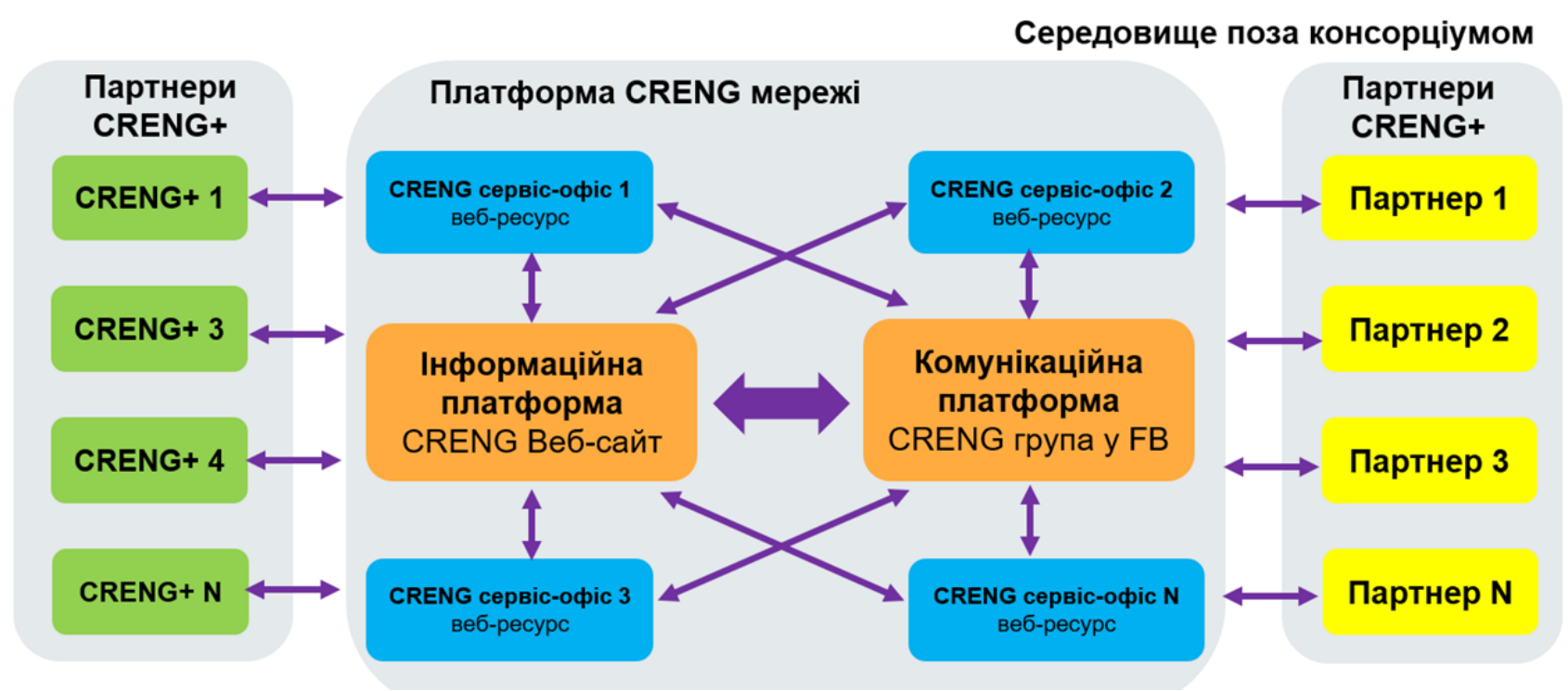

Рис. 1. Схема CRENG Мережі

Вплив проскту CRENG очікується на індивідуальному, інституційному, регіональному, національному та міжнародному рівнях в короткостроковій (до закінчення фінансування) та довгостроковій (протягом 5 років після закінчення фінансування) перспективах.

Для забезпечення та масштабування впливу проєкту на різних рівнях розроблено план заходів із донесення результатів проєкту (Dissemination and Sustainability Plan) до різних категорій цільової аудиторії: студентів, академічних та адміністративних працівників вищих навчальних заходів, менеджерів транспортної галузі, компаній-роботодавців тощо.

Основними інструментами реалізації Dissemination and Sustainability Plan $€$ :

$C R E N G$ веб-платформа - електронний інформаційний ресурс, який базується на офіційному веб-сайті проєкту та окрім загальної інформації про діяльність проекту містить всі розроблені матеріали (проектну документацію, методичне забезпечення дисциплін, тексти магістерських програм, публікації, презентації лекторів тощо). Додатковими засобами розповсюдження інформації про проєкт 
є сторінки проекту CRENG на офіційних веб-сайтах партнерів, та група проєкту y Face Book.

CRENG сервіс-офic - створений в кожному університеті-партнері структурний підрозділ, діяльність якого сфокусована на встановлені взаємодії академічного та бізнес-середовища 3 метою подальшого розвитку напрямку інжинірингу криз та ризиків в освіті на науці. Серед основних функцій CRENG сервіс-офісу визначені: популяризація проєкту CRENG, моніторинг ринку праці, залучення роботодавців до оцінки якості навчання, залучення компаній до співпраці у сфері виконання та впровадження результатів наукових досліджень тощо. 3 метою популяризації діяльності для кожного CRENG сервіс-офісу створено сторінку y Face Book.

CRENG+ Угода про співпрац̧ю - домовленість між організаціями-членами консорціуму проєкту CRENG та зацікавленими організаціями поза консорціумом щодо спільного ефективного використання результатів проєкту CRENG. Домовленість настає після підписання CRENG+ Угоди про співпрацю між одним учасником консорціуму проєкту CRENG та партнером поза консорціумом.

Внутрішнє забезпечення якості

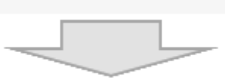

Рівень проекту

Відповідальні: координатор проекту, команда менеджменту проекту

Рівень інституції

Відповідальні: локальні координатори
Зовнішнє забезпечення якості

\section{Незалежний зовнішній} експерт

NEO

Національні Еразмус+ Офіси

\section{Аспекти оцінки}

Відповідність виконання плану проекту:

повнота проведення заходів, дотримання дедлайнів, використання бюджету, досягнення заявлених показників успіху

Впливи: короткострокові, довгострокові

Якість результатів проекту: навчальні матеріали, тренінги, заходи,

\section{Методи оцінки}

Анкетування цільових груп Інтерв'ю із цільовими групами Аналіз звітів

Аналіз інформаційних ресурсів проекту

Аналіз проектної документації

Порівняння із запланованими

показниками

\section{Рис. 2. Системи забезпечення якості проскту CRENG}


CRENG Мережа - об'єднання всіх інструментів реалізації Dissemination and Sustainability Plan на основі CRENG веб-платформи з метою ефективного використання результатів проєкту, забезпечення їх сталості та високого впливу на всіх рівнях. Інформаційну функцію мережі виконує $C R E N G$ веб-платформа, комунікаційну — група у Face Book.

Одним із базових аспектів успішної реалізації проекту є забезпечення якості його результатів. На рівні проєкту розроблено загальний План забезпечення якості (Quality Assurance Plan). План адаптований кожним членом консорціуму відповідно до завдань, які він виконує в проєкті. Загальна структура системи забезпечення якості проєкту CRENG представлена на рис. 2.

Всю інформацію про проєкт, його результати та заходи розміщено на офіційному веб-сайті проекту CRENG https://creng.eu/.

Ю.В. Булгакова

Менеджер проєкту CRENG 


\section{ВСТУП}

Управління кризами і ризиками вже багато років є невід’ємною складовою успішного бізнесу багатьох світових брендів, компаній та корпорацій. Керівники підприємств різних галузей розуміють, що чітке і швидке прийняття та реагування на невизначеності - це один з головних факторів їх конкурентної переваги.

Сучасний світ вимагає змін в формуванні компетентностей, навичок, вмінь і якостей керівників компаній та організації бізнес-процесів різних ступенів складності. Готовність швидко змінюватися та адекватно реагувати на кризи та ризики стають важливими якостями фахівців у галузі транспорту.

3 метою системного підходу до формування компетенцій здобувача вищої освіти кваліфікації «Магістр 3 транспортних технологій» розроблена та впроваджена освітньо-професійна програма «Інжиніринг криз та ризиків у сфері транспортних послуг». Основний фокус цієї програми - здатність магістрів здійснювати виробничо-технологічну, організаційно-управлінську діяльність на підприємствах транспорту усіх форм власності в умовах невизначеності та уразливості підприємницької діяльності. Також програмою передбачено вміння магістрів здійснювати науково-дослідну технологічну та проєктну роботи з метою напрацювання комплексних стратегічних рішень на базі проєктно-технологічних та навчальних закладів.

Відповідно до освітньої програми «Інжиніринг криз та ризиків у сфері транспортних послуг» інтегральна компетентність здобувача вищої освіти формується як здатність розв'язувати складні спеціалізовані задачі та практичні проблеми в галузі транспорту, що передбачає:

1. Застосування теорій і методів логістики та надійності елементів транспортних систем.

2. Застосування інформаційних технологій, наукомістких комп'ютерних технологій та моделювання.

3. Управління проєктами, проведення досліджень та здійснення інновацій в галузі транспортних технологій.

Представлена колективна монографія має на меті надати цілісне розуміння понять «криза» $\mathrm{i}$ «ризик» та сформувати комплекс загальних і фахових компетентностей стосовно питань аналізу, оцінки, моделювання та управління кризовими ситуаціями на транспорті. Матеріали монографії є здебільшого новими в українській науковій літературі в галузях транспортних технологій, управління ланцюгами поставок і логістичними системами.

В розділі 1 проаналізовано вплив людського фактору на функціонування транспортних систем. Читачам монографії представлено аналіз терміну «людський 
фактор», обгрунтовано важливість врахування людського фактору на етапі проектування технічних систем та технологічних процесів. Досліджено психофізіологічні особливості діяльності операторів людино-машинних систем. Розглянуто варіанти взаємодії людини 3 компонентами моделі систем «людина-технічна система-виробниче середовище», цей системний підхід дозволить знизити ризики настання небажаних подій в області безпеки праці та безпеки руху, забезпечивши позитивний соціально-економічний ефект.

Об'єктом дослідження розділу 2 є соціо-технічні системи, які набувають значних змін в сучасних умовах переформатування соціально-економічних відносин, а також технологічних та технічних напрямків. Проаналізовані визначення поняття «система» у різних сферах науки. Вперше запропонована не тільки узагальнена класифікація, а й основні властивості різних соціо-технічних систем. На основі досліджень автори сформулювали основні етапи реалізації системного підходу при створенні складних соціо-технічних систем. Розглянуто структура та складові безпеки сучасних соціо-технічних систем та визначені найважливіші 3 них.

Автори розділу 3 сфокусувалися на висвітленні питань управління ланцюгами поставок та мережами. Проаналізовано рівні складності ланцюгів поставок, їх структура, функції та вплив сучасних цифрових технологій на елементи логістичних ланцюгів та мереж. Досліджено можливості використання різних стратегій управління ланцюгами поставок, їх переваги та недоліки. Запропоновано SWOTаналіз чинників, що враховуються при розробці логістичної стратегії. Наведено визначення понять «неоднозначність» та «невизначеність» в контексті прийняття рішень в умовах ланцюгів поставок. Також розглянуто концепцію попиторієнтованих мереж поставок, мета якої реагувати на попит в режимі реального часу завдяки мережі споживачів, постачальників і працівників.

Актуальні питання оцінки ризиків та моделювання транспортного процесу представлено в розділі 4. Авторами розділу досліджено зв'язок між управління ризиками та управлінням транспортним процесом. Сформульовано ризики на залізничному транспорті, їх причини та наслідки. Виконано аналіз підходів до моделювання залізничних транспортних систем, розглянута класифікація та переваги використання імітаційних моделей. Запропоновано використання дискретноподійної парадигми у середовищі AnyLogic, що дозволило авторам побудувати імітаційну модель приймально-відправного парку сортувальної станції для ефективної системи управління ризиками при організації складних транспортних процесів.

В розділі 5 досліджено технології Big Data та питання інформаційної безпеки для транспортних систем. Сформульовані основні принципи роботи 3 великими даними та завдання аналітики Big Data у транспортній галузі. Представлено 
докладну характеристику методів аналізу великих даних, умови їх застосування, основні переваги та недоліки. Наведено інструменти та складові машинного навчання, використання нейронних мереж для розпізнавання або генерації зображень і відео, складні алгоритми управління або прийняття рішень та ін.

Актуальні питання управління ризиками в транспортних системах досліджено в розділі 6. За допомогою міжнародного стандарту ISO 31000:2009 надана характеристика процесу та етапів ризик-менеджменту. Висвітлено особливості застосування різноманітних методів оцінювання ризику залежно від характеру та умов функціонування об’єкта дослідження. Розкрито сутність ризиків на морському, автомобільному, залізничному та авіаційному видах транспорту. Проаналізовано критерії та чинники транспортних ризиків, оцінка і прийнятність ризику. Запропоновано стратегії зменшення та контролю ризику в транспортних системах.

Основи гуманітарної логістики та транспортного обслуговування в надзвичайних ситуаціях представлено в розділі 7. Проведено кількісний аналіз історії небезпечних подій та зроблені висновки стосовно необхідності запасів гуманітарної допомоги. Сформульовано роль гуманітарної логістики в сучасному світі. Висвітлено аспекти комплексного підходу до організації надання гуманітарної допомоги за участю державних органів, академічних закладів, постачальників та громади. Запропоновано рекомендації щодо знань та вмінь фахівця з гуманітарної логістики. Наведено приклади розв’язання оптимізаційних задач гуманітарної логістики та транспортного обслуговування в надзвичайних ситуаціях.

В розділі 8 об'єктом дослідження є безпека на транспорті. Авторами запропоновано системний підхід до управління безпекою руху поїздів MSD, створений на основі методу статистичної закономірності. Представлено класифікатори причинно-наслідкових зв'язків для аналізу транспортних подій. Розроблено шкалу станів безпеки залізничної системи та іiі елементів. Проведено аналіз соціальних аспектів взаємодії транспорту та середовища, наведено вплив фізичних показників екологічної шкоди транспорту та пов’язаних із цим витрат для суспільства.

Характеристику криз та вплив глобальних ризиків на сучасну світову економіку розглянуто в розділі 9. Висвітлено вплив природних ризиків на логістичні системи, запропоновані етапи прийняття рішень при управлінні ризиками стихійних лих. Досліджені водні кризи, їх наслідки та шляхи вирішення водного стресу. Автори розділу сфокусувалися на управлінні зростаючими ризиками кібербезпеки та проаналізували поєднання стратегій інвестицій в безпеку і кіберстрахування. Сформульовані напрямки управління ризиками логістичної системи, проблематика культури ризику на підприємстві та використання ключових індикаторів ризику.

В розділі 10 проаналізовано комплекс неспеціалізованих, пов'язаних з особистісними якостями навичок soft skills. Наведено чинники, які вимагають активної 
життєвої позиції і проактивності, що пов'язані з професійною діяльністю. Подано рекомендації щодо формування аналітичного та критичного мислення для успішного досягнення поставлених цілей. Висвітлена роль кризового менеджменту та управління проєктною командою, досліджено роль керівника проєкту.

Розділи 1, 4 і 10 підготовлені колективом авторів 3 ДВНЗ «Дніпровський національний університет залізничного транспорту імені академіка В. Лазаряна» (м. Дніпро).

Матеріали розділів 2, 5, 6, 7 і 8 розроблені колективом авторів з Державного університету інфраструктури та технологій (м. Київ).

Розділи 3 і 9 підготовлені авторами з ДВНЗ «Приазовський державний технічний університет» (м. Маріуполь).

Монографія адресована широкому колу фахівців:

- здобувачам вищої освіти і аспірантам, що спеціалізуються з питань транспортних технологій та логістичних ланцюгів поставок;

- науково-педагогічним працівникам вищих навчальних закладів;

- керівникам промислових підприємств, бізнес-структур і органів влади, які цікавляться питаннями організації ефективного ризик-менеджменту.

Основні результати досліджень, описані у монографії, вже використовуються в навчальному процесі українських університетів-партнерів за міжнародним проєктом CRENG. 


\title{
РОЗДІЛ 1 \\ ДОСЛІДЖЕННЯ ВПЛИВУ ЛЮДСЬКОГО ФАКТОРУ НА ФУНКЦІОНУВАННЯ ТРАНСПОРТНИХ СИСТЕМ
}

\author{
O.I. Саблін ${ }^{1}$ \\ В.Л. Горобець ${ }^{2}$
}

\section{1. ВСТУП}

Людський фактор має суттєвий вплив на безпеку та ефективність функціонування транспортних систем. Його врахування на етапі проектування технічних систем та технологічних процесів дозволяє розробляти оптимальні умови виробничої та інженерно-технічної діяльності персоналу відповідно до його функціональних обов'язків, фізичних та інтелектуальних можливостей i обмежень. Результати досліджень в сфері людських факторів використовуються для створення умов праці відповідно до сучасних ергономічних вимог, узгодження психофізіологічних та особистісних характеристик працівників, особливостей їх поведінки при індивідуальній і груповій діяльності з умовами праці та функціональними обов'язками для забезпечення безпеки людини і виробничих процесів.

Людський фактор $є$ багатозначним терміном, одним із визначень якого $\epsilon$ прояв можливості у певних ситуаціях з тих чи інших причин приймати людиною помилкові рішення, зокрема у професійній діяльності. Людські фактори в техніці являють собою набір проявів в конкретних умовах діяльності характеристик і особливостей людини (або групи людей) i технічних засобів (машин), що розглядаються як система «людина-машина», функціонування якої спрямоване на досягнення поставленої мети $[1,2]$. Людський фактор також може бути визначений як набір властивих людині психофізіологічних особливостей, які повинні прийматися до уваги для виключення неправильних дій.

У [3] розроблено нормативні засади врахування людських факторів в системі управління безпекою руху на залізничному транспорті і описано підходи щодо запобігання транспортних подій від дії людських факторів. У документі розглядаються поведінкові, медичні, експлуатаційні фактори, фактори, що пов'язані 3 конструкцією устаткування, збором і передачею даних, а також такі, як концентрація і уважність, ступінь втоми по відношенню до робочого навантаження, здатність оцінки ситуації в нестандартній і аварійної ситуації, умови роботи, розташування і конструкція устаткування, рівень підготовки і кваліфікації співробітників, взаємодія співробітників, присутність контролерів, методики роботи.

\footnotetext{
${ }^{1}$ Докт. техн. наук, завідувач кафедри «Безпека життєдіяльності»

Дніпровського національного університету залізничного транспорту імені академіка В. Лазаряна, Дніпро

2 Докт. техн. наук, професор кафедри «Безпека життєдіяльності»

Дніпровського національного університету залізничного транспорту імені академіка В. Лазаряна, Дніпро
} 
Аналіз сучасного стану проблеми безпеки на транспорті показує переважну (50-75\%) роль людського фактору в причинах порушення безпеки руху і транспортних подій [4]. Для зниження ролі людського фактору на найбільш складних і відповідальних етапах транспортних процесів і забезпечення діяльності операторів відповідно до високих стандартів безпеки необхідно широке впровадження сучасних інформаційно-аналітичних сервісів підтримки прийняття рішень, що $\epsilon$ важливою задачею менеджменту безпеки на транспорті. Крім того формування механізмів прийняття правильних управлінських рішень для попередження помилок і відмов у роботі людино-машинних систем є важливим з точки зору відбору, навчання та контролю діяльності персоналу.

\section{2. ОСНОВНИЙ МАТЕРІАЛ}

\section{1. Психофізіологічні особливості діяльності операторів людино-машинних} систем

Людський фактор часто інтерпретують як пояснення причин катастроф і аварій, що виникають у наслідок помилкових дій людини. Помилкові дії не завжди обумовлені психофізіологічними характеристиками людини і не завжди відповідають рівню складності виконуваних функцій або завдань. Помилки, викликані людським фактором, як правило, відбуваються ненавмисно, коли людина виконує дії, розцінюючи їх як найбільш вірні.

Незважаючи на значний розвиток автоматизованих систем управління, виключити повністю участь людини у виробничих процесах неможливо. Зі збільшенням складності людино-машинних систем ускладняється діяльність людиниоператора. При цьому з одного боку зростає ймовірність помилок в діяльності людини, а з іншого - наслідки таких помилкових дій.

Технічний прогрес значно ускладнює машинні системи при обмеженості людських можливостей (рис. 1), тому людина-оператор при управлінні технічними об'єктами потребує допоміжних систем підтримки прийняття управлінських рішень. Отже, роль людського фактору в забезпеченні безпеки роботи людиномашинних систем не зменшується, а, навпаки, зростає.

Фізична праця в системі «людина-машина» пов'язана з виконанням як фізичних так і розумових функцій. При цьому діяльність людини здійснюється як за встановленим так і випадковим алгоритмами, правилами, інструкціями i технологічними графіками. У першому випадку ця діяльність жорстко регламентована, а в другому можливі випадкові несподівані події при виконанні технологічного процесу, наприклад, несподівана поява сигналів.

Розумова праця (інтелектуальна діяльність) пов'язана 3 прийомом і переробкою інформації і переважно вимагає зосередження уваги, напруги сенсорного апарату, пам'яті, а також активізації емоційних процесів і мислення. Операторська 
праця вимагає підвищеної відповідальності та високої нервово-емоційної напруги. Управлінська праця визначається високим ступенем динамічності інформації, iї обсягу, дефіцитом часу для підготовки і прийняття рішень, необхідністю вирішення періодично виникаючих конфліктних ситуацій. Творча праця вимагає підвищеної уваги, інтелектуальної діяльності, нервово-емоційної напруги.

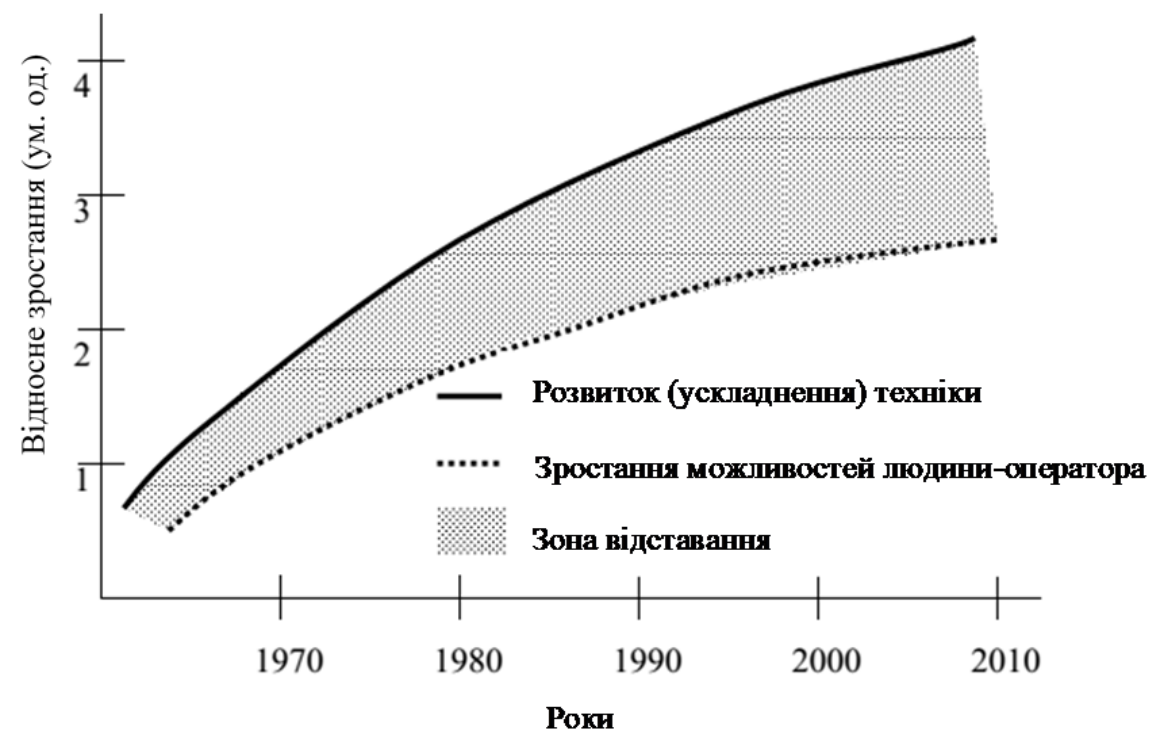

Рис. 1. Співвідношення розвитку (ускладнення) техніки і зростання можливостей людини-оператора

Джерело: [5]

Кількісною оцінкою фізичної праці є важкість, а розумової - напруженість праці, яка визначається інформаційним навантаженням на людину. На виробництві розрізняють чотири рівні умов праці людини:

- комфортні;

- відносно дискомфортні;

- екстремальні;

- надекстремальні.

Кількісні показники важкості та напруженості праці визначають розрахунковим шляхом. Для цього за допомогою експертних оцінок кожен фактор виробничих умов оцінюють за шестибальною шкалою. Інтегральна оцінка важкості або напруженості праці обчислюється за формулою [6]:

$$
I_{\text {п }}=x_{\text {оп }}+\left|\sum \frac{x_{i j}\left(6-x_{0 \Pi}\right)}{6(n-1)}\right|
$$

де $x_{\text {оп }}$ - найбільш значимий за рангом елемент умов праці на $i$-му робочому місці; $n$ - число елементів на робочому місці;

$x_{i j}$ - бальна оцінка $i$-го фактору на $j$-му робочому місці. 
Кожен елемент умов праці на робочому місці залежно від своєї величини $\mathrm{i}$ тривалості дії (експозиції) отримує оцінку від 1 до 6. При експозиції менше 90\% часу восьмигодинної робочої зміни фактична оцінка елемента в балах складатиме

$$
x_{\Phi i}=\frac{x_{\max } T_{\Phi i}}{480},
$$

де $x_{\max }$ - максимальна оцінка елемента при експозиції від 90\% і більше;

$T_{\phi i}$ - фактична тривалість дії елемента протягом робочої зміни, хв; 480 - фонд робочого часу при восьмигодинний робочої зміни (хв).

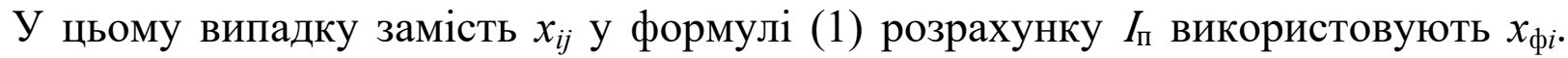
При наявності на робочому місці факторів, що мають 3 урахуванням експозиції оцінку 2 бали і більше, в розрахунок оцінки приймають тільки ці біологічно значущі чинники. Фактори 3 оцінкою 1 і 2 бали в розрахунок не приймають. Категорію важкості і напруженості праці визначають за інтегральною оцінкою $I_{\text {п }}$ (табл. 1).

Таблиця 1

Інтегральна бальна оцінка тяжкості і напруженості праці за категоріями

\begin{tabular}{|l|c|c|c|c|c|c|}
\hline Категорія важкості праці & I & II & III & IV & V & VI \\
\hline Інтегральна оцінка $I_{\text {п }}$ бал & 18 & $19-33$ & $34-45$ & $46-53$ & $54-59$ & $59,1-60$ \\
\hline
\end{tabular}

Джерело: [6]

Одним з основних показників надійності роботи системи «людина-машина» $\epsilon$ ймовірність того, що напрацювання на відмову (помилкову дію людини) не перевищить заданого часового обмеження, яка визначається у вигляді

$$
P(T \leq t)=\left\{P_{N}(T \leq t) \cdot P_{T}(T \leq t)\right\},
$$

де $P_{N}$ і $P_{T}$ - ймовірності відмов (помилкових дій), зумовлені впливом людського фактору і надійністю технічного засобу (машини);

$T$ - час роботи до першої відмови;

$t$ - час, протягом якого визначається ймовірність відмов.

Закономірності залежності ймовірності відмов $P_{N}$ і $P_{T}$ при $T \leq t$ у людини визначаються біологічною природою організму, а у машини конструкцією, властивостями матеріалів і умовами експлуатації.

При аналізі надійності систем «людина-машина» об'єктами дослідження $є$ всі можливі випадкові події і величини, які діють відповідно як на стан людини, так і машини. Типова функція інтенсивності потоку відмов $\lambda(t)$ приведена на рис. 2. 


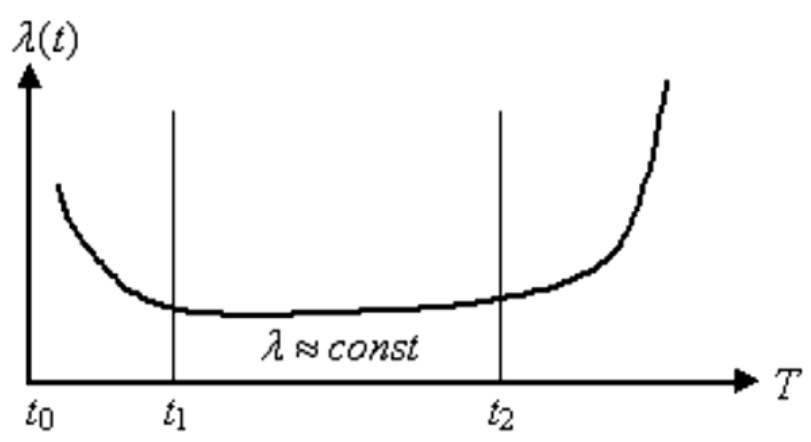

\section{Рис. 2. Типова функція імовірності відмов машин} Джерело: [18]

На цій залежності від часу виділяється три характерних ділянки:

$\left(t_{0}<T<t_{1}\right)$ - інтервал часу, на якому інтенсивність відмов зменшується внаслідок конструктивних доробок в процесі виробничих випробувань, підробітки деталей і вузлів та інших технічних причин;

$\left(t_{1}<T<t_{2}\right)$ - інтервал часу, на якому інтенсивність відмов практично постійна і мінімальна, що характеризує стійку роботу машини;

$\left(T>t_{2}\right)$ - час початку зростання інтенсивності відмов з причин фізичного зносу.

Інтенсивність виникнення відмов в системі «людина-машина» через вплив людського фактору, що полягають в помилкових рішеннях або діях протягом працездатного стану людини, за формою практично збігається з графіком, представленим на рис. 2.

Він також поділяється на три часові інтервали:

- інтервал $\left(t_{0}<T<t_{1}\right)$ характеризує період оперативної адаптації людини до робочого процесу після відпочинку;

- інтервал $\left(t_{1}<T<t_{2}\right)$ характеризує основний трудовий процес, при якому здійснюється плавний, близький до лінійного, перехід термодинамічної стану людини від слабо нерівноважного до сильно нерівноважного;

- інтервал $\left(T>t_{1}\right)$ характеризує сильно нерівноважний термодинамічний стан в результаті втоми, при якому організм втрачає свою працездатність і потребує відпочинку. Графік добових змін інтенсивності відмов організму людини наведено на рис. 3 , де позначено $t_{\mathrm{W}}$ - час праці, $t_{\mathrm{R}}$ - час відпочинку, де $t_{\mathrm{W}}+t_{\mathrm{R}}=24$ год.

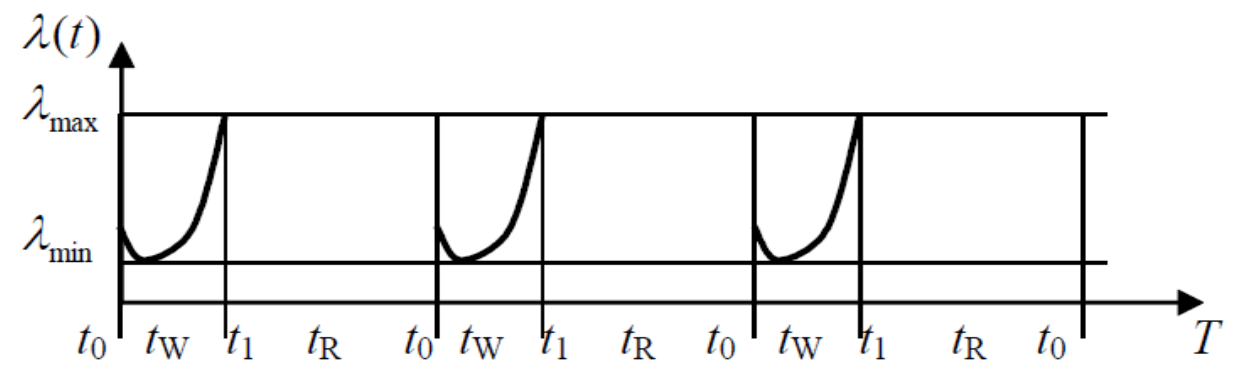

Рис. 3. Графік добових змін інтенсивності відмов організму людини Джерело: [24] 
Як видно 3 рис. 3 , кожну добу протягом часу $t_{\mathrm{W}}$ роботи системи «людинамашина» відбуваються зміни термодинамічної стану організму людини від слабо нерівноважного на початку роботи до сильно нерівноважного в кінці. За час відпочинку $t_{\mathrm{R}}$ в організмі людини відбувається повне відновлення його стану і $з$ початку наступної доби процеси повторюються. Найбільш сприятливим часом роботи 3 точки зору інтенсивності відмов в більшості випадків $\epsilon$ робота, що починається з ранку, так як перед цим за час сну зазвичай відбувається найбільш повне відновлення всіх функцій організму від попередніх навантажень.

Транспортні і багато інших виробничих процесів є цілодобовими, тому людина, задіяна у них працює, як правило, в три зміни. Інтенсивність відмов через людський фактор в цьому випадку корелює із номером, а отже часом робочої зміни. Графік порівняльних добових робочих змін інтенсивності відмов людини при тризмінній роботі наведено на рис. 4.

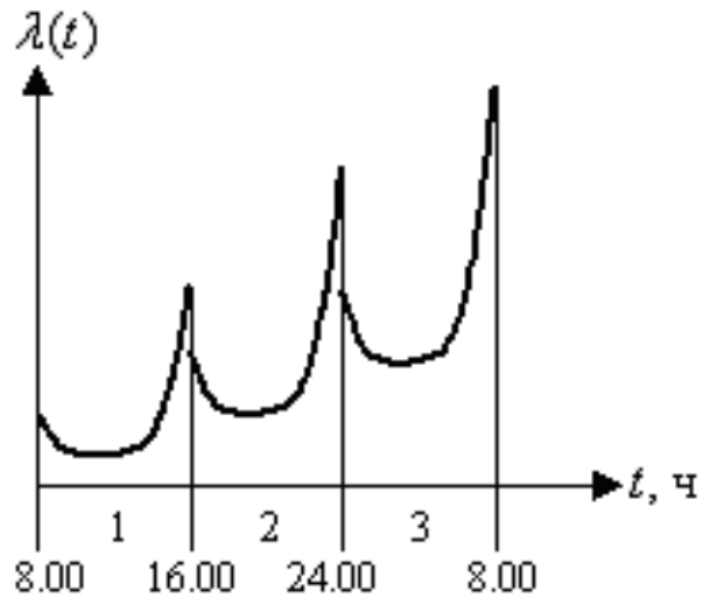

Рис. 4. Графіки інтенсивності відмов людини у добових змінах Джерело: [24]

При роботі у вечірню зміну трудовий процес починається при початковій втомі, що виникла під час діяльності між пробудженням і початком роботи. При роботі у нічну зміну трудовий процес починається вже при значній втомі і до кінця досягає максимальної величини. Як видно з рис. 4, найменша інтенсивність відмов припадає на першу зміну, максимальна - на третю. Середнє співвідношення інтенсивності відмов визначається умовами праці людини, технічними параметрами машин і умовами їх експлуатації.

Величину ймовірності відмов через людський фактор $P_{N}$ можна представити як певну частку загальної ймовірності відмов $P$ системи «людина-машина» у вигляді виразу:

$$
P_{N}=\sum k_{N} \cdot P,
$$

де $k_{N}$ - коефіцієнт значимості людського фактору в різних областях техносфери.

$$
-20-
$$


У табл. 2 представлені дані про роль людського фактору в різних небезпечних та аварійних ситуаціях, техногенних катастрофах відповідно для різних сфер діяльності [7].

Таблиця 2

Коефіцієнт $k_{N}$ значущості людського фактору

\begin{tabular}{|c|l|c|}
\hline № 3/п & \multicolumn{1}{|c|}{ Області техносфери } & $\boldsymbol{k}_{\boldsymbol{N}}$ \\
\hline 1 & Атомна енергетика & 0,55 \\
\hline 2 & Промислове та цивільне будівництво & 0,7 \\
\hline 3 & Ракетно-космічна техніка & 0,35 \\
\hline 4 & Військова авіація & 0,85 \\
\hline 5 & Цивільна авіація & 0,65 \\
\hline 6 & Трубопровідний транспорт & 0,3 \\
\hline 7 & Автомобільний транспорт & 0,8 \\
\hline 8 & Технологічне обладнання & 0,4 \\
\hline
\end{tabular}

Джерело: [7]

На залізничному транспорті цей коефіцієнт, за різними експертними оцінками знаходиться в межах від 0,5 до $0,75[5,7,16]$.

\section{2. Людський фактор в системі «людина-технічна система-виробниче} середовище»

Більш точний аналіз діяльності людини в системі «людина-машина-середовище» повинен включати не менш важливі компоненти: живу і не живу матерію і суспільство (рис. 5).

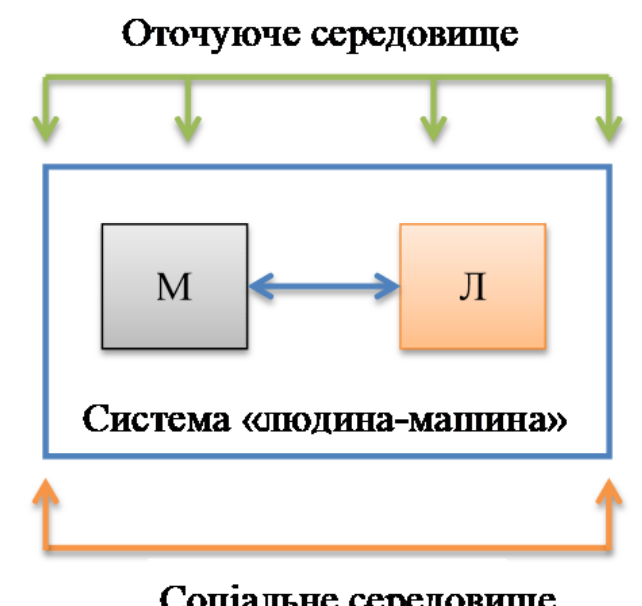

Соціальне середовище

Рис. 5. Система «людина-машина-середовище» Джерело: [1,2] 
Поняття «людський фактор» тісно пов'язано з поняттям «ергономіка», розвиток якої почався в двадцяті роки минулого століття. У п'ятдесяті роки почався новий етап досліджень в області психології праці. 3'являються такі поняття, як «інженерна психологія». Основними сферами діяльності, де проводяться дослідження в даній області, $\epsilon$ військова і авіакосмічна галузі.

Окремий напрямок робіт того часу був пов'язаний з роботою антропологів. Спочатку ці дослідження були спрямовані на пропаганду та забезпечення раціонального використання антропометричних даних у виробничих процесах. У зв'язку зі значними методологічними труднощами для ефективного використання цих даних у практиці проектування обладнання, значний обсяг робіт був присвячений поширенню адекватної інформації про антропометрію та ії використання в ергономіці.

Значні дослідження в області теорії людино-машинних систем в космонавтиці, авіації і військово-морському флоті проведені у напрямку узагальнення і систематизації таких понять в ергономіці як «оператор», «помилка», «надійність», «ефективність» та ін., а також була розроблена теорія для комплексного аналізу людино-машинних систем, що включає в себе аналіз і оцінку ефективності, якості і надійності системи і оператора. Тоді ж створено узагальнений структурний метод, який є основою для проведення функціонально-структурного аналізу завдань і розрахунку часу відгуку оператора, ймовірності його помилки i інших показників.

Для аналізу і оцінки впливу людського фактору міжнародною організацією цивільної авіації (ICAO) рекомендовано використовувати концептуальну модель SHEL [8], розроблену професором Е. Едвардсом в 1972 році (рис. 6). Назва моделі сформовано з перших букв іiі компонентів на англійській мові:

- суб'єкт - Liveware (людина);

- об'єкт - Hardware (машина);

- процедури - Software (технологічні карти, правила, інструкції т.д.);

- оточуюче середовище - Environment.

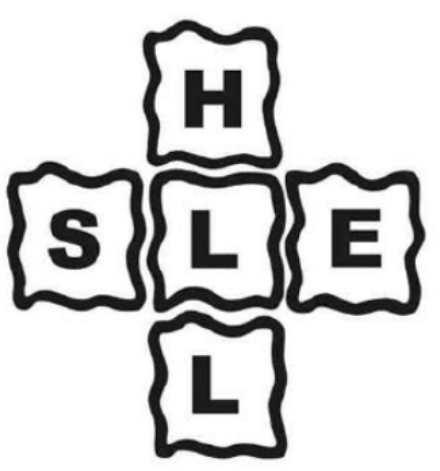

Рис. 6. Модель SHEL

Джерело: [1-3, 8] 
Працездатність персоналу з однаковими функціональними обов'язками як правило може мати відчутні відмінності і піддаватися багатьом обмеженням. Тому важливим завданням $є$ узгодження відповідним чином інших компонентів моделі з її центральною частиною:

- «людина-машина»: персонал і технічні системи, включаючи обладнання;

- «людина-процедури»: персонал і такі матеріали, як технологічні карти, процедури, інструкції і т.д.;

- «людина-середовище»: персонал і умови навколишнього середовища, включаючи внутрішні і зовнішні по відношенню до робочого простору чинники;

- «людина-людина»: відносини між працівниками, включаючи колег.

Модель дозволяє аналізувати участь людини у виробничій діяльності в горизонтальній площині взаємодії. Прикладами $є$ робота таких операторів як поїзний диспетчер, черговий по станції, машиніст поїзда.

У разі аналізу впливу людини по вертикалі управління Д. Ризоном розроблена модель організаційних «патогенів» або помилок [8]. Вона передбачає наявність двох шляхів поширення «патогеннів», по одному 3 них йдуть системні помилки, а по іншому - людські помилки. При цьому модель передбачає, що найбільш важливі «патогени» виникають на високих рівнях керівництва, оскільки саме там приймаються рішення стратегічного характеру. Крім того, Ризон розділив людські «патогени» або помилки на типи і ознаки, представивши це у вигляді класифікації небезпечних дій людей, які можуть привести до небажаного події.

Підводячи підсумок, можна зробити висновок, що в даний час існують різні підходи до вивчення функціонування складних людино-машинних систем, де розглядається взаємодія як підсистем «людина-машина», так і «людина-людина». При цьому, по-перше, такі дослідження проводяться в більшій мірі для працівників диспетчерсько-операторського персоналу, а по-друге, розглядається тільки певна, досить вузька сукупність професійно-важливих якостей працівників, необхідних для виконання конкретного виду професійної діяльності: фізіологічні або психосоціальні характеристики та професійна компетентність працівників. При цьому проблема підвищення безпеки функціонування людини в складних людиномашинних системах нетривіальна і лежить за межами однієї галузі знань. Для оптимізації керованих людиною систем, з метою підвищення безпеки праці, використовуються результати досліджень в області психології, фізіології, гігієни, соціології, культурології, технічних та інженерних дисциплін. Відповідно, розв'язок даної проблеми можливий лише на основі комплексного, системного підходу, заснованого на результатах перерахованих вище досліджень. 


\section{3. Методологія і нормативно-правова база в сфері управління ресурсами, ризиками і надійністю об' сктів транспортної інфраструктури}

Реформування транспортних компаній вимагає застосування новітніх підходів до вирішення завдань підвищення надійності, безпеки і економічної ефективності функціонування транспортної галузі. Вивчення європейського досвіду дозволяе реалізувати гармонізацію вітчизняної нормативної бази в цій області з європейськими підходами, визначеними в рамках комплексу стандартів і методології RAMS (Reliability — безвідмовність, Avaliability — готовність, Mantability ремонтопридатність, Safety - безпека), в які входять стандарти EN 50126, EN 50128, EN 50129 (міжнародні IEC 62278, IEC 62279, IEC 62425) [9-11].

Метою впровадження цієї методології є скорочення вартості життєвого циклу об'єктів транспортної системи в умовах забезпечення високого рівня надійності та безпеки перевізного процесу. Для досягнення цієї мети зазначеними стандартами ставиться ряд завдань, що вимагають розробки:

- методології продовження призначеного терміну служби об'єктів залізничного транспорту і підтримки прийняття рішень для визначення граничного стану;

- механізмів підвищення мотивації підрозділів компанії до поліпшення показників експлуатаційної надійності та безпеки функціонування об'єктів залізничного транспорту;

- системи управління людськими, матеріальними, фінансовими та іншими ресурсами на основі алгоритмів оптимального розподілу;

- методології управління ризиками виробничої діяльності на транспорті;

- інформаційної технології підтримки прийняття рішень щодо управління ризиками, ресурсами і надійністю на етапах життєвого циклу;

- методології управління надійністю об'єктів транспорту, включаючи систему показників експлуатаційної надійності, методи їх розрахунку і аналізу;

- нормативної бази, включаючи міждержавні, національні та галузеві стандарти і методики.

Данна методологія нажаль не повністю враховує питання щодо впливу людського фактору на формування оптимальних умов функціонування транспортних систем. На думку європейських фахівців концепція RAMS вимагає інтеграції в методологію врахування людського фактору (рис. 7) [12].

Автоматизація технологічних процесів, застосування безлюдних і необслуговуваних технологій є одним із шляхів зниження впливу людських помилок на процес функціонування складних технічних систем. Науково-дослідні роботи, що проводяться, в тому числі автором [13], дозволяють мінімізувати участь людини в процесі експлуатації технічних систем залізничного транспорту. Застосування сучасної мікропроцесорної техніки в системах залізничної автоматики і телемеханіки, заснованих на методах безпечного управління об'єктами, підвищує 
надійність роботи систем і безпеку транспортних процесів. Автоматизація процесу контролю і визначення технічного стану пристроїв знижує експлуатаційні витрати i збільшує ефективність процесу технічного обслуговування зменшуючи при цьому можливий негативний вплив обслуговуючого персоналу на функціонування пристроїв автоматики. Разом з тим повністю виключити участь людини у виробничих процесах в даний час не представляється можливим.

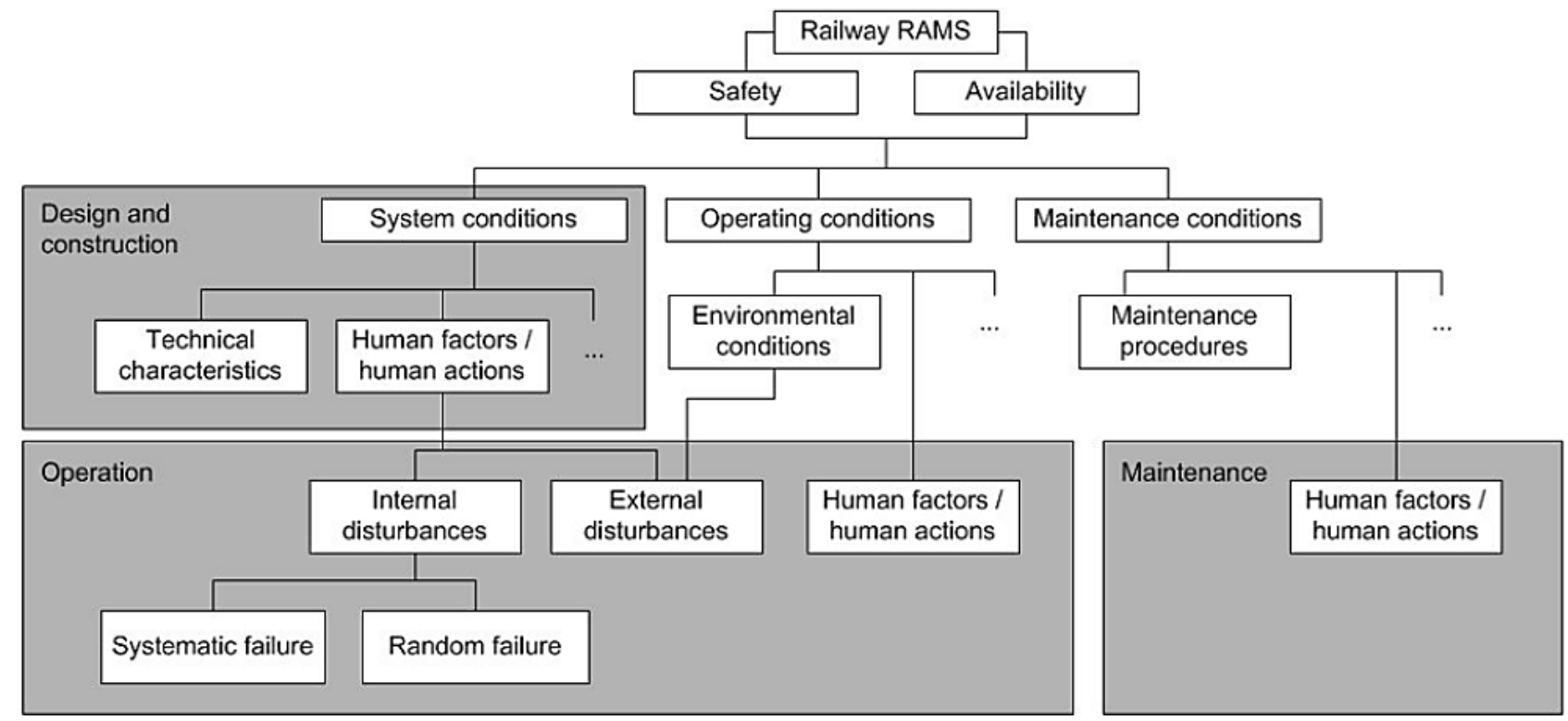

Рис. 7. Інтегрування людського фактору у методологію RAMS Джерело: [12]

\section{4. Методи моделювання впливу людського фактору на безпеку функціонування людино-машинних систем}

Моделювання $\epsilon$ ефективним інструментом щодо проведення аналізу причин помилкових дій людини. Аналіз причин, наприклад, виробничого травматизму, показує, що основною причиною цього $\epsilon$ порушення людиною технології виробництва робіт. Це виражено як у безпосередньому порушенні технологічного процесу, так і в порушенні трудової і виробничої дисципліни, незастосуванні засобів індивідуального захисту, застосуванні несправного обладнання, машин, механізмів тощо. У зв'язку з цим, з огляду на існуючі концептуальні моделі систем «людина-технічна система-виробниче середовище» $[1,2,5]$, може бути використана технологія, що $є$ поєднанням моделі SHEL оцінки впливу людини на функціонування людино-машинної системи з урахуванням взаємозв'язків і закономірностей моделей (рис. 8). Формалізація отриманої моделі може бути виконана на основі теорії графів (рис. 9). 


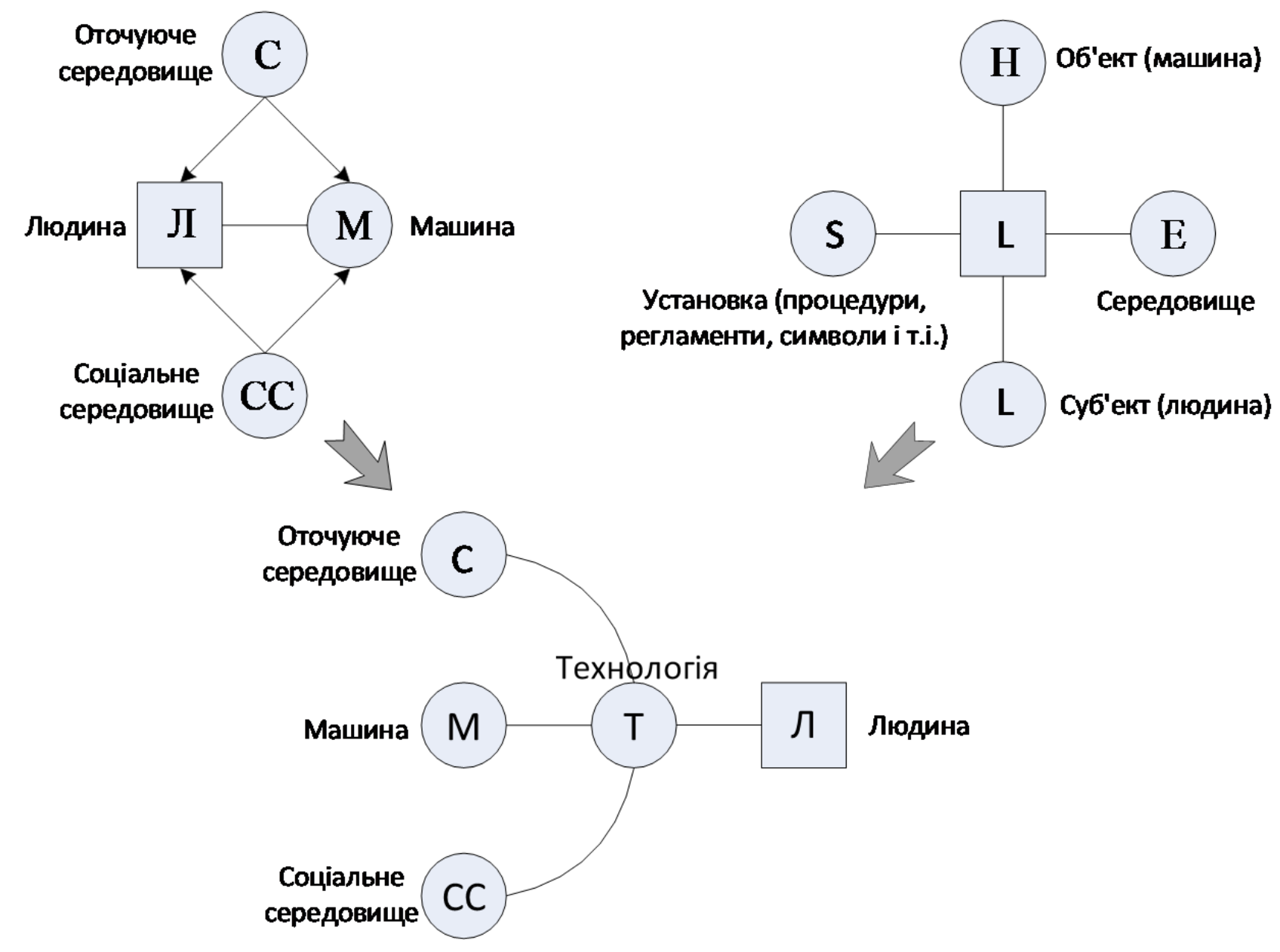

Рис. 8. Формування моделі оцінки впливу людського фактору на базі моделі SHEL

Джерело: [1, 2, 5, 13]

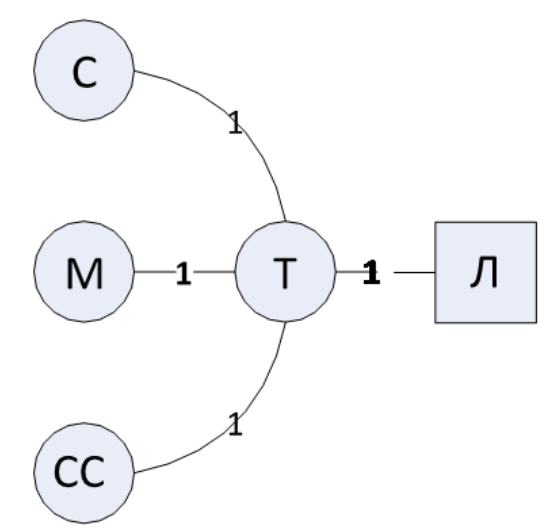

\begin{tabular}{|c|c|c|c|c|c|}
\hline & $Л$ & $\mathrm{~T}$ & $\mathrm{C}$ & $\mathrm{M}$ & $\mathrm{CC}$ \\
\hline$Л$ & 0 & 1 & 0 & 0 & 0 \\
\hline $\mathrm{T}$ & 1 & 0 & 1 & 1 & 1 \\
\hline $\mathrm{C}$ & 0 & 1 & 0 & 0 & 0 \\
\hline $\mathrm{M}$ & 0 & 1 & 0 & 0 & 0 \\
\hline $\mathrm{CC}$ & 0 & 1 & 0 & 0 & 0 \\
\hline
\end{tabular}

Рис. 9. Граф і матриця суміжності моделі Джерело: [13, 14] 
Представлена на рис. 9 модель відображає ідеальний і найбільш безпечний сценарій взаємодії всіх іiї компонентів, тобто коли працівник в точності діє в рамках вимог технології виробництва робіт. Тоді небажані події, що можуть виникати, будуть викликані причинами, не пов'язаними з помилковими діями людини, що реалізує технологічний процес. До таких причин належать як безпосередньо недосконалість технологічного процесу, так і конструктивні недоліки, недосконалість, ненадійність машин, механізмів, вплив природних чинників, протиправні втручання і т. ін.

В транспортних системах небажані події, що викликані останніми причинами, відбуваються набагато рідше, ніж 3 причин, пов'язаних 3 помилковими діями людини. Тому більш точною є модель у вигляді зваженого графа і його матриці суміжності, що представлена на рис. 10.

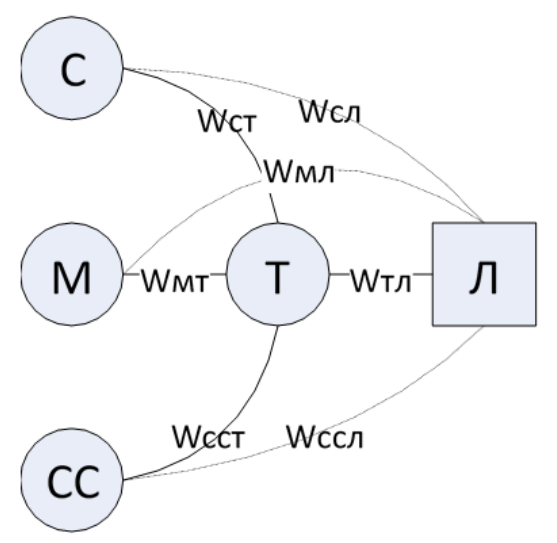

\begin{tabular}{|c|c|c|c|c|c|}
\hline & $\pi$ & $\mathrm{T}$ & $\mathrm{C}$ & $\mathrm{M}$ & $\mathrm{CC}$ \\
\hline$\pi$ & 0 & $\mathrm{~W}_{\text {ТЛ }}$ & $\mathrm{W}_{\mathrm{cл}}$ & $\mathrm{W}_{\mathrm{MJ}}$ & $\mathrm{W}_{\text {ссл }}$ \\
\hline $\mathrm{T}$ & $\mathrm{W}_{\text {тл }}$ & 0 & $\mathrm{~W}_{\mathrm{cT}}$ & $\mathrm{W}_{\mathrm{MT}}$ & $\mathrm{W}_{\mathrm{CT}}$ \\
\hline C & $\mathrm{W}_{\mathrm{c} \Omega}$ & $\mathrm{W}_{\mathrm{cT}}$ & 0 & 0 & 0 \\
\hline $\mathrm{M}$ & $\mathrm{W}_{\text {мл }}$ & $\mathrm{W}_{\mathrm{MT}}$ & 0 & 0 & 0 \\
\hline CC & $\mathrm{W}_{\text {ссл }}$ & $\mathrm{W}_{\mathrm{cct}}$ & 0 & 0 & 0 \\
\hline
\end{tabular}

Рис. 10. Зважений граф моделі оцінки впливу людського фактору і його матриця суміжності

\section{Джерело: [13, 14]}

При цьому з'являються додаткові зв'язки (ребра графа) з вагами $\mathrm{W}_{\text {сл }}, \mathrm{W}_{\text {мл }}$,

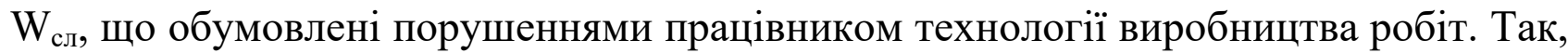
наприклад, ваговий коефіцієнт $\mathrm{W}_{\text {сл }}$ визначає порушення, пов'язані з невживанням засобів індивідуального та колективного захисту тощо, $\mathrm{W}_{\text {мл }}$ - застосування несправного обладнання, машин, механізмів тощо, $\mathrm{W}_{\text {ссл }}-3$ незадовільною організацією виробництва робіт і т.д.

Вагові коефіцієнти приймають значення $\mathrm{W}_{\mathrm{ij}} \in[0,1]$ i для конкретної професії визначаються на основі статистичних даних з розслідування небажаних подій, що відбулися, з урахуванням їх зв'язків. Між собою вони пов'язані рівняннями

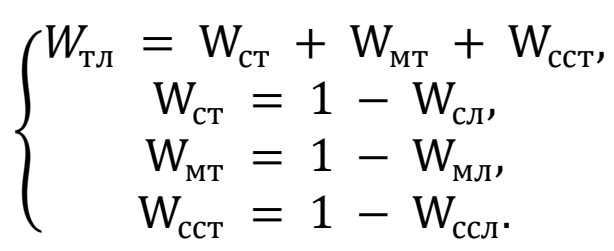


Сума $W_{\text {сл }}+W_{\text {мл }}+W_{\text {ссл }}$ і є оцінкою впливу людського фактору на функціонування системи. При цьому для граничних і проміжних сценаріїв взаємодії елементів моделі коефіцієнти графа можуть приймати наступні значення:

$$
\left\{\begin{array}{l}
W_{\text {ст }}=1, \\
W_{\mathrm{MT}}=1, \\
\mathrm{~W}_{\text {сст }}=1, \\
\mathrm{~W}_{\text {сл }}=0, \\
\mathrm{~W}_{\text {мл }}=0, \\
\mathrm{~W}_{\text {ссл }}=0,
\end{array}\right.
$$

$$
\left\{\begin{array}{l}
0 \ll \mathrm{W}_{\text {ст }}<1, \\
0 \ll \mathrm{W}_{\text {мт }}<1, \\
0 \ll \mathrm{W}_{\text {сст }}<1, \\
0<\mathrm{W}_{\text {сл }} \ll 1, \\
0<\mathrm{W}_{\text {мл }} \ll 1, \\
0<\mathrm{W}_{\text {ссл }} \ll 1,
\end{array}\right.
$$$$
\left\{\begin{array}{l}
\mathrm{W}_{\mathrm{cт}}=0, \\
\mathrm{~W}_{\mathrm{MT}}=0, \\
\mathrm{~W}_{\text {сст }}=0, \\
\mathrm{~W}_{\text {сл }}=1, \\
\mathrm{~W}_{\text {мл }}=1, \\
\mathrm{~W}_{\text {ссл }}=1,
\end{array}\right.
$$

Тобто значення коефіцієнтів (2) відповідають найбільш безпечному стану взаємодії елементів системи, а (4) - найбільш небезпечному стану. Значення коефіціснтів (3) відповідають проміжному стану (реальний випадок) і приведені для незначного відхилення системи від безпечного стану. Графічні інтерпретації варіантів взаємодії людини з іншими компонентами моделі представлені на рис. 11.
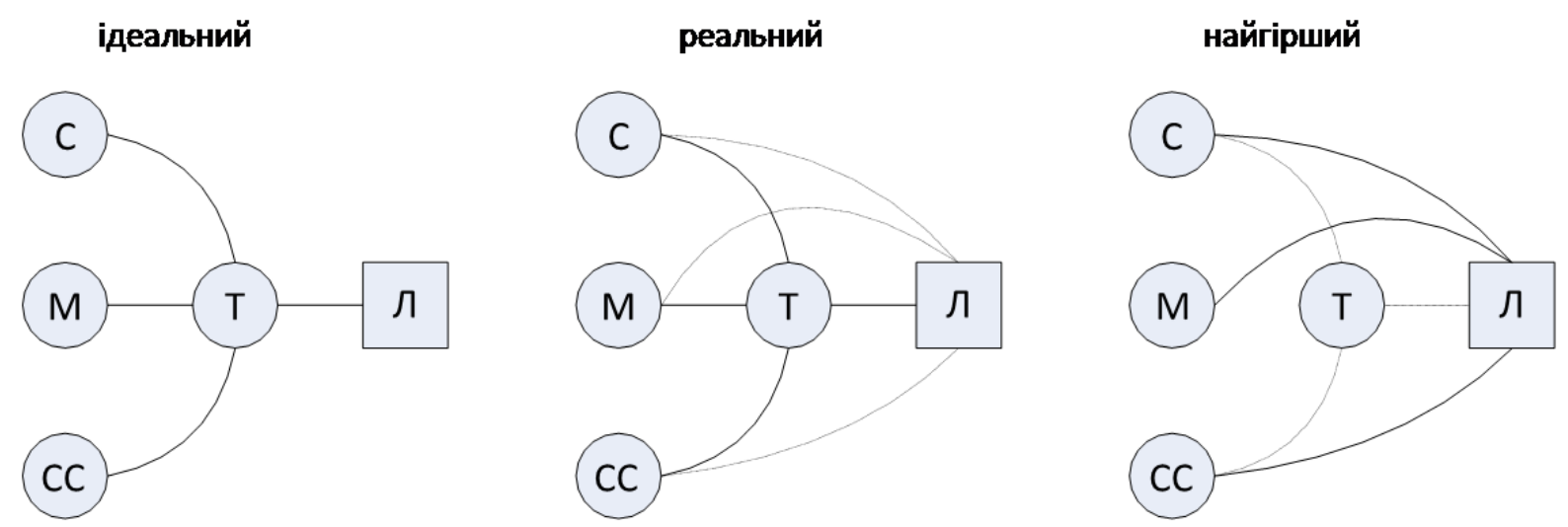

Рис. 11. Варіанти взаємодії людини 3 іншими компонентами моделі систем «людина-технічна система-виробниче середовище»

Джерело: [13, 14]

Уточнюючи цю модель в частині розкриття факторів, що визначають iï компоненти, які є вершинами графа (так, наприклад, людину характеризують антропометричні, фізіологічні, психологічні, психосоціальні та інші фактори [14]) можна розширити можливості врахування впливу людського фактору для більш глибокого аналізу причинно-наслідкових зв'язків, що обумовлюють помилкові дії людини у виробничій діяльності.

Для цього отримана модель може бути представлена у вигляді кортежу [15]

$$
<H, L, S, T, E>\text {, }
$$


що складається 3 наступних параметрів, які впливають на безпеку: $H-$ людські фактори, $L-$ фактори соціального середовища, $S$ - технологічні чинники, $T-$ технічні фактори, $E$ - фактори навколишнього середовища.

При цьому кожен з параметрів являє собою множину

$$
H=\left\{H^{p h}, H^{p l}, H^{p s}, H^{p r}\right\},
$$

де $H^{p h}$ - фізичні (антропометричні) характеристики людини;

$H^{p l}$ - фізіологічні характеристики людини;

$H^{p s}$ - психосоціальні характеристики людини;

$H^{p r}$ - професійні характеристики людини.

$$
L=\left\{L^{n e}, L^{f a}\right\},
$$

де $L^{\text {ne }}$ - найближче соціальне оточення;

$L^{f a}$ - віддалене соціальне оточення.

$$
S=\left\{S^{q u}, S^{q t}\right\}
$$

де $S^{q u}$ - якісні характеристики технології;

$S^{q t}$ - кількісні характеристики технології.

$$
T=\left\{T^{r e}, T^{s a}, T^{e r}\right\},
$$

де $T^{r e}$ - показники надійності технічного засобу;

$T^{s a}$ - показники безпеки технічного засобу;

$T^{e r}$ - ергономічні характеристики технічного засобу.

$$
E=\left\{E^{i n}, E^{e x}\right\}
$$

де $E^{\text {in }}$ - характеристики внутрішнього довкілля;

$E^{e x}$ - характеристики зовнішнього довкілля.

3 урахуванням моделі, представленої на рис. 8, структурна схема системи «людина-технічна система-виробниче середовище» матиме вигляд на рис. 12. Приклад ще більшої деталізації компонентів моделі представлено в табл. 3. 


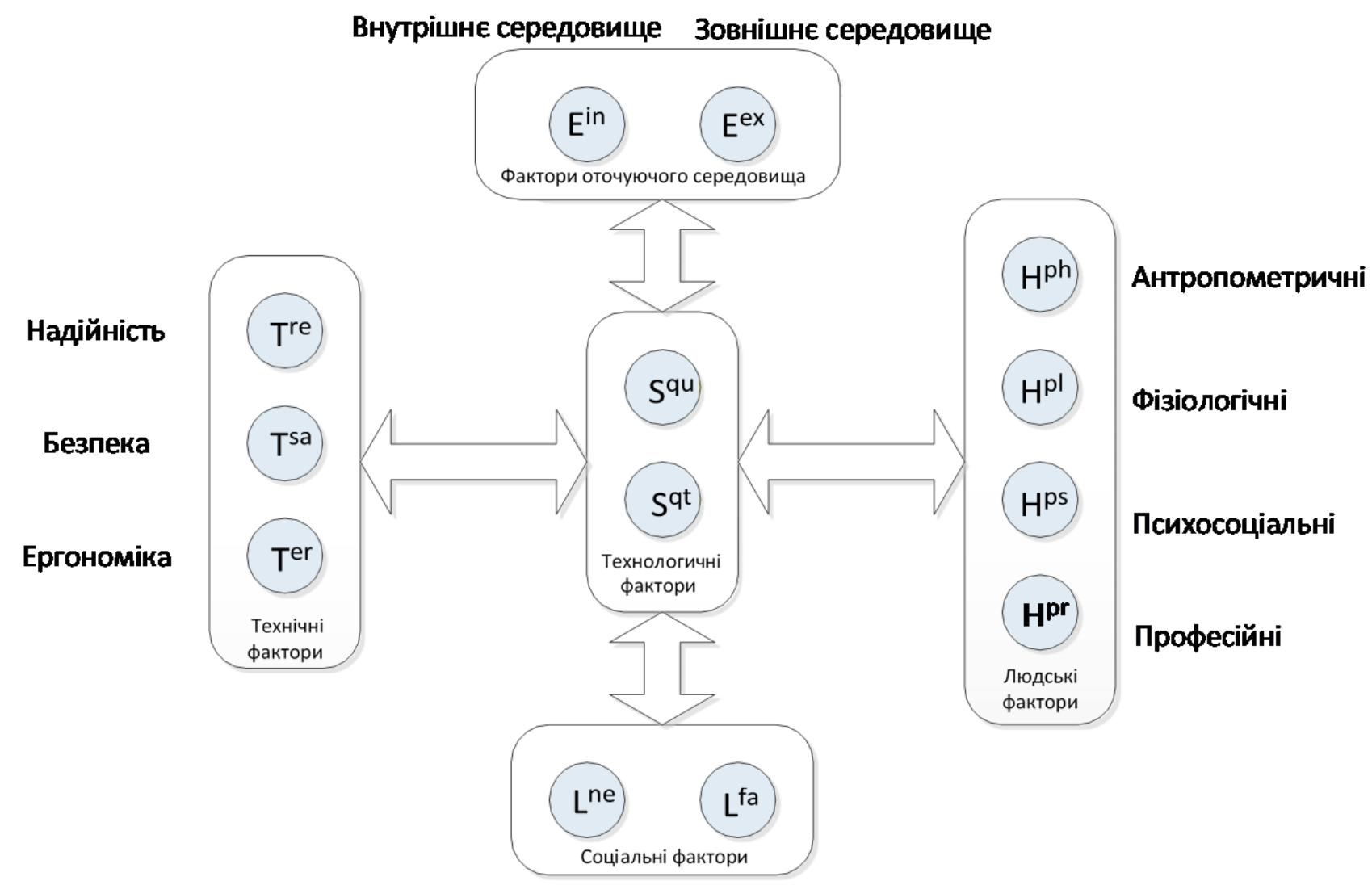

Рис. 12. Структурна схема системи «людина-технічна система-виробниче середовище»

Джерело: [13]

Таблиця 3

Складові системи «людина-технічна система-виробниче середовище»

\begin{tabular}{|c|c|c|}
\hline Фактори & Позначення & Опис \\
\hline 1 & 2 & 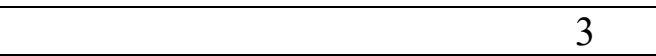 \\
\hline \multirow{13}{*}{ 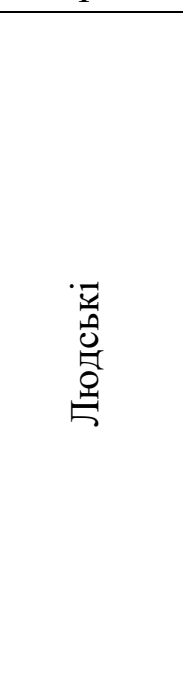 } & $H^{p h 1}$ & Зріст \\
\hline & $H^{p h 2}$ & Вага \\
\hline & $H^{p h 3}$ & Вік \\
\hline & $H^{p l 1}$ & 3ip \\
\hline & $H^{p l 2}$ & Слух \\
\hline & $H^{p l 3}$ & Витривалість \\
\hline & $H^{p l 4}$ & Сила \\
\hline & $H^{p s 1}$ & Мотивація \\
\hline & $H^{p s 2}$ & Стресостійкість \\
\hline & $H^{p s 3}$ & Конфліктність \\
\hline & $H^{p s 4}$ & Лідерські якості \\
\hline & $H^{p 5}$ & Моральні якості \\
\hline & $H^{p r 1}$ & Знання \\
\hline
\end{tabular}


Закінчення табл. 3

\begin{tabular}{|c|c|c|}
\hline 1 & 2 & 3 \\
\hline & $H^{p r 2}$ & Уміння \\
\hline & $H^{p r 3}$ & Досвід \\
\hline & \multicolumn{2}{|r|}{$\ldots$} \\
\hline \multirow{5}{*}{ 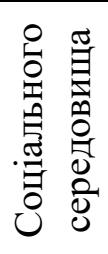 } & $L^{\text {ne } 1}$ & Колеги по роботі \\
\hline & $L^{n e 2}$ & Безпосередній керівник \\
\hline & $L^{n e 3}$ & Близькі родичі \\
\hline & $L^{f a 1}$ & Вище керівництво \\
\hline & &. \\
\hline \multirow{5}{*}{ 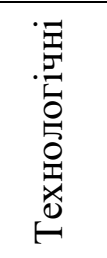 } & $S^{q u 1}$ & Якість технологічної документації \\
\hline & $S^{q u 2}$ & Повнота технологічної документації \\
\hline & $S^{q t 1}$ & Тривалість виконання робіт \\
\hline & $S^{q t 2}$ & Трудомісткість і машиноємності виконання робіт \\
\hline & \multicolumn{2}{|r|}{$\ldots$} \\
\hline \multirow{10}{*}{ 声 } & $T^{r e 1}$ & Імовірність безвідмовної роботи \\
\hline & $T^{r e 2}$ & Інтенсивність відмов \\
\hline & $T^{r e 3}$ & Коефіцієнт готовності \\
\hline & $T^{\mathrm{sa1}}$ & Імовірність безпечної роботи \\
\hline & $T^{\mathrm{sa} 2}$ & Імовірність небезпечної відмови \\
\hline & $T^{\mathrm{sa} 3}$ & Середнє напрацювання на небезпечну відмову \\
\hline & $T^{e r 1}$ & Гігієнічні показники \\
\hline & $T^{e r 2}$ & Антропометричні показники \\
\hline & $T^{e r 3}$ & Психофізіологічні показники \\
\hline & \multicolumn{2}{|r|}{ 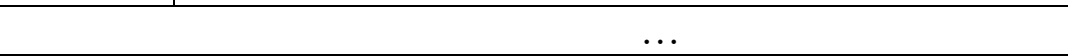 } \\
\hline \multirow{5}{*}{ 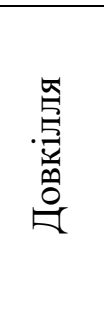 } & $E^{i n 1}$ & Показники мікроклімату \\
\hline & $E^{\text {in } 2}$ & Рівень освітленості \\
\hline & $E^{i n 3}$ & Рівень шкідливих виробничих чинників \\
\hline & $E^{e x 1}$ & Час доби \\
\hline & $E^{e x 2}$ & Пора року \\
\hline
\end{tabular}

Джерело: [3, 14]

Таким чином, зазначене моделювання полягає в дослідженні і оцінці впливу всієї сукупності людських факторів на безпеку функціонування людино-машинних систем. При цьому варто відзначити, що, в роботах, присвячених вирішенню подібних завдань на залізничному транспорті, як правило, досліджується вплив тільки однієї групи факторів, наприклад, психофізіологічних якостей працівників або їх професійних компетенцій $[6,16]$.

Одним 3 методів моделювання, що запропоновано американським кібернетиком М. Мінським, $є$ метод структурного представлення знань у вигляді ієрархічно впорядкованої структури даних (фрейму), мінімально необхідних для опису 
стереотипних ситуацій [17]. Надалі теорія фреймів розвивалася в роботах [18]. Когнітивні карти, що відносяться до того ж класу систем уявлення знань, що i фрейми [19], були запропоновані Е. Толменом для позначення цілісного образу або уявлення деякої обстановки, яка склалася в ході попереднього досвіду людини і визначає тї поведінку.

Згодом когнітивні карти використовувалися в роботах Р. Аксельрода при розробці методології когнітивного моделювання, призначеного для аналізу і прийняття рішень в слабо визначених ситуаціях. Розвиваючи теорію нечітких множин, основні положення якої були сформульовані Л. Заде i, використовуючи ії математичний апарат, Б. Коско ввів поняття нечіткої когнітивної карти. Методологія нечіткого когнітивного моделювання застосовується при дослідженні слабо формалізованих і слабо структурованих систем з елементами невизначеності і в даний час розвивається в напрямку вдосконалення апарату аналізу та моделювання ситуації. Його використовують для організації підтримки і прийняття стратегічних рішень в політиці, макроекономіці, екології, менеджменті, медицині, при вирішенні завдань управління ризиками і забезпечення інформаційної безпеки $[15,20,21]$.

Систему (5) складно формалізувати, оскільки вона володіє великою невизначеністю елементів, що входять до неї, тому не представляється можливим отримати точний математичний опис для моделювання функціонування такої системи. Тож уявімо модель оцінки впливу людського фактору у вигляді узагальненої нечіткої когнітивної карти.

Когнітивна карта являє собою причинно-наслідкову мережу, у вигляді орієнтованого графа (рис. 13), що відображає якусь галузь знань. Формально когнітивну карту можна представити у вигляді кортежу

$$
G=\langle\mathrm{C}, W>,
$$

де $\mathrm{C}=\left\{\mathrm{c}_{1}, \mathrm{c}_{2}, \ldots, \mathrm{c}_{n}\right\}-$ множина факторів, які називаються концептами (вершини графа), $W=\left\{w_{i j}=w\left(\mathrm{c}_{i}, \mathrm{c}_{j}\right)\right\}$ - множина зв'язків між концептами (ребра графа).

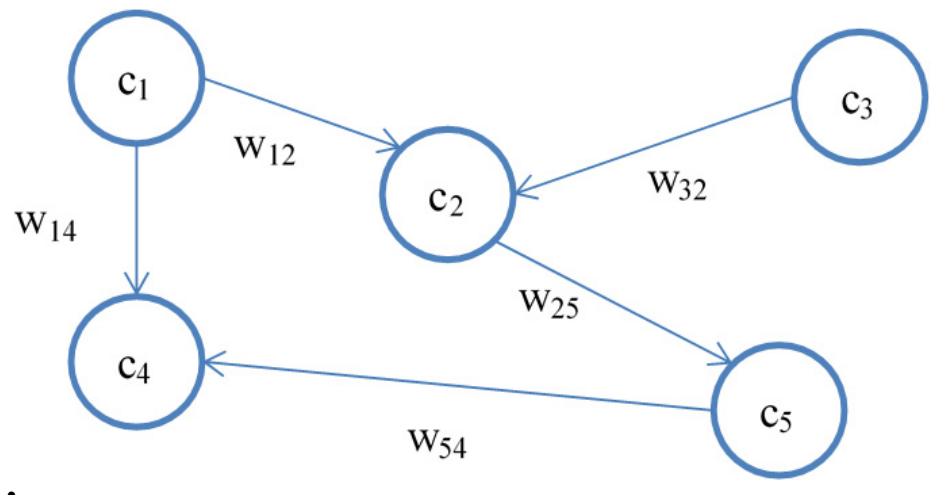

Рис. 13. Когнітивна карта

Джерело: [21] 
Таким чином, елементи $c_{i}$ і $c_{j}$ пов'язані відношенням $w$. В результаті зміна значення концепту $c_{i}$ (причини) призводить до зміни значення концепту $c_{j}$ (слідства), а саме, зростання значення концепту-причини призводить до збільшення значення концепту-слідства, якщо причинно-наслідковий зв'язок позитивний i, навпаки, до зменшення цього значення при негативному причинно-наслідковому зв'язку.

У разі нечітких когнітивних карт, взаємовплив або зв'язок між концептами можуть відрізнятися за силою або вагою впливу. Тоді орієнтований граф, що представляє когнітивну карту, є зваженим, при цьому ваги ребер графа мають ряд властивостей [20]:

1) $w_{i j} \in[-1,1]$

2) $w_{i j}=0$, якщо $c_{i}$ не залежить від $c_{j}$ (вплив відсутній);

3) $w_{i j}=1$ при максимальному позитивному впливі $c_{i}$ на $c_{j}$, коли будь-які зміни, що відбуваються в системі і пов'язані 3 концептом $c_{j}$, однозначно визначаються діями, що відносяться до концепту $c_{i}$;

4) $w_{i j}=-1$ при максимальному негативному впливі, коли будь-які зміни, пов'язані 3 концептом $c_{j}$, однозначно стримуються діями, пов'язаними 3 концептом $c_{i}$.

Властивості коефіцієнтів $w_{i j}$, визначаючи нечіткість когнітивної карти, дозволяють оцінювати силу впливу $\left|w_{i j}\right|$ значеннями лінгвістичної змінної (термами) відповідно до певної шкали, наприклад: 0,1 - дуже слабкий вплив; 0,3 - слабкий вплив; 0,5 - істотний; 0,7 - сильний; 0,9 - дуже сильний. Сукупність ваг ребер $w_{i j}$ задається матрицею суміжності графа $W=\left\|w_{i j}\right\|$.

Існує два види когнітивного аналізу: статичний і динамічний. Статичний представляє собою аналіз шляхів впливу одних концептів на інші через треті в поточній ситуації. В даному типі аналізу використовуються тільки значення вагових коефіцієнтів матриці суміжності графа, на основі яких визначаються такі системні показники, як консонанс, дисонанс, взаємний вплив і т.д.

Динамічний аналіз - це генерація і аналіз сценаріїв розвитку ситуації в часі, коли при цьому враховуються також нечіткі значення концептів $\mathrm{c}_{i} \in[0,1]$. Поділ концептів на вхідні, проміжні та цільові дозволяє сформулювати пряму задачу прогноз розвитку ситуації в часі (зміна значень цільових концептів) на основі заданих значень вхідних концептів і зворотну задачу — визначення значень вхідних концептів для заданого цільового стану. Динамічний аналіз проводиться на основі моделювання імпульсного процесу, коли вхідним концептам задаються елементарні збурення, які тягнуть за собою зміну (посилення або ослаблення) значень всіх інших концептів по ланцюжку.

Когнітивне моделювання виконується в декілька етапів і складається 3 наступної послідовності дій:

1. Формулювання мети і завдань моделювання. 
2. Вивчення ситуації, що розглядається з позиції поставленої мети, куди входить збір інформації про ситуацію, ії систематизація, аналіз існуючої статистичної та якісної інформації про ситуацію, визначення властивих досліджуваної ситуації умов, обмежень і вимог.

3. Виділення основних факторів, що впливають на розвиток ситуації (в тому числі: цільових - визначають результат розвитку ситуації, проміжних, вхідних, що є важелями впливу на ситуацію).

4. Визначення взаємозв'язків між факторами і їх напрямки впливу (позитивне чи негативне).

5. Побудова когнітивної карти.

6. Визначення сили або ваги взаємозв'язків між факторами.

7. Перевірка адекватності моделі, зіставлення отриманих результатів 3 даної ситуації, яка при тих же вихідних умовах була в минулому.

8. Формулювання висновків і рекомендацій відповідно до поставленої мети.

Коли, наприклад, розглядаються ситуації з виробничим травматизмом, цільовими концептами можуть бути як причини цього травматизму (рис. 14), так і результат помилок працівників. Разом з тим, побудова когнітивних карт і подальший аналіз отриманої моделі $є$ трудомісткими процесами, які вимагають участі відповідних експертів, що значно обмежує можливості застосування цього методу моделювання.

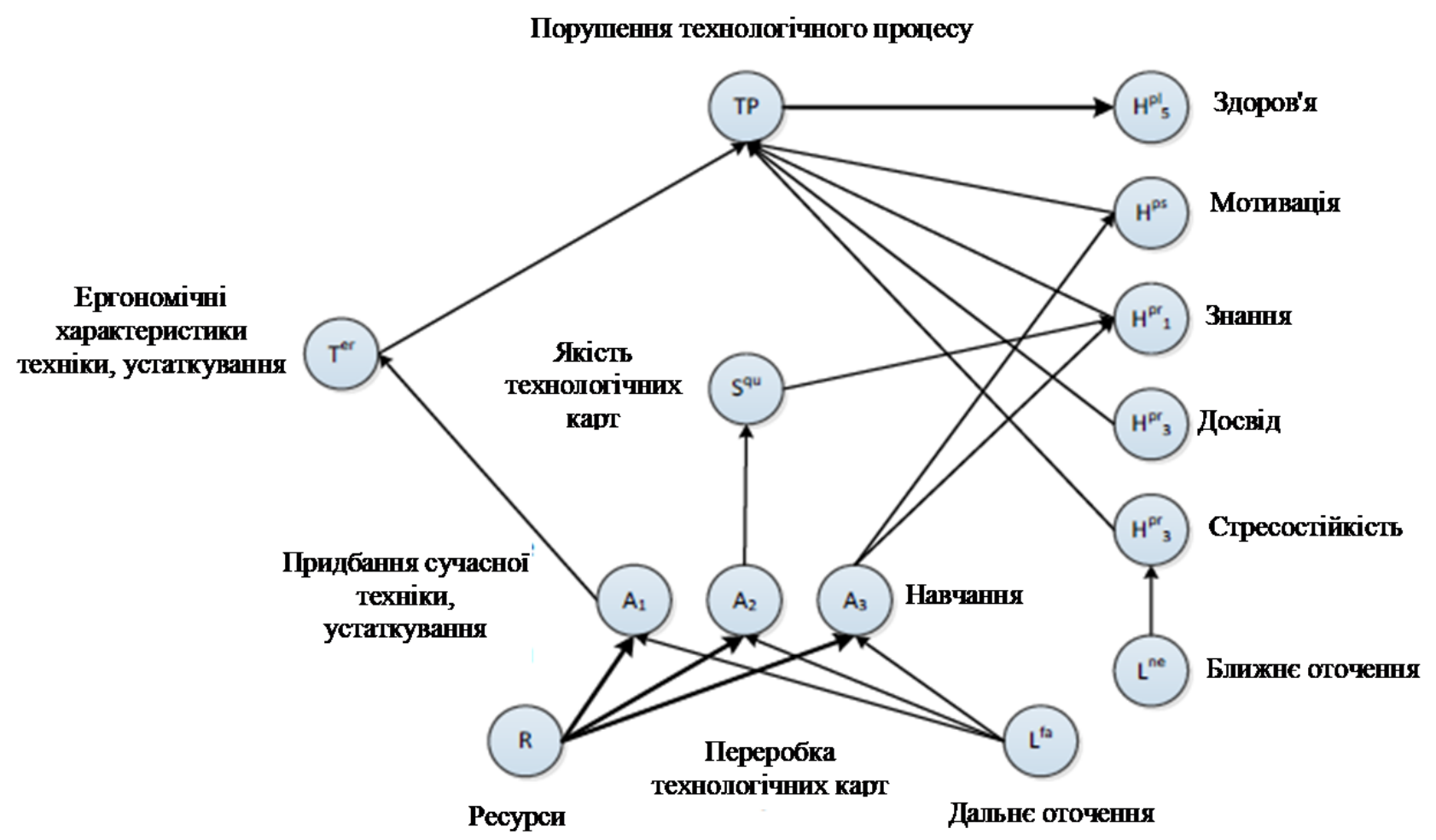

\section{Рис. 14. Когнітивна карта оцінки впливу людського фактору на пору- шення технологічного процесу}

Джерело: [18, 21] 
3 іншого боку можна розглядати компоненти системи (5) незалежно один від одного, проводячи оцінку їх відповідності між собою де оцінюваним компонентом системи є працівник. Для цього може бути використано кваліметричні методи аналізу.

Кваліметричний метод аналізу [22] дозволяє отримати кількісну оцінку ступеня відповідності працівника певному виду професійної діяльності на основі аналізу сукупності багатьох його характеристик і властивостей [23].

Суть методу полягає в побудові методики оцінки, а потім її використанні (рис. 15). На першому етапі кваліметричного аналізу необхідно побудувати дерево властивостей і виявити оцінювані показники.

У нашому випадку, дерево властивостей включатиме в себе вище позначені характеристики (властивості) працівника (рис. 16). Перелік цих характеристик для кожної професії будуть індивідуальні. Підходи до їх виявлення представлені в [24, 25].

Першим етапом за даним методом знаходяться групові коефіцієнти важливості властивостей, які потім нормуються. Для знаходження коефіцієнтів важливості можна використовувати аналітичні методи (регресійного або кореляційного аналізу), але частіше використовуються методи експертних оцінок.

\begin{tabular}{|c|c|c|c|}
\hline \multirow{3}{*}{ 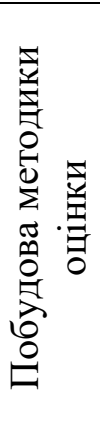 } & $\begin{array}{l}\text { 1. Побудова дерева властивостей } \\
\text { i дерева показників об’єкта }\end{array}$ & \multirow{3}{*}{ 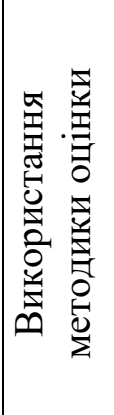 } & $\begin{array}{l}\text { 1. Визначення значень } \\
\text { відносних показників } \\
\text { властивостей }\end{array}$ \\
\hline & $\begin{array}{l}\text { 2. Визначення значень } \\
\text { коефіцієнтів важливості } \\
\text { показників властивостей }\end{array}$ & & $\begin{array}{l}\text { 2. Визначення значень } \\
\text { абсолютних показників } \\
\text { властивостей }\end{array}$ \\
\hline & $\begin{array}{l}\text { 3. Визначення еталонних } \\
\text { і мінімальнодопустімих значень } \\
\text { показників властивостей. }\end{array}$ & & $\begin{array}{l}\text { 3. Визначення значень } \\
\text { показника якості об’єктів }\end{array}$ \\
\hline
\end{tabular}

Рис. 15. Етапи кваліметричного аналізу

Джерело: [22-24]

Наступним кроком визначаються еталонні (оптимальні) і мінімальнодопустимі значення абсолютних показників властивостей (якості) для оцінюваної професії. Варто зазначити, що ці показники в кваліметрії визначаються як значення, досягнуті в світі на часовий період, коли проводиться оцінювання. У нашому випадку ці значення повинні бути прив'язані до конкретної професії. Наприклад, якщо еталонне значення гостроти зору - 1,0 для будь-якої професії, то еталонне значення зросту або такої психосоціальної якості, як конфліктність, будуть відрізнятися у різних професій. Те ж саме стосується і мінімальнодопустимих значень абсолютних показників властивостей. 


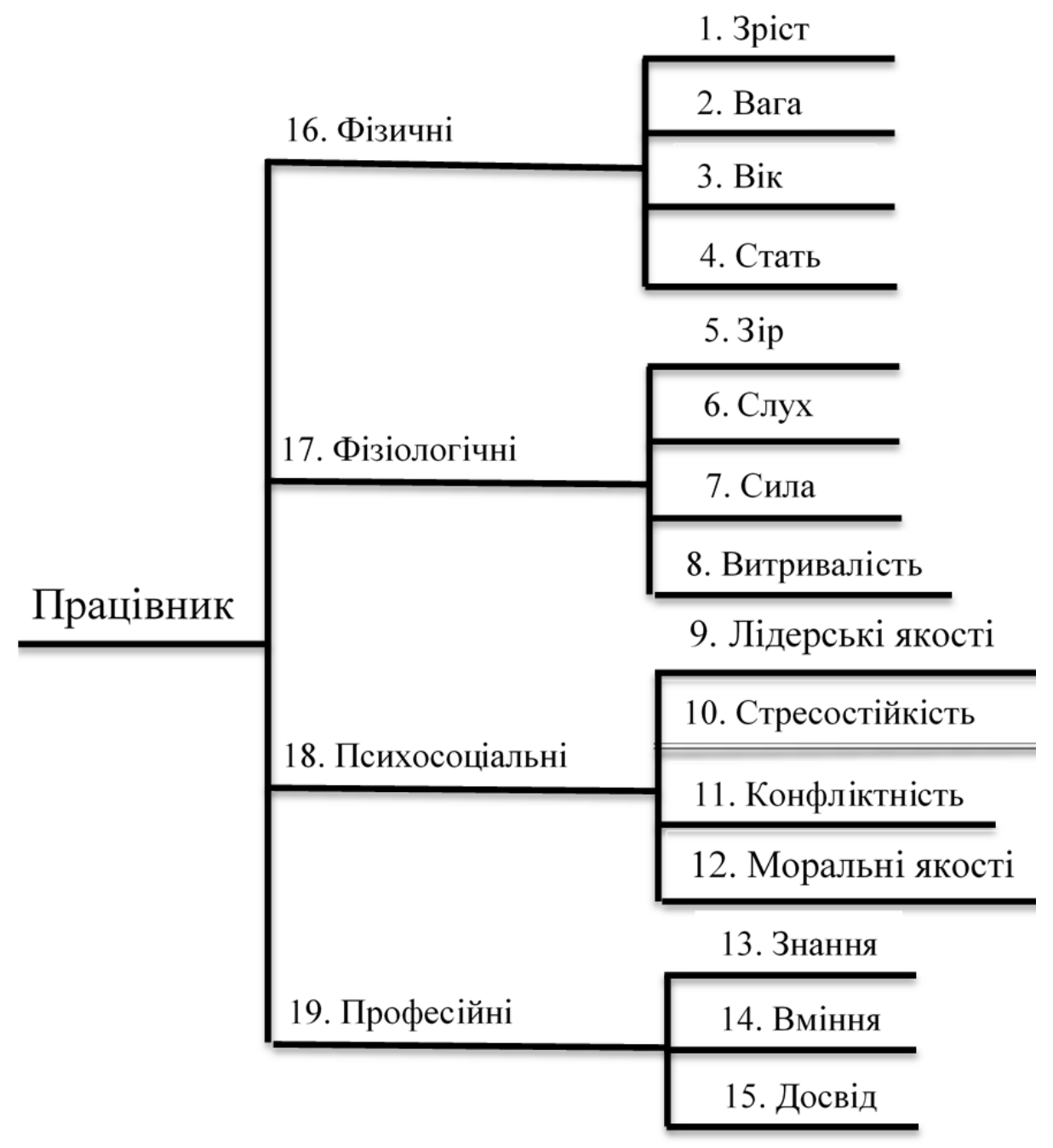

\section{Рис. 16. Приклад дерева властивостей} Джерело: [25]

Після цього визначаються значення абсолютних показників властивостей конкретного працівника. Деякі значення (більшість фізичних і фізіологічних) можна визначити методами прямих фізичних вимірювань (вага, рівень слуху). Інші за допомогою відповідних тестувань. Наприклад, використовуються тести, що визначають рівень професійних знань або психосоціальні якості людини (16-ти факторний особистісний опитувальник Кеттелла, Мінесотський багатоаспектний особистісний опитувальник та ін.).

Для забезпечення порівнянності значень абсолютних показників виконують їх перевід в відносні значення за допомогою операції нормування.

В основі детермінованого моделювання, представленого вище, лежить можливість побудови моделі людино-машинної системи по теоретично передбачуваних прямих зв'язках між компонентами i факторами моделі. Разом 3 тим, таке моделювання обмежене розміром поля прямих зв'язків. При недостатньому рівні 
знань про природу прямих зв’язків того чи іншого фактору моделі, необхідний комбінований підхід до оцінки впливу людського фактору. При наявності достатнього обсягу статистичних даних можна застосувати стохастичне моделювання та аналіз, що направлені на вивчення непрямих зв'язків між факторами моделі і виступають в якості інструменту поглиблення детермінованого аналізу факторів, за якими не можна побудувати детерміновані моделі.

\section{5. Зниження ролі людського фактору і професійних ризиків у виробничій діяльності}

Одним із ефективних інструментів ідентифікації, аналізу, оцінки, а отже і попередження небезпек у виробничій діяльності є методи експертних оцінок, у тому числі оцінок професійних ризиків [26].

В якості експертів при проведенні оцінки ризиків можуть виступати група спеціалістів, сформована в рамках, наприклад, структурного підрозділу, в яку входять головний інженер, спеціаліст з охорони праці, технолог, а також досвідчені керівники середньої ланки і фахівці. Крім того, в якості експертів можуть залучатися самі працівники, для врахування їх думок щодо різних факторів, що впливають на безпеку їх праці. Етапи процесу оцінки професійних ризиків в структурному підрозділі підприємства представлено на рис. 17.

Анкетування всіх працівників структурного підрозділу для обліку ї думок про функціонування системи управління охороною праці в підрозділі

Ідентифікація небезпек на робочих місцях працівників травмонебезпечних професій, шляхом виявлення чинників, що впливають на безпеку робочого місця і заповнення протоколу спостережень

Занесення виявлених небезпек в карту ідентифікації небезпек та оцінки ризиків, з подальшою оцінкою серйозності наслідків впливу небезпеки та ймовірності виникнення небезпеки для визначення підсумкової величини ризику

Зведення ризиків, що відносяться в категорії «небажаний» і неприпустимий »в реєстр неприпустимих ризиків

Формування пропозицій до плану коригувальних заходів по кожному виявленому ризику і визначення планованої величини ризику

Рис. 17. Етапи оцінки професійних ризиків у виробничій діяльності Досерело: [26] 
Етап анкетування є однією з основних форм обліку думок респондентів у різних дослідженнях. Процес проведення анкетування умовно можна розділити на чотири етапи: підготовка опитувальних листів, безпосередньо анкетування, обробка отриманих даних, прийняття управлінських рішень на основі отриманих результатів.

При підготовці до проведення ідентифікації небезпек та оцінки ризиків, а також, в подальшому, для розробки пропозицій щодо коригуючих заходів, експертна група проводить анкетування працівників за допомогою листів опитування. Дане дослідження проводиться анонімно з подальшим агрегуванням результатів анкет за професіями. Підвищення ефективності процесу проведення анкетування і обробки результатів можливе на основі використання опитувальних форм в google (web-технологіi), які відрізняються відкритістю, доступністю, мінімальним часом, навчання співробітників для використання платформи і впровадження іiі в виробничий процес.

Інтерпретація балів по результатам анкетування здійснюється 3 використанням табл. 4.

Таблиця 4

Інтерпретація балів небезпеки відповідно до опитувальних листів

\begin{tabular}{|c|c|l|}
\hline Рівень ризику & Бал & \multicolumn{1}{|c|}{ Рекомендовані заходи } \\
\hline Незначний & $0-10$ & $\begin{array}{l}\text { Зниження ризику не потрібно, але групи вразливих } \\
\text { осіб потребують додаткового захису. Проводитья } \\
\text { ослаблений контроль. Рекомендуються заходи 3 під- } \\
\text { тримки даного рівня }\end{array}$ \\
\hline Прийнятний & $11-32$ & $\begin{array}{l}\text { Розглянути можливі шляхи вирішення проблем } \\
\text { в майбутньому }\end{array}$ \\
\hline Середній & $33-67$ & $\begin{array}{l}\text { Планування заходів, спрямованих на усунення недо- } \\
\text { ліків }\end{array}$ \\
\hline Високий & $68-89$ & $\begin{array}{l}\text { Планування заходів і пріоритетна ї реалізація, } \\
\text { спрямована на усунення або зниження негативного } \\
\text { впливу недоліків }\end{array}$ \\
\hline Дуже високий & $90-$ & $\begin{array}{l}\text { Розглянута проблема несе загрозу для життя і здо- } \\
\text { ров'я, необхідні негайні заходи, що спрямовані на } \\
\text { усунення або зниження негативного впливу }\end{array}$ \\
\hline
\end{tabular}

Джерело: [26]

Використовуючи результати аналізу анкетування, можна виявити «слабкі місця» в системі безпеки та управління охороною праці структурного підрозділу на основі розрахованої величини балів значущості проблем 3 досліджуваних 
факторів. Отримані результати в подальшому необхідно враховувати при формуванні пропозицій щодо плану коригувальних заходів.

Далі проводиться ідентифікація небезпек на робочих місцях. Для іiї проведення, експертна група визначає перелік робочих місць. При цьому місця вибираються так, щоб отримати максимально достовірну уяву про небезпеки, які існують в структурному підрозділі.

Вибрані робочі місця структурного підрозділу повинні представляти всі типи виконуваних в підрозділі робіт, але на першому етапі з огляду на великий обсяг проведених робіт можлива ідентифікація небезпек тільки для працівників травмонебезпечних професій, або діяльність яких пов'язана з більш шкідливими умовами. При визначенні меж оцінюваного робочого місця експертна група досліджує територію, що входить в робочий простір і знаходиться на його межах.

Після визначення меж робочого місця проводиться спостереження за діяльністю працівників та співбесіда 3 ними. Для його проведення використовується анкета для спостережень, що враховує специфіку робочого місця і досліджуваної діяльності. Отриманий в результаті протокол спостережень повинен відображати найважливіші фактори, що впливають на безпеку робочого місця:

- виробничий процес;

- зміст робочого місця;

- безпека праці при роботі на виробничому обладнанні;

- фактори навколишнього середовища на робочому місці;

- ергономічні чинники;

- проходи і проїзди;

- можливості для порятунку і надання першої допомоги.

Заповнюючи його, експертна група виявляє небезпеки на робочому місці. Всі виявлені небезпеки (результати оцінки зі знаком «-») вносяться в карту ідентифікації небезпек та оцінки ризиків із значенням умови їх виникнення.

Далі оцінюється ймовірність виникнення небезпеки і серйозність наслідків від їі впливу для визначення рівня ризику. За основу бальної оцінки взяті типові рівні частот виникнення подій, типові рівні тяжкості наслідків, а також форма матриці ризиків 3 [27, 28]. Співвідношення балів, частот, наслідків та рівнів ризику представлено в табл. 5-7.

Необхідно відзначити, що залежність балів від відповідного рівня частоти або тяжкості наслідків $\epsilon$ нелінійною в силу нелінійного характеру залежності між кількісними значеннями показників відповідних рівнів.

Виходячи із значень ймовірності виникнення небезпеки і серйозності наслідків впливу небезпеки, експертна група визначає категорію ризику по матриці класифікації ризиків. За отриманими результатами відповідно до табл. 8 приймається рішення про необхідність обробки ризику і іiі пріоритетності. 
Таблиця 5

\section{Оцінка ймовірності виникнення небезпеки}

\begin{tabular}{|l|c|l|c|l|}
\hline \multicolumn{1}{|c|}{$\begin{array}{c}\text { Рівень } \\
\text { частоти }\end{array}$} & $\begin{array}{c}\text { Частота } \\
\text { подій у рік, } \boldsymbol{f}\end{array}$ & $\begin{array}{l}\text { Інтерпретація } \\
\text { частоти }\end{array}$ & Бал & \multicolumn{1}{|c|}{ Опис } \\
\hline Часте & $f>10^{-2}$ & $\begin{array}{l}\text { Випадок раз } \\
\text { в 3 місяці }\end{array}$ & 32 & $\begin{array}{l}\text { Імовірність частого виникнення. Постійна } \\
\text { наявність небезпеки }\end{array}$ \\
\hline Ймовірне & $\begin{array}{c}5 \times 10^{-3} \leq f< \\
<10^{-2}\end{array}$ & $\begin{array}{l}\text { Випадок раз на } \\
1 \text { рік }\end{array}$ & 16 & $\begin{array}{l}\text { Неодноразове виникнення. Очікується } \\
\text { часте виникнення небезпечної події }\end{array}$ \\
\hline Випадкове & $\begin{array}{l}10^{-3} \leq f< \\
<5 \times 10^{-3}\end{array}$ & $\begin{array}{l}\text { Випадок раз на } \\
3 \text { роки }\end{array}$ & 10 & $\begin{array}{l}\text { Імовірність неодноразового виникнення. } \\
\text { Очікується неодноразове виникнення } \\
\text { небезпечної події }\end{array}$ \\
\hline Рідкісне & $\begin{array}{c}5 \times 10^{-4} \leq f< \\
<10^{-3}\end{array}$ & $\begin{array}{l}\text { Випадок раз на } \\
5 \text { років }\end{array}$ & 5 & $\begin{array}{l}\text { Імовірність того, що подія буде іноді } \\
\text { виникати протягом життєвого циклу } \\
\text { об'єкта є. Обгрунтоване очікування } \\
\text { виникнення небезпечної події }\end{array}$ \\
\hline $\begin{array}{l}\text { Вкрай } \\
\text { рідкісне }\end{array}$ & $\begin{array}{l}10^{-4} \leq f< \\
5 \times 10^{-4}\end{array}$ & $\begin{array}{l}\text { Випадок раз на } \\
10 \text { років }\end{array}$ & 2 & $\begin{array}{l}\text { Імовірність виникнення малоймовірна, } \\
\text { але можлива. Можна припустити, що } \\
\text { небезпечна подія може виникнути } \\
\text { у винятковому випадку }\end{array}$ \\
\hline $\begin{array}{l}\text { Мало } \\
\text { ймовірне }\end{array}$ & $f \leq 10^{-4}$ & $\begin{array}{l}\text { Менше одного } \\
\text { випадку за } \\
10 \text { років }\end{array}$ & 1 & $\begin{array}{l}\text { Імовірність виникнення вкрай } \\
\text { малоймовірна. Можна припустити, що } \\
\text { небезпечна подія не виникне }\end{array}$ \\
\hline
\end{tabular}

Джерело: [26]

Оцінка серйозності наслідків впливу небезпеки

Таблиця 6

\begin{tabular}{|l|c|l|}
\hline $\begin{array}{c}\text { Pівні тяжкості } \\
\text { наслідків }\end{array}$ & Бал & \multicolumn{1}{|c|}{ Наслідки за видами ризику } \\
\hline Катастрофічний & 9 & $\begin{array}{l}\text { Загибель 1 або більше осіб або тяжка шкода здо- } \\
\text { ров'ю 5 або більше людей, пов'язаних 3 функціо- } \\
\text { нуванням транспорту }\end{array}$ \\
\hline Критичний & 5 & $\begin{array}{l}\text { Тяжка шкода здоров'ю до 5 осіб, пов'язаних } \\
\text { з функціонуванням транспорту. Загибель 1 люди- } \\
\text { ни або тяжка шкода здоров'ю 1 або більше людей } \\
\text { в результаті умисних або необережних дій самого } \\
\text { потерпілого або інших осіб, не пов'язаних } \\
\text { з функціонуванням транспорту }\end{array}$ \\
\hline Несуттєвий & 2 & Шкода здоров'ю середньої тяжкості \\
\hline Незначний & 1 & Легка шкода здоров'ю \\
\hline
\end{tabular}

Джерело: [27] 
Таблиця 7

Матриця класифікації ризиків

\begin{tabular}{|c|c|c|c|c|}
\hline Рівні частоти & \multicolumn{4}{|c|}{ Рівні ризику } \\
\hline $\begin{array}{l}\text { Часте } \\
(32)\end{array}$ & $\begin{array}{c}\text { Небажаний } \\
\text { (32) }\end{array}$ & $\begin{array}{c}\text { Неприпустимий } \\
\text { (64) }\end{array}$ & $\begin{array}{c}\text { Неприпустимий } \\
(160)\end{array}$ & Неприпустимий (288) \\
\hline $\begin{array}{l}\text { Ймовірне } \\
(16)\end{array}$ & $\begin{array}{l}\text { Допустимий } \\
(16)\end{array}$ & $\begin{array}{c}\text { Небажаний } \\
\text { (32) }\end{array}$ & $\begin{array}{c}\text { Неприпустимий } \\
(90)\end{array}$ & Неприпустимий (144) \\
\hline $\begin{array}{c}\text { Випадкове } \\
(10)\end{array}$ & $\begin{array}{c}\text { Допустимий } \\
(10)\end{array}$ & $\begin{array}{c}\text { Небажаний } \\
(20)\end{array}$ & $\begin{array}{c}\text { Небажаний } \\
(50)\end{array}$ & Неприпустимий (90) \\
\hline $\begin{array}{l}\text { Рідкісне } \\
\text { (5) }\end{array}$ & $\begin{array}{c}\text { Такий, що не } \\
\text { приймається } \\
\text { в розрахунок (5) }\end{array}$ & Допустимий (10) & $\begin{array}{c}\text { Небажаний } \\
\text { (25) }\end{array}$ & $\begin{array}{c}\text { Небажаний } \\
\text { (45) }\end{array}$ \\
\hline $\begin{array}{c}\text { Вкрай рідкісне } \\
\text { (2) }\end{array}$ & $\begin{array}{c}\text { Такий, що не } \\
\text { приймається } \\
\text { в розрахунок (2) }\end{array}$ & $\begin{array}{c}\text { Такий, що не } \\
\text { приймається } \\
\text { в розрахунок (4) }\end{array}$ & $\begin{array}{c}\text { Допустимий } \\
\text { (10) }\end{array}$ & $\begin{array}{c}\text { Допустимий } \\
\text { (18) }\end{array}$ \\
\hline $\begin{array}{c}\text { Малоймовірне } \\
\text { (1) }\end{array}$ & $\begin{array}{l}\text { Такий, що не } \\
\text { приймається } \\
\text { в розрахунок (1) }\end{array}$ & $\begin{array}{l}\text { Такий, що не } \\
\text { приймається } \\
\text { в розрахунок (2) }\end{array}$ & $\begin{array}{c}\text { Такий, що не } \\
\text { приймається } \\
\text { в розрахунок (5) }\end{array}$ & $\begin{array}{c}\text { Такий, що не } \\
\text { приймається } \\
\text { в розрахунок (9) }\end{array}$ \\
\hline & $\begin{array}{l}\text { Незначний } \\
\text { (1) }\end{array}$ & $\begin{array}{l}\text { Несуттєвий } \\
\text { (2) }\end{array}$ & $\begin{array}{l}\text { Критичний } \\
\text { (5) }\end{array}$ & Катастрофічний (9) \\
\hline & & Рівн & еті наслідки & \\
\hline
\end{tabular}

Джерело: [27, 28]

Таблиця 8

Рішення, що приймаються відносно ризику

\begin{tabular}{|c|l|}
\hline Рівень ризику & \multicolumn{1}{|c|}{ Рішення } \\
\hline $\begin{array}{c}\text { Неприпустимий } \\
(\mathrm{R} \geq 64)\end{array}$ & Ризик повинен виключитися. Обробка ризику необхідна. \\
\hline \multirow{2}{*}{$\begin{array}{c}\text { Небажаний } \\
(20 \leq \mathrm{R}<64)\end{array}$} & $\begin{array}{l}\text { Ризик повинен бути знижений, обробка ризику необхідна. } \\
\text { зниження ризику неможливо або недоцільно, обробка ризику зводиться до } \\
\text { усунення наслідків. }\end{array}$ \\
\hline $\begin{array}{c}\text { Допустимий } \\
(10 \leq \mathrm{R}<20)\end{array}$ & $\begin{array}{l}\text { Ризик приймається при відповідному моніторингу і контролю і за згодою } \\
\text { керівнцтва організації, обробка ризику не потрібна або зводиться до } \\
\text { усунення наслідків. }\end{array}$ \\
\hline $\begin{array}{c}\text { Такий, що не } \\
\text { приймаєтья } \\
\text { в розрахунок } \\
(\mathrm{R}<10)\end{array}$ & $\begin{array}{l}\text { Ризик приймається без згоди керівництва організації, обробка ризику не } \\
\text { потрібні. }\end{array}$ \\
\hline
\end{tabular}

Джерело: [29] 
Експертна група заносить до реєстру неприпустимих ризиків структурного підрозділу неприпустимі і небажані ризики, а також запропоновані заходи по їх обробці, оцінюючи для кожного ризику його плановане (залишкове) значення і витрати, необхідні для реалізації коригувальних заходів. Керівник структурного підрозділу повинен передати копію реєстру неприпустимих ризиків структурного підрозділу на регіональний рівень для формування бази даних загального реєстру неприпустимих ризиків і розробки програми коригувальних заходів.

Слід зазначити, що після проведення оцінки професійних ризиків за даною методикою, на регіональному рівні 3'являється можливість вирішити задачу оптимізації плану коригувальних заходів в умовах обмежених ресурсів, тобто максимально знизити ризики 3 наперед заданим рівнем фінансування заходів 3 охорони праці.

\section{3. ВИСНОВКИ}

Вплив людського фактору на відмови технічних засобів в транспортних системах слід розглядати у контексті недоліків інформаційного забезпечення, помилок, викликаних зовнішніми і внутрішніми подіями, обмеженістю ресурсів підтримки і прийняття рішень, психофізіологічним станом людини.

Значний досвід врахування впливу людського фактору в авіації дозволяє розробити концепцію управління ресурсами оперативно-управлінського персоналу інших видів транспорту, що сприяє забезпеченню їх заданої надійності. Сучасне технічний стан залізничного транспорту викликає необхідність дослідження людського фактору, створення концепції управління людським фактором, що забезпечує підвищення організаційно-технологічної надійності виробництва. Удосконалення техніки і технологій, впровадження на залізничному транспорті нових інструментів управління охороною праці та системи менеджменту безпеки руху дозволить знизити кількість небажаних інцидентів, але роль людського фактору в них залишається високою.

Основним резервом підвищення безпеки виробничої діяльності є формування єдиного, системного підходу з обліку і управління людським фактором на всіх етапах взаємодії працівника і роботодавця. Це дозволить значно знизити ризики настання небажаних подій в області безпеки праці та безпеки руху, забезпечивши позитивний соціально-економічний ефект.

Розглянутий формалізований підхід до подання складових системи «людинатехнічна система-виробниче середовище» дозволяє розширити можливості оцінки та аналізу впливу людського фактору на основі методів математичного моделювання. Перспективними методами моделювання в даному випадку представляються методи нечіткого когнітивного моделювання та кваліметричного аналізу 
елементів людино-машинної системи, що дозволяють враховувати антропометричні, фізіологічні, психосоціальні та професійні характеристики працівників.

Використання методів оцінки та аналізу професійних ризиків дозволяє виявити найбільш значущі ризики порушення безпечних умов праці і сформувати адресні коригувальні заходи на основі методів експертних оцінок, що забезпечить зниження ролі людського фактору у виробничих процесах.

\section{ЛITEPATУРA}

1. Артемов, А.Д. Человеческий фактор в эксплуатации авиационной техники: монография / А.Д. Артемов, Н.Д. Лысаков, Е.Н. Лысакова. - М., 2018. - 156 с.

2. Тиц, С. Н. Человеческий фактор [Электронный ресурс] : электрон. учеб. пособие / С. Н. Тиц; Минобрнауки России, Самар. гос. аэрокосм, ун-т им. С. П. Королева (нац. исслед. ун-т). - Самара, 2015. - 64 с.

3. Человеческие факторы в системе управления безопасностью движения: СТО РЖД 02.039-2011 [Введен в действие 2011-09-21] - М. : Трансинфо, 2011. - 19 с.

4. Аналіз стану безпеки руху, польотів, судноплавства та аварійності на транспорті в Україні за 2014 рік [Електронний ресурс]: звіт департаменту безпеки на транспорті Міністерства інфраструктури України, 2015. - Режим доступу: https://mtu.gov.ua/ files/аналіз за 2014 рік.pdf.

5. Либерман, А.Н. Техногенная безопасность: человеческий фактор / А.Н. Либерман; СПб.: 2006. - $101 \mathrm{c}$.

6. Грошев, Г.М. Эргономика на железнодорожном транспорте: учебное пособие / Г.М. Грошев, М.В. Иванов, И.Ю. Романова и др.; под ред. Г.М. Грошева, М.В. Иванова. М.: ГОУ «Учебно-методический центр по образованию на железнодорожном транспорте», 2009. - 390 с.

7. Махутов, Н.А. Влияние человеческого фактора на безопасность технических систем / Н.А. Махутов, Р.С. Ахметханов, Е.Ф. Дубинин, и др. // Научный информационный сборник «Проблемы безопасности и чрезвычайных ситуаций». - 2014. - № 3. С. $80-98$.

8. Основные принципы учета человеческого фактора в руководстве по техническому обслуживанию воздушных судов. Монреаль: Международная организация гражданской авиации (ИКАО), 2003. - 229 с.

9. Standard IEC 62278:2002 (EN 50126-1:1999) «Railway aplications - The specification and demonstration of reliability, availability, maintainability and safety (RAMS)». 2002. $78 \mathrm{p}$.

10. Standard IEC 62279:2002 (EN 50128:2001) «Railway aplications - Communication, signalling and processing systems Software for railway control and protection systems». 2002. - $106 \mathrm{p}$.

11. Standard IEC 62425:2007 (EN 50129:2003) «Railway aplications - Communication, signalling and processing systems - Safety related electronic systems for signalling». 2007. — $96 \mathrm{p}$.

12. Hammerl, M. (2009) Human factors in the railway system safety analysis process [Electronic resource] / M. Hammerl, F. Vanderhaegen // 3rd International rail human factors conference (France). 2009. - Mode of access:. https://core.ac.uk/download/pdf/ 11137175.pdf.

13. Завьялов, А.М. Пути повышения качества эксплуатации объектов инфраструктуры железнодорожного транспорта / А.М. Завьялов, П.А. Неваров // Наука и техника транспорта. - 2015. - № 2. - С. 98-105. 
14. Кукин, П.П. Безопасность технологических процессов и производств / П.П. Кукин, В.Л. Лапин, Н.Л. Пономарев. - М. : Высш. шк., 2007. - 335 с.

15. Завьялов, А.М. Применение теории нечетных множеств в решении задач управления рисками / А.М. Завьялов // Инновационные факторы развития Транссиба на современном этапе : материалы междунар. науч.-практ. конф. посвящ. 80-летию СГУПС. Новосибирск, 2013. - Ч. 2. - С. 454-461.

16. Нерсесян, Л.С. Железнодорожная психология / Л.С. Нерсесян; - 2-е изд. - М. : ООО «РЕИНФОР», 2005. - $534 \mathrm{c}$.

17. Минский, М. Фреймы для представления знаний / М. Минский; под ред. Ф.М. Кулакова. М. : Энергия, 1979. - 151 с.

18. Котик, М.А. Природа ошибок человека-оператора: на примере управления транспортными средствами / М.А. Котик, А.М. Емельянов. - М. : Транспорт, 1993. - 252 с.

19. Плотинский, Ю.М. Модели социальных процессов: учебное пособие для высших учебных заведений / Ю.М. Плотинский; — 2-е изд., перераб. и доп. — М. : Логос, 2001. $296 \mathrm{c}$.

20. Силов, В.Б. Принятие стратегических решений в нечеткой обстановке / В.Б. Силов. - М. : ИНПРО-РЕС, 1995. - $228 \mathrm{c.}$

21. Евстафьев, Г.А. Нечёткие когнитивные карты применительно к управлению рисками информационной безопасности / Г.А. Евстафьев // Известия Южного федерального университета. Технические науки. - 2009. - Т. 100. — № 11. - С. 45-52.

22. Азгальдов, Г.Г. Квалиметрия: первоначальные сведения. Справочное пособие с примером для АНО «Агентство стратегических инициатив по продвижению новых проектов» : учеб. пособие / Г.Г. Азгальдов, А.В. Костин, В.В. Садовов. - М. : Высш. шк., 2010. - $143 \mathrm{c}$.

23. Аксенов, В.А. Пути снижения влияния человеческого фактора на безопасность производственных процессов / В.А. Аксенов, А.М. Завьялов, Ю.В. Завьялова и др. // Техносферная и экологическая безопасность на транспорте (Санкт-Петербург, 26-28 октября 2016 г.) : материалы V юбилейной междунар. науч.-практ. конф. - СПб., 2016. C. 6-9.

24. Бодров, В.А. Психология профессиональной пригодности: учебное пособие для вузов / В.А. Бодров. - М. : ПЕР СЭ, 2001. - 511 c.

25. Бондарев, И.П. Отбор персонала: практика. / Бондарев, И.П., Вылегжанин О.И., Зубова Л.В. - Екатеринбург : ИД «УралЮрИздат», 2014. - 348 с.

26. Профессиональный риск. Теория и практика расчета: Монография / Под ред. А.Г. Хрупачева, А.А. Хадарцева. - Тула: ТулГУ, 2011. - 330 с.

27. Аксенов, В.А. Повышение эффективности профилактики производственного травматизма работников путевого комплекса на основе учета человеческого фактора / В.А. Аксенов, А.М. Завьялов, Л.А. Асташкина // Наука и техника транспорта. — 2015. - № 4. C. $11-15$.

28. Безопасность функциональная. Управление рисками на железнодорожном транспорте: межгосударственный стандарт ГОСТ 33433-2015. - М. : Стандартинформ, 2016. - 35 с.

29. Завьялов, А.М. Пути снижения влияния человеческого фактора на безопасность перевозочного процесса в локомотивном хозяйстве железнодорожного транспорта / А.М. Завьялов, Л.А. Асташкина, Ю.В. Завьялова // Современные подходы к обеспечению гигиенической, санитарно-эпидемиологической и экологической безопасности на железнодорожном транспорте : сб. тр. ученых и специалистов транспортной отрасли, II выпуск. — М: ВНИИЖГ — 2016. — С. 137-144. 


\section{РОЗДІЛ 2 \\ ДОСЛІДЖЕННЯ СОЦІО-ТЕХНІЧНИХ СИСТЕМ}

О.Г. Юрченко
Ю.В. Булгакова

\section{1. ВСТУП}

Протягом останніх років в дослідженні соціо-технічних систем, як науці, відбулись значні зміни. Глобалізація та стрімкий розвиток сучасних знань й технологій призвела до загальної відкритості багатьох процесів, що стало головною причиною розуміння важливості кожного індивідуума окремо.

В сучасному світі соціо-технічні системи є невід'ємною частиною людського життя. Людський процес існування в наш час повністю пов'язаний зі складними соціо-технічними системами, що зумовлює надзвичайну актуальність детального аналізу та дослідження соціо-технічних систем.

Важливе значення відіграє наукове обгрунтування функціонування соціотехнічних систем в сучасних умовах, коли відбувається радикальна зміна соціально-економічних відносин. Нові вимоги до побудови і поведінки соціо-технічних систем диктують ринкові відносини, підприємницька активність, розвиток різних форм власності, зміна функції та методів державного регулювання й управління. Організаційна діяльність зазнає колосального впливу від революційних змін в технологічних та технічних напрямках.

Соціальні та технічні системи зазвичай аналізуються різними способами. Методи опису та аналізу до цих систем застосовують зазвичай теж різні. При цьому сучасні транспортні підприємства одночасно можна віднести як до технічних, так і до соціальних систем, які утворюють цілісну інтегровану платформу. Такі системи можуть досліджуватись 3 різних позицій: технічних, організаційносоціальних, юридично-правових, фінансово-економічних та інших. Перехід до ефективних форм організації і управління, побудова на наукових принципах, стає головною умовою успіху майбутніх реформ.

\section{2. ОСНОВНИЙ МАТЕРІАЛ}

\section{1. Визначення поняття «система» у різних сферах науки}

Існує значна кількість різних визначень поняття «система», що використовуються залежно від контексту, галузі знань та мети дослідження.

\footnotetext{
${ }^{3}$ Канд. техн. наук, доцент кафедри «Управління комерційною діяльністю залізниць», Державного університету інфраструктури та технологій, Київ

${ }^{4}$ Канд. техн. наук, доцент, начальник відділу міжнародних зв'язків

Національного авіаційного університету, Київ
} 
Практично всі міркування на тему систем та їх організації мають філософський характер. Це зумовлено тим, що в поняття «система» в основному вкладається узагальнюючий характер будь-якої складної, часом незрозумілої, сукупності елементів та процесів, що їх пов'язують [1].

Основною відмінною рисою є те, що в понятті «система» присутня подвійність: $з$ одного боку, це поняття використовується для позначення об'єктивно існуючих феноменів, а 3 іншого боку — як метод вивчення і представлення феноменів, тобто як суб'єктивна модель реальності. У зв'язку з цією подвійністю автори визначень виділяють щонайменше два аспекти: як відрізнити системний об'єкт від несистемного, і — як побудувати систему шляхом виділення ії 3 навколишнього середовища [2].

Спробуємо виокремити та конкретизувати деякі загальні підходи та дослідження та у визначенні поняття «система».

Загальновідомо, що система - це набір взаємодіючих частин, що функціонують як ціле, які відрізняються від навколишнього середовища розпізнаваними межами. Існує велика різноманітність систем від тих, в яких усі взаємодії частин фіксовані, (прикладом є технічна система - двигун та ін.), до тих, в яких взаємодії частин нічим не обмежені (наприклад, газ) [1]. 3 точки зору даного дослідження, доволі цікавими є системи, що допускають як фіксовані, так і мінливі взаємодії компонентів. Такими системами є складні соціо-технічні системи, що поєднують соціальні та технічні системи [3]. 3 усього різноманіття визначень «системи» найбільш поширеним $є$ : система - це цілісна сукупність деяких елементів, що не зводиться до простої суми своїх частин, тобто яка являє собою щось більше, ніж просто суму частин [5]. Це щось, відсутнє в частинах системи, взятих самих по собі, та абсолютно необхідне, щоб елементи утворили систему, представляє со6ою інтегруючий початок.

Але роблячи акцент не стільки на фізичну організацію системи, скільки на систему організаційно-управлінських процесів, відзначимо, що система - це функціонально певна структурно впорядкована 3 адаптивною реорганізацією безліч елементів. Зовнішні та внутрішні функції якої, характеризуються відповідними обмінними потоками, а адаптивна організація і дезорганізація $є$ визначальною для іiі існування [3].

Загалом під системою можна розуміти цілісність взаємопов'язаних елементів та взаємозв'язків між ними, яким притаманні певні властивості, мета, цілі та функції [4].

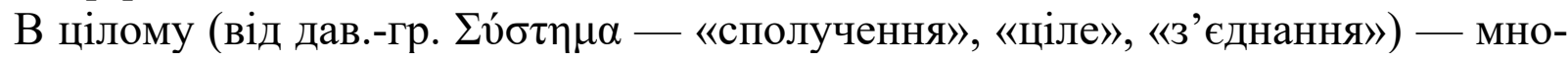
жина взаємопов'язаних елементів, що утворюють єдине ціле, взаємодіють із середовищем та між собою, і мають мету.

Різноманітність систем досить велика, й істотну допомогу при їх вивченні надає класифікація. Проте, класифікація - це тільки модель реальності, тому необхідно підкреслити відносність будь-яких класифікацій. Власне сама класифікація виступає в якості інструменту системного аналізу [2]. Класифікація допомагає 
структурувати об’єкт (проблему), а розроблена класифікація є моделлю цього об’єкту. Повної та детальної класифікації систем на даний час не існує, більше того, остаточно не розроблені ïi принципи. Різні автори пропонують різні принципи класифікації, а подібним по суті — дають різні назви (рис. 1).

\section{Залежно від походження}

За об'сктивністю існування

\section{Діючі системи}

\section{За ступенем централізованості}

\section{За розмірністю елементів}

За однорідністю та різноманітністю структурних елементів

\section{За траскторісю розвитку}

\section{Від здатності системи ставити собі мету}

\section{За складністю}

За ступенем детермінованості

За рівнем організованості

За ступенем відкритості

\section{Рис. 1. Узагальнена класифікація систем}

Авторська розробка

Залежно від походження системи поділяються на природні та штучні (створювані, антропогенні).

Природні системи - це системи, об'єктивно існуючі в дійсності, в живій і неживій природі і суспільстві. ці системи виникли в природі без участі людини.

Штучні системи - це системи, створені людиною. Крім того, можна говорити про третій клас систем - змішані системи, куди відносяться ергономічні (машина - людина-оператор), автоматизовані, біотехнічні, організаційні, роботизовані та інші системи.

За об’єктивністю існування. Всі системи можна розділити на дві великі групи: реальні (матеріальні або фізичні) і абстрактні (символічні) системи.

Реальні системи складаються з виробів, обладнання, машин і взагалі 3 природних і штучних об’єктів. Абстрактні системи по суті є моделями реальних 
об'єктів - це мова, системи числення, ідеї, плани, гіпотези і поняття, алгоритми і комп'ютерні програми, математичні моделі, системи наук.

Іноді виділяють ідеальні або конщептуальні системи - системи, які висловлюють принципову ідею або зразкову дійсність - зразковий варіант наявної або системи, що проектується (розробляється). Також можна виділити віртуальні системи - не існують в дійсності модельні або розумові уявлення реальних об'єктів, явищ, процесів (можуть бути як ідеальними, так і реальними системами).

Діючі системи. Такі системи здатні забезпечувати виконання технологічних процесів, діючи за програмами, які задаються людиною. У діючих системах можна виокремити такі системи: технічні, ергатичних, технологічні, економічні, соціальні, організаційні та системи управління.

Технічні системи - матеріальні системи, які вирішують завдання за програмами, розробленими людиною; сама людина при цьому не є елементом таких систем. Якщо в системі присутня людина, яка виконує певні функції суб'єкта, тоді мова йде про ергатичні системі.

Технологічна формальна система - це сукупність операцій (процесів) для досягнення деяких цілей (вирішення певний завдань). Структура такої системи визначається набором методів, методик, регламентів, правил та нормативів.

Технологічна матеріальна система - це сукупність реальних пристроїв, інструментів і матеріалів (технічне забезпечення системи), що виконують операції (процесне забезпечення системи) та зумовлюють їх якість і тривалість.

Економічна система - це система процесів, що виникли в економіці. Сукупність економічних відносин, що виникають в процесі виробництва, розподілу, обміну та споживання економічних продуктів і регламентуються сукупністю відповідних принципів, правил і законодавчих норм.

Соціальна система - це сукупність заходів, спрямованість них на соціальний розвиток життя людей. До таких заходів відносяться: покращення соціальноекономічних і виробничих умов праці, покращення життя працівників та житлових умов та ін.

Організаційна система - це сукупність елементів, що забезпечують координацію дій, функціонування та розвиток основних функціональних елементів об'єкта. Елементами такої системи є органи управління, які мають право приймати управлінські рішення — це керівники підрозділу або навіть окремі організації.

Систему, в якій реалізується функція управління, називають системою управління. Система управління має два головних елемента: керовану підсистему (об’єкт управління) і керуючу підсистему (здійснює функцію управління). Стосовно до технічних систем керуючу підсистему називають системою регулювання, а до соціально-економічним - системою організаційного управління.

За ступенем централізованості. Централізованою системою називається система, в якій певний елемент відіграє головну, домінуючу роль у функціонуванні системи. Такий головний елемент є провідною частиною системи або іiї 
центром. При цьому невеликі зміни провідної частини викликають значні зміни всієї системи: як бажані, такі небажані. До недоліків централізованої системи можна віднести низьку швидкість адаптації (пристосування до змін умов навколишнього середовища), а також складність управління через значний потік інформації, що підлягає переробці в центральній частині системи.

Децентралізована система - система, в якій відсутній головний елемент. Найважливіші підсистеми в такій системі мають приблизно однакову цінність і побудовані не навколо центральної підсистеми, а з'єднані між собою послідовно або паралельно.

За розмірністю елементів. Система, яка має один вхід та один вихід називається одномірною. Якщо входів або виходів більше одного - багатомірною. Необхідно розуміти умовність одномірної системи — в реальності убудь-який об'єкт має нескінченну кількість вході та виходів.

За однорідністю та різноманітністю структурних елементів. Системи бувають гомогенні, або однорідні, і гетерогенні, або різнорідні, а також змішаного типу. В гомогенних системах структурні елементи системи однорідні, тобто мають однакові властивості. У зв'язку з цим в гомогенних системах елементи взаємозамінні. Гетерогенні системи складаються з різнорідних елементів, які не мають властивістю взаємозамінності.

За траєкторією розвитку. Система називається лінійною, якщо вона описується лінійними рівняннями (алгебраїчними, диференціальними, інтегральними та ін.), в іншому випадку - нелінійною. Для лінійних систем притаманний принцип суперпозиції: реакція системи на будь-яку комбінацію зовнішніх впливів дорівнює сумі реакцій на кожен з цих впливів, що діють на систему окремо.

Дискретна система - це система, що має хоча б один елемент дискретного діiі. В свою чергу дискретний елемент - це елемент, вихідна величина якого, змінюється дискретно, тобто стрибками, навіть при плавній зміні вхідних величин.

Всі інші системи відносяться до систем безперервної діï. Система безперервної дії (безперервна система) складається тільки з елементів безперервної дії, тобто елементів, виходи яких змінюються плавно при плавній зміні вхідних величин.

Від здатності системи ставити собі мету розрізняють каузальні і иүілеспрямовані (цілеспрямовані, активні) системи.

Каузальні системи - це системи, для яких внутрішньо мета не притаманна

Якщо така система і має цільову функцію (наприклад, автопілот), то ця функція задана ззовні користувачем.

Цілеспрямовані системи - це системи, здатні до вибору своєї поведінки залежно від внутрішньо сформульованої мети. У цілеспрямованих системах мета формується всередині системи.

Елемент цілеспрямованості завжди присутній в системі, що включає в себе людей. Питання найчастіше полягає в ступені впливу цієї цілеспрямованості на функціонування об’єкту. Якщо розглядати ручне виробництво, то вплив так званого 
людського фактору дуже великий. Окрема людина, група людей або весь колектив здатні поставити мету своєї діяльності, яка відрізняється від мети компанії.

За складністю. Існує декілька підходів при класифікації систем за складністю, й, на жаль, немає ні єдиного визначення цього поняття, ні чіткої межі, яка відділяє прості системи від складних. Різними авторами пропонувалися різні класифікації складних систем. Наприклад, ознакою простої системи вважається порівняно невеликий обсяг інформації, необхідний для ії успішного управління. Системи, в яких не вистачає інформації для ефективного управління, вважають складними.

Умовно можна виділити два види складності: структурну і функціональну. Структурна складність. Наприклад, можна розділити системи на прості, складні і дуже складні. Прості - це найменш складні системи. Складні — це системи, що відрізняються розгалуженою структурою і великою різноманітністю, внутрішніх зв'язків. Дуже складна система - це складна система, яку не можливо описати детально. Безумовно такий розподіл досить умовний і між такими різновидами важко провести межу.

Функиіональна складність. Для кількісної оцінки функціональної складності можна використовувати алгоритмічний підхід, наприклад кількість арифметикологічних операцій, необхідних для перетворення вхідних значень у вихідні, або обсяг ресурсів (час, що розраховується, або пам'ять, що використовується), які використовуються в системі при вирішенні деяких задач.

Крім того, виділяють такий тип складності, як динамічна складність. Вона виникає тоді, коли змінюються зв'язки між елементами.

За ступенем детермінованості. Якщо входи об'єкту однозначно визначають його виходи, тобто його поведінку можна однозначно передбачити (з ймовірністю 1), тоді об'єкт є детермінованим, в іншому випадку - недетермінованим (стохастичним). Детермінованість характерна для менш складних систем; стохастичні системи складніше ніж детерміновані, оскільки їх складніше описувати та досліджувати.

За рівнем організованості. Якщо під час дослідження вдається визначити елементи системи, їхній взаємозв'язок між собою й з цілями системи та вид детермінованих (аналітичних або графічних) залежностей, тоді можна представляти об’єкт у вигляді добре організованої системи.

Якщо на меті не має визначити всі компоненти та їх зв’язок з цілями системи, тоді об'єкт представляється у вигляді погано організованої (або дифузійної) системи.

Клас самоорганізованих (тих, що розвиваються), систем характеризується низкою ознак та особливостей, які, як правило, обумовлені наявністю в системі активних елементів, які роблять систему цілеспрямованою.

За ступенем відкритості. Відкриті системи постійно обмінюються інформацією, енергією або іншими елементами 3 середовищем. Система закрита (замкнута), якщо до неї не надходять і з неї не виходить інформація або енергія. 
Отже, в загальних рисах можна сформулювати основні властивості системи (рис. 2).

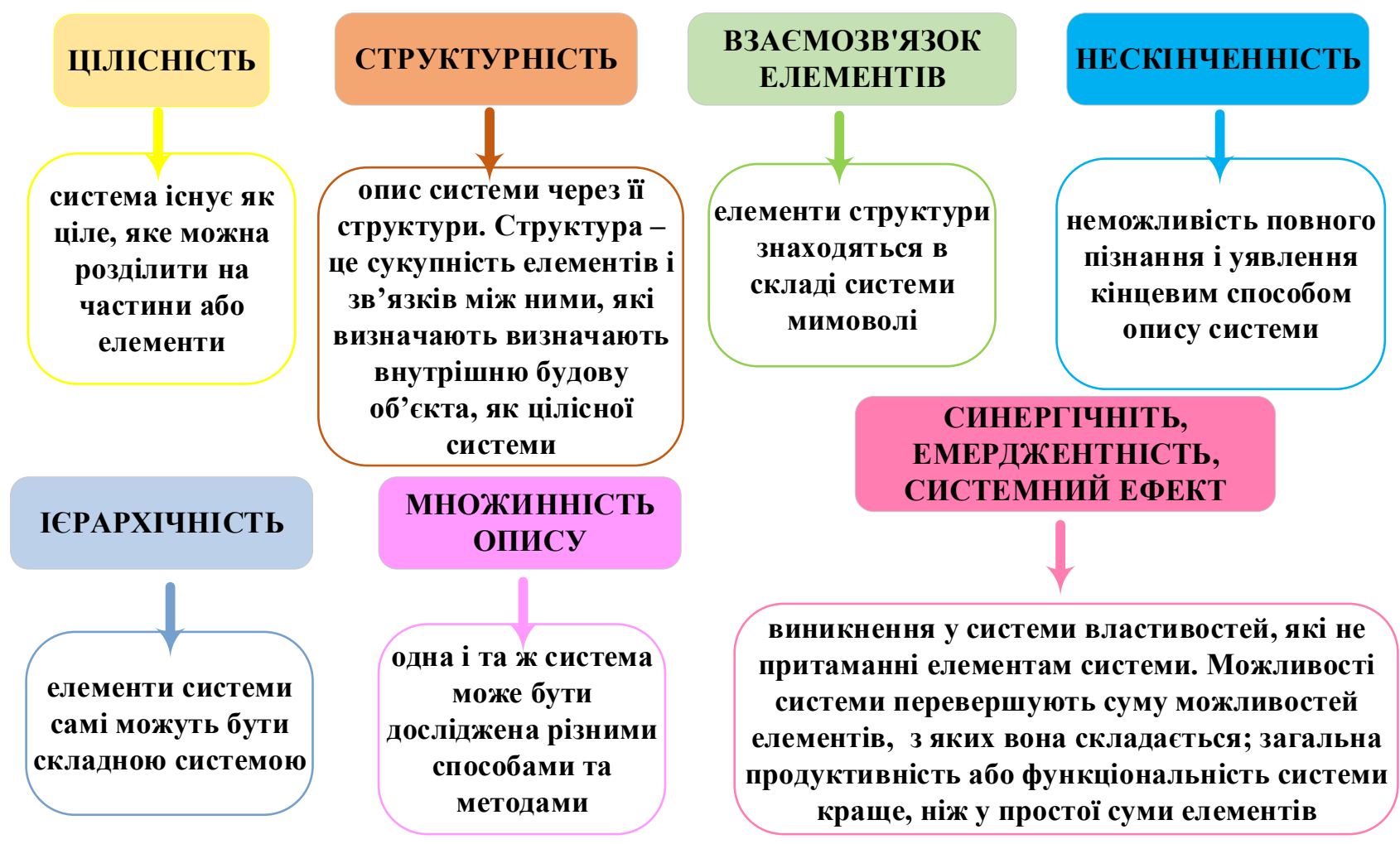

Рис. 2. Основні властивості системи

Авторська розробка

\section{2. Характеристика соціо-технічної системи}

Аналізуючи основні визначення поняття «система», можна зробити припущення щодо визначення поняття «соціо-технічна система».

Отже, соиіо-технична система - сукупність технологічного процесу виробництва та трудових відносин. Організація розглядається системно й в якості системи. Людина розглядається як компонент організації (соціальний компонент) нарівні з технікою. Соціальні та технічні компоненти разом забезпечують виконання робіт, тому організації є соціо-технічними системами. Концепція соціотехнічних систем на противагу теоріям технологічного детермінізму, який стверджував визначальний вплив технології на людину в процесі виконання ним трудових операцій, грунтується на ідеї взаємодії людини і машини. Проектування технічних і соціальних умов здійснюється таким чином, щоб технологічна ефективність та гуманітарні аспекти не суперечили один одному (рис. 3). 


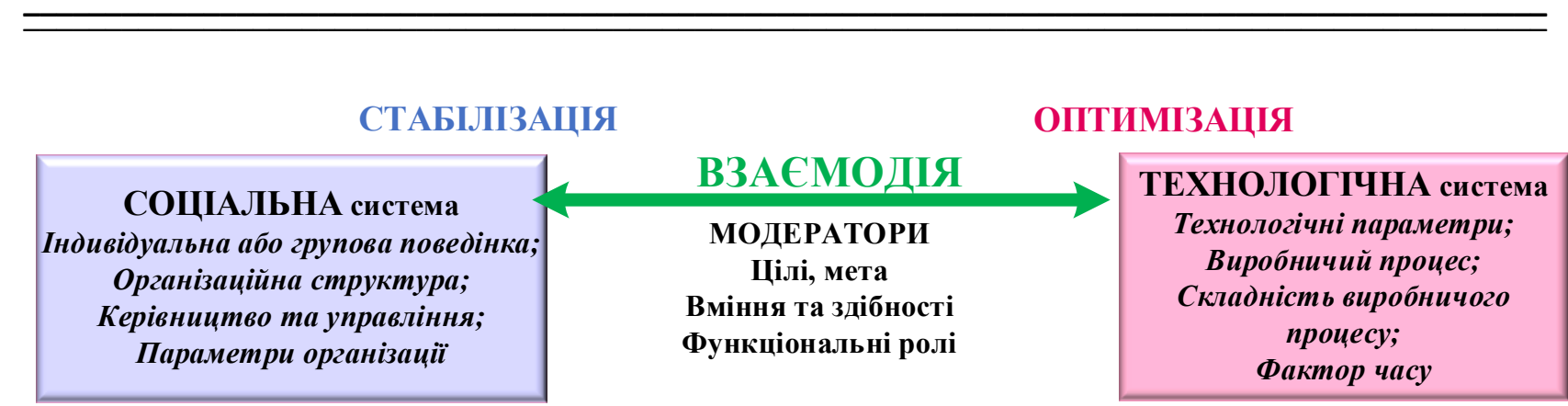

\section{Рис. 3. Організаційна соціо-технічна модель}

Авторська розробка

Застосування концепції соціо-технічних систем використовується в багатьох проблемних галузях при реалізації національних проєктів, проєктів цифрової економіки, систем охорони здоров'я, інформаційної безпеки, а також в цілому для проєктної діяльності. Проте практичне застосування стримується недостатністю формалізму в опрацюванні прикладних методик, моделей, прикладів і обмежується загально-філософськими міркуваннями. Зокрема, в теорії управління проектами для врахування соціальних аспектів діяльності потрібно вводити самостійну концепцію проєктного офісу.

Сучасна концепція соціо-технічних систем в протилежність теорії технологічного детермінізму, яка стверджує односторонню дію технології на людину, грунтується на ідеї взаємодії людини і техніки, тобто на взаємозалежних впливах. Соціо-технічна система складається $з$ таких підсистем як: технічна підсистема включає пристрої, інструменти і технології, що перетворюють вхідні дані у вихідні певним способом, який покращує ефективність функціонування системи; та соціальна підсистема включає людей, їх знання, уміння, настрій, ціннісні установки, відношення до виконуваних функцій, управлінську структуру, систему заохочень. Основними показниками соціо-технічної системи є: ефективність, керованість, стійкість, надійність. Беручи до уваги те, що процес життєдіяльності соціо-технічної системи відбувається у певному середовищі - навколишньому, виробничому, технологічному тощо, необхідно враховувати важливі чинники - такі як взаємодія з іншими системами - організаціями, що можуть виступати як конкуренти [6].

Таким чином, систему, як правило, розкриває структура, яка характеризує взаємодію між іï елементами та виходить 3 властивостей останніх або оточення, а також функціонал, який регламентує відношення між певним елементом системи і системою в цілому та визначає можливість керувати нею. Якщо в системах існують не самі лише односторонні причинно-наслідкові залежності, тоді використовуються комплексні, або, складні системи [4].

Ці властивості визначаються як зворотними зв'язками системи, так і особливостями окремих іiї елементів. У множині складних систем використовують соціальні, технічні, ергатичні, технологічні, економічні, організаційні та управлінські системи. Наприклад, розвиток соціальних систем можна представити схемою (рис. 5). 


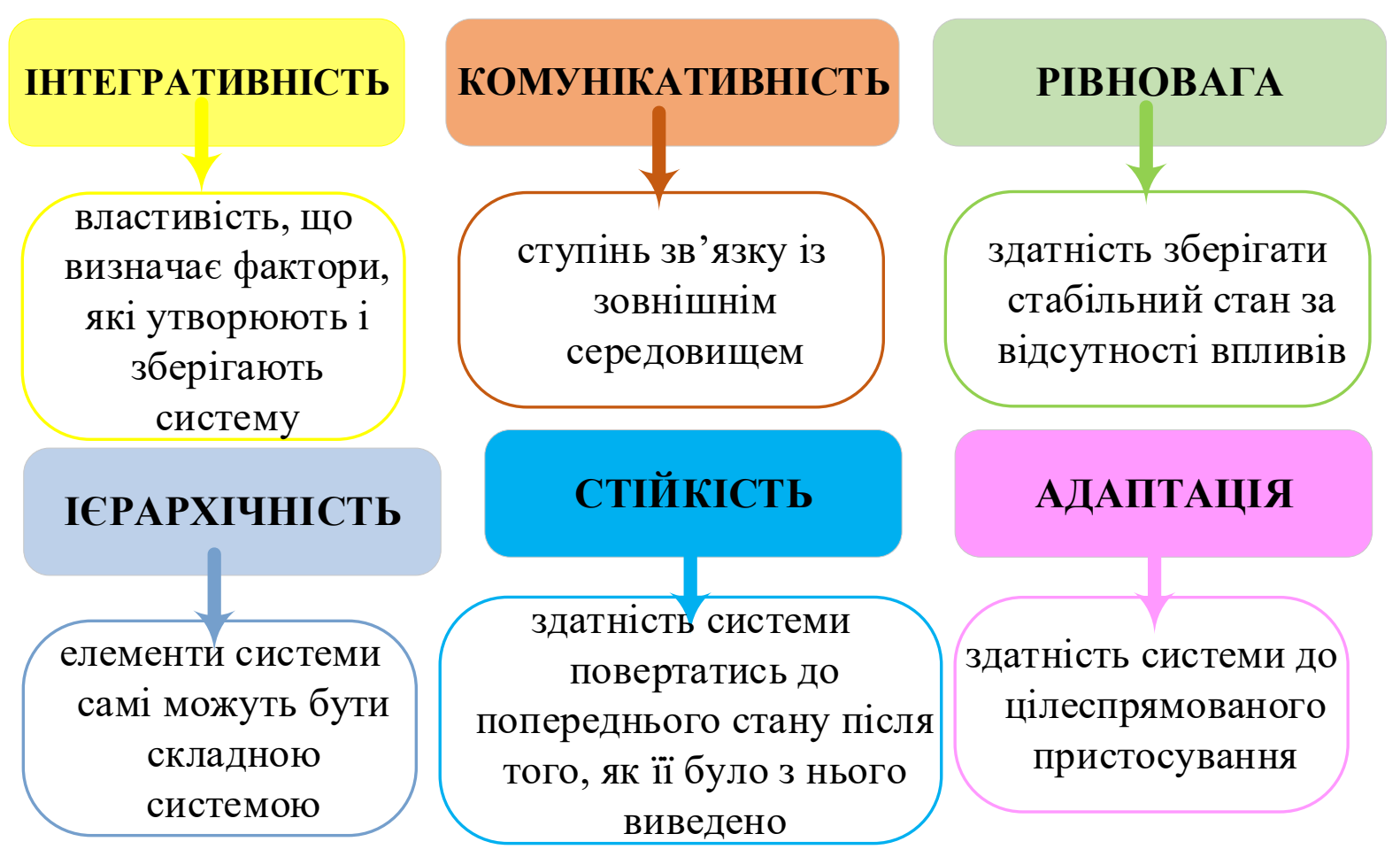

Рис. 4. Основні властивості складних систем Авторська розробка

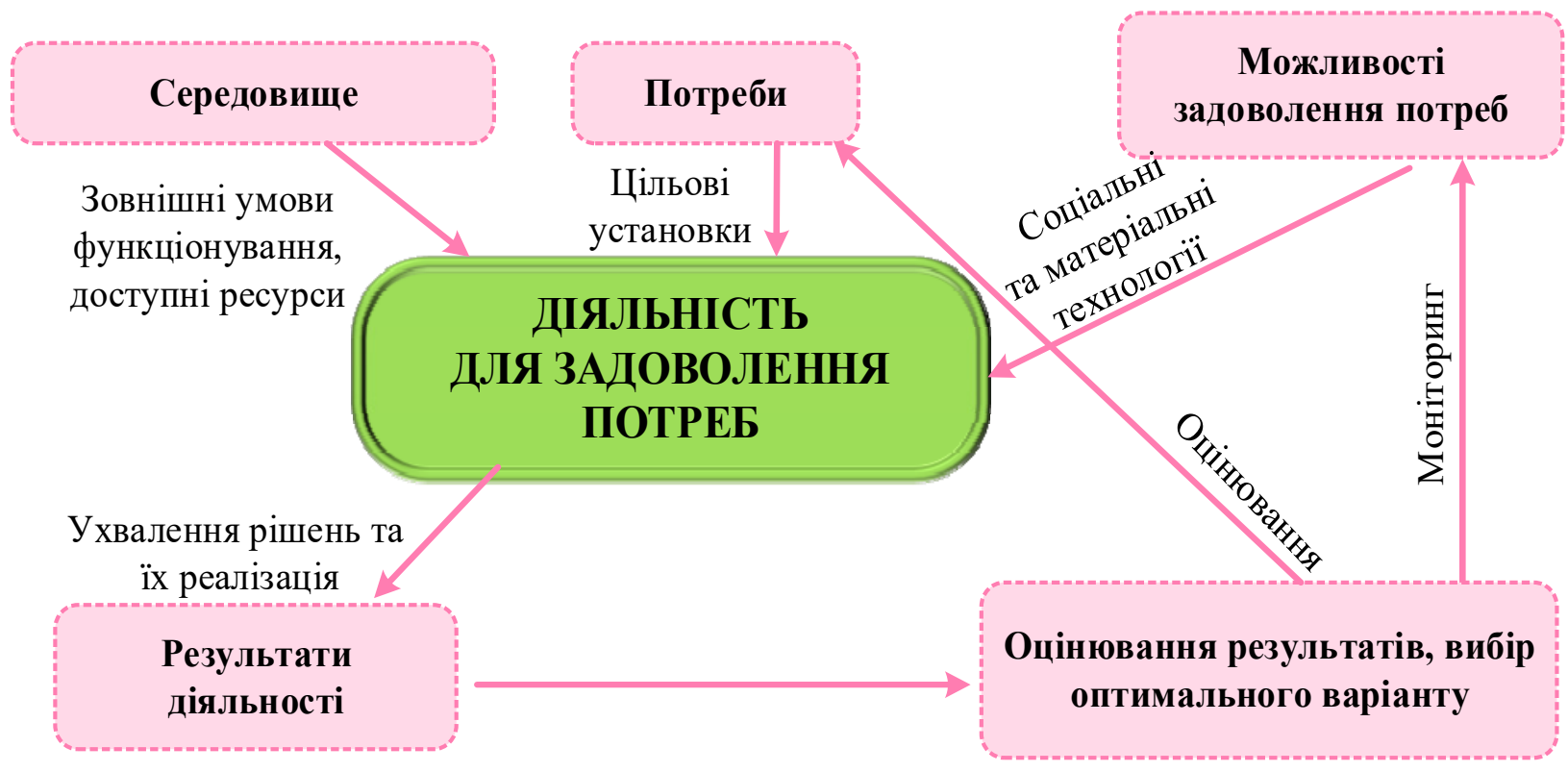

\section{Рис. 5. Розвиток соціальних систем Джерело: [1]}

Зазначені системи включають у себе ті елементи «людського фактору», які впливають на кожного окремого індивіда та на групи людей, зокрема в сенсі їхнього ставлення до роботи, на організаційну культуру, на керівництво та управління в цілому [4]. 
Складні технічні системи представляють собою матеріальні системи, які за певними алгоритмами, але без участі людини розв'язують заздалегідь визначені завдання. Залежно від технології роботи вони містять такі змінні характеристики: коли і де має виконуватися кожне завдання; в який спосіб воно має виконуватися; який взаємозв’язок між цими завданнями.

Складні ергатичні, або соціо-технічні системи - це системи, складовою яких є людина-оператор зі своїми знаннями, уміннями, що взаємодіють з технічним пристроєм у процесі. Наприклад: виробництва матеріальних цінностей, управління певними процесами, обробки інформації тощо. Вони сприяють підвищенню ефективності вирішення відповідних завдань або покращенню їхньої результативності (рис. 6):

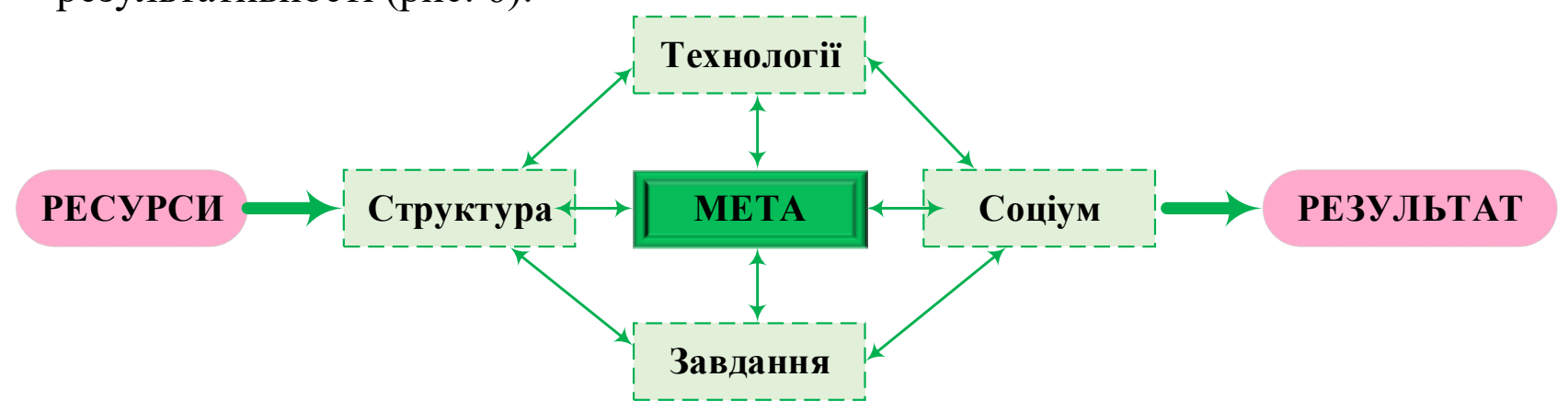

Рис. 6. Узагальнена структурно-логічна схема соціо-технічної системи Авторська розробка

Головними характеристиками соціо-технічної системи можна вважати такі:

- організаційна структура управління, що забезпечує пересічним працівникам реальні права щодо участі в керуванні;

- новий підхід до розробки робочих місць і визначення ролі виконавця в процесі ухвалення управлінських рішень;

- нова схема розміщення обладнання, яка має відповідати потребам перспективної форми організації праці, забезпечуючи прискорене проходження матеріальних потоків на виробництві;

- нові форми й методи підготовки та перепідготовки кадрів, що гуртуються на гнучкій кадровій політиці;

- нові критерії при оцінці економічної ефективності використання сучасних технологій.

Як один із найбільш відомих загальнометодологічних принципів створення складних соціо-технічних систем використовується системний підхід - напрямок методології наукового пізнання, в основу якого покладено розгляд кожного явища (процесу, об’єкта) як певної системи (рис. 7) [4].

В рамках дослідження системного підходу автори роботи [7] розглядали алгоритми прийняття ефективних управлінських рішень з використанням методу статистичної закономірності. За визначенням авторів сутність методу полягає 
у комплексному аналізі й постійній актуалізації закономірностей у статистиці безпеки експлуатації залізничного транспорту як системи.

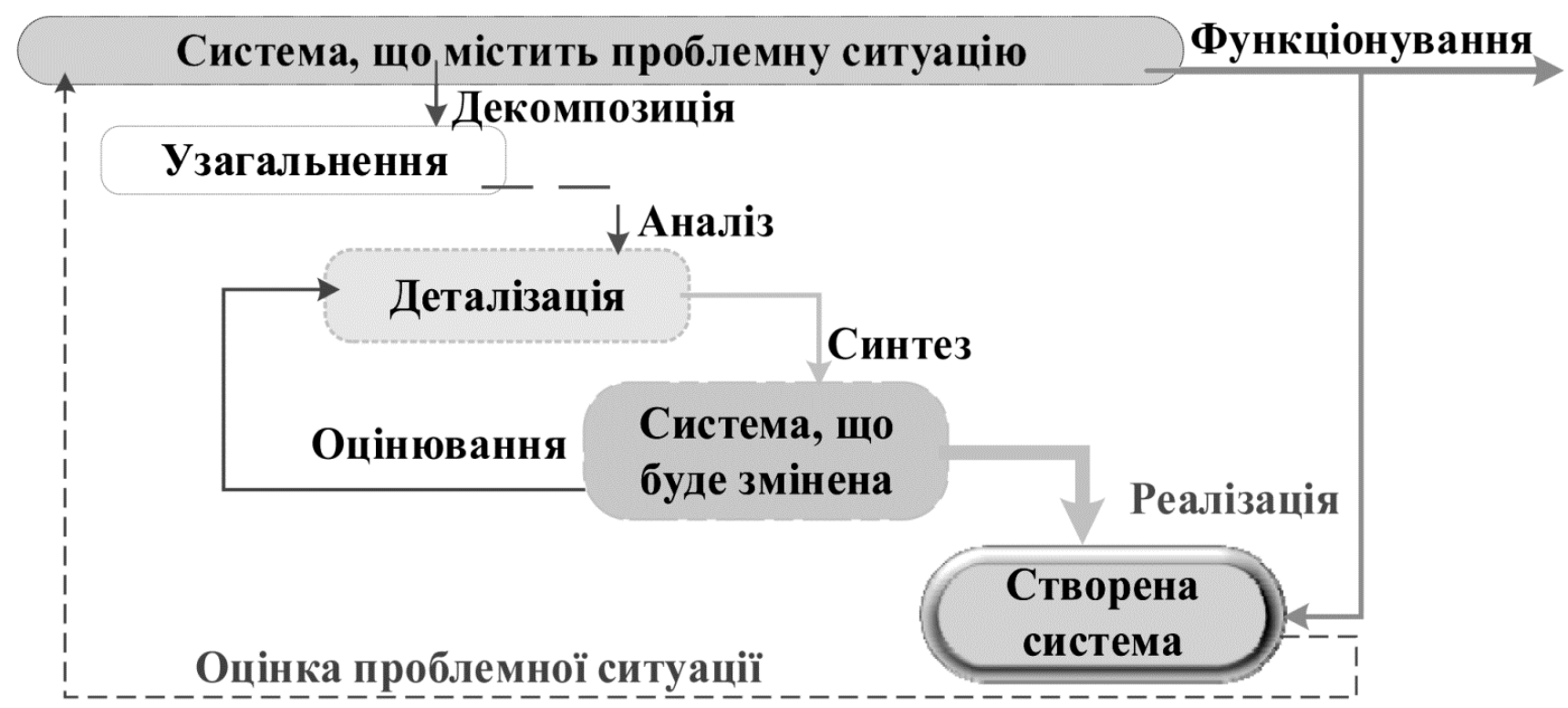

Рис. 7. Системний підхід вирішенні проблемної ситуації Джерело: [1]

На основі досліджень можна сформулювати основні етапи реалізації системного підходу: формування проблеми; формалізація мети або сукупності цілей; визначення альтернативних засобів, за допомогою яких можна досягти поставлених цілей; визначення ресурсів, необхідних при використанні кожної системи; побудова математичної моделі, тобто формалізованих залежностей між цілями та альтернативними засобами їх досягнення; визначення критеріїв вибору найкращої альтернативи.

При реалізації етапів системного підходу, можна визначити основні принципи:

- принцип системності, або єдності - розгляд і вивчення об'єктів дослідження як цілісних систем. Передбачає розгляд системи, з одного боку, як цілого, а 3 другого - сукупності компонентів (елементів, підсистем);

- принцип кінцевої мети - зведення до абсолютного пріоритету кінцевої або глобальної мети (основної функції, основного призначення тощо);

- принцип зв’язності - кожний компонент системи розглядається разом iз його зв’язками з оточенням; принцип модульності - здебільшого в системі є сенс реалізувати декомпозицію на складові різного ступеня загальності, розглядаючи іiі як сукупність певних модулів і зв'язків між ними;

- принцип ієрархічності пізнання - найчастіше в системі доцільно реалізувати ієрархічну побудову або впорядкувати ії складові за важливістю.

Принцип вимагає трирівневого вивчення об'єкта: 


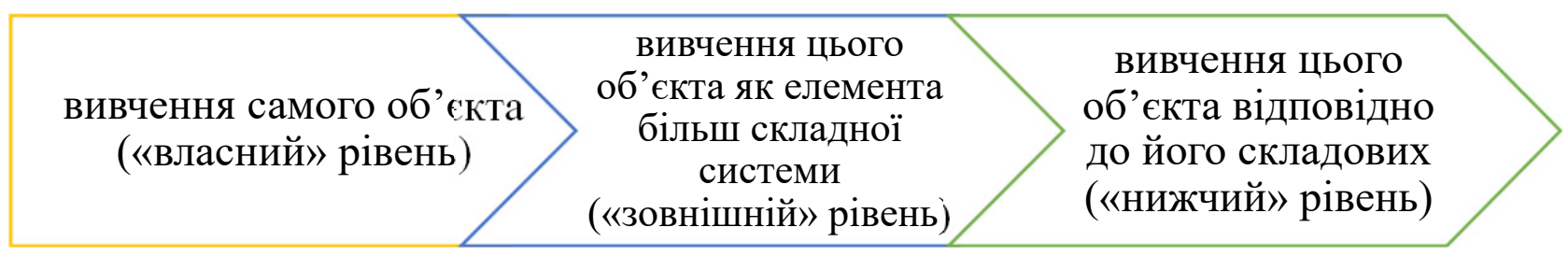

Рис. 8. Принцип ісрархічного вивчення об' скта

Авторська розробка

- принцип функціональності - спільний розгляд структури i функцій об'єкта з огляду на пріоритет функцій над структурою.

- принцип розвитку - має закладатися при побудові штучних систем як здатність до вдосконалення, розвитку системи за умови збереження якісних особливостей;

- принцип децентралізації - в управлінні системою співвідношення між централізацією та децентралізацією визначається призначенням та метою системи. При цьому ступінь централізації має бути мінімальний, що забезпечить досягнення остаточної мети;

- принцип невизначеності - дуже часто ми працюємо з системою, про яку далеко не все знаємо й не все розуміємо в иї поведінці. Тому невизначеності та випадковості доводиться брати до уваги при визначенні стратегії і тактики розвитку системи;

- принцип формалізації - системний підхід має на меті здобуття кількісних характеристик, створення методів, що звужують неоднозначність понять, визначень, оцінок тощо;

- принцип інтеграції - спрямованість системного підходу на вивчення інтегративних властивостей і закономірностей системи, розкриття базисних механізмів формування єдиного цілого.

Як головні інструменти системного підходу використовують системний аналіз і синтез. Аналіз і синтез - загальнонаукові методи, являють собою протилежно спрямовані (аналіз - від цілого до частини, синтез - від частин до цілого) і водночас нерозривно пов'язані між собою способи дослідження.

Використовуючи системний аналіз та підхід при дослідженні впливу людського фактора в роботі [8] було прийнято дві форми його прояву: людський фактор як вплив конкретної особи (виконавця) і людський фактор, опосередкований організаційними структурами та технологією виконання робіт. Технологічний (організаційний) людський фактор має місце, коли неможливо (недоцільно) виділити однозначно вплив конкретної особи, а вдасться виділити (визначити) організаційну структуру або технологічний процес (його частину).

Системний аналіз - методологія дослідження таких властивостей і відношень в об'єктах, які важко піддаються спостереженню та розумінню в разі подання цих об’єктів у вигляді окремих складових елементів, ознак, а натомість 
припускають поглиблене вивчення як цілеспрямовані системи, що постають 3 їхніми характерними властивостями та взаємними відношеннями, що розглядаються як відношення між цілями та засобами їх реалізації.

Системний аналіз успадкував шість основних етапів системного підходу (рис.8). Від інших методів дослідження він відрізняється тим, що:

- враховує принципову складність об'єкта дослідження;

- бере до уваги розгалужені та стійкі взаємні зв'язки його з оточенням; ураховує неможливість спостереження ряду властивостей об'єкта та навколишнього середовища;

- на базі відомих властивостей складних систем дозволяє виявити нові конкретні властивості та взаємні зв'язки конкретного об'єкта дослідження;

- передбачає визначення (відшукання чи конструювання) об'єкта, з яким надалі оперуватиме;

- орієнтується не на розв'язання «правильно сформульованих» задач, а на пошук правильної постановки задачі та вибір відповідних методів іії вирішення.

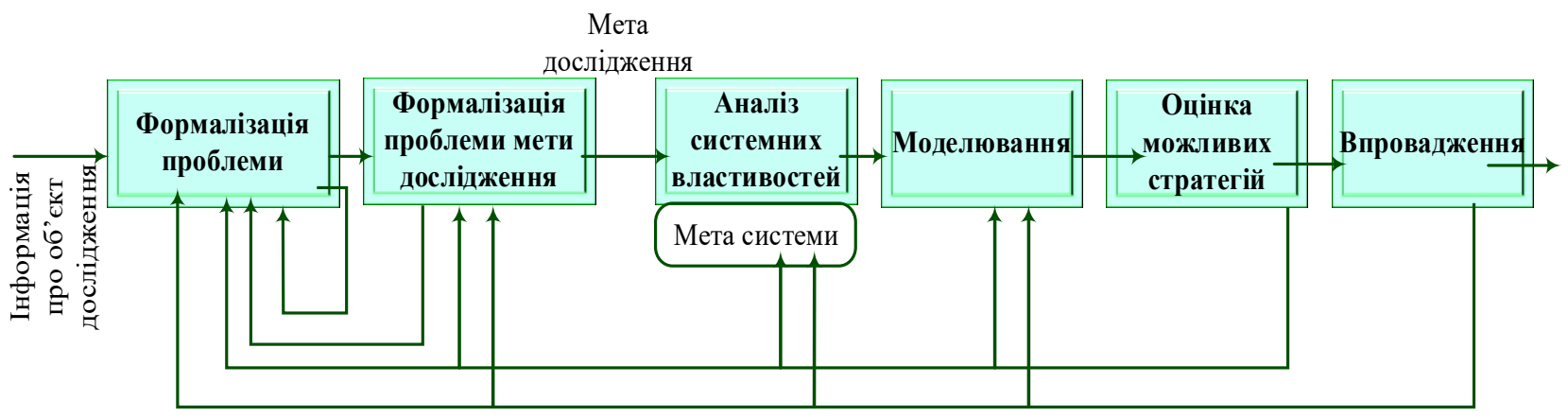

\section{Рис. 9. Спрощений вигляд взаємозв'язку основних етапів системного аналізу}

Авторська розробка

Системний аналіз, як правило, спрямований на розв'язання складних слабко-структурованих проблем, в яких переважають якісні, маловідомі і невизначені аспекти. Мета застосування системного аналізу до конкретної проблеми (події) полягає в підвищенні ступеня обгрунтованості знайденого розв'язання. Саме завдяки системному аналізу вдається виділити такі ознаки даної події, згідно з якими можна було б здійснити об'єднання, систематизацію фактів, розмістивши їх у певному (хронологічному, функціональному, структурному) порядку. Невід'ємною складовою системного аналізу виступає моделювання - процес, що включає в себе дослідження реальної соціо-технічної системи, побудову моделі (об'єкта, подібного до свого прототипу, що завдяки цієї подібності відіграє роль засобу опису, пояснення та прогнозування його поведінки) цієї системи, дослідження ії властивостей та перенесення здобутих відомостей на модельовану систему [9]. 
Відомо багато різноманітних методологій і методів опису складних соціотехнічних систем. Найбільш відомі серед них - методи специфікації систем, що базуються на теоріях відношень і графів. Зазвичай, під час опису соціо-технічної системи розглядають здебільшого функціональні, технічні, організаційні, документальні, алгоритмічні, програмні, інформаційні види структури зазначених систем (рис. 10):

\begin{tabular}{|c|c|c|}
\hline \multicolumn{3}{|c|}{ ПРИКЛАДНІ ТЕХНОЛОГї̈, ЯКІ ВИКОРИСТОВУЮТь } \\
СИСТЕМНИЙ АНАЛІЗ
\end{tabular}

Рис. 10. Класифікація моделей і методів системного аналізу Джерело: [1] 
Структура соціо-технічної системи залежить від складових елементів та зв’язків між ними (табл. 1). Для інформаційних об'єктів функціональної моделі може бути побудована інформаційна модель, що описує відношення між елементами системи у вигляді структур даних (склад та взаємозв'язки).

У спрощеному вигляді таку модель можна побудувати в три кроки (рис. 11):

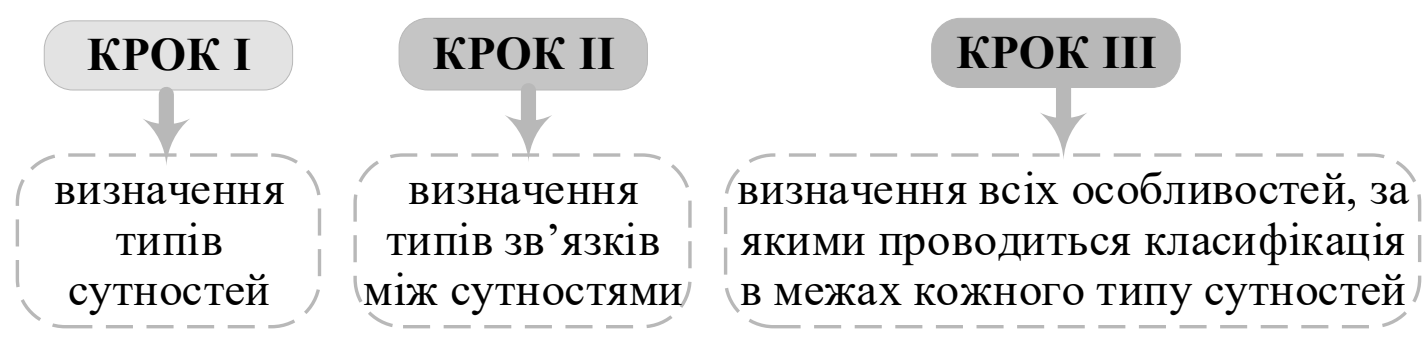

Рис. 11. Спрощений вигляд побудови інформаційної моделі

Авторська розробка

Сучасні соціо-технічні системи забезпечують великий спектр форм подання інформації таметодів іiї перетворення, зокрема переведення з однієї форми в іншу залежно від характеру завдань, як потрібно виконати. Наприклад, подання інформації можливе у формі формалізованих і неформалізованих текстів природною мовою, формалізованих i неформалізованих графічних зображень, реляційних відношень, аудіоповідомлень, відеозображень тощо. Опис форм подання інформації в цілому визначає характер взаємодії людини-оператора 3 інформаційною моделлю, а також структуру останньої (табл. 1) [1].

Таблиця 1

Види структури соціо-технічної системи, елементи цих систем та зв'язки між ними

\begin{tabular}{|c|c|c|}
\hline Вид структури & Елементи структури & $\begin{array}{c}\text { Зв'язки між елементами } \\
\text { структур }\end{array}$ \\
\hline Функціональна & Функції, завдання, процедури & Інформаційні \\
\hline Технічна & Пристрої, компоненти, комплекси & Лінії та канали зв’язку \\
\hline Організаційна & $\begin{array}{c}\text { Колективи людей і окремих } \\
\text { виконавців }\end{array}$ & $\begin{array}{c}\text { Інформаційні, супідрядності } \\
\text { та взаємодії }\end{array}$ \\
\hline Документальна & Документи & Взаємодії та супідрядність \\
\hline Алгоритмічна & Алгоритми & Інформаційні \\
\hline Програмна & Програмні модулі й вироби & Керівні \\
\hline Інформаційна & $\begin{array}{c}\text { Форми існування та подання } \\
\text { інформації в системі }\end{array}$ & $\begin{array}{c}\text { Операційні перетворення } \\
\text { інформації в системі }\end{array}$ \\
\hline
\end{tabular}

Джерело: [1] 
Динамічна модель показує часові характеристики системи, а також послідовність взаємодії функцій у часі. Отже, вона описує інформаційні процеси (динаміку функціонування), оперуючи такими поняттями, як стан системи, події, перехід із одного стану в інший, умови переходу, послідовність подій.

Таким чином, динамічну модель можна побудувати за чотири кроки (рис. 12):

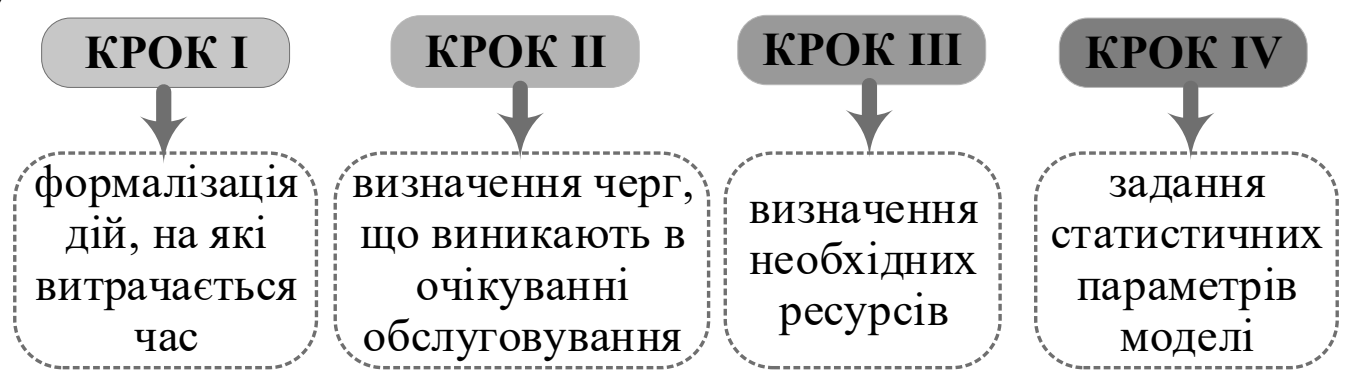

\section{Рис. 12. Спрощений вигляд побудови динамічної моделі}

Авторська розробка

Отже, зазначена сукупність моделей дає можливість описати як існуючі, так і майбутні соціо-технічні системи.

Досліджуючи соціо-технічні проєкти, які за своєю природою є соціальноспрямованими, можна відзначити, що їх основу складають три основні групи проектів (рис. 13): інфраструктурні, інвестиційні, інноваційні [1]. Як правило, ці проекти носять змішаний характер і поєднують в собі різні ознаки 3 точки зору різних класифікаційних груп.

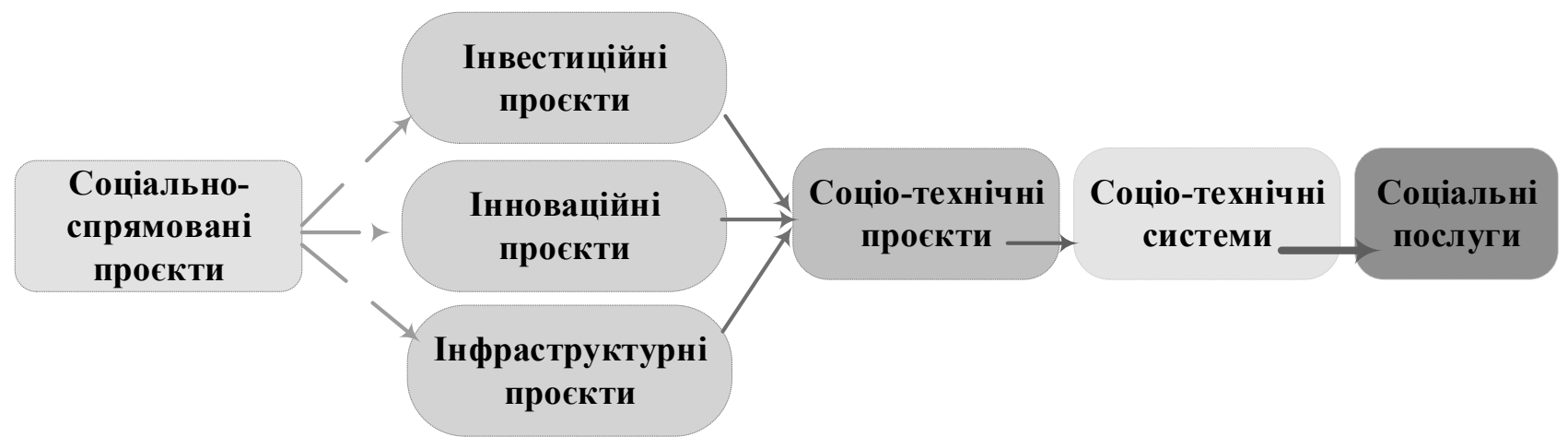

\section{Рис. 13. Формування соціальної послуги}

Джерело: [3]

Сойіо-технічний проєкт - це довгостроковий стратегічний проект, який визначає конкурентоспроможність конкретної території, іiі стійкий і збалансований розвиток. Для реалізації проекту, як правило, створюється спеціальна компанія з нульовим балансом, щоб не допустити змішування зобов'язань і вкладень за даним проєктом і за іншими зобов'язаннями третіх осіб. У табл. 2 наведені приклади соціо-технічних проектів, соціо-технічних систем і соціальних послуг, які вони забезпечують. 
Таким чином, можна зробити два висновки. По-перше, серед основних переваг реалізації соціо-технічного проєкту можна виділити можливість отримання синергічного ефекту, вираженого в збільшенні продуктивності праці, правильного розподілу завдань і ризиків, дотримання принципу життєвого циклу, підвищення якості, економічності, результативності та ефективності наданих соціальних послуг. I по-друге, основною проблемою при реалізації соціо-технічного проєкту є питання можливого розподілу витрат, ризиків та відповідальності між його учасниками [1].

\section{Приклад соціо-технічних просктів}

Таблиця 2

\begin{tabular}{|c|c|c|}
\hline Соціо-технічний проскт & Соціо-технічна система & Соціальна послуга \\
\hline Проектування, & Залізничні призначені для & Надання послуг \\
реконструкція або & обслуговування пасажирів, & залізничного \\
модернізація залізничних & користувачів, які потребують & транспорту \\
колій та & послуг залізничного & (перевезення \\
інфраструктурних & транспорту на умовах & пасажирів, \\
об'єктів прилеглих до них & договорів або виконання робіт & транспортування \\
& для власних потреб & вантажів тощо) \\
\hline
\end{tabular}

\section{Джерело: [1]}

Концепція соціо-технічних систем, на противагу теоріям технологічного детермінізму, які стверджували односторонню дію технології на людину в процесі виконанні нею трудових операцій, грунтується на ідеї взаємодії людини і машини. Важливою особливістю розглянутих соціо-технічних систем є емерджентність не тільки властивостей, а також й елементів, що пов'язані особливими системоутворюючими зв'язками.

Саме наявність системного і соціального ефекту системи дає перевагу при досягненні мети, заради якої елементи й об'єднуються в систему, тобто досягнення мети окремими елементами поза системою або менш імовірно, ніж в системі, або взагалі неможливо.

Важливим фактом $\epsilon$ те, що кожна з систем може входити як підсистема до складу більшої системи; у свою чергу підсистеми можутьбути як системи молодшої ієрархічної приналежності. Воснові подання такої структури лежить поняття ієрархії підзавдань, які вирішуються системою зі своїми об'єктами і критеріями. Ця ієрархія відображається в ієрархію математичних моделей з відповідними обмеженнями та ієрархії технічних засобів.

Ієрархічним структурам управління притаманні такі характеристики [1]:

- послідовне вертикальне розташування підсистем, які складають систему (вертикальна декомпозиція);

- пріоритет дій чи права підсистем верхнього рівня; 
- залежність дій підсистем верхнього рівня від фактичного виконання нижніми рівнями своїх функцій.

Такі особливості потребують спеціальних підходів до математичного опису процесу розвитку складної системи управління, на основі якої можна було б проявити залежності показників ефективності від параметрів системи і зовнішнього середовища, iї структури і алгоритмів взаємодії елементів.

Це можливо лише на основі багаторівневого ієрархічного опису із застосуванням різних формальностей, які дають можливість подати досліджувану систему як елемент більш широкої системи: розглядати ії як єдине ціле - визначити структуру з необхідним ступенем деталізації. Для забезпечення потрібної точності і зручності, обліку багатьох характеристик системи можна використовувати різні рівні опису.

Перший рівень відповідає інформаційному опису, тобто розглядаються інформаційні зв'язки соціо-технічної системи із зовнішнім середовищем і іï роль в отриманні і переробці інформації. Другий рівень виявляє функціональні елементи та відносини між ними. Третій рівень дає можливість визначити організаційну структуру соціо-технічної системи з відповідними засобами управління.

Багаторівневий опис системи має низку загальних властивостей:

- вибір рівня опису безпосередньо залежить від мети дослідження;

- розробка моделей на різних рівнях проводиться паралельно;

- вимоги до умов роботи підсистем верхнього рівня виступають як обмеження підсистем нижнього рівня;

- на нижніх рівнях опису виконується найбільша деталізація.

При розвитку складної соціо-технічної системи виникає ряд особливостей, пов’язаних з взаємодією підсистем, що входять до неї:

- більші підсистеми функціонують на верхньому рівні, який визначає ширші аспекти поведінки системи в цілому. Підсистема верхнього рівня $є$ «командною» відносно інших і координує роботу підсистем нижнього рівня;

- період прийняття рішень на верхньому рівні завжди більший, ніж на нижніх.

При цьому необхідно враховувати таку обставину:

- сигнали від верхнього рівня не можуть надходити частіше, ніж інформація від нижніх, так як інакше не буде координації нижніх підсистем;

- підсистема верхнього рівня завжди має справу з повільнішими аспектами поведінки всієї системи, вона завжди чекає результати реакції підсистем нижніх рівнів, наприклад, реакцію підсистем різних рівнів можна розбити за частотою діючих збурень;

- на верхніх рівнях опис і проблеми менш структуровані, мають невизначеності, більш складні для формалізації. Таким чином, проблеми прийняття рішень на верхніх рівнях більш складні.

При дослідженні процесів функціонування складних систем [1], можна спостерігати одночасну присутність у них як негативних, так і позитивних зворотних зв’язків. На використанні цих понять грунтується імітаційне динамічне моде- 
лювання. Процеси, що відбуваються в складних соціо-технічних системах, як правило, відразу не вдається представити у вигляді математичних співвідношень чи алгоритмів. Тому характеристики стабільної ситуації або її зміни, часто використовуються терміни, запозичені з теорії автоматичного регулювання, біології, філософії. Узагальнемо та систематизуємо ці терміни рис. 14. Стан рівноваги, в який система здатна повертатися, називають стійкимстаном рівноваги.
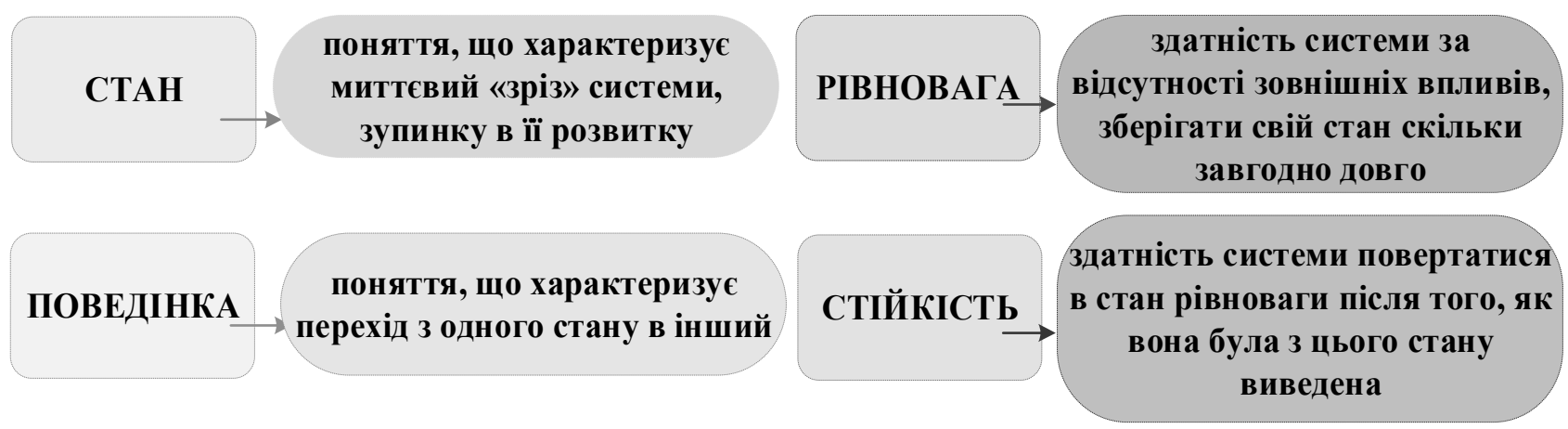

Рис. 14. Узагальнені терміни для характеристики ситуації та її змін Авторська розробка

Систематизуючи та досліджуючи закономірності в управлінні соціо-технічними системами необхідно відзначити характерні риси - закони та закономірносmi. Об’єктивні закони управління, на відміну від державних (правових) законів, що регулюють суспільні відносини, - це істотні, необхідні і загальні форми взаємозв’язків між керуючим суб'єктом і керованим об'єктом, між системою управлення та соціальним середовищем, що описуються науковою теорією. Закони управління висловлюють необхідність і загальність тих напрямків управлінської діяльності та відносин, які історично складаються, закріплюються і відтворюються у структурі та функціях управління.

Закономірні (обумовлені законом) структурні та функціональні взаємозв’язки не діють неминуче, а проявляються у вигляді тенденцій, через безліч конкретних явищ і обставин, індивідуальних актів поведінки і дій, що підпорядковуються імовірнісним «правилам гри». Виконання (реалізація) законів залежить від багатьох умов (змінних), але перш за все від керуючого суб'єкта, його знань, здібностей, а також і від керованого об'єкта.

Основні функції законів управління складаються в тому, що вони:

- утворюють теоретичний фундамент науки;

- сприяють переходу від емпіричного підходу до професійного;

- дозволяють правильно оцінити ситуацію, що виникла;

- дозволяють аналізувати закордонний (іноземний) досвід;

- характеризують якісні властивості та зв'язки процесів і явищ.

Проте закони управління диктують свої вимоги:

- в реалізації принципів управління; 
- в функціональному розподілі праці;

- в структурі системи управління та в механізмі й методах управління;

- в процесі управління.

Можна визначити загальні та специфічні закони управління. До загальних законів управління відносяться: закон спеціалізації управління. закон інтеграції управління, закон економії часу.

Закон спеціалізації управління. Сучасне виробництво грунтується на використанні новітніх технологічних процесів, технічних засобів, високого рівня організації виробництва, інформаційних систем. Для управління таким виробництвом необхідні вузькоспеціалізовані знання і навички (skills) в різних галузях науки і техніки, що призводить до розподілу загальних функцій, а саме їх появі в конкретних умовах, на різних рівнях [2].

Закон інтегращуї управління. Інтеграція, тобто об’єднання, виникає з потреби самого виробництва і управління ним. Це об'єднання, з одного боку, спеціалізованих управлінські дій на різних етапах управління в єдиний управлінський процес, а з іншого - підрозділів, виробництв в єдиний виробничий організм підприємство. Підприємства в свою чергу можуть об'єднуватися в різні організаційні форми ринкової економіки. Межі цього об’єднання регулюються точними відносинами виробництва і управління. Інтеграційні процеси відбуваються до тих пір, поки вони сприяють високим темпам нововведень, мобільності технологічної переорієнтації, впровадження винаходів, високому рівню зайнятості в умовах гострої конкурентної боротьби.

Закон економії часу. Закон економії часу справедливий не тільки для сфери матеріального виробництва. Будь-яка економія в кінцевому рахунку зводиться до економії часу. Ефективність управління залежить від швидкості реакції на потреби ринку та мобілізації всіх змінних для задоволення цих потреб. У глобальних масштабах закон економії часу може впливати на рівень економічного розвитку регіону або країни в цілому.

Специфічні закони управління висловлюють найбільш суттєві зв’язки і відносини різних сторін управління між собою та з елементами зовнішнього середовища. Ці закони зачіпають ті сторони управління, для яких характерний взаємний вплив: коли зміна форми та змісту однієї сторони управління викликає стійкі та цілком певні зміни іншої.

На даному рівні розвитку теорії серед законів управління можна виділити:

- закон єдності і цілісності системи управління;

- закон збереження пропорційності і оптимального співвідношення всіх елементів системи управління;

- закон залежності, ефективності вирішення завдань управління від обсягу використаної інформації;

- закон відповідності потрібного і наявного часу при вирішенні завдань управління; 
- закон сумісності технічних засобів і систем управління супідрядних і взаємодіючих систем.

Закономірність - первинне формулювання закону на початку його теоретичного осмислення і дослідження.

Закони та закономірності встановлюють загальні (рис. 15), істотні і необхідні зв’язки між явищами, що вивчаються.

системність

формування

управління відповідність системи управління меті, особливостям, стану та

тенденціям розвитку виробничої системи пропорційне поєднання сукупності підсистем і елементів системи управління пропорційне поєднання централізації $\mathrm{i}$ децентралізації управління за рівнями управління пропорційність виробництва i управління мінімізація

кількості ступенів управління єдність системи управління

\section{Рис. 15. Основні узагальнені закономірності управління} Авторська розробка

Закономірності безпосередньо взаємодіють, впливаючи один на одного своїми властивостями, утворюючи інтегровану, результуючу силу.

Управління як діяльність проявляється в сукупності управлінських проиесів цілеспрямовані рішення та дії, які виконуються в певній послідовності та комбінації. В сукупності такі процеси утворюють цикл, що включає взаємопов' язані фази.

Метою конкретного управлінського процесу є зміна або збереження управлінської ситуації - сукупності обставин, які впливають, або можуть в майбутньому мати позитивний чи або негативний вплив.

При чому до елементів процесу управління можна віднести: управлінську роботу, іiі предмет та засоби.

Управлінська робота - сукупність дій і операцій, які забезпечують підготовку та реалізацію окремих рішень.

Предметом і продуктом в управлінні $є$ інформація про існуючу проблему і способи ії вирішення. В результаті обробки вона перетворюється в управлінське рішення, яке є основою проведення конкретних дій.

Управлінська робота відноситься до категорії інтелектуальної (розумової) праці, що проявляється у вигляді нервово-психічних зусиль у трьох формах: евристичної, адміністративної, операторної.

Складність управлінської роботи можна охарактеризувати:

- масштабами, кількістю і багатогранністю проблем, що вирішуються, зв’язків між ними, різноманітністю методів, організаційних принципів, що застосовуються;

- необхідністю приймати нові, нетрадиційні рішення, часто в умовах невизначеності й ризику, що вимагає глибоких професійних знань, досвіду; 
- необхідністю оперативно самостійно діяти, брати на себе ризик і нести відповідальність.

Управлінська робота складається з окремих видів робіт, об’єктом яких є носії інформації. Кожна робота є самостійним комплексом управлінських операцій, яких може бути до тисячі, а кожна 3 них складатись 3 декількох десятків елементів. Управлінські операції поділяються на творчі, логічні, та технічні.

Документально зафіксована послідовність виконання елементів управлінського процесу, яка визначає зміст, послідовність, структуру складових його операцій - управлінська процедура.

Найчастіше процедури виконуються за правилами, які визначають, що і як повинно бути виконаним в конкретній ситуації. Це захищає кожного учасника управлінського процесу від тиску ззовні, звільняє від особистої залежності.

Для стійкості соціальної системи, а отже іiі життєздатності, вона повинна мати керуючий елемент - систему управління, яка здійснює інтеграцію і контроль функціонування окремих ii частин, надходження ресурсів, результатів та ін. та їхнє корегування на основі зворотного зв'язку (feed back). Система управління є складною організацією, що включає такі взаємопов'язані елементи: органи (суб’єкти) управління - посади, підрозділи; комунікаційні канали; набір методів, технологій, норм, правил, процедур, повноважень, що визначають поведінку працівників і порядок виконання ними тих чи інших дій.

При цьому система управління характеризується:

- технічним оснащенням;

- складом, підпорядкованістю, інформаційним навантаженням елементів, способом їхньої взаємодії;

- рівнем централізації чи децентралізації повноважень;

- структурою зв’язків та ступенем спеціалізації і регламентації функцій;

- стабільністю або мінливістю поведінки;

- відкритістю або закритістю.

Певне співвідношення суб'єктів управління, пов'язаних між собою комунікаційними каналами, утворює структуру цієї системи, яка відображатиме статику управління, а сукупність методів, технологій тощо — його механізм.

Узагальнюючи інформацію щодо структури та функціонування системи

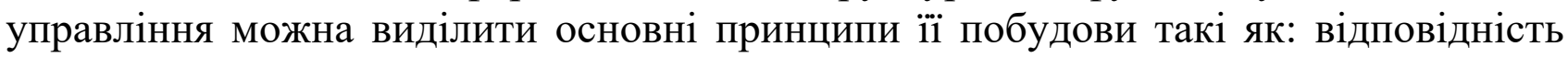
меті організації; орієнтир на певний рівень компетентності персоналу; допущення неформальних зв’язків; забезпечення ефективного контролю; гнучкість і адаптивність.

Як і будь-яка органічна система, система управління знаходиться в постійному розвитку. Це розвиток може бути екстенсивним (шляхом збільшення числа суб'єктів, зв'язків між ними) та інтенсивним (за рахунок раціоналізації функцій, процедур та ін.). 
Структурно система управління складається з керуючої та керованої підсистем, межі між якими досить умовні. Вони взаємодіють 3 допомогою механізму управління, який відповідною частиною належить до кожної з них. Під керуючої підсистемою можна розуміти ту частину системи управління, яка виробляє, приймає та передає управлінське рішення, забезпечує його виконання. Вона має ієрархічну структуру на чолі з центральною ланкою: це може бути індивід або колектив (наприклад, рада директорів). Поняттю «керуюча підсистема» $є$ дуже близьким поняття «суб'єкт управління», проте вони не однакові. До складу суб'єкта входять тільки ті елементи підсистеми, які пов'язані з прийняттям рішень (на якому б рівні вони не знаходилися).

Фактично суб'єкт - це особа, що здійснює діяльність, спрямовану на практичне перетворення предметної дійсності. При чому суб'єкти в основному класифікуються за характером, змістом і масштабом діяльності.

Проте до керованої підсистеми відносяться елементи, які сприймають керуючий вплив й адаптують відповідно до нього поведінку того об'єкта, на який він спрямований.

В той же час об'єкт управління представляє собою все елементи організації, які, сприймаючи управлінський вплив, підпорядковують йому своє функціонування і розвиток. Як об'єкт можна розглядати групу людей, окрему особистість, процес, відносини та ін. Але при цьому потрібно враховувати, що об'єкт управління відрізняється від суб'єкта функціями, які виконуються. Тому, наприклад, одна й та ж сама особа в різних ситуаціях може бути і тим, і іншим. Зазвичай суб'єкт управління за масштабом менший за об'єкт й складність його нижче, але він активніший та динамічніший; об'єкт же, навпаки, інертний.

Іноді виникає ситуація, коли подальший розвиток об'єкта управління може розвиватись декількома різними напрямками. Це дає підстави для виникнення ситуації невизначення (ентропії). Чим більше існує варіантів подальших дій й чим складніше вибирати 3 них кращий, тим його ступінь вище і тим складніше здійснювати управління.

Якщо управління має офіційний характер, тоді його суб'єкт організаційно і юридично оформляються у вигляді посади, що утворюють підрозділ управління (управлінський апарат). Але суб’єкт може діяти і без такого оформлення. Головне, щоб він генерував і виконував відповідні рішення.

Фактично від суб'єкта управління необхідно відрізняти суб'єкти управлінської діяльності - живих людей - керівників і співробітників підрозділів управління. Тому важливо виділити можливі зв'язки між суб'єктом та об'єктом управління та їхній влив на власне механізм управління (рис. 16). 


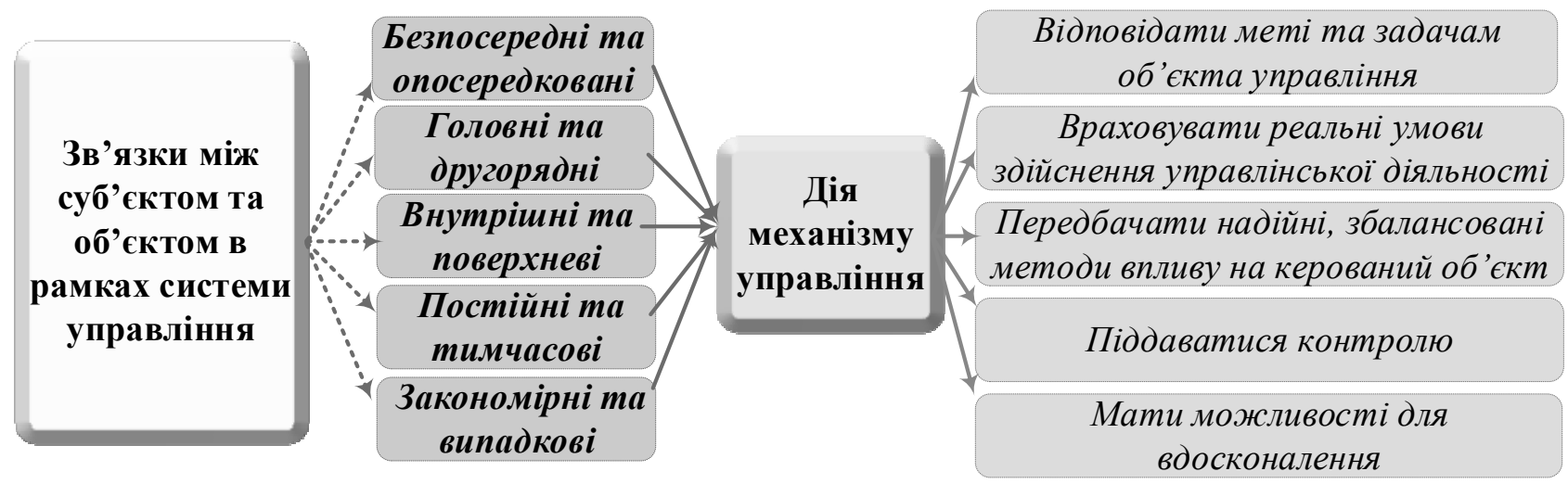

Рис. 16. Принцип дії механізму управління

Авторська розробка

Система управління повинна бути ефективною, тому до ознак іiі ефективності можна віднести:

- високу оперативність, надійність, якість прийнятих рішень;

- мінімізацію витрат часу, пов'язаних з їхньою підготовкою;

- економію загальних витрат і витрат на утримання апарату управління;

- покращення техніко-економічних показників основної діяльності та умов праці;

- зниження частки адміністративних працівників в персоналі організації.

Таким чином, формалізуємо заходи, за допомогою яких можна підвищити ефективність функціонування системи: більш надійні зворотні зв'язки; своєчасність та повнота інформації; врахування соціально-психологічних особливостей учасників; забезпечення оптимальної кількості та розміру підрозділів.

\section{3. Безпека соціо-технічних систем}

На сьогоднішній день інформація має надзвичайну цінність, яка може визначатися не тільки обсягами ресурсів, витраченої на ії створення, але й розміром прибутку, отриманого від іiі можливої реалізації. Одна за найважливіших проблем сучасності - захист інформації, надійне забезпечення збереження та встановлення статусу використання. Становлення інформаційного суспільства має як позитивні, так і негативні наслідки: пришвидшилася передача інформації великого обсягу, прискорилась іï обробка та впровадження, але занепокоєння викликає поширення фактів протизаконного збору і використання інформації, несанкціонованого доступу до інформаційних ресурсів, незаконного копіювання інформації в електронних системах, викрадення інформації з архівів, банків та баз даних, порушення технологій обробки інформації, запуску програм-вірусів, знищення та модифікація даних в інформаційних системах, перехоплення інформації в технічних каналах іiі витоку, маніпулювання суспільною та індивідуальною свідомістю. 
Перехід суспільства до інформаційного змінив статус інформації - може бути як засобом забезпечення безпеки, так і загрозою та небезпекою. Одним із головних пріоритетів є розвиток інформаційного суспільства та впровадження новітніх інформаційно-комунікаційних технологій в усі сфери суспільного життя. Саме цим зумовлена актуальність забезпечення інформаційної безпеки інтересів людини, суспільства та держави в цілому. Тривалий час розуміння інформаційної безпеки в наукових та нормативно-правових джерелах ототожнювалося тільки з безпекою інформації, що значно звужувало іiі сутність. Саме тому 3 низки питань, присвячених розгляду проблеми забезпечення інформаційної безпеки, найбільш вивченими та дослідженими іiі аспектами $є$ безпека інформації (інформаційнотехнічна безпека) [11].

Одна з основних внутрішньовиробничих функціональних складників безпеки підприємства - інформаційна. Вона полягає у здійсненні ефективного інформаційно-аналітичного забезпечення господарської діяльності підприємства. Належні служби підприємства виконують певні функції, які в сукупності характеризують процес створення та захисту інформаційного складника безпеки підприємства. Тобто до них належать: збирання всіх видів інформації щодо діяльності того чи іншого суб'єкта господарювання; аналіз одержуваної інформації з обов’язковим дотриманням загальноприйнятих принципів і методів; прогнозування тенденцій розвитку науково-технологічних, економічних i політичних процесів; оцінка рівня безпеки за всіма складниками та розробка рекомендацій для підвищення цього рівня [10].

В сучасному суспільстві, в тому числі, давно вже звикли до словосполучення «інформаційна безпека», яке зайняло своє місце серед інших видових щодо поняття «безпека» термінів (економічна, екологічна, психологічна, національна безпека тощо).

Безпека сучасних соціо-технічних систем складається з декількох складових. Найбільш важливими з них є такі: економічна, екологічна, промислова, інформаційна тощо. На перший погляд незалежні складові комплексної безпеки соціотехнічних систем при більш детальному аналізі представляються вже взаємозалежними [11]. Отже, ймовірними ризиками таких подій можуть бути: порушення інформаційної безпеки призводить до порушення екологічної, промислової безпеки, наприклад, якщо розглядати такі об'єкти, як хімічно-небезпечні або атомні станції. Другий приклад: порушення інформаційної безпеки може призвести до порушення економічної безпеки, якщо розглядати такий об'єкт як певну фінансову установу. Очевидно, що таких прикладів є багато. Таким чином, взаємозалежність ризиків різних типів можна представити у вигляді структури (рис. 17).

Основою даної структури є інформаційна безпека. Це дозволяє стверджувати, що підвищення рівня інформаційної безпеки зменшує ризики економічної, екологічної, промислової безпеки тощо. 


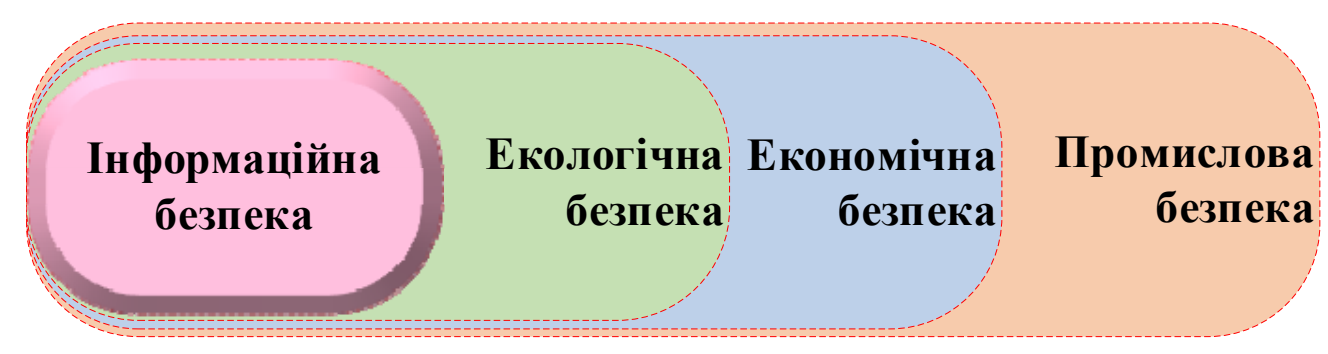

\section{Рис. 17. Взаємозалежність ризиків}

Джерело : [6]

Проте, незважаючи на використання терміну «інформаційна безпека» в суспільстві, далеко не всі з тих, хто до нього звертається, розуміють складність проблемної області, до якої він відноситься. Пересічне уявлення про інформаційну безпеку формується під впливом того факту, що інформація в сучасному суспільстві усвідомлюється як важливий ресурс, який здатний принести його господарю певні прибутки, а тому цей ресурс потребує захисту від сторонніх посягань та випадкового ушкодження. Звідси й виникає проблема захисту інформації, що розуміється як забезпечення ії основних властивостей: конфіденційності, цілісності та доступності.

Якщо детально досліджувати питання інформаційної безпеки, то можна сформулювати загальну характеристику означених властивостей інформації. Доступність - це можливість використання інформації щоразу, коли в цьому виникає необхідність. Інформація стає недоступною в разі ії блокування або знищення. Цілісність інформації (повнота і точність) порушується при фальсифікації, несанкціонованій модифікації, викривленні тощо. Конфіденційність - властивість інформації не підлягати розголосу. Безпека конфіденційної інформації порушується внаслідок іiі несанкціонованого копіювання, викрадення або втрати. Об'єктом захисту тут виступає інформація, механізми, організаційні структури і форми, в яких існують інформаційні потоки. Тобто, мається на увазі безпека інформації, тоді як поняття інформаційної безпеки цим змістом не вичерпується. Поняття «безпека інформації» та «інформаційна безпека» безумовно пов'язані між собою. Оскільки зміст поняття «безпека» визначається вибором об'єкту захисту, то якщо цим об'єктом виступає власне інформація, то поняття «інформаційна безпека» і «безпека інформації» є синонімами. Але якщо в якості об'єкта / суб'єкта захисту розглядається деякий суб'єкт інформаційних відносин, то слово «інформаційна» в даному значенні вказує на напрямок діяльності, яка може заподіяти шкоду об'єкту / суб'єкту захисту. У цьому випадку поняття «інформаційна безпека» розуміється як стан захищеності деякого об'єкту / суб’єкту від загроз інформаційного характеру. Отже, поняття «інформаційна безпека» $є$ близьким по відношенню до поняття «безпека інформації», а їх взаємозамінність $\epsilon$ неприпустимою. У сучасних умовах поряд із задачею захисту інформації надзвичайно актуальною стає проблема 
захисту від інформації. Інформація знаходиться в межах соціо-технічної системи, де найменш захищеними ланками є не механізми і технології, а люди [11].

Таким чином, інформаційну безпеку можна визначити як стан захищеності свідомості і буття соціальних суб'єктів від інформаційних загроз, який визначається рівнем реальної чи потенційної шкоди, заподіяної внаслідок деструктивного інформаційного впливу або порушення безпеки інформації. Тобто дуалістичність сутності інформації полягає в тому, що: вона може виступати і об’єктом захисту, і засобом, інструментом впливу на функціонування соціальних систем, причому цей вплив може носити як позитивний, так і негативний характер.

Підсумовуючи, в загальному випадку серед загроз інформаційній безпеці можна виділити (рис.18):

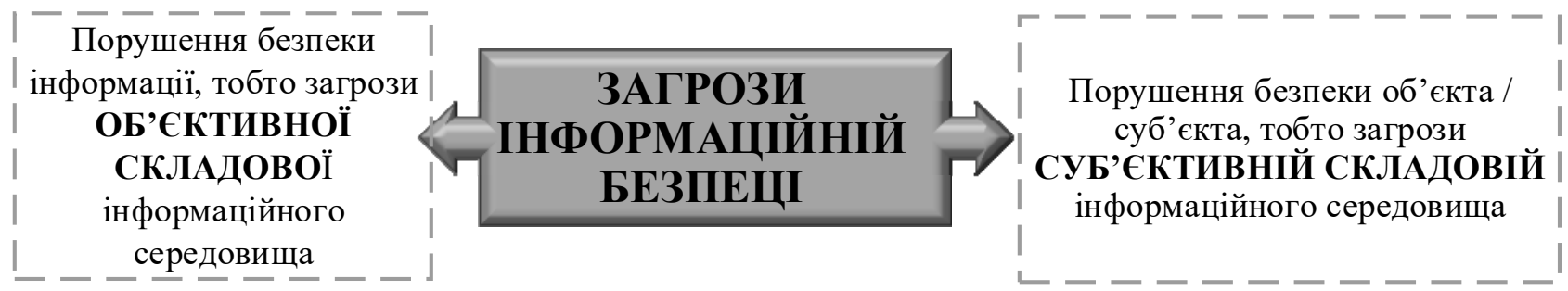

\section{Рис. 18. Загрози інформаційній безпеці в загальному випадку}

Авторська розробка

Ці групи загроз інформаційній безпеці пов'язані між собою. Загрози об'єктивній складовій інформаційного середовища, впливають на суб'єктивну складову, адже людині набагато важче прийняти рішення, сформувати свою власну позицію, адекватну реальному стану речей, в умовах інформаційної нестачі, викривлення та фальсифікації інформації. Деструктивний інформаційний вплив на індивідуальну та суспільну свідомість здійснюється саме через канали розповсюдження і передачі інформації. Постійне ускладнення суспільного життя, перевантаженість інформацією у поєднанні з розгортанням інформаційної нерівності сприяє формуванню у людей стереотипної свідомості, знижує здатність до адекватного та критичного сприйняття нової інформації. Кожна людина в процесі свого розвитку отримує певні навички та знання, напрацьовує деякі поведінкові схеми та алгоритми, формує власні переконання, вподобання та пріоритети. Очевидно, що все це здійснюється на основі інформації, яку отримує людина із зовнішнього світу [11].

Отже, під впливом контрольованого потоку інформації у людини цілком реально сформувати так само контрольовану, наперед задану «інформаційними модераторами» свідомість, разом із відповідними навичками, знанням та вподобаннями. 3 іншого боку, так само, як і всі інші вміння та навички, вміння працювати з інформацією, орієнтуватися в їі різноманітті, оцінювати їі достовірність, приймати на іiі основі рішення, - всі вони формуються на основі попереднього практичного досвіду. 
Традиційний, перевірений часом спосіб навчання полягає у поступовому переході від простого до складного, від базових, елементарних навичок до більш професійних та специфічних. I якщо людина не отримала елементарних знань, то більш складні знання та навички стають недосяжними для неї. Це дає можливість говорити про соціальну, ментальну складову інформаційної нерівності, яка впливає на відповідну складову інформаційної безпеки і полягає у нездатності людини самостійно орієнтуватися в інформаційному просторі, зокрема здійснювати пошук, верифікацію, аналіз отриманої інформації, а також приймати рішення на іiі основі та синтезувати нову інформацію [11].

Отже, для інформаційної безпеки людини та суспільства велике значення має той факт, що, крім відсутності обмеження у доступі до інформації та наявності відповідних інформаційних навичок, для адекватного іiі сприйняття необхідно докласти значних зусиль, а бажання їх докладати виникає все менше й менше. Зорієнтуватися у безлічі інформаційних повідомлень, які представлені у різних видах та форматах, доповнюють або суперечать один одному дійсно складно - це потребує певних навичок, вільного часу та відповідного бажання. Саме тому забезпечення інформаційної безпеки не є зобов'язанням виключно державних інституцій, а більшою частиною лягає на плечі кінцевих споживачів інформації.

\section{3. ВИСНОВКИ}

Досліджено поняття та властивості систем, соціо-технічних систем, а також проаналізований системній підхід для проектування складних соціо-технічних систем. Встановлено, що для створення складних соціо-технічних систем, як головні інструменти системного підходу, використовують системний аналіз і синтез. Описано соціо-технічні проєкти, які утворюють соціо-технічні системи для реалізації продукту у вигляді соціальних послуг. Встановлено, що важливою особливістю розглянутих соціо-технічних систем є системний ефект не тільки властивостей, а також й елементів, що пов'язані системоутворюючими зв'язками. Система за рахунок системного та соціального ефекту забезпечує певні переваги при досягненні мети, які відсутні у їі частин, досліджуваних окремо.

Розглянуто значення інформації та визначено одну з найважливіших проблем в сучасності - безпека інформації. Досліджено різницю між змістом схожих за загальними рисами понять «інформаційна безпека» та «безпека інформації». Під час дослідження було розглянуто структуру та складові безпеки сучасних соціо-технічних систем та визначено найважливіші з них.

Таким чином, оскільки головним джерелом добробуту людини $є$ інформація, то інформаційна безпека повинна забезпечувати збереження цілісності особи та ії здатності до розвитку, враховуючи сучасні умови становлення інформаційного суспільства. 


\section{ЛITEPATУРА}

1. Чимшир, В. I. Проектно-орієнтоване управління процесами соціотехнічних систем: монографія / В.І. Чимшир. - Одеса : КУПРІСНКО СВ, 2018. - 196 с.

2. Гусев, А. А. Управление социально-техническими системами : курс лекций для студентов направления подготовки 190700.62 - «Технология транспортных процессов» (бакалавры) всех форм обучения / А. А. Гусев. — Екатеринбург : УрГУПС, 2015. $128 \mathrm{c}$.

3. Чимшир, В. И. Сложность как граница управляемости сложной социотехнической системой / В.И. Чимшир // Вісник Національного технічного університету «ХПІ». З6ірник наукових праць. Нові рішення в сучасних технологіях. - Харків, 2011. №43. - C.101-105.

4. Бурячок, В. Л. Інформаційний та кіберпростори: проблеми безпеки, методи та засоби боротьби: Посібник / В.Л. Бурячок, С.В. Толюпа, В.В. Семко, Л.В. Бурячок, П.М. Складанний, Н.В. Лукова-Чуйко. - К. : ДУТ - КНУ, 2016. — 178 с.

5. Тесленко, П. А. Проект как управляемая организационно-техническая система / П.А. Тесленко // Вісник Національного технічного університету «ХПІ». З6ірник наукових праць. Тематичний випуск: Нові рішення в сучасних технологіях. - Харків, 2010. — № 57. - С. 198-202.

6. Дудатьєв, А. В. Інформаційна безпека соціотехнічних систем в умовах інформаційної війни [Електронний ресурс] / А. В. Дудатьєв // Інформаційні технології та комп'ютерна інженерія. - 2011. - № 3. - С. 75-79. - Режим доступу: http://nbuv.gov.ua/ UJRN/Itki_2011_3_13.

7. Самсонкин, В. Н. Метод статистической закономерности в управлении безопасностью движения на железнодорожном транспорте: монография / В.Н. Самсонкин, В.А. Друзь. - Донецк: ДИЖТ, 2005. - 158 с.

8. Самсонкін, В. М. Теорія безпеки на залізничному транспорті: монографія / В.М. Самсонкін, В.І. Мойсеєнко. - Київ: «Каравела», 2014. - 248 с.

9. Baxter G., Sommerville I. Socio-technical systems: From design methods to systems engineering [Electronic resource] / G. Baxter, I. Sommerville // Interacting with Computers. 2011. - Vol. 23, Issue 1. Pages 4-17. Mode of access: https://doi.org/10.1016/j. intcom.2010.07.003.

10. Убийвовк, I. I. Інформаційна безпека діяльності підприємств [Електронний ресурс] / I.I. Убийвовк // Причорноморські економічні студії. - 2016. - Вип. 9(2). С. 126-131. — Режим доступу: http://nbuv.gov.ua/UJRN/bses_2016_9\%282\%29_29.

11. Архипова, Є. О. Технічна та соціальна складові інформаційної безпеки / С.О. Архипова // Глушковські читання: Матеріали конференції до 90-річчя 3 дня народження академіка В.М. Глушкова — К.: НТУУ «КПІ», 2013. — С. 48-51. 


\title{
РОЗДІЛ 3 \\ УПРАВЛІННЯ ЛАНЦЮГАМИ ПОСТАВОК ТА МЕРЕЖАМИ
}

\section{1. ВСТУП}

\author{
M.B. Xapa ${ }^{5}$ \\ І.В. Ніколаєнко ${ }^{6}$
}

Розділ присвячено презентації матеріалу з дисципліні «Управління ланцюгом постачань та мережами».

Розвиток управління ланцюгами поставок в 90-х рр. XX століття має цілком об'єктивні причини. Саме тоді явно позначилися тенденції: перевищення пропозиції над попитом, глобалізація ринків і інформатизація бізнесу. Зазначені тенденції викликали зміни в стратегіях забезпечення конкурентоспроможності підприємств, які були змушені максимально враховувати потреби клієнтів і, отже, індивідуалізувати продукцію (кастомізація виробництва). В цей же час почали активно освоюватися ринки Південно-Східної Азії, Південної Америки, а трохи пізніше - Східної Європи та України.

Багато розвинених країн 3 міркувань екології та економії на порівняно дешевій робочій силі перенесли в ці регіони свої виробничі потужності, як наслідок, почав стрімко збільшуватися обсяг перевезень. Все це в сукупності призвело до того, що оптимізація всього ланцюгу створення доданої вартості (Value Chain), а не тільки окремих функцій власного підприємства, стала вирішальним фактором забезпечення конкурентоспроможності та прибутковості бізнесу, що і визначило розвиток науки і практики управління ланцюгами поставок [1].

На думку більшості фахівців, відправним пунктом до появи і розвитку концепції управління ланцюгами поставок (Supply Chain Management або SCM) стало також прагнення до зниження ризиків і невизначеностей на основі моделей кооперації та ешелонованого (тобто на декількох підприємствах одночасно) управління запасами $[2,3]$. У $70-80$-ті pp. XX століття також активно розвивалася концепція синхронізації процесів постачань, виробництва і дистрибуції - система Just-in-Time (JIT — «Точно, своєчасно»).

Багато фахівців пов'язують появу і розвиток управління ланцюгами поставок 3 необхідністю раціонального використання виробничих потужностей. Не маючи можливості управляти ланцюгами поставок, підприємства змушені були планувати виробництво з урахуванням значних запасів сировини, матеріалів і незавершеного виробництва, оскільки процеси поставок не були синхронізовані ні 3 постачальниками, ні з клієнтами. З'явилися корпоративні інформаційні системи і інтернет-технології, які дозволили значно підвищити ефективність координації

5 Канд. техн. наук, доцент кафедри «Транспортні технології підприємств»

ДВНЗ «Приазовський державний технічний університет», Маріуполь

${ }_{6}^{6}$ Канд. техн. наук, доцент кафедри «Технології міжнародних перевезень і логістика»

ДВНЗ «Приазовський державний технічний університет», Маріуполь 
процесів в ланцюзі поставок. Саме інтеграція і координація істотно відрізняе ідеологію управління ланцюгами поставок від традиційних підходів до міжфірмової кооперації.

Наука і практика реального управління ланцюгами поставок довела ефективність вибудовування бізнесу виходячи з цілісного розгляду всіх елементів процесу створення споживчої вартості продукту, а не тільки витрат і доходів власного підприємства без урахування впливу міжфірмових зв'язків 3 постачальниками і відносин з клієнтами.

У нашій країні про управління ланцюгами поставок почали дізнаватися в 90-х рр. Саме тоді з'явилися перші перекладні видання відомих зарубіжних авторів Д. Бауерсокса і Д. Клосса [4], М. Крістофера [5], а пізніше К. Ламберта і Д. Стоку [6], які в основному були орієнтовані на стратегічне управління ланцюгами постачань. Питання логістики досліджені в наукових працях багатьох українських вчених, зокрема К. В. Захарова [7], А. Г. Кальченко [8], С. В. Крикавского [9], В.К. Губенко [10], М.Ю. Григорак [11], О.М. Сумця [12] та багатьох інших.

Як в Україні, так і за кордоном управління ланцюгами поставок розглядається 3 трьох основних позицій [13]:

- бізнес-концепція;

- самостійна наукова дисципліна;

- середовище інформаційної взаємодії підприємств.

Встановлення взаємозв'язків між цими трьома напрямками є в даний час одним із важливих завдань.

Актуальність питань, які представлені у даному розділі пов'язана з багатогранністю сфери управління ланцюгами поставок і з сучасними реаліями інформаційного суспільства, що сприяе стрімкому розвитку сучасних інструментаріїв логістики, до яких слід віднести: технологію Big Data; GRID технологію; технологію Blockchain; сенсорні технології; технології цифровізації транспорту.

\section{2. ОСНОВНИЙ МАТЕРІАЛ}

\section{1. Структура ланцюга поставок}

Будь яке підприємство промисловості, торгівлі чи сфери послуг для забезпечення своєї діяльності утворює цілісну структуру [14], що включає крім постачальників і споживачів велике число контрагентів - посередників. До логістичних посередників відносяться фірми, які надають відповідні послуги центральної (фокусної) компанії ланцюга поставок: експедитори, перевізники, склади, термінали, митні брокери, страхові компанії, агенти, стивідорні компанії і т.п.

Крім того, в цьому просторі функціонують і інституційні контрагенти - митні служби, органи контролю, нагляду та ліцензування (санітарна інспекція, ветеринарна і карантинна служби, податкова служба тощо). $Є$ також і такі посередники, 
як банки, компанії інформаційного сервісу, рекламні компанії і т.п. Залежно від кількості ланок ланцюга поставок, розрізняють три рівні складності [12].

Прямий ланцюг поставок складається 3 трьох учасників: постачальника, фокусної компанії (промислової чи торгової фірми) і покупця (споживача), що беруть участь у виробництві і просуванні потоків: продукції, послуг, фінансів та інформації. При цьому, як правило, фокусна компанія визначає структуру ланцюга постачань і управління взаємовідносинами з контрагентами по бізнесу.

Розширений ланцюг поставок включає додатково постачальників і споживачів другого рівня.

Максимальний ланцюг поставок складається з фокусної компанії і всіх іiі контрагентів (аж до постачальників вихідної сировини і природних ресурсів), визначаються ресурси фокусної компанії - на вході, і мережі розподілу - до кінцевих (індивідуальних) споживачів, а також логістичних, інституційних та інших посередників (рис. 1).

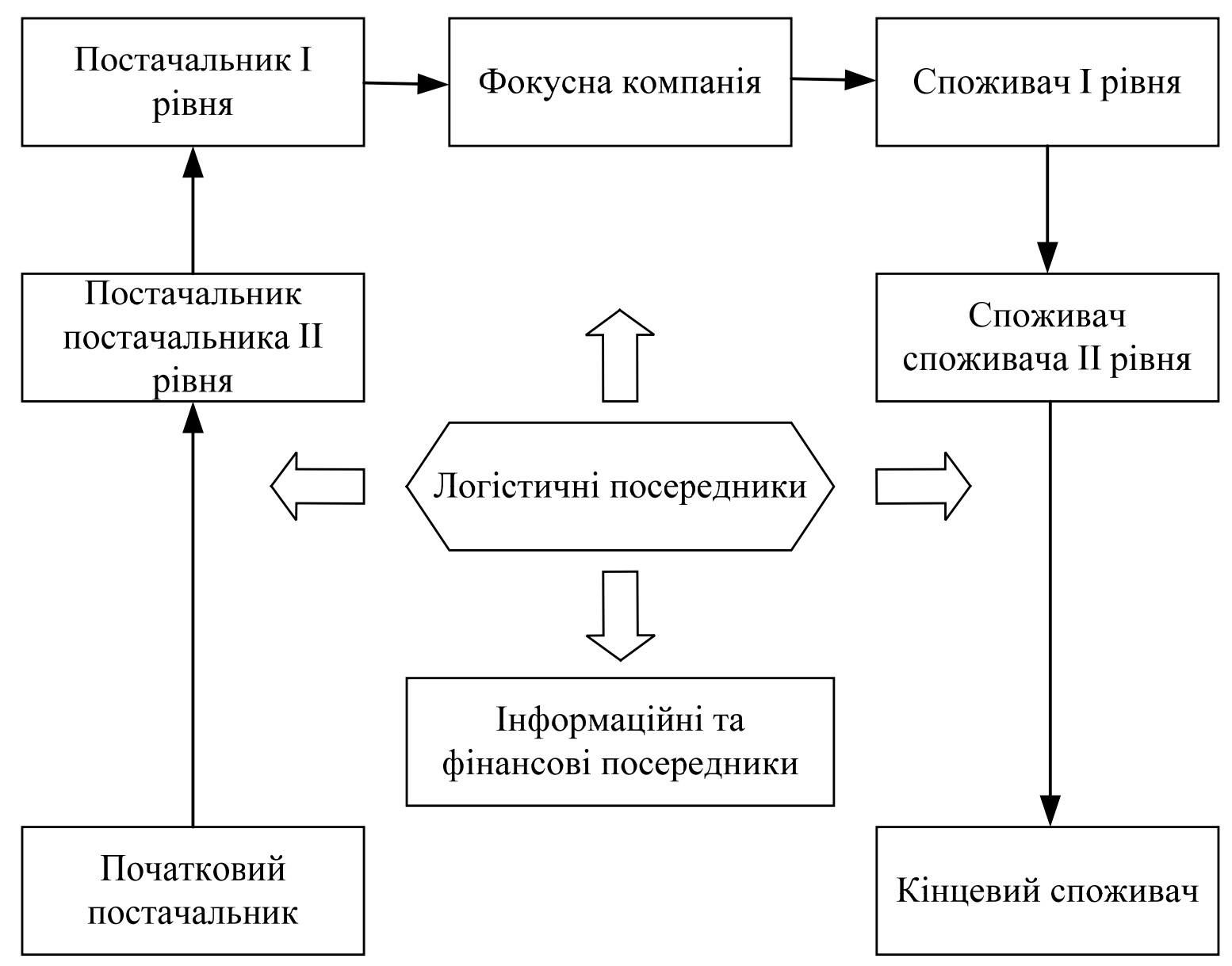

Рис. 1. Узагальнений вид максимального ланцюга поставок Джерело: [1] 
За своєю суттю ланцюг поставок - це впорядковані послідовності постачальників і споживачів, причому кожен споживач також $є$ постачальником, і так триває до тих пір, поки готовий продукт не надійде до кінцевого користувача. Тому можливо казати про «мережеву структуру ланцюгів поставок», в яких кожна компанія (організація або окремий структурний підрозділ) постачають один одному продукцію або послуги, додаючи певну споживчу вартість до товару.

Відповідно до прийнятого поділу ланцюгів поставок на об’єктне і процесне уявлення існують такі їх визначення.

Ланцюг поставок (об'єктне уявлення) - це сукупність організацій (підприємств-виробників, складів, дистриб'юторів, 2PL $\div$ 5PL провайдерів, експедиторів, оптової та роздрібної торгівлі), взаємодіючих в матеріальних, фінансових і інформаційних потоках, а також потоках послуг від джерел вихідної сировини до кінцевого споживача [12].

Особливостями ланцюгів поставок $\epsilon$, перш за все:

- юридична незалежність учасників ланцюга;

- наявність фокусної компанії, тобто виробника кінцевої продукції або послуги: підприємства, що здійснює збірку кінцевої продукції (ОЕМ - Original Equipment Manufacturer) у виробництві, торговельної мережі в торгівлі або логістичного провайдера;

- коопераційні і координаційні зв'язки з постачальниками і клієнтами. Ці особливості, поряд з цілим рядом переваг щодо зниження витрат, підвищення гнучкості поставок і обліку ринкових вимог, викликали і ряд нових проблем. До їх числа, в першу чергу, слід віднести:

- прийняття рішень менеджерами незалежних від фокусної компанії організацій, що викликає підвищення ризиків;

- збільшення залежності від постачальників і клієнтів;

- поява нових видів витрат.

Традиційна структура ланцюга поставок представлена на рис. 2.

Виділення в ланцюзі поставок його структурних складових продиктовано завданнями більш глибокого і детального їх розгляду з метою реалізації управлінських функцій: організації, планування, регулювання, координації, обліку, контролю, аналізу. При реалізації функцій управління важливо виділити підсистеми, ланки та елементи ланцюга поставок, за якими повинні бути закріплені матеріальні і фінансові ресурси, а також визначити склад і повноваження управлінського і робочого персоналу.

Ланцюг поставок (процесне уявлення) — це сукупність потоків і відповідних їм коопераційних і координаційних процесів між різними учасниками ланцюга створення споживчої вартості. 


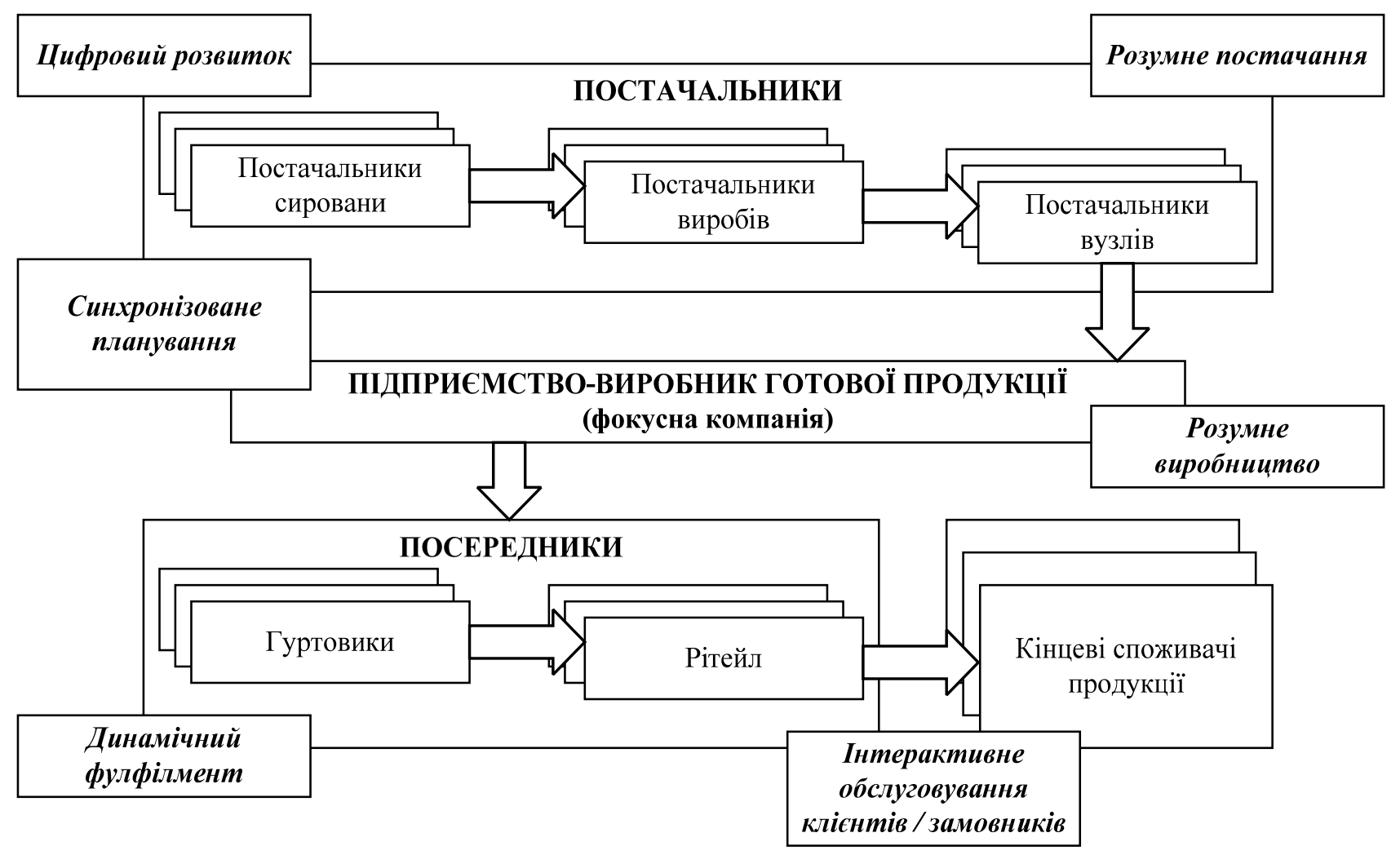
вацій

Рис. 2. Трансформація ланцюга поставок під впливом цифрових інноАвторська розробка

Існують різні підходи до опису бізнес-процесів. Найбільш поширеною є модель, яка запропонована в [6], в якій управління ланцюгами поставок розглядається як інтеграція восьми ключових бізнес-процесів:

- управління взаємовідносинами зі споживачами;

- обслуговування споживачів;

- управління попитом;

- управління виконанням замовлень;

- управління виробництвом/операціями;

- управління постачанням;

- розробка продукту і доведення його до комерційного використання;

- управління зворотними матеріальними потоками.

Серед факторів, що визначають внутрішню і зовнішню середу ланцюга поставок, можливо виділити: складність системи, невизначеність і стохастичність їі параметрів, конфлікт інтересів суб'єктів всередині ланцюга поставок, динамічність ланцюга поставок.

Ланцюг поставок являє собою складну багаторівневу систему, до складу якої входить велика кількість контрагентів, пов'язаних між собою технологічним 
ланцюжком. Проектувати ланцюг поставок, а потім керувати ним таким чином, щоб при цьому витрати всієї системи були мінімальні, а сервіс залишався на заданому рівні, досить складно.

Невизначеність зовнішнього і внутрішнього середовища притаманна кожному ланцюгу поставок. На невизначеність (стохастичність) параметрів зовнішніх і внутрішніх факторів в ланцюзі постачань істотно впливають попит, терміни поставок, рівні товарних запасів, виробничі можливості, час транспортування, природні та людські фактори і т.ін. На даний час розроблені методи, моделі та концепції для максимального зниження невизначеності безпосередньо в ланцюгах поставок [15]. До них відносяться:

- включення надмірності структур ланцюга поставок, таких як додаткові склади, страхові запаси і запаси виробничих потужностей;

- вдосконалення інформаційного обміну, доступності прогнозів попиту для всіх учасників ланцюга поставок, координації та узгодження для поліпшення якості поставок;

- включення системи моніторингу та регулювання ланцюга поставок при виникненні порушень або відхилень від плану.

Велика кількість учасників ланцюга поставок зумовлює і наявність їх інтересів, часто прямо протилежних, що призводить до виникнення конфліктів. Наприклад, метою виробника $\epsilon$ виготовлення і продаж великих партій товару, так як при цьому знижуються питомі витрати на виробництво одиниці продукції, а метою продавця - покупка продукції невеликими партіями i, як наслідок цього, скорочення рівня запасів в дистрибутивної мережі, а значить, зниження витрат і втрат. Таким чином, природні цілі виробників безпосередньо входять в конфлікт з природними цілями продавців.

Параметри ланцюга поставок постійно змінюються, чому сприяють численні обставини, що впливають на відносини всередині ланцюга поставок, такі, наприклад, як попит споживачів і можливості постачальників. Так, збільшення кількості альтернативних постачальників одного і того ж ресурсу, призводить до зниження вартості цього ресурсу i, відповідно, зацікавленості самих постачальників в його виробництві.

\section{2. Стратегія і планування в ланцюгах поставок 2.2.1. Логістичні стратегіï}

Залежно від ступеня значимості для організації і горизонту планування планові рішення діляться на три типи:

1) стратегічні - найбільш важливі, що задають загальний напрям діяльності організації (надають довгостроковий вплив, вимагають великих ресурсів і вважаються найбільш ризикованими); 
2) тактичні - пов'язані з реалізацією стратегії в середньостроковому плані (опрацьовуються більш детально, вимагають менших ресурсів і пов'язані з меншим ризиком);

3) оперативні - детально опрацьовані і стосуються видів діяльності на найближчий час, для їх виконання потрібні досить обмежені ресурси (ризик може бути виключений або зменшений).

Існують такі рівні стратегічних формацій (рис. 3):

1. Місія - декларація, в якій вказуються найбільш загальні цілі організації, сформульовані в інтересах суспільства, клієнтів, інвесторів і працівників.

2. Корпоративна стратегія показує, як корпорація, що здійснює диверсифіковану діяльність, планує реалізувати свою місію.

3. Бізнес-стратегія (для диверсифікованих або мультидивізійних компаній) формулює, як кожен вид бізнесу в рамках диверсифікованої діяльності буде вносити свій вклад в корпоративну стратегію.

4. Функціональні стратегії описують стратегічний напрям кожної актуальною для підприємства функції (зокрема, логістичної), яка реалізується в організації.

Стратегії високого рівня задають мету і загальну спрямованість діяльності організації, а функціональні стратегії показують, як їх можна реалізувати [9]. Логістична стратегія організації складається зі стратегічних рішень, прийомів, планів і методів, пов'язаних з управлінням ланцюгом поставок, і дозволяє реалізувати вже сформовану стратегію підприємства в цілому.

До найбільш загальних логістичних стратегій відносять «струнку» стратегію. Виділяють також динамічну і засновану на стратегічних союзах стратегії.
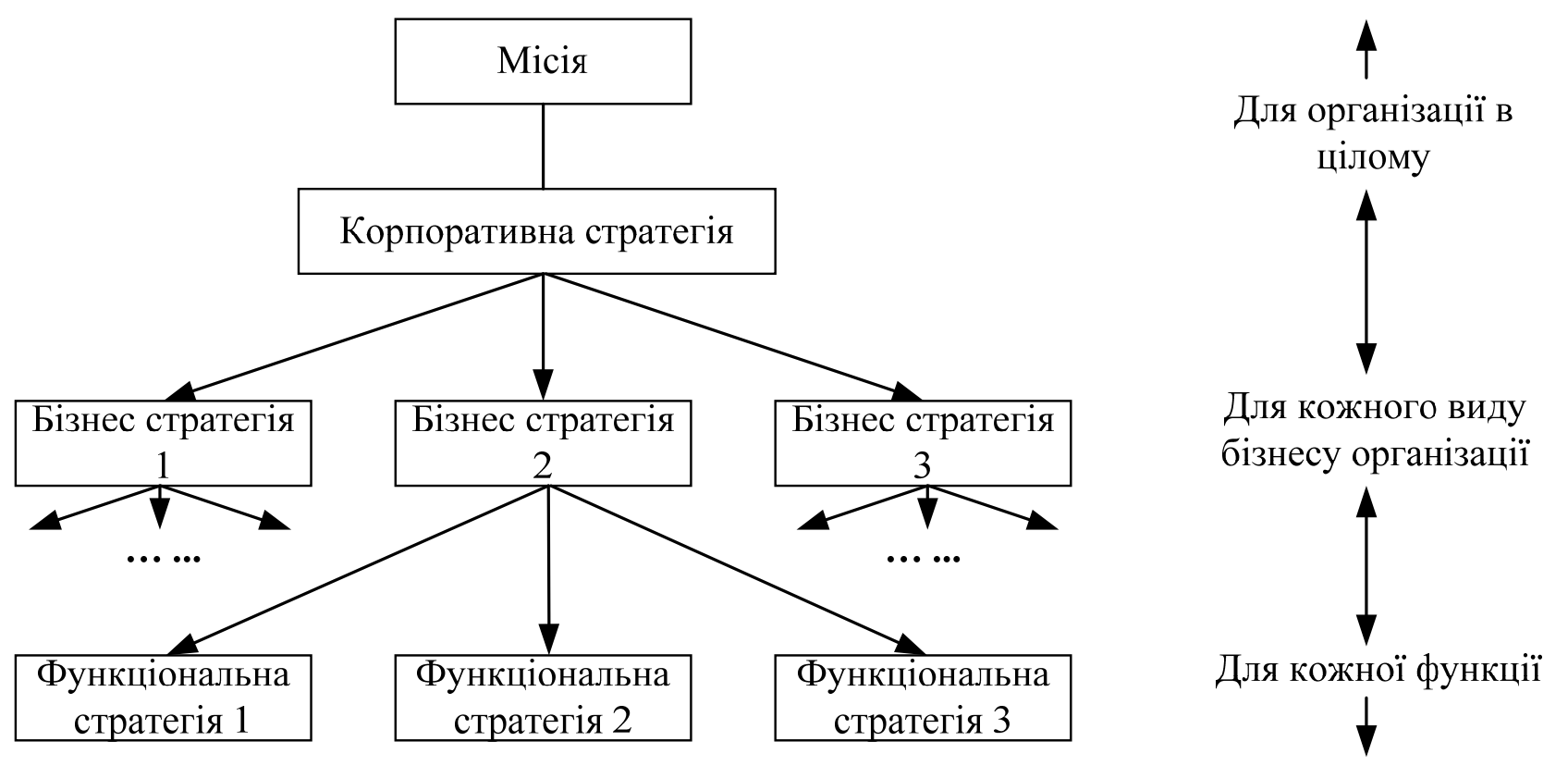

Рис. 3. Рівні стратегічних формацій

Джерело: [2] 
«Струнка» стратегія базується на принципах управління витратами, тобто виробництві тих же або продуктів або послуг, які можливо порівняти, що і у конкурентів, але 3 меншими витратами. Мета «стрункої» логістики - виконувати кожну операцію, використовуючи менше ресурсів: працівників, простору, запасів, обладнання, часу і т.ін. Для цього відшукуються способи усунення непродуктивних витрат ресурсів.

Перші спроби здійснення «струнких» операцій були проведені у виробничій сфері з ініціативи фірми Тоуоta. Використані для цього методи привели до таких успішних результатів, що їх почали використовувати і в інших областях діяльності підприємства і в кінцевому підсумку виникла ідея «ощадливого виробництва». Компанія Toyota виявила наступні ділянки в ланцюгу постачань виробництва, де, швидше за все, можуть даремно губитися ресурси [1]:

1. Якість ресурсів, що поставляються (сировини, матеріалів, комплектуючих, деталей і т.д.) і готової продукції може бути занадто низьким, щоб задовольнити запити споживачів.

2. Надмірний рівень виробництва або потужностей, тобто виробництво зайвої продукції або наявність потужностей, які в даний час не затребувані.

3. Погано налагоджений процес. Наявність непотрібних операцій, занадто складний або тривалий процес.

4. Очікування. Операціям доводиться чекати на початок або завершення (наприклад, виконавцям - надходження матеріалів; обладнанню - переналагодження).

5. Переміщення. Продуктам під час операцій доводиться здійснювати непотрібні, занадто довгі, зустрічні або інші незручні переміщення.

6. Запас. Наявність занадто великого запасу призводить до зайвих витрат і втрат при їх зберіганні.

Типовим підходом до реалізації «стрункої» стратегії є: детальний аналіз поточних операцій і подальша відмова від тих з них, які не додають споживчої цінності; усунення зупинок, спрощення переміщень; використання більш досконалої технології; розміщення потужностей ближче до споживачів; пошук можливостей отримати економію на масштабах; усунення 3 ланцюга поставок непотрібних ланок та інше. Слід враховувати, що «стрункі» стратегії можуть не працювати в дуже динамічних або невизначених умовах. У цих випадках можна скористатися більш гнучкою стратегією, заснованою на динамічності.

Мета динамічної стратегії - забезпечити високу якість обслуговування споживачів за рахунок оперативного реагування на появу нових або зміну попередніх умов.

До інших стратегій, які часто зустрічаються і в яких ставка робиться на більш конкретні аспекти діяльності, належать такі:

1. Стратегія диференціації. Вона полягає в прагненні підприємства до унікальності, наприклад в схемі обслуговування споживачів.

2. Стратегія на основі параметра часу. Така стратегія забезпечує експресдоставку продукції і концентрується в основному на усунення непотрібних витрат 
часу в ланцюзі поставок, тобто таких, протягом яких вартість до продукції не додається. Запити на таке обслуговування існують завжди, про що свідчить значне число компаній, що займаються саме експрес-доставкою.

3. Стратегії на основі захисту навколишнього середовища (чиста логістика). У таких стратегіях, наприклад, ставка може робитися на виробництво продукції з використанням натуральних інгредієнтів, об'єднання дрібних товарних партій вантажів, багаторазове використання тари, виробництво продукції, що не вимагає спеціальної утилізації, переробку використовуваних матеріалів, відходів та інше.

4. Стратегії підвищеної продуктивності (віддачі). Ставка робиться на максимально можливе використання наявних ресурсів. Якщо «струнка» стратегія шукає способи позбутися від непотрібних потужностей (приміщень, транспорту та ін.) і ресурсів, то дана стратегія скоріше погодиться залишити існуючі потужності, але буде шукати способи ефективного використання цих надлишків (здача в оренду, надання нових послуг іншим організаціям і т.ін.).

5. Стратегії доданої вартості. Ці стратегії мають на меті додати якомога більше споживчої цінності до кінцевого продукту. Наприклад, в рамках дистрибуції пральних машин компанія може організувати їх доставку, установку, підключення, навчання використанню, організувати вивезення старих машин, запропонувати укласти контракт на обслуговування і т.ін.

6. Стратегії диверсифікації або спеціалізації. Ці стратегії орієнтовані відповідно на максимально широкий або вузький діапазон послуг, асортимент продукції, видів діяльності. Наприклад, існують транспортні компанії, що пропонують перевезення будь яких вантажів: від листа до контейнерів, а інші транспортні компанії займаються доставкою тільки довгомірних вантажів та інше.

7. Стратегія фокусування. Така стратегія характеризується концентрацією на задоволенні потреб одного сегмента або конкретної групи покупців, без прагнення охопити увесь ринок. Мета стратегії: задовольняти потреби споживачів обраного цільового сегмента за рахунок своїх компетенцій краще, ніж менш компетентні конкуренти.

8. Стратегії зростання. Вони засновані на прагненні отримати економію на масштабах шляхом розширення обслуговуються географічних зон, освоєння більшої кількості видів діяльності, збільшення частки ринку.

\subsubsection{SWOT-аналіз при розробці логістичної стратегії}

Стратегія описує принциповий образ дій, обраний для того, щоб досягти поставлених цілей. При проектуванні логістичної стратегії вихідною точкою стає всебічний аналіз стратегії вищого рівня (рис. 4), що дозволяє зрозуміти, яким чином логістика може внести свій вклад в їі реалізацію. Крім того, необхідно враховувати:

- середу, в якій ведеться бізнес, що включає фактори, які впливають на логістику, але якими вона управляти не може; 
- особливу компетенцію організації, яка визначається факторами, якими організація може керувати і які вона використовує, щоб відрізнитися від інших (рис. 3).

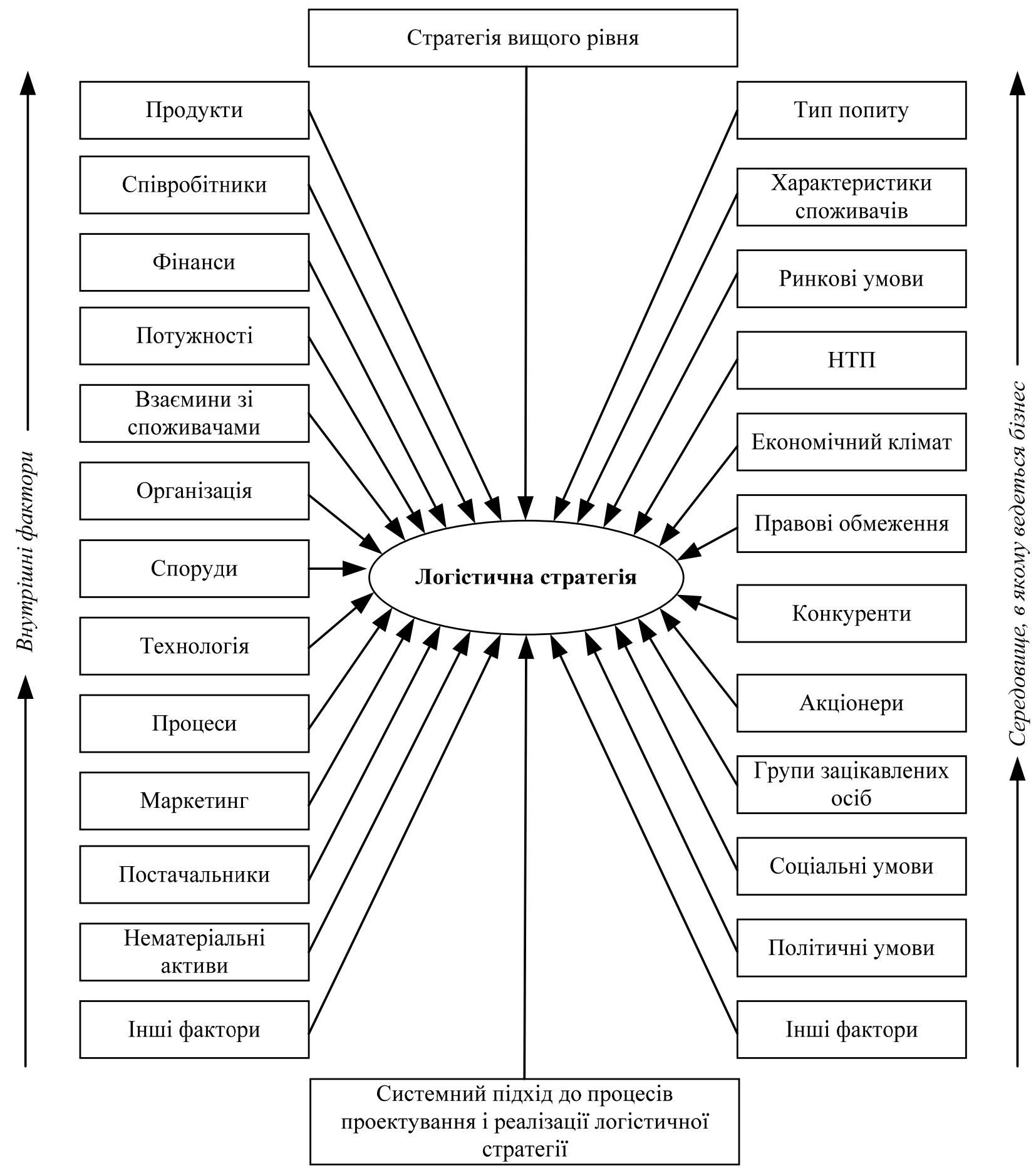

Рис. 4. SWOT-аналіз чинників, що враховуються при розробці логістичної стратегії

Авторська розробка 
Середовище, в якому ведеться бізнес, і особливі компетенції вказують, яке становище організація займає в даний час, а стратегія вищого рівня - яке вона хоче займати в майбутньому. Тоді логістична стратегія показує, як організація буде переходити від нинішнього стану до майбутнього. Для отримання інформації про середовище ведення бізнесу і про необхідні особливих компетенціях застосовують логістичний аудит. Його метою є збір важливої інформації про існуючі методи і умови проведення логістичної діяльності. Відповідно до двох зазначених напрямів пошуку інформації логістичний аудит ділиться на зовнішній, який займається середовищем дії логістики, і внутрішній, який аналізує спосіб виконання операцій усередині організації і виявляє ділянки, що потребують вдосконалення.

В ході SWOT-аналізу вивчаються сильні і слабкі сторони організації, тобто іï внутрішні операції і особливі компетенції; можливості та загрози, які проявляються в середовищі, в якій ведеться бізнес. Ключовим фактором середовища, в якому ведеться бізнес, є тип попиту, який обумовлює вибір «стрункої» або динамічної стратегії. Так, «струнка» стратегія працює найкраще в умовах, коли попит стабільний або передбачуваний. Динамічна стратегія краще працює в ситуаціях широкого асортименту продукції, коли складно точно спрогнозувати попит, коли він різко змінюється, коли операції виконуються на замовлення.

При переході до реалізації стратегії необхідно розглядати рішення по кожній логістичної функції від постачання до постачання. Можливо виділити наступні найбільш важливі області, в яких в першу чергу треба приймати рішення: конфігурація ланцюга поставок, розміщення елементів інфраструктури та організація допоміжних процесів.

\subsection{3. Планування в ланцюгах поставок}

Планування логістичної діяльності — це систематичний процес пошуку можливостей діяти, прогнозування наслідків цих дій, розробки логістичного проекту, формування управлінських рішень, конкретних заходів і термінів їх виконання для досягнення поставлених цілей в майбутньому. Для організації ефективного планування на підприємстві повинна існувати система планування. Основними вимогами до такої системи є документальне забезпечення; стандартизація; організованість; точність; узгодженість; безперервність; гнучкість; циклічність; повнота. Перед початком планування необхідно чітко визначити:

- об’єкт планування (що планується);

- суб'єкт планування (хто планує);

- горизонт планування (на який термін);

- засоби планування (за допомогою чого планувати: фінансові кошти, обчислювальна техніка);

- методику планування (як планувати);

- узгодження планів (яких, з ким і на яких умовах). 
Кожен з видів планування за термінами і по деталізації конкретизує і створює передумови для виконання планів вищого рівня.

Основні кроки стандартного підходу, який називають планування вимог по ресурсах, для планування потужностей:

- вивчення прогнозу попиту і визначення необхідної потужності;

- вивчення потужності, яка наявна в даний час;

- виявлення різниці між необхідною і наявної потужностями;

- запропонування альтернативних варіантів, що дозволяють усунути цю різницю;

- порівняння планів і вибір з них найкращого;

- реалізування найкращих варіантів, при необхідності - модифікування плану;

- контроль результатів.

\section{3. Управління в ланцюгах поставок}

\subsection{1. Система управління в ланцюгах поставок}

Система управління SCM повинна вирішувати такі завдання:

1. Проектування і управління конфігурацією дистриб'юторської мережі: число, розташування і мережеві представництва постачальників, виробничі потужності, розподільні центри, склади, пункти перевантаження і споживачі.

2. Формування і реалізація стратегії розповсюдження товару: питання оперативного контролю (централізованого, децентралізованого або спільного); схеми доставок, способи транспортування, стратегія поповнення запасів і контроль транспортування.

3. Оптимізація логістичної діяльності для досягнення найменших загальних витрат. Обов'язкове застосування системного підходу при плануванні логістичних дій.

4. Формування єдиного інформаційного простору: інтеграція процесів повинна охоплювати весь ланцюг постачань, забезпечуючи спільність ключової інформації, такої як запити, прогнози, товарні запаси, транспортування і т.д.

5. Управління запасами: кількість і розташування складських запасів, у тому числі сировини, незавершеного виробництва і готової продукції.

6. Управління грошовими потоками: регулювання умов і методів оплати між учасниками ланцюга поставок.

Стратегічний рівень управління в ланцюзі поставок [17] передбачає:

- стратегічну оптимізацію мережі, включаючи кількість, розташування і розмір складських приміщень, розподільні центри та виробничі потужності;

- стратегічне партнерство з постачальниками, дистриб'юторами і споживачами при створенні каналів зв'язку для важливої інформації і поліпшення таких оперативних показників, як наскрізне складування, пряме перевезення і комплексна стороння логістика; 
- управління життєвим циклом продукції та виробничими потужностями, 3 тим щоб існуючу і нову продукцію можна було оптимально інтегрувати в ланцюг поставок;

- сегментування споживачів i, відповідно, продукції для кореляції корпоративних завдань з виробничої стратегією і принципами розподілу товару;

- рішення «де виробляти» і «зробити самому або купити»;

- узгодження загальної організаційної стратегії з принципами поставки.

Тактичний рівень передбачає наступне:

- рішення виробничих питань, в тому числі залучення підрядників, настройка процесу планування;

- рішення складських питань, включаючи кількість і розміщення складів, якість складування;

- вирішення питань транспортування, в тому числі частота поставок, маршрути і укладення договорів;

- порівняльний аналіз операцій, спрямованих на суперництво 3 конкурентами, впровадження кращих практик на підприємстві.

Оперативний рівень управління включає в себе:

- планування виробництва для кожного виробничого підприємства в ланцюгу поставок;

- прогнозований попит, координування прогнозованого попиту всіх споживачів і повідомлення прогнозу всім постачальникам;

- щоденне планування розподілу, в тому числі в ланках в ланцюзі поставок;

- планування постачання, включаючи поточні потреби складу і прогнозований попит, спільно з усіма постачальниками;

- прийом постачань, в тому числі транспортування від постачальників і отримання товарних запасів;

- виробничу діяльність, включаючи споживання матеріалів і рух готової продукції;

- видачу продукції, складське зберігання і транспортування споживачам;

- оцінку здійсненності замовлень, облік всіх обмежень в ланцюзі постачань, включаючи всіх постачальників, виробничі потужності, розподільні центри та інших споживачів, аналіз виконання поставок;

- від виробничого рівня до рівня поставки облік всіх випадків пошкодження під час перевезення і їх врегулювання на рівні споживача за допомогою відшкодування збитку у страховій компанії;

- управління складськими запасами, що швидко псуються, і запобігання накопиченню продукції, яка швидко псується.

Управління організаційними змінами в ланцюгах поставок. Навіть найдосконаліша господарська система вимагає постійного коректування, яка обумовлена змінами внутрішнього та зовнішнього середовища. Зовнішнє середовище активно змінюється під впливом ринкової кон'юнктури, інновацій, розвитку нових техно 
логій і т.ін. Внутрішні зміни, такі як зміна учасників ланцюга постачань, коригування взаємовідносин між ними, вдосконалення інформаційних технологій, розробка нового продукту і т. ін., також призводять до необхідності здійснювати організаційні зміни в ланцюзі поставок.

Для того щоб ланцюг поставок відповідав цим змінам, необхідно використовувати методологію системного аналізу, яка дозволяє враховувати виникаючі обставини і оцінювати альтернативи майбутнього розвитку подій. Здійснювання організаційні зміни системи, що складається з цілісної сукупності організацій масштабне заняття, що вимагає детального опрацювання і серйозних вкладень часу і фінансів [13]. Проте, безперервне поліпшення процесів, що протікають в ланцюзі поставок, - необхідна стратегія бізнесу на конкурентному ринку. Управління організаційними змінами в ланцюгах постачань можна здійснювати, грунтуючись на п'яти основних підходах:

1) методика швидкого аналізу рішення (FAST);

2) бенчмаркінг процесів;

3) інжиніринг процесів;

4) реінжиніринг процесів;

5) оптимізація ланцюга постачань.

Методика швидкого аналізу рішення використовується найчастіше на оперативному або тактичному рівнях управління. Являє собою підхід, який концентрує увагу групи на конкретному процесі для визначення способів, якими можна його поліпшити. Спочатку визначається проблема, потім збирається група фахівців і розробляє узагальнену блок-схему змін, а також план заходів, здатних поліпшити показники процесу. У разі якщо результати роботи групи визнаються задовільними, відбувається реалізація пропозицій.

Інший підхід з управління організаційними змінами - бенчмаркінг. Це порівняння показників діяльності своїх процесів 3 показниками діяльності процесів іншої організації, тобто використання кращої практики. При бенчмаркингі бізнеспроцесу ключові процеси ідентифікуються і порівнюються з кращими еквівалентними процесами для визначення розбіжностей.

Інжиніринг проводиться, якщо $є$ необхідність поліпшити вже існуючі процеси, і застосовується до тих з них, які досить успішно працюють і зараз. Інжиніринг доцільно використовувати в тому випадку, якщо поліпшення показників діяльності організації зможе забезпечити їй конкурентну перевагу. При цьому будується імітаційна модель поточного стану компанії, при реалізації якої відбувається модернізація процесу за рахунок використання засобів автоматизації, механізації, застосування інформаційних технологій. Одночасно з цим усуваються дублюючі функції, відбувається стандартизація та спрощення методів, скорочується тривалість циклу, процес захищається від помилок.

Реінжиніринг процесу являє собою підхід до поліпшення бізнес-процесів організації, заснований на розробці нового процесу, і $є$ найбільш радикальним способом впровадження структурних змін з використанням інноваційних технологій. 
Даний підхід використовується в тих випадках, коли процес настільки застарів, що його збереження не є доцільним.

Оптимізацію ланцюга поставок це - інтеграція ключових бізнес-процесів і координація дій контрагентів ланцюга 3 метою синхронізування всіх видів діяльності, які здійснюються в ході виробництва і дистрибуції, які додають артості для кінцевого споживача, і усунення видів діяльності, які вартості не додають. Управління ланцюгами поставок направлено на оптимізацію всієї системи для того, щоб домогтися більш високої якості обслуговування при більш низьких загальних витратах. Можна вказати п'ять основних способів, за допомогою яких це можна зробити [16]:

1) скорочення всіх видів втрат і діяльності, що не додають вартості, наприклад вантажопереробки, зберігання їх надлишкових запасів;

2) поліпшення обслуговування споживачів, наприклад скорочення часу виконання замовлення;

3) поліпшення комунікацій в ланцюзі поставок, особливо пов'язаних 3 прогнозуванням діяльності контрагентів і інтегрованим плануванням;

4) скорочення часу на розробку нової продукції;

5) більш повна координація зусиль зі стикування один з одним всіх ланок в ланцюзі поставок.

Переваги оптимізації ланцюга поставок. За даними найбільших аналітичних компаній (AMR Research, Forrester Research), при грамотній організації функціонування SCM компанії отримують такі важливі конкурентні переваги:

- збільшення прибутку від 5 до 15\%;

- зменшення вартості і часу обробки замовлення від 20 до 40\%;

- зменшення складських запасів від 20 до 40\%;

- скорочення часу виходу на ринок від 15 до 30\%;

- скорочення закупівельних витрат від 5 до 15\%;

- скорочення виробничих витрат від 5 до 15\%.

\subsection{2. Моделі і методи управління ланцюга поставок}

Міжнародна організація Рада по ланцюгах поставок (The Supply-Chain Council - SCC), синтезувавши в собі передові досягнення концепції SCM, розробила 3 метою більш ефективного аналізу, планування і проектування ланцюгів поставок так звану SCOR-модель (Supply-Chain Operations Reference Model) - «Рекомендовану модель операцій в ланцюгах поставак».

3 метою розвитку та вдосконалення стандартів SCOR-моделі Рада по ланцюгам поставок розробила Design Chain Operations Reference model (DCOR рекомендована модель операцій в ланцюгах проектування), яка охоплює 
створення продукту, дослідницькі проекти і розробку. Модель DCOR може бути використана як окремо, так і разом з моделлю SCOR.

SCOR-модель - це референтна модель, що передбачає власну мову для опису взаємин між учасниками ланцюга поставок. У даній моделі застосовується система оцінки ефективності роботи цього ланцюга і бібліотека типових бізнеспроцесів. За допомогою SCOR-моделі створюються єдині процеси, які можна порівняти і пристосовані для оцінки всередині ланцюга поставок. В моделі визначені типові бізнес-процеси, горизонтальні і вертикальні зв'язки і бізнес-правила, що діють в різних областях. Використання SCOR-моделі дозволяе оцінити процес проходження матеріального потоку по ланцюгу поставок комплексно і в динаміці.

Модель DCOR може бути використана як окремо, так i разом з моделлю SCOR. Як i SCOR-модель, DCOR-модель заснована на виділенні п'яти базисних бізнес-процесів (табл. 1).

Таблиця 1

Базисні бізнес-процеси

\begin{tabular}{|c|c|}
\hline $\begin{array}{l}\text { БiзH } \\
\text { DCC }\end{array}$ & Характеристика ключових бізнес-процесів \\
\hline $\begin{array}{l}\text { Plan } \\
\text { (планування) }\end{array}$ & $\begin{array}{l}\text { Створення та затвердження заходів на певний проміжок часу, } \\
\text { які представляють проєктне призначення ресурсів для вимог } \\
\text { ланцюга проектування }\end{array}$ \\
\hline L & $\begin{array}{l}\text { Ідентифікація та декомпозиція напрямків досліджень шляхом } \\
\text { обробки інформації, оцінки та архівації отриманих дослідних } \\
\text { даних (ідентифікація джерел досліджень, сорсингу, затвер- } \\
\text { дження стандартів (сертифікація) матеріалів / продукції, що } \\
\text { відповідають вимогам замовника) }\end{array}$ \\
\hline $\begin{array}{l}\text { n } \\
\text { ктування) }\end{array}$ & $\begin{array}{l}\text { Нням шляхом оновлення, створен- } \\
\text { ізації форми продукту або онов- } \\
\text { основі використання, тестування, } \\
\text { роцесів і процесів розміщення }\end{array}$ \\
\hline $\begin{array}{l}\text { Intę } \\
\text { (iHTe }\end{array}$ & $\begin{array}{l}\text { Процес управління інтеграцією шляхом випуску варіацій } \\
\text { оновленого і нового продукту для ланцюга постачань, } \\
\text { виконання або випуску проєктої документації оновленого або } \\
\text { нового продукту для маркетингових або підтримуючих акцій }\end{array}$ \\
\hline $\begin{array}{l}\text { Amend } \\
\text { (вдосконалення) }\end{array}$ & $\begin{array}{l}\text { Процес управління вдосконаленням на основі збору і аналіз } \\
\text { результатів проєктування продукту шляхом організації та } \\
\text { підтримки зворотного зв'язку про розширення можливості } \\
\text { цього продукту }\end{array}$ \\
\hline
\end{tabular}

Джерело: [1] 
Крім п'яти основних управлінських процесів, які обумовлюють організаційну структуру DCOR-моделі, необхідно відзначити три типи процесів моделі:

1) planing (планування);

2) execution (виконання);

3) enable (забезпечення).

Процесні категорії DCOR фокусуються на трьох областях:

1) Prodact Refresh (оновлення продукту);

2) New Product (новий продукт);

3) New Technology (нова технологія).

Радою по ланцюгам поставок передбачається також розробка третьої моделі CCOR (Customer Chain Operations Reference model, Рекомендована модель по ланцюгах споживачів), яка разом з двома існуючими складе так звану Integrated Business Reference Framework (IBRF, Рекомендована інтегрована бізнес структура). IBRF - це інструмент для бізнес-планування, який зможе зв'язати воєдино всі ланцюжки управління вартістю, тобто допоможе пов'язати вимоги покупців, управління даними про продукт, управління життєвим циклом продукту, час циклу і витрати циклу. 3 впровадженням цієї структури організації вперше знайдуть можливість поєднати в повному ланцюгу створення цінності продукту ланцюг проектування, ланцюг поставок і ланцюг споживачів. Як тільки бізнес-процес описано в стандартних термінах референтної моделі, він може бути однозначно ідентифікований. Всі елементарні операції і їх послідовності стають вимірюваними, керованими і контрольованими. Таким чином, досягається можливість перенастроювання процесів на досягнення конкурентної переваги або їх гнучкого зміни відповідно до конкурентними завданнями.

3 огляду на економічну невизначеність і зростаючі ризики, пов'язані з функціонуванням ланцюгів поставок, дослідники 3 коледжу менеджменту Технологічного інституту штату Джорджія (Georgia Institute of Technology's College of Management) вивчали зв'язок між ефективністю ланцюга поставок і практичними заходами, які сприяють ії підвищенню в компаніях, які працюють в сфері високих технологій, виробничих підприємствах, у виробників товарів широкого вжитку, виробників фармацевтичних продуктів і на підприємствах роздрібної торгівлі. Ці дослідження проводилися більш ніж в 60 компаніях Європи і Північної Америки.

Ці успішні компанії витрачають менше коштів на дистрибуцію, забезпечують більш високий рівень обслуговування клієнтів і ефективніше управляють товарноматеріальними запасами в порівнянні з конкурентами.

Практичний досвід цих компаній, які зуміли вибудувати ефективні ланцюга поставок і результати дослідження, проведеного компанією McKinsey дозволяють виділити шість спеціальних методів управління:

1. Узгодження стратегії управління ланцюгом поставок із загальною стратегією компанії, постановка чітких цілей. 
2. Узгодження стратегії управління ланцюгом поставок із загальною стратегією компанії, постановка чітких цілей.

3. Сегментація ланцюга поставок для усунення надлишкової складності, пов'язаної з виробництвом продукції і наданням послуг

4. Вибудовування мережі поставок таким чином, щоб забезпечувалося оптимальне співвідношення між цільовими показниками по рівню обслуговування, витратами і ризиками.

5. Використання методів «ощадного виробництва» для оптимізації всіх ланок ланцюга поставок.

6. Розробка інтегрованого підходу до планування продажів і виробництва $(\mathrm{S} \& \mathrm{OP})$.

Експерти в галузі управління ланцюгами поставок прогнозують як буде виглядати «досконалий» ланцюг поставок в найближчому майбутньому, приділяючи основну увагу управлінню відносинами з постачальниками, логістики вхідних потоків, крос-докінгу, прийому товарів, поповненню товарних запасів та управлінню розміщенням товарів, плануванню асортименту і управлінню запасами, RFID-технології (радіочастотна ідентифікація), яка в найближчі роки залишиться затребуваною технологією, застосуванню системного підходу до планування попиту і виробництва. Окрема увага приділяється зміцненню ланцюга поставок 3 використанням уніфікованих правил визначення країни походження товарів та систематизації нових правил електронної торгівлі.

Як підкреслювалося в другому розділі, на невизначеність параметрів зовнішніх і внутрішніх факторів в ланцюзі поставок істотно впливають попит, терміни поставок, рівні товарних запасів, виробничі можливості, час транспортування, природні та людські фактори і т.д. Далі розглянемо основні актуальні аспекти сучасного стану ланцюгів поставок.

\section{4. Актуальні аспекти сучасного стану ланзюгів поставок}

\subsection{1. Неоднозначність в контексті ланцюга постачань}

Сучасний світ постійно змінюється, стає все більш нестабільним 3 кожним днем, де великі і маленькі зміни стають все більш непередбачуваними - i вони стають все більш і більш драматичними й відбуваються все швидше і швидше.

Каталізатором змін у світових ланцюгах поставок став 2020 рік, змінилися їх внутрішні та зовнішні контексти, зявилися нові тренди, інновації та можливості.

Оскільки події розвиваються зовсім несподіваним чином, стає неможливо визначити причину і наслідок.

Передбачати події або передбачити, як вони будуть розгортатися, стає все важче; історичні прогнози і минулий досвід втрачають свою актуальність і рідко застосовуються в якості основи для передбачення форми подій в майбутньому. 
Стає майже неможливим планувати інвестиції, розвиток і зростання, оскільки стає все більш незрозумілим, в якому напрямку буде рухатися.

Вимоги, що пред'являються до сучасних організацій і менеджменту, більш суперечливі і парадоксальні, ніж будь-коли, кидаючи виклик нашим системам особистих цінностей. У світі, де «що» відходить на другий план у порівнянні 3 «чому?» і «як?», прийняття рішень вимагає мужності, усвідомленості і готовності робити помилки.

VUCA - це акронім англійських слів «volatility» (мінливість), «uncertainty» (невизначеність), «соmplexity» (складність) і «ambiguity» (неоднозначність). Світ VUCA - це світ, в якому завдання прогнозування важко реалізувати. Бізнессередовище в контексті VUCA-світу характеризується такими ознаками.

Таблиця 2

Неоднозначність в контексті ланцюга постачань

\begin{tabular}{|c|c|c|}
\hline Концепція & Визначення & Контекст (и) \\
\hline $\begin{array}{l}\text { Двозначність } \\
\text { продуктивності }\end{array}$ & $\begin{array}{l}\text { Труднощі, з якими стикаються } \\
\text { особи, які приймають рішення } \\
\text { (покупці), з точною оцінкою } \\
\text { результативності (постачальників) }\end{array}$ & $\begin{array}{l}\text { Модель розподілу } \\
\text { потужностей і } \\
\text { управління якістю } \\
\text { виробника }\end{array}$ \\
\hline $\begin{array}{l}\text { Інформаційна } \\
\text { двозначність }\end{array}$ & $\begin{array}{l}\text { Інтерпретація неадекватної } \\
\text { інформації }\end{array}$ & $\begin{array}{l}\text { Тактова частота } \\
\text { продукту та інтеграція } \\
\text { ланцюга поставок }\end{array}$ \\
\hline $\begin{array}{l}\text { Причинна } \\
\text { невизначеність }\end{array}$ & $\begin{array}{l}\text { Стосується неоднозначного } \\
\text { характеру причинно-наслідкових } \\
\text { зв'язків між діями і результатами } \\
\end{array}$ & $\begin{array}{l}\text { Вирішальні фактори } \\
\text { передачі знань і теорія } \\
\text { переваги ресурсів } \\
\end{array}$ \\
\hline $\begin{array}{l}\text { Екстремальна } \\
\text { двозначність }\end{array}$ & $\begin{array}{l}\text { Особи, які приймають рішення не зна- } \\
\text { ють, що майбутні сценарії можливі }\end{array}$ & $\begin{array}{l}\text { Стале управління } \\
\text { ланцюгом поставок }\end{array}$ \\
\hline $\begin{array}{l}\text { Невизначеність } \\
\text { ролі }\end{array}$ & $\begin{array}{l}\text { Невпевненість в своїх повноважен- } \\
\text { нях та обов'язках в ланцюгу } \\
\text { поставок }\end{array}$ & $\begin{array}{l}\text { Рольова небезпека між } \\
\text { партнерами по ланцюгу } \\
\text { поставок }\end{array}$ \\
\hline $\begin{array}{l}\text { Двозначність } \\
\text { відносин }\end{array}$ & $\begin{array}{l}\text { Розуміння двох бізнес-операцій, } \\
\text { потреб та стратегій }\end{array}$ & $\begin{array}{l}\text { Адаптація управління } \\
\text { поставками та зв’язком } \\
\text { постачальник-покупець }\end{array}$ \\
\hline $\begin{array}{l}\text { Невизначеність ча- } \\
\text { су обслуговування }\end{array}$ & $\begin{array}{l}\text { Невизначеність щодо ймовірностей } \\
\text { часу обробки }\end{array}$ & \begin{tabular}{|l|} 
Час обробки. Неодно- \\
значність та конкурен- \\
тоспроможність порту \\
\end{tabular} \\
\hline $\begin{array}{l}\text { Невизначеність } \\
\text { щодо ймовірностей }\end{array}$ & $\begin{array}{l}\text { Перевага для азартних ігор на } \\
\text { відомих ймовірностях, ніж на } \\
\text { неоднозначних }\end{array}$ & $\begin{array}{l}\text { Кілька практичних } \\
\text { застосувань }\end{array}$ \\
\hline
\end{tabular}

Джерело: [18] 
Volatility (мінливість, нестабільність, нестійкість, волатильність) - ситуація змінюється швидко і непередбачувано, хаотично, на основі даних змін не можна передбачати майбутню ситуацію або планувати дії. Жорстоке збільшення чотирьох вимірів змін: тип, швидкість, обсяг і масштаб.

Uncertainty (невизначеність) — те «місце», де основні руйнівні зміни трапляються. I минуле в даному місці не $\epsilon$ провісником майбутнього, адже визначення того, що гряде, є вкрай скрутним.

Complexity (складність) - те «місце», де безліч складних для розуміння фактів, причин і чинників формують проблеми. Складність «без чіткого зв'язку між причиною і наслідком зачіпає всі організації».

Ambiguity (неоднозначність, неясність, двозначність, невизначеність) - те «місце», де складно відповісти на питання «хто, що, коли і чому» [22].

Багато рішень в ланцюгах поставок, такі як закупівлі, розподіл потужностей, укладання договорів, планування, відстрочка і прогнозування попиту, можуть бути змодельовані як проблеми прийняття рішень в умовах невизначеності і неоднозначності (табл. 2).

Неоднозначність відповідає ситуації, коли недостатньо інформації для визначення об'єктивних ймовірностей і коли навіть суб'єктивний розподіл ймовірностей не може бути визначений однозначно [18].

В простій формі під неоднозначністю мається на увазі, що ситуація відкрита для більш ніж однієї інтерпретації, при цьому однозначна ситуація описується як та, що має чітке розуміння, оскільки вона має одне значення. Оскільки організація та управління пов'язані з осмисленням ситуацій або подій, цілком можливо, що виникає багато непослідовних інтерпретацій.

\subsection{2. Попит-оріснтовані мережі та ланцюги поставок}

Концепція попит-орієнтованих мереж поставок (Demand Driven Supply Networks - DDSN) розроблена компанією AMR Research. Дослідження AMR Research визначає попит-орієнтовані мережі поставок як систему технологій і процесів, яка відчуває і реагує на попит в режимі реального часу завдяки мережі споживачів, постачальників і працівників.

Метод планування DDSC використовує техніку «тяжіння попиту». Це дає ринку можливості обмінюватися додатковою інформацією та більш ефективно співпрацювати 3 іншими учасниками ланцюга поставок. Ринок, керований попитом, як правило, більш еластичний у порівнянні з традиційними методами ланцюга поставок. Наприклад, ціни на ринку, керованому попитом, реагують на будь-які зміни попиту, тоді як протилежні реагують на зміни пропозиції. Таким чином, попит визначається споживачами, в той час як традиційні методи Supply Chain Management в першу чергу визначаються постачальниками. 
Щоб впровадити DDSN, компанії повинні розглядати попит на різних рівнях, включаючи бажання споживача користуватися по черзі різними вигодами, спочатку доступністю (швидкістю доставки) товару, а потім ціною. Відчувати і реагувати на попит в реальному часі не означає просто виконувати замовлення. Це означає швидке застосування бізнес оцінок до всього попиту.

Виробники, що працюють за контрактом, залучені розробники нової продукції, незалежні постачальники логістичних послуг - все це частини швидкої трансформації ланцюга поставок з вертикально інтегрованих корпорацій в бізнес мережі, побудовані на вузькій спеціалізації ланок. Для того щоб мережа була успішною, повинні існувати наскрізні і надійні стандарти i загальні канали комунікацій.

DDSN має три стратегічних області - управління попитом, управління пропозицією і управління продуктом.

Традиційний ланцюг поставок майже не звертає уваги на управління попитом, яке визначається як «процес, необхідний для формування, сприйняття і реагування на попит». Управління попитом включає функції маркетингу, продажів, післяпродажного обслуговування, управління ціною і функції прогнозування / планування. Половина рішення задачі пошуку оптимального співвідношення попиту і пропозиції (supply/demand balance) відноситься до компетенції управління попитом.

У DDSN встановлюється взаємодія складових функцій для реального управління попитом. Прогнозування продажів - надійне джерело інформації для діяльності, в якій всі обмеження ясні, маркетинг взаємодіє з ланцюгами поставок для просування існуючих товарів і запуску нових; продажу і послуги покладаються на логістику для визначення статусу замовлення. Вся ця інформація необхідна для формування найбільш точного уявлення про попит в поточний момент часу.

Концепцію планування потреби в матеріалах на основі попиту (DDMRP) було створено Керол Птак та Чадом Смітом на початку XXI століття і представлено у книзі «Вимоги до потреб, що регулюються попитом» [23].

Для того, щоб впоратися 3 поточними ринковими проблемами, DDMRP використовує відомі концепції, взяті з MRP (Планування матеріальних вимог), DRP (Планування вимог до розподілу), Lean, 6 Sigma та TOC (Теорія обмежень), a також конкретні нововведення.

Стратегія попит-орієнтованого ланцюга поставок не переслідує конкретних цілей «ощадного виробництва». Замість цього потрібно правильно визначити розмір запасів і розмістити їх в стратегічно вигідних місцях (рис. 5). Буферні запаси відіграють важливу роль в керованому попитом ланцюгу поставок, який в ідеалі управляється відповідно до таких принципів:

1. Встановлюються незалежні буферні кадастри, які виступають в якості точки поділу. Це допомагає запобігти збільшенню природної мінливості процесів в ланцюгах поставок. 
2. Рівні буферних запасів підтримуються відповідно до типового попиту та відомостей про мінливість.

3. Кожне складське місце поповнюється відповідно до оптимізованого циклу і послідовності, що відповідають споживанню запасів.

4. Виключне накопичення запасів в місцях зберігання буферних запасів покриває сезонні піки, маркетингові кампанії, періоди планових простоїв виробництва та інші заплановані події.

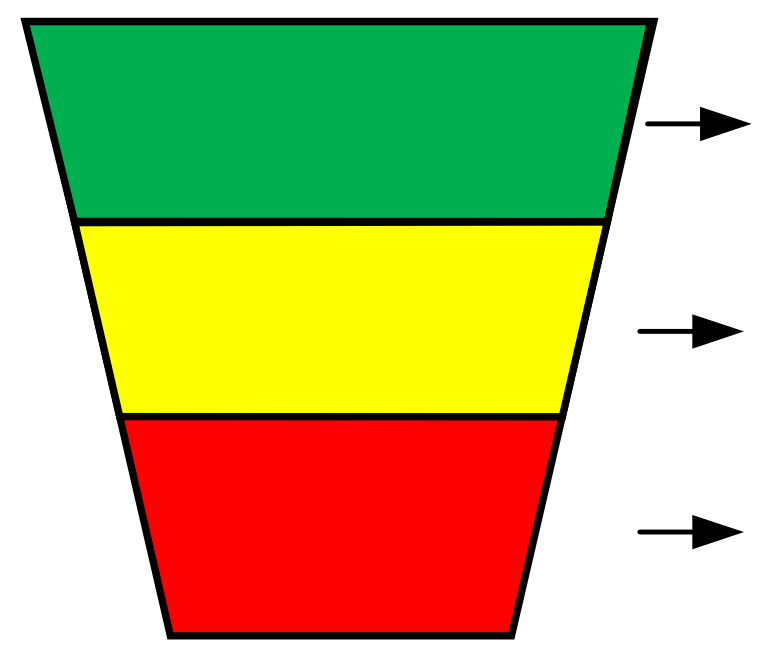

Зелена зона визначає кратність циклу замовлення. Якщо $\epsilon$ велика мінімальна партія, буде велика зелена зона і рідше будуть поповнення.

Жовта зона розраховується: розмір lead-time на виробництво/постачання помножене на середнс споживання.

Червона зона призначена для того, щоб гасити варіабельність, яка виникає в системі.

\section{Рис. 5. Параметри, необхідні для визначення розміру буферів запасу DDMRP} Джерело: [20]

Ці стратегічні буфери є точками поділу для управління джерелами мінливості i ïx основним наслідком: ефектом батога (Bullwhip Effect).

Щоб встановити точки розв'язки, необхідно проаналізувати деякі важливі критерії: час терпимості клієнта, потенційний час виконання замовлення на ринку, горизонт видимості замовлень на продаж, зовнішня мінливість, використання запасів і гнучкість, а також захист критичних операцій.

Що стосується мінливості, тут визначені чотири основних джерела мінливості DDMRP:

- мінливість пропозиції: з точки зору часу та кількості;

- варіативність попиту: з точки зору часу та кількості;

- операційна мінливість: через управління процесом 3 потенційними поломками, варіаціями часу роботи та проблемами якості;

- варіативність управління: у стратегії, що використовується для управління системою, і в способі ії пояснення для різних команд.

Загальна перевага DDSC полягає в тому, що вигоди можуть отримати всі учасники ланцюга поставок: постачальники сировини, виробники, роздрібні торговці і навіть кінцеві споживачі. Деякі з багатьох переваг впровадження підходу DDSC включають: 
1. Розширення взаємодії і співпраці всередині організації, оскільки всі використовують один і той же формат.

2. Більш ефективний спосіб для організації задоволення потреби клієнтів, партнерів та інвесторів.

3. Можливість домогтися безперервності бізнесу.

4. Досягнення більшої видимості в короткостроковій і довгостроковій перспективі.

5. Можливість швидше реагувати на зміни попиту.

6. Можливість зменшити оборотний капітал.

7. Скорочення транспортних витрат.

8. Зменшення часу планування продажів і планування операцій.

9. Обмеження шкоди навколишньому середовищу і репутації компанії за рахунок відмови від необхідності знищувати запаси.

\subsection{3. Синхромодальність в логістиці}

Синхромодальність - це надання ефективних, надійних, гнучких і стійких послуг за допомогою координації та співпраці зацікавлених сторін і синхронізації операцій в рамках мережі або одного ланцюга поставок, що керуються інформаційними та комунікаційними технологіями (IKT) та інтелектуальною транспортною системою (ITC) [17].

Інформація в режимі реального часу важлива для синхромодальної логістики. Фактично, інші функції сильно залежать від інформації в реальному часі. В ідеалі в синхромодальному ланцюзі постачань зацікавлені сторони повинні мати можливість мати глобальне уявлення про статус своєї діяльності і події, що впливають на них. Володіючи цими знаннями, можна прийняти ефективні процедури перепланування і негайно відреагувати на несподівані події.

Обмін інформацією в режимі реального часу між усіма зацікавленими сторонами може поліпшити видимість, в той час як гнучкість, тобто здатність розробляти послуги, здатні адаптуватися і реагувати на збої, може сприяти розвитку надійної інфраструктури.

В даний час учасники ланцюга поставок пов'язані один з одним прямо або побічно, i їх взаємини пов'язані не тільки з фізичним переміщенням товарів, а й з обміном інформацією. Коли зацікавлені сторони будують ланцюги поставок на основі таких складних мереж, стає необхідним мати координуючого посередника для досягнення балансу між співпрацею і конкуренцією. 3 цих причин сучасні підприємства сильно покладаються на так званих постачальників логістичних послуг (LSP), які пропонують своїм клієнтам ряд різних послуг, від простих транспортних операцій до повного управління ланцюгом поставок.

В залежності від своїх потреб і зручності, компанії вирішують передати на аутсорсинг постачальникам логістичних послуг деякі види діяльності або повну

$$
-96-
$$


логістику свого ланцюга поставок. Вантажовідправник домовляється 3 постачальником послуг логістичного обслуговування щодо доставки продукції за певних витрат, тривалості та стійкості, але надає LSP свободу рішення щодо організації перевезення відповідно до цих специфікацій. Постачальник логістичних послуг може гнучко застосовувати різні режими транспортування залежно від інформації в режимі реального часу, умов руху та доступності ресурсів. Синхромодальне планування пропонує можливість поліпшити транспортні послуги 3 точки зору стійкості, витрат та якості [19].

Постачальники логістичних послуг та вантажовідправники мають різні бізнес-моделі та операційні стратегії. LSP, які досліджують синхромодальність як бізнес-модель, схильні лише враховувати, як це впливає на їхні власні транспортні операції. 3 іншого боку, вантажовідправники також зацікавлені в його більш широкому впливі на ендогенні елементи у системах виробництва та розподілу, таких як запаси та графіки виробництва. Як наслідок, перспектива синхромодальності на основі вантажовідправника набагато ширша, ніж у LSP (табл. 3).

Різновиди перспектив синхромодальності

Таблиця 3

\begin{tabular}{|c|c|c|}
\hline $\begin{array}{l}\text { Точка зору } \\
\text { (позиція) }\end{array}$ & Транспортна перспектива & $\begin{array}{c}\text { Перспектива ланцюга } \\
\text { поставок }\end{array}$ \\
\hline Організація & В основному LSP & Вантажовідправники \\
\hline Сфера дії & Транспортна мережа & Наскрізний ланцюг поставок \\
\hline Складність & $\begin{array}{l}\text { Обсяг мережі та } \\
\text { інтермодальні зв'язки }\end{array}$ & $\begin{array}{l}\text { Компроміси та синергія } \\
\text { в ланцюгу поставок }\end{array}$ \\
\hline Мета & $\begin{array}{l}\text { Гнучка транспортна } \\
\text { мережа, де ефективно } \\
\text { використовуються всі види } \\
\text { транспорту та } \\
\text { полегшується зміна режиму }\end{array}$ & $\begin{array}{l}\text { Синхронізований ланцюг } \\
\text { поставок, де компроміси між } \\
\text { запасами та транспортуван- } \\
\text { ням перекалібруються для } \\
\text { використання мульти- } \\
\text { модальної гнучкості }\end{array}$ \\
\hline $\begin{array}{l}\text { Кількісний метод } \\
\text { повторного } \\
\text { пошуку }\end{array}$ & $\begin{array}{l}\text { Алгоритми планування } \\
\text { перевезень }\end{array}$ & $\begin{array}{l}\text { Оптимізація ланцюга } \\
\text { поставок, наприклад, моделі, } \\
\text { що інтегрують рішення щодо } \\
\text { транспортування та } \\
\text { інвентаризації }\end{array}$ \\
\hline
\end{tabular}

Джерело: [21]

Синхромодальність 3 точки зору ланцюга поставок визначається як мультимодальна стратегія, яка включає гнучкий вибір видів вантажних перевезень і управління вантажовідправниками в ланцюгах поставок [21]. 
Ця перспектива переосмислює рішення щодо вибору способу транспортування та заохочує вантажовідправників переглянути свої транспортні стратегії з позицій цілісної перспективи ланцюга поставок.

\section{3. ВИСНОВКИ}

1. До кризи логістика сприймалася як центр витрат, тому компанії прагнули оптимізувати витрати, делегуючи функції зберігання, перевезень, доставки контрагентам, що пропонують найнижчі ставки на ринку послуг. В останні роки було широко поширене створення складних ланцюгів поставок, в яких працюють різнорідні групи віддалених постачальників. Така модель заснована на технологіях, транспорті і повному взаємозв'язку між учасниками, це сприяє розвитку глобальних потоків.

2. Всі ланцюги поставок працюють на ефекті масштабу. Однак при забороні на перевезення будь-яких товарів, крім засобів життєзабезпечення, яка виникла в результаті пандемії, вантажопотік істотно скоротився, транспорт не заповнювався, вартість перевезення зросла в десятки разів.

3. Ситуація сьогодні демонструє, що такий підхід не дозволяє впоратися зі збільшеними навантаженнями. Тільки довгострокові відносини та управління взаємовідносинами 3 контрагентами на основі показників ефективності, плюс сучасні інформаційні технології дозволяють легко масштабувати логістику в періоди не прогнозованих стрибків і падінь.

4. Гнучкість ланцюгів поставок, яка і раніше була важливим інструментом, стала обов'язковою умовою, що дозволяє працювати зі стабільно зростаючими обсягами в умовах пандемії для е-commerce i деяких сфер оффлайн-бізнесу, які зіштовхнулися з підвищеним попитом.

5. Перегляд поточної моделі є актуальним для швидкого відновлення обсягів виробництва і продажів після закінчення режиму обмежень. 3 цією метою впроваджуються різні портальні рішення, наприклад такі як система управління замовленнями Order Management System (OMS) або Supplier Portal — портал постачальників. Ці системи показують наявність обраного товару на доступних складах, автоматизують вибір найближчого, відстежують рух по кожному замовленню, знижують кількість повернень і допомагають спілкуватися з постачальниками при розміщенні замовлень, полегшують документообіг, передають вимоги про ідентифікацію вантажомісць, планують прибуття перевізника.

6. Для досягнення довгострокового успіху модернізуються всі точки перетину в ланцюгах поставок, це - цифрові рішення для обслуговування клієнтів, транспортування, доставка на останній милі. Головні тренди це розвиток колаборацій, кооперації, об’єднання сервісів, збільшення попиту на послугу «збірні вантажі», впровадження новітніх IT-технологій, передача логістики на аутсорсинг. Прогресивні ланцюги постачань практикують підхід, заснований на концепції 
життєвого циклу, і оцінюють загальний вплив на навколишнє середовище продуктів і операцій по всій довжині ланцюга постачань, прагнучи мінімізувати негативні чинники своєї діяльності.

7. Сучасне управління ланцюгами поставок, яке засноване на цифровізації процесів і враховує сьогоднішні реалії — це неминучі зміни бізнес-процесів, пов’язані не тільки з кризою Covid-19, але і з трансформаціями сучасної економіки.

\section{ЛІТЕРАТУРА}

1. Christopher, Martin. Logistics and Supply Chain Management: Creating Value-Adding Networks / M. Christopher. - 3rd edition. - FT Prentice Hall, 2005. — 276 p.

2. Харрісон А. Управління логістикою: розробка стратегій логістичних операцій / А. Харрісон, Ван Хоук Ремко ; пер. $з$ англ. ; за наук. ред. О. Є. Міхейцева. - Дн. : Баланс-Бізнес-Букс, 2007. - 368 с.

3. Harrison, T. P. Principles for the strategic design of supply chains / T. P. Harrison, H.L. Lee, J. J. Neale // The Practice of Supply Chain Management. — New York: Springer, 2005. P. 3-12.

4. Бауэрсокс, Д. Дж. Логистика. Интегрированная цепь поставок / Д. Дж. Бауэрсокс, Д. Дж. Клосс - М. : ЗАО Олимп-бизнес, 2008. — 640 с.

5. Кристофер М. Логистика и управление цепочками поставок / М. Кристофер; под ред. В. С. Лукинского. - СПб. : Питер, 2004. - 316 с.

6. Сток Дж. Стратегическое управление логистикой / Дж. Сток, Д. М. Ламберт. - М. : ИНФРА-М, 2005. - $797 \mathrm{c.}$

7. Захаров, К. В. Логистика, эффективность и риски внешнеэкономических операций / К. В. Захаров, А. В. Цыганок, В. П. Бочарников, А. К. Захаров. — К. : ИНЭКС, 2000. $237 \mathrm{c}$.

8. Кальченко, А. Г. Логістика: підручник / А. Г. Кальченко. - К.: КНЕУ, 2006. - 284 с.

9. Крикавський, Є. Логістика та управління ланцюгами поставок: навч. посібник / Є. Крикавський, О. Похильченко, М. Фертч. - Львів: Видавництво Львівської політехніки, 2017. - $844 \mathrm{c}$.

10. Губенко, В. К. Логистическая централизация материальных потоков: теория и методология логистических распределительных центров: монография /В.К. Губенко. Донецк : НАН Украины, Институт экономики промышленности, 2007. — 495 с.

11. Григорак, М. Ю. Інтелектуалізація ринку логістичних послуг: концепція, методологія, компетентність: монографія / М.Ю. Григорак. - К.: Сік Груп Україна, 2017. - 513 с.

12. Сумец, А. М. Логистика: теория, ситуации, практические задания: учебн. Пособие / А.М. Сумец. - К. : Хай-Тек Пресс, 2008. - 320 с.

13. Чухрай, Н. Формування ланцюга поставок: питання теорії та практики: монографія / Н. Чухрай, О. Гірна — Львів : «Інтелект-Захід», 2007. - 232 с.

14. Пономарьова, Ю. В. Логістика: навчальний посібник / Ю. В. Пономарьова. - друге вид., перероб. та доп. - К. : ЦНЛ, 2005. - 328 с.

15. Клименко, С. М. Обгрунтування господарських рішень та оцінка ризиків / С. М. Клименко, О. С. Дуброва. - К. : КНЕУ, 2005. - 252 с.

16. Шехтер, Д. Логистика. Искусство управления цепочками поставок / Д. Шехтер, Г. Сандер. - М.: Претекст, 2008. - 230 с. 
17. Giusti, R., Manerba, D., Bruno, G., \& Tadei, R. Synchromodal logistics: An overview of critical success factors, enabling technologies, and open research issues [Electronic resource] / Transportation Research Part E: Logistics and Transportation Review. - 2019. 129, 92-110. Mode of access: https://doi.org/10.1016/j.tre.2019.07.009.

18. Gunessee, S., Subramanian, N. Ambiguity and its coping mechanisms in supply chains lessons from the Covid-19 pandemic and natural disasters [Electronic resource] / International Journal of Operations \& Production Management. ahead-of-print. — 2020. Mode of access: https://doi.org/10.1108/IJOPM-07-2019-0530.

19. Mes, M., Iacob, Maria-Eugenia. Synchromodal Transport Planning at a Logistics Service Provider [Electronic resource] / Logistics and Supply Chain Innovation: Bridging the Gap between Theory and Practice. — 2015. — Mode of access: https://research.utwente.nl/en/ publications/synchromodal-transport-planning-at-a-logistics-service-provider.

20. Miclo, R., Lauras, M., Fontanili, F., Lamothe, J., Melnyk, S. Demand Driven MRP: assessment of a new approach to materials management [Electronic resource] / International Journal of Production Research. — 2018. — 57. — 1-16. https://doi.org/10.1080/00207543. 2018.1464230.

21. Dong, Ch., Boute, R., Mckinnon, A., Verelst, M. Investigating synchromodality from a suply chain perspective [Electronic resource] / Transportation Research Part D: Transport and Environment. - 2017. - Mode of access: https://www.researchgate.net/publication/ 317392497_Investigating_synchromodality_from_a_supply_chain_perspective.

22. Легомінова, С. В. Концептуальні засади стратегічного управління конкурентними перевагами підприємств / С.В. Легомінова // Глобальні та національні проблеми економіки. - 2017. -№ 18. - С. 250-255.

23. Ptak, C., Smith, C. Demand Driven Material Requirements Planning (DDMRP) [Electronic resource] / Industrial Press. — 2016. — Mode of access: https://www.amazon.com/DemandMaterial-Requirements-Planning-Version/dp/0831136286. 


\title{
РОЗДІЛ 4 \\ ОЦНКА РИЗИКІВ ПЕРЕВІЗНОГО ПРОЦЕСУ ЗАСОБАМИ ІМІТАЦЙНОГО МОДЕЛЮВАННЯ
}

\author{
P.В. Вернигора ${ }^{7}$ \\ А. М. Окороков ${ }^{8}$ \\ С. Б. Демченко 9
}

\section{1. ВСТУП}

Ризик властивий будь-якій формі людської діяльності; це пов’язано з безліччю умов і факторів, що впливають на позитивний результат прийнятих людьми рішень. Аналіз практичного досвід показує, що ризик недоотримання запланованих результатів особливо проявляється при спільності товарно-грошових відносин і конкуренції учасників господарського обороту.

Актуальність теми оцінки ризиків визначається процесами, що відбуваються в економіці. У подібній ситуації прагнення економічного суб'єкта стабільно й успішно розвиватися стикається 3 апаратом управління його діяльністю, що тільки формується [1].

Останніми роками становище транспортно-дорожнього комплексу країни значно погіршилося. Унаслідок спаду обсягів перевезень стрімко скоротилися прибутки транспортних підприємств, хронічною стала криза платежів, граничного рівня досягла зношеність основних виробничих фондів, що призводить до зростання потреб у реконструкції, ремонті та технічному обслуговуванні. Незадовільно вирішуються питання технічних інновацій і технологічної модернізації, не забезпечуються мінімальні соціальні умови працівників галузі, не повною мірою використовуються потенціальні можливості транспортно-дорожнього комплексу з розвитку експорту транспортних послуг. Перераховані фактори потребують розроблення такого механізму отримання обгрунтованих оцінок і критеріїв безпеки, який буде враховувати всю сукупність соціально-економічних чинників, зокрема ймовірність виникнення та наслідки можливих відмов та аварій.

Ризик виникнення несприятливих подій є однією з головних проблем сучасного виробництва та критерієм оцінки ефективності і безпечності будь-яких нових проектів та організаційно-технічних заходів, спрямованих на удосконалення існуючих виробничих систем. Разом 3 тим, можна констатувати, що існуючі методи та підходи, спрямовані на вирішення вказаних задач оцінки ризиків та їх наслідків,

\footnotetext{
${ }^{7}$ Декан факультету «Управління процесами перевезень», канд. техн. наук, доцент кафедри «Транспортні вузли» Дніпровського національного університету залізничного транспорту імені В.Лазаряна, Дніпро

8 Завідувач кафедри «Управління експлуатаційною роботою», канд. техн. наук, доцент кафедри «Управління експлуатаційною роботою» Дніпровського національного університету залізничного транспорту імені В.Лазаряна, Дніпро

9 Канд. техн. наук, доцент кафедри «Транспортні вузли» Дніпровського національного університету залізничного транспорту імені В.Лазаряна, Дніпро
}

$$
-101-
$$


на сьогодні не є достатньо ефективними через безліч проблем, пов’язаних з економічними, технічними, ресурсними можливостями підприємств загалом, а також із труднощами у власне оцінці та прогнозуванні певних технологічних процесів в умовах невизначеності, тобто у разі неповноти або неточності інформації [2].

Оцінка ризиків дозволяє організації враховувати, якою мірою події можуть вплинути на досягнення іiі цілей. Оцінка ризику складається 3 ідентифікації ризику, його аналізу та порівняльної оцінки. Для цього використовується кількісні або якісні методи оцінки, або, досить часто, їх поєднання.

Методи якісної оцінки часто використовуються у випадках неможливості кількісного визначення ризиків, а також у випадках, коли досить надійні дані, необхідні для кількісної оцінки, або не можна отримати, або отримання і аналіз таких даних виявляються занадто вартісними. Методи кількісної оцінки, як правило, вимагають більшої точності і використовуються по відношенню до більш складних і комплексних видів діяльності на додаток до якісних методів. Якісні методи є найбільш придатними щодо ризиків, даними про історію появи і частоту мінливості яких володіє організація i які, внаслідок цього, можна надійно спрогнозувати [3].

До найбільш ефективних методів прогнозування поведінки складних систем у різних умовах та оцінки показників їх функціонування наразі $є$ імітаційне моделювання. В загальному випадку під імітаційним моделюванням розуміється процес проведення комп'ютерних експериментів 3 математичними моделями складних систем реального світу. Імітаційне моделювання використовується в тих випадках, коли проведення реальних експериментів, наприклад, 3 економічними або технічними системами, вимагає значних витрат та/або не може бути реалізоване на практиці. Крім того, часто на практиці збір необхідної інформації для прийняття рішень або неможливий, або вимагає значних витрат. В подібних випадках відсутні фактичні дані замінюються величинами, отриманими в процесі імітаційного експерименту (тобто генеруються моделлю) [4].

\section{2. ОСНОВНИЙ МАТЕРІАЛ}

\section{1. Проблеми оцінки та управління ризиками в транспортних системах}

Те, як сприймається та оцінюється ризик, багато в чому залежить від того, хто оцінює ризик, якою інформацією він володіє, які алгоритми, методи та моделі вони використовують, та які критерії прийнятності використовують. Ключем до управління ризиками є чіткість термінології [5]. Виділяють сім основних способів розуміння ризику, який є предметом наукових досліджень. Згідно з цією класифікацією ризик можна розуміти як [6]:

- можливість нещасного випадку;

- потенціал реалізації небажаних, негативних наслідків події; 
- вплив пропозиції (наприклад, виникнення збитків), яка є непевною;

- наслідки діяльності та пов'язані з цим невизначеності;

- невизначеність та тяжкість наслідків діяльності щодо того, що цінує людина;

- випадки деяких конкретних наслідків діяльності та пов'язаних 3 ними невизначеностей;

- відхилення від контрольного значення та пов'язані з цим невизначеності.

Ризик можна визначити по-різному, як це видно з наведених вище визначень; при цьому у більшості з них зустрічається поняття «невизначеність».

Оцінка ризику на транспорті протягом багатьох років $\epsilon$ предметом численних досліджень та наукових публікацій по всьому світу. Ризик також тісно пов'язаний 3 проблемою вибору, що стосується прийняття рішення щодо ризику небезпечної поведінки із знанням того, що може статися аварія, або спробами обмежити, зменшити або усунути ризик виникнення аварії, відповідно до існуючих умов. Також виявлено, що ризик на транспорті є поєднанням ймовірності активації небезпечної події та спричинених у зв'язку з цим збитків. У своїх дослідженнях автори проекту чітко підкреслили, що, на відміну від багатьох галузей техніки, наразі не розроблено єдиного методу управління ризиками для транспорту. Створено лише основу для відповідної методології, яка базується на стандартних елементах: аналіз ризиків, їх оцінка, а також усунення ризиків та контроль за залишковими ризиками [5].

Управління транспортними мережами, включаючи агентське управління, розробку програми та проекту доставки, представляє собою досить складне завдання, що містить в собі значну невизначеність. Адміністратори, планувальники та інженери координують безліч організаційних та технічних ресурсів для продуктивного управління транспортною мережею.

Управління ризиками є неявною діяльністю під час управління транспортним процесом (рис. 1).

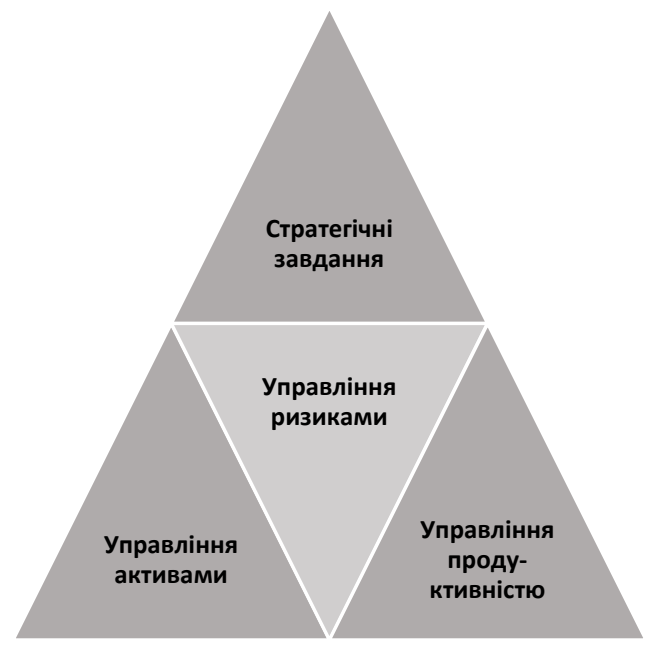

Рис. 1. Зв'язок управління ризиками з управлінням транспортним процесом Джерело: [7]

$$
-103-
$$


Транспортні агенції встановлюють стратегічні цілі та завдання (наприклад, надійний та ефективний рух людей та товарів), але успіх при цьому непевний. Внутрішні та зовнішні ризикові події можуть вплинути на досягнення цих цілей. Так само агенції встановлюють ефективність заходів та розробляють системи управління активами для оптимізації інвестиційних рішень. Ризик широко поширений на транспорті, і це спрямовує транспортні агенції на розвиток чітких стратегій управління ризиками на підприємстві.

Міжнародний стандарт ISO 31000 визначає ризик як «вплив невизначеності на цілі». Отже, ризик - це все, що може бути перешкодою на шляху досягнення цілей і завдань.

Управління ризиками — це процес аналітичних та управлінських заходів, спрямованих на виявлення і реагування на невизначеності управління складною організацією та їі активами.

Ризиком можна керувати на різних рівнях (рис. 2).

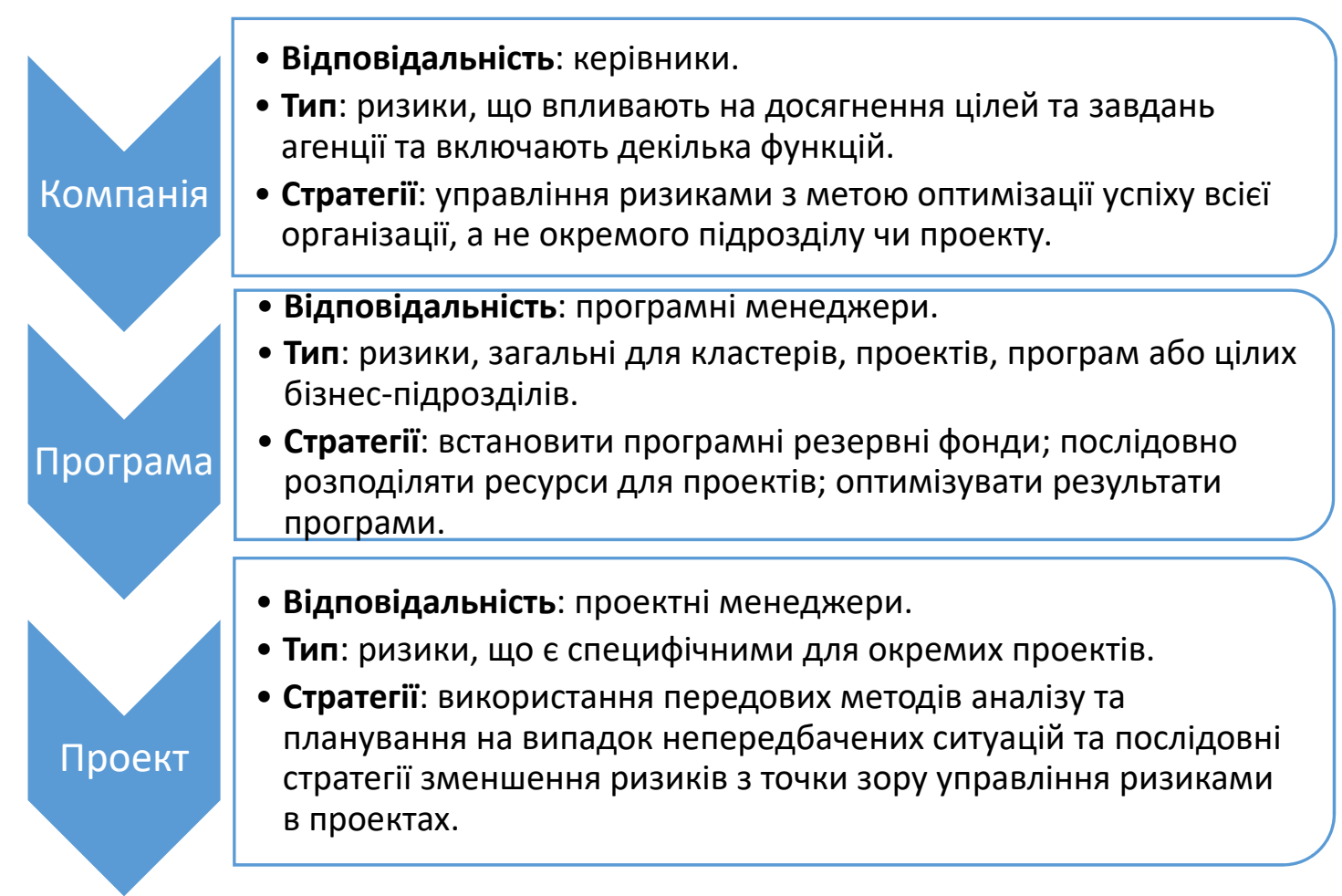

\section{Рис. 2. Рівні управління ризиками підприсмства Джерело: [7]}

Управління ризиками на підприємстві - це термін, який використовують керівники при обговоренні даної проблематики. 3 цією метою управління ризиками на підприємстві включає три рівні — компанія, програма та управління ризиками проекту.

Відповідальність за управління ризиками компанії несуть керівники вищої ланки. Керівники отримують вигоду від процесу, але вони також відповідають за його ідентифікацію і стійкість процесу. Агентськими ризиками є невизначеності,

$$
-104-
$$


які можуть вплинути на досягнення стратегічні цілей компанії (наприклад, агентство репутація, цілісність даних, фінансування, безпека, лідерство). Агентське управління ризиками на рівні компанії $є$ послідовним застосуванням методів управління невизначеностями у досягненні стратегічних цілей агентства. Отже, агентське управління ризиками не має завданням поставити відмітку про виконання, але складається з процесу послідовного вдосконалення та впровадження [7].

Коли ми рухаємося вниз по ієрархії, управління ризиками на рівні програми передбачає управління ризиками в мережі або в декількох проектах (наприклад, ризики, властиві міському або регіональному транспортному плануванню, ризики зростання вартості енергоносіїв і т. ін.).

Нарешті, ризики можуть бути унікальними для конкретного проекту. Проектний ризик управління співвідноситься 3 персоналом, знайомим з особливостями цього проекту та іншими технічними експертами та зацікавленими сторонами (наприклад, локальна особливість транспортної мережі, обмежена пропускна здатність тощо) [7].

Незважаючи на рівень управління ризиками, сама методика управління загалом не змінюється та являє собою класичну схему, що зображена на рис. 3.

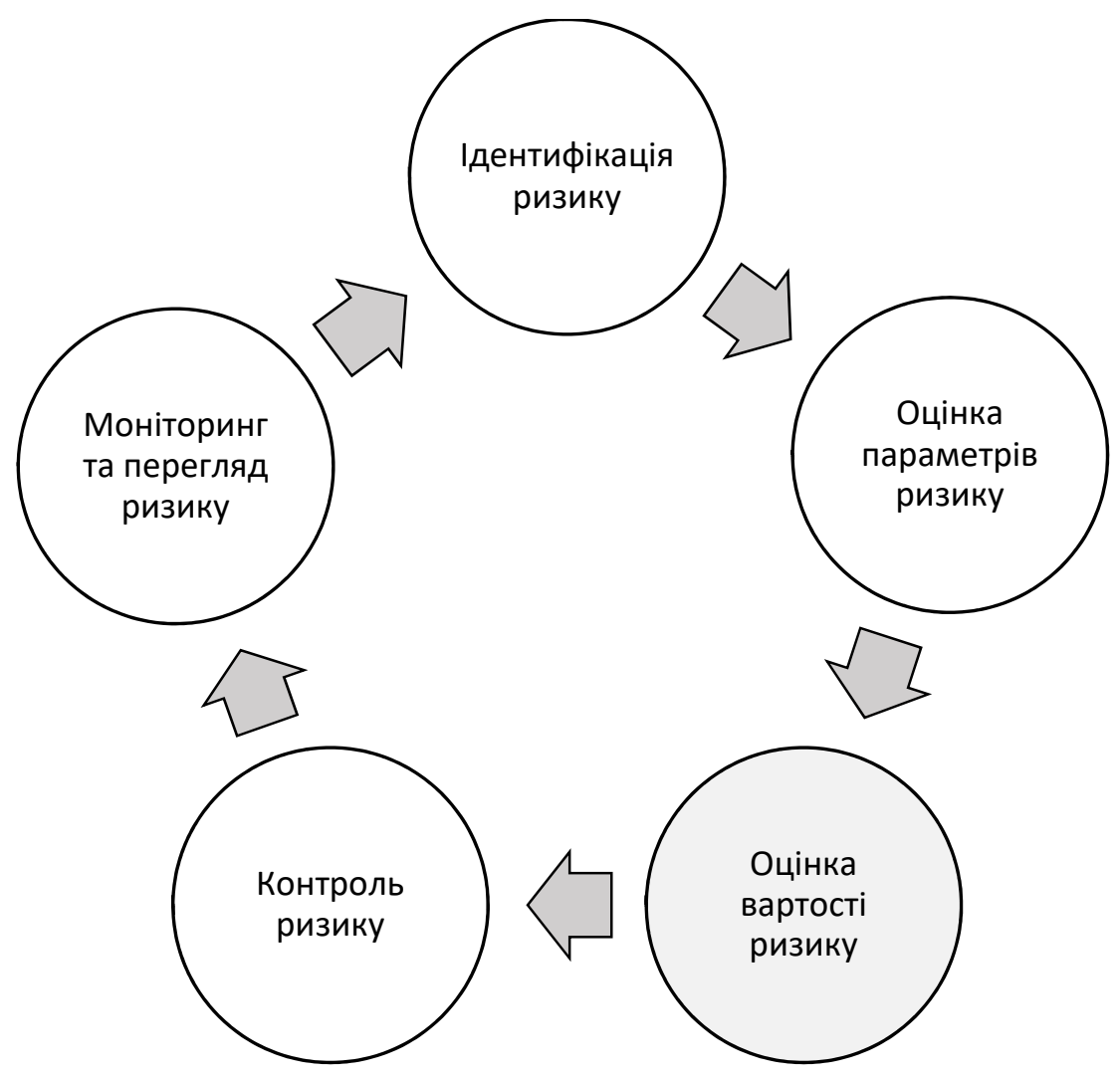

Рис. 3. Процес управління ризиком

Джерело: адаптовано з [8] 
Під ризиком на залізничному транспорті розуміється ймовірність втрат, збитків у процесі здійснення перевезень залізничними шляхами сполучення. Ризики на залізничному транспорті характеризуються складністю та різноманітністю, тому їх необхідно класифікувати за окремими ознаками [2]. Найважливішими ознаками класифікації ризиків на залізничному транспорті є:

- об'єкт прояву;

- джерела виникнення;

- етапи транспортування;

- різновиди перевезень;

- можливість впливати на ризики;

- час виникнення;

- розмір збитків тощо.

За об'єктами прояву ризиків: ризики часто ототожнюють із їхніми певними носіями, тому, в-першу чергу, необхідно виділити ризикогенні об'єкти на залізничному транспорті. До таких об'єктів можна віднести пасажирів та працівників, рухомий склад та залізничні засоби, вантажний та пасажирський вагонні парки, контейнери, вантаж або багаж (вантажобагаж), будівлі, споруди тощо.

За джерелами виникнення ризиків на залізничному транспорті можна виділити ризики втрат і збитків, які є результатом впливу різних суб'єктів, процесів і явищ. Ці ризики можна класифікувати так [2]:

1. Природно-кліматичні ризики, зумовлюються впливом стихійних сил, що супроводжується випаданням опадів, затопленнями, ударами блискавок тощо.

2. Антропогенні ризики, які викликані впливом людини на виникнення надзвичайних ситуацій. Ймовірність впливу дій людини на виникнення ризиків на залізничному транспорті визначається багатьма факторами, але всі їх можна розділити на дві складові нецілеспрямованої та цілеспрямованої дії. До ризиків нецілеспрямованих дій людини відносяться помилки машиністів, диспетчерів, контролерів та інших суб'єктів, які можуть бути викликані відсутністю необхідних знань, виникненням невідомих ситуацій, порушень правил безпеки руху на залізничному транспорті або виробничої дисципліни. Тобто дії людини можуть бути помилковими, як наприклад, небезпечний маневр машиніста або несвоєчасними халатність.

3. Статистика надзвичайних подій на залізничному транспорті та їх розслідування показує, що найбільш розповсюдженими $є$ помилки людей спільно з поганою організацією перевізного процесу, а частка суто технічних відмов займає незначну частину.

4. Технічні ризики, що зумовлені технічним станом рухомого складу та залізничної інфраструктури, а саме: заводський брак, механічне ушкодження, несправність рухомого складу інфраструктури тощо. Ризики в процесі експлуатації пов'язані з несправністю основних елементів рухомого складу інфраструктури та недостатнім контролем за їхніми механічними властивостями.

$$
-106-
$$


5. Макроекономічні ризики, які формуються під впливом процесів на макроекономічному рівні та під дією ринкових факторів. До таких ризиків у першу чергу відносяться: зменшення обсягів залізничних перевезень унаслідок зміни кон'юнктури транспортного ринку; зменшення обсягу фінансових ресурсів унаслідок зростання цін на енергоносії та продукцію інших підприємств тощо.

За етапом транспортування: дослідження ризиків з точки зору їх класифікації вимагає структуризації процесу перевезення залізничним транспортом. Перевізна діяльність на залізничному транспорті включає сукупність організаційно та технологічно пов'язаних операцій із підготовки, здійснення та завершення переміщення пасажирів, вантажів, багажу (вантажобагажу), кожна з яких супроводжується ризиками. Тому ризики можна поділити залежно від етапу транспортування пасажирів, вантажів, багажу (вантажобагажу) на ризики етапів: підготовки до переміщення; здійснення переміщення; завершення переміщення.

За різновидом перевезень: у процесі здійснення залізничних перевезень ризики поділяються на ризики, які характерні для вантажних перевезень, для пасажирських перевезень і ті, що супроводжують всі перевезення залізницями.

Ризики, які супроводжують пасажирський рухомий склад, істотно відрізняються від ризиків, що супроводжують вантажні вагони чи локомотиви. Ризики пошкодження чи знищення пасажирського рухомого складу не тільки істотно нижчі ніж вантажні, що обумовлено більш високим рівнем організації безпеки руху, а й відрізняються своєю специфікою, наприклад, одним із ризиків, який загрожує пасажирському рухомому складу — це вандалізм.

Перевезення вантажів на залізничному транспорті неминуче пов'язані з різноманітними ризиками, які виникають як у процесі транспортування, так і під час виконання навантажувально-розвантажувальних робіт і тимчасовому зберіганні.

Ризики пошкодження чи руйнування вантажного рухомого складу збільшуються у разі взаємодії залізничного транспорту з іншими різновидами транспорту: у процесі здійснення розвантажувальних і навантажувальних робіт на території морського терміналу тощо.

\section{2. Імітаційне моделювання як метод дослідження складних систем та оцінки ризиків їх функціонування}

\subsection{1. Поняття модель та моделювання}

Як зазначалось оцінка та прогнозування ризиків у складних системах, зокрема при організації залізничних перевезень, $є$ досить складним завданням, оскільки вимагає врахування впливу великої кількості різних факторів, стохастичного характеру процесів та невизначеності умов функціонування. На практиці досліджувати функціонування та проводити оптимізаційні експерименти безпосередньо на реальних об'єктах у більшості випадків не є можливим: будувати нові об'єкти, руйнувати або вносити зміни в уже наявну інфраструктуру може бути занадто 
дорого, небезпечно або просто неможливо. Ще у більшій мірі це відноситься до нових систем, які тільки проектуються. Тому реальні об'єкти заміщують їх моделями, на яких і здійснюють дослідження та виконують експерименти [9].

Що ж собою представляє модель? Часто під моделлю розуміють систему, яку використовують для дослідження та пізнання іншої системи [10]. Термін «модель» походить від латинського слова «modulus», тобто зразок, пристрій, еталон. У широкому значенні - це будь-який аналог (уявний, умовний: зображення, опис, схема, креслення і т. п.) певного об’єкта, процесу, явища («оригіналу» даної моделі), який використовується як його «замінник».

Отже, модель - це реально існуюча або абстрактна система, яка, замінюючи і відображаючи в пізнавальних процесах іншу систему - оригінал, перебуває 3 нею у відношенні схожості. При побудові моделі об'єкт (систему) і його (ii) властивості спрощують, але чим ближче модель до оригіналу, тим ефективніше його дослідження. Таким чином, моделювання - це заміщення одного об'єкта іншим 3 метою отримання інформації про властивості об'єкта-оригіналу за допомогою об'єкта-моделі [11] (рис. 4).
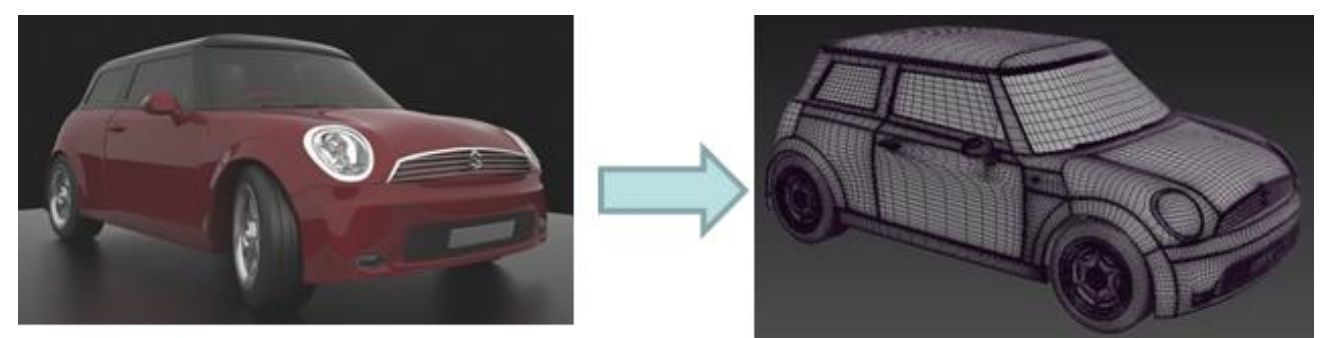

Рис. 4. Заміщення реального об'єкта його моделлю

Джерело: авторська розробка

Варто зазначити, що наразі не існує загальних правил, методик чи алгоритмів побудови моделей, що підходять для будь-яких задач дослідження. У кожному випадку, в залежності, від характеру задачі та цілей дослідження обираються відповідні типи моделей, рівень абстракції (спрощення), мова програмування, методика проведення експериментів тощо. Моделювання досі більше мистецтво, ніж наука [12]. По суті, моделювання є пошуком рішення задачі в захищеному від ризику світі моделей, в якому можна помилятися, скасовувати операції, повертатися в минуле і починати спочатку (рис. 5) [13].

Для вирішення задач, пов'язаних 3 моделюванням та дослідженням процесів та систем, науковцями розроблено та використовується широкий набір методів та підходів - відповідно існує і широкий спектр різноманітних моделей, які можна класифікувати за різними ознаками. Так, наприклад в [10] пропонується класифікація моделей, що представлена на рис. 6. 


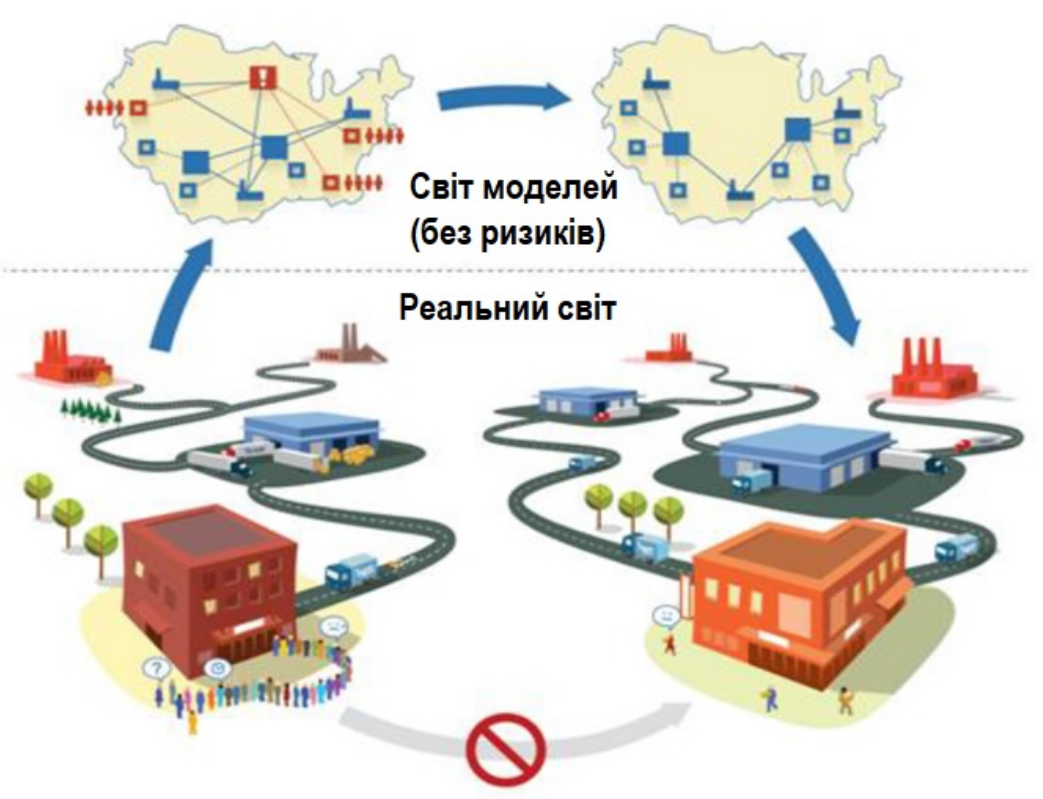

Рис. 5. Порівняння реального світу та «світу моделей» Джерело: [13]

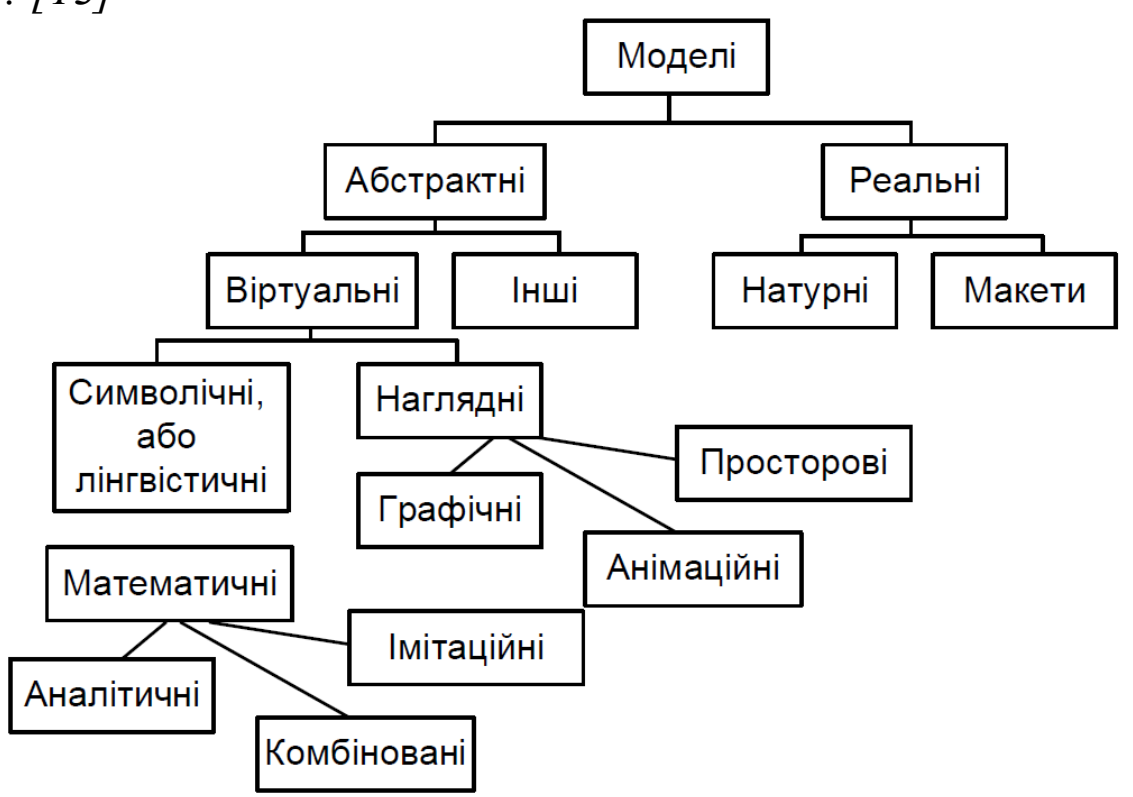

\section{Рис. 6. Класифікація моделей}

Джерело: [10]

Очевидно, що реальні (натурні та макетні) моделі найбільш точно відповідають реальним об'єктам, які досліджуються і мають відповідно найменший рівень абстракції [12]. Однак їх висока вартість та обмежена функціональність є суттєвим недоліком на користь широкого застосування абстрактних моделей, серед яких найбільш поширеними є математичні моделі. Математичні моделі для дослідження характеристик процесу функціонування систем можна розділити на аналітичні, імітаційні і комбіновані (рис. 6). 
Для аналітичної моделі характерно те, що процеси функціонування елементів системи записуються у вигляді деяких функціональних співвідношень (алгебраїчних, інтегрально-диференціальних) або логічних умов (рис. 7). Окремим виглядом аналітичної моделі є графічне представлення певної функціональної залежності виду $Y=f(X)$.

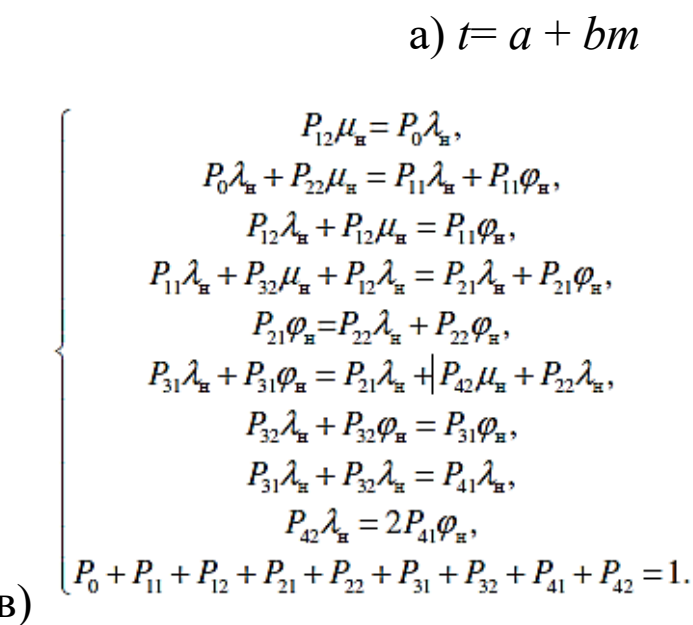

Г)

б) $S=f(t, V)$

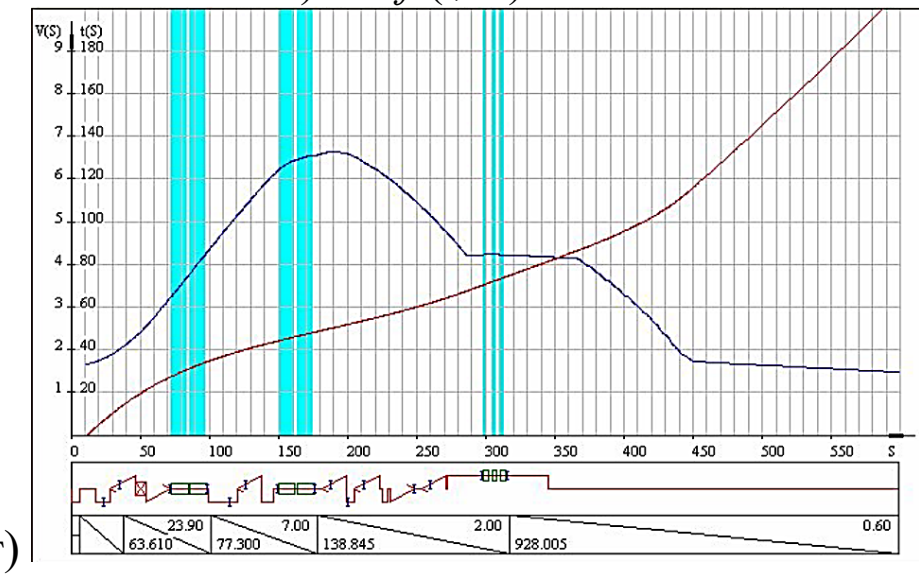

\section{Рис. 7. Приклади аналітичних моделей:}

а) модель тривалості маневрового піврейсу; б) модель залежності величини переміщення; б) модель стану динамічної системи; в) графік скочування відчепу з гірки

Джерело: авторська розробка

В імітаційній моделі відтворюється процес функціонування системи у часі, причому імітуються елементарні явища, що складають процес, iз збереженням їх логічної структури і послідовності протікання в часі, що дозволяє за початковими даними отримати відомості про стани процесу в певні моменти часу, які дають можливість оцінити характеристики системи [12].

\subsection{2. Поняття імітаційного моделювання}

Функціонування складних динамічних систем, як правило, представляє собою стохастичний процес, що пов'язано, з одного боку, зі складністю зв'язків та залежностей між елементами таких систем, які часто носять ймовірнісний характер, а, з іншого - пояснюється значною кількістю випадкових факторів, що впливають на роботу складних систем та призводять до невизначеності умов. Така характеристика у повній мірі відноситься і до транспортних систем. Так, у наслідок різноманітних причин транспортні потоки можуть характеризуватись значними коливаннями, що, у свою чергу, спричинює нерівномірність у роботі транспортних систем, які обслуговують ці потоки. Окрім того, на роботу транспорту суттєво впливають, як відмова технічних пристроїв, так і наявність людського фактору, що призводить до незапланованих відхилень у роботі.

Разом $з$ тим, побудувати адекватну аналітичну модель, у якій функціонування системи формалізується на основі алгебраїчних або диференціальних виразів, 
часто буває досить складно або взагалі неможливо. Тому при аналітичному аналізі складних стохастичних процесів приймаються ті чи інші припущення та спрощення, що зменшує рівень достовірності як самої аналітичної моделі, так і отриманих за її допомогою рішень.

У зв'язку зі стрімким розвитком інформаційних і комп'ютерних технологій у середині XX століття можливості моделювання реальних об'єктів розширилися. 3'явилися нові методи і технології, що дозволяють моделювати складні об'єкти і процеси. Поява нових систем (пакетів) моделювання привело до створення нового типу комп'ютерних моделей — «імітаційних моделей».

Імітаційне моделювання є сучасним та потужним інструментом дослідження поведінки складних систем. Методи імітаційного моделювання дозволяють зібрати необхідну інформацію про поведінку системи в тих чи інших експлуатаційних умовах (за тих чи інших вхідних даних) шляхом створення та дослідження іiї комп'ютерної моделі. Імітаційне моделювання, на відміну від аналітичних моделей, безпосередньо не вирішує оптимізаційних задач, а представляє собою інструментарій для оцінки та прогнозування параметрів та характеристик системи, робота якої моделюється [9].

Імітаційне моделювання (від лат. imitatio - наслідування, копіювання) означає процес імітування поведінки системи на моделі (у більшості випадків 3 використанням комп’ютерної техніки ) з метою одержання характеристик цієї системи.

Згідно 3 [12] «імітаційне моделювання являє собою процес створення моделі реальної системи та проведення експериментів на цій моделі з метою оцінки влаштування системи, а також ефективності її функціонування. Таким чином, процес імітаційного моделювання включає конструювання моделі системи, і іiі застосування для вивчення деякої проблеми».

Дамо ще одне визначення. Імітаційна модель - логіко-математичний опис об'єкта (системи), який може бути використаний для проведення експериментів на ЕОМ з метою проектування, аналізу та оцінки функціонування об'єкта (системи). Іншими словами, сучасна імітаційна модель представляє собою комп'ютерну програму-симулятор, яка описує структуру та відтворює поведінку існуючої або нової системи в часі. Таким чином, імітаційне моделювання базується на відтворенні (імітації) за допомогою ЕОМ розгорнутого у часі процесу функціонування системи з врахуванням іiї взаємодії з зовнішнім середовищем [9].

\subsection{3. Методологія імітаційного моделювання}

Імітаційна модель завжди $є$ виконуваною моделлю - після іiі запуску вона будує для траєкторію змін стану системи. Можна сказати, що імітаційна модель це набір правил, згідно з якими система переходить 3 одного стану в інший. Правила можуть задаватися різними способами, наприклад, диференціальними рівняннями, діаграмами станів, діаграмами процесів, розкладами [13].

Всі імітаційні моделі являють собою моделі типу так званого чорного ящика (рис. 8). 


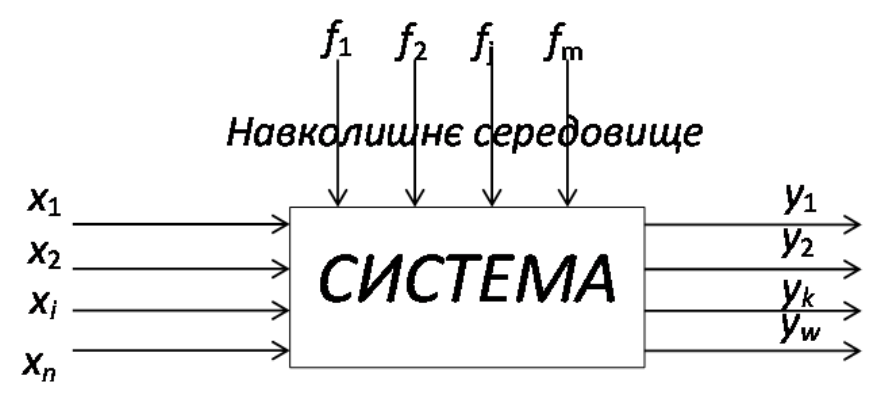

Рис. 8. Модель «чорного ящика»

Джерело: [10]

Це означає, що вони забезпечують видачу вихідного сигналу системи, коли на iii вхід надходить вхідний сигнал (сигнали). Тому для отримання результатів необхідно забезпечити функціонування імітаційних моделей, а не «вирішувати» їх, як це виконується при використанні аналітичних моделей. Імітаційні моделі не дозволяють сформувати рішення в тому вигляді, як це має місце в аналітичних моделях. Вони можуть лише слугувати як засіб для аналізу поведінки системи в умовах, які визначаються експериментатором.

При розробці імітаційної моделі зазвичай детально моделюється функціонування лише тих елементів досліджуваного процесу, які найбільше цікавлять дослідника; для інших елементів моделюються лише кінцеві результати їх функціонування. Такий підхід дозволяє суттєво спростити побудову імітаційних моделей для складних систем.

Оскільки імітаційне моделювання застосовується для опису стохастичних процесів, то воно базується на використанні випадкових чисел, величин та функцій. При цьому для отримання оцінки параметрів системи з заданою точністю необхідно провести не один дослід, а серію експериментів з ії імітаційною моделлю. Оцінку ж необхідних параметрів отримують шляхом статистичної обробки результатів експериментів. Кількість експериментів, яку необхідно виконати 3 моделлю, визначається вимогами до точності отриманих результатів та може бути встановлено статистичними методами [9].

\subsection{4. Переваги імітаційних моделей}

Основними перевагами імітаційного моделювання, в першу чергу, у порівнянні з аналітичними моделями $€[13]$ :

- безризикове середовище. Моделювання дозволяє безпечно застосувати і проаналізувати можливі сценарії «що якщо».

- економія часу та грошей. Віртуальні експерименти з імітаційними моделями обійдуться набагато дешевше і займуть менше часу, ніж експерименти з реальними системами.

- візуалізація. Можливість представлення імітаційних моделей в 2D i 3D зробить будь-які ідеї і концепції більш наочними, їх простіше перевіряти і обговорювати з колегами. 
- розуміння динаміки. На відміну від аналітики на основі таблиць або методом лінійної оптимізації, моделювання дає можливість спостерігати поведінку реальної системи в часі з необхідним рівнем детальності.

- підвищена точність. Імітаційна модель відображає набагато більше деталей, ніж аналітична. Це робить імітаційну модель точніше, а прогнози на іiї основі більш визначеними.

- керування невизначеністю. Невизначеність у часі і результати операцій легко відображається за допомогою імітаційної моделі (за рахунок використання випадкових величин), що дозволяе оцінити ступінь ризику і знайти найбільш надійні рішення.

\subsection{5. Класифікація імітаційних моделей}

Імітаційні моделі класифікують за різними ознаками (рис. 9).

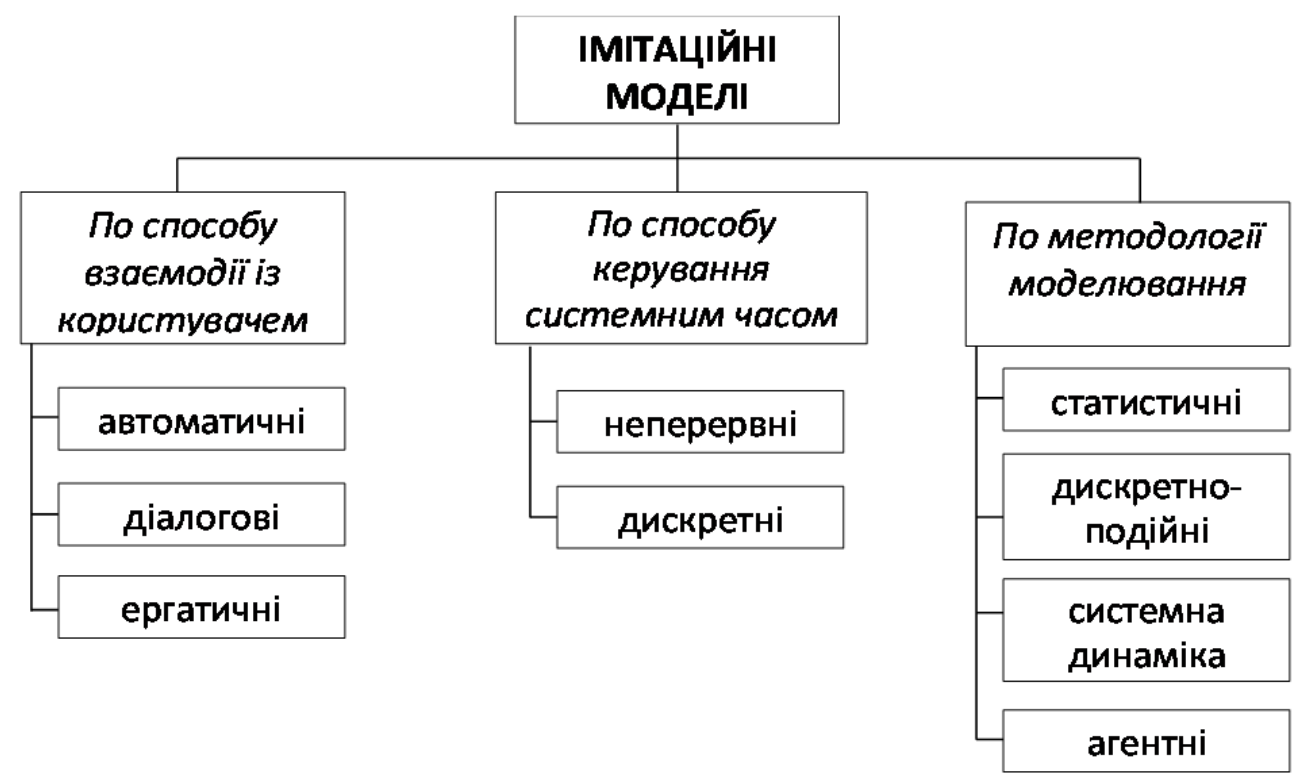

\section{Рис. 9. Класифікація імітаційних моделей}

Джерело: [14]

Статистичне (чисельне) моделювання є різновидністю імітаційного моделювання. Спочатку воно з'явилося в теорії випадкових процесів і математичної статистики як спосіб обчислення статистичних характеристик випадкових процесів шляхом багаторазового відтворення перебігу процесу за допомогою моделі цього процесу. Цей підхід до дослідження реального процесу був названий методом статистичних випробувань (методом Монте-Карло). Для знаходження стійких рішень (характеристик) при чисельному статистичному моделюванні потрібно його багаторазове відтворення з подальшою статистичною обробкою. Тут проводиться імітація впливу численних випадкових факторів на різні елементи моделі. Кожен вплив на процес в моделі представляється у вигляді «розіграшу» випадкового явища за допомогою процедури, яка дає випадковий результат. 
Безліч таких реалізацій в ході одного варіанта імітації дає одну реалізацію (історію) процесу. Потім обчислюються середні статистичні показники по багатьом реалізаціям [12].

Дискретно-подійне моделювання - підхід до моделювання, що пропонує абстрагуватися від безперервної природи подій і розглядати тільки основні події, що моделюються, такі, як: «очікування», «обробка замовлення», «рух з вантажем», «розвантаження» та інші. Основний об'єкт в цій системі - пасивний транзакт (заявка на обслуговування). «Переміщаючись» за моделлю, транзакти стають в черги до пристроїв, захоплюють і звільняють ці пристрої, розщеплюються, знищуються i т. д. Таким чином, дискретно-подійну модель можна розглядати як глобальну схему обслуговування заявок (рис. 10). Дискретно-подійне моделювання найбільш розвинене і має величезну сферу застосування - від логістики та систем масового обслуговування до транспортних і виробничих систем. Цей вид моделювання найбільш підходить для моделювання виробничих, зокрема транспортних, процесів. Він був заснований Джеффрі Гордоном в 1960-х роках [13, 15].

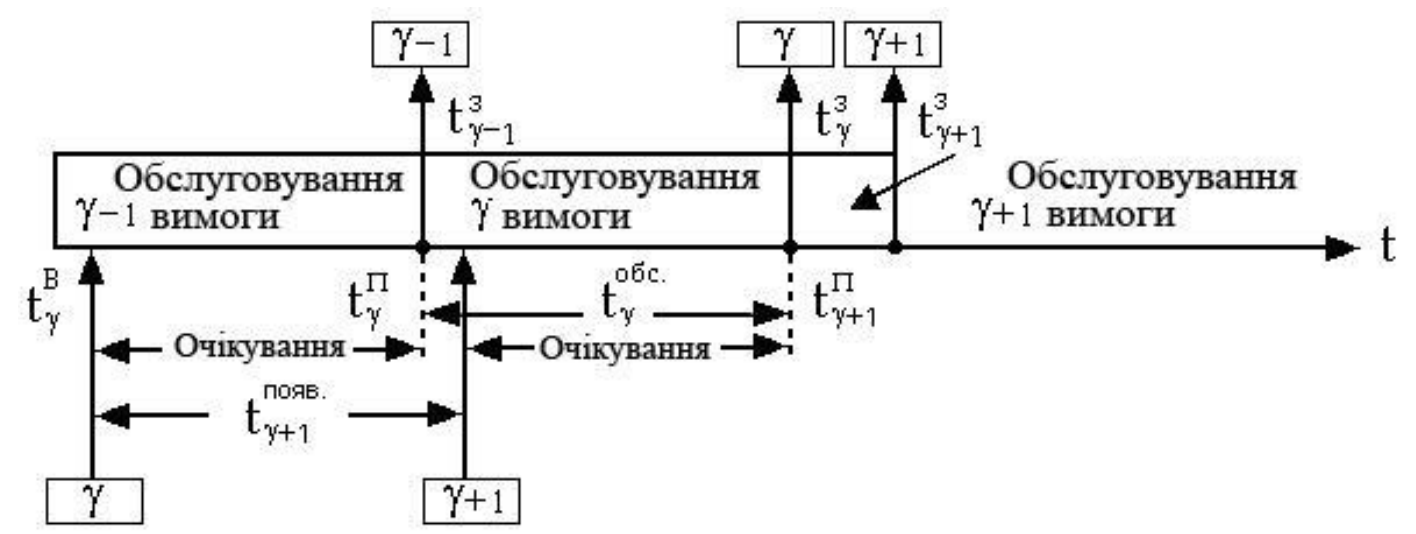

\section{Рис. 10. Дискретно-подійна модель системи обслуговування Джерело: [11]}

Системна динаміка - парадигма моделювання, де для досліджуваної системи будуються графічні діаграми причинних зв'язків і глобальних впливів одних параметрів на інші в часі, а потім створена на основі цих діаграм модель імітується на комп'ютері. Такий вид моделювання більш всіх інших парадигм допомагає зрозуміти суть того, що відбувається виявлення причинно-наслідкових зв'язків між об'єктами і явищами. За допомогою системної динаміки будують моделі бізнес-процесів, розвитку міста, моделі виробництва, динаміки популяції, екології та розвитку епідемії (рис. 11). Системна динаміка - це підхід імітаційного моделювання, який своїми методами і інструментами дозволяє зрозуміти структуру і динаміку складних систем. Системна динаміка головним чином використовується в довгострокових, стратегічних моделях і приймає високий рівень абстракції. Метод був заснований Джеєм Форрестером в 1950 роках $[13,15]$. 


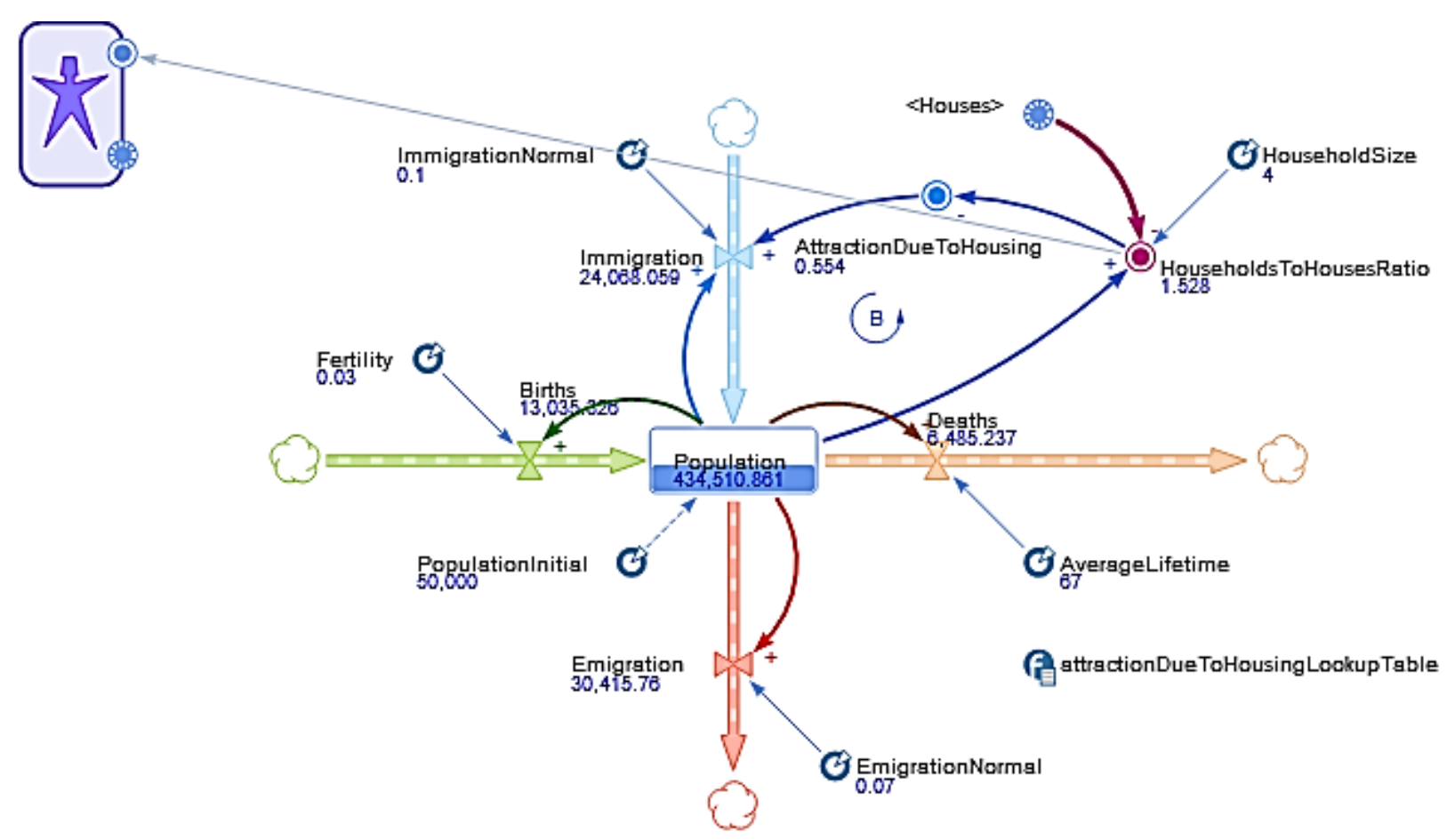

Рис. 11. Модель системної динаміки чисельності населення Джерело: [16]

Агентне моделювання - відносно новий (1990-ті ... 2000-і рр.) напрямок в імітаційному моделюванні, який використовується для дослідження децентралізованих систем, динаміка функціонування яких визначається не глобальними правилами і законами (як в інших парадигмах моделювання), а навпаки, коли ці глобальні правила і закони є результатом індивідуальної активності членів групи (рис. 12). Мета агентних моделей — отримати уявлення про ці глобальні правила, загалом поведінці системи, виходячи 3 припущень про індивідуальну, приватну поведінку її окремих активних об'єктів і взаємодії цих об’єктів в системі [15].

Агент - певна сутність, що володіє активністю, автономним поведінкою, може приймати рішення відповідно до деяким набором правил, взаємодіяти з оточенням, а також самостійно змінюватися.

a)

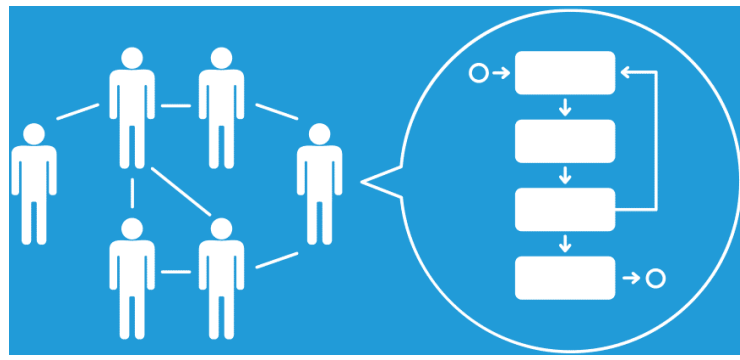

Рис. 12. Агентне моделювання:

а) парадигма агентного моделювання; б) агентна модель пасажирського вокзалу Джерело: [13, 16]

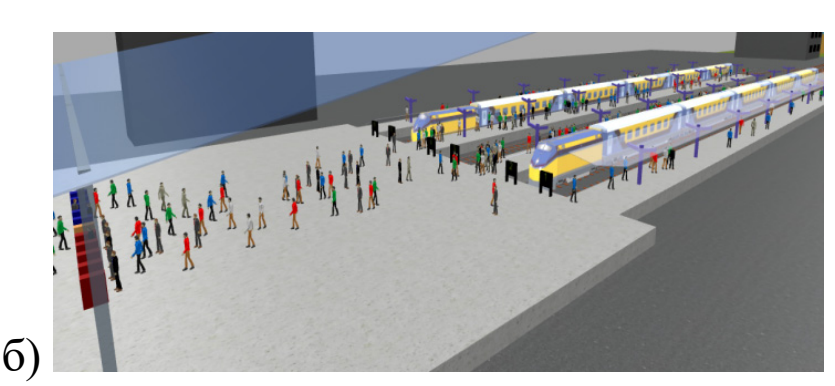

б) 
Агентами можуть бути: люди (споживачі, пасажири, працівники, пацієнти, клієнти, солдати і ін.); транспорт, обладнання (автомобілі, крани, літаки, вагони, верстати, ...); нематеріальні речі (проекти, продукти, інновації, ідеї, інвестиції ...,); організації (компанії, політичні партії, країни, ...). Середовище - деякий простір, в якому знаходяться агенти, що характеризується своїми станами і факторами, агенти знаходяться в певному місці цього простору, з можливістю орієнтування і пересування в даному просторі. Правила взаємодії - закони взаємодії агентів у довкіллі, з процедурами прийняття рішення і вибору стратегії при черговому кроці взаємодії [15].

Як зазначалось, імітаційні моделі відносяться до абстрактних; при цьому кожній з вказаних парадигм відповідає різний рівень абстрагування (рис. 13) від реальної системи (об'єкта/процесу).

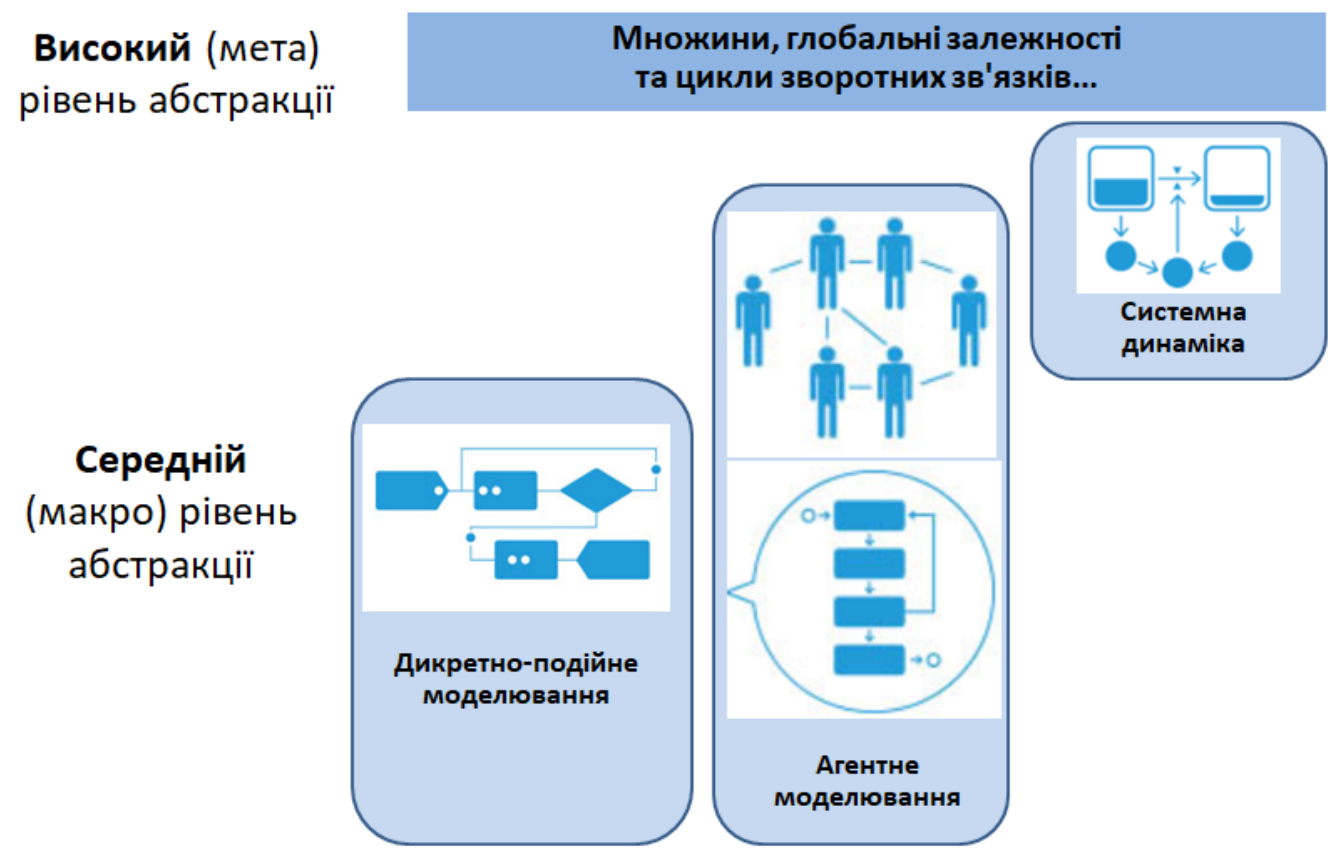

Низький (мікро) рівень абстракції

Окремі об'єкти, їх розміри, рух, фізична взаємодія...

Рис. 13. Застосування парадигми імітаційного моделювання в залежності від рівня абстрагування

Джерело: [13]

Низькому (оперативному) рівню абстракції (мікрорівень) відповідають моделі фізичного рівня, в яких об'єкти реального світу моделюються максимально докладно. На цьому рівні враховується фізична взаємодія, розміри, швидкості, відстані. Рух автомобіля, вивантаження вагону, скочування вагону з гірки, робота навантажувача - всі ці приклади вимагають низького рівня абстракції при їх моделюванні. 
Інші моделі мають середній (тактичний) рівень абстракції (макрорівень). Наприклад, при моделюванні роботи парку залізничної станції необхідно враховувати кількість колій, локомотивів, штат співробітників, технологію обслуговування, однак при цьому безпосередню взаємодію між працівниками або вагонів 3 рейками можна виключити із розгляду.

Моделі високого (стратегічного) рівня абстракції (мета рівень) найчастіше оперують узагальненими поняттями, такими як сукупність споживачів або статистика рівня зайнятості, а не окремими об'єктами. Так як взаємодія між об'єктами відбувається на високому рівні, такі моделі допомагають зрозуміти взаємозв'язки в системі без необхідності моделювати проміжні кроки та детальну взаємодію між окремими елементами системи. Прикладом такої моделі може бути вплив тарифної політики Укрзалізниці на обсяги перевезень.

\section{3. Аналіз підходів до моделювання залізничних транспортних систем}

Залізнична транспортна система є складовою загальної транспортної системи держави, що наразі забезпечує близько 55\% від загального вантажообігу (а без урахування трубопровідного транспорту — до 80\%) [17]. Ключовими елементами залізничної системи є залізничні станції та ділянки. Саме пропускна здатність станцій та ділянок в значній мірі визначає рівень ефективності та працездатності залізничної системи в цілому, ії здатність до безперебійного забезпечення перевезень вантажів та пасажирів. При цьому, з одного боку, вказані об'єкти залізничної системи повинні мати достатній резерв пропускної та переробної спроможності для ефективної роботи в умовах нерівномірності транспортних потоків, 3 іншого невиправдане збільшення технічного потенціалу станцій та ділянок призводить до зростання як капітальних інвестицій, так і експлуатаційних витрат на утримання. Для вирішення зазначеної складної та суперечливої задачі необхідна достовірна кількісна та якісна оцінка планованих заходів щодо вдосконалення конструкції і технології роботи залізничних станцій та ділянок, а також прогнозування можливих ризиків від реалізації того чи іншого інвестиційного проекту. Ефективним засобом аналізу та оцінки показників функціонування станцій та залізничних ділянок, їх технікотехнологічних і економічних параметрів $є$ імітаційне моделювання. Використання імітаційних моделей при виконанні проектних робіт дозволяє приймати раціональні та обгрунтовані рішення, спрямовані як на підвищення ефективності залізничних транспортних об’єктів, так і на зменшення впливу ризиків на перевізний процес [18].

\subsection{1. Імітаційні моделі залізничних станцій та ділянок}

Дослідження із проблем створення імітаційних моделей залізничних станцій та ділянок для вивчення й оптимізації їх роботи були розпочаті в $60-\mathrm{x}$ роках минулого століття 3 появою серійних ЕОМ. У зазначених роботах для аналізу завантаження технічних обладнань станцій пропонувалося використовувати 
статистичне моделювання технологічних процесів. При цьому для обліку нерівномірності роботи станцій моделюється випадковий вхідний потік поїздів, а тривалість обслуговування поїзда на станції моделюється як випадкова величина із заданим законом розподілу. За результатами моделювання визначаються «вузькі» місця на станції, затримки й простої поїздів. У фундаментальних роботах того періоду $[19,20]$ були сформульовані найбільш загальні принципи формалізації станцій i вузлів, методологія побудови їх функціональних моделей, наведені описи моделюючих алгоритмів і результати досліджень. Автори рекомендують застосовувати системний підхід до побудови моделі залізничної станції або вузла. При цьому станція або вузол розглядається як багатофазна система масового обслуговування, у яку надходять заявки на обслуговування (поїзди, вагони, локомотиви тощо.). Станція структурно представляється у вигляді набору різних технологічно зв'язаних блоків, кожному з яких відповідає певна фаза обслуговування заявки.

Однією із проблем, що виникають при розробці моделей станцій, є складність формалізації схем колійного розвитку для моделювання переміщень рухомого складу. Так, в [21] запропонований спосіб формалізації схеми станції, який не вимагає розбивки горловин на елементи. Для моделювання пересувань складається таблиця можливих маршрутів, яка доповнюється таблицею ворожості маршрутів. В [22] колійний розвиток представляється як орієнтований граф, вершинам якого відповідають стрілочні переводи, ізольовані стики, тупики, світлофори.

У багатьох роботах для моделювання роботи об'єктів транспортної інфраструктури пропонується використовувати апарат теорії масового обслуговування та дискретно-подійну парадигму [23, 24]. Так, в [24] модель станції являє собою набір програмних модулів, кожний з яких моделює початок і закінчення операцій певної технологічної фази. При цьому враховуються випадкові коливання вхідного потоку об'єктів і нерівномірність їх обслуговування.

Розвиток засобів обчислювальної техніки, і в першу чергу ПЕОМ, перехід до нової інформаційної технології керування у 1990-х роках поклали початок роботам зі створення так званих імітаційних систем. У зазначених системах процедури імітаційного моделювання використовуються в комбінації з оптимізаційними методами; при цьому в цих системах реалізується діалог «людина - ЕОМ» на всіх стадіях імітаційного експерименту. Одним із перших імітаційних комплексів для моделювання залізничних станцій стала система моделювання роботи сортувальної станції ІСТРА [25]. Імітаційна модель використовувалась у 1990-2000-х рр. для оперативного планування роботи станцій в змінних умовах та стала основою для розробки автоматизованого робочого місця маневрового диспетчера.

Метод моделювання станцій, заснований на використанні математичного апарату марківських випадкових процесів, розроблено в УкрДУЗТ [26]. Автори розглядають станцію як багатофазну одноканальну СМО. Для станції побудований орграф станів, на базі якого складається система рівнянь Колмогорова для знаходження граничних імовірностей окремих її станів. Зазначені ймовірності дозволяють

$$
-118-
$$


визначити основні техніко-технологічні параметри станції, необхідні для оптимізації iï потужності. Даний метод досить ефективний, однак його складність різко зростає при переході до багатоканальних СМО і збільшенні числа колій на станції.

«Вузьким» місцем на сортувальній станції є сортувальна гірка. В зв'язку 3 цим велика кількість наукових робіт присвячена розробці підходів до моделювання сортувальних процесів на гірках. Серед багатьох таких робіт варто виділити фундаментальну працю [27], в якій розроблено потужну імітаційну модель сортувального процесу, методологія його досліджень, зокрема, щодо оптимізації режимів гальмування відчепів.

У залізничних вузлах таким «вузьким» місцем $є$ перетин (розв'язка) залізничних ліній в одному рівні. Для дослідження таких розв'язок також побудовано цілий ряд імітаційних моделей. Зокрема в [28] на основі системного та комплексного підходу вирішується питання імітаційного моделювання руху потоку поїздів по перетинанням залізничних ліній. Модель має ієрархічну структуру. На метарівні модель розглядається як СМО, призначена для пропуску потоків поїздів примикають ліній. На макрорівні в модель розв'язки включені: модель руху поїздів і модель системи управління рухом поїздів та їх пропуском через перетину. Модель руху поїздів побудована на основі диференціальних рівнянь, в яких в якості незалежних змінних використовується час або шлях. сигналів автоблокування, а також наявності діючих обмежень швидкості. У якості моделі системи управління рухом поїздів і їх пропуском через розв'язку запропоновано використовувати детерміновані кінцеві автомати.

Широке поширення останнім часом одержали моделі транспортних об'єктів, розроблені з використанням апарата мереж Петрі. Технологічний процес обробки поїздів у таких моделях представляється послідовністю позицій (станів) і переходів. При цьому переходи імітують обробку об'єктів протягом заданого часу, а позиції характеризують поточний стан системи й визначають умови переходів. При виконанні умов перехід спрацьовує, у результаті чого змінюється поточна розмітка мережі. Зокрема, в [29] розглядаються можливості використання апарата мереж Петрі для моделювання сортувальних станцій і інших транспортних комплексів та розроблена методика формалізації комплексу «сортувальна станція - ділянки, що примикають» у вигляді мережі Петрі. У даній роботі показано, що шляхом ускладнення структури мережі можна досягти будь-якого ступеню деталізації системи. Модель, побудована на основі мереж Петрі, дозволяс фіксувати стан системи в довільний момент часу, а також визначити за результатами моделювання інтегральні показники тривалості виконання окремих операцій і число оброблених об'єктів. Є також можливість дослідження моделі шляхом варіювання окремих кількісних параметрів. Мережі Петрі також застосовуються для моделювання переміщення транспортних об'єктів (поїздів, локомотивів) у моделях залізничної мережі [30]. При цьому реальна конфігурація мережі залізниць задається відповідною мережею Петрі. Кожна позиція мережі моделює певний елемент залізничної мережі (блок-дільниця, світлофор, роздільний пункт і ін.). 
В [31] запропонована імітаційна модель сортувальної станції, розроблена на основі теорії масового обслуговування, а також сітьового планування й управління. Їі програмна реалізація виконана з використанням сучасного об'єктно-орієнтованого підходу. Технологічний процес обробки транзитного вагонопотоку формалізований у моделі на основі сітьового графіка. При цьому переходи між окремими операціями можуть бути детермінованими, імовірнісними й умовними. Умовні переходи реалізуються при настанні певних подій. Імовірнісні переходи розігруються відповідно до заданого вектора ймовірностей і дозволяють урахувати багатоваріантність організації технологічного процесу. Відмітною рисою моделі є можливість інтерактивної участі оператора, який на основі надаваної інформації (графіки показників, діаграми використання ресурсів) може втручатися в процес моделювання, вибираючи той або інший варіант технологічної послідовності виконання операцій.

Дискретно-подійний підхід до побудови імітаційної моделі сортувальної станції застосовано у [32]. Кожна підсистема станції (парк прибуття, сортувальна гірка, сортувальний та приймально-відправний парк, підходи) реалізована у вигляді окремого модуля, а взаємодія між модулями здійснюється шляхом обміну спеціальних повідомлень. Для координації та організації модулів в модель введено модуль керування, який також імітує функції диспетчерського апарату.

Для дослідження графіків руху поїздів та завантаженості ділянок на залізничних напрямках у [33] розроблено імітаційну модель, що враховує топологію залізничного напрямку та параметри поїздопотоків. Відмінною рисою моделі є інформаційний модуль, який відображає графік виконаного руху на часовій сітці та поточні експлуатаційні показники. Модель використовує дискретно-подійний підхід; при цьому залізничний напрямок формалізований як СМО, заявками в якому є вантажні та пасажирські поїзди, а фазами обслуговування - їх просування (з врахуванням можливих зупинок) між станціями напрямку.

У роботі [34] запропонована імітаційна модель роботи залізничного вузла на основі агентного моделювання: на інфраструктурному рівні агентами є залізничні колії, локомотиви, бригади; на сервісному рівні агентами є під’їзні колії, вантажні райони, сортувальні гірки, витяжні колії тощо; керуючі агенти (агенти, що моделюють роботу вузлового диспетчера, чергового по станції, маневрового диспетчера тощо) забезпечують взаємодію агентів інфраструктурного та сервісного рівнів.

Науковцями ДНУЗТ розроблено концепцію ергатичного моделювання залізничних станції, яка передбачає безпосередню участь людини в процесі моделювання для виконання функцій диспетчера станції [18]. Вказана концепція була реалізована у цілому комплексі ергатичних моделей, на основі яких також були розроблені імітаційні навчальні тренажери-симулятори для підготовки диспетчерського персоналу станцій. 


\subsection{2. Сучасні системи імітаційного моделювання}

Розробка ефективної та адекватної імітаційної моделі складної системи чи процесу представляє собою досить непросте завдання, оскільки потребує від розробника як професійного досвіду у програмуванні, так і глибоких знань у відповідній прикладній галузі. Однак, як правило, професійні програмісти не $є$ технологами, а технологи не є програмістами. Для вирішення вказаної проблеми, починаючи 3 70-х років минулого сторіччя, поступово створюються спеціалізовані мови для програмування саме імітаційних моделей, що згодом, з розвитком комп'ютерної техніки, перетворились на спеціалізовані програмні комплекси та системи імітаційного моделювання. Такі комплекси представляють собою програмні редактори, які дозволяють користувачу, маючи базові навички програмування, створювати потужні імітаційні моделі, досліджувати їх роботу та виконувати пошук оптимальних параметрів.

Одним 3 перших таких програмних засобів, мова для якого була розроблена ще у $60 \ldots 70$-х роках минулого століття, став GPSS (General Purpose Simulation System). Його розробником є Джефрі Гордон - автор концепції дискретно-подійного моделювання, на якій власне і базується мова GPSS. Наразі існують версії GPSS різних розробників, найбільш сучасна та функціональна 3 яких — GPSS World - версія для OC Windows, що розроблена компанією Minuteman Software. Мова GPSS призначена, в перш чергу, для моделювання різноманітних систем масового обслуговування. Для побудови імітаційної моделі на мові GPSS корисно представити ії у вигляді схеми, на якій з'єднані елементи СМО - пристрої, накопичувачі, вузли та джерела. Описом моделі на мові GPSS є сукупність операторів (блоків), що характеризують процеси обробки вимог - виникнення транзактів, затримки їх в пристроях, очікування транзактів в черзі, виведення із СМО [35].

Для моделювання та дослідження транспортних систем в останні роки широко використовуються продукти німецької компанії PTV Group, зокрема, такі як Visum та Vissim. Так, Visum дає можливість моделювати транспортні мережі громадського та індивідуального транспорту, пасажиропотоки, досліджувати плани розвитку транспортних систем міст. При цьому використовуються дані геоінформаційних систем, а також візуалізація процесу моделювання. Vissim призначена для моделювання мультимодальних транспортних потоків та взаємодії різних видів транспорту [36].

Серед найбільш поширених програмних продуктів, призначених для використання системно-динамічного підходу, можна виділити Vensim, Powersim та IThink [37].

Серед сучасних імітаційних систем однією з найбільш популярних та функціональних наразі $є$ AnyLogic [16]. В даній системі реалізовано усі три сучасні парадигми моделювання: системна динаміка, дискретно-подійна та агентна; при цьомy AnyLogic дозволяє їх поєднувати у будь-якій конфігурації в одній моделі. Перевагами даної системи є: графічне середовище розробки моделей AnyLogic значно прискорює процес створення моделей; створення власних бібліотек дозволяє розробнику багаторазово використовувати вже написані модулі; об'єктно- 
орієнтований підхід піднімає процес розробки моделей на новий рівень; інтуїтивний графічний інтерфейс спрощує перехід з інших інструментів імітаційного моделювання на AnyLogic [13].

AnyLogic включає «Залізничну бібліотеку», яка дозволяє ефективно моделювати та візуалізувати функціонування залізничних об'єктів будь-якого масштабу і рівня складності - від окремих станцій і залізничних ліній, до залізничних вузлів і колій незагального користування великих промислових підприємств. Окрім того, програмний продукт містить велику кількість прикладів - готових моделей 3 різних галузей: логістики, транспорту, медицини, бізнесу, соціальних явищ тощо, а також зручну та зрозумілу систему допомоги, навчальні матеріали, покрокові інструкції [16, 37].

\section{4. Побудова імітаційної моделі приймально-відправного парку сортувальної станції у середовищі AnyLogic}

Враховуючи наведені вище переваги, у середовищі AnyLogic авторами була побудована імітаційна модель приймально-відправного парку сортувальної станції. Розроблена модель у подальшому була використана для дослідження роботи парку та оцінки різних варіантів проектних рішень щодо удосконалення його технічних та технологічних параметрів 3 врахуванням ризиків експлуатаційної надійності [37].

Приймально-відправний парк станції розглядається у моделі як система масового обслуговування, заявками в якій є вантажні поїзди, а обслуговуючими пристроями - приймально-відправні колії, бригади оглядачів вагонів, маневрові локомотиви. Процес функціонування технологічної лінії з обробки поїздів розглядається як дискретно-подієвий процес, відповідно модель побудована на дискретно-подієвій платформі. Кожна заявка (поїзд), що обслуговується у системі (парку) у кожний момент часу перебуває на обслуговуванні у певному елементі технологічного ланцюга. Перехід між етапами (елементами) обробки представляє собою умовну межу, і не має власної тривалості.

Авторами була розроблена і реалізована у редакторі AnyLogic потокова діаграма процесу обслуговування поїздів у приймально-відправному парку станції, яка є основою імітаційної моделі (рис. 14).

Кожен блок діаграми являє собою елемент певного типу, призначений для виконання відповідних функцій. Блоки «Генератор» (Source) і «Черга на вході» (Queue) моделюють вхідний потік поїздів і формують їх чергу у випадку зайнятості всіх станційних колій. Блоки «Вибір» (SelectOutput) дозволяють виконувати перевірку вільності колій для формування і реалізації маршруту прибуття поїзда. У випадку зайнятості всіх колій вказаний елемент блокує потік поїздів за допомогою блоку «Затримка» (Hold), тим самим збільшуючи чергу поїздів Queue на підході до станції. 
Зайнятість та звільнення колій у моделі здійснюється за допомогою блоків Sieze, ResourcePool та Release. Елемент Seize при проходженні через нього поїзда використовує задану кількість (як правило, одиницю) ресурсу (колійний розвиток парку), який перебуває у відповідному елементі ResourcePool. При цьому кількість pecyрсів у блоці ResourcePool зменшується на одиницю.

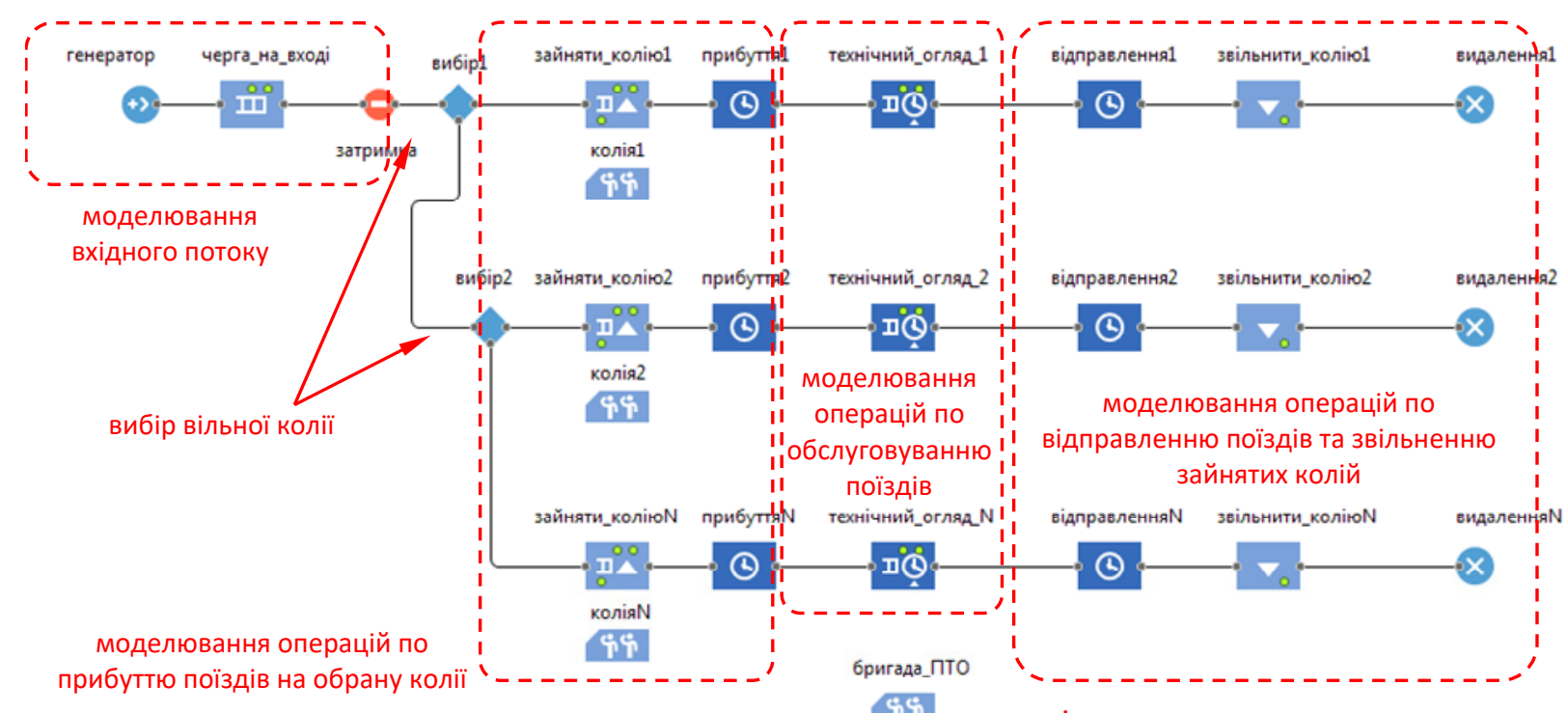

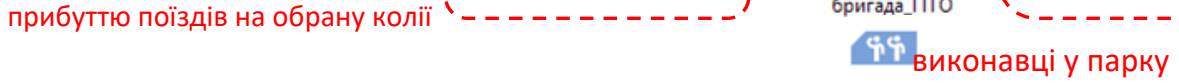

\section{у парку}

Рис. 14. Фрагмент потокової діаграми процесу обслуговування поїздів

Дюерело: Авторська розробка

Якщо всі ресурси вичерпані (відповідна колія або усі станційні колії зайняті), то черговий поїзд буде затриманий. У процесі моделювання за допомогою елемента ResourcePool можна відстежувати поточну завантаженість відповідних ресурсів (колій, працівників, локомотивів тощо). Елемент Release після закінчення обслуговування поїзда звільняе відповідний ресурс (приймально-відправну колію). Аналогічним чином моделюється процес заняття і звільнення бригад ПТО при виконанні технічного огляду составів. Для цього використовується спеціальний блок Service, що представляє собою об'єднання елементів Sieze, ResourcePool та Release. Тривалість виконання технологічних операцій моделюється за допомогою блоку Delay, що дозволяє затримувати заявки на елементах потокової діаграми на час, який може бути представлено, як конкретним значенням, так і функцією (наприклад, функцією розподілу випадкової величини).

Для збору статистики про тривалість знаходження поїздів на певних елементах моделі (фазах обслуговування), зокрема, і на підходах до парку, та у цілому у системі обслуговування (у приймально-відправному парку) у відповідних точках потокової діаграми встановлюються елементи TimeMeasureStart (на початку необхідної ділянки/елементу діаграми) та TimeMeasureEnd (в кінці необхідної ділянки/елементу діаграми). Дані цих елементів (в даному випадку — про простої 
поїздів) можна візуалізувати у вигляді графіків, діаграм або зберегти у файл для подальшого аналізу.

Розроблена модель була використана для аналізу надійності різних технічних i технологічних параметрів приймально-відправних парку сортувальної станції в різних експлуатаційних умовах (при різних параметрах вхідного потоку вантажних поїздів). За допомогою моделі були побудовані діаграми завантаження окремих елементів парку, а також визначені «вузькі місця». На основі цих даних розроблено ряд організаційно-технічних заходів щодо підвищення експлуатаційної надійності приймально-відправних парку (збільшення числа приймально-відправних колій, зміна штату працівників, що беруть участь в обробці поїздів та ін.). Відповідні зміни були внесені в імітаційну модель парку. За результатами серії експериментів з моделлю були отримані експлуатаційні показники роботи парку (простої поїздів по неприйому та під обробкою в парку) і його окремих елементів (коефіцієнти завантаження). Ці показники стали основою для відповідних технікоекономічних розрахунків щодо оцінки ефективності заходів, спрямованих на вдосконалення технічного оснащення і технології роботи парку з врахуванням можливих експлуатаційних та економічних ризиків.

\section{5. Оцінка варіантів техніко-технологічних рішень в умовах ризиків}

Методологія кількісної оцінки величини ризику базується на широкому застосуванні апарату теорії ймовірностей та математичної статистики. Порівняння альтернативних рішень в умовах ризику, як правило, здійснюється за величиною економічного ефекту, в якості якого може розглядатися як прибуток від діяльності, так і експлуатаційні витрати $E$. При цьому величина економічного ефекту носить стохастичний характер i може бути оцінена за допомогою наступних статистичних характеристик [38]:

- математичне очікування - середньозважене значення випадкової величини, яке визначається як:

$$
M(E)=\sum_{i=1}^{n} E_{i} P_{i}
$$

де $P_{i}$ — ймовірність реалізації величини $E_{i}$.

- дисперсія - характеризує міру розсіву випадкової величини відносно іiі математичного очікування та визначається як:

$$
D(E)=M\left(E^{2}\right)-M(E)^{2},
$$

де $M\left(E^{2}\right)$ - середнє значення квадрату випадкової величини $E$.

- середньоквадратичне відхилення - характеризує абсолютне відхилення випадкової величини від іï математичного очікування та визначається як: 


$$
\sigma(E)=\sqrt{D(E)} .
$$

Середньоквадратичне відхилення $\sigma(E)$ на практиці часто застосовується як міра величини ризику [39].

- коефіцієнт варіації - характеризує відносне відхилення випадкової величини від ії математичного очікування та визначається як:

$$
v(E)=\frac{\sigma(E)}{M(E)} .
$$

Коефіцієнт варіації $v(E)$ характеризує питому величину ризику на одиницю економічного ефекту [39].

Розглянемо сутність статистичного методу порівняння варіантів в умовах ризику на прикладі задачі про вибір оптимальної стратегії обслуговування поїздів у парку залізничної станції. Так, аналізом встановлено, що прибуття поїздів на станцію може характеризуватися як згущене $\lambda_{1}-3$ ймовірністю 0,2 , рівномірне $\lambda_{2}-3$ ймовірністю 0,3 і розріджене $\lambda_{3}-3$ ймовірністю 0,5 . Технологічний процес обслуговування поїздів може бути побудований за трьома стратегіями: $A_{1}$, $A_{2}, A_{3}-3$ розрахунком, відповідно, на згущене, рівномірне та розріджене прибуття поїздів. Вказані стратегії відрізняються кількістю приймально-відправних колій, груп в бригаді ПТО та маневрових локомотивів, що залучаються до обслуговування вхідного потоку поїздів. Використання кожної зі стратегій несе ризики невідповідності рівня технічного оснащення парку станції потрібній переробній спроможності у відповідності до фактичної інтенсивності прибуття поїздів. Так, залучення недостатньої кількості виконавців та технічних засобів в періоди згущеного прибуття поїздів призведе до зростання витрат, пов'язаних зі збільшенням величини простою рухомого складу в очікуванні обслуговування та через його затримки на підходах до станції. В той же час, надмірна переробна спроможність спричинить неефективне використання технічних засобів та призведе до відповідних надлишкових витрат на утримання [18]. Таким чином, необхідно обрати оптимальну стратегію обслуговування поїздів, яка б дозволяла в умовах вказаного ризику мінімізувати експлуатаційні витрати станції.

Величина експлуатаційних витрат $E$ з достатньою точністю може бути визначена за допомогою імітаційного моделювання роботи приймально-відправного парку станції (див. п. 2.4). Для умов даного прикладу, в табл. 1 представлені середньодобові значення витрат $E$ за визначеними стратегіями при різній інтенсивності вхідного потоку поїздів. 
Таблиця 1

Добові експлуатаційні витрати за стратегіями, грн

\begin{tabular}{|c|c|c|c|}
\hline \multirow{2}{*}{ Стратегія } & \multicolumn{3}{|c|}{ Інтенсивність вхідного потоку } \\
\cline { 2 - 4 } & $\lambda_{1}$ & $\lambda_{2}$ & $\lambda_{3}$ \\
\hline$A_{1}$ & 19300 & 24500 & 36400 \\
\hline$A_{2}$ & 39200 & 15400 & 20200 \\
\hline$A_{3}$ & 57500 & 34800 & 16500 \\
\hline
\end{tabular}

Авторська розробка

Виконаємо розрахунок статистичних характеристик величини експлуатаційних витрат при організації роботи станції за кожною зі стратегій:

- стратегія $A_{1}$

$M\left(E_{1}\right)=19300 \times 0,2+24500 \times 0,2+36400 \times 0,5=29410$ грн.;

$M\left(E_{1}^{2}\right)=19300^{2} \times 0,2+24500^{2} \times 0,2+36400^{2} \times 0,5=917053000 \mathrm{гpн}^{2}$;

$D\left(E_{1}\right)=917053000-29410^{2}=52104900$ грн $^{2}$;

$\sigma\left(E_{1}\right)=\sqrt{52104900}=7218,37$ грн.;

$v\left(E_{1}\right)=\frac{7218,37}{29410}=0,25$.

- стратегія $A_{2}$

$M\left(E_{2}\right)=39200 \times 0,2+15400 \times 0,2+20200 \times 0,5=22560$ грн.;

$M\left(E_{2}^{2}\right)=39200^{2} \times 0,2+15400^{2} \times 0,2+20200^{2} \times 0,5=582496000 \mathrm{rpн}^{2} ;$

$D\left(E_{2}\right)=582496000-22560^{2}=73542400$ грн $^{2}$;

$\sigma\left(E_{2}\right)=\sqrt{73542400}=8575,69$ грн.;

$v\left(E_{2}\right)=\frac{8575,69}{22560}=0,38$.

- стратегія $A_{3}$

$M\left(E_{3}\right)=57500 \times 0,2+34800 \times 0,2+16500 \times 0,5=30190$ грн;

$M\left(E_{3}^{2}\right)=57500^{2} \times 0,2+34800^{2} \times 0,2+16500^{2} \times 0,5=1160687000 \mathrm{rpH}^{2} ;$

$D\left(E_{3}\right)=1160687000-30190^{2}=249250900$ грн $^{2}$;

$\sigma\left(E_{3}\right)=\sqrt{249250900}=15787,68$ грн;

$v\left(E_{3}\right)=\frac{15787,68}{30190}=0,52$.

Для зручності аналізу зведемо результати розрахунків в табл. 2. 
Таблиця 2

Показники ризику за стратегіями

\begin{tabular}{|c|c|c|c|}
\hline Стратегія & $M(E), \mathbf{\Gamma р H}$ & $\sigma(E), \mathbf{\Gamma р H}$ & $v(E)$ \\
\hline$A_{1}$ & 29410 & 7218,37 & 0,25 \\
\hline$A_{2}$ & 22560 & 8575,69 & 0,38 \\
\hline$A_{3}$ & 30190 & 15787,68 & 0,52 \\
\hline
\end{tabular}

Авторська розробка

Далі за результатами розрахунків необхідно виконати порівняння альтернатив. В загальному випадку серед двох стратегій $A$ та $B$ слід обрати стратегію $A$, якщо [40]:

$$
\begin{aligned}
& M\left(E_{A}\right)<M\left(E_{B}\right), \sigma\left(E_{A}\right)<\sigma\left(E_{B}\right), v\left(E_{A}\right)<v\left(E_{B}\right) ; \\
& M\left(E_{A}\right)<M\left(E_{B}\right), \sigma\left(E_{A}\right) \approx \sigma\left(E_{B}\right), v\left(E_{A}\right)<v\left(E_{B}\right) ; \\
& M\left(E_{A}\right) \approx M\left(E_{B}\right), \sigma\left(E_{A}\right)<\sigma\left(E_{B}\right), v\left(E_{A}\right)<v\left(E_{B}\right) .
\end{aligned}
$$

У той же час при порівнянні альтернатив необхідно враховувати ставлення особи, яка приймає рішення (ОПР), до ризику: нейтральне, обережне, схильне до ризику [41]. При нейтральному ставленні до ризику ОПР орієнтується тільки на середній очікуваний кінцевий економічний результат та обирає альтернативу 3 найменшою величиною експлуатаційних витрат $M(E)$. Обережний до ризику ОПР, окрім величини витрат оцінює також і величину ризику $\sigma(E)$. ОПР в цьому випадку буде схильний обрати альтернативу з меншою величиною ризику $\sigma(E)$, що в разі настання несприятливої події дозволить мінімізувати економічні втрати. I навпаки, схильний до ризику ОПР надасть перевагу альтернативі з більшою величиною ризику $\sigma(E)$, що в разі сприятливої ситуації дозволить досягти найкращого економічного результату.

Таким чином, кожна альтернатива може бути представлена двомірним вектором $(M(E) ; \sigma(E))$. У відповідності до цього порівняння альтернатив зводиться до порівняння відповідних векторів при заданому відношенні ОПР до ризику $F(M(E) ; \sigma(E)) \rightarrow \min$. При цьому величина витрат $M(E)$ оцінюється завжди однозначно: чим менший даний показник, тим він краще для ОПР при будь-якому його відношенні до ризику. Отже, оцінка альтернатив при різному ставленні ОПР до ризику може бути формалізована як [41]: 


$$
F=\left\{\begin{array}{l}
M(E) \text { - для нейтральних до ризику ОПР; } \\
M(E)-\alpha \sigma(E)^{2}-\text { для обережних до ризику ОПР; } \\
M(E)+\beta \sigma(E)^{2}-\text { для схильних до ризику ОПР }
\end{array}\right.
$$

де $\alpha, \beta$ - відповідно коефіцієнт індивідуальної обережності та схильності ОПР до ризику.

Для визначення вказаних коефіцієнтів досить вказати дві такі різні альтернативи, які ОПР вважає еквівалентними з точки зору співвідношення витрат та ризиків. Припустимо, ОПР вважає еквівалентними альтернативи: $X$ з параметрами $\left(M\left(E_{X}\right) ; \sigma\left(E_{X}\right)\right)$ та $Z$ з параметрами $\left(M\left(E_{Z}\right) ; \sigma\left(E_{Z}\right)\right)$. Тоді справедливими $\epsilon$ наступні вирази [41]:

$$
\begin{aligned}
& \alpha=\frac{M\left(E_{Z}\right)-M\left(E_{X}\right)}{\sigma\left(E_{Z}\right)^{2}-\sigma\left(E_{X}\right)^{2}}, \\
& \beta=\frac{M\left(E_{Z}\right)-M\left(E_{X}\right)}{\sigma\left(E_{X}\right)^{2}-\sigma\left(E_{Z}\right)^{2}} .
\end{aligned}
$$

При нейтральному відношенні до ризику ОПР виконує порівняння лише на основі величини $M(E)$; при цьому згідно табл. 2 оптимальною буде альтернатива $A_{2}$, що характеризується мінімальною величиною експлуатаційних витрат.

Для випадку відмінного від нейтрального ставлення ОПР до ризику визначення індивідуальних коефіцієнтів $\alpha$ та $\beta$ здійснюється шляхом введення фіктивних стратегій $A_{4}^{*}$ та $A_{5}^{*}$ (див. табл. 3).

При обережному ставленні до ризику еквівалентними можуть вважатись, наприклад, стратегії $A_{1}(29410 ; 7218,37)$ та $A_{4}^{*}(6000 ; 4000,00)$. При цьому індивідуальний коефіцієнт обережності $\alpha$ складе (9):

$$
\alpha=\frac{6000-29410}{4000,00^{2}-7218,37^{2}}=0,000648 .
$$

3 використанням вказаного коефіцієнту розрахуємо значення функції $F$ за альтернативами (див. табл. 4). 
Таблиця 3

Вихідні дані для порівняння стратегій

\begin{tabular}{|c|c|c|}
\hline Стратегія & $M(E), \mathbf{\Gamma р H}$ & $\sigma(E)$, грн \\
\hline$A_{1}$ & 29410 & 7218,37 \\
\hline$A_{2}$ & 22560 & 8575,69 \\
\hline$A_{3}$ & 30190 & 15787,68 \\
\hline$A_{4}^{*}$ & 6000 & 4000,00 \\
\hline$A_{5}^{*}$ & 24000 & 18000,00 \\
\hline
\end{tabular}

Авторська розробка

Таблиця 4

Порівняння стратегій при обережному ставленні до ризику

\begin{tabular}{|c|c|c|c|}
\hline Стратегія & $M(E), \mathbf{\Gamma р H}$ & $\sigma(E), \mathbf{\Gamma p H}$ & $F(M(E) ; \sigma(E))$ \\
\hline$A_{1}$ & 29410 & 7218,37 & $\mathbf{6 3 1 7 3 , 9 5}$ \\
\hline$A_{2}$ & 22560 & 8575,69 & 70215,51 \\
\hline$A_{3}$ & 30190 & 15787,68 & 191704,54 \\
\hline
\end{tabular}

Авторська розробка

Як видно з таблиці, ОПР з розглянутим ступенем обережності до ризику слід обрати стратегію $A_{1}$, яка забезпечує мінімум функції $F$ і, відповідно, мінімальні економічні збитки в результаті настання несприятливої події.

В разі схильності до ризику еквівалентними можуть вважатись, наприклад, стратегії $A_{3}(30190 ; 15787,68)$ та $A_{5}^{*}(24000 ; 18000,00)$. При цьому індивідуальний коефіцієнт схильності $\beta$ складе (10):

$$
\beta=\frac{24000-30190}{15787,68^{2}-18000,00^{2}}=0,000083 .
$$

3 використанням вказаного коефіцієнту розрахуємо значення функції $F$ за альтернативами (див. табл. 5).

Як видно $з$ таблиці, ОПР з розглянутим ступенем схильності до ризику слід обрати стратегію $A_{3}$, яка забезпечує мінімум функції $F$ і, відповідно, мінімальні витрати при настанні сприятливої події.

Для зручного порівняння стратегій множину альтернатив доцільно представити як набір точок в двомірному декартовому просторі; при цьому кожна стратегія може бути зображена у вигляді точки 3 координатою $(\sigma(E) ; M(E))$ (рис. 14). За 
вказаним рисунком можна визначити найкращу стратегію для ОПР з нейтральним ставленням до ризику — в точці $A_{2}$ забезпечується мінімум витрат.

Таблиця 5

Порівняння стратегій при схильності до ризику

\begin{tabular}{|c|c|c|c|}
\hline Стратегія & $M(E), \mathbf{\Gamma р H}$ & $\sigma(E), \mathbf{\Gamma р H}$ & $F(M(E) ; \sigma(E))$ \\
\hline$A_{1}$ & 29410 & 7218,37 & 25085,30 \\
\hline$A_{2}$ & 22560 & 8575,69 & 16455,98 \\
\hline$A_{3}$ & 30190 & 15787,68 & $\mathbf{9 5 0 2 , 1 8}$ \\
\hline
\end{tabular}

Авторська розробка

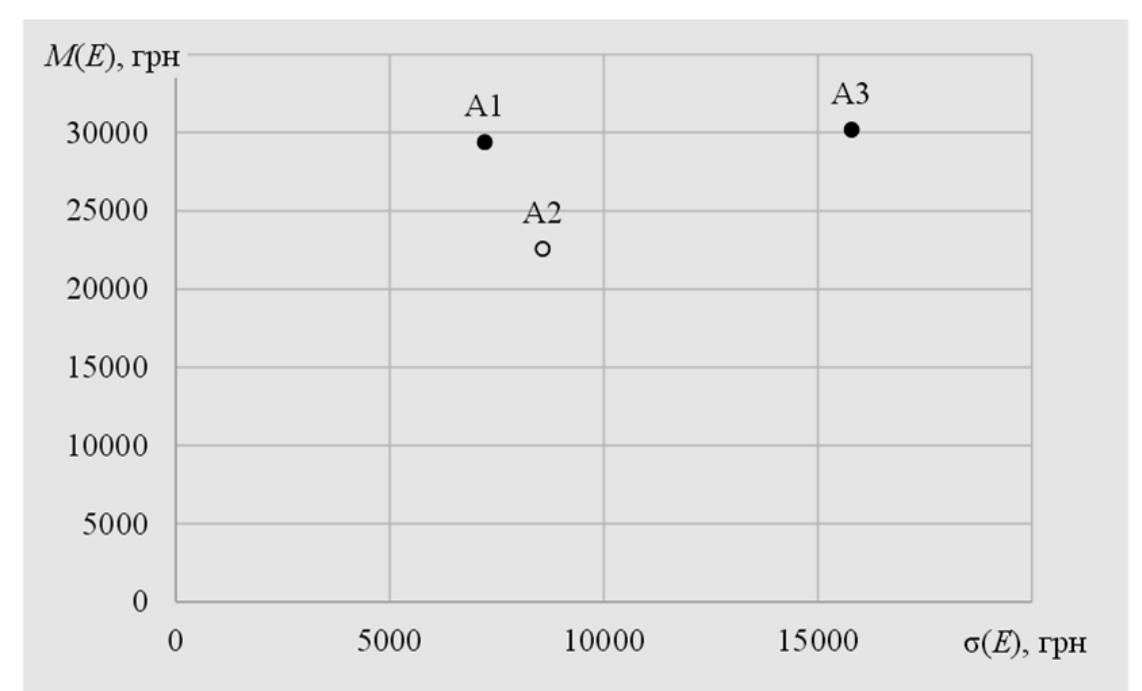

\section{Рис. 14. Графічне представлення стратегій}

Джерело: Авторська розробка

За допомогою функції $F(M(E) ; \sigma(E))$ можливо визначити множину точок, що еквівалентні одна одній. Графічно вказані точки будуть розташовуватись на одній параболі, якій в [41] надається визначення як лінії рівня (див. рис. 15).

При порівнянні стратегій за величиною витрат кращими $\epsilon$ точки, що лежать на більш низьких лініях рівня. 3 цього випливає, що при фіксованому рівні ризику $\sigma_{1}$ відносно альтернативи $A_{1}\left(\sigma_{1} ; M_{1}\right)$ більш кращою $є$ альтернатива $A_{1}^{*}\left(\sigma_{1} ; M_{2}\right)$. Очевидно також, що всі точки, що лежать на горизонтальній прямій $M_{0} A_{1}^{* *}$ будуть завідомо менш кращі, ніж безризиковий еквівалент точки $A_{1}$, представлений точкою $J\left(0 ; M_{0}\right)$, оскільки у всіх інших точках на цій прямій буде мати місце ненульовий ризик при збереженні середнього очікуваного доходу на однаковому рівні. Для того, щоб досягти безризикового еквівалента, для кожної точки прямої 
$M_{0} A_{1}^{* *}$ необхідне таке збільшення середнього очікуваного доходу альтернативи, яке б компенсувало ризик. Наприклад, для точки $A_{1} *\left(\sigma_{1} ; M_{0}\right)$ буде потрібно збільшення середнього очікуваного доходу на величину $M_{2}-M_{0}$. Побудуємо лінії рівня для розглянутих вище стратегій $A_{1}-A_{3}$ (рис. 16).

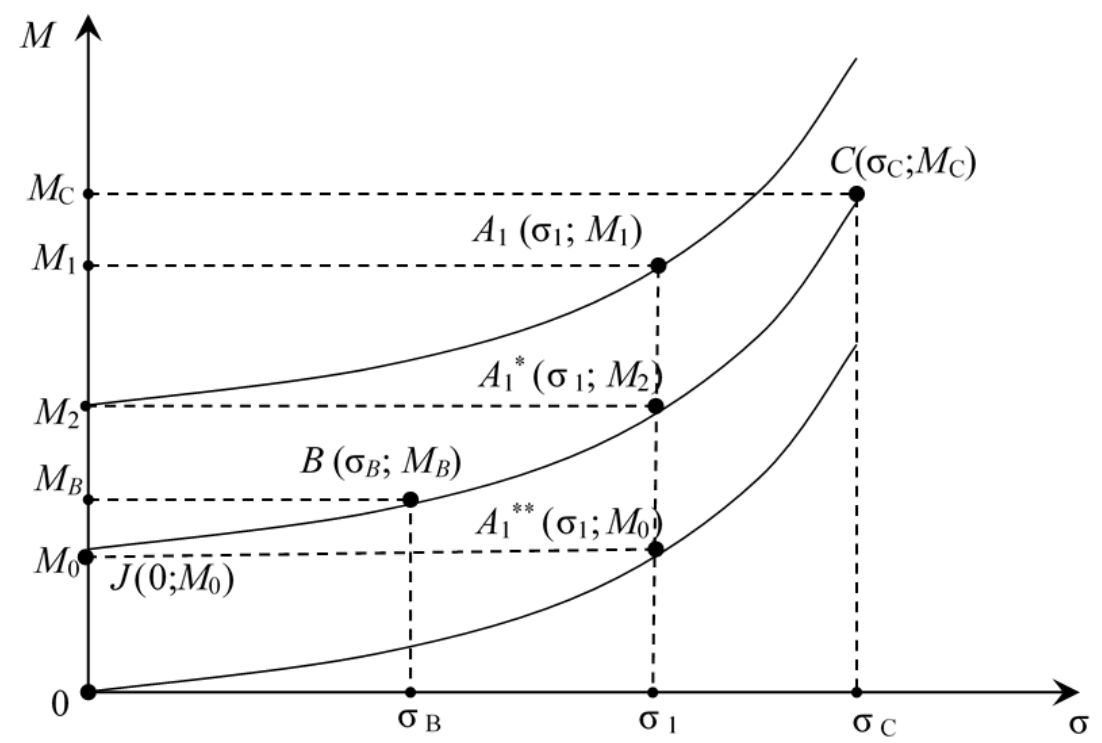

Рис. 15. Графічне представлення ліній рівня Джерело: [41]

a)

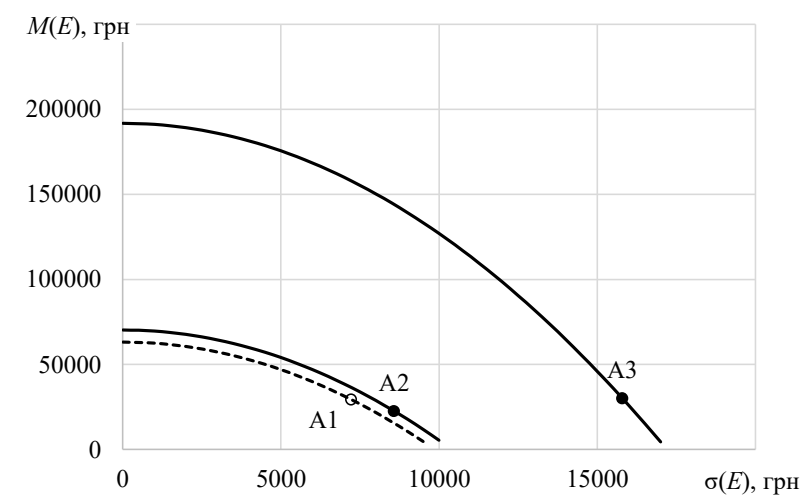

б)

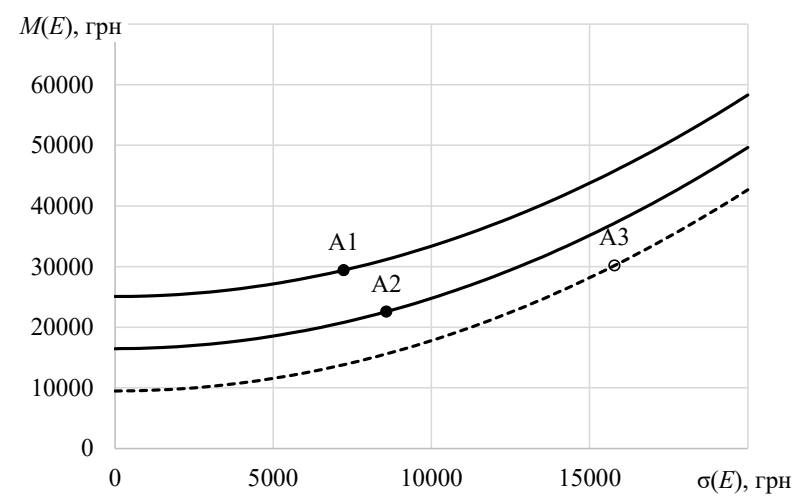

Рис. 16. Лінії рівня за альтернативами при ставленні до ризику:

a) обережному; б) схильному.

Джерело: Авторська розробка

Як видно с рис. $16 a$, для ОПР з обережним ставленням до ризику найкращими $\epsilon$ стратегії, що еквівалентні точці $A_{1}$, яка розташована на нижній лінії рівня. В той же час, у випадку схильності до ризику найкращими будуть стратегії, що еквівалентні точці $A_{3}$ (див. рис. 16 б). 
Таким чином, графічне зображення стратегій надає наочності процесу порівняння варіантів та дозволяє ОПР здійснити пошук альтернативних рішень, що будуть еквівалентними до прийнятих стратегій.

Наведена методика, дозволяє в залежності від ставлення до ризику, оцінити економічну ефективність різних стратегій прийнятих рішень щодо техніко-технологічних параметрів системи (у даному випадку — приймально-відправного парку сортувальної станції). При цьому основою для техніко-економічних розрахунків $\epsilon$ результати імітаційного моделювання роботи транспортної системи (парку) в різних експлуатаційних умовах та при різних техніко-технологічних параметрах.

\section{3. ВИСНОВКИ}

Виконані у результаті роботи над даним розділом дослідження та їх аналіз дозволяють зробити наступні висновки.

1. Ризики не є об'єктивним фактором, що впливає на якість перевізного процесу та ефективність роботи будь-якої транспортної системи.

2. Транспорт є складною, динамічною, недетермінованою, стохастичною, керованою та ергатичною системою, кожен елемент якої $є$ потенційним джерелом ризиків.

3. Ризики перевізного процесу можна розділити на ризики, пов'язані з безпекою руху та технологічні ризики, пов'язані здебільшого з невідповідністю техніко-технологічних параметрів транспортних систем існуючим або перспективним умовам їх функціонування.

4. Найбільш поширеним критерієм оцінки рівня ризиків, в першу чергу, технологічних, $є$ економічні показники - наприклад, втрати через неприймання поїздів на станцію, втрати через перевищення термінів доставки вантажів, втрати через зменшення вантажопотоку тощо.

5. Не зважаючи на різноманітність ризиків, що мають місце у транспортних системах, для управління комплексом ризиків може бути використаний стандартний підхід, що базується на циклі «ідентифікація - оцінка — контроль».

6. Залізничні станції є одним із головних елементів залізничної системи країни. Рівень їх технічної та технологічної забезпеченості в значній мірі визначає ефективність та надійність перевізного процесу. Визначення найбільш раціонального значення цього рівня представляє складне завдання, оскільки, з одного боку станції повинні мати достатній резерв пропускної та переробної спроможності для ефективної роботи в умовах нерівномірності транспортних потоків, з іншого невиправдане збільшення технічного потенціалу станцій та ділянок призводить до зростання як капітальних інвестицій, так і експлуатаційних витрат на утримання.

7. У зв'язку із складністю транспортних процесів та практичною неможливістю проведення дослідницьких експериментів на реальних транспортних об'єктах (зокрема, і станціях), найбільш ефективним методом дослідження та прогнозуван-

$$
-132-
$$


ня поведінки таких систем в різних експлуатаційних умовах та пов'язаних 3 цим ризиків перевізного процесу є імітаційне моделювання.

7. Серед існуючих наразі систем імітаційного моделювання однією 3 найбільш функціональних є програмний пакет AnyLogic, який дозволяє користувачу, що має базові навички програмування, створювати потужні імітаційні моделі складних систем, зокрема, і транспортних, а також надає широкі можливості для проведення оптимізаційних експериментів, візуалізації процесу моделювання та аналізу результатів.

8. Найбільш застосовним для побудови імітаційних моделей залізничних транспортних систем є дискретно-подійний підхід, широкі можливості для реалізації якого надає середовище AnyLogic. Виходячи 3 цього, авторами на основі дискретно-подійної парадигми у середовищі AnyLogic була побудована імітаційна модель приймально-відправного парку сортувальної станції.

9. За результатами серії експериментів з моделлю були отримані експлуатаційні показники роботи парку (простої поїздів по неприйому та під обробкою в парку) та його окремих елементів (коефіцієнти завантаження). Ці показники стали основою для відповідних техніко-економічних розрахунків щодо оцінки ефективності заходів, спрямованих на вдосконалення технічного оснащення і технології роботи парку з врахуванням можливих експлуатаційних та економічних ризиків.

10. При оцінці інвестиційних проектів, спрямованих на приведення технічних та технологічних параметрів транспортних систем до існуючих або планованих умов функціонування техніко-економічні показники кожного проекту необхідно визначати з врахуванням впливу можливих ризиків від їх реалізації на перевізний процес. При цьому ключове місце посідає суб'єктивне ставлення особи, яка приймає рішення (ОПР), до ризику.

11. На основі методики, яка, зокрема, враховує суб'єктивне ставлення ОПР до ризиків, були розраховані економічні показники інвестиційних стратегій щодо удосконалення технічних та технологічних параметрів приймально-відправного парку сортувальної станції. На основі отриманих результатів побудовані відповідні номограми, які дозволяють отримати кількісну оцінку кожної інвестиційної стратегії з врахуванням можливих ризиків та ставлення до них ОПР.

12. Таким чином, поєднання сучасних підходів щодо оцінки ризиків та методів прогнозування їх впливів на основі імітаційного моделювання є потужною основою до побудови ефективної системи управління ризиками при організації складних, зокрема, транспортних процесів. Широке впровадження такого підходу дозволить отримувати як обгрунтовану оцінку втрат від можливих ризиків при організації перевезень, так і визначати найбільш ефективні інвестиційні стратегії щодо забезпечення надійності функціонування транспортних систем. 


\section{ЛІТЕРАТУРА}

1. Безруцький, В. В. Небезпечні виробничі ризики та надійність: навчальний посібник / В. В. Безруцький, М. І. Адаменко. — Харків: НТУ «ХПІ», 2016. - 386 с.

2. Ткаченко, О. І. Ризики у транспортних процесах: навчальний посібник / О. І. Ткаченко. Харків: ХНУМГ ім. О. М. Бекетова, 2017. - 115 с.

3. Руководство по управлению рисками / Комитет ПАРТАД по внутреннему контролю, внутреннему аудиту и управлению рисками, 2018. - 91 с.

4. Гринчар, Н. Н. Комплексная оценка проектов технического перевооружения на транспорте с учетом экономических рисков: дис. канд. экон. Наук / Н. Н. Гринчар. М.: МГУПС (МИИТ), 2017. — 187 с.

5. Tubis, A. Risk Assessment in Road Transport - Strategic and Business Approach [Text] / A. Tubis. - Journal of Konbin, 2018, 45(1). p. 305-324

6. Aven, T. Risk assessment and risk management: review of recent advances on their foundation [Text] / T. Aven. - European Journal of Operational Research, 2016, 253. p. 1-13.

7. Joyce A. Curtis Transportation Risk Management: International Practices for Program Development and Project Delivery [Text] / Joyce A. Curtis, Joseph S. Dailey, Daniel D'Angelo and etc. - U.S. Department of Transportation, 2012. 84 p.

8. Sasidharan, M. A review of risk management applications for railways [Text] / M. Sasidharan, Dr. M. P.N. Burrow, Dr. G. S. Ghataora, Dr. M.E. - Torbaghan. Railway engineering, 2017.

9. Козаченко, Д. М. Основи дослідження операцій: приклади та задачі. Навчальний посібник для ВНЗ / Д.М. Козаченко, Р.В. Вернигора, В. В. Малашкін - Дніпропетровськ: Вид-во ДНУЗТ, 2015. - 277 с.

10. Задачин, В. М. Моделювання систем: конспект лекцій / В. М. Задачин, І. Г. Конюшенко. - Харків: Вид. ХНЕУ, 2010. - 268 с.

11. Давідіч Ю. О. Конспект лекцій з дисципліни «Моделювання транспортних систем» (для магістрів усіх форм навчання спеціальності 275 - Транспортні технологіі) / Ю. О. Давідіч, Г. І. Фалецька; Харків. нац. ун-т. міськ. госп-ва ім. О. М. Бекетова. Харків : ХНУМГ, 2019. - $71 \mathrm{c.}$

12. Шеннон, Р. Имитационное моделирование систем - искусство и наука. Москва: Мир, 1978. - $420 \mathrm{c}$.

13. Григорьев, И. AnyLogic за три дня. Практическое пособие по имитационному моделированию. - AnyLogic, 2017 - 273 с.

14. Имитационное моделирование в задачах машиностроительного производства в 2-х томах, Т. 1: учеб. пособие /под редакций А.Н. Шелкового - Харьков.: НТУ «ХПИ», 2016. - $407 \mathrm{c}$.

15. Ivanov, D. Operations and Supply Chain Simulation with AnyLogic. - Berlin: Berlin School of Economics and Law, 2017. — 97 p.

16. Офіційний сайт компанії AnyLogic [Електрон. ресурс] - Режим доступу: https:// www.anylogic.com/

17. Офіційний сайт Державної служби статистики України [Електрон. ресурс] - Режим доступу: http://www.ukrstat.gov.ua.

18. Функциональное моделирование работы железнодорожных станций : монография / В. И. Бобровский, Д. Н. Козаченко, Р. В. Вернигора, В. В. Малашкин; Днепропетр. нац. ун-т ж.-д. трансп. им. акад. В. Лазаряна. - Днепропетровск, 2015. - 244 с.

19. Персианов, В. А. Моделирование транспортных систем / В. А. Персианов, К. Ю. Скалов, Н. С. Усков - М.: Транспорт, 1972. — 208 с. 
20. Таль, К. К. Основные вопросы применения методов моделирования при проэктировании станции и узлов. / К. К. Таль // Межвуз. сб. научн. тр. - Вып. 47. - М.: ЦНИИС 1971. - C. 56-96.

21. Пилипченк, П. А. Структурное моделирование работы сортировочной станции / П. А. Пилипченко // Применение математических методов и ЭВМ в эксплуатации железных дорог: Сб. научн. тр. - Вып. 497. - М.: МИИТ. - 1975. - С. 60-64.

22. Бобровський, В. І. Базова модель колійного розвитку в імітаційних моделях залізничних станцій / В. І. Бобровський, Д. М. Козаченко, Р. В. Вернигора // Зб. наук. праць УкрДАЗТ: Серія «Удосконалення вантажної і комерційної роботи на залізницях України», Вип. 62. - Харків: УкрДАЗТ, 2004. - С. 20-25.

23. Лещинский, Е.И. Имитационное моделирование на железнодорожном транспорте / Е. И. Лещинский - М.: Транспорт, 1977. - 176 с.

24. Грунтов, П. С. Прогнозирование работы сортировочных станций методом моделирования на ЭВМ / П. С. Грунтов, В. А. Захаров - Гомель: БелИИЖТ. - 1981. - 152 с.

25. Козлов, П. А. Моделирование железнодорожных станций с помощью системы ИСТРА / П. А. Козлов, А. Э. Александров - Екатеринбург: УрГУПС., - 2000. - 41 с.

26. Нагорный, Е. В. Моделирование технологического процесса обработки вагонов, информации и перевозочных документов экспортно-импортного вагонопотока по прибытию на передаточных пограничных станциях / Е. В Нагорный, Т. В. Бутько, Н. Ф. Титов // Концепція підвищення ефективності вант. перевезень на залізн. Транспорті: Міжвуз. зб. наук. праць - Харків: ХарДАЗТ - 1998. - Вип. 33.- С. 125-129.

27. Оптимизация режимов торможения отцепов на сортировочных горках: Монография / В.И. Бобровский, Д.Н. Козаченко, Н.П. Божко, Н.В. Рогов, Н. И. Березовый, А.В. Кудряшов - Дн-вск: Изд-во Маковецкий, 2010. - 260 с.

28. Бобровский, В.И. Имитационная модель развязки линий в железнодорожном узле/ В. И. Бобровский // Концепція підвищення ефективності вант. перевезень на залізн. трансп.: Міжвуз. зб. наук. пр.- Харків: ХарДАЗТ, 1999, Вип. 38. - С. 35-42.

29. Нагорный, Е. В. Моделирование функционирования комплекса «Сортировочная станция - прилегающие участки» с помощью сетей Петри / Е. В. Нагорный, Е. С. Алешинский // Информационно-управляющие системы на железнодорожном транспорте. 2000. № 2. - C. 98-103.

30. Bartkevicius, S. Train traffic simulation with coloured Petri Nets and schedule optimization / S. Bartkevicius, V. Bagdonos //Elektron ir elektrotech. - 2005. - №3 - C. 18-23.

31. Сукач, Е. И. Стенд имитационного моделирования сортировочной станции железнодорожной сети /Е. И. Сукач //Проблеми програмування - 2009. - №3. C. 81-89.

32. Вернигора, Р. В. Дослідження процесів составоутворення на сортувальних станціях методами імітаційного моделювання/ Р. В. Вернигора, О. В. Пугач // ВосточноЕвропейский журнал передовых технологий. — 2010. — №6/4. — С. 52-55.

33. Козаченко, Д. М. Моделювання роботи залізничного напрямку / Д. М. Козаченко, Г. Я. Мозолевич, О. В. Власюк // Вісник ДНУЗТ. - Дніпропетровськ: ДНУЗТ, 2009. Вип. 28. - С. 143-148.

34. Запара, Я. В. Імітаційна модель технології роботи залізничного вузла / Я. В. Запара, С. В. Запара // Інформаційно-керуючі системи на транспорті. — 2012. — № 2. - С. 79-86.

35. Стеценко, І. В. Моделювання систем: навч. посіб. / І. В. Стеценко; - Черкаси: ЧДТУ, 2010. - 399 с.

36. Офіційний сайт PTV Group [Електрон. ресурс] - Режим доступу: https://company.ptvgroup.com. 
37. Вернигора, Р. Анализ эксплуатационной надежности железнодорожных станций на основе имитационного моделирования в Anylogic / Р. Вернигора, В. Малашкин, А. Окороков, О. Золотаревская // Інжиніринг криз та ризиків транспортних послуг: Зб. доповідей міжн. наук.-метод. конф. - Маріуполь: Приазов. держ. техн. ун-т. — 2021. C. $138-141$.

38. Кігель, В. Р. Ризикологія: теоретичні основи та прикладні задачі, моделі і методи: навчальний посібник для студентів економічних спеціальностей / В. Р. Кігель. - К.: Міленіум, 2017. - 230 с.

39. Гурнович, Т. Г. Оценка и анализ рисков : учебник / Т. Г. Гурнович, Е. А. Остапенко, С. А. Молчаненко ; под общ. ред. Т. Г. Гурнович. - Москва : КНОРУС, 2019. - 252 с.

40. Пазюк, К. Т. Теория риска и моделирование рисковых решений : учебное пособие / К. Т. Пазюк. - Хабаровск : Изд-во Тихоокеан. гос. ун-та, 2017. - 116 с.

41. Бродецкий, Г. Л. Управление рисками в логистике : учеб. пособие для студ. Учреждений высш. проф. образования / Г. Л. Бродецкий, Д. А.Гусев, Е. А.Елин. - М.: Издательский центр «Академия», 2010. - 192 с. 


\section{РОЗДІЛ 5 \\ ІННОВАЦІЙНІ ТЕХНОЛОГІЇ ВІG DАТА ТА ІНФОРМАЦІЙНОЇ БЕЗПЕКИ В УПРАВЛІННІ ТРАНСПОРТНИМИ СИСТЕМАМИ}

О.В. Галан ${ }^{10}$

\section{1. ВСТУП}

Big Data технології — це передові технології XXI-го століття, використання яких може привести до поліпшення якості послуг, нових заощаджень, підвищення використання ресурсів та ефективності. Це також сприяє розробці нових сервісів та бізнес-моделей на основі можливостей «Інтернету речей» та аналітики великих даних. Сучасна тенденція автоматизації та обміну даними полягає в застосуванні та адаптації нових технологій для досягнення нових рівнів ефективності. Повна архітектура великих даних включає в себе кіберфізичні системи, Інтернет речей (IoT) та хмарні обчислення, які працюють разом для створення «розумних транспортних систем», надають можливість кращої роботи в галузі експлуатації та технічного обслуговування транспорту за допомогою «самонавчальних систем», які прогнозують збій, ставлять діагнози та проводять дії з обслуговування.

\section{2. ОСНОВНИЙ МАТЕРІАЛ}

\section{1. Поняття «Big Data»}

Великі дані (англ. Big Data) в інформаційних технологіях — набори інформації (як структурованої, так і неструктурованої) настільки великих розмірів, що традиційні способи та підходи (здебільшого засновані на рішеннях класу бізнесової аналітики та системах управління базами даних) не можуть бути застосовані до них.

Альтернативне визначення великих даних - феноменальне прискорення нагромадження даних та їх ускладнення.

Peсурс Wikipedia пропонує наступне визначення:

Великі дані (англ. Big data) — серія підходів, інструментів і методів обробки структурованих і неструктурованих даних величезних обсягів і значного різноманіття для отримання сприймаються людиною результатів, ефективних в умовах безперервного приросту, розподілу по численних вузлів обчислювальної мережі, що сформувалися в кінці 2000-х років, альтернативних традиційним системам управління базами даних і рішень класу Business Intelligence.

Таким чином під Big Data будемо розуміти не якийсь конкретний обсяг даних і навіть не самі дані, а методи їх обробки, які дозволяють розподілено обробляти

\footnotetext{
${ }^{10}$ Канд. техн. наук, доцент кафедри «Інформаційні технології та дизайн» Державного університету інфраструктури та технологій, Київ
} 
інформацію. Ці методи можна застосувати як до великих масивів даних (таких як зміст усіх сторінок в інтернеті), так і до незначних.

До основних переваг використання технологї̈ Big Data можна віднести:

- отримання якісно нових знань за рахунок комплексного аналізу усієї інформації у єдиному аналітичному сховищі; бізнесу;

- розширення функціональності існуючих інформаційних систем підтримки

- збільшення ефективності використання апаратних ресурсів серверів;

- забезпечення мінімальної вартості використання всіх видів інформації за рахунок можливості використання ПЗ з відкритим кодом і хмарних технологій.

Робота 3 ними дає безпрецедентні можливості оптимізації багатьох сфер нашого життя: державного управління, медицини, телекомунікацій, фінансів, транспорту, виробництва та ін.

\section{2. Світовий обсяг даних}

Аналітики компанії IBS «весь світовий обсяг даних» оцінили такими величинами:

2003 р. - 5 ексабайт даних (1 ЕБ = 1 млрд гігабайтів),

2008 р. - 0,18 зетабайт (1 ЗБ = 1024 ексабайта),

2015 р. - понад 6,5 зетабайт,

2018 р. - 33 зетабайти,

2020 р. - 40-45 зетабайт,

2025 р. - 160-175 зетабайт (прогноз).

Дані ростуть через збільшення числа нових користувачів інтернету, які щодня публікують великі масиви нової інформації. До 2025 року 75\% населення буде так чи інакше працювати з тим чи іншим видом інформації. До 2025 року щорічно кількість гігабайт на одну особу буде зростати — в середньому на $21 \%$ в рік. В 2025 році в середньому користувач мережі інтернет взаємодіятиме 3 даними кожні 18 секунд.

Графічне представлення перспектив росту як сервісів, так і програмного забезпечення та технічних ресурсів для обробки Big Data подано на рис. 1.

Підприємствам доведеться проводити модернізацію серверів з урахуванням значного зростання числа користувачів. У деяких країнах, таких як Китай, ОАЕ вже підійшли до вирішення даного завдання. Там створюється «розумне місто», йде запуск програми «Відкриті дані», яка повинна допомогти сформувати в місті нову економіку. За оцінками влади ОАЕ, до 2021 року економіка, заснована на великих даних, буде приносити додатково 10,4 млрд дирхам, а це близько \$3 млрд. 


\section{Big Data Revenue Worldwide from 2016 to 2027, by major segment (in billion U.S. dollars)}

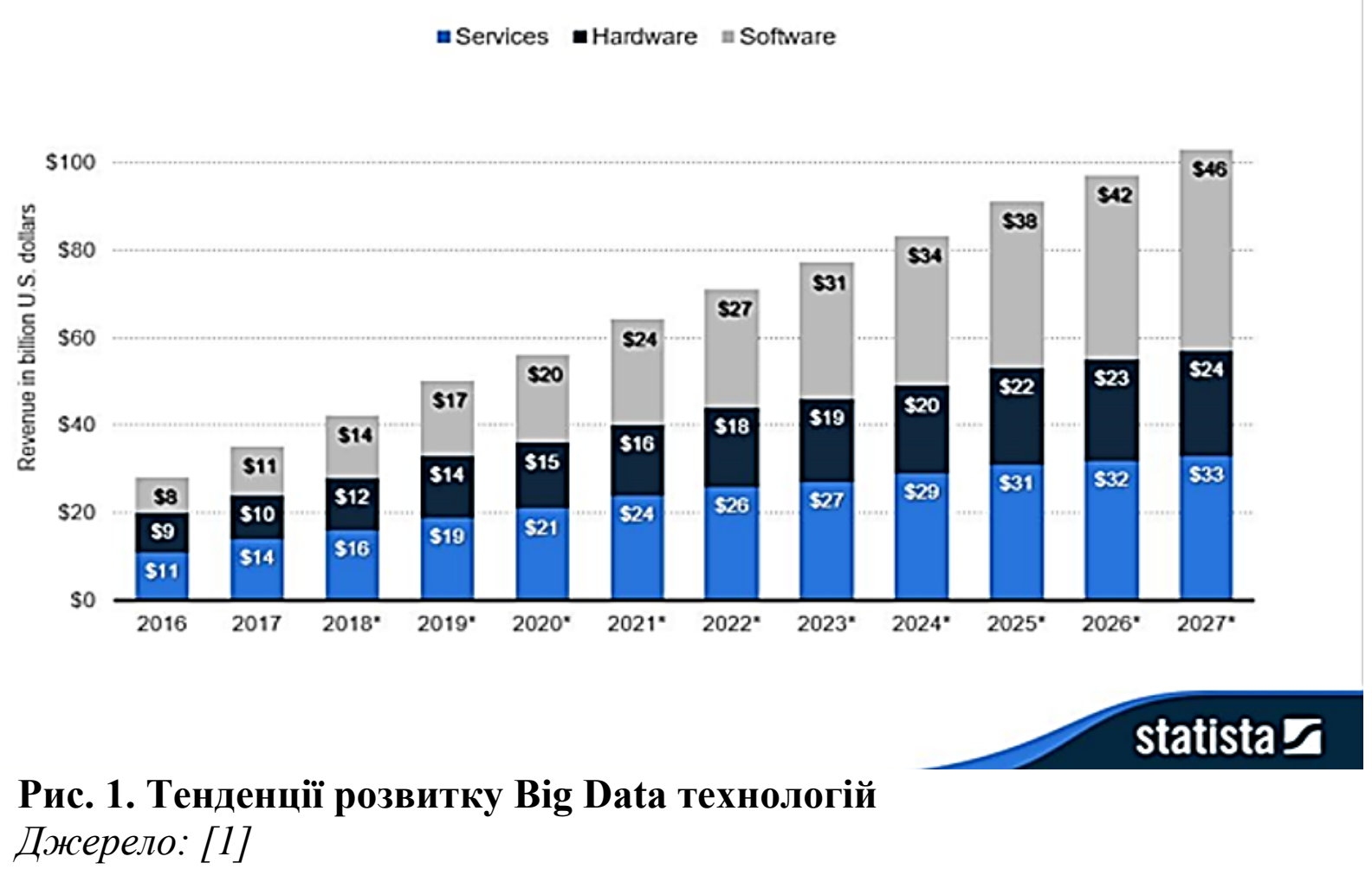

\section{3. Джерела Big Data}

Кілька прикладів того, що може бути джерелом даних, для яких необхідні методи роботи з великими даними:

- список поведінки користувачів в інтернеті;

- GPS-сигнали від автомобілів для транспортної компанії;

- дані, що знімаються з датчиків у великому адронному колайдері;

- оцифровані книги бібліотек;

- інформація про транзакції всіх клієнтів банку;

- інформація про всі покупки у великій рітейл мережі і т.д.;

- соціальні мережі і їх інформація (Facebook містить 50 млрд. фотографій),

- медичні спостереження;

- фото-, відео-архіви;

- наукові дані (астрономія, геном людини, дослідження атмосфери, біохімія і т. д.);

- біржі, банківська сфера (лише Walmart здійснює більше 1 млн. транзакцій кожну годину).

На рис. 2 наведено кількість даних, яка генерується у світі за одну хвилину у 2018 і у 2020 роках та вказані джерела таких даних. Ми можемо відзначити значне 
зростання кількості даних, що генеруються, при чому відбувається зміщення домінантних ресурсів.
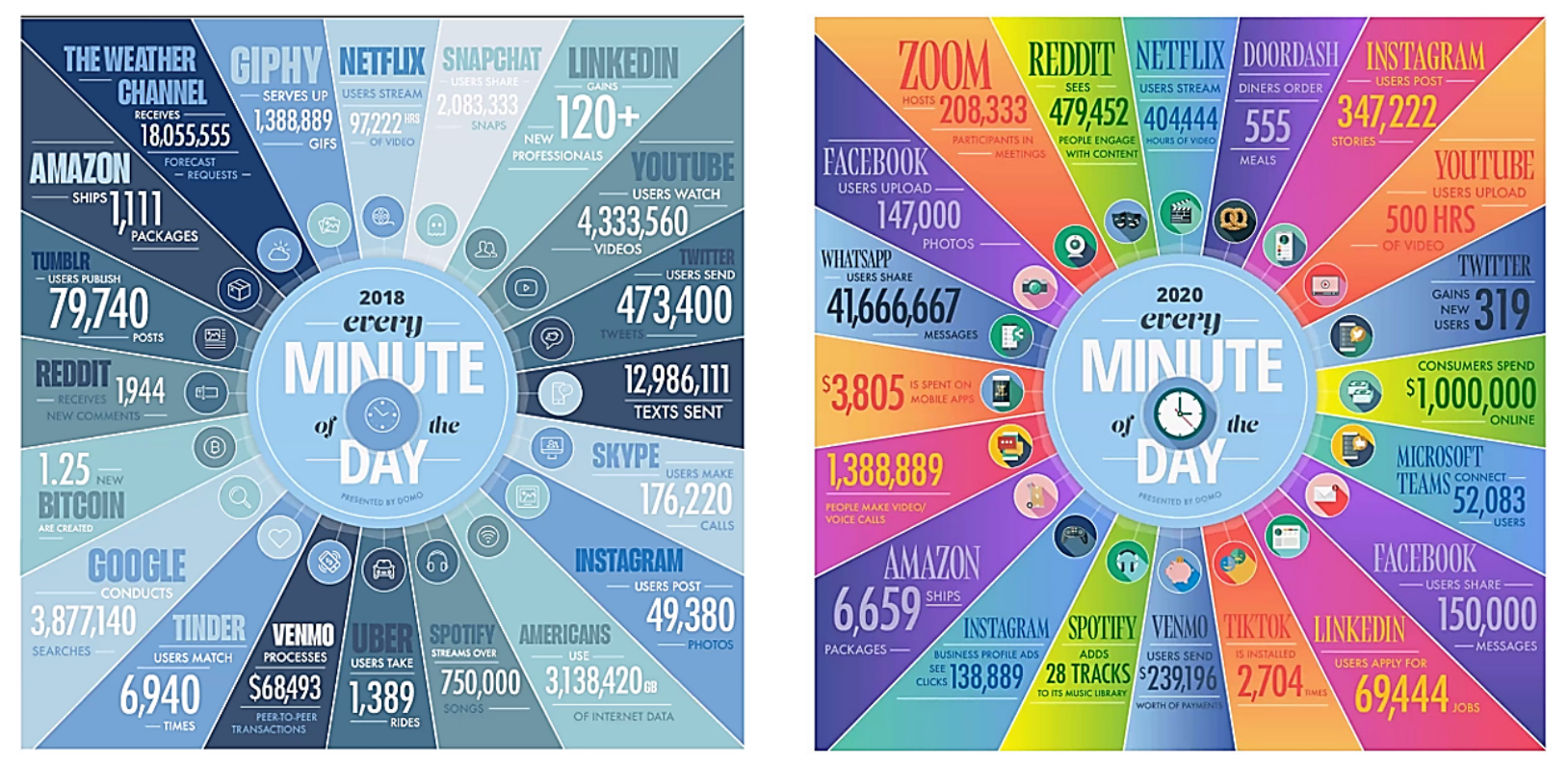

Рис. 2. Кількість даних, яка генерується у світі за одну хвилину у 2018 i у 2020 роках

Джерело: [2]

Схематично, джерела Big Data можна подати наступним чином (рис. 3):

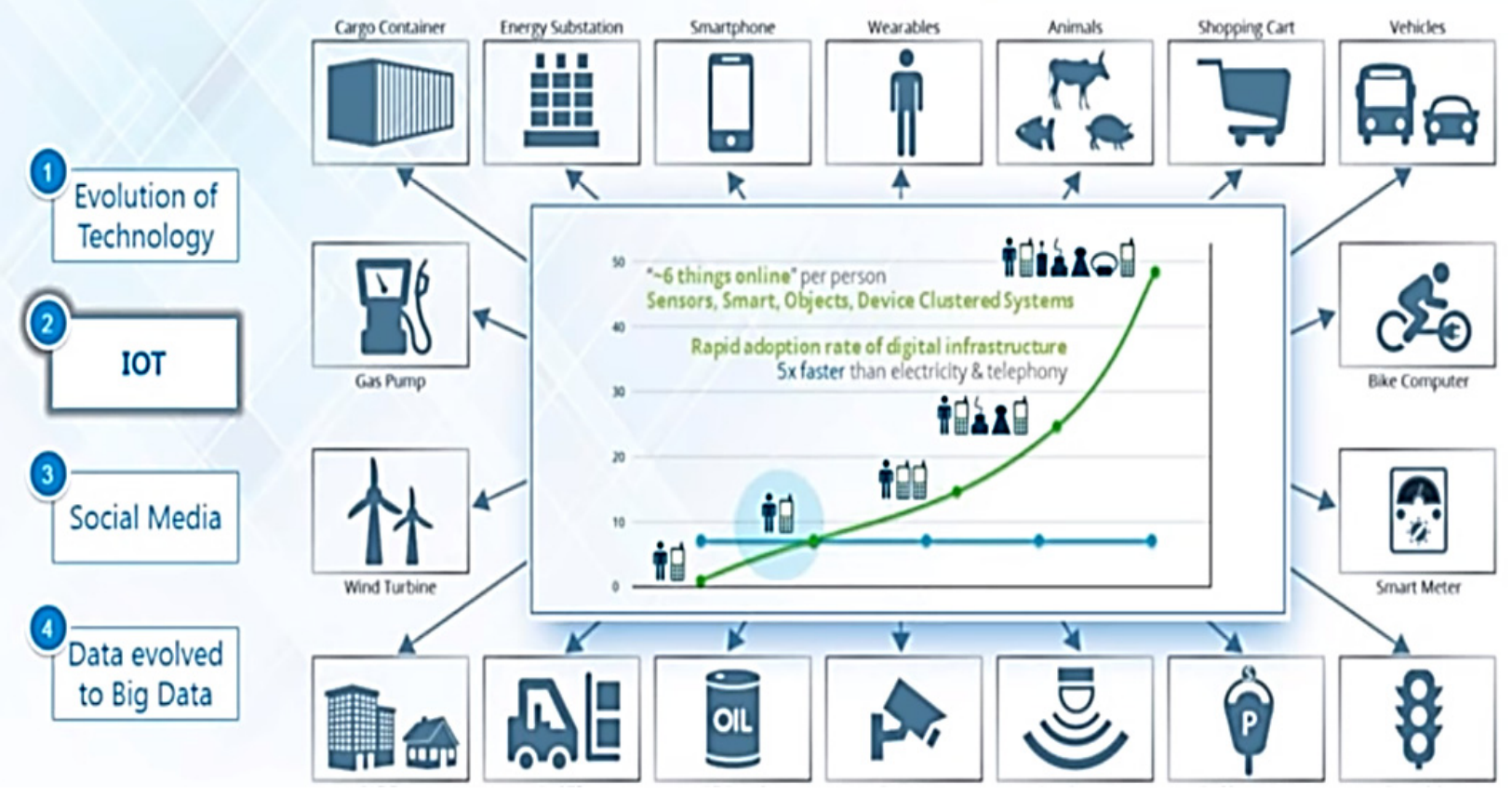

Рис. 3. Джерела Big Data

Джерела: [3, 4] 


\subsection{Tри «V» та принципи роботи 3 великими даними}

Визначальними характеристиками для Big Data $\epsilon$, крім їх фізичного об’єму, i інші, що підкреслюють складність завдання обробки і аналізу цих даних.

Набір ознак VVV (volume, velocity, variety - фізичний обсяг, швидкість приросту даних і необхідності їх швидкої обробки, можливість одночасно обробляти дані різних типів) був вироблений компанією Meta Group в 2001 році з метою вказати на рівну значущість управління даними по всім трьом аспектам (рис. 4).

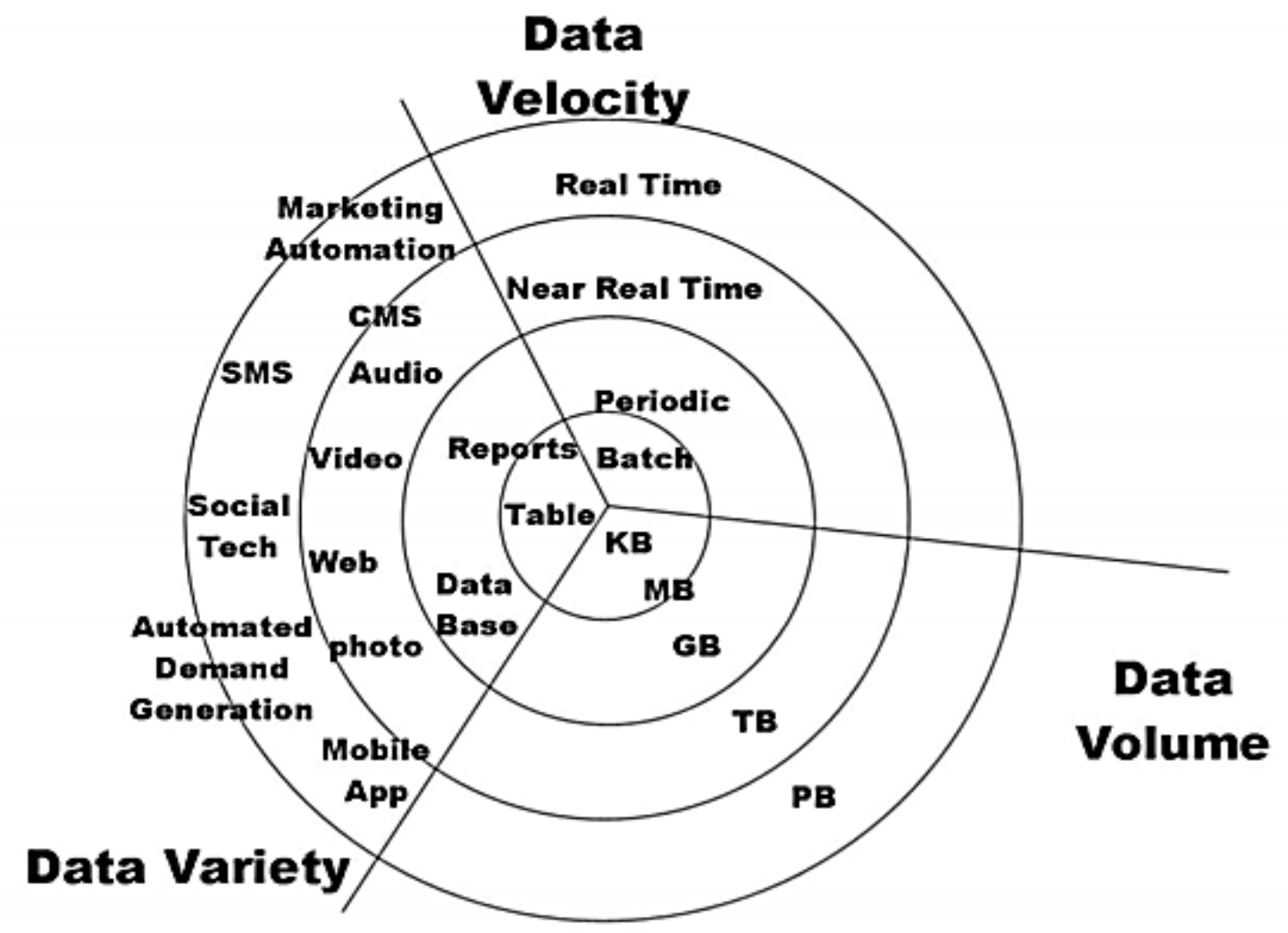

\section{Pис. 4. Набір ознак Big Data}

Джерело: [10]

Надалі з'явилися інтерпретації з чотирма V (додавалася veracity - достовірність), п’ятьма V (viability - життєздатність i value - цінність), сім'ю V (variability - мінливість i visualization - візуалізація). Але компанія IDC, наприклад, інтерпретує саме четвертий V як value (цінність), підкреслюючи економічну доцільність обробки великих обсягів даних у відповідних умовах (рис. 5).

Виходячи з вищенаведених визначень, основні принципи роботи з великими даними такі:

Горизонтальна масштабованість. Це - базовий принцип обробки великих даних. Як вже говорилося, більших даних з кожним днем стає все більше. Відповідно, необхідно підвищувати кількість обчислювальних вузлів, за якими розподіляються ці дані, причому обробка має відбуватися без погіршення продуктивності. 

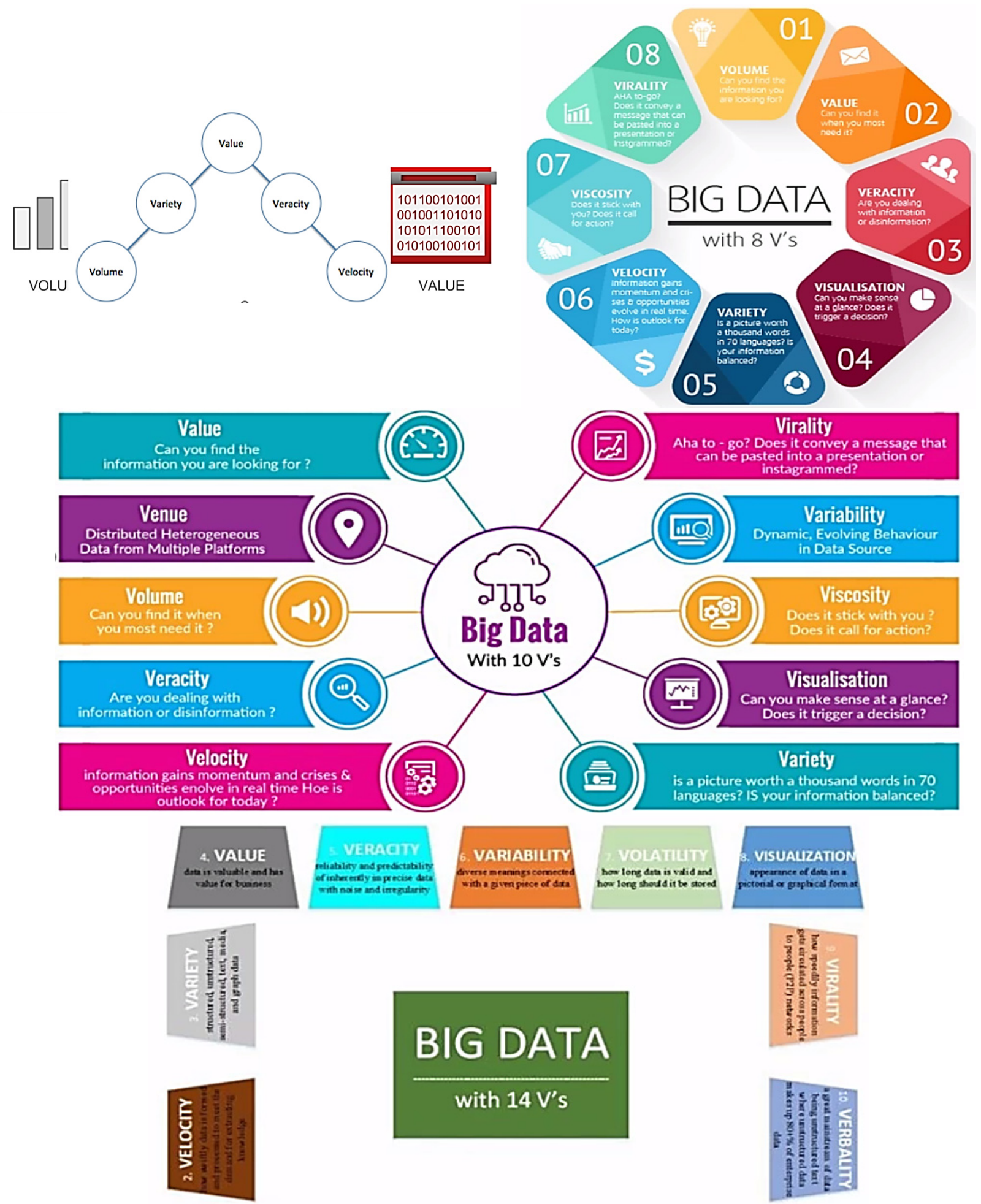

\section{BIG DATA}
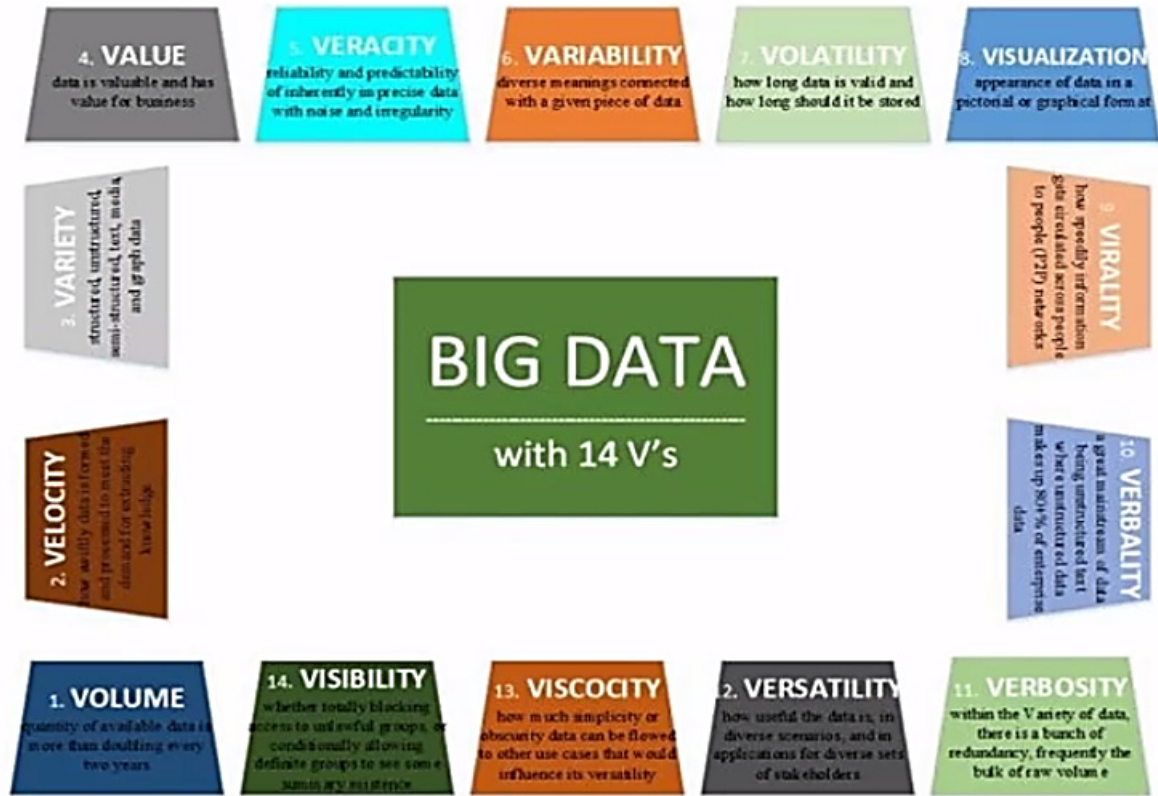

\section{with 14 V's}

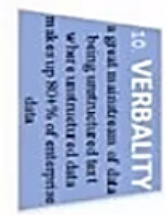

\section{Рис. 5. Розширений набір ознак Big Data}

Джерела: [15-18] 
Відмовостійкість. Цей принцип випливає з попереднього. Оскільки обчислювальних вузлів в кластері може бути багато (іноді десятки тисяч) і їх кількість, не виключено, буде збільшуватися, зростає і ймовірність виходу комп'ютерів 3 ладу. Методи роботи з великими даними повинні враховувати можливість таких ситуацій і передбачати превентивні заходи.

Локальність даних. Так як дані розподілені по великій кількості обчислювальних вузлів, то, якщо вони фізично знаходяться на одному сервері, і обробляються на іншому, витрати на передачу даних можуть стати невиправдано великими. Тому обробку даних бажано проводити на тій же машині, на якій вони зберігаються.

Ці принципи відрізняються від тих, які характерні для традиційних, централізованих, вертикальних моделей зберігання добре структурованих даних. Всі сучасні засоби роботи з великими даними так чи інакше відповідають цим трьом принципам. Відповідно, для роботи з великими даними розробляють нові підходи і технології.

\section{5. Методи та техніки аналізу Big Data}

Міжнародна консалтингова компанія McKinsey, що спеціалізується на вирішенні завдань, пов'язаних зі стратегічним управлінням, виділяє 11 методів і технік аналізу, які можна застосувати до Big Data (рис. 6).

- Методи класу Data Mining (отримання даних, інтелектуальний аналіз даних, глибинний аналіз даних) - сукупність методів виявлення в даних раніше невідомих, нетривіальних, практично-корисних знань, необхідних для прийняття рішень. До таких методів, зокрема, відносяться навчання асоціативним правилами (association rule learning), класифікація (розбиття на категорії), кластерний аналіз, регресійний аналіз, виявлення та аналіз відхилень.

- Краудсорсінг - класифікація і збагачення даних силами широкого, невизначеного кола осіб, які виконують цю роботу без вступу в трудові відносини.

- Змішування і інтеграція даних (data fusion and integration) - набір технік, що дозволяють інтегрувати різнорідні дані з різноманітних джерел з метою проведення глибинного аналізу (наприклад, цифрова обробка сигналів, обробка природної мови, включаючи тональний аналіз, та ін.).

- Машинне навчання - використання моделей, побудованих на базі статистичного аналізу або машинного навчання для отримання комплексних прогнозів на основі базових моделей.

- Штучні нейронні мережі, мережевий аналіз, оптимізація, в тому числі генетичні алгоритми (genetic algorithm) - евристичні алгоритми пошуку, які використовуються для вирішення завдань оптимізації та моделювання шляхом випадкового підбору, комбінування і варіації шуканих параметрів з використанням механізмів, аналогічних природному відбору в природі). 


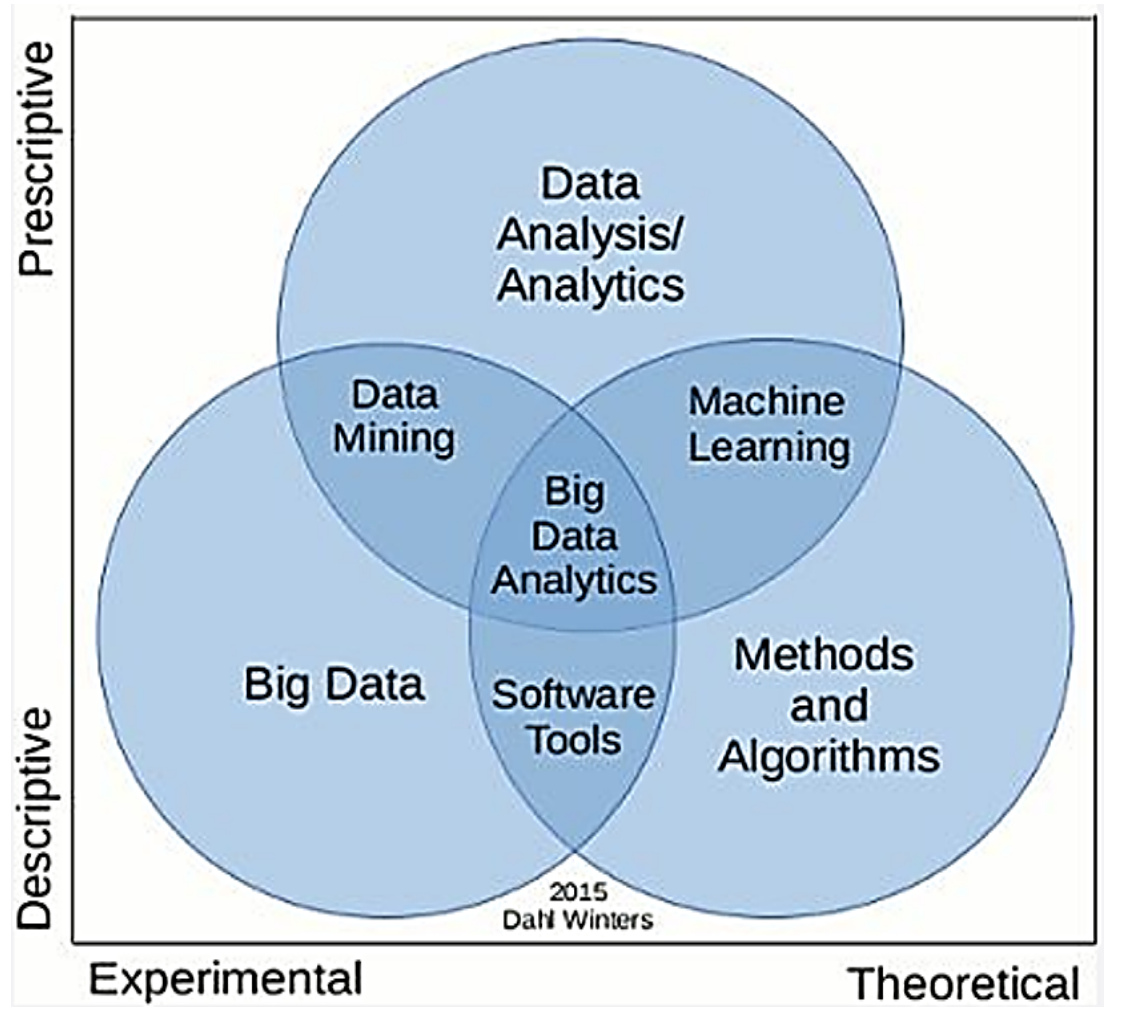

Рис. 6. Область досліджень Big Data Джерело: [19]

- Розпізнавання образів - це віднесення вихідних даних до певного класу за допомогою виділення істотних ознак, що характеризують ці дані, із загальної маси несуттєвих даних.

- Імітаційне моделювання (simulation) - метод, що дозволяє будувати моделі, що описують процеси так, як вони проходили б у дійсності. Імітаційне моделювання можна розглядати як різновид експериментальних випробувань.

- Просторовий аналіз (spatial analysis) - клас методів, які використовують топологічну, геометричну і географічну інформацію, отрману з даних.

- Статистичний аналіз - аналіз часових рядів, А / B-тестування (A / B testing, split testing - метод маркетингового дослідження; при його використанні контрольна група елементів порівнюється з набором тестових груп, в яких один або кілька показників були змінені, для того щоб з'ясувати, які з змін покращують цільовий показник).

- Візуалізація аналітичних даних - подання інформації у вигляді малюнків, діаграм, з використанням інтерактивних можливостей та анімації як для отримання результатів, так і для використання в якості вихідних даних для подальшого аналізу. Дуже важливий етап аналізу великих даних, що дозволяе представити найважливіші результати аналізу в найбільш зручному для сприйняття вигляді. 


\section{6. Завданнями аналітики Big Data у транспортній галузі}

Аналітика Big Data може впливати на кілька аспектів залізничного сектору і може подолати організаційні, експлуатаційні та технічні складності, включаючи економічні ефекти, людські фактори та обробку інформації.

Серед основних завдань аналітики Big Data у транспортній галузі можна виділити:

- Створення алгоритмів прогнозування в реальному часі 3 неоднорідних джерел даних, які дозволять справлятися зі збереженням конфіденційністі обробки даних, стисненням даних та обрання певних функцій.

- Створення масштабованих структур даних на основі збору між-доменних джерел даних за допомогою рівня віртуалізації між процесом збору даних та процесом аналізу даних. Це включає нові рішення, що поєднують нові можливості бази даних для інтеграції різнорідних джерел даних у високоефективну систему доступу на основі Хмарних технологій.

- Імплементація обміну великими даними за допомогою відкритих інтерфейсних шлюзів із системами моніторингу, що забезпечують синхронізацію часових міток та позицій, неоднорідну підтримку зв’язку, включаючи мобільність та агрегацію, та пріоритетні протоколи передачі інформації в реальному часі.

- Застосування методів візуалізації інфографіки.

Позитивні ефекти аналітики великих даних для транспортних мереж відображені на рис. 7.

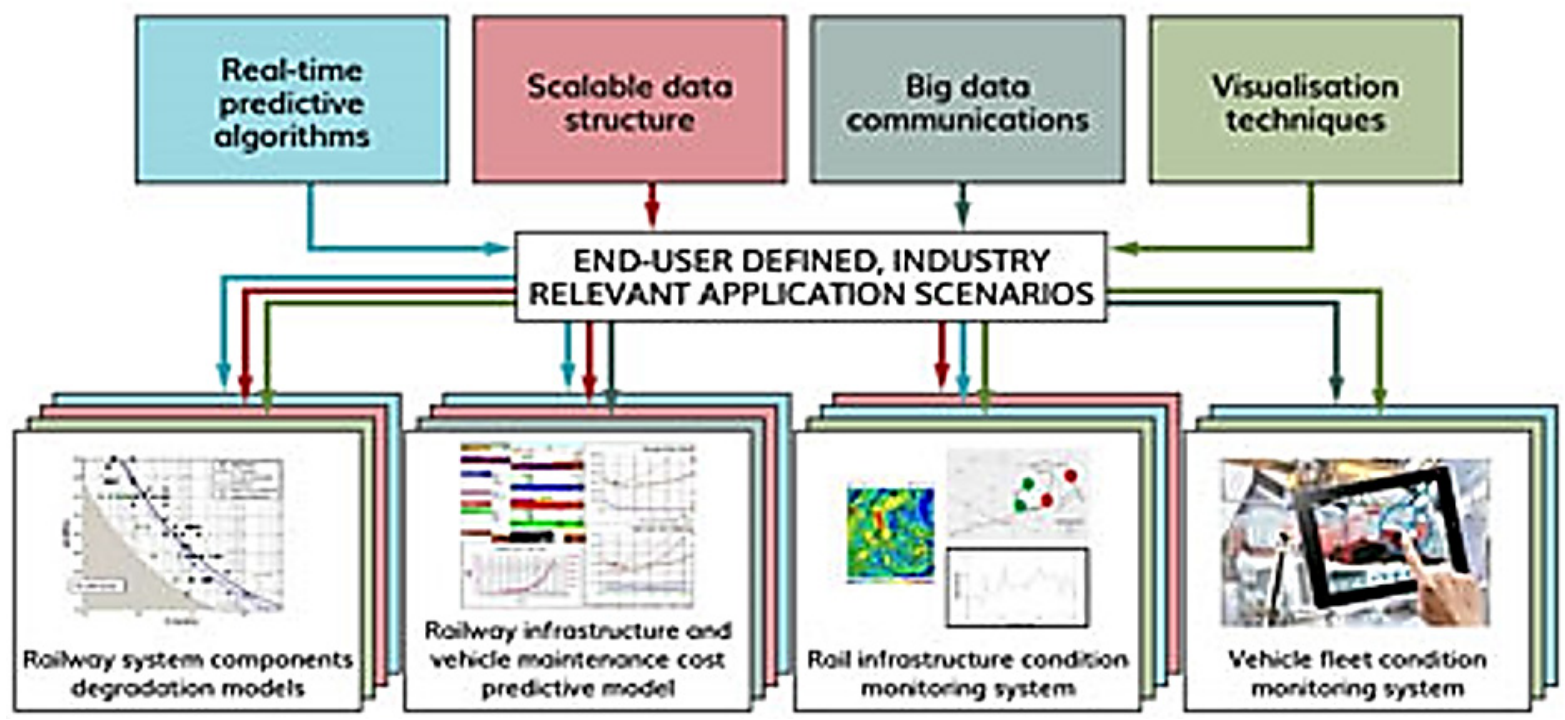

Рис. 7. Аналітика Big Data

Джерела: [5-8]

На рис. 8 показано загальний сценарій: інформація про стан транспортного засобу передається в загальну хмару даних, для подальшого прогнозу стану цього транспортного засобу (навантаження, температура, частота вібрацій). 


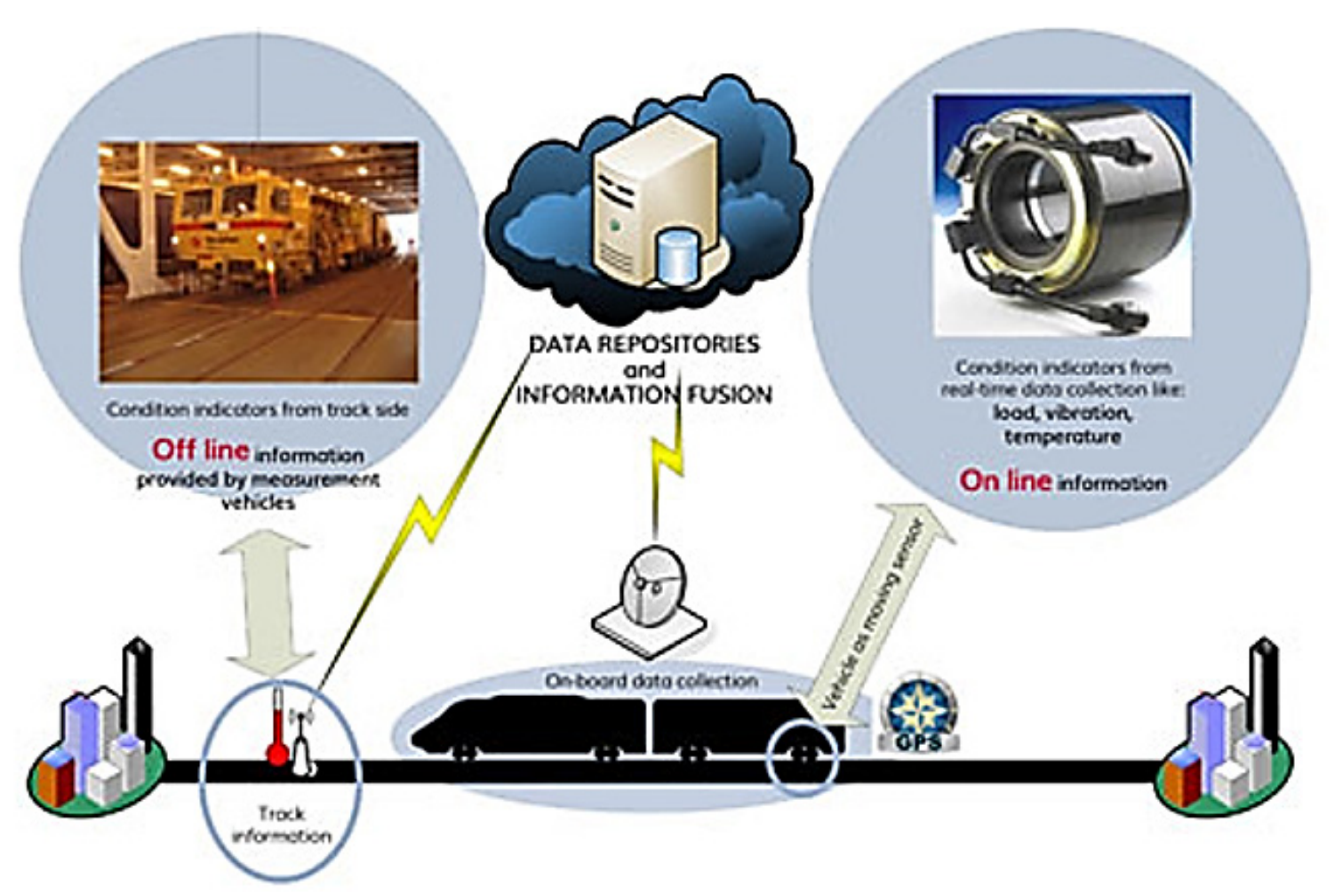

Рис. 8. Загальний сценарій обміну даними

Джерела: [5-8]

Big Data в транспортній галузі сприятимуть досягненню цілі, яку можна описати наступними словами: «Транспорт є основою для нашої економіки та суспільства». Мобільність є життєво важливою для внутрішнього ринку та для якості життя громадян. Транспорт сприяє економічному зростанню та створенню робочих місць: він повинен бути стійким у світлі нових викликів, з якими ми стикаємося.

Транспорт є глобальним, тому для ефективних заходів необхідне міцне міжнародне співробітництво. Багато європейських компаній є світовими лідерами в галузі інфраструктури, логістики, систем управління трафіком та виробництвом транспортного обладнання. Оскільки інші регіони світу розпочинають великі, амбітні програми модернізації транспорту та інвестиції в інфраструктуру, важливо, щоб український транспортна галузь продовжувала розвиватися, щоб зберегти своє конкурентне становище.

\section{7. Методи аналізу великих даних}

Спочатку в сукупність підходів і технологій включалися кошти масовопаралельної обробки невизначено-структурованих даних, такі як СУБД NoSQL, алгоритми MapReduce i проект Hadoop. Надалі до технологій великих даних стали відносити й інші рішення, що забезпечують подібні за характеристиками можливості по обробці надвеликих масивів даних, а також деякі апаратні засоби. 
Апаратно-програмних комплекси, що надають предвстановлені рішення для обробки великих даних: Aster MapReduce appliance (корпорації Teradata), Oracle Big Data appliance, Greenplum appliance (корпорації EMC, на основі рішень поглиненої компанії Greenplum).

NoSQL (від англ. Not Only SQL, не тільки SQL) - загальний термін для різних нереляційних баз даних і сховищ, що не позначає якусь одну конкретну технологію або продукт. Звичайні реляційні бази даних добре підходять для досить швидких i однотипних запитів, а на складних і гнучко побудованих запитах, характерних для великих даних, навантаження перевищує розумні межі і використання СУБД стає неефективним.

Серед NoSQL-рішень, які застосовуються, виділяють: MongoDB - кросплатформна документо-орієнтована система керування базами даних 3 підтримкою JSON та динамічних схем, Apache Cassandra - маштабована база даних, орієнтована на стійкість до відмов та HBase - маштабована розподілена база даних $з$ підтримкою структурованого зберігання даних великого обсягу.

Бази даних NoSQL (рис. 9) добре підходять для багатьох сучасних додатків, наприклад мобільних, ігрових, інтернет-додатків, коли потрібні гнучкі масштабовані бази даних з високою продуктивністю і широкими функціональними можливостями, здатні забезпечувати максимальну зручність використання.

Гнучкість. Як правило, бази даних NoSQL пропонують гнучкі схеми, що дозволяє здійснювати розробку швидше і забезпечує можливість поетапної реалізації. Завдяки використанню гнучких моделей даних БД NoSQL добре підходять для частково структурованих і неструктурованих даних.

Масштабованість. Бази даних NoSQL розраховані на масштабування 3 використанням розподілених кластерів апаратного забезпечення, а не шляхом додавання дорогих надійних серверів. Деякі постачальники хмарних послуг проводять ці операції в фоновому режимі, забезпечуючи повністю керований сервіс.

Висока продуктивність. Бази даних NoSQL оптимізовані для конкретних моделей даних (наприклад, документної, графової або з використанням пар «ключзначення») і шаблонів доступу, що дозволяє досягти більш високої продуктивності в порівнянні з реляційними базами даних.

Широкі функціональні можливості. Бази даних NoSQL надають API i типи даних з широкою функціональністю, які спеціально розроблені для відповідних моделей даних.

Роботу NoSQL можна охарактеризувати теоремою CAP, яка дозволяє вибирати лише два будь-яких компоненти 3 трьох - послідовність, доступність, розподілення (рис. 10).

Іншим рішенням розподілених файлових систем для задач Big Data виступає Наdоор екосистема.

Серед програмного забезпечення, пов'язаного з Наdoop, виділяють: Арасhе Ambari - інструмент для управління та моніторингу Hadoop кластерів, Аpache Avro - система серіалізації даних, Apache Hive - iнфраструктура сховище даних, 
яка забезпечує агрегацію даних, Apache Pig - високорівнева мова потоків даних й програмний каркас для паралельних обчислень, Apache Spark - високопродуктивний рушій для обробки даних, що зберігаються в кластері Hadoop та ін. (рис. 11).

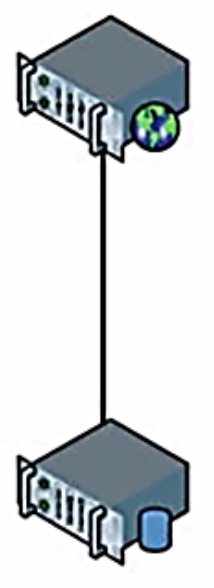

Single database $\&$ single web server

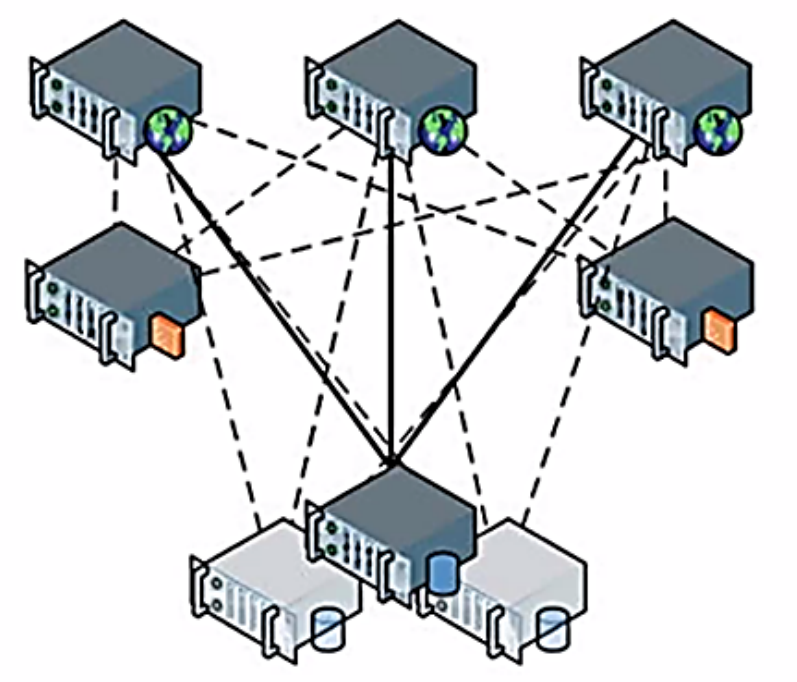

Scaling up by adding 2 web servers, 2 Memcached servers, and 2 read-only database slaves

\section{- - Read only traffic _ Read/Write traffic}

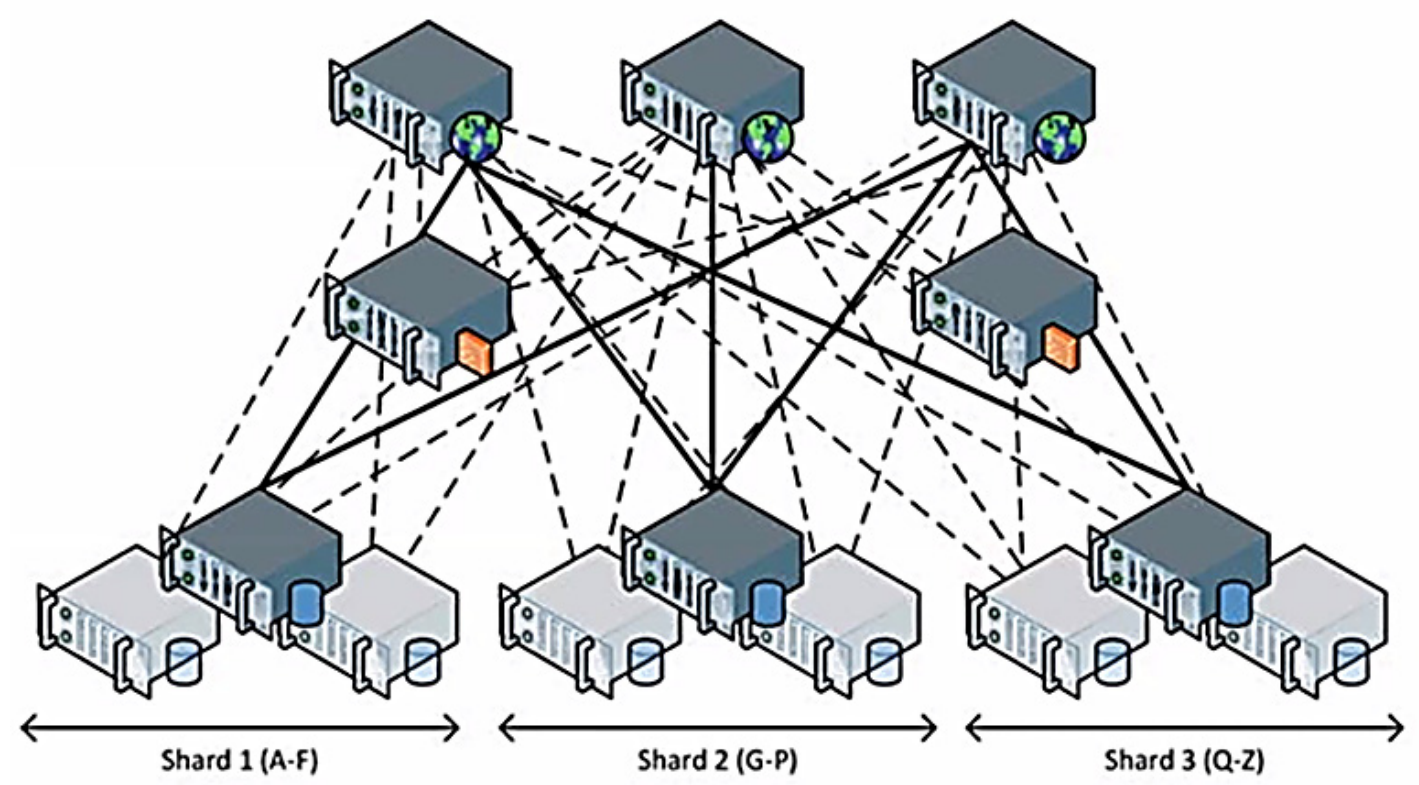

Web servers

Memcached servers

Master databases

Read-only slave databases

Puc. 9. NoSQL

Джерело: [15] 


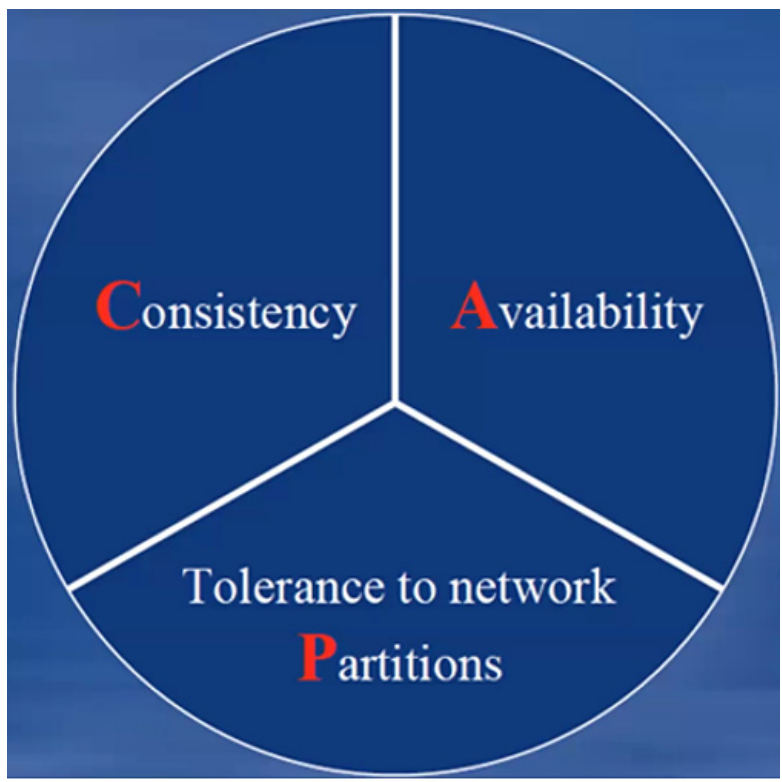

Рис. 10. Теорема СAP

Джерело: [20]

\section{Apache Hadoop Ecosystem}

\begin{tabular}{|c|c|c|c|c|c|c|c|}
\hline & & & Provision & g, Managi & d Moni & ng Hadoo & $\begin{array}{l}\text { mbari } \\
\text { Clusters }\end{array}$ \\
\hline 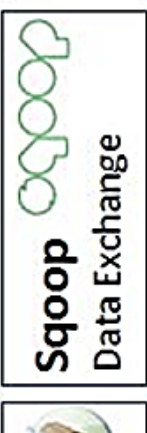 & 㩆 & 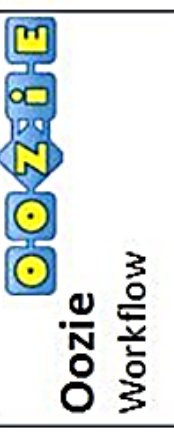 & 8 & 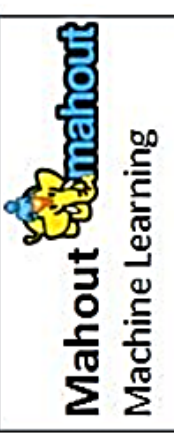 & 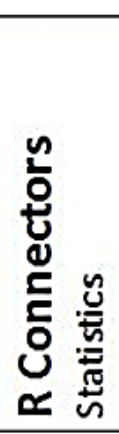 & 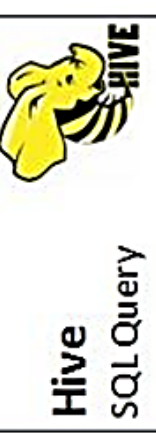 & 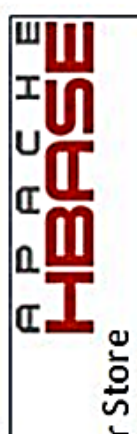 \\
\hline 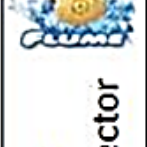 & 일 & $\int_{r=}^{\circ}$ & & $\begin{array}{r}\text { YA } \\
\text { Distribute }\end{array}$ & $\begin{array}{l}\text { Map F } \\
\text { cessing }\end{array}$ & $\begin{array}{l}\text { duce v2 } \\
\text { amework }\end{array}$ & 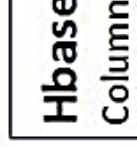 \\
\hline 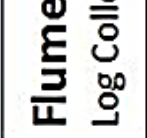 & 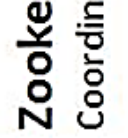 & $\begin{array}{l}\text { HDFS } \\
\text { Hadoop }\end{array}$ & buted Fil & ystem & & & \\
\hline
\end{tabular}

Рис. 11. Hadoop екосистема

Джерело: [21] 
Hadoop - вільно поширюваний набір утиліт, бібліотек і фреймворк для розробки і виконання розподілених програм, що працюють на кластерах з сотень і тисяч вузлів. Вважається однією з основоположних технологій великих даних.

Hadoop - це проект з відкритим вихідним кодом, що знаходится під управлінням Apache Software Foundation. Hadoop використовується для надійних, масштабованих и розподілених обчислень, але може також застосовуватися i як сховище файлів загального призначення, здатно вмістити петабайт даних. Багато компаній використовують Наdoop в дослідницьких й виробничих цілях.

Hadoop складається $з$ двох ключових компонентів:

- розподілена файлова система Hadoop (англ. HDFS), яка відповідає за зберігання даних на кластері Hadoop;

• система MapReduce, призначена для обчислень і обробки великих обсягів даних на кластері.

На основі цих ключових компонентів створено кілька підпроектів, таких як Pig, Hive, HBase і т.д.

MapReduce - модель розподілених паралельних обчислень в комп'ютерних кластерах, представлена компанією Google. Відповідно до цієї моделі додаток поділяється на велику кількість однакових елементарних завдань, що виконуються на вузлах кластера та потім природним чином приводяться в кінцевий результат.

MapReduce - це модель програмування і каркас для створення програмного забезпечення, призначених для високошвидкісної обробки великих обсягів даних на великих паралельних кластерах обчислювальних вузлів (рис. 12):

- забезпечує автоматичне розпаралелювання і розподіл завдань;

- має вбудовані механізми збереження стійкості і працездатності при збоях окремих елементів.

MapReduce $\epsilon$ дуже потужним інструментом обробки даних, однак він може виявитися досить складним для створення і підтримки, в той час як у багатьох компаніях працюють бізнес-аналітики, які добре вміють писати запити на мові SQL, але не вміють писати код на Java. Також, у багатьох організаціях $є$ програмісти, які вміють писати код на скриптових мовах. Hive i Pig — це два проекти, які розроблялися незалежно один від одного і які призначені для того, щоб допомогти таким аналітикам i програмістам ефективно використовувати MapReduce для аналізу великих масивів даних.

Hive - це надбудова над Наdoop для того, щоб полегшити виконання таких завдань, як підсумовування даних, непрограмовані запити і аналіз великих наборів даних:

- Hive може бути використаний тими, хто знає мову SQL;

- Hive створює завдання MapReduce, які виконуються на кластері Hadoop;

• визначення таблиць в Hive надбудовуються над даними в HDFS. 


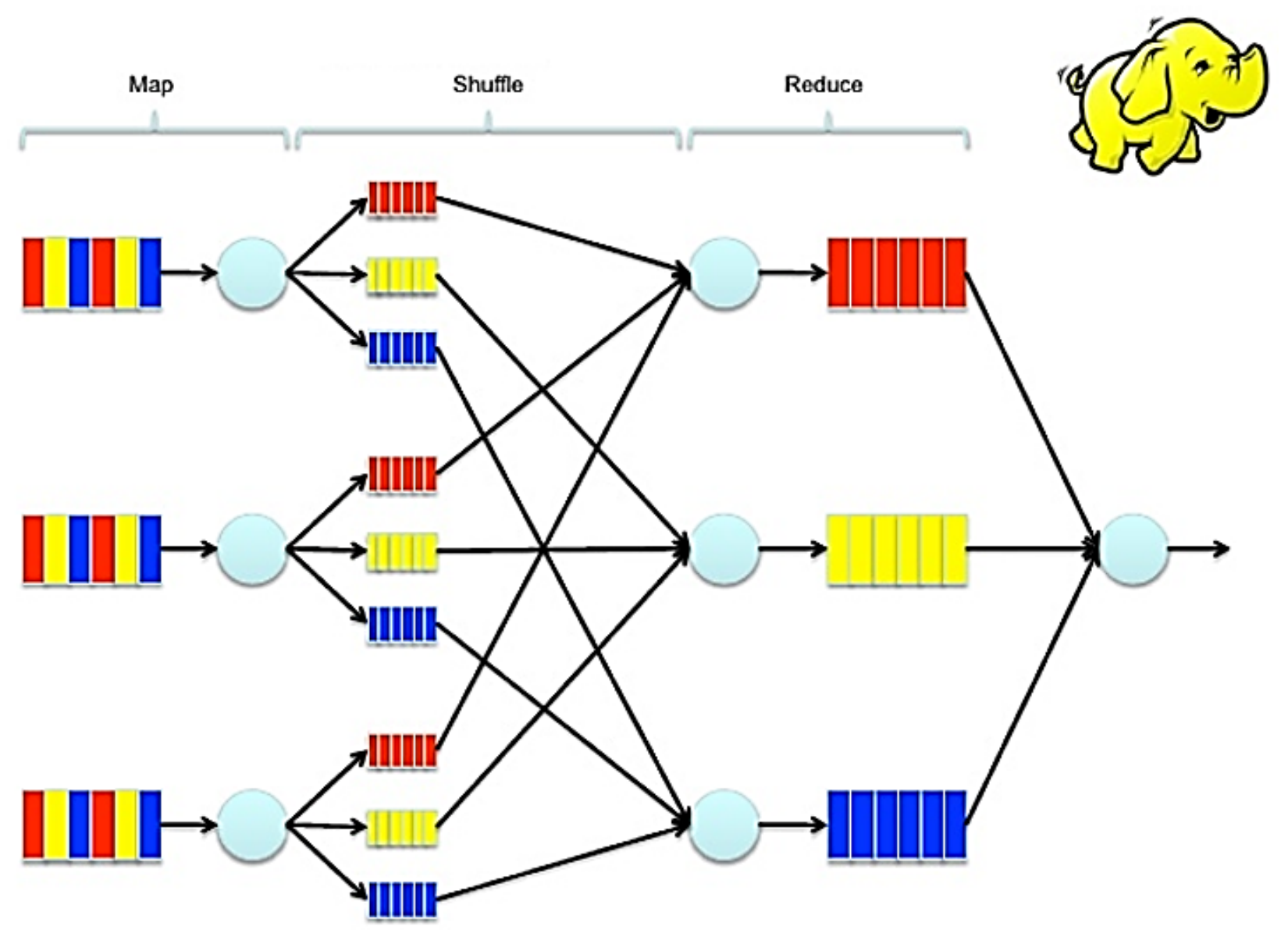

Рис. 12. Парадигма Мар-Reduce Джерело: [21]

Pig - це платформа, призначена для аналізу великих наборів даних і складається з мови високого рівня для написання програм аналізу даних та інфраструктури для запуску цих програм. Мова характеризується відносно простим синтаксисом. Написані сценарії приховано перетворюються в завдання MapReduce, які виконуються на кластері Hadoop.

HBase - це колоночная база даних, розташована поверх HDFS, яка здатна вмістити величезні масиви даних (від гігабайтів до петабайт даних). HВаse використовується тоді, коли потрібен довільний доступ до даних, що зберігаються в HDFS, в реальному часі і з правом запису і читання.

Модель доступу до даних в HBase має наступні обмеження:

•пошук ряду по одному ключу;

• не підтримуються транзакції;

•доступні тільки операції по одному рядку.

YARN (Yet Another Resource Negotiator - «ще один ресурсний посередник») модуль, що з'явився з версією 2.0 (2013), що відповідає за управління ресурсами кластерів і планування завдань. 
Якщо в попередніх випусках ця функція була інтегрована в модуль МарReduce, де була реалізована єдиним компонентом (JobTracker), то в YARN функціонує логічно самостійний модуль - планувальник ресурсів (ResourceManager), абстрагується всі обчислювальні ресурси кластера і керуючий їх наданням додаткам розподіленої обробки.

Працювати під управлінням YARN можуть як MapReduce - програми, так і будь-які інші розподілені додатки, що підтримують відповідні програмні інтерфейси; YARN забезпечує можливість паралельного виконання декількох різних завдань в рамках кластера та їх ізоляцію (за принципами мультиарендності).

Hadoop Common - це бібліотеки управління файловими системами, які підтримуються Наdoop і сценарії створення необхідної інфраструктури та управління розподіленою обробкою, для зручності виконання яких створено спеціалізований спрощений інтерпретатор командного рядка (FS shell, filesystem shell), що запускає з оболонки операційної системи команди виду: hdfs dfs - command URI, де command - команда інтерпретатора, a URI - список ресурсів із префіксами, що вказують тип підтримуваної файлової системи (наприклад hdfs://example.com/file1 або file://tmp/local/file2). Більшість команд інтерпретатора реалізована за аналогією з відповідними командами Unix (такі, наприклад, cat, chmod, chown, chgrp, cp, $\mathrm{du}, \mathrm{ls}, \mathrm{mkdir}, \mathrm{mv}, \mathrm{rm}$, tail), є команди специфічні для Hadoop (наприклад, count підраховує кількість каталогів, файлів і байтів по заданому шляху, expunge очищає корзину, a setrep модифікує коефіцієнт реплікації для заданого ресурсу).

Hadoop MapReduce - програмний каркас для програмування розподілених обчислень в рамках парадигми MapReduce. Розробнику програми для Hadoop MapReduce необхідно реалізувати базовий обробник, який на кожному обчислювальному вузлі кластера забезпечить перетворення вихідних пар «ключ - значення» в проміжний набір пар «ключ - значення» (клас, який реалізує інтерфейс Марper, названий по функції вищого порядку Мар), і обробник, який зведе проміжний набір пар в остаточний, скорочений набір (згортку, клас, який реалізує інтерфейс Reducer). Каркас передає на вхід згортки відсортовані висновки від базових обробників, зведення складається 3 трьох фаз - shuffle (тасування, виділення потрібної секції виводу), sort (сортування, угруповання по ключах висновків від розподільників - досортування, що виконується у разі, коли різні атомарні обробники повертають набори з однаковими ключами, при цьому, правила сортування на цій фазі можуть бути задані програмно і використовувати будь-які особливості внутрішньої структури ключів) і власне reduce (усічення) - отримання результуючого набору. Для деяких видів обробки згортка не потрібна, і каркас повертає в цьому випадку набір відсортованих пар, отриманих базовими обробниками.

Однією з основних цілей Наdoор спочатку було забезпечення горизонтальної масштабованості кластера допомогою додавання недорогих вузлів (обладнання масового класу - Commodity Hardware), без використання потужних серверів та дорогим мережам збереження даних. Функціонуючі кластери розміром в тисячі вузлів підтверджують здійсненність і економічну ефективність таких систем, так, 
станом на 2011 рік відомо про великі кластери Hadoop в Yahoo (більше 4 тис. вузлів з сумарною ємністю зберігання 15 ПБайт кожен), Facebook (близько 2 тис. вузлів на 21 ПБайт) і Ebay (700 вузлів на 16 ПБайт).

Проте, вважається, що горизонтальна масштабованість в Наdoор - системах обмежена, для Hadoop до версії 2.0 максимально можливо оцінювалася в 4 тис. вузлів при використанні 10 MapReduce - завдань на вузол. Багато в чому цьому обмеженню сприяла концентрація в модулі MapReduce функцій контролю за життєвим циклом завдань, вважається, що з виносом іiї в модуль YARN в Hadoop 2.0 і децентралізацією - розподілом частини функцій 3 моніторингу на вузли обробки - горизонтальна масштабованість підвищилася.

Ще одним обмеженням Наdoop-систем є розмір оперативної пам'яті на вузлі імен (NameNode), що зберігає весь простір імен кластера для розподілу обробки, притому загальна кількість файлів, яку здатний обробляти вузол імен -100 млн. Для подолання цього обмеження ведуться роботи з розподілу вузла імен, єдиного в поточній архітектурі на весь кластер, на кілька незалежних вузлів. Іншим варіантом подолання цього обмеження $є$ використання розподілених СКБД поверх HDFS, таких як HBase, роль файлів і каталогів в яких 3 точки зору програми грають записи в одній великій таблиці бази даних.

Існують тенденції як до зниження обчислювальної потужності вузлів і використанню процесорів з низьким енергоспоживанням (ARM, Intel Atom), так і застосування високопродуктивних обчислювальних вузлів одночасно 3 мережевими рішеннями з високою пропускною здатністю (InfiniBand в Oracle Big Data Appliance, високопродуктивна мережа зберігання даних на Fibre Channel та Ethernet пропускною здатністю 10 ГБіт/с в шаблонних конфігураціях FlexPod для «великих даних»).

Масштабованість Нadoop-систем в значній мірі залежить від характеристик оброблюваних даних, перш за все, їх внутрішньої структури та особливостей по вилученню з них необхідної інформації, і складності завдання з обробки, які, в свою чергу, диктують організацію циклів обробки, обчислювальну інтенсивність атомарних операцій, i, в кінцевому рахунку, рівень паралелізму і завантаженість кластера.

У керівництві Hadoop (перших версій, раніше 2.0) вказувалося, що прийнятним рівнем паралелізму є використання 10-100 примірників базових обробників на вузол кластера, а для задач, що не вимагають значних витрат процесорного часу - до 300; для згорток вважалося оптимальним використання їх за кількістю вузлів, помноженому на коефіцієнт $з$ діапазону від 0,95 до 1,75 і константу mapred.tasktracker.reduce.tasks.maximum. 3 великим значенням коефіцієнта найбільш швидкі вузли, закінчивши перший раунд відомості, раніше отримають другу порцію проміжних пар для обробки, таким чином, збільшення коефіцієнта надлишково завантажує кластер, але при цьому забезпечує більш ефективне балансування навантаження.

У YARN замість цього використовуються конфігураційні константи, що визначають значення доступної оперативної пам'яті і віртуальних процесорних ядер, 
доступних для планувальника ресурсів, на підставі яких і визначається i визначається рівень паралелізму.

\section{8. Методи класу Data Mining. Інтелектуальний аналіз даних}

Data Mining - це поєднання широкого математичного інструментарію (від класичного статистичного аналізу до нових кібернетичних методів) і останніх досягнень в сфері інформаційних технологій. В технології Data Mining гармонійно об’єдналися строго формалізовані методи і методи неформального аналізу, тобто кількісний і якісний аналіз даних.

Data Mining (видобуток даних, інтелектуальний аналіз даних, глибинний аналіз даних) - збірна назва, що використовується для позначення сукупності методів виявлення в даних раніше невідомих, нетривіальних, практично корисних і доступних інтерпретації знань, необхідних для прийняття рішень в різних сферах людської діяльності. Термін введений Григорієм Пятецкий-Шапіро в 1989 році.

Основу методів Data Mining становлять різноманітні методи класифікації, моделювання і прогнозування. До методів Data Mining нерідко відносять статистичні методи (дескриптивний аналіз, кореляційний і регресійний аналіз, факторний аналіз, дисперсійний аналіз, компонентний аналіз, дискримінантний аналіз, аналіз часових рядів). Такі методи, проте, припускають деякі апріорні уявлення про аналізовані дані, виникає певна розбіжність з цілями Data Mining (виявлення раніше невідомих нетривіальних і практично корисних знань).

Одне 3 найважливіших призначень методів Data Mining полягає в наочному поданні результатів обчислень, що дозволяє використовувати інструментарій Data Mining людьми, які не мають спеціальної математичної підготовки. У той же час, застосування статистичних методів аналізу даних вимагає володіння теорією ймовірностей і математичної статистики.

Знання, що отримуються методами Data mining, прийнято представляти у вигляді моделей. Моделі подання знань Data Mining:

- асоціативні правила;

- дерева рішень;

- кластери;

- математичні функції.

Методи побудови таких моделей прийнято відносити до області штучного інтелекту. До методів і алгоритмів Data Mining відносяться:

- штучні нейронні мережі;

- дерева рішень, символьні правила;

- методи найближчого сусіда i k-найближчого сусіда;

- метод опорних векторів;

- байєсівські мережі;

- лінійна регресія; 
- кореляційно-регресійний аналіз;

- ієрархічні методи кластерного аналізу;

- неієрархічні методи кластерного аналізу, в тому числі алгоритми k-середніх i k-медіани;

- методи пошуку асоціативних правил, в тому числі алгоритм Apriori;

- метод обмеженого перебору;

- еволюційне програмування і генетичні алгоритми;

- різноманітні методи візуалізації даних і безліч інших методів.

Більшість аналітичних методів, що використовуються в технологіï Data Mining — це відомі математичні алгоритми і методи. Новим в їх застосуванні є можливість їх використання при вирішенні тих чи інших конкретних проблем, обумовлена новими технічними та програмними можливостями.

\subsection{Machine learning}

Машинне навчання (Machine learning, ML) - сукупність методів в області штучного інтелекту, набір алгоритмів, які застосовують, щоб створити машину, яка вчиться на власному досвіді, яка обробляє величезні масиви вхідних даних і знаходить в них закономірності.

Не варто плутати поняття Data science та Machine learning. Ці інструменти багато в чому перетинаються, але все ж вони різні і кожен зі своїми завданнями.

Штучний інтелект (Artificial intelligence, AI) — різноманітні технологічні та наукові рішення i методи, які допомагають зробити програми за подобою інтелекту людини. Artificial intelligence включає в себе безліч інструментів, алгоритмів і систем, серед яких також всі складові Data science i Machine learning.

Data science - наука про методи аналізу даних і вилучення з них цінної інформації, знань. Вона перетинається 3 такими областями як машинне навчання і наука про мислення (Cognitive Science), а також з технологіями для роботи з великими даними (Big Data). Результатом роботи Data science $є$ проаналізовані дані і знаходження правильного підходу для подальшої обробки, сортування, вибірки, пошуку даних.

Штучна нейронна мережа (ШНM, англ. artificial neural networks, ANN) за допомогою штучних нейронів моделює роботу людського мозку (нейронів), яка вирішує певне завдання, самонавчається з урахуванням попереднього досвіду. I 3 кожним разом робить все менше помилок. Нейронні мережі $є$ одним 3 видів машинного навчання, а не окремим інструментом.

Мета машинного навчання - частково або навіть повністю автоматизувати рішення різних складних аналітичних задач. Приклад застосування машинного навчання подано на рис. 13. 


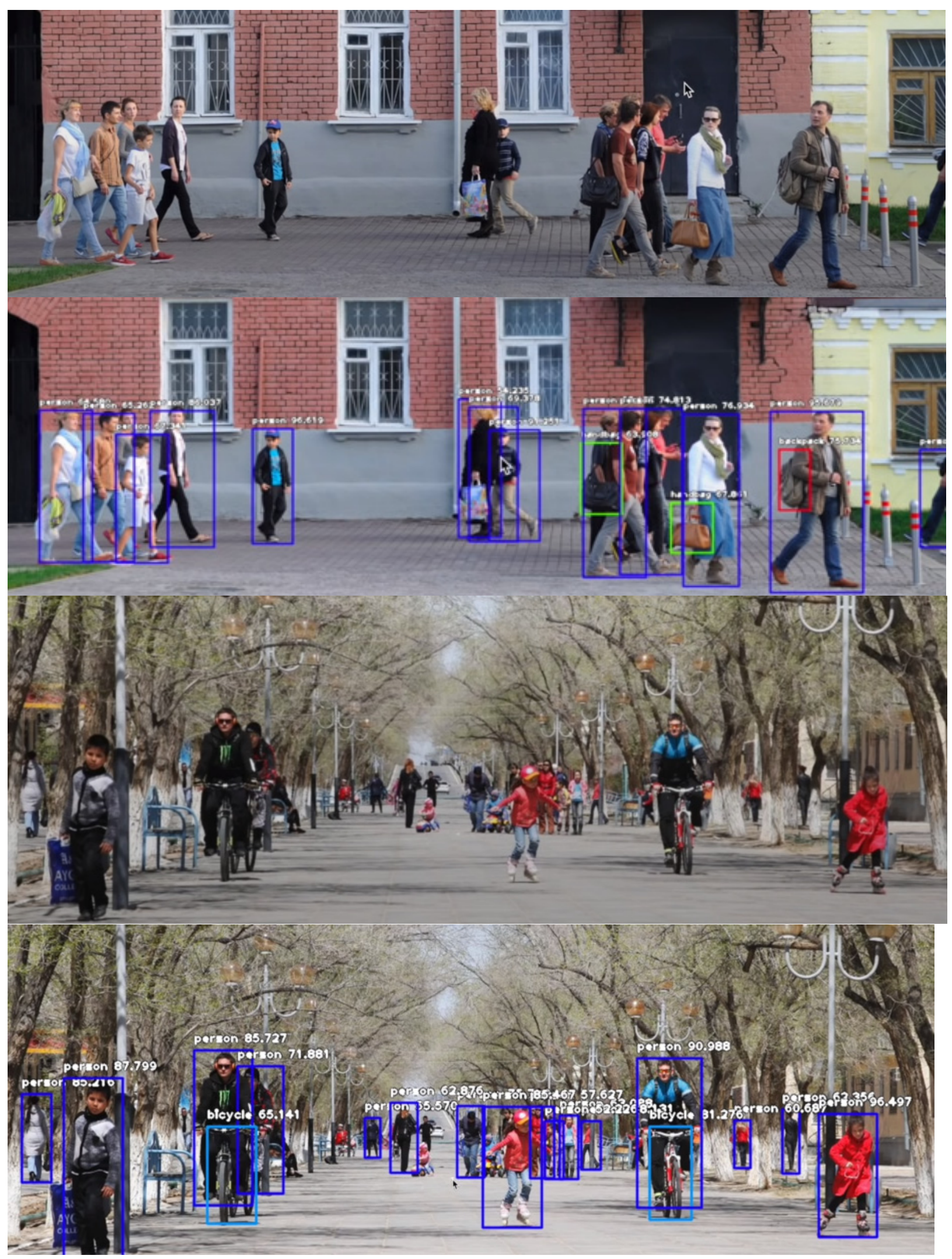

Рис. 13. Реалізація системи «розумного міста» засобами Machine learning Джерело [11] 
Тому, в першу чергу машинне навчання покликане давати максимально точні прогнози на підставі вхідних даних, щоб власники бізнесів, маркетологи і співробітники могли приймати правильні рішення в своїй роботі. В результаті навчання машина може передбачати результат, запам'ятовувати його, при необхідності відтворювати, вибирати кращий з декількох варіантів.

На даний момент машинне навчання охоплює широкий спектр додатків від банків, ресторанів, заправок до роботів на виробництві. Нові завдання, що виникають практично щодня, призводять до появи нових напрямків машинного навчання.

Машинне навчання будується на трьох китах:

- дані - базова інформація, надати яку зазвичай просять клієнта або користувача. Сюди входять будь-які вибірки даних, роботі з якими потрібно навчити систему;

- ознаки - ця частина роботи проводиться в тісній співпраці з клієнтом або користувачем. Визначаються ключові бізнес-потреби і спільно вирішуються, які саме характеристики і властивості повинна відстежувати система в результаті навчання;

- алгоритм - вибір методу для вирішення поставленого бізнес-завдання.

За ознакою наявності вчителя, навчання ділиться на навчання з учителем (Supervised Learning), без вчителя (Unsupervised Learning) і з підкріпленням (Reinforcement Learning).

- Навчання 3 учителем застосовують коли потрібно навчити машину розпізнавати об'єкти або сигнали. Загальний принцип навчання з учителем це «Дивись, це двері, і це теж двері і ось це теж двері».

- Навчання без вчителя використовує принцип «ця річ така ж як інші». Алгоритми вивчають подібності і можуть виявити відмінність і виконати виявлення аномалій, розпізнаючи, що є незвичайним або несхожим.

- Навчання $з$ підкріпленням використовують там, де перед машиною стоїть завдання - правильно виконати поставлені завдання у зовнішньому середовищі маючи безліч можливих варіантів дії. Наприклад, в комп'ютерних іграх, трейдингових операціях, для безпілотної техніки.

За типом застосовуваних алгоритмів можна виділити два види:

А) класичне навчання - відомі і добре вивчені алгоритми навчання, розроблені в основному більше 50-ти років тому для статистичних бюро. Підходить в першу чергу під завдання роботи 3 даними - класифікація, кластеризація, регресія і т.п. Застосовують для прогнозування, сегментації клієнтів і так далі.

Б) нейронні мережі і глибоке навчання (Deep Learning) - найбільш сучасний підхід до машинного навчання. Нейронні мережі застосовуються там де потрібні розпізнавання або генерація зображень і відео, складні алгоритми управління або прийняття рішень, машинний переклад і подібні складні завдання. Кілька підходів можна об'єднати і тоді вийдуть ансамблі моделей.

При вмілому підході, комбінуючи різні види машинного навчання, можна домогтися автоматизації більшості рутинних бізнес-процесів. Іншими словами, 
алгоритми і роботи, підготовлені за допомогою машинного навчання, можуть виконувати всю рутинну роботу. Людям залишається творча частина: складання стратегій, ведення переговорів, укладення договорів та інше. Це важливий фактор, оскільки машина не може вийти за задані їй рамки, а людський мозок здатний мислити непересічно.

Штучні нейронні мережі (ШНМ, англ. artificial neural networks, ANN), або конективістські системи (англ. connectionist systems) — це обчислювальні системи, натхнені біологічними нейронними мережами, що складають мозок тварин. Такі системи навчаються задач (поступально покращують свою продуктивність на них), розглядаючи приклади, загалом без спеціального програмування під задачу.

ШНМ грунтуються на сукупності з'єднаних вузлів, що називають штучними нейронами (аналогічно до біологічних нейронів у головному мозку тварин). Кожне з'єднання (аналогічне синапсу) між штучними нейронами може передавати сигнал від одного до іншого. Штучний нейрон, що отримує сигнал, може обробляти його, й потім сигналізувати штучним нейронам, приєднаним до нього (рис. 14).

В поширених реалізаціях ШНМ сигнал на з'єднанні між штучними нейронами є дійсним числом, а вихід кожного штучного нейрону обчислюється нелінійною функцією суми його входів. Штучні нейрони та з’єднання зазвичай мають вагу, яка підлаштовується в перебігу навчання. Вага збільшує або зменшує силу сигналу на з'єднанні. Штучні нейрони можуть мати такий поріг, що сигнал надсилається лише якщо сукупний сигнал перетинає цей поріг. Штучні нейрони зазвичай організовано в шари. Різні шари можуть виконувати різні види перетворень своїх входів. Сигнали проходять від першого (вхідного) до останнього (вихідного) шару, можливо, після проходження шарами декілька разів.
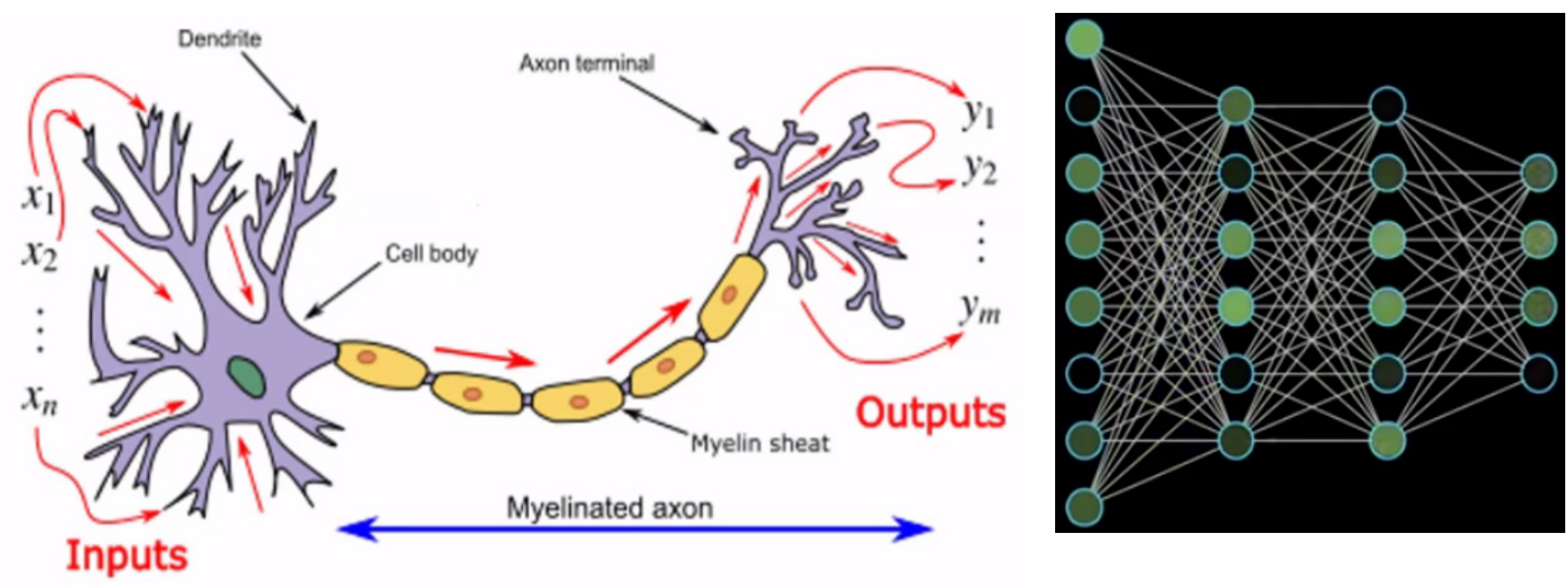

\section{Рис. 14. Аналогія біологічних нейронів та штучних нейронних мереж} Досерело [22] 
Первинною метою підходу ШНМ було розв'язання задач таким же способом, як це робив би людський мозок. 3 часом увага зосередилася на відповідності певним розумовим здібностям, ведучи до відхилень від біології. ШНМ використовували в ряді різноманітних задач, включно з комп'ютерним баченням, розпізнаванням мовлення, машинним перекладом, соціально-мережевим фільтруванням, медичним діагностуванням.

\subsection{0. Переваги Python y BigData}

Python - інтерпретована об'єктно-орієнтована мова програмування високого рівня зі строгою динамічною типізацією. Розроблена в 1990 році Гвідо ван Россумом. Структури даних високого рівня разом із динамічною семантикою та динамічним зв'язуванням роблять її привабливою для швидкої розробки програм, а також як засіб поєднування наявних компонентів. Python підтримує модулі та пакети модулів, що сприяє модульності та повторному використанню коду. Інтерпретатор Python та стандартні бібліотеки доступні як у скомпільованій, так і у вихідній формі на всіх основних платформах. В мові програмування Python підтримується кілька парадигм програмування, зокрема: об'єктно-орієнтована, процедурна, функціональна та аспектно-орієнтована.

Мова Python має багато переваг, яких більше, ніж в інших мовах, таких як Java, R та багато інших. Програми мови Рython можна легко перенести на будь-яку бажану мову програмування будь-якого напрямку досліджень про дані або проекти великих даних у будь-який час, що забезпечує вищу ефективність Python.

Для штучного інтелекту, Інтернету речей та багатьох інших сучасних напрямків розвитку технологій Руthon став однією з найбільш підходящих мов програмування. Python розповсюджується вільно на основі ліцензії подобної GNU General Public License.

Серед переваг Python у BigData можна виділити наступне:

1. Візуалізація даних - у мові програмування Pуthon існує багато пакетів візуалізації у порівнянні з іншими мовами програмування. У цьому Pуthon легко перемагає конкуруючу мову програмування R. NetworkX, Pyga, Matplotit, Plotly це деякі з пакетів візуалізації на мові програмування Python.

2. Необмежена обробка даних- розробники можуть завантажувати великий обсяг даних для обробки даних через пакети Python, i це не обмежує обробку даних.

3. Підтримка великої громади - існує велика спільнота експертів та розробників, де проблеми вирішуються в режимі реального часу за допомогою та знаннями, якими обмінюються один з одним.

4. Масштабованість Python - найкраща мова програмування, що стосується масштабованості. Це може значно збільшити швидкість обробки даних, коли збільшується їх кількість. Інші мови програмування, такі як Јava або R, не можуть масштабуватися, як мова програмування Python та не здатні обробляти великий

$$
-159-
$$


обсяг даних. 3 іншого боку, мова програмування Руthon дуже плавна і проста в обробці великоого обсягу даних.

5. Гнучкість - мова програмування Руthon також є однією з найбільш гнучких мов. За допомогою неї можна легко створити резервну копію бази даних MySQL, просто завантаживши пї.

6. Простота навчання - мову програмування Python можна достатньо швидко вивчити, оскільки не програміст також може обробляти синтаксис Python. Крім того, підтримка великої спільноти допомагає вирішити багато питань мови програмування Python та використовувати Рython у реальних додатках.

7. Висока сумісність з Наdoop - однією з основних причин вибору Python для Big Data $\epsilon$ те, що він може створити безпечну можливість сумісності між великими даними та Hadoop. У Python $€$ такі пакунки, як, наприклад, PyDoop Package, який забезпечує чудову підтримку Hadoop MapReduce, використовуючи переваги API HDFS. Набагато менших зусиль у програмуванні потрібно для вирішення складної проблеми за допомогою MapReduce API Hadoop.

8. Багато потужних наукових бібліотечних пакетів - у бібліотеці Python $\epsilon$ багато пакетів наукових бібліотек, які найкраще підходять для обробки великих даних. Деякі найважливіші бібліотеки на Python:

- SciРy — цей пакет бібліотеки Руthon використовується для технічних та наукових обчислень. Існує багато видів модулів для завдань інженерії даних та науки про дані, таких як швидке перетворення Фур'є, вирішувачі ODE, сигнали та обробка зображень, інтерполяція та лінійна алгебра.

• NumPy — оригінальний пакет для наукових обчислень даних, який підтримує багато речей, таких як проста інтеграція з різними базами даних, підтримка багатовимірного масиву загальних даних, визначення випадкових чисел, перетворення Фур'є, лінійна алгебра та багато іншого.

- Pandas - використовується для аналізу даних. Існує багато різних видів операцій, що виконуються з використанням Pandas, таких як маніпулювання даними, що здійснюється на основі цифрових таблиць і таблицях часових рядів. У цій бібліотеці також $є$ деякі функції, які допомагають обробляти різні структури даних.

9. Область програмування - у структурі даних існує багато видів концепцій, таких як Кадри даних, Матриця, Словники, Кортежі, Набори, Зв'язані списки та багато інших, які підтримуються мовою програмування Pуthon, оскільки він підпадає під концепцію об'єктно-орієнтованого програмування (ООП).

10. Сфера дії платформ - розробка мобільних додатків, розробка веб-сайтів, веб-додатків, додатків для обробки даних, графічного інтерфейсу користувача та багато іншого легко підтримується мовою програмування Python. Це тому, що мова програмування Python $€$ мовою загального призначення.

11. Підтримка обробки неструктурованих даних — Python підтримує обробку даних, в першу чергу, обробку неструктурованих даних. Це $\epsilon$ вагомою перевагою, оскільки часто необхідно обробляти неструктуровані дані, наприклад із соціальних мереж, які містять дані зображень, текстові дані, голосові дані та ін. Усі

$$
-160-
$$


неструктуровані дані швидко обробляються за допомогою вбудованої функції Python для ідентифікації типу даних.

12. Надшвидка обробка даних - Pуthon має характеристику, яка забезпечує надшвидку обробку даних, оскільки програми пишуться простими та лаконічними кодами.

13. Менші коди - однією із найкращих характеристик мови програмування Python $€$ те, що декількома рядками кодування програма може легко реалізувати додатки та програми. Крім того, Руthon має хорошу читабельність та може автоматично визначати типи даних завдяки вбудованим функціям.

\subsection{1. Безпека Big Data}

Безпека Big Data викликає постійне занепокоєння, оскільки вагомою ціллю потенційних зловмисників. Одна атака на програмне забезпечення може стати причиною появи великих проблем. Ще гірше, несанкціонований користувач може отримати доступ до даних Big Data для зняття та продажу цінної інформації. Втрати можуть бути серйозними. IP та конфіденційна інформація користувача може розповсюджуватися серед сторонніх покупців, користувач може зазнати штрафів та судових рішень з боку регуляторів, і може мати великі репутаційні втрати.

Забезпечення великих платформ даних вимагає поєднання традиційних інструментів безпеки, нещодавно розроблених наборів інструментів та інтелектуальних процесів для контролю за безпекою протягом усього життя платформи.

Мiciя безпеки Big Data досить чітка: слідкувати за несанкціонованими користувачами та вторгненнями з брандмауерами, автентифікацією користувачів, навчанням кінцевих користувачів та системами захисту від вторгнення (IPS) та системами виявлення вторгнень (IDS). Якщо хтось отримає доступ, необхідно зашифрувати дані під час транзиту.

Це виглядає як будь-яка стратегія захисту мережі. Однак великі середовища даних додають ще один рівень безпеки, оскільки засоби захисту повинні працювати протягом трьох етапів обробки даних, серед яких не всі $є$ в мережі:

1) введення даних (дані, що надходять),

2) збереження даних (дані, що зберігаються)

3) виведення даних (дані, що надходять до програм та звітів).

Етап 1: Джерела даних. Big Data походять з різних джерел та типів даних. Окремо створені користувачем дані можуть включати дані CRM або ERM, дані про транзакцію та бази даних, а також велику кількість неструктурованих даних, таких як повідомлення електронної пошти або в соціальних мережах. Крім того, $\epsilon$ машинні дані, включаючи журнали та датчики. На цьому етапі потрібно захистити дані під час транзиту від джерел до платформи.

Етап 2: Збережені дані. Захист збережених даних потребує зрілих наборів інструментів безпеки, включаючи шифрування, аутентифікацію користувача 
і захист, а також планування вторгнень. Для цього відбувається запуск наборів інструментів безпеки на всій платформі розподіленого кластера 3 багатьма серверами та вузлами. Крім того, інструменти безпеки повинні захищати файли журналів та інструменти аналітики під час роботи всередині платформи.

Етап 3: Вихідні дані. Причина складності та дороговизни платформ великих даних полягає в тому, що можна проводити змістовну аналітику на великих обсягах даних та різних типах даних, яка виводить результати у програми, звіти та інформаційні панелі. Ця надзвичайно цінна інформація створює ціль для вторгнення, тому важливим $€$ шифрування результатів. Крім того, необхідно забезпечити відповідність на цьому етапі, тобто переконатись, що результати, які надходять до кінцевих користувачів, не містять регульованих даних.

\section{Типові виклики безпеки Big Data:}

- Передові аналітичні інструменти для неструктурованих великих даних та нереляційних баз даних (NoSQL) - це новітні технології активного розвитку. Захист програмного забезпечення та процесів може бути важким для цих нових наборів інструментів.

- Зрілі засоби безпеки ефективно захищають вхід та зберігання даних. Однак вони можуть не мати однакового впливу на вихід даних 3 декількох інструментів аналітики в декілька локацій.

- Адміністратори великих даних можуть прийняти рішення про отримання даних без дозволу чи повідомлення. Незалежно від того, чи є мотивація цікавістю чи злочинною вигодою, інструменти безпеки повинні стежити і оповіщати про підозрілий доступ незалежно від його походження.

• Розмір даних терабайт, петабайт і т.д., занадто великий для звичайних перевірок безпеки. Оскільки більшість платформ великих даних базуються на кластері, тобто відбувається на декількох вузлах та серверах, це створює загальну вразливість даних.

- Якщо власник великих даних нерегулярно оновлює засоби безпеки даних від навколишнього середовища, це загрожує втратою та експозицією даних.

Жоден із цих засобів захисту Big Data не $\epsilon$ новим. Новим $\epsilon$ ï масштабованість та можливість захищати кілька типів даних на різних етапах.

Інструменти шифрування повинні захищати дані під час транзиту та в режимі спокою, і вони повинні робити це в великих обсягах даних. Шифрування також повинно діяти на багатьох різних типах даних, створених як користувачами, так і службових даних. Інструменти шифрування також повинні працювати з різними наборами інструментів аналітики та їх вихідними даними, а також із загальними форматами зберігання великих даних, включаючи системи управління реляційними базами даних (RDBMS), нереляційними базами даних, такими як NoSQL, та спеціалізованими файловими системами, такими як розподілена файлова система Hadoop (HDFS).

Централізоване управління ключами протягом багатьох років $\epsilon$ найкращою практикою безпеки. Ця технологія в значній мірі використовується у середовищі великих даних, особливо у широкому географічному розповсюдженні 
даних. Найкращі практики включають автоматизацію, керовану політику, ведення журналів, доставку ключів за запитом та абстрагування управління ключами.

Контроль доступу користувачів може бути найосновнішим інструментом безпеки мережі, але багато компаній практикують мінімальний контроль, оскільки це потребує значних вивтрат. Це досить небезпечно на мережевому рівні і може бути згубним для великої платформи даних. Контроль доступу користувачів вимагає підходу, який автоматизує доступ на основі налаштувань користувача та ролей. Автоматизація контролює складні рівні управління користувачами, такі як декілька налаштувань адміністратора, які захищають платформу великих даних від атаки.

Системи виявлення та запобігання вторгнень $є$ робочою базою безпеки, яка залишається цінною для великої платформи даних, оскільки цінність даних та розподілена архітектура піддається регулярним спробам вторгнення. IPS дозволяє адміністраторам безпеки захищати велику платформу даних від вторгнення, i, якщо вторгнення вдається, IDS створює захист перед тим, як це завдає значної шкоди.

Фізична безпека - створення обмеженого доступу під час розгортання власної великої платформи даних, або ретельна перевірка щодо безпеки центру хмарних даних постачальника послуг. Системи фізичної безпеки можуть заборонити доступ до центрів обробки даних стороннім людям або співробітникам, які не мають відповідних прав.

Нижче представлені декілька представницьких компаній із забезпечення безпеки Big Data великих даних.

Thales (Vormetric): Платформа Vormetric Data пропонує контроль безпеки та шифрування на всіх трьох етапах даних та на великих платформах даних: вхідних даних, збережених даних та результатів. Його технології включають шифрування, управління ключами та контроль доступу. Він також проводить аудит та звіти 3 метою управління та дотримання норм.

Cloudwick: Платформа Cloudwick Data Analytics (CDAP) грунтується на дистрибутиві Hadoop Intel Xeon та Cloudera. CDAP — це керований центр захисту даних, який об'єднує функції захисту від безлічі наборів інструментів аналітики, проектів машинного навчання та традиційних IDS та IPS.

IBM: IBM Security Guardium стежить за безпекою та дотриманням даних, а також за великими даними та середовищем NoSQL. Вона включає в себе відкриття та класифікацію чутливих даних, оцінку вразливості та моніторинг даних та файлів. Guardium також маскує, шифрує, блокує, оповіщає та обмежує підозрілі спроби доступу.

Logtrust: Logtrust співпрацює з Panda Security, щоб забезпечити розширений інструмент звітності (ART) та Panda Adaptive Defense. ART автоматично повідомляє про атаки та підозрілі цифрові поведінки та виявляє внутрішні загрози системам та мережам великих даних. Panda Adaptive Defense співвідносить дані з декількох джерел, що $є$ критичним для великих середовищ даних 3 кількома вузлами та джерелами даних. 
Gemalto: Gemalto SafeNet захищає великі платформи даних у хмарі, центрі обробки даних та віртуальних середовищах. Набір інструментів включає потужні рішення для аутентифікації та цифрового підпису, в режимі спокою та шифрування в русі та безпеку та управління криптографічними ключами. Gemalto інтегрується $з$ провідними великими постачальниками даних, включаючи MongoDB, Cloudera, Couchbase, DataStax, Hortonworks, IBM ra Zettaset.

\section{3. ВИСНОВКИ}

Стрімкий розвиток інформаційних технологій, зокрема, прогрес в методах збору, зберігання і обробки даних дозволив багатьом організаціям збирати величезні масиви даних, які необхідно аналізувати. В транспортних системах використовують складні технології, організації та технічні рішення. Для контролю такої складності життєздатним рішенням $є$ застосування інтелектуальних комп'ютеризованих систем. Аналітика великих даних у транспортній сфері може задовольнити наступні потреби:

- довгострокові потреби та соціально-економічне зростання: за допомогою технологій великих даних можна розробити загальну методологію для покращення інфраструктурного потенціалу, безпеки та впливу на навколишнє середовище;

- розумні процеси в транспортній системі: інтелектуалізація в транспортній сфері тісно пов'язана з методологіями експлуатації та обслуговування, спрямованими на системи самоконфігурації, самообслуговування та саморемонту, щоб максимізувати потужність та використання залізничного обладнання.

\section{ЛITEPATУРA}

1. Business Data Platform: Big Data Renvenue Wordwide from 2016 to 2027 [Electronic resource] / Mode of access: statista.com.

2. Data never sleeps 8.0. How much data is generated every minute [Electronic resource] / Mode of access: internetlivestats.com.

3. Alyson, Y. Our partnership with Imperial College London: The Digital Asset Research Lab. [Electronic resource] / Alyson Y. - 2017. — Mode of access: https://blog.blockchain.com/ 2017/01/19/our-paretnership-withimperial-college-london-the-digital-asset-research-lab/.

4. Polonski, V. The evolution of social networking sites: The rise of content-centric platforms, which favor the perpetual present. [Electronic resource] / Polonski V. - 2014. - Mode of access: http://www.kellogg.ox.ac.uk/blog/the-evolution-of-social-networking/.

5. Big data in railways. Common Occurrence for Railways : technical document ERA-PRG-004TD-003 V 1.0 [Electronic resource] / European Union Agency for railways. - 12.10.2016. 25 p. - Mode of access: https://www.era.europa.eu/sites/default/files/activities/docs/cor big_data_en.pdf.

6. Gismondi, D. Big Data Trenitalia Rolling Stock Maintenance [Electronic resource] / Danilo Gismondi // Improving Rolling Stock Maintenance Using Big Data. - Issue 4 - 2016. 25 July. — Mode of access: https://www.globalrailwayreview.com/article/ 28433/big-datatrenitalia-rolling-stock-maintenance/.

$$
-164-
$$


7. Galar, D. Big data in railway operations and maintenance [Electronic resource] / Diego Galar, Ramin Karim, Uday Kumar // Improving Rolling Stock Maintenance Using Big Data. Issue 4. - 2017. - 10 August. - Mode of access: https://www.globalrailwayreview. com/article/61515/big-data-railway-operations-maintenance-2/.

8. Osetskyi, V. Big Data Solutions: Example of the Development Cost [Electronic resource] / Victor Osetskyi // Existek — 2018. — 13 Jun. — Mode of access: https://medium.com/existek/big-data-solutions-example-of-the-development-cost-e3d173d97064.

9. Faeze Ghofrani: Recent applications of big data analytics in railway transportation systems: A survey [Electronic resource] / Faeze Ghofrani, QingHe, Rob M.P.Goverde, Xiang Liu // Transportation Research Part C 90. - 2018. - 21p. - Mode of access: https://www. acsu.buffalo.edu/ qinghe/papers/journal/2018\%20TRC\%20Rail\%20Big\%20Data.pdf.

10. Big Data, методы и техники анализа больших данных. [Электронный ресурс] / Режим доступа: https://www.it.ua/ru/knowledge-base/technology-innovation/big-data-bolshie-dannye.

11. Огурцов, А. Машинное обучение - это легко. [Электронный ресурс] / Огурцов А. // 2017. - Режим доступа: https:/habr.com/ru/post/319288/.

12. Что такое базы данных NoSQL? [Электронный ресурс] - Режим доступа: https://aws. amazon.com/ru/nosql/.

13. Шутов, И. Python. Высокоуровневый язык программирования [Электронный ресурс] / Шутов И. - 2018. - Режим доступа: https://habr.com/ru/hub/python/.

14. Петров, A. Big Data от А до Я: Hadoop [Электронный pecypc] / Петров А. 05.10.2015. — Режим доступа: https://habr.com/ru/company/dca/blog/268277/.

15. Guy Harrison Next Generation Databases: NoSQL, NewSQL and Big Data [Electronic resource] / Guy Harrison // December 2015. - 256 p. - Mode of access: https://www. amazon.com/Next-Generation-Databases-NoSQLand-Data/dp/1484213300.

16. Robinson, I. Graph Databases, 2th Edition [Electronic resource] / Ian Robinson, Jim Webber, Emil Eifrem // O'Reilly - Media June 2015. — Mode of access: https://www.oreilly.com/library/view/graph-databases-2nd/9781491930885/.

17. Keuper, F. Smart Big Data Management [Electronic resource] / Frank Keuper, Dietmar Schmidt, Marc Schomann // 2014. - 450 p. - Mode of access: https://www.amazon.co.uk/Smart-Data-Management-Frank-Keuper/dp/3832537686.

18. Chang, F. Bigtable: A distributed Storage System for Structured Data. Fay Chang ect. OSDI [Electronic resource] / Fay Chang, Jeffrey Dean, Sanjay Ghemawat, Wilson C. Hsieh, Deborah A. Wallach Mike Burrows, Tushar Chandra, Andrew Fikes, Robert E. Gruber // 2006. — 14 p. - Mode of access: https://static.googleusercontent.com/media/research. google.com /ru//archive/bigtable-osdi06.pdf.

19. The Fields of Data Science [Electronic resource] / 2017. — Mode of access: http:/www.zarantech.com/blog/i2/.

20. Brewer, E. A. Towards Robust Distributed Systems [Electronic resource] / E. A. Brewer // PODC Conf. Keynote. - 2000. - 12p. - Mode of access: https://people.eecs.berkeley.edu/ brewer/cs262b-2004/PODC-keynote.pdf.

21. Mapreduce-Framework - Mapreduce.Wiki [Electronic resource] / 2017. - Mode of access: http://code.google.com/p/mapreduce-framework/wiki/MapReduce.

22. Loc Vu-Quoc Human neurons [Electronic resource] / Loc Vu-Quoc // 2019. — Mode of access: https://en.wikiversity.org/wiki/User:Prof._Loc_Vu-Quoc. 


\title{
РОЗДІЛ 6 \\ УПРАВЛІННЯ РИЗИКАМИ ТА ЗАСОБИ ПРОГНОЗУ \\ ТА ЗМЕНШЕННЯ ВПЛИВУ В ТРАНСПОРТНИХ СИСТЕМАХ
}

\author{
О.А. Горецький ${ }^{11}$
}

\section{1. ВСТУП}

Слово «ризик» та різні словосполучення з ним широко вживаються на сучасному етапі. Але «ризик» для різних спеціалістів та галузей господарства різні. В розділі ми спробуємо з'ясувати та охарактеризувати поняття «ризик» в транспортних системах різних видів транспорту та які саме смисли вкладаємо в це поняття.

Ризик - невизначеність, пов'язана 3 певною ймовірністю, потенціал різноманітних дій в майбутньому, ймовірність виникнення несприятливої або випадкової події, нестабільна економічна ситуація, невизначеність, що виникає через зміни, які важко передбачити, або через події, можливості яких неможливо точно розрахувати.

Також «ризик» означає потенційні зміни очікуваного результату. Зазвичай ризик пов'язаний з певною ймовірністю реалізації несприятливої події [1].

Ризик також визначається як ситуація прийняття рішень, де можливі потенційні наслідки нестабільності i, ймовірно, їх зміна. Ризик визначається як потенціал реалізації небажаних впливів.

Через багатогранність, багатоаспектність самого поняття в Україні та світі немає вичерпної та єдиного вірного тлумачення.

Ризик проявляється у всіх сферах діяльності людини, на всіх етапах функціонування і розвитку об'єкта, їхньої взаємодії з навколишнім середовищем і всередині себе. Транспортна галузь не є винятком [2].

Згідно [3] ризик - поєднання ймовірності настання шкоди та тяжкості цієї шкоди.

Звичайно, ризиками потрібно керувати. Для цього широко застосовуються принципи ризик-менеджменту. Управління ризиками (ризик-менеджмент) займається запобіганням, прийняттям рішень, вжиттям заходів, управлінням кризисними ситуаціями та відновленням з урахуванням наслідків непередбачуваних подій [4].

\section{2. ОСНОВНИЙ МАТЕРІАЛ}

\section{1. Міжнародний стандарт ISO 31000:2009}

Унормування в системі ризиків та кризових ситуацій займається Міжнародна організація зі стандартизації. Нею запропоновано нормативи системи ISO 31000, які призначені для сімейства стандартів, пов'язаних із управлінням ризиками.

\footnotetext{
${ }^{11}$ Канд. істор. наук, доцент кафедри «Технологій транспорту та управління процесами перевезень» Державного університету інфраструктури та технологій, Київ
} 
Метою ISO 31000:2009 є забезпечення загальних керівних принципів з управління ризиками. ISO 31000 спрямований на забезпечення загальновизнаної парадигми для практиків і компаній, що використовують процеси управління ризиками, щоб замінити безліч існуючих стандартів, методологій та парадигм, які відрізнялися між галузями, з урахуванням питань і регіонів [5].

У цей час стандарт ISO 31000 включає:

- ISO 31000:2018 - Менеджмент ризиків. Принципи та настанови [6];

- ISO / IEC 31010:2009 - Керування ризиками. Методи загального оцінювання ризику [7];

- ISO Guide 73:2009 - Керування ризиками. Словник термінів [8].

ISO 31000 був опублікований як стандарт 13 листопада 2009 р. та надає стандартний підхід щодо здійснення управління ризиками. Переглянуті і узгоджені ISO / ISO Guide 73 було опубліковано в той самий час. Мета ISO 31000:2009 застосування і адаптація для «будь-яких державних, приватних або громадських підприємств, об'єднань, груп або індивіду».

Таким чином, загальна сфера ISO 31000 - в сімействі стандартів управління ризиками - не розроблення для певної групи промисловості системи управління, мається на увазі, швидке забезпечення оптимальної структури практики і керівництва усіх операцій, пов'язаних з управлінням ризиками.

\section{2. Стійкість та оцінка ризиків в транспортних системах}

Важливим в транспортних системах $є$ стійкість. Згідно [9] після катастрофи система може не відновитись до свого попереднього стану, але вона володіє здатністю адаптуватися, самоорганізовуватися, оновлюватись, навчатися, впроваджувати інновації та трансформуватися. Це дуже важливо при проектуванні систем, тобто, до впровадження ії в експлуатацію.

Виділяють 5 кроків оцінки ризиків.

Зміст кроків оцінки ризиків

Таблиця 1

\begin{tabular}{|l|l|}
\hline \multicolumn{1}{|c|}{ Кроки } & \multicolumn{1}{c|}{ Зміст кроків } \\
\hline Крок 1- Оцінка потреб & $\begin{array}{l}\text { Передбачає високорівневу оцінку стійкості } \\
\text { та ризику транспортних систем }\end{array}$ \\
\hline Крок 2-Проектний обсяг & $\begin{array}{l}\text { Після визначення обсягу проекту на кроці 2, } \\
\text { крок 3 оцінює стійкість транспортної системи } \\
\text { за допомогою інструмента матриці стійкості }\end{array}$ \\
\hline Крок 3- Оцінка стійкості & Аналіз переваг та недоліків \\
\cline { 1 - 1 } Крок 4- Оцінка ризику & Багатокритеріальний аналіз \\
\hline $\begin{array}{l}\text { Крок 5 - Техніко-економічне } \\
\text { обгрунтування / Аналіз варіантів }\end{array}$ &
\end{tabular}

Джерело: [9] 
Стійкість - це здатність окремої людини, громади чи країни справлятися, адаптуватися та швидко оговтуватися від стресу та потрясінь, спричинених катастрофою, насильством чи конфліктом.

Автори [10] пропонують використовувати матрицю стійкості, яка використовується в армії США.

\begin{tabular}{|c|l|l|l|l|}
\cline { 2 - 5 } \multicolumn{1}{c|}{} & Підготовка & Сприйняття & Відновлення & Адаптування \\
\hline Фізична & & & & \\
\hline Інформаційна & & & & \\
\hline Пізнавальна & & & & \\
\hline Соціальна & & & \\
\cline { 2 - 5 }
\end{tabular}

Рис. 1. Огляд побудови матриці з циклом подій по горизонталі та системними сферами діяльності по вертикалі

Докерело: [10]

Когнітивні соціальні значення стійкості вимагають розуміння здатності системи діяти впродовж руйнівної події: передбачати, готувати, планувати, поглинати, витримувати, справлятися, реагувати, відновлюватись, адаптуватися.

Фізична область включає параметри фізичних аспектів системи в просторі та часі, де домінують системна інфраструктура та обладнання.

Інформаційна область включає створення або збір, аналіз та розповсюдження інформації.

Пізнавальна область включає організаційні та інституційні компоненти системи, зокрема, що стосується прийняття рішень: хто уповноважений приймати рішення.

Соціальна сфера включає людський вимір системи, особливо тих людей, які не пов'язані з управлінням та управлінням системою. Це включає взаємодію, співпрацю та самосинхронізацію окремих громадян та громадських груп.

\section{3. Оцінка ризиків}

Згідно з [6] деякі з основних переваг реалізації оцінки ризиків включають:

- надання інформації особам, що приймають рішення;

- сприяння розумінню ризиків, щоб допомогти у виборі варіантів лікування;

- виявлення важливих факторів ризику та слабких ланок в системах;

- порівняння ризиків в альтернативних системах, технологіях чи підходах;

- інформування про ризики та невизначеності;

$$
-168-
$$


- допомога у встановленні пріоритетів;

- розуміння ризику та його потенційного впливу на цілі;

- сприяння запобіганню інцидентів на основі розслідування після інциденту;

- вибір різних форм обробки ризику;

- відповідність нормативним вимогам;

- надання інформації, яка допоможе оцінити, чи слід приймати ризик;

- оцінка ризиків утилізації після закінчення терміну експлуатації.

\subsection{1. Елементи оцінки ризиків}

Оцінка ризиків містить наступні блоки та елементи.

Спілкування та консультування із зацікавленими сторонами

- розробка плану спілкування

- визначення контексту належним чином

- забезпечення розуміння та врахування інтересів зацікавлених сторін

- об'єднання різних областей знань для виявлення та аналізу ризиків

- забезпечення належного врахування різних поглядів при оцінці ризиків

- забезпечення належного виявлення ризиків

• забезпечення схвалення та підтримки плану дій (заходів)

Встановлення зовнішнього контексту

- фактори природного, політичного, правового, регуляторного, фінансового, економічного та конкурентного середовища

- ключові фактори та тенденції, що впливають на цілі системи

- сприйняття та цінності зовнішніх зацікавлених сторін

\section{Встановлення внутрішнього контексту}

- можливості організації з точки зору ресурсів та знань

- інформаційні потоки та процеси прийняття рішень

- внутрішні зацікавлені сторони

- цілі та стратегії

Встановлення контексту ризику управління

• визначення підзвітності та відповідальності

- визначення обсягу діяльності з управління ризиками

- визначення масштабу проекту, процесу, функції чи діяльності з точки зору часу та місця

- визначення взаємозв'язків між конкретним проектом чи діяльністю та іншими проектами чи діями організації

• визначення методологій оцінки ризиків

- визначення критеріїв ризику

- визначення того, як оцінюється ефективність управління ризиками

- виявлення та конкретизація рішень та дій, які мають бути прийняті

\section{Рис. 2. Елементи оцінки ризиків}

Джерело: [6] 


\subsection{2. Процес оцінки ризику}

Метою ідентифікації ризиків є виявлення того, що може статися або які ситуації можуть існувати, що може вплинути на досягнення цілей системи чи організації.

Аналіз ризику, як правило, включає оцінку діапазону потенційних наслідків, які можуть виникнути в результаті події, ситуації чи обставини, та пов'язаних 3 ними ймовірностей для вимірювання рівня ризику. На даному етапі визначається та вивчається невизначеність та чутливість подій, проводиться аналіз наслідків та аналіз вірогідності та виконується оцінка ймовірності настання події.

Оцінка ризику передбачає порівняння передбачуваних рівнів ризику з критеріями ризику, визначеними при встановленні контексту, з метою визначення значущості рівня та типу ризику. Виділяють 3 рівня: високий, середній та низький.

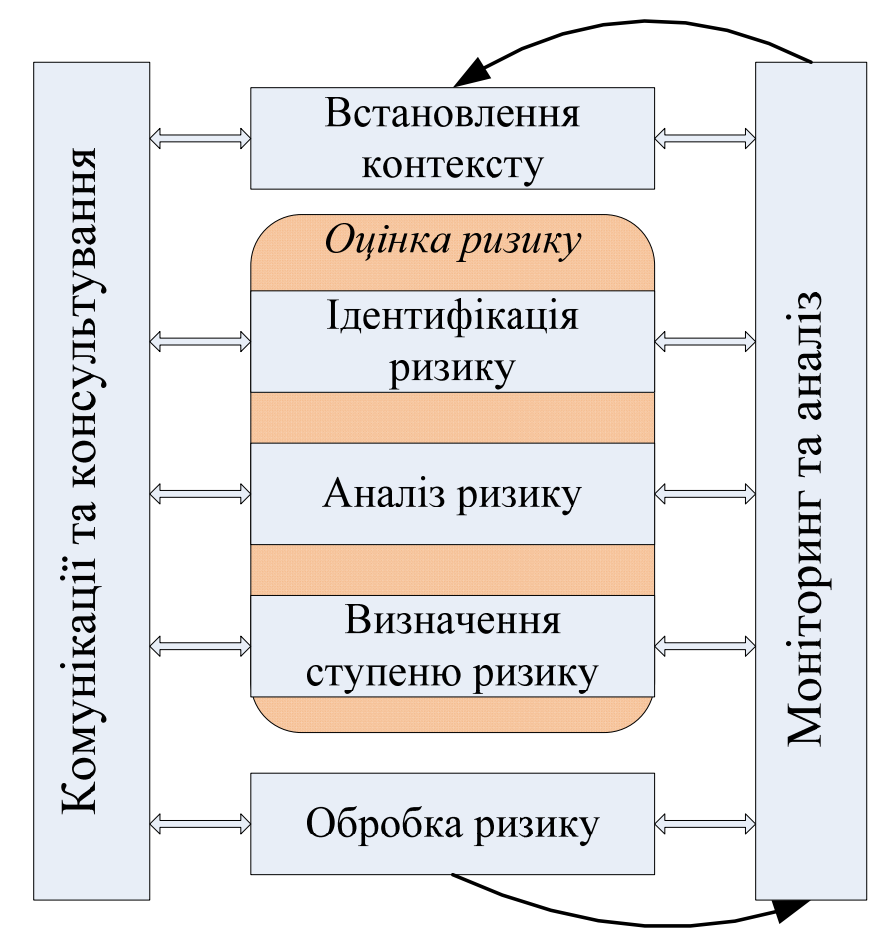

\section{Рис. 3. Процес ризик-менеджменту}

Джерело: [6]

Ризик, пов'язаний з конкретною небезпечною ситуацією, залежить від наступних елементів [3] (див. рис. 4).

Для зменшення ризиків до допустимого рівня слід використовувати наступну процедуру (див. рис. 5). 


\begin{tabular}{|c|c|c|}
\hline \multicolumn{1}{c|}{ Ризик } & Тяжкість \\
пов'язаний з & залежить & шкоди, яка \\
небезпекою, & від & може виникнути \\
що & & в результат \\
розглядається & & небезпеки, яка \\
& & розглядається \\
\hline
\end{tabular}

Імовірність нанесення даних збитків

Схильність до впливу

та небезпечної ситуації

Частковість присутності небезпечної події

Можливість уникнути або обмежити збитки

Рис. 4. Елементи ризику

Джерело: [3]

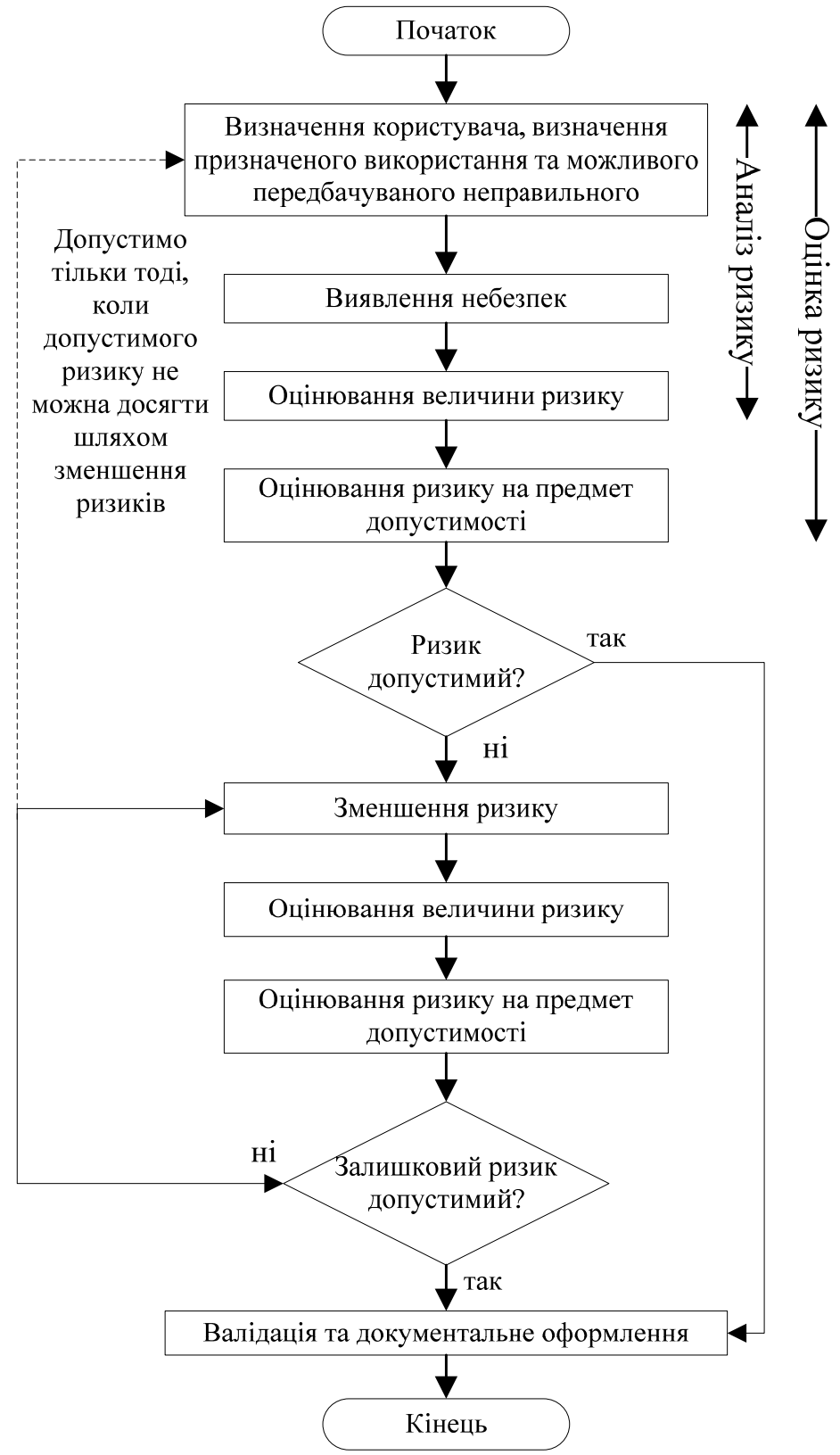

Рис. 5. Ітеративний процес оцінки ризику та зменшення ризику Джерело: [3] 
Зниження ризику («триступеневий метод»):

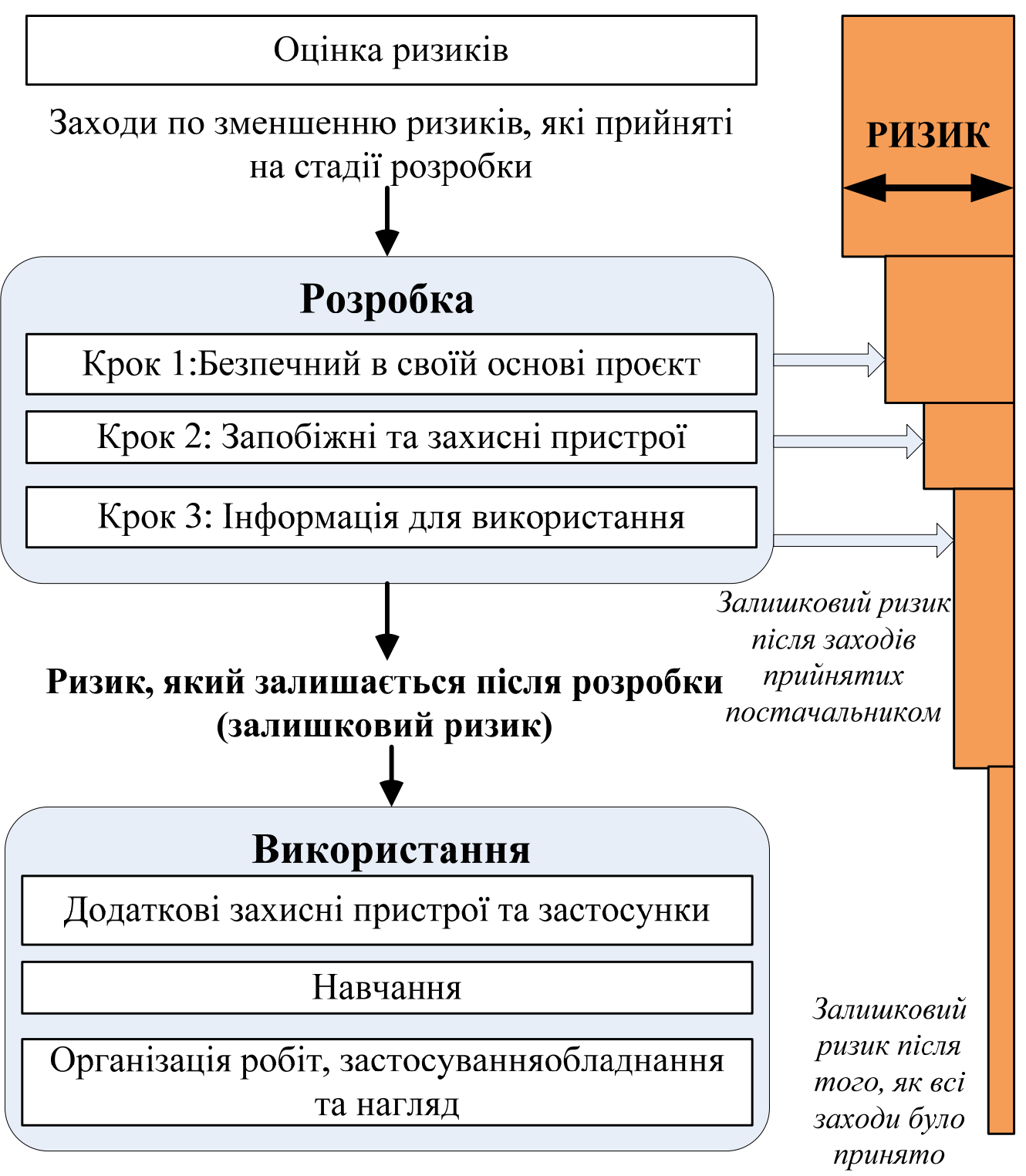

Рис. 6. Зменшення ризику: комбінація зусиль на етапах проектування та використання

Джерело: [3]

\section{4. Планування криз}

Кризове планування можна визначити як оцінку та усунення вразливостей, щоб уникнути або мінімізувати вплив криз. Основна увага приділяється діяльності, яку слід вирішити до появи кризи.

Розглянемо 4 кроки планування криз. 
Таблиця 2

Кроки планування криз

\begin{tabular}{|l|l|}
\hline \multicolumn{1}{|c|}{ Крок і назва } & \multicolumn{1}{|c|}{ Дії } \\
\hline $\begin{array}{l}\text { Крок } 1-\text { Кри- } \\
\text { зисна команда }\end{array}$ & $\begin{array}{l}\text { формування ефективної управлінської команди має вирішальне значення } \\
\text { для фінансового успіху організації }\end{array}$ \\
\hline $\begin{array}{l}\text { Крок } 2-\text { Аналіз } \\
\text { вразливостей }\end{array}$ & $\begin{array}{l}\text { Пристосувавши перелік потенційних криз, кризовій групі слід проаналі- } \\
\text { зувати події не тільки щодо ймовірності їх виникнення, а й оцінити пов'язані } \\
\text { з цим фінансові, операційні, людські ресурси та зв'язки з громадськістю. }\end{array}$ \\
\hline $\begin{array}{l}\text { Крок } 3-\text { Ство- } \\
\text { рення стратегії }\end{array}$ & $\begin{array}{l}\text { Кризисна група може взятися за розробку всебічних стратегій уникнення } \\
\text { або пом'якшення кризових подій }\end{array}$ \\
\hline $\begin{array}{l}\text { Крок } 4- \\
\text { Опрацювання } \\
\text { планів }\end{array}$ & $\begin{array}{l}\text { Створення ефективної кризової команди, створення всебічних стратегій } \\
\text { кризового планування, реалізація стратегій досить детально на функціо- } \\
\text { нальних рівнях, а також навчання та підготовка працівників до ефективної } \\
\text { та ефективної роботи в кризових ситуаціях повинні забезпечити пом'як- } \\
\text { шення будь-якої кризи або ії уникнення. }\end{array}$ \\
\hline
\end{tabular}

Джерело: [26]

\section{5. Класифікація типів методів загального оцінювання ризику}

Розглянемо класифікацію типів методів загального оцінювання ризику та їх коротку характеристику [7].

\section{I. Методи пошуку:}

1) перелік контрольних запитань - проста форма ідентифікування ризику. Метод, який уможливлює складання переліку типових невизначеностей, які потрібно розглядати. Користувачі звіряють його з попередньо розробленими переліком, кодексами чи стандартами;

2) попереднє аналізування небезпечних чинників - простий індуктивний метод аналізування, призначеність якого - ідентифікувати небезпечні чинники та небезпечні ситуації й події, які можуть завдати шкоди конкретним видам діяльності, технічному засобу чи системі.

\section{II. Допоміжні методи:}

1) структуроване опитування $i$ «мозкова атака» - засіб збирання великої кількості ідей і оцінок, ранжованих групою експертів. «Мозкову атаку» можна стимулювати за допомогою навідних запитань або методів опитування «один на один» чи «один з багатьма»;

2) метод Дельфi - спосіб поєднання експертних суджень, які можуть сприяти ідентифікуванню джерела та впливу, кількісному оцінюванню ймовірності й наслідків і оцінюванню ризику. Йдеться про метод спільної роботи, який дає змогу досягти консенсусу серед експертів. Метод передбачає здійснення експертами аналізування та голосування незалежно; 
3) SWIFT (структурований метод «Що — якщо») — система спонукання групи експертів до ідентифікування ризиків. Зазвичай використовують на засіданнях тематичних робочих груп за участі координатора. Зазвичай пов'язана з аналізуванням ризику та методом оцінювання ризику;

4) загальне оичінювання надійності людини (HRA) - загальне оцінювання надійності людини (HRA) стосується впливу людей на дієвість системи. Можна використовувати для оцінювання впливів помилок персоналу на систему.

\section{III. Аналізування сценарію:}

1) аналізування першопричини (аналізування окремої втрати) - окрему втрату, яка сталася, аналізують для того, щоб зрозуміти зумовлювальні чинники й те, як систему чи процес можна поліпшити, щоб надалі уникати цих утрат. Під час аналізування розглядають, які засоби контролювання були наявні на момент утрати та як їх можна поліпшити;

2) аналізування сиенарію - можливі майбутні сценарії визначають уявленням або екстраполюванням на основі розгляданих фактичних та інших ризиків за припущення того, що кожний з цих сценаріїв може бути зреалізовано. Для цього можна застосовувати формалізовані чи неформалізовані, якісні чи кількісні підходи;

3) загальне оцінювання екологічного ризику - ідентифікують та аналізують небезпечні чинники, також ідентифікують можливі способи впливу небезпечного чинника на конкретний цільовий об'єкт. Інформацію про рівень впливу та характер шкоди, спричиненої певним рівнем впливу, поєднують, щоб установити міру ймовірності виникнення конкретної шкоди;

4) аналізування впливу на діяльність - дає змогу проаналізувати те, як ключові ризики дестабілізування могли б впливати на роботу організації, а також ідентифікувати та кількісно визначити можливості, необхідні для керування ними;

5) аналізування дерева відмов - метод, за яким спочатку зазначають небажану подію (кінцеву подію) і потім визначають усі способи, у які вона могла б відбутися. Усі елементи зображають графічно у формі логічної деревоподібної схеми. Після того, як дерево відмов буде розроблено, треба розглянути способи послаблення чи усунення потенційних причин або джерел;

6) аналізування дерева подій — використання індуктивного мислення для переведення ймовірностей різних першопочаткових подій у можливі результати;

7) аналізування причин і наслідків - поєднання аналізування дерева відмов i дерева подій, яке дає змогу враховувати затримки в часі. Розглядають як причини, так і наслідки певної першопочаткової події;

8) аналізування причинно-наслідкових зв'язків - вплив може мати певну кількість зумовлювальних чинників, які може бути згруповано в різні категорії. Зумовлювальні чинники часто визначають застосуванням «мозкової атаки» $\mathrm{i}$ їх подають у формі деревоподібної структури чи діаграми Ісікави.

\section{IV. Функційне аналізування:}

1) FMEA ma FMECA — MEA (аналізування виду та наслідків відмов) — це метод, який дає змогу ідентифікувати характер відмов і чинники їх виникнення,

$$
-174-
$$


а також їхні впливи. $Є$ кілька типів FMEA: FMEA проекту (чи продукції), який застосовують до складників і продукції, FMEA системи, який застосовують до систем, FMEA процесу, який застосовують до виробничих і складальних процесів, FMEA послуг і FMEA програмних засобів. FMEA можна доповнювати аналізуванням критичності, за якого визначають важливість кожного виду відмов, застосовуючи якісний, напівкількісний чи кількісний підхід (FMECA). Аналізування критичності може базуватися на ймовірності того, що характер відмови спричинить відмову системи, або на рівні ризику, асоційованому з характером відмови, або на ступені пріоритетності ризику;

2) технічне обслуговування, зорієнтоване на забезпечення безвідмовності метод ідентифікування політик, які треба запроваджувати для керування відмовами так, щоб ефективно та результативно досягати необхідного рівня безпеки, готовності та економічності функціювання всіх типів устаткування;

3) аналізування паразитних ефектів (аналізування паразитних схем) 一 методологія, яка дає змогу ідентифікувати помилки проектування. Паразитний стан це прихований стан технічного засобу, програмного засобу чи їх поєднання, який може спричинювати виникнення небажаної події, чи може перешкоджати виникненню бажаної події та який не може бути спричинений відмовою якогось складника. Ці стани мають випадковий характер, а їх виявлення утруднене навіть за проведення найсуворіших стандартизованих випробувань системи. Паразитні стани можуть спричинювати неправильне функціювання, зниження готовності систем, програмні затримки чи навіть смерть або травмування персоналу;

4) $Н A Z O P$ - дослідження небезпечних чинників $i$ працездатності - загальний процес ідентифікування ризику, щоб визначити можливі відхили від передбаченої чи очікуваної дієвості. Передбачає використання системи, базованої на керувальних словах. Оцінюють критичність відхилів;

5) НАССР (Аналізування небезпечних чинників і критичні точки контролю) систематичний, проактивий i превентивний метод забезпечування якості продукції, надійності та безпечності процесів за допомогою вимірювання та моніторингу перебування конкретних характеристик у визначених межах.

\section{V. Загальне оцінювання засобів контролю:}

1) LOPA (Аналізування рівнів захисту) — дає змогу оцінювати засоби контролювання та їхню результативність (Інша можлива назва — аналізування бар'єрів);

2) аналізування за схемою «краватка-метелик» - простий схематичний спосіб описування й аналізування варіантів розвитку ризику, починаючи з небезпечних чинників та закінчуючи наслідками, 3 критичним перевірянням засобів контролювання. Його можна розглядати як поєднання логіки дерева відмов, що уможливлює аналізування причини події (графічно поданої у формі «краваткиметелика») і дерева подій, що уможливлює аналізування наслідків.

\section{VI. Статистичні методи:}

1) Марковське аналізування — марковське аналізування, яке інколи також називають аналізуванням «простору станів», зазвичай використовують для 
аналізування ремонтопридатних складних систем, що можуть бути в багатьох станах, зокрема в різних станах справності;

2) імітаційне моделювання за методом Монте-Карло - імітаційне моделювання за методом Монте-Карло використовують, щоб виявити сукупну зміну в системі внаслідок змінення в системі певної низки вхідних даних, які мають визначений розподіл і пов'язані з результатом визначеними взаємозв'язками. Це аналізування можна використовувати стосовно конкретної моделі, у якій взаємодії різноманітних вхідних даних може бути визначено математично. Вхідні дані можуть базуватися на різноманітних типах розподілу відповідно до характеру невизначеності, що вони призначені представляти. У разі загального оцінювання ризику загальноприйнято використовувати трикутні розподіли або бета-розподіли;

3) Байєсівське аналізування - статистична процедура, яка передбачає використання даних апріорного розподілу для загального оцінювання ймовірності результату. Точність результату, що його виводять байєсівським аналізуванням, залежить від точності апріорного розподілу. Байєсівські мережі довіри уможливлюють моделювання причин і наслідків у різноманітних сферах установленням імовірнісних взаємозв'язків різноманітних вхідних даних, щоб вивести результат.

Наведемо приклади методів загального оцінювання ризику (табл. 3).

Таблиця 3

Застосовність методів аналізування для загального оцінювання ризику

\begin{tabular}{|c|c|c|c|c|c|}
\hline \multirow{3}{*}{$\begin{array}{c}\text { Методи та засоби } \\
\text { аналізування }\end{array}$} & \multicolumn{5}{|c|}{ Процес загального оцінювання ризику } \\
\hline & \multirow{2}{*}{$\begin{array}{l}\text { Ідентифікува } \\
\text { ння ризику }\end{array}$} & \multicolumn{3}{|c|}{ Аналізування ризику } & \multirow{2}{*}{$\begin{array}{c}\text { Оцінювання } \\
\text { ризику }\end{array}$} \\
\hline & & Наслідок & Імовірність & $\begin{array}{l}\text { Рівень } \\
\text { ризику }\end{array}$ & \\
\hline 1 & 2 & 3 & 4 & 5 & 6 \\
\hline «Мозкова атака» & 33 & H3 & H3 & H3 & H3 \\
\hline $\begin{array}{l}\text { Структуроване чи напів- } \\
\text { структуроване опитування }\end{array}$ & 33 & H3 & H3 & H3 & H3 \\
\hline Метод Дельфі & 33 & H3 & H3 & $\mathrm{H} 3$ & $\mathrm{H} 3$ \\
\hline $\begin{array}{l}\text { Переліки контрольних } \\
\text { запитань }\end{array}$ & 33 & H3 & H3 & H3 & H3 \\
\hline $\begin{array}{l}\text { Попереднє аналізування } \\
\text { небезпечних чинників (РНА) }\end{array}$ & 33 & $\mathrm{H} 3$ & $\mathrm{H} 3$ & H3 & H3 \\
\hline $\begin{array}{l}\text { Дослідження небезпечних } \\
\text { чинників і працездатності } \\
\text { (HAZOP) }\end{array}$ & 33 & 33 & 3 & 3 & 3 \\
\hline $\begin{array}{l}\text { Аналізування небезпечних } \\
\text { чинників і критичні точки } \\
\text { контролю (НАССР) }\end{array}$ & 33 & 33 & H3 & H3 & 33 \\
\hline $\begin{array}{l}\text { Загальне оцінювання } \\
\text { екологічного ризику }\end{array}$ & 33 & 33 & 33 & 33 & 33 \\
\hline $\begin{array}{l}\text { Структурований метод } \\
\text { «Що - якщо» (SWIFT) }\end{array}$ & 33 & 33 & 33 & 33 & 33 \\
\hline Аналізування сценаріїв & 33 & 33 & 3 & 3 & 3 \\
\hline
\end{tabular}


Закінчення табл. 3

\begin{tabular}{|c|c|c|c|c|c|}
\hline 1 & 2 & 3 & 4 & 5 & 6 \\
\hline $\begin{array}{l}\text { Аналізування впливу на } \\
\text { діяльність }\end{array}$ & 3 & 33 & 3 & 3 & 3 \\
\hline Аналізування першопричини & H3 & 33 & 33 & 33 & 33 \\
\hline $\begin{array}{l}\text { Аналізування видів і } \\
\text { наслідків відмов }\end{array}$ & 33 & 33 & 33 & 33 & 33 \\
\hline Аналізування дерева відмов & 3 & H3 & 33 & 3 & 3 \\
\hline Аналізування дерева подій & 3 & 33 & 3 & 3 & $\mathrm{H} 3$ \\
\hline $\begin{array}{l}\text { Аналізування причин } \\
\text { і наслідків }\end{array}$ & 3 & 33 & 33 & 3 & 3 \\
\hline $\begin{array}{l}\text { Аналізування причинно- } \\
\text { наслідкових зв'язків }\end{array}$ & 33 & 33 & H3 & H3 & H3 \\
\hline $\begin{array}{l}\text { Аналізування рівнів захисту } \\
\text { (LOPA) }\end{array}$ & 3 & 33 & 3 & 3 & H3 \\
\hline Дерево рішень & H3 & 33 & 33 & 3 & 3 \\
\hline $\begin{array}{l}\text { Загальне оцінювання } \\
\text { надійності людини }\end{array}$ & 33 & 33 & 33 & 33 & 3 \\
\hline $\begin{array}{l}\text { Аналізування за схемою } \\
\text { «краватка- метелик» }\end{array}$ & H3 & 3 & 33 & 33 & 3 \\
\hline $\begin{array}{l}\text { Технічне обслуговування, } \\
\text { зорієнтоване на } \\
\text { забезпечення безвідмовності }\end{array}$ & 33 & 33 & 33 & 33 & 33 \\
\hline $\begin{array}{l}\text { Аналізування паразитних } \\
\text { схем }\end{array}$ & 3 & H3 & H3 & H3 & H3 \\
\hline Марковське аналізування & 3 & 33 & H3 & H3 & $\mathrm{H} 3$ \\
\hline $\begin{array}{l}\text { Імітаційне моделювання за } \\
\text { методом Монте-Карло }\end{array}$ & H3 & H3 & H3 & H3 & 33 \\
\hline $\begin{array}{l}\text { Байесова статистика і мережі } \\
\text { Байеса }\end{array}$ & H3 & 33 & H3 & H3 & 33 \\
\hline Криві FN & 3 & 33 & 33 & 3 & 33 \\
\hline Показники ризику & 3 & 33 & 33 & 3 & 33 \\
\hline $\begin{array}{l}\text { Матриця «наслідок- } \\
\text { імовірність» }\end{array}$ & 33 & 33 & 33 & 33 & 3 \\
\hline Аналізування витрат і вигод & 3 & 33 & 3 & 3 & 3 \\
\hline $\begin{array}{l}\text { Багатокритерійне аналізу- } \\
\text { вання рішень (MCDA) }\end{array}$ & 3 & 33 & 3 & 33 & 3 \\
\hline
\end{tabular}

Примітка:

1) Завжди застосовний - 33.

2) Незастосовний - Н3.

3) Застосовний - 3 .

Джсерело: [7] 


\section{6. Ризики на морському транспорті}

\subsection{1. Засади морської діяльності}

Морська діяльність відігравала і досі має важливу роль у бізнесі, торгівлі та економіці багатьох країн. До ключових сфер морської діяльності належать:

I. Морський транспорт:

1) Прибережне судноплавство

2) Перевезення людей як у внутрішньому, так і за кордоном

3) Міжнародні перевезення

4) Круїзне судноплавство

II. Рибальство

III. Морські фермерства

IV. Операції континентального шельфу (тобто нафту і газу):

1) Бурові операції

2) Послуги з постачання

3) Прокладка трубопроводу

4) Підводна діяльність

V. Наука та вишукування.

Морські аварії можуть призвести до трьох різних наслідків:

1) Шкода для людей: травми та летальні випадки.

2) Забруднення навколишнього середовища.

3) Економічні втрати: пошкодження або втрата судна та вантажу, втрата доходу тощо.

Розглянемо прояви аварій.

1. Зіткнення суден - Зіткнення між кораблями

2. Контакт / удар - Вдаряння між судном та іншими надводними об'єктами

3. Посадка на мілину та посадка на берег - Попадання на морське дно або берег

4. Втрата плавучості та затоплення - Відкриття та затоплення корпусу

5. Несправність або відмова обладнання - Несправність або відмова техніки безпосередньо відповідає за аварію

6. Пожежа та вибух - Пожежа, вибух або викид небезпечних вантажів

7. Зникнення

8. Інше різне [11].

Важливу роль в морських перевезеннях відіграє страхування. Без такого інструмента неможливо здійснювати перевезення в міжнародному сполученні та проводити будь-які роботи. Згідно дослідження [12] в Україні в сфері страхування на морському транспорті діє така класифікація ризиків на морському транспорті.

Оскільки загальна картина ризику для даної діяльності або системи може бути дуже складною і включати багато різних аспектів, часто доводиться розбивати іiї на сценарії ризику. Рівняння обчислює загальний ризик для даної діяльності / 
системи як суму ризиків для кожного виду аварії та кожної фази аварійного процесу:

$$
R=\sum \sum p_{i j} \cdot c_{i j}
$$

де $R$ - загальний ризик;

$i$ - кількість сценаріїв, які можуть призвести до певного наслідку;

j - кількість фаз у межах кожного випадкового результату (наприклад, ініціююча подія, пом'якшення, втеча, евакуація та порятунок);

$c_{i j}$ - міра наслідків для відповідного сценарію та фаза аварійного процесу, наприклад $n$ - смертельних випадків, $m$ - т розливу тощо;

$p_{i j}$ - ймовірність (або частота) відповідного наслідку $c_{i j}$ для даного сценарію та випадкова фаза.

\section{Класифікація ризиків на морському транспорті}

Таблиця 4

\begin{tabular}{|c|c|}
\hline Ознака & Види ризиків \\
\hline \multirow[t]{3}{*}{ Об’єкт прояву ризику } & Майнові ризики \\
\hline & Особисті ризики \\
\hline & Ризики відповідальності \\
\hline \multirow[t]{5}{*}{ Походження ризику } & Природні ризики \\
\hline & Антропогенні ризики \\
\hline & Технічні ризики \\
\hline & Ринкові ризики \\
\hline & Політичні ризики \\
\hline \multirow{2}{*}{$\begin{array}{l}\text { Можливість впливати на } \\
\text { ризик }\end{array}$} & Ризики, які залежать від членів екіпажу \\
\hline & Ризики, які не залежать від членів екіпажу \\
\hline \multirow[t]{3}{*}{ Етап транспортування } & Ризики на етапі підготовки до транспортування \\
\hline & Ризики на етапі транспортування \\
\hline & Ризики на етапі завершення транспортування \\
\hline \multirow[t]{2}{*}{ Вид перевезень } & Ризики вантажних перевезень \\
\hline & Ризики пасажирських перевезень \\
\hline \multirow{2}{*}{$\begin{array}{l}\text { Територія виникнення } \\
\text { ризику }\end{array}$} & Внутрішньодержавні ризики \\
\hline & Міжнародні ризики \\
\hline \multirow[t]{4}{*}{ Розмір збитків } & Катастрофічні ризики \\
\hline & Великі ризики \\
\hline & Середні ризики \\
\hline & Малі ризики \\
\hline \multirow[t]{2}{*}{ Можливість страхування } & Страхові ризики \\
\hline & Нестрахові ризики \\
\hline
\end{tabular}

Дюерело: [12] 


\subsection{2. Критерії ризику}

Охарактеризуємо критерії ризику.

Таблиця 5

Критерії ризику

\begin{tabular}{|c|c|c|c|}
\hline Тип & $\begin{array}{l}\text { Позна- } \\
\text { чення }\end{array}$ & Назва & Опис \\
\hline 1 & 2 & 3 & 4 \\
\hline \multirow[t]{9}{*}{$\begin{array}{l}\text { Нещасний } \\
\text { випадок на } \\
\text { виробництві }\end{array}$} & LTI-rate & $\begin{array}{l}\text { Коефіцієнт частоти травм } \\
3 \text { тимчасовою } \text { втратою } \\
\text { працездатності }\end{array}$ & $\begin{array}{l}\text { Кількість втрат часу на } 10^{6} \text { годин } \\
\text { працівника }\end{array}$ \\
\hline & AIR & $\begin{array}{l}\text { Середній } \\
\text { індивідуальний ризик }\end{array}$ & $\begin{array}{l}\text { Кількість летальних випадків на од- } \\
\text { ного працівника }\end{array}$ \\
\hline & IIR & Частота травматизму & $\begin{array}{l}\text { (Кількість травм, про які повідом- } \\
\text { ляється, у фінансовому році) / (Се- } \\
\text { редня кількість зайнятих протягом } \\
\text { року) X } 10^{5}\end{array}$ \\
\hline & S-rate & Ступінь тяжкості & $\begin{array}{l}\text { Кількість втрачених робочих днів } \\
\text { внаслідок тимчасової втрати пра- } \\
\text { цездатності на } 10^{6} \text { працівників-го- } \\
\text { дин. Смертельні випадки та } 100 \% \\
\text { постійна втрата працездатності } \\
\text { становлять } 7500 \text { днів робочих днів }\end{array}$ \\
\hline & TRI-rate & $\begin{array}{l}\text { Загальна кількість за- } \\
\text { фіксованих травм }\end{array}$ & $\begin{array}{l}\text { Загальна кількість травм, що підля- } \\
\text { гають реєстрації (включаючи травми } \\
3 \text { тимчасовою втратою працездат- } \\
\text { ності, пов'язані з медичним лікуван- } \\
\text { ням та травми, що призвели до } \\
\text { переведення на іншу роботу або об- } \\
\text { меження роботи) на } 10^{6} \text { годин роботи }\end{array}$ \\
\hline & - & $\begin{array}{l}\text { Середня } \quad \text { кількість } \\
\text { втрачених днів }\end{array}$ & S-rate / TRI-rate \\
\hline & FAR & $\begin{array}{l}\text { Рівень смертельних } \\
\text { аварій }\end{array}$ & $\begin{array}{l}\text { Кількість летальних випадків на } 10^{8} \\
\text { робочих годин }\end{array}$ \\
\hline & - & $\begin{array}{l}\text { Кількість нещасних } \\
\text { випадків }\end{array}$ & $\begin{array}{l}\text { Смертельні випадки на } 1000 \text { лю- } \\
\text { дино-годин }\end{array}$ \\
\hline & PLL & $\begin{array}{l}\text { Потенційні нещасні } \\
\text { випадки із смертним } \\
\text { наслідком }\end{array}$ & $\begin{array}{l}\text { Кількість летальних випадків, які } \\
\text { пережили (або передбачили) протя- } \\
\text { гом певного періоду часу, напри- } \\
\text { клад кількість втрачених життів за } \\
\text { рік у судноплавстві }\end{array}$ \\
\hline \multirow[t]{2}{*}{$\begin{array}{l}\text { Пов’язані } \\
3 \text { професійною } \\
\text { діяльністю }\end{array}$} & $\begin{array}{l}\text { WRD- } \\
\text { rate }\end{array}$ & $\begin{array}{l}\text { Рівень захворювань, } \\
\text { пов’язаних з роботою }\end{array}$ & $\begin{array}{l}\text { Кількість нових випадків можливих } \\
\text { захворювань, пов'язаних з роботою, } \\
\text { що призводять до відсутності на } \\
\text { роботі на } 10^{6} \text { годин людино-годин }\end{array}$ \\
\hline & - & Відсоток лікарняних & S-rate/LTI-rate \\
\hline
\end{tabular}


Закінчення табл. 5

\begin{tabular}{|c|c|c|c|}
\hline 1 & 2 & 3 & 4 \\
\hline Забруднення & - & Норма викидів & $\begin{array}{l}\text { Викиди внаслідок аварії, кг / м на } \\
\text { тонну виробництва, напр. викиди } \\
\text { фтору в кг на тонну виробленого } \\
\text { первинного алюмінію }\end{array}$ \\
\hline \multirow[t]{3}{*}{$\begin{array}{l}\text { Матеріальні } \\
\text { втрати }\end{array}$} & - & Норма втрат & $\begin{array}{l}\text { Кількість аварій або втрат на ви- } \\
\text { роблену одиницю, напр. зіткнень за } \\
10^{5} \text { морських миль }\end{array}$ \\
\hline & - & Коефіцієнт втрат & $\begin{array}{l}\text { Кількість суден (або тоннаж) пов- } \\
\text { ністю втрачених на кількість суден } \\
\text { (або тоннаж), що перебувають під } \\
\text { загрозою, наприклад втрата торгов-- } \\
\text { го судна у всьому світі на загальну } \\
\text { кількість торговельних суден }\end{array}$ \\
\hline & - & $\begin{array}{l}\text { Відносний } \\
\text { коефіцієнт втрат }\end{array}$ & $\begin{array}{l}\text { Коефіцієнт збитковості для діяль- } \\
\text { ності поділений на світовий коефіці- } \\
\text { єнт збитків. Коефіцієнт збитків один } \\
\text { (1) відповідає середньому світовому } \\
\text { показнику, а вищий коефіцієнт } \\
\text { втрат вказує на більші збитки, ніж } \\
\text { середній світовий показник }\end{array}$ \\
\hline
\end{tabular}

Джерело: [11]

При аналізі аварій на норвезьких кораблях [13] було визначено основні причинні фактори зіткнень та посадки та згруповано таким чином:

1. Зовнішні умови (тобто вплив зовнішніх сил, таких як погана погода та хвилі, зменшення зорових умови тощо).

2. Функціональний збій (тобто вихід 3 ладу або погіршення стану технічного обладнання, функцій та систем).

3. Недостатні інформаційні ресурси (тобто неадекватні ергономічні умови, планування, організація та навчання).

4. Відмова навігації (тобто невдача при маневруванні та експлуатації, погане розуміння ситуації тощо).

5. Людська помилка (тобто людська невдача, промахи / прогалини та порушення або відхилення від процедур, правил та інструкцій).

6. Інші судна (тобто вплив відмов, допущених іншими суднами).

\section{7. Ризики на автомобільному транспорті \\ 2.7.1. Ризики в автомобільному транспорті}

На автомобільному транспорті величина ризику найчастіше визначається ймовірністю настання випадків дорожньо-транспортних пригод (зокрема зі смертельними наслідками), яку з достатнім ступенем точності можна виявити 3 статистичних 
даних. Тобто ризик для людини може бути виміряний числом летальних випадків (травм), що відбулися за одиницю часу від даного виду діяльності.

Найефективнішім аналіз ризику виникнення небажаних подій може бути:

- на стадії проектування автомобільних доріг;

- у процесі оцінки діяльності дорожніх організацій і органів управління дорожнього господарства з безпеки дорожнього руху;

- під час аудиту для оцінки небезпеки ділянок доріг;

- у процесі розроблення заходів щодо безпеки дорожнього руху на окремих ділянках дороги та на дорозі загалом.

Але першочерговим завданням є визначення факторів ризику ДТП, які можна розділити на наступні групи $[2,14,15]$ :

1. Фактори, що впливають на рівень ризику:

- економічні;

- демографічні;

- заходи в галузі міського планування;

- фактори, що впливають на тривалість часу в дорозі або на вибір способу пересування;

- співвідношення високошвидкісного руху з вразливістю користувачів доріг).

2. Фактори ризику, що впливають на ймовірність потрапляння в аварію:

- перевищення швидкості;

- фізіологічні аспекти (алкогольне або наркотичне сп’яніння, втома, поганий зір водія);

- ізда в темний час доби;

- фактори, пов'язані з транспортним засобом (несправний стан гальмівної системи, загальний технічний стан транспортного засобу, періодичність проходження технічних оглядів);

- недоліки у конструктивному вирішенні доріг;

- недостатня видимість, обумовлена станом навколишнього середовища).

3. Фактори ризику, що впливають на важкість аварії:

- ступінь витривалості людини;

- перевищення швидкісного режиму;

- невикористання ременів безпеки, захисних шоломів;

- наявність в крові алкоголю;

- недостатня інженерна забезпеченість дорожніх споруд).

4. Фактори ризику, які зумовлюють важкість посттравматичних ускладнень:

- затримки $з$ виявленням ДТП;

- пожежа;

- витік шкідливих речовин;

- труднощі під час рятування людей у процесі евакуації;

- відсутність адекватної медичної допомоги. 
Визначення значущості факторів ризику під час проведення його аналізу є дуже складним завданням.

Класичною з позиції градації значущості факторів ризику ДТП є Матриця Хеддона (табл. 6), в якій виділено три фази ДТП (до її виникнення, в процесі й після) і три групи факторів: особистісні особливості людини (учасника руху), характеристики транспортного засобу та особливості навколишнього середовища (передусім, стан доріг).

Таблиця 6

Матриця Хеддона

\begin{tabular}{|c|c|c|c|c|}
\hline \multirow[b]{2}{*}{ Фаза } & \multirow[b]{2}{*}{ Процес } & \multicolumn{3}{|c|}{ Фактори, що залежать від } \\
\hline & & Людини & $\begin{array}{c}\text { Транспортного } \\
\text { засобу та } \\
\text { обладнання }\end{array}$ & $\begin{array}{l}\text { Навколиш- } \\
\text { нього } \\
\text { середовища }\end{array}$ \\
\hline До аварії & $\begin{array}{c}\text { Попере- } \\
\text { дження } \\
\text { аварії }\end{array}$ & $\begin{array}{l}\text { - інформованість; } \\
\text { - поведінкові } \\
\text { установки; } \\
\text { - проблеми зі } \\
\text { здоров’ям; } \\
\text { - поліцейський } \\
\text { контроль }\end{array}$ & $\begin{array}{l}\text { - експлуатаційна } \\
\text { придатність дороги; } \\
\text { - освітлення; } \\
\text { - стан гальмівної } \\
\text { системи; } \\
\text { - дотримання } \\
\text { швидкісного режиму }\end{array}$ & $\begin{array}{l}\text { - дизайн та } \\
\text { розмітка дороги; } \\
\text { - обмеження } \\
\text { швидкості; } \\
\text { - споруди і при- } \\
\text { строї для пішоходів }\end{array}$ \\
\hline $\begin{array}{c}\text { Під час } \\
\text { аварії }\end{array}$ & $\begin{array}{c}\text { Попере- } \\
\text { дження } \\
\text { травмуван } \\
\text { ня під час } \\
\text { аварії }\end{array}$ & $\begin{array}{l}\text { - використання } \\
\text { ременів безпеки; } \\
\text { - проблеми зі } \\
\text { здоров’ям }\end{array}$ & $\begin{array}{l}\text { - наявність та } \\
\text { використання ременів } \\
\text { безпеки; } \\
\text { - інші пристосування } \\
\text { для забезпечення } \\
\text { безпеки; } \\
\text { - протиаварійний } \\
\text { дизайн автомобіля }\end{array}$ & $\begin{array}{l}\text { - дорожні об’єкти, } \\
\text { що запобігають } \\
\text { аварії }\end{array}$ \\
\hline $\begin{array}{l}\text { Після } \\
\text { аварії }\end{array}$ & $\begin{array}{c}\text { Підтримка } \\
\text { життя }\end{array}$ & \begin{tabular}{|l} 
- навички надання \\
першої допомоги; \\
- доступність \\
медичної допомоги
\end{tabular} & $\begin{array}{l}\text { - легкий доступ до } \\
\text { місця події; } \\
\text { - ризик загоряння }\end{array}$ & $\begin{array}{l}\text { - наявність служб } \\
\text { порятунку; } \\
\text { - наявність заторів } \\
\text { на дорогах }\end{array}$ \\
\hline
\end{tabular}

Джерело: [16]

Однак наявність людського фактору в усіх трьох фазах дає можливість дійти до висновків, що життя людини $є$ найціннішим та найважливішим аспектом у питанні попередження ДТП, а також визначення імовірності або ризику виникнення аварії.

Щодо особливостей «людського» фактору, можна виділити такі основні характеристики людини, які впливають на безпеку руху, як:

- стан здоров'я; 
- психофізіологічний статус (почуття внутрішнього комфорту / дискомфорту, наявність втоми, швидкість реакції, культура та навички водіння, зокрема дотримання швидкісного режиму руху, використання ременів безпеки, дотримання інших правил дорожнього руху, наявність алкогольного або наркотичного сп'яніння тощо).

Згідно з дослідженнями, що були проведені вченими ризик виникнення аварії, що призводить до травм, пропорційний квадрату швидкості; ймовірність серйозної аварії пропорційна швидкості в кубі; ймовірність аварії зі смертельним результатом - швидкості в четвертій степені. Збільшення середньої швидкості на 1 км/год призводить до зростання кількості аварій із травмами на 3\% та збільшення кількості аварій із смертельним результатом на 4-5\%. Перевищення швидкості на 5 км/год понад 60 км/год дає таке саме зростання відносного ризику аварії з отриманням травм, яке можна порівняти з рівнем вмісту алкоголю в крові - 0,05 г/дл.

Взаємодія факторів у сфері забезпечення безпеки дорожнього руху (табл. 1) дає можливість стверджувати про тісний зв'язок елементів у системі «людина транспортний засіб — дорога — середовище» (далі — ЛТДС).

Показники ризику пов’язані з оцінкою ймовірності настання ДТП або ступенем небезпеки для людини, що використовуються для оцінки ризику ДТП у системі ЛТДС, в загальному вигляді визначають:

1) рівень ризиків ДТП, в залежності від кількості транспортних засобів (рівень небезпеки транспортних засобів);

2) рівень ризиків ДТП, що характеризують небезпеку дорожньої мережі і території.

Ці показники оцінки ризиків небезпечних подій можуть бути використані для аналізу безпеки й оцінки ступеня ризику різних територій, проведення зонування територій або дороги за ступенем небезпеки виникнення небезпечних подій [17].

Після того, як визначені оптимальні підходи до виявлення небезпек та ризиків, можна ефективно використовувати результати їхнього аналізу, а також впроваджувати заходи 3 впровадження об’єктивних рішень щодо прийнятного рівня ризику скоєння ДТП, встановлювати вимоги та рекомендації з управління безпекою на автомобільній дорозі або іiі ділянці.

Під час оцінки небезпеки ділянок дороги можуть бути використані показники ризику ДТП і загибелі людини в ДТП, які характеризують «роботу» ділянки дороги з урахуванням забезпечення пропуску транспортних засобів. Показник ризику ДТП на ділянці дороги (мережі доріг) можна представити у вигляді такі формули:

$$
R_{D}=\frac{D}{N \cdot L \cdot m \cdot 365}
$$

де $D$ - кількість усіх ДТП на дільниці дороги за період, що аналізується;

$N$ - середньорічна добова інтенсивність руху, авт. / добу;

$L$ - довжина ділянки дороги, що розглядається, км (1 км);

$m$ - кількість років у розрахунковому періоді. 
Показник ризику загибелі людини у ДТП на ділянці дороги можна навести у вигляді такі формули:

$$
R_{P}=\frac{P}{N \cdot L \cdot m \cdot 365},
$$

де $P$ - кількість загиблих у ДТП на дільниці дороги за період, що аналізується.

Одночасне використання цих двох показників ризику дає можливість оцінити небезпеку ділянки за ймовірністю скоєння ДТП і загибелі на них людей.

Відповідно до розподілу Пуассона, якщо ймовірність ДТП постійна і середнє число ДТП те саме базове час дорівнює $m$, то ймовірність $P(x)$ ДТП становитиме:

$$
P(x)=\frac{m^{x} e^{-m}}{x}
$$

Залежно від отриманих значень показників аварійності умови руху на ділянках доріг можуть характеризуватися як безпечні, малонебезпечні, небезпечні й дуже небезпечні (табл. 7).

Ступінь небезпеки ділянок автомобільної дороги

Таблиця 7

\begin{tabular}{|c|c|c|}
\hline $\begin{array}{c}\text { Характеристики } \\
\text { ділянки дороги за } \\
\text { ступенем небезпеки }\end{array}$ & $\begin{array}{c}\text { Ризик ДТП } \\
\text { на } \mathbf{1} \text { авт./км пробігу }\end{array}$ & $\begin{array}{c}\text { Ризик загибелі людини } \\
\text { в ДТП на 1 авт./км } \\
\text { пробігу }\end{array}$ \\
\hline Безпечні & $<1,1 \times 10^{-7}$ & $<5,7 \times 10^{-7}$ \\
\hline Мало небезпечні & $1,1-2,8 \times 10^{-7}$ & $5,7-8,6 \times 10^{-7}$ \\
\hline Небезпечні & $2,9-4,4 \times 10^{-7}$ & $8,7-11,6 \times 10^{-7}$ \\
\hline Дуже небезпечні & $>4,4 \times 10^{-7}$ & $>11,6 \times 10^{-7}$ \\
\hline
\end{tabular}

Джерело: [2]

\section{8. Управління ризиками на залізничному транспорті \\ 2.8.1. Ризики на залізничному транспорті}

Під ризиком на залізничному транспорті розуміється ймовірність втрат, збитків у процесі здійснення перевезень залізничними шляхами сполучення. Ризики на залізничному транспорті характеризуються складністю та різноманітністю, тому їх необхідно класифікувати за окремими ознаками $[17,18]$. Найважливішими ознаками класифікаиії ризиків на залізничному транспорті є:

- об'єкт прояву;

- джерела виникнення;

- етапи транспортування; 
- різновиди перевезень;

- можливість впливати на ризики;

- час виникнення;

- розмір збитків тощо.

Охарактеризуємо значущі ризики за визначеними ознаками докладніше.

За об'сктами прояву ризиків.

Ризики часто ототожнюють із їхніми певними носіями, тому в-першу чергу необхідно виділити ризикогенні об’єкти на залізничному транспорті. До таких об’єктів можна віднести пасажирів та працівників, рухомий склад та залізничні засоби, вантажний та пасажирський вагонні парки, залізничні контейнери, вантаж або багаж (вантажобагаж), будівлі, споруди та багато іншого.

\section{За джерелами виникнення ризиків.}

На залізничному транспорті автори дослідження [2] виділяють ризики втрат і збитків, які є результатом впливу різних суб'єктів, процесів і явищ. Ці ризики можна класифікувати так:

1. Природно-кліматичні ризики;

2. Антропогенні ризики;

3. Технічні ризики;

4. Макроекономічні ризики.

За принципом централізованого підходу до класифікації ризиків можна виділити наступні [19] (рис. 7).

\section{За етапом транспортування.}

Дослідження ризиків з точки зору їх класифікації вимагає структуризації процесу перевезення залізничним транспортом. Перевізна діяльність на залізничному транспорті включає сукупність організаційно та технологічно пов'язаних операцій із підготовки, здійснення та завершення переміщення пасажирів, вантажів, багажу (вантажобагажу), кожна з яких супроводжується ризиками. Тому ризики можна поділити залежно від етапу транспортування пасажирів, вантажів, багажу (вантажобагажу) на ризики етапів: підготовки до переміщення; здійснення переміщення; завершення переміщення.

\section{За різновидом перевезень.}

У процесі здійснення залізничних перевезень ризики поділяються на ризики, які характерні для вантажних перевезень, для пасажирських перевезень i ті, що супроводжують всі перевезення залізницями.

Ризики, які супроводжують пасажирський рухомий склад, істотно відрізняються від ризиків, що супроводжують вантажні вагони чи локомотиви. Ризики пошкодження чи знищення пасажирського рухомого складу не тільки істотно нижчі ніж вантажні, що обумовлено більш високим рівнем організації безпеки руху, а й відрізняються своєю специфікою, наприклад, одним із ризиків, який загрожує пасажирському рухомому складу — це вандалізм. 
I. Класифікація за джерелами виникнення

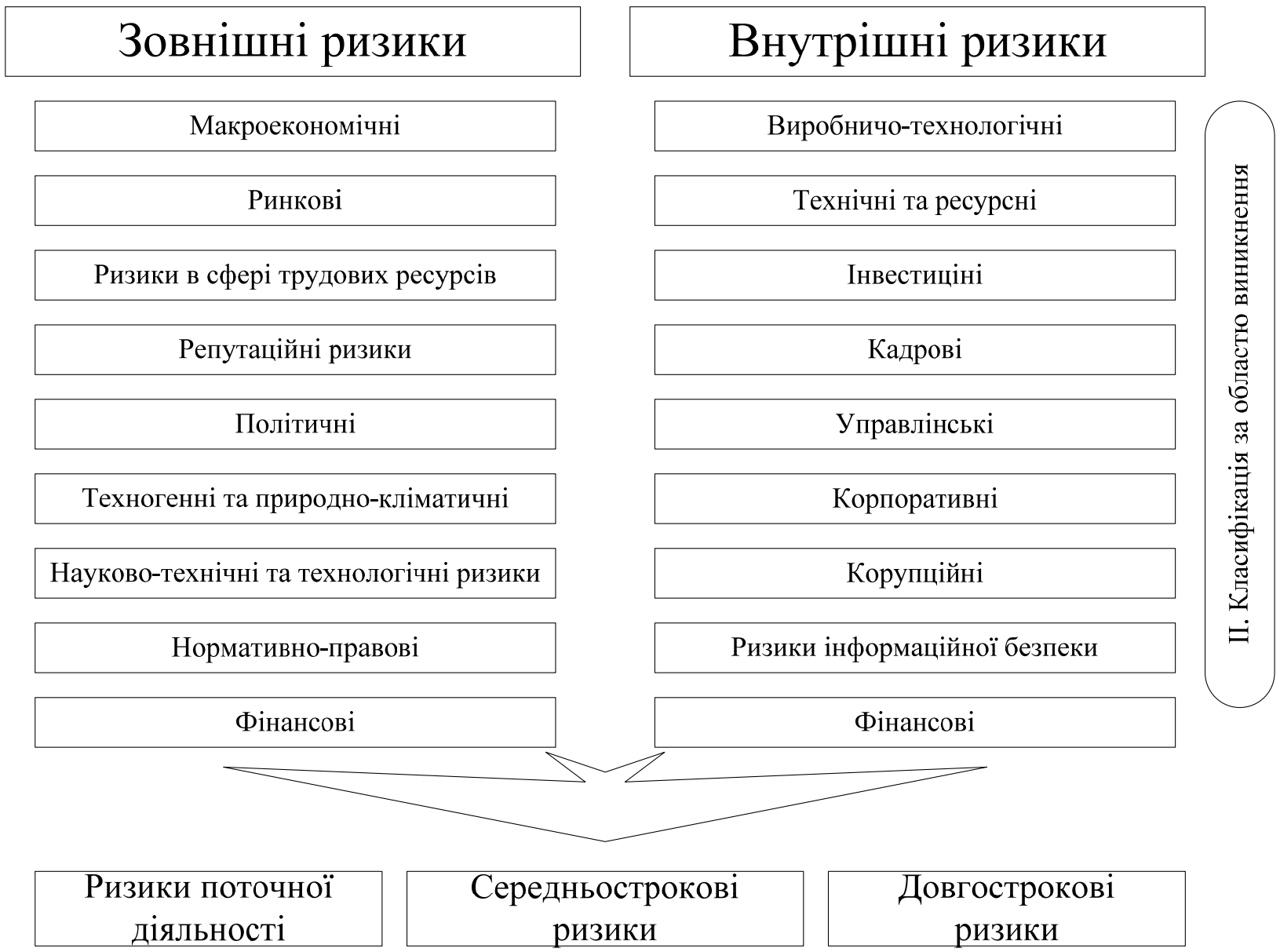

III. Класифікація за критерієм часового періоду провалення

\section{Рис. 7. Принцип централізованого підходу до класифікації ризиків Докерело: [19]}

Перевезення вантажів на залізничному транспорті неминуче пов'язані з різноманітними ризиками, які виникають як у процесі транспортування, так і під час виконання навантажувально-розвантажувальних робіт і тимчасовому зберіганні.

Ризики пошкодження чи руйнування вантажного рухомого складу збільшуються у разі взаємодії залізничного транспорту з іншими різновидами транспорту: у процесі здійснення розвантажувальних і навантажувальних робіт на території морського терміналу тощо. 


\subsection{2. Цілі і завдання управління ризиками на залізничному транспорті}

Управління ризиками (менеджмент ризиків) — процес прийняття і виконання управлінських рішень, спрямованих на зниження ймовірності виникнення несприятливого результату і мінімізацію можливих втрат, викликаних його реалізацією.

Основним завданням управління ризиками на залізничному транспорті $є$ досягнення і підтримка допустимого рівня безпеки руху та експлуатації залізничного транспорту.

Управління ризиками на залізничному транспорті має здійснюватися в суворій відповідності до вимог державних стандартів.

В Свропейському союзі для забезпечення безпеки на залізничному транспорті застосовують значну кількість нормативних документів, основні з яких Directive (EU) 2016/798 on railway safety та Directive (EU) 2004/49/EC on safety on the Community's railways [20]. Залізничні оператори та менеджери інфраструктури повинні отримати урядове схвалення своїх планів управління безпекою, які підготовлені за результатами оцінки ризиків.

Схема (рис. 8) демонструє три виміри: залізничну систему, життєвий цикл цієї системи та процес управління ризиками.

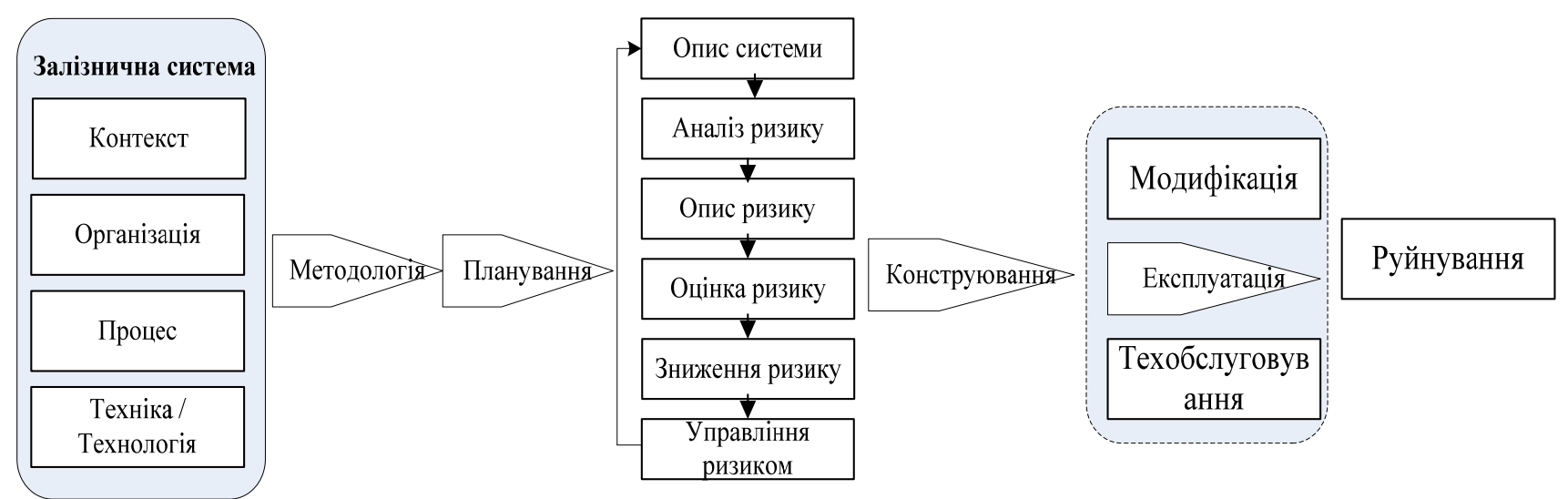

Рис. 8. Загальний підхід до ризик-менеджменту Джерело: [21]

Незважаючи на те, що небажані події трапляються на етапі будівництва та експлуатації, найкориснішим є врахування всього життєвого циклу залізниці. Тому управління ризиками повинно починатися 3 фази проектування системи, враховуючи як нормальний режим, так і режим погіршення для цієї системи. Потім результати управління ризиками в системі для фази проектування передаються залученій організації фази будівництва, і подібний підхід застосовується до наступного етапу як цикл. Архітектура національної системи управління ризиками на залізниці буде використана для побудови загальнодержавної програми управління залізничними ризиками та виконання правил безпеки. Процедура аналізу небезпек та оцінки ризиків представлена на рис. 9. 


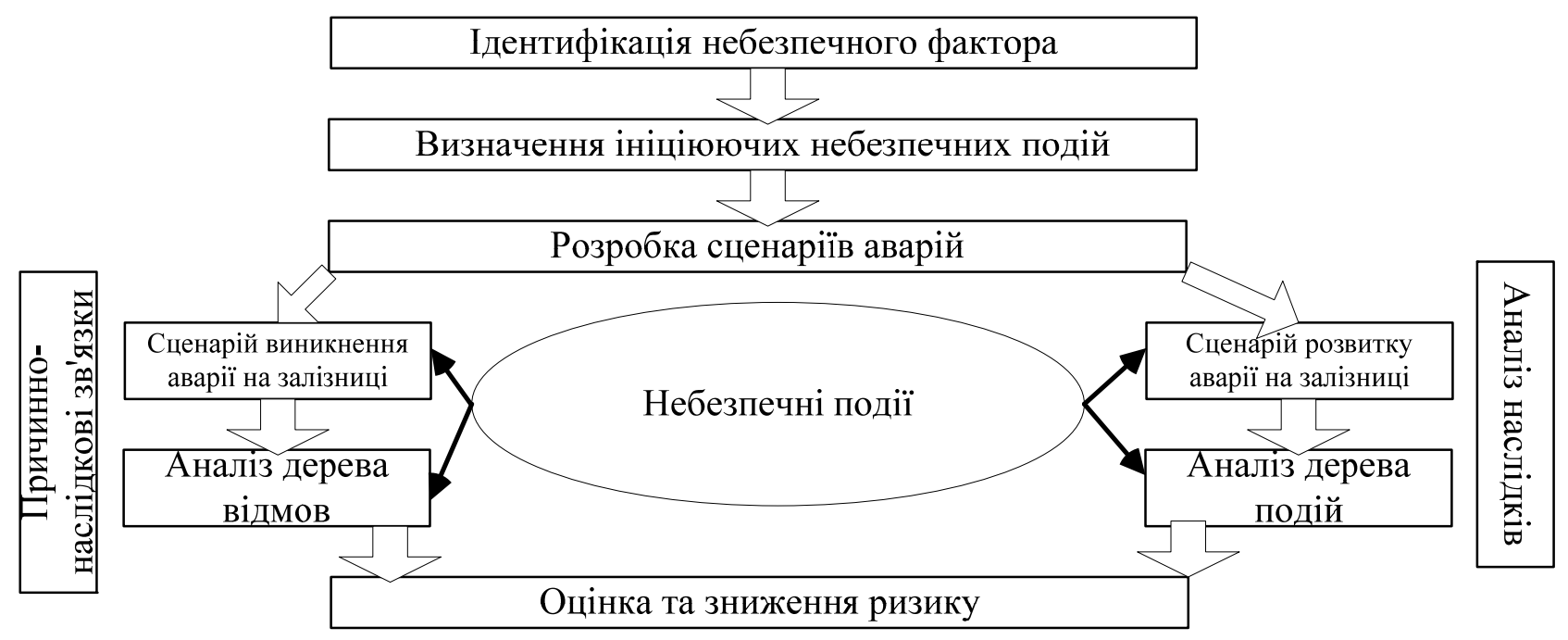

Рис. 9. Загальна процедура оцінки ризику на залізничному транспорті Джерело: [21]

В даному прикладі управління ризиками частоту кожної небезпечної події оцінювали за даними історичних аварій та структурованими експертними судженнями, використовуючи техніку FTA (аналіз дерева несправностей). Крім того, для оцінки тяжкості кожної небезпечної події застосовувались техніка ЕТА (аналіз дерева подій) та інші техніки безпеки. Нарешті, ризики для пасажирів, персоналу та громадськості можна оцінити як кількість еквівалентних смертей.

Для проведення ідентифікації небезпеки потрібно розуміти, що включає в себе ризик, як розпізнати та як визначити. Тобто потрібні розуміння послідовності виникнення аварій та прогресу. На етапі ідентифікації небезпеки використовують наступну процедуру, і були розроблені сценарії залізничних аварій для визначення цих послідовностей:

1. Визначення системи, межа: встановлення мети ідентифікації небезпеки та іiі межі.

2. Виявлення небезпечних подій, небезпек і перешкод: включаючи визначення заходів, які зупиняють зростання аварій.

3. Розробка сценаріїв появи аварій: визначення взаємозв'язку між небезпечними подіями, небезпеками та перешкодами.

4. Розробка сценаріїв прогресу аварій: врахування відповідних ключових факторів, що впливають.

5. Управління сценарієм аварій: складання журналу небезпек.

Розглянемо функціональну модель розвитку ризику на залізничному транспорті (рис. 10). 


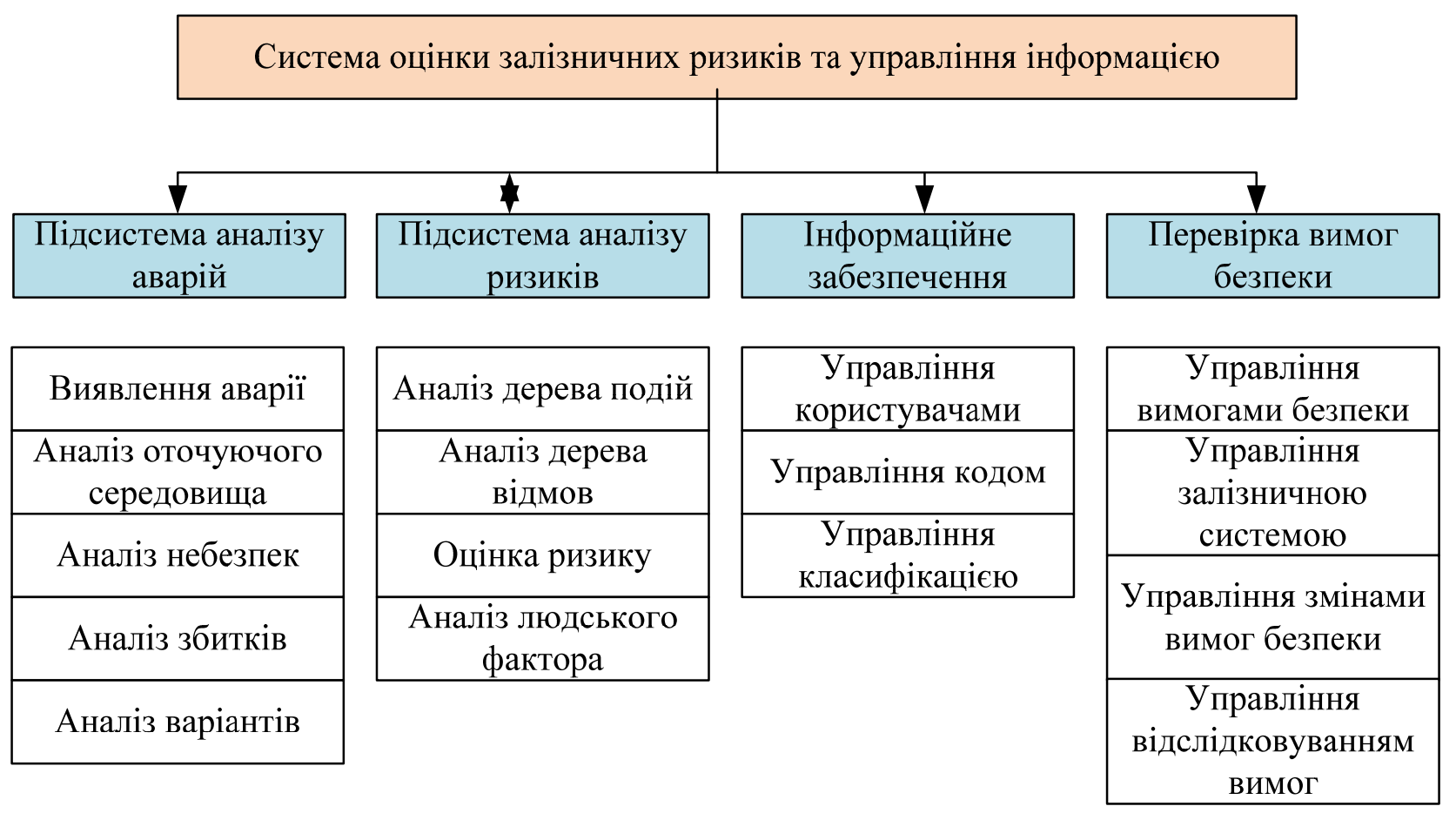

\section{Рис. 10. Функціональна структура оцінки залізничного ризику та управ- ління інформацісю}

Джерело: [21]

\subsection{3. Ризик в RAMS та його аналіз}

Засоби досягнення відповідності вимогам RAMS залізниці пов'язані з управлінням факторами, що впливають на RAMS протягом життєвого циклу системи. Ефективне управління вимагає створення механізмів і технологій захисту від джерел помилок, що відбуваються при реалізації і обслуговуванні системи. Такий захист вимагає враховувати як випадкові, так і систематичні відмови.

Способи, що використовуються для досягнення відповідності вимогам RAMS, грунтуються на концепції, що полягає у вживанні заходів по зменшенню можливих збитків, що виникають в результаті помилки на етапах життєвого циклу. Запобіжні заходи являють собою поєднання:

a) заходів профілактики, спрямованих на зниження можливих збитків,

b) заходів захисту, спрямованих на зниження тяжкості наслідків збитку.

Стратегія досягнення відповідності вимогам RAMS для системи, що включає використання заходів профілактики і / або заходів захисту, повинна бути обгрунтована.

Поняття ризику включає два елементи:

- можливість виникнення події або поєднання подій, що ведуть до небезпечної ситуації або частота виникнення таких подій;

- наслідок небезпечної ситуації. 
Аналіз ризику повинен проводитися на різних етапах життєвого циклу системи особою, відповідальною за цей етап, і документуватися. Як мінімум, документація повинна містити:

a) метод аналізу;

b) вихідні положення, обмеження і обгрунтування методу;

c) результати виявлення небезпечних ситуацій;

d) результати оцінки ризику і рівні їх достовірності;

е) результати компромісних досліджень;

f) дані, їх джерела та рівні достовірності;

g) посилання.

У табл. 8 в якісних поняттях наведені типові категорії ймовірності та частоти виникнення небезпечних ситуацій і опис кожної категорії стосовно залізничної системі. Застосовувані категорії, їх кількість і їх чисельний масштаб визначаються адміністративним органом залізниці відповідно до застосуванням.

Частота виникнення небезпечних ситуацій

Таблиця 8

\begin{tabular}{|c|c|}
\hline Категорія & Опис \\
\hline $\begin{array}{l}\text { Часте } \\
\text { виникнення }\end{array}$ & $\begin{array}{l}\text { Імовірність частого виникнення. Постійно буде присутня } \\
\text { небезпечна ситуація }\end{array}$ \\
\hline $\begin{array}{l}\text { Можливе } \\
\text { виникнення }\end{array}$ & $\begin{array}{l}\text { Неодноразове виникнення. Очікується часте виникнення не- } \\
\text { безпечної ситуації }\end{array}$ \\
\hline $\begin{array}{l}\text { Рідкісне } \\
\text { виникнення }\end{array}$ & $\begin{array}{l}\text { Імовірність неодноразового виникнення. Очікується неодно- } \\
\text { разове виникнення небезпечної ситуації }\end{array}$ \\
\hline $\begin{array}{l}\text { Малоймовірне } \\
\text { виникнення }\end{array}$ & $\begin{array}{l}\text { Імовірність того, що подія буде іноді виникати протягом } \\
\text { життєвого циклу системи. Обгрунтоване очікування виник- } \\
\text { нення небезпечної ситуації. }\end{array}$ \\
\hline $\begin{array}{l}\text { Немож } \\
\text { виникн }\end{array}$ & $\begin{array}{l}\text { Імовірність виникнення малоймовірна, але можлива. Можна } \\
\text { припустити, що небезпечна ситуація може виникнути у винят- } \\
\text { ковому випадку. }\end{array}$ \\
\hline $\begin{array}{l}\text { Неймовірне } \\
\text { виникнення }\end{array}$ & $\begin{array}{l}\text { Імовірність виникнення вкрай малоймовірна. Можна припус- } \\
\text { тити, що небезпека не виникне. }\end{array}$ \\
\hline
\end{tabular}

Дюеерело: [22]

\subsection{4. Оцінка і прийнятність ризику}

Розглянемо спосіб створення матриці «Частота / наслідок » для оцінки результату аналізу ризику, класифікації за категоріями ризику, заходів щодо зменшення ризику або усунення неприпустимого ризику i досягнення прийнятного ризику. 
Оцінка ризику повинна здійснюватися за допомогою поєднання частоти виникнення небезпечної ситуації і тяжкості їі наслідків, для встановлення ступеня ризику, який створюється небезпечною ситуацією. Матриця «Частота / Наслідок» приведена в табл. 9.

Щодо прийнятності ризику повинна грунтуватися на загальноприйнятих принципах. Існує певна кількість принципів, які можна застосовувати.

Таблиця 9

Матриця «Частота / Наслідок»

\begin{tabular}{|l|l|l|l|l|}
\hline \multicolumn{1}{|c|}{$\begin{array}{c}\text { Частота виникнення } \\
\text { небезпечної події }\end{array}$} & & & \\
\hline Часте виникнення & & & & \\
\hline Можливе виникнення & & & & \\
\hline Рідкісне виникнення & & & & \\
\hline Малоймовірне виникнення & & & & \\
\hline Неможливе виникнення & & & & \\
\hline Неймовірне виникнення & Незначний & Несуттєвий & Критичний & Катастрофічний \\
\hline & Рівні тяжкості наслідки небезпечної події \\
\hline
\end{tabular}

Джерело: [22]

У табл. 10 дано визначення якісних категорій ризику і дій, які застосовуються щодо кожної категорії. Адміністративний орган залізниці несе відповідальність за встановлення принципу, який необхідно застосовувати, рівнів ризику, які допускаються, і зіставлення цих рівнів за різними категоріями ризику.

Таблиця 10

Якісні категорії ризику

\begin{tabular}{|c|l|}
\hline Категорія ризику & \multicolumn{1}{|c|}{ Дії щодо кожної категорії } \\
\hline Неприпустимий & Повинен виключатися \\
\hline Небажаний & $\begin{array}{l}\text { Може бути прийнятним тільки тоді, коли зниження } \\
\text { ризику неможливо і за погодженням 3 адміністративним } \\
\text { органом залізниці і органом нагляду за безпекою }\end{array}$ \\
\hline Допустимий & $\begin{array}{l}\text { Прийнятний при належному контролі і за згодою адмі- } \\
\text { ністративного органу залізниці }\end{array}$ \\
\hline $\begin{array}{c}\text { Не приймається в } \\
\text { розрахунок }\end{array}$ & $\begin{array}{l}\text { Прийнятний 3 / без згоди адміністративного органу заліз- } \\
\text { ниці }\end{array}$ \\
\hline
\end{tabular}

Джерело: [22] 


\section{9. Управління ризиками та кризами на авіаційному транспорті 2.9.1. Передумови дослідження ризиків на авіаційному транспорті}

Для розвитку авіаційної безпеки враховуються всі наявні фактори і здійснюється постійний розвиток та вдосконалення комплексу заходів авіаційної безпеки із залученням людських і матеріальних ресурсів [23].

Але аварії завжди виникають внаслідок об'єднання декількох факторів: людський фактор (пілоти, наземний персонал, пасажири), зовнішні умови (погодні умови, місцевість, сторонні об'єкти, світлові умови, стан аеропортів), відмова техніки (двигун, гідравліка, шасі, авіоніка, планер, система управління, прибори).

Також досліджувались авіаційні події, що відбулися на різних етапах польоту: при зльоті, наборі висоти, горизонтального польоту та зниження. У процентному співвідношенні кількість авіаційних подій виникає: при зльоті $-11 \%$, при наборі висоти - 7\%, при горизонтальному польоті - 5\%, при зниженні літака $-31 \%$, при приземленні - 25\%, при гальмуванні - 21\% [23]. Порівняльна характеристика причин і ризиків даних авіаційних подій, а також рішення даних проблем наведені у табл. 11.

Таблиця 11

Авіаційні події на різних етапах польоту та рішення щодо безпеки польотів

\begin{tabular}{|c|c|c|}
\hline Етап польоту & Проблема & Прийняті міри / Рішення \\
\hline Зльот & $\begin{array}{l}\text { Шасі літака не прибирається всереди- } \\
\text { ну флюзеляжа через технічні причини }\end{array}$ & $\begin{array}{c}\text { Перед стартом літак перевіряють } \\
\text { згідно з встановленим } \\
\text { регламентам }\end{array}$ \\
\hline Набір висоти & $\begin{array}{c}\text { Руйнування корпусу літака внаслідок } \\
\text { перепадів тиску. В середині минулого } \\
\text { століття випускали літаки De Havilland } \\
\text { Comet, салон яких був захищений від } \\
\text { перепаду тиску, але декілька з них } \\
\text { потерпіли авіакатастрофу. Після цього } \\
\text { випуск цих літаків був припинений }\end{array}$ & $\begin{array}{c}\text { Салон літака стали продувати } \\
\text { зсередини для компенсації тиску } \\
\text { зовнішнього і внутрішнього (че- } \\
\text { рез це під час зльоту у багатьох } \\
\text { пасажирів тимчасово виникає } \\
\text { глухота - «закладає вуха») }\end{array}$ \\
\hline $\begin{array}{c}\text { Горизонтальний } \\
\text { політ }\end{array}$ & Ризик зіткнення з іншим літаком & $\begin{array}{l}\text { 3'явились системи } \\
\text { попередження }\end{array}$ \\
\hline Зниження & Ризик зіткнення з птахами & $\begin{array}{c}\text { На шасі додали фари і малюнки, } \\
\text { що відлякують пташок }\end{array}$ \\
\hline Приземлення & Проблема з випуском шасі & $\begin{array}{c}\text { Розроблена технологія посадки } \\
\text { літака на рухому вантажівку }\end{array}$ \\
\hline Гальмування & $\begin{array}{c}\text { Відмова антиблокувальної системи } \\
\text { гальмування і, як наслідок, занос } \\
\text { літака та з'їздом з посадкової смуги }\end{array}$ & $\begin{array}{c}\text { Впровадження дублюючих } \\
\text { механізмів гальм }\end{array}$ \\
\hline
\end{tabular}

Джерело: [23] 
Кожна авіаційна подія реєструється у пов’язані між собою бази даних та аналізуються провайдерами аеронавігаційних послуг, авіакомпаніями та іншими авіаційними підприємствами. Міжнародні організації, такі як ICAO (Міжнародна організація цивільної авіації), IATA (Міжнародна асоціація повітряного транспорту ), FAA (Федеральне управління цивільної авіації США) на основі баз даних авіаційних подій проводять поглиблений аналіз та розробляють рекомендації для всіх виробників літаків та вносять зміни до стандартів з безпеки польотів.

Найуспішніша у світі авіакомпанія Pan American припинила своє існування через ряд факторів, що відбулися з нею. Крім ряду авіаційних катастроф, згідно 3 якими авіакомпанія виплатила страхові виплати, не останню роль у завершенні діяльності авіакомпанії зіграло і неефективна система управління ризиками Рап American. Фінансову стабільність компанії підірвали не тільки великі суми страхових виплат по авіакатастрофам, але й відсутність стратегії при виникненні ризиків та можливі шляхи виходу з кризи. Тому останньою крапкою неповернення і банкротством у 1991 році стала паливна криза та війна в Персицькій затоці.

США, країни Свросоюзу, Китай, Японія та 99 країн підписали Монреальську міжнародну конвенцію, яка регламентує виплати родичам загиблих в авіакатастрофах з літаками міжнародних рейсів.

\subsection{2. Елемент «Виявлення небезпечних факторів» в системі безпеки польотів}

Для авіаційного транспорту запровадженні системи безпеки польотів (БП), які регламентуються нормативними актами [24, 25].

Виявлення небезпечних факторів та управління ризиками для БП є, як правило, основними процесами управління безпекою польотів.

Небезпечні фактори можуть бути частиною будь-якої виробничої системи. Прикладами факторів і процесів, на які потрібно звертати увагу при виявленні небезпечних факторів, є:

а) фактори проектування, у тому числі використовувані технічні засоби та об'єкт проектування;

б) правила та експлуатаційні процедури, у т. ч. документація, чек-листи, а також їх використання в реальних виробничих умовах;

в) мовний зв’язок, у т. ч. технічні засоби, термінологія та мова;

г) фактори персоналу, зокрема політика організації з питань прийняття на роботу, підготовки персоналу, оплати праці та виділення відповідних ресурсів;

г) організаційні фактори, зокрема узгодженість виробничих завдань і завдань з БП, виділення ресурсів, інтенсивність виробничих умов, корпоративна культура БП;

д) фактори умов праці, зокрема навколишній шум, вібрація, температура, освітлення, наявність захисних засобів та спецодягу; 
е) фактори регуляторного нагляду, зокрема застосування та забезпечення виконання авіаційних правил; сертифікація обладнання, персоналу та діяльності; відповідність нагляду;

є) засоби захисту (defences), зокрема забезпечення адекватних систем реєстрації та попередження; стійкість обладнання до помилок та відмов;

ж) діяльність людини з урахуванням стану здоров’я та фізичних вад.

Небезпечні фактори можуть бути виявлені після того як сталася авіаційна подія чи інцидент або шляхом проактивних і прогностичних методів, що направлені на виявлення небезпечних факторів до того, як вони спричинять виникнення АП чи інциденту. Джерела інформації для виявлення небезпечних факторів можуть бути як в внутрішні так і зовнішні.

Виявлення небезпечних факторів та повідомлення про них, як правило, стосується кожного працівника. Кожний працівник у разі необхідності має вміти виявляти небезпечні фактори та повідомляти про них.

Весь персонал авіаційної організації, як правило, проходить підготовку у сфері управління безпекою польотів за програмами, що відповідають їх посадовим обов'язкам.

Авіаційна організація може призначити працівників, основними обов'язками яких буде виявляти та аналізувати небезпечні фактори. Як правило, такі працівники перебувають у штаті підрозділу забезпечення БП та відповідають за виявлення небезпечних факторів.

Рекомендуємо авіаційній організації офіційно запроваджувати процес виявлення небезпечних факторів, який чітко висвітлюється в документах 3 управління безпекою польотів.

Системний підхід до виявлення небезпечних факторів, як правило, гарантує, виявлення більшості небезпечних факторів. Для застосування системного підходу пропонуємо використовувати чек-листи, які розробляються на основі аналізу подій та даних з БП.

Контрольні чек-листи рекомендуємо розглядати на групових розборах для визначення небезпечних факторів за напрямками діяльності. На розборах можуть бути присутні представники експлуатаційного і технічного персоналу за напрямками діяльності. Розбори рекомендуємо проводити під керівництвом відповідального керівника або керівника з БП.

При прийнятті рішень щодо врахування небезпечних факторів можна використовувати наступні визначення:

а)Найгірші наслідки. Найбільш несприятливі очікувані умови, наприклад: надзвичайно висока інтенсивність повітряного руху під час порушення виробничої діяльності внаслідок екстремальних погодних руйнувань;

б) Імовірний випадок. Існують підстави вважати, що під час виробничої діяльності виникне передбачуване поєднання екстремальних умов. 


\subsection{3. Елемент «Оцінка і зниження ризику для БП» в системі безпеки польотів}

Після того, як будуть виявлені небезпечні фактори, пропонуємо оцінити ризик потенційних наслідків, до яких може призвести небезпечний фактор. Оцінка ризику для БП може представляти собою аналіз потенційних небезпечних факторів, які, як встановлено, несуть загрозу виробничій діяльності організації. Під час аналізу рекомендовано ризик оцінювати за двома критеріями: імовірність настання події чи умов, які наносять шкоду, та серйозність наслідків події чи умови, якщо вони настануть.

Процес прийняття рішення стосовно ризику та його прийнятності може здійснюватися за допомогою застосування матриці прийнятності ризику. Незважаючи на те, що матриця є необхідною для оцінки ризику, іiі використання, як правило, здійснюється помірковано. Формування і остаточна структура матриці, як правило, здійснюється авіаційною організацією.

Після оцінки ризику, авіаційна організація може вжити заходів стосовно його усунення чи зниження до найменшого прийнятного рівня.

Управління ризиками, як правило, є ключовим етапом процесу управління безпекою польотів в авіаційній організації. На рис. 11 зображено приклад процесу управління ризиками.

\section{Управління ризиком}

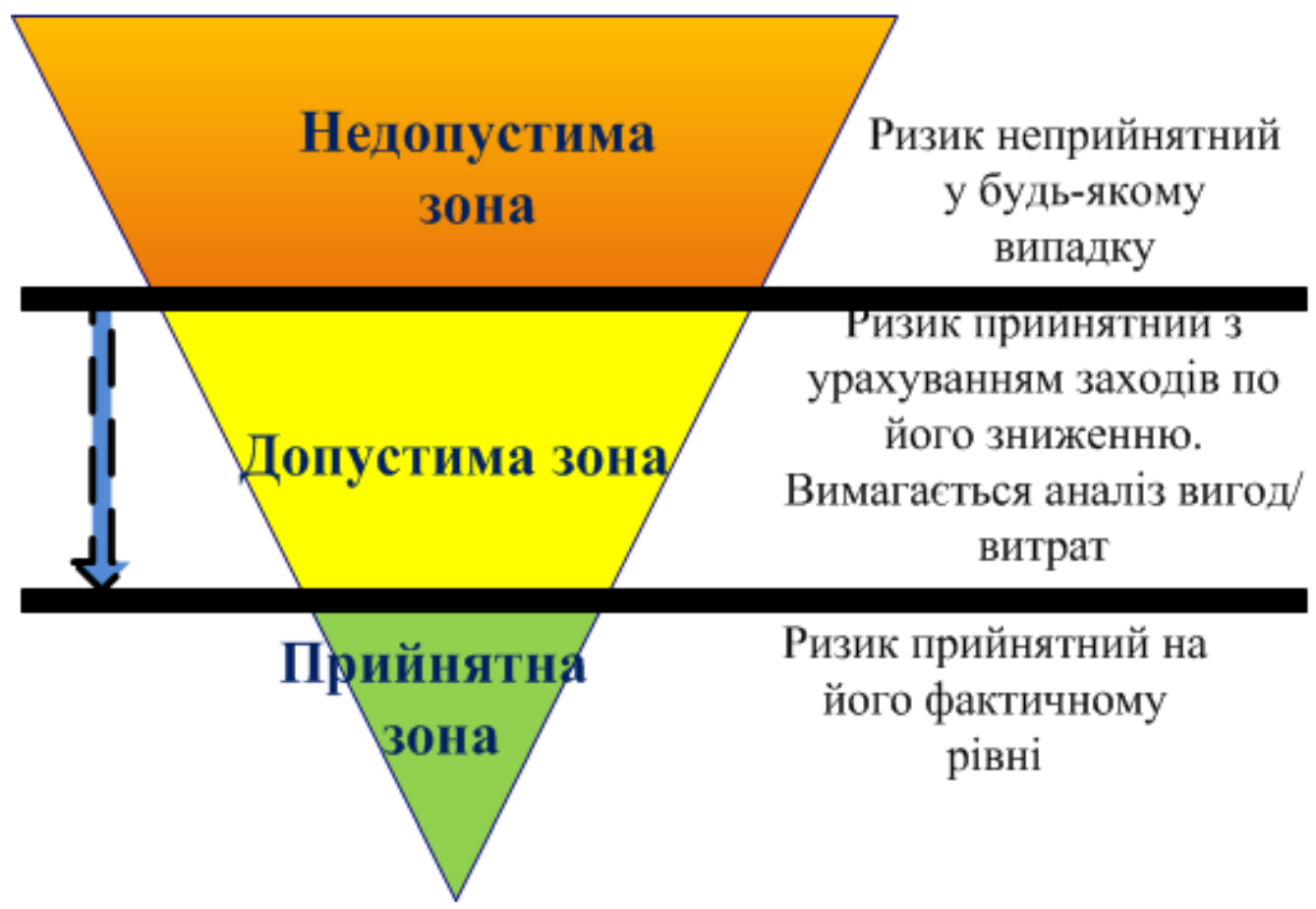

Рис. 11. Приклад процесу управління ризиками

Джерело: [25] 
Ризики, які за результатами оцінки потрапляють до недопустимої зони, є неприйнятними за будь-яких обставин. Імовірність чи серйозність наслідків небезпечних факторів настільки значна, а потенціал небезпеки завдання збитків становить таку загрозу для діяльності організації, що необхідне вжиття термінових заходів для зменшення небезпеки. Авіаційній організації рекомендується два шляхи переміщення неприйнятного ризику до допустимої чи прийнятної зони:

а)виділити ресурси для зниження потенціалу наслідків ризику;

б)якщо заходи щодо зменшення рівня небезпеки вжити неможливо, припинити даний вид діяльності.

Ризики, які за результатами оцінки потрапляють в допустиму зону, можуть бути прийнятними за умови, що вжиті заходи по їх зниженню гарантують, що прогнозована імовірність та серйозність наслідків небезпечного фактора перебуває під контролем організації.

При визначенні того, що є «прийнятним» в системі управління ризиками, рекомендовано враховувати як технічну можливість подальшого зменшення ризику, так і відповідність затрат. Для цього, як правило, виконується аналіз вигод / затрат. Якщо ризик в системі перебуває на найменшому прийнятному рівні, це означає, що подальше його зниження або практично неможливе, або не виправдане $з$ точки зору затрат.

Ризики, які за результатами оцінки потрапляють в прийнятну зону, можуть бути прийнятними на їх фактичному рівні та не вимагають будь-яких заходів по контролю за ними.

Якщо в авіаційній організації відсутня база даних з безпеки польотів, вона може виконати оцінку імовірності лише на підставі тенденцій в авіаційній галузі чи, в гіршому випадку, суб’єктивно.

Таблиця 12

\section{Імовірність виникнення події чи умов}

\begin{tabular}{|c|c|c|}
\hline Імовірність виникнення події чи умов & Значення & Величина \\
\hline Часто (від 1 до $10^{-3}$ за годину) & Трапляється дуже часто & 5 \\
\hline Періодично (від $10^{-3}$ до $10^{-5}$ за годину) & Трапляється інколи & 4 \\
\hline Рідко (від $10^{-5}$ до $10^{7}$ за годину) & Імовірність виникнення мала & 3 \\
\hline Малоймовірно (від $10^{-7}$ до $10^{-9}$ за годину) & Дуже мала імовірність виникнення & 2 \\
\hline Майже не можливо $\left(<10^{-9}\right.$ за годину) & Імовірність настання майже & 1 \\
\hline
\end{tabular}

Джерело: [25]

Категорії, що характеризують імовірність виникнення небезпечних подій чи умов заносяться до таблиці імовірності ризику. Кожній категорії присвоюється відповідна величина. 3 урахуванням специфіки діяльності кожна авіаційна організація може визначити категорії імовірності. У табл. 1 наведено приклад таблиці імовірності ризику. 
Після того як виконана оцінка імовірності виникнення небезпеки, як правило, виконується оцінка серйозності їі наслідків.

Серйозність ризику оцінюється як імовірні наслідки виникнення небезпечної події чи умов. При цьому може бути врахована імовірність найгірших наслідків, що можуть наступити внаслідок небезпечного фактора. Оцінити серйозність наслідків, як правило, можна шляхом опрацювання наступних питань:

а) імовірна кількість загиблих (працівників компанії, пасажирів, третіх осіб);

б) імовірний рівень нанесення майнових чи фінансових збитків (знищення майна експлуатанта, збитки авіаційній інфраструктурі, збитки третьої сторони, фінансові чи економічні наслідки для держави тощо);

в) імовірність впливу на природне середовище (витік палива чи інших небезпечних продуктів, фізичне порушення природного середовища);

г) можливі політичні наслідки та інтерес з боку засобів масової інформації.

Таблиця 13

Приклад типової таблиці серйозності ризику

\begin{tabular}{|l|l|c|}
\hline Серйозність події & \multicolumn{1}{|c|}{ Значення } & Рівень \\
\hline Катастрофічна & $\begin{array}{l}\text { - значні людські жертви; } \\
\text { - знищення обладнання, майна }\end{array}$ & A \\
\hline Небезпечна & $\begin{array}{l}\text { - серйозні тілесні ушкодження; } \\
\text { - значне пошкодження обладнання, майна } \\
\text { - серйозне зменшення рівня безпеки польотів, настання фізич- } \\
\text { ного стресу чи такого робочого навантаження, коли немає впев- } \\
\text { неності в правильному і повному виконанні завдань } \\
\text { персоналом }\end{array}$ & \\
\hline Значна & $\begin{array}{l}\text { - серйозний інцидент; } \\
\text { - незначні тілесні ушкодження; } \\
\text { - суттєве зменшення рівня безпеки польотів, зниження можли- } \\
\text { востей персоналу справлятися з несприятливими експлуатацій- } \\
\text { ними умовами внаслідок збільшення робочого навантаження чи } \\
\text { виникнення умов, що знижують ефективність їхньої роботи }\end{array}$ \\
\hline Незначна & $\begin{array}{l}\text { - інцидент; } \\
\text { - пошкодження; } \\
\text { - виробничі обмеження; } \\
\text { - застосування правил на випадок аварійної ситуації; }\end{array}$ & В \\
\hline Несуттєва & Несуттєві наслідки & Е \\
\hline
\end{tabular}

Джерело: [25]

Після оцінки ризику з точки зору імовірності і серйозності, як правило, виконують оцінку прийнятності наслідків небезпечного фактора. Цей процес називається оцінкою прийнятності ризику для БП.

Матрицю оцінки ризику рекомендується розробляти в кожній авіаційній організації та заносити до документації по СУБП. Для організацій обслуговування

$$
-198-
$$


повітряного руху при складанні матриці пропонуємо враховувати вимоги до єдиного Свропейського простору (Single European Sky Common Requirements). Приклад матриці оцінки ризику (табл. 14).

Таблиця 14

Матриця оцінки ризику

\begin{tabular}{|c|c|c|c|c|c|}
\hline $\begin{array}{c}\text { Імовірність } \\
\text { ризику }\end{array}$ & \multicolumn{5}{|c|}{ Серйозність ризику } \\
\cline { 2 - 6 } & $\begin{array}{c}\text { катастрочічна } \\
\mathbf{A}\end{array}$ & $\begin{array}{c}\text { небезпечна } \\
\mathbf{B}\end{array}$ & $\begin{array}{c}\text { 3начна } \\
\mathbf{C}\end{array}$ & $\begin{array}{c}\text { незначна } \\
\mathbf{D}\end{array}$ & $\begin{array}{c}\text { несуттсва } \\
\mathbf{E}\end{array}$ \\
\hline $\begin{array}{c}\text { часто } \\
5\end{array}$ & $5 \mathrm{~A}$ & $5 \mathrm{~B}$ & $5 \mathrm{C}$ & $5 \mathrm{D}$ & $5 \mathrm{E}$ \\
\hline $\begin{array}{c}\text { періодично } \\
4\end{array}$ & $4 \mathrm{~A}$ & $4 \mathrm{~B}$ & $4 \mathrm{C}$ & $4 \mathrm{D}$ & $4 \mathrm{E}$ \\
\hline $\begin{array}{c}\text { рідко } \\
3\end{array}$ & $3 \mathrm{~A}$ & $3 \mathrm{~B}$ & $3 \mathrm{C}$ & $3 \mathrm{D}$ & $3 \mathrm{E}$ \\
\hline $\begin{array}{c}\text { малоймовірно } \\
2\end{array}$ & $2 \mathrm{~A}$ & $2 \mathrm{~B}$ & $2 \mathrm{C}$ & $2 \mathrm{D}$ & $2 \mathrm{E}$ \\
\hline $\begin{array}{c}\text { майже неможливо } \\
1\end{array}$ & $1 \mathrm{~A}$ & $1 \mathrm{~B}$ & $1 \mathrm{C}$ & $1 \mathrm{D}$ & $1 \mathrm{E}$ \\
\hline
\end{tabular}

Джерело: [25]

Після того, як отриманий індекс ризику, він може переноситься до матриці прийнятності ризику, яка характеризує критерії прийнятності. Якщо ризик потрапляє в недопустиму зону, він є неприйнятним для безпеки польотів. В такому випадку пропонуємо авіаційній організації:

а) виділити ресурси для зниження наслідків впливу небезпечного фактора;

б)виділити ресурси для зниження масштабу чи потенціалу наслідків, що можуть бути викликані небезпечним фактором;

в) припинити даний вид діяльності, якщо зменшити небезпеку неможливо. Приклад матриці прийнятності ризику наведено на рис. 12.

На підставі даних, отриманих внаслідок оцінки ризику, організація може приймати рішення про необхідність зменшення оціненого ризику. Існує, як правило, три загальні стратегії зменшення/контролю ризику:

а) Уникнення ризику. Процедура чи діяльність припиняється, оскільки ризик перевищує вигоду від продовження такої процедури чи діяльності.

б) Зниження ризику. Частота операцій чи виду діяльності зменшується або вживаються заходи зі зниження величини наслідків прийнятних ризиків. Прикладами стратегії зі зниження ризику є:

в) Ізолювання впливу ризику. Вживаються заходи з метою локалізації впливу наслідків небезпечного фактора або створення резерву для захисту від них. Прикладами стратегії з ізолювання впливу ризику є: 
Стратегія зменшення/контролю ризику може грунтуватися на впровадженні додаткових засобів захисту безпеки польотів чи удосконаленні існуючих засобів захисту.

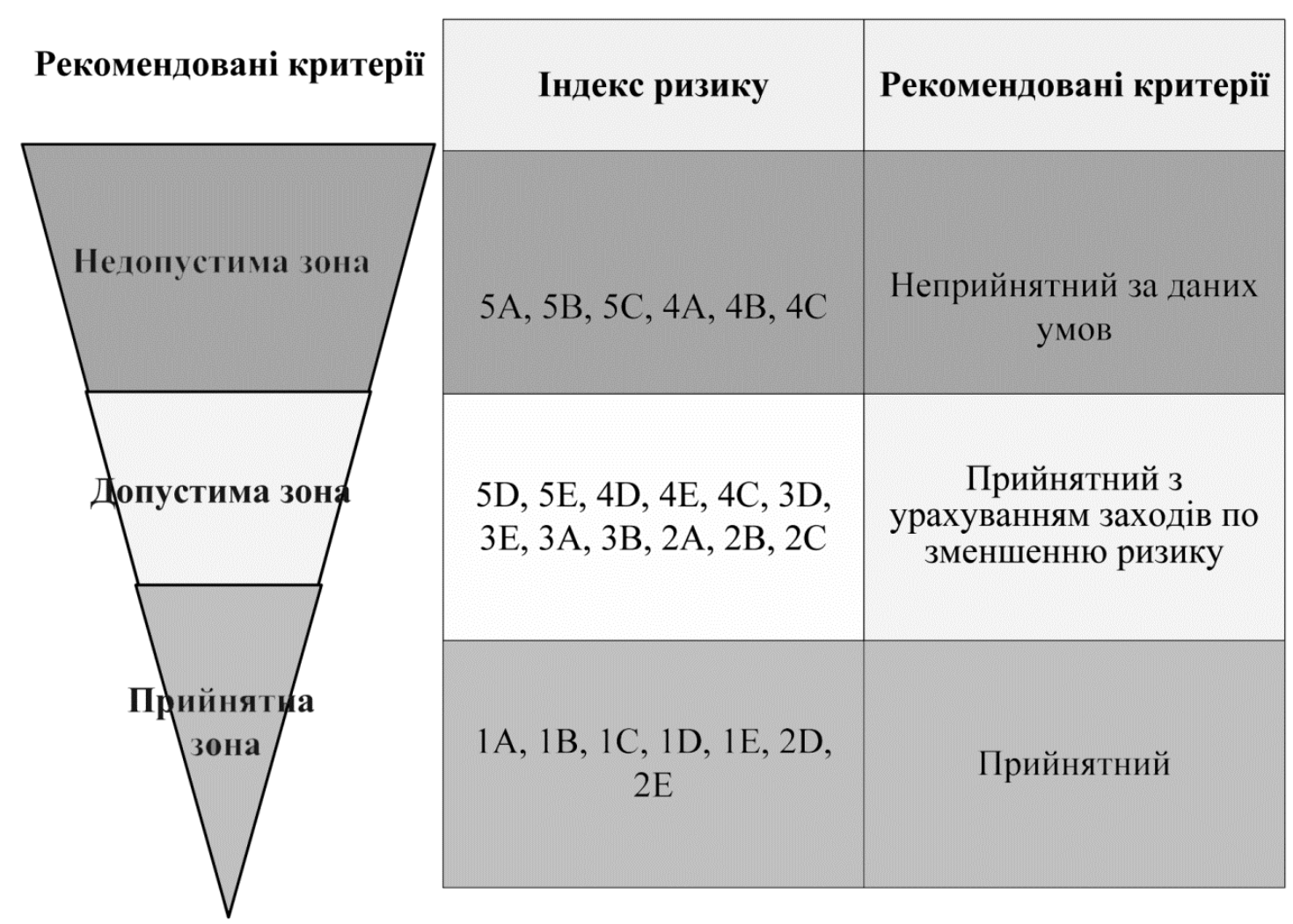

Рис. 12. Матриця прийнятності ризику

Джерело: [25]

\section{3. ВИСНОВКИ}

В даному розділі було розглянуто ряд питань щодо усвідомлення самого поняття «ризик». Для цього наведено різні визначення поняття, підходів до визначення ризиків та класифікація різних методів виявлення та управління ризиками.

Важливим, 3 нашої точки зору, в даному розділі $є$ класифікація видів та проявів ризиків для різних видів транспорту, що $\epsilon$ важливим в сучасних умовах транспортування та взаємодії різних видів транспорту.

\section{ЛІТЕРАТУРА}

1. Palšaitis, Ramūnas, Petraška, Artūras (2012). Heavyweight and oversized cargo transporttation risk management. Transport and Telecommunication, 13 (1): 51-56.

2. Ткаченко, I.O. Ризики у транспортних процесах: навч. посібник / I.O. Ткаченко. Харків: ХНУМГ ім. О. М. Бекетова, 2017. - 114 с. 
3. ISO IEC Guide 51:2014 Safety aspects - Guidelines for their inclusion in standards. Electronic documents. Official Journal of the European Union, 2016.

4. Millot, P. (2014). Risk Management in Life Critical Systems. John Wiley \& Sons, Inc.

5. Березуцький, В.В. Небезпечні виробничі ризики та надійність: навчальний посібник для студентів за напрямком підготовки 6.170202 «Цивільна безпека» / В.В. Березуцький, М.I. Адаменко. - Харків: ФОП Панов А.М. 2016. — 385 с.

6. Менеджмент ризиків. Принципи та настанови: ДСТУ ISO 31000:2018. — [Чинний від 01.01.2019]. — К.: ДП «УкрНДНЦ», 2018. - 19 с.

7. Керування ризиком. Методи загального оцінювання ризику: ДСТУ IEC/ISO 31010:2013. - [Чинний від 01.07.2014]. - К.: ДП «УкрНДНЦ», 2013. — 80 с.

8. Керування ризиками. Словник термінів: ДСТУ ISO Guide 73:2013. — [Чинний від 01.07.2014]. — К.: ДП «УкрНДНЦ», 2013. — 17 с.

9. Nakat E., Salim Z. (2015). Disaster Risk Management in the Transport Sector, A Review of Concepts and International Case Studies, World Bank Group.

10. Fox-Lent, Cate, Linkov, Igor (2018). Resilience Matrix for Comprehensive Urban Resilience Planning, Resilience-Oriented Urban Planning. pp $29-47$.

11. Kristiansen, Svein (2005). Maritime Transportation Safety Management and Risk Analysis. $523 \mathrm{p}$.

12. Панченко, О.І. Класифікація ризиків як складова забезпечення страхового захисту на морському транспорті / O.I. Панченко, X.I. Штирхун // Вісник Чернігівського державного технологічного університету. — 2013. - № 1. С. 239 - 245. — (Серія: Економічні науки).

13. Karlsen, J. E., Kristiansen, S., (1980). Analysis of Causal Factors and Situation Dependent Factors. Project: Cause Relationships of Collisions and Groundings. Report, Det Norske Veritas, Høvik, Norway. pp. 80-1144.

14. Маханець, Л. Л. Моделювання ризику в зовнішньоекономічній діяльності: дис. ... канд. екон. наук : 08.03.02 / Маханець Любов Леонідівна. - Київ, 2002. — 204 с.

15. Коромыслов, А. А. Управление рисками в логистических процессах грузовых перевозок воздушным транспортом: дис... канд. экон. наук : 08.00.05 / Коромыслов Александр Анатольевич. - Саратов, 2005. — 197 с.

16. Слюсарь, Н.Н. Управление экологическими рисками транспортировки взрывчатых веществ железнодорожным транспортом: дис... канд. техн. наук : 03.00.16 / Слюсарь Наталья Николаевна. - Пермь, 2004. - 149 с.

17. Рачинська, А. В. Класифікація ризиків на залізничному транспорті як основа формування системи економічної безпеки його функціонування / А.В. Рачинська // Економіка і суспільство. - 2016. - № 6. - С. 81-87.

18. Сич, Є. М. Стратегія розвитку залізничного транспорту України / Є.М. Сич, Н.I. Богомолова // Збірник наукових праць Київського університету економіки і технологій транспорту. «Економіка і управління». — 2005. — № 7. - С. 98-105.

19. Гапанович, В.А. Система управления рисками крупных компаний. Практика оценки рисков в ОАО «РЖД» и направления развития. / В.А. Гапанович, И.Б. Шубинский, О.Б. Проневич, В.Э. Швед // Проблемы анализа риска. - 2018; № 15(2) - С. 6-21.

20. Directive (EU) $2016 / 798$ on railway safety, Electronic documents. Official Journal of the European Union, 2016.

21. Leitner, Bohus (2017). A General Model for Railway Systems Risk Assessment with the Use of Railway Accident Scenarios Analysis. Procedia Engineering. 18: 150-159.

22. IEC 62278:2002 Railway applications - Specification and demonstration of reliability, availability, maintainability and safety (RAMS), Electronic documents. International Standard. 2002. 
23. Чабан, Г. М. Актуальні питання попередження ризику в цивільній авіації України / Г. М. Чабан // Економіка та держава. - 2019. - № 2. - С. 130-134.

24. Положення про систему управління безпекою польотів на авіаційному транспорті. наказ Державіаслужби від 25.11. 2005 р. № 895. Офіційний вісник України. 2005. № 51, С. 199.

25. Методичні рекомендації з впровадження систем управління безпекою польотів [Електронний ресурс]: наказ Державної авіаційної служби України від 26 липня 2012 р. № 528. Режим доступу: https://zakon.rada.gov.ua/rada/show/v0528763-12\#Text.

26. Hough, Michelle \& Spillan, John. (2011). Crisis Planning: Increasing Effectiveness, Decreasing Discomfort. Journal of Business \& Economics Research (JBER). Volume 3, Number 4, 2005. 3. 10.19030/jber.v3i4.2762 


\section{РОЗДІЛ 7 \\ ОСНОВИ ГУМАНІТАРНОЇ ЛОГІСТИКИ ТА ТРАНСПОРТНОГО ОБСЛУГОВУВАННЯ В НАДЗВИЧАЙНИХ СИТУАЦІЯХ}

\section{В.К. Мироненко ${ }^{12}$}

\section{1. ВСТУП}

Історія людства повна катастроф, стихійних лих, епідемій та інших небезпечних подій, які терзали його навіть у мирний час, а бувало, що ставали і наслідком воєн. Подібні події приносять небезпеку, шкоду та страждання людям, які потребують гуманітарної допомоги.

\section{2. ОСНОВНИЙ МАТЕРІАЛ}

\section{1. Історія та види небезпечних подій}

Почнемо з термінології [1].

Катастро́фа - велика за масштабами аварія чи інша подія, що призводить до тяжких (або неповоротних) наслідків.

Стихі́йне ли́хо - це надзвичайне природне явище, що діє з великою руйнівною силою, завдає значної шкоди району, в якому відбувається, порушує нормальну життєдіяльність населення, знищує матеріальні цінності.

Епіде́мія - тип хвороби, яка є новою для даної популяції впродовж періоду збереження імунної «пам'яті» та поширюється зі швидкістю, що значно перевищує очікувану, грунтуючись на попередньому досвіді. Українське законодавство визначає: «епідемія - масове поширення інфекційного захворювання серед населення відповідної території за короткий проміжок часу», що не відповідає світовому визначенню, яке поширює поняття епідемії на усі випадки масового ураження, в тому числі й отруєння.

Що стосується історії, то нижче наведена таблиця [1] з хронологією та коротким описом того, які катастрофи та стихійні лиха у всьому світі спіткали людство за останні півтори тисячі років.

\footnotetext{
12 Докт. техн. наук, професор, завідувач кафедри «Управління комерційною діяльністю залізниць» Державного університету інфраструктури та технологій, Київ
}

$$
-203-
$$


Таблиця 1

Історія небезпечних подій: основні катастрофи та стихійні лиха у світі

\begin{tabular}{|c|c|c|c|c|c|}
\hline № & Час, рік & $\begin{array}{l}\text { Небезпечна } \\
\text { подія, місце }\end{array}$ & Вид події & Наслідки події & $\begin{array}{c}\text { Надана } \\
\text { допомога }\end{array}$ \\
\hline 1 & 2 & 3 & 4 & 5 & 6 \\
\hline 1 & $\begin{array}{l}3 \text { вересня } \\
2014\end{array}$ & $\begin{array}{l}\text { Індія - } \\
\text { Пакистан }\end{array}$ & Повені & $\begin{array}{l}557 \text { людей загинуло, } \\
\text { постраждали 2,500 поселень, } \\
80,000 \text { людей втратили житло }\end{array}$ & 0.1 млрд. \$ \\
\hline 2 & $\begin{array}{l}14-17 \\
\text { червня } \\
2013\end{array}$ & Північ Індії & Повені & $\begin{array}{l}\text { 5,748 людей загинуло, } \\
\text { 4,200 поселень, 110,000 } \\
\text { людей евакуйовані }\end{array}$ & 0.17 млрд. \$ \\
\hline 3 & $\begin{array}{l}\text { Липень } \\
2011- \\
\text { серпень } \\
2012\end{array}$ & Схід Африки & Посуха & $\begin{array}{l}12.4 \text { млн. людей потребували } \\
\text { iжi, } 9.5 \text { млн. на межі голоду, } \\
\text { 50,000-260,000 людей } \\
\text { загинули }\end{array}$ & 1.3 млрд. \$ \\
\hline 4 & $\begin{array}{l}12 \text { січня } \\
2012\end{array}$ & Гаїті & $\begin{array}{l}\text { Землетрус (7.0 балів } \\
\text { за шкалою Ріхтера) }\end{array}$ & $\begin{array}{l}0.2 \text { млн. людей загинуло, } \\
2 \text { млн. втратили житло, } 3 \text { млн. } \\
\text { людей потребували негайної } \\
\text { допомоги }\end{array}$ & 0.315 млрд. \$ \\
\hline 5 & $\begin{array}{l}11 \text { березня } \\
2011\end{array}$ & $\begin{array}{l}\text { Тогоку, } \\
\text { Японія }\end{array}$ & $\begin{array}{l}\text { Землетрус та цунамі } \\
\text { (9.0 балів за шкалою } \\
\text { Ріхтера) }\end{array}$ & $\begin{array}{l}15 \text { млн. людей загинуло або } \\
\text { поранено, 2,814 зникли } \\
\text { безвісти, пошкоджені або } \\
\text { зруйновані 250,000 будівель }\end{array}$ & 235 млрд. \$ \\
\hline 6 & $\begin{array}{l}22 \text { лютого } \\
2011\end{array}$ & $\begin{array}{l}\text { Крайстчерч, } \\
\text { Нова Зеландія }\end{array}$ & $\begin{array}{l}\text { Землетрус (6.3 балів } \\
\text { за шкалою Ріхтера) }\end{array}$ & $\begin{array}{l}185 \text { людей загинуло, } 238 \text { зник- } \\
\text { ли безвісти, } 164 \text { поранено }\end{array}$ & 16 млрд. \$ \\
\hline 7 & $\begin{array}{l}8 \text { жовтня } \\
2005\end{array}$ & Пакистан & $\begin{array}{l}\text { Землетрус (7.6 балів } \\
\text { за шкалою Ріхтера) }\end{array}$ & $\begin{array}{l}75,000 \text { людей загинуло, } \\
106,000 \text { поранено }\end{array}$ & 5.4 млрд. \$ \\
\hline 8 & $\begin{array}{l}23 \text { серпня } \\
2005\end{array}$ & США & $\begin{array}{l}\text { Ураган Katrina (Ка- } \\
\text { тегорія } 4 \text { за шкалою } \\
\text { Саффіра-Симпсона) }\end{array}$ & 1,833 людей загинуло & 108 млрд. \$ \\
\hline 9 & $\begin{array}{l}2 \text { травня } \\
2008\end{array}$ & М'янма & $\begin{array}{l}\text { Циклон Nargis } \\
\text { (Кат. 4) }\end{array}$ & $\begin{array}{l}\text { 84,500 людей загинуло та } \\
\text { 53,800 зникли безвісти, } \\
\text { зруйновано } 37 \text { поселень }\end{array}$ & 10 млрд. \$ \\
\hline 10 & $\begin{array}{l}5 \text { лютого } \\
2008\end{array}$ & Афганістан & Снігові бурі & $\begin{array}{l}926 \text { людей загинуло, замерзли } \\
100,000 \text { овець та кіз і } \\
315,000 \text { великої рогатої худоби }\end{array}$ & \\
\hline 11 & $\begin{array}{l}26 \text { грудня } \\
2004\end{array}$ & $\begin{array}{l}\text { Індійський } \\
\text { океан }\end{array}$ & $\begin{array}{l}\text { Землетрус та цунамі } \\
\text { (9.1-9.3 балів за } \\
\text { шкалою Ріхтера) } \\
\end{array}$ & $\begin{array}{l}\text { Постраждали 0.23-0.31 млн. } \\
\text { людей }\end{array}$ & 14 млрд. \$ \\
\hline 12 & $\begin{array}{l}\text { Червень- } \\
\text { серпень } \\
2003\end{array}$ & $\begin{array}{l}\text { Європейська } \\
\text { Хвиля спеки }\end{array}$ & Хвиля спеки/посуха & $\begin{array}{l}\text { Втрачено } 75 \text { \% врожаю } \\
\text { зернових, 70,000 людей } \\
\text { померло }\end{array}$ & Немає даних \\
\hline 13 & $\begin{array}{l}26 \text { січня } \\
2001\end{array}$ & $\begin{array}{l}\text { Гуджарат, } \\
\text { західна Індія }\end{array}$ & $\begin{array}{l}\text { Землетрус (7.7 балів } \\
\text { за шкалою Ріхтера) }\end{array}$ & $\begin{array}{l}\text { 20,000 людей загинуло, } \\
167,000 \text { поранено, 400,000 бу- } \\
\text { динків зруйновано, } \\
600,000 \text { людей втратили житло }\end{array}$ & Немає даних \\
\hline
\end{tabular}


Закінчення табл. 1

\begin{tabular}{|c|c|c|c|c|c|}
\hline 1 & 2 & 3 & 4 & 5 & 6 \\
\hline 14 & $\begin{array}{l}\text { Лютий- } \\
\text { березень } \\
2000\end{array}$ & $\begin{array}{l}\text { Мозамбік, } \\
\text { Південь } \\
\text { Африки }\end{array}$ & Повені & $\begin{array}{l}800 \text { людей загинуло, } \\
44,000 \text { людей втратили } \\
\text { житло, вражено 1,400 кв. км } \\
\text { орних земель, загинуло } \\
20,000 \text { голів худоби }\end{array}$ & 0.015 млрд. \$ \\
\hline 15 & $\begin{array}{l}1994- \\
1998\end{array}$ & $\begin{array}{l}\text { Північна } \\
\text { Корея } \\
\end{array}$ & Голод & $\begin{array}{l}\text { 240,000-3,500,000 людей } \\
\text { загинуло }\end{array}$ & $\begin{array}{l}\text { Протягом } \\
4 \text { років }\end{array}$ \\
\hline 16 & $\begin{array}{l}14 \text { серпня } \\
1992\end{array}$ & $\begin{array}{l}\text { Узбережжя } \\
\text { Західної } \\
\text { Африки } \\
\end{array}$ & $\begin{array}{l}\text { Ураган Andrew } \\
\text { (Кат. 5) }\end{array}$ & $\begin{array}{l}65 \text { людей загинуло і } \\
175,000 \text { втратили житло }\end{array}$ & 26 млрд. \$ \\
\hline 17 & \begin{tabular}{|l}
13 \\
листопада \\
1985 \\
\end{tabular} & $\begin{array}{l}\text { Невадо дель } \\
\text { Руїз, Колумбія }\end{array}$ & $\begin{array}{l}\text { Виверження } \\
\text { вулкана }\end{array}$ & 25,000 людей загинуло & 1 млрд. \$ \\
\hline 18 & $\begin{array}{l}12 \text { листо- } \\
\text { пада } 1970\end{array}$ & $\begin{array}{l}\text { Бхола, } \\
\text { Бангладеш }\end{array}$ & Циклон (Кат. 3) & 500,000 людей загинуло & 0.49 млрд. \$ \\
\hline 19 & \begin{tabular}{|l} 
Червень \\
$\quad$ серпень \\
1931
\end{tabular} & $\begin{array}{l}\text { Ріка Янцзи, } \\
\text { Китай }\end{array}$ & Повені & 3,700,000 людей зе & Немає даних \\
\hline 20 & $\begin{array}{l}16 \text { грудня } \\
1920\end{array}$ & $\begin{array}{l}\text { Haiyuan, } \\
\text { Китай }\end{array}$ & Землетрус & 240,000 людей загинуло & Немає даних \\
\hline 21 & 1918 & $\begin{array}{l}\text { Іспанський } \\
\text { грип (Spanish } \\
\text { influenza) }\end{array}$ & Епідемія & $\begin{array}{l}\text { 40-100 мільйонів людей } \\
\text { померло }\end{array}$ & Немає даних \\
\hline 22 & $\begin{array}{l}28 \text { липня } \\
1876 \\
\end{array}$ & $\begin{array}{l}\text { Tangshan, } \\
\text { Китай } \\
\end{array}$ & $\begin{array}{l}\text { Землетрус (7.8 балів } \\
\text { за шкалою Ріхтера) }\end{array}$ & $\begin{array}{l}240,000 \text { людей загинуло та } \\
164,000 \text { поранених }\end{array}$ & Немає даних \\
\hline 23 & $\begin{array}{l}1775- \\
1782\end{array}$ & $\begin{array}{l}\text { Північна } \\
\text { Америка }\end{array}$ & Епідемія віспи & 11,000 людей загинуло & Немає даних \\
\hline 24 & $\begin{array}{l}1600-\text { ті } \\
\text { роки }\end{array}$ & $\begin{array}{l}\text { Європа, } \\
\text { «Велика біла } \\
\text { чума» }\end{array}$ & Епідемія & $\begin{array}{l}\text { Переважна смертність була } \\
\text { через туберкульоз }\end{array}$ & Немає даних \\
\hline 25 & $1348-1351$ & $\begin{array}{l}\text { Свропа, } \\
\text { «Чорна } \\
\text { смерть» }\end{array}$ & Епідемія & $\begin{array}{l}\text { Вимерло 25-60\% населення } \\
\text { Свропи (75-200 млн. людей) }\end{array}$ & Немає даних \\
\hline 26 & $\begin{array}{l}11 \text { жовтня } \\
1138\end{array}$ & Алеппо, Сирія & Землетрус & 230,000 людей загинуло & Немає даних \\
\hline 27 & 526 & $\begin{array}{l}\text { Антіохія, } \\
\text { Сирія }\end{array}$ & Землетрус & $\begin{array}{l}\text { 250,000-300,000 людей } \\
\text { загинуло }\end{array}$ & Немає даних \\
\hline
\end{tabular}

${ }^{\text {a } О б с я г ~ д о п о м о г и ~ н а в е д е н о ~ н а ~ ч а с, ~ к о л и ~ т р а п и л а с я ~ н е б е з п е ч н а ~ п о д і я ~}$ Джерело [2] 


\section{2. Кількісний аналіз історії небезпечних подій}

Дані, наведені у табл. 1, потребують осмислення та опрацювання. Хоч якою б не була їхня історична достовірність, але треба дати їм якомога об'єктивну кількісну оцінку. Це зроблено за допомогою табл. 2 і отриманих на ії основі залежностей (рис. 1-3).

Таблиця 2

Дані про основні катастрофи та стихійні лиха у всьому світі, підготовлені для статистичного опрацювання

\begin{tabular}{|c|c|c|c|c|c|c|}
\hline Рік & Подія & $\begin{array}{c}\text { Загинуло, } \\
\text { тис. осіб }\end{array}$ & $\begin{array}{l}\text { Поранено, } \\
\text { тис. осіб }\end{array}$ & $\begin{array}{c}\text { Безвісти } \\
\text { пропали, } \\
\text { тис. осіб }\end{array}$ & $\begin{array}{c}\text { Втратили } \\
\text { житло, } \\
\text { тис. осіб }\end{array}$ & $\begin{array}{c}\text { Втрачено } \\
\text { худоби, } \\
\text { тис. голів }\end{array}$ \\
\hline 526 & Землетрус & 275 & & & & \\
\hline 1138 & Землетрус & 230 & & & & \\
\hline 1351 & Чорна чума & 200000 & & & & \\
\hline 1665 & Біла чума & 100 & & & & \\
\hline 1782 & Віспа & 11 & & & & \\
\hline 1876 & Землетрус & 240 & 164 & & & \\
\hline 1918 & $\mid$ «ІІпанка» & 100000 & & & & \\
\hline 1920 & Землетрус & 240 & & & & \\
\hline 1931 & Повені & 3700 & & & & \\
\hline 1970 & Циклон & 500 & & & & \\
\hline 1985 & Вулкан & 25 & & & & \\
\hline 1992 & Ураган & 0,065 & & & 175 & \\
\hline 1998 & Голод & 3500 & & & & \\
\hline 2000 & Повені & 0,8 & & & 44 & 20 \\
\hline 2001 & Землетрус & 20 & 167 & & 600 & \\
\hline 2003 & Спека & 70 & & & & \\
\hline 2003 & SARS & & & & & \\
\hline 2004 & Землетрус & 310 & & & & \\
\hline 2005 & Ураган & 1,833 & & & & \\
\hline 2005 & Землетрус & 75 & 106 & & & \\
\hline 2008 & Сніжні бурі & 0,926 & & & & 415 \\
\hline 2008 & Циклон & 84,5 & & 53,8 & 74 & \\
\hline 2011 & Землетрус & 0,185 & 0,164 & 0,238 & & \\
\hline 2011 & Землетрус & & & & & \\
\hline 2012 & Землетрус & 200 & & & 2000 & \\
\hline 2012 & Посуха & & & & & \\
\hline 2013 & Повені & & & & & \\
\hline 2014 & Повені & & & & & \\
\hline 2019 & COVID-19 & & & & & \\
\hline
\end{tabular}

Авторська розробка 
До табл. 2 додані (відсутні у табл. 1) епідемія SARS у 2003 році, та пандемія COVID-19, що почалася 2019 року і ще не закінчилася.

Далі на рис. 1-3 наведена динаміка, по роках наявної історії небезпечних подій, яка характеризується їх частотою, тобто проміжком часу (у роках), який минув від попередньої події подібного роду до події, що трапилася у даному році, що розглядається.

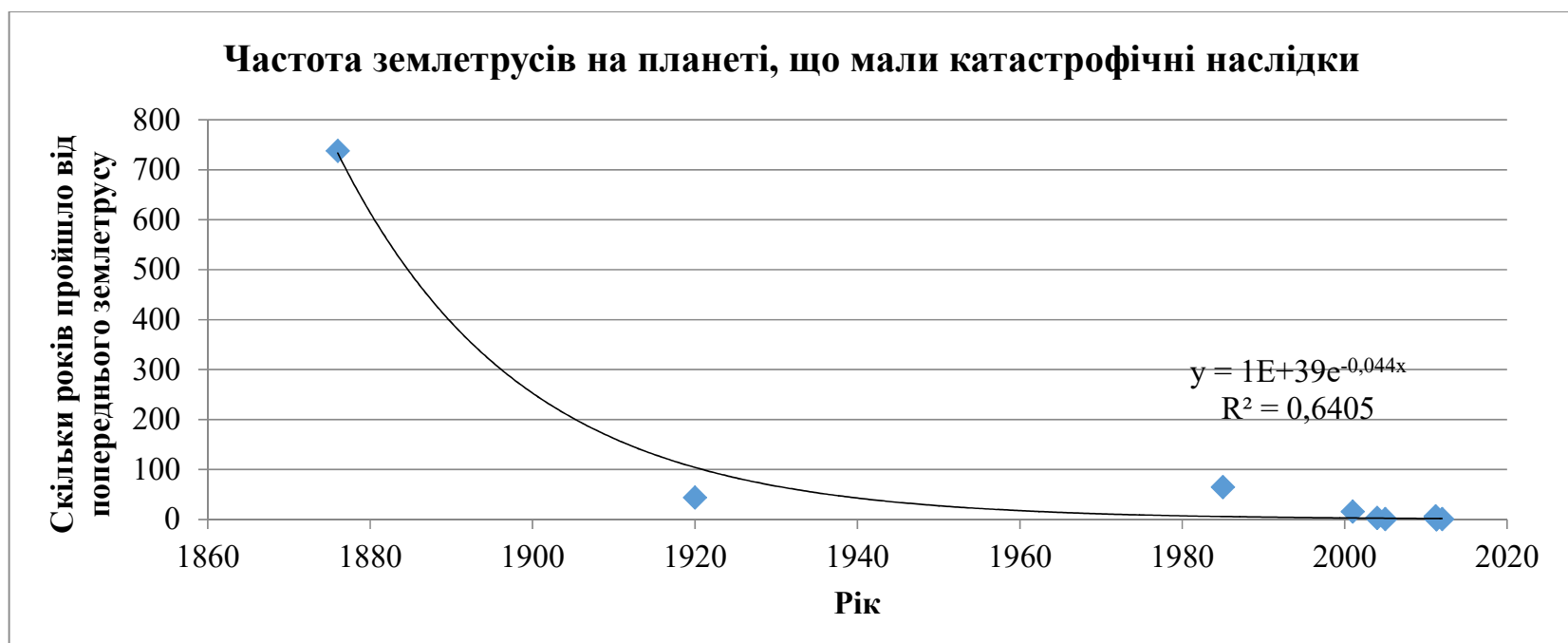

Рис. 1. Частота землетрусів на планеті, що мали катастрофічні наслідки Авторська розробка

Динаміка епідемій взагалі нагадує рух людства до катастрофи та загибелі від хвороб (рис. 2). Епідемії, пандемії трапляються в світі все частіше. Останній прилад COVID-19 у нас у всіх перед очима.

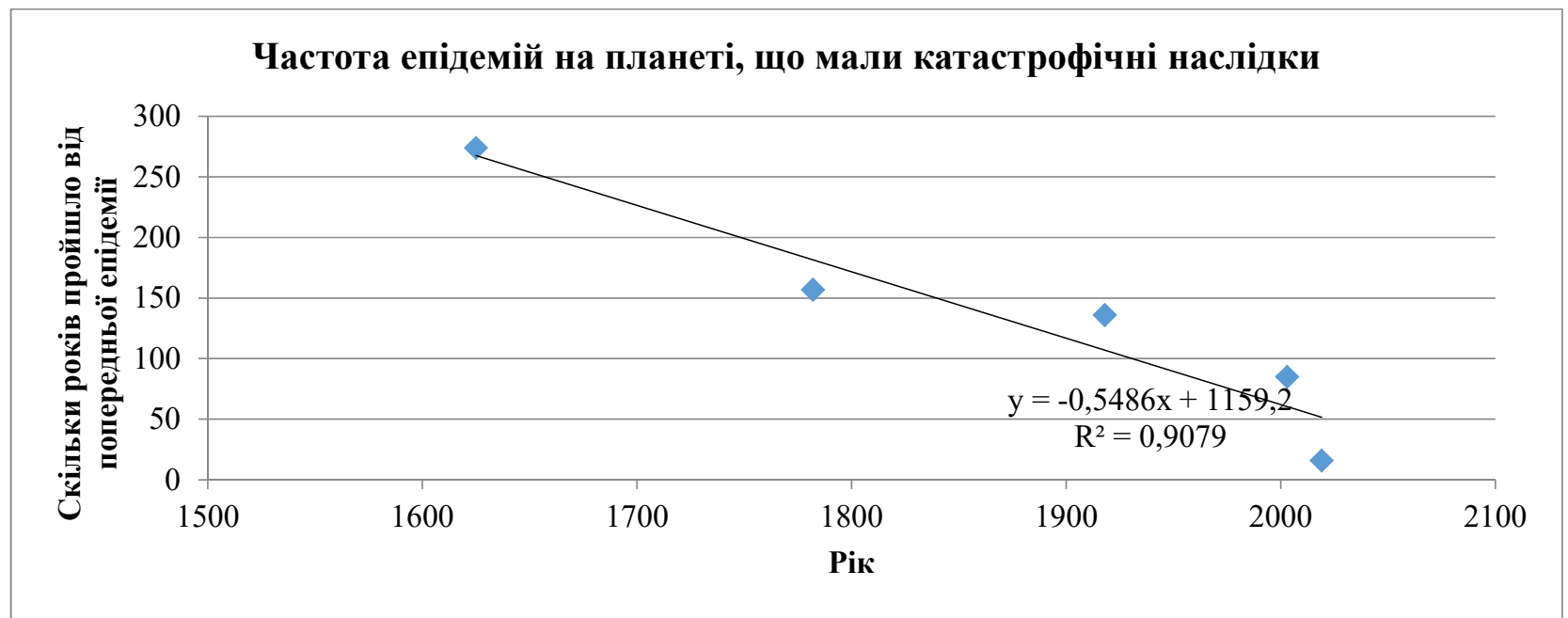

Рис. 2. Частота епідемій на планеті, що мали катастрофічні наслідки Авторська розробка 
Стихійні лиха (повені, посухи, циклони, урагани тощо), напевне пов'язані із глобальними змінами клімату, теж трапляються усе частіше (рис. 3).

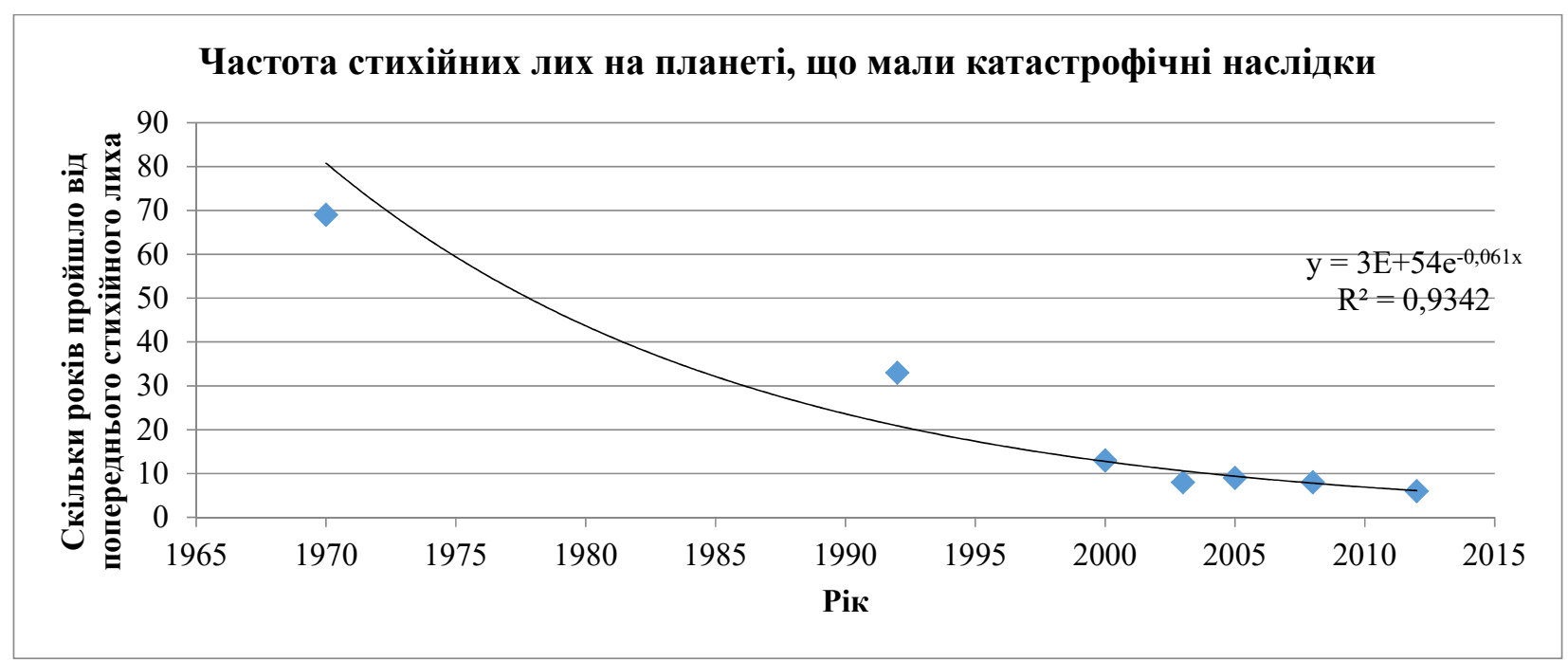

Рис. 3. Частота стихійних лих на планеті, що мали катастрофічні наслідки Авторська розробка

Як бачимо з рис. 1-3, проміжки часу між небезпечними подіями планетарного масштабу (землетруси, цунамі, епідемії, пандемії, урагани, циклони тощо) мають виразну тенденцію до скорочення. Небезпечні події наступають усе частіше, їх ймовірність усе вища. Світ, у якому ми живемо, стає все більш небезпечним, навіть не рахуючи воєн, техногенних та соціальних катастроф.

\section{3. Чому вчить історія небезпечних подій}

Треба додати, що наведена вище історична картина ще далеко не повна. Адже були і є небезпечні події меншого масштабу, так би мовити, «локальні катастрофи», які, втім, завдають конкретним людям у конкретних місцевостях не менших страждань і шкоди. Приклад — регулярні потужні повені на Закарпатті і Прикарпатті.

Напевно, через інформаційну «закритість» тодішнього Радянського Союзу до сумного переліку, що наведений у табл. 1, не потрапила аварія на Чорнобильській AEC. Тепер, через чверть століття після цієї події, варто ії згадати через масштаби втрат і заради пам'яті тих, хто першими героїчно боролися з іiі катастрофічними наслідками.

Трагедія сталася 26 квітня 1986 року о 1 год. 23 хв. на четвертому енергоблоці АЕС, де стався потужний хімічний вибух, який спричинив руйнування частини реакторного блоку і машинного залу.

Внаслідок вибуху виникла пожежа, яка перекинулася на дах третього енергоблоку. Майже одразу на місце аварії приїхали пожежники. Вогонь гасили до 
5 години ранку. Проте, у середині самого четвертого блоку його вдалося ліквідувати лише 10 травня, коли більша частина графіту згоріла.

Після вибуху та пожежі утворилася радіоактивна хмара, яка накрила не лише території сучасної України, Білорусі та Росії, але й території багатьох європейських країн - Швеції, Австрії, Норвегії, Німеччини, Фінляндії, Греції, Румунії, Словенії, Литви, Латвії. За Міжнародною шкалою ядерних подій (INES) цю аварію класифікували за найвищим - сьомим рівнем небезпеки.

Від самого початку Москва та керівництво УРСР приховували факт аварії та наслідки екологічної катастрофи. Першою про підвищення рівня радіації повідомила Швеція. Лише 28 квітня 1986 р. в СРСР з'явилося перше офіційне повідомлення.

У перші дні після аварії було евакуйоване населення 10-кілометрової зони, надалі зону евакуації розширили до 30 кілометрів. Загалом в Україні радіоактивно забрудненими стали 2293 населених пунктів, у яких на кінець вісімдесятих років минулого сторіччя мешкало понад 2,6 млн. осіб. В результаті цієї катастрофи 3 сільськогосподарського користування було виведено понад 5 млн. га земель.

Задля запобігання розповсюдженню радіації наприкінці 1986 року зруйнований реактор накрили спеціальним «саркофагом». За оцінками спеціалістів, під ним залишилося близько 95\% палива, яке було в реакторі на момент аварії, а також значна кількість радіоактивних речовин, які складаються із залишків зруйнованого реактора. 3 міркувань безпеки 15 грудня 2000 року роботу Чорнобильської АЕС було припинено. Водночас об’єкт «Укриття», зведений у 1986 році, поступово руйнувався.

Проміжний висновок. Історія Чорнобильської аварії та інших небезпечних подій в історії людства вчить тому, що їх неможливо точно спрогнозувати, передбачити усі їхні наслідки, але слід бути постійно до них готовими. Досвід показує, що ця готовність залежить від створення необхідних запасів гуманітарної допомоги, а ефективність цієї допомоги залежить від того, наскільки точно за видами, кількістю і часом вона доставляється туди, де в ній є потреба. Очевидно, що це співпадає із завданнями та функціями транспортної логістики у ланцюгу поставок специфічних предметів гуманітарної допомоги. Проте специфіка гуманітарних операцій (зокрема неможливість їх заздалегідь спланувати, критично стислий час, збереження людських життів та здоров'я як головні критерії прийняття рішення) настільки велика, що у другій половині XX століття виділилася гуманітарна логістика як окрема сфера людської діяльності та пов'язаних з нею наукових знань.

\section{4. Що таке гуманітарна логістика?}

Усі знають, що логістика виникла у військовій сфері ще в часи Олександра Македонського. Існують різні напрямки та розділи транспортної логістики, складської логістики, логістики торгівлі. Як окремі сфери діяльності виділяються: 
Логістика ресурсів крові. Логістика організації виборів. Логістика пенітенціарних закладів. Логістика кризових ситуацій. Логістика туризму...[3, 4, 5].

Тож нічого дивного, що існує і гуманітарна логістика. Звернемося до англомовної Вікіпедії [6]. Ось переклад.

...Хоча логістика в основному використовується в комерційних ланцюгах поставок, вона також $\epsilon$ важливим інструментом при ліквідації наслідків стихійних лих.

Гуманітарна логістика - це галузь логістики, яка спеціалізується на організації доставки та складування запасів під час стихійних лих або складних надзвичайних ситуацій для постраждалого району та людей.

Однак це визначення зосереджується лише на фізичному потоці товарів до кінцевих пунктів призначення, а насправді гуманітарна логістика набагато складніша і включає прогнозування та оптимізацію ресурсів, управління запасами та обмін інформацією. Таким чином, хорошим і ширшим визначенням гуманітарної логістики є:

Гуманітарна логістика - це процес планування, впровадження та контролю ефективного, економічно вигідного потоку та зберігання товарів і матеріалів, а також відповідної інформації від пункту походження до місця споживання з метою полегшення страждань вражених людей.

Джерело [2] містить п. 1.4, в якому визначено роль різних зацікавлених сторін в управлінні катастрофами (The Role of Different Stakeholders in Disaster Management).

Різні зацікавлені сторони повинні грати різні та конкретні ролі в управлінні катастрофою. Гуманітарний ланцюг поставок як природних, так i техногенних катастроф складається з різних зацікавлених сторін, а саме:

- Академічна спільнота.

- Державні органи, приватний сектор та організації з ліквідації наслідків стихійних лих.

- Інші зацікавлені сторони (місцева громада, громади, які постраждали від стихійних лих, та донори).

Важливу роль для посилення ефекту гуманітарних зусиль у ситуаціях після стихійних лих відіграють технології [7].

До чого в гуманітарній логістиці академічна спільнота? Насправді ії роль дуже важлива:

Академічне співтовариство відіграє важливу роль у навчанні та дослідженнях гуманітарної логістики. Ключові ролі академічного співтовариства - це освіта, дослідження та розвиток бази знань для обміну передовим досвідом.

Щоб краще зрозуміти суть та функції гуманітарної логістики, наведемо приклади з життя [8] (авторський переклад).

\section{Вирішення проблем відбудови в Косово}

Після закінчення війни була потрібна масштабна програма відбудови, щоб забезпечити належне житло для біженців та ВПО (внутрішньо переміщених осіб), які повертаються. Відразу по закінченню війни $100 \%$ будівельних матеріалів та інструментів повинні були надходити із зовнішніх джерел від сусідів Косова. Для перевезення товарів до Косова потрібно було мобілізувати сотні вантажівок, а по-

$$
-210-
$$


тім у країні було потрібно кілька тисяч вантажівок, сільськогосподарських тракторів з причепами чи інших легких транспортних засобів, щоб доставити ці товари до кінцевих пунктів призначення. Дороги не були побудовані для такого інтенсивного руху; достатні запаси пального були відсутні; приміщення для зберігання та передачі були зруйновані або розграбовані; комунальні об'єкти ще не були відремонтовані; безпека все ще була проблемою; а системи відстеження транспортних засобів та вантажів часто були ручними. Місцевий персонал повинен був навчитися більшості відповідних аспектів управління ланцюгами поставок.

\section{Ірак: швидкість доставки}

Березневого суботнього ранку 2003 року мені зателефонував керівник нашої регіональної команди в Аммані з проханням терміново перевезти предмети першої необхідності в надзвичайних ситуаціях, матеріали та транспортні засоби. Я негайно зателефонував нашому головному логісту, який далі телефонував нашому логістичному персоналу в Італії, Німеччині та США. До ранку понеділка ми отримали пропозиції на наші запити. До ранку у вівторок було обрано та мобілізовано перевізника. До ранку в середу всі товари були підготовлені до відвантаження. Ранком четверга літак був на злітній смузі в аеропорту Бріндізі. Того ж дня в Аммані він приземлився з 40 тонами вантажів і був розвантажений та вивантажений протягом декількох годин. Серед вивантаженого були три транспортних вантажівки, 10000 розбірних контейнерів для води та таблеток для ії очищення, 6300 ковдр та 1800 пластикових брезентів. До вихідних — через сім днів після первинного телефонного дзвінка - ці товари прямували до регіональних пунктів призначення у готовності до можливого напливу біженців з Іраку.

\section{Пересування людей із зон конфлікту}

Коли розгорається конфлікт, велику кількість людей часто доводиться переселяти із районів конфлікту в безпечні зони - у тимчасові транзитні центри, центри розшуку, табори ВПО та табори біженців. Хоча зазвичай це роль $\mathrm{OOH}$, в цьому часто просять взяти участь НУО (неурядові організації) та інші організації. Логістика має вирішальне значення для успішної операції: знайти та мобілізувати необхідні великі транспортні засоби та забезпечити достатню кількість палива, що не є простим завданням, коли паливо відсутнє на місцевих ринках. Крім того, всі потреби у підтримці людей, що перевозяться, залежать від логістики: потреби їжі, води, санітарії та житла.

Тут нема чого додати, дійсно приклади з життя. Хіба що замінити «Косово» на «ОРДЛО».

Фахівець $з$ гуманітарної логістики, як видно $з$ наведених прикладів, повинен бути дуже різностороннім. Він повинен володіти професійними компетенціями у багатьох сферах - від транспортних технологій і логістики до кризис- та рискменеджменту, від знання системи цивільного захисту до основних понять медицини катастроф, міжнародного транспортного права і митної справи. 
Таблиця 3

Матриця гуманітарних дій

\begin{tabular}{|c|c|c|c|}
\hline \multirow{2}{*}{$\begin{array}{c}\text { Завдання } \\
\text { та функ- } \\
\text { ції ГЛ }\end{array}$} & \multicolumn{3}{|c|}{ Учасники } \\
\hline & Академічні заклади & Державні органи & $\begin{array}{c}\text { Інші зацікавлені } \\
\text { сторони }\end{array}$ \\
\hline $\begin{array}{l}\text { Готов- } \\
\text { ність }\end{array}$ & \begin{tabular}{|l|} 
Започаткування програм \\
обізнаності та розвитку, \\
навчальних програм на рівні \\
села, кварталу чи району; \\
інститути проводять передові \\
дослідницькі курси
\end{tabular} & $\begin{array}{l}\text { (Три «Пі»)3 P’s-planning, } \\
\text { preparing, and practice; } \\
\text { організація тренувань; } \\
\text { навчання людей для } \\
\text { прищеплення правильної } \\
\text { системи цінностей }\end{array}$ & $\begin{array}{l}\text { Громади, які слід } \\
\text { зробити стійкими до } \\
\text { стихійних лих }\end{array}$ \\
\hline $\begin{array}{l}\text { Реагу- } \\
\text { вання }\end{array}$ & $\begin{array}{l}\text { Співпраця уряду / } \\
\text { дослідників / місцевої } \\
\text { екосистеми задля кращого } \\
\text { реагування на катастрофи }\end{array}$ & $\begin{array}{l}\text { Заходи реагування з метою } \\
\text { швидкої евакуації та } \\
\text { реабілітації }\end{array}$ & $\begin{array}{l}\text { Координація } \\
3 \text { державними } \\
\text { органами для } \\
\text { ефективної логістики }\end{array}$ \\
\hline Технології & \begin{tabular}{|l|} 
Ефективність інформаційно- \\
комп’ютерних технологій \\
(ІКТ) при координації під час \\
управління катастрофами та \\
реагування на них. Вивчення \\
ефективності систем підтрим- \\
ки прийняття рішень (СППР) \\
та ГІС у підготовці та лікві- \\
дації наслідків стихійних лих
\end{tabular} & $\begin{array}{l}\text { Активність та прозорість } \\
\text { державної політики та } \\
\text { систем; ефективні мережі } \\
\text { поставок в райони, що } \\
\text { постраждали від стихійних } \\
\text { лих; використання } \\
\text { цифрової карти / } \\
\text { комунікаційні технології / } \\
\text { Інтернет }\end{array}$ & $\begin{array}{l}\text { Створення мережі } \\
\text { постачальників для } \\
\text { реагування на } \\
\text { надзвичайні ситуації } \\
\text { та підготування } \\
\text { довгострокових угод }\end{array}$ \\
\hline $\begin{array}{l}\text { Координа- } \\
\text { ція }\end{array}$ & $\begin{array}{l}\text { Мінімізація шкоди } \\
\text { екосистемі; необхідність } \\
\text { підвищувати цінність } \\
\text { безкорисливості; розвиток } \\
\text { спільної бази знань }\end{array}$ & $\begin{array}{l}\text { Участь людей та суспільст- } \\
\text { ва; підтримувати стосунки } \\
3 \text { третіми особами або залу- } \\
\text { ченими установами; запит } \\
\text { на належне та скоордино- } \\
\text { ване спрямування та } \\
\text { використання ресурсів }\end{array}$ & $\begin{array}{l}\text { Координація між } \\
\text { попитом громади, яка } \\
\text { постраждала } \\
\text { внаслідок стихійних } \\
\text { лих, та відповідними } \\
\text { пропозиціями донорів }\end{array}$ \\
\hline Закупівлі & $\begin{array}{l}\text { Ініціативні, екстрені та } \\
\text { прискорені закупівлі; } \\
\text { ефективність політики } \\
\text { закупівель для реагування на } \\
\text { катастрофи; вивчення } \\
\text { гнучких моделей реагування } \\
\text { на катастрофи на основі вигід } \\
\text { та витрат }\end{array}$ & $\begin{array}{l}\text { Правила закупівель у ви- } \\
\text { падках стихійних лих чіткі, } \\
\text { але установи не завжди до } \\
\text { цього готові, тому існує } \\
\text { необхідність у ефектив- } \\
\text { ному механізмі }\end{array}$ & \\
\hline
\end{tabular}

\section{Джерело [2]; Авторське доопраиювання}

Чим практично займаються в сфері гуманітарної логістики (ГЛ) різні їі учасники (зацікавлені сторони)? Відповідь на це питання у згаданому вище джерелі [2]. 


\section{5. Міжнародна співпраця та організації в галузі гуманітарної логістики}

Гуманітарна допомога часто вимагає міжнародної співпраці, а однією з функцій гуманітарної логістики є організувати в кожній конкретній надзвичайній ситУації ЕФЕКТИВНИЙ ГУМАНІТАРНИЙ ЛАНЦЮГ ПОСТАВОК від донорів ГУманітарної допомоги до іï реципієнтів у постраждалих районах. Тут не обійтись між спеціалізованих організацій та міжнародної співпраці.

Серед організацій, що працюють у сфері надання та розподілу гуманітарної допомоги, слід відзначити Червоний Хрест (штаб-квартира в Женеві, Швейцарія) та Організацію об’єднаних націй (ООН, штаб-квартира в Нью-Йорку), які мають відповідні структури в Україні.

Більше інформації про Червоний хрест та Товариство Червоного Хреста України можна знайти на їх офіційних веб-сайтах [9, 10].

Ось приклад діяльності Товариства Червоного Хреста України.

Логістичний супровід гуманітарної допомоги Донбасу забезпечуватиме Червоний Хрест (Корреспондент.net, 11 серпня 2014, 20:37)

Агентство ООН у справах біженців (УВКБ ООН) доправило 92 тони гуманітарного вантажу в Луганськ. Гуманітарний вантаж забезпечить вкрай необхідну допомогу та підтримку цивільному населенню, яке постраждало внаслідок конфлікту [11].

10 вересня 2020 року до Луганська прибув гуманітарний конвой Агентства ООН у справах біженців (УВКБ ООН). Це перший конвой з моменту введення карантинних заходів у зв'язку з пандемісю коронавірусу, коли майже весь рух через «лінію розмежування» було припинено 3 метою попередження поширення COVID-19, включаючи обмеження руху гуманітарних конвоїв.

\section{6. Гуманітарний логіст — «синтетичний фахівець»}

Як було сказано вище, фахівець з гуманітарної логістики повинен бути дуже різностороннім. Він повинен «синтезувати» в своїй діяльності знання та вміння з багатьох суміжних галузей.

Він повинен знати технологію та організацію перевезень та надання транспортних послуг, володіти принципами та інструментами транспортної логістики, розуміти, що його професійна діяльність спрямована на надання ефективної гуманітарної допомоги в умовах жорстких ресурсних обмежень 3 метою ПОЛЕГШЕННЯ СТРАЖДАНЬ ЛЮДЕЙ, і це те, що його відрізняє від транспортного логіста, який працює у сфері комерційних, а не гуманітарних ланцюгів поставок.

Отже, складається така картина взаємозв’язків між розглянутими вище галузями діяльності. На найвищий рівень ієрархії понять можна поставити управління ланцюгами поставок (УЛП), по відношенню до якого логістика, транспортна логістика (ТЛ) і транспортні технології (ТТ) є засобами, інструментами виконання 
певних функцій. Транспортні технології безперервно розвиваються і пройшли в своій еволюції від унімодальних (один вид транспорту на всьому шляху доставки) до бімодальних, інтермодальних та мультимодальних (багато видів транспорту), як це показано на схемі нижче (рис. 4).

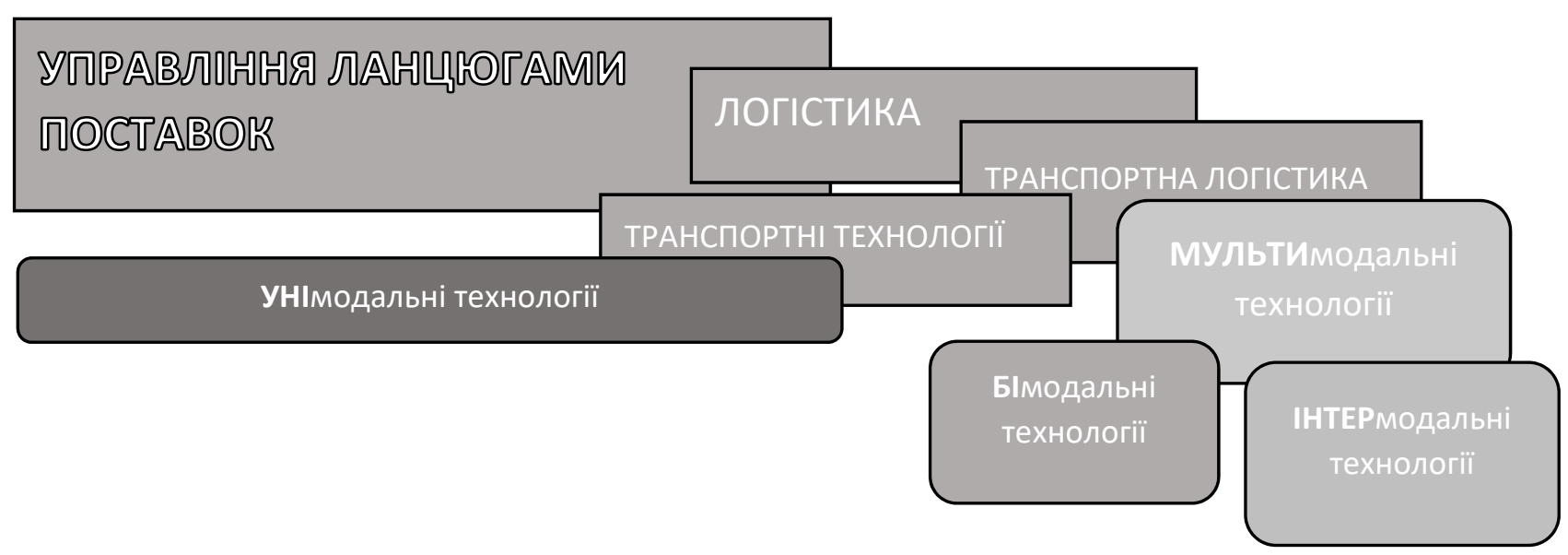

\section{Рис. 4. Транспортні технології} Авторська розробка

У багатьох дослідженнях відзначається, що часто найбільш ефективними для надання та розподілу гуманітарної допомоги $є$ інтермодальні та мультимодальні технології, деякі види та можливості яких описані нижче.

\section{7. Суміжні галузі - інтермодальний та мультимодальний транспорт}

Транспортні технології безперервно розвиваються і пройшли в своїй еволюції від унімодальних (один вид транспорту на всьому шляху доставки) до мультимодальних (багато видів транспорту).

Розглянемо деякі з транспортних технологій, що поєднують можливості двох чи більше видів транспорту.

\section{Технологія бімодального транспорту RoadRailer}

Що таке технологія RoadRailer? Перші роуд-рейлери для бімодальних залізнично-автомобільних перевезень з'явилися у США у 1950-х роках. Це перевезення у спеціальних поїздах, сформованих з автомобільних напівпричепів.

Роудрейлери - це залізничні вагони з комбінованими ходовими частинами. Вони мають постійні або знімні взаємозамінні ходові частини і призначені для руху по залізницях і автомобільних дорогах.

Склади (состави поїздів) з роудрейлерів формуються і розформовується на спеціально обладнаних коліях залізничних станцій. При формуванні складів передня частина роудрейлера зчіплюється 3 задньою частиною попереднього.

$$
-214-
$$


Перший роудрейлер подається заднім ходом автомобілем-тягачем на залізничні колії, потім опускаються опорні катки і з-під його виїжджає автомобіль-тягач. Потім подається другий роудрейлер, третій і т. д.

Після формування складу подається локомотив, до якого причеплено спеціальний візок, що встановлюється під передню частину роудрейлера, що знаходиться в голові складу, і опорні катки піднімаються. При розформування складів операції проводяться в зворотному порядку. Краще уявлення про цю технологію дають відео $[19,20,21]$, посилання на які наведені в кінці списку джерел до даного розділу.

Мають досвід таких перевезень Британія, Бразилія, Канада, Нова Зеландія, Німеччина, Австрія, Австралія.

Технологія бімодального транспорту Modalohr

В Західній Європі більшого розповсюдження набула технологія системи Modalohr, або LOHR, за назвою французької компанії, яка виробляє залізничний рухомий склад для цього виду бімодальних перевезень. Особливістю такого рухомого складу $є$ верхня поворотна частина залізничного вагона-платформи (приблизно на $45^{\circ}$ до осі вагона і колії), на яку можуть заїжджати (чи навантажуватися вертикально) автотранспортні засоби. Наочне уявлення про цю технологію можна отримати з відео $[22,23]$, посилання на які наведені в кінці списку джерел.

У бімодальному транспорті «жорстко» зв'язані між собою за допомогою різних технологічних рішень два види транспорту — автомобільний та залізничний. Але в перевезенні вантажу може брати участь і більша кількість видів транспорту, в різних сполучення і послідовності. Тому є поняття «інтермодальні» та «мультимодальні» перевезення.

Ці терміни часто плутають або вживають некоректно. Навіть серед фахівців можна зустріти різні їх тлумачення. Почнемо 3 документа [12] Європейської економічної комісії $\mathrm{OOH}$, офіційний переклад з англійської на російську мову (одну з робочих мов $\mathrm{OOH}$ ) наведено нижче.

G. ИНТЕРМОДАЛЬНЫЕ ГРУЗОВЫЕ ПЕРЕВОЗКИ G.I. ВВЕДЕНИЕ

G.I-01. Интермодальные грузовые перевозки

Мультимодальные перевозки грузов (в одной и той же грузовой единице или на одном и том же транспортном средстве) последовательно используемыми видами транспорта без обработки самих грузов при изменении вида транспорта. Под интермодальным транспортным средством подразумевается дорожное транспортное средство, железнодорожное транспортное средство или судно. Обратные перевозки порожних контейнеров/съемных кузовов и обратное перемещение порожних грузовых дорожных транспортных средств/прицепов сами по себе не являются составной частью интермодальных перевозок, поскольку в этом случае не транспортируется никаких грузов. Такие перевозки ассоциируются с интермодальными перевозками, поэтому целесообразно собирать данные о перемещении порожних транспортных средств вместе с данными об интермодальных перевозках. 


\section{G.I-02. Мультимодальные грузовые перевозки}

Перевозка грузов по меньшей мере двумя разными видами транспорта. Интермодальные перевозки являются отдельным видом мультимодальных перевозок. Международные мультимодальные перевозки часто осуществляются на основании договора полной мультимодальной перевозки.

Вітчизняні фахівці, зокрема з Комітету з мультимодальних перевезень Асоціації «Український логістичний альянс» [13], вважають, що ці формулювання неповні, і доповнюють їх, вводячи «умови мультимодальності» для інтермодальних перевезень:

- два чи більше види транспорту;

- один оператор мультимодального перевезення, який за нього несе відповідальність перед клієнтом за доставку вантажу від його приймання до видачі;

- один договір мультимодального перевезення;

- одна ціна, яку платить клієнт за договором мультимодального перевезення, що включає всі тарифи, плати, збори.

Коли ці умови виконуються, то такі мультимодальні перевезення є найбільш зручними для клієнтів, однак потребують відповідних ресурсів, знань та вмінь від оператора мультимодального перевезення, який відповідає за його організацію.

\section{8. Суміжні галузі - цивільний захист і медицина катастроф}

$€$ така сфера діяльності, в якій професійно і постійно займаються надзвичайними ситуаціями, і ця сфера діяльності називається цивільний захист.

Наслідки надзвичайних ситуацій звичайно такі, що першочергово постраждалим потрібна медична допомога. Тому для здійснення цивільного захисту набули розвитку такі специфічні види медицини, як медицина катастроф, медицина надзвичайних ситуацій, медицина екстремальних ситуацій (екстремальна медицина).

Як правило, надання медичної допомоги неможливе без доставки її засобів на місце надзвичайної ситуації або забезпечення доступу постраждалих до таких засобів. Приклад останній, хоч і одиничний, але яскравий - отруєння Навального в Росії та подальші події, про які $є$ інформації в Google.

Розглянемо далі питання цивільного захисту та медичної допомоги, заради яких і здійснюються функції гуманітарної логістики.

Передусім, сферу цивільного захисту законодавчо врегульовує Кодекс цивільного захисту [14].

Кодекс визначає, що цивільний захист - це функція держави, спрямована на захист населення, територій, навколишнього природного середовища та майна від надзвичайних ситуацій шляхом запобігання таким ситуаціям, ліквідації їх наслідків і надання допомоги постраждалим у мирний час та в особливий період.

Надзвичайні ситуації класифікуються за характером походження, ступенем поширення, розміром людських втрат та матеріальних збитків.

$$
-216-
$$


Залежно від характеру походження подій, що можуть зумовити виникнення надзвичайних ситуацій на території України, визначаються такі види надзвичайних ситуацій: 1) техногенного характеру; 2) природного характеру; 3) соціальні; 4) воєнні.

Додаткові відомості за темою «Цивільний захист» можна знайти у джерелі [15].

Медицина катастроф. (Медицина надзвичайних ситуацій. Медицина екстремальних ситуацій. Екстремальна медицина).

Медицина катастроф - це галузь медицини, яка представляє собою особливу систему наукових знань та своєрідну форму практичної діяльності що спрямовані на розробку стратегії та тактики надання екстреної медичної допомоги великій кількості постраждалих в надзвичайних ситуаціях при гострій нестачі медичних сил та засобів системи охорони здоров'я.

Основні поняття медицини катастроф висвітлені в роботі [16].

Ця робота, зокрема, містить класифікацію катастроф.

Залежно від кількості постраждалих, катастрофи розподіляються на:

- малі (під час котрих було поранено та загинуло 50-100 осіб, чи потребують госпіталізації 10-50 осіб);

- середні (під час котрих було поранено та загинуло 101-1000 осіб, чи потребують госпіталізації 51-250 осіб);

- великі (під час котрих було поранено та загинуло понад 1000 осіб, чи потребують госпіталізації понад 250 осіб).

У 2013 році був прийнятий Закон України «Про екстрену медичну допомогу» [17], який визначає організаційно-правові засади забезпечення громадян України та інших осіб, які перебувають на іiі території, екстреною медичною допомогою, у тому числі під час виникнення надзвичайних ситуацій та ліквідації їх наслідків.

Відповідно до цього закону домедична допомога - невідкладні дії та організаційні заходи, спрямовані на врятування та збереження життя людини у невідкладному стані та мінімізацію наслідків впливу такого стану на ії здоров'я, що здійснюються на місці події особами, які не мають медичної освіти, але за своїми службовими обов'язками повинні володіти основними практичними навичками з рятування та збереження життя людини, яка перебуває у невідкладному стані, та відповідно до закону зобов'язані здійснювати такі дії та заходи. Вдале вирішення задач організації медичного забезпечення населення при аваріях, катастрофах і стихійних лихах у більшості визначається основними принципами екстреної медичної допомоги (ЕМД).

Розрізняють 3 фази надання допомоги постраждалим при катастрофах.

Перша фаза (ізоляції). Тривалість цієї фази визначається від моменту катастрофи до початку виконання рятувальних робіт (хвилини, години, добу). Вона характеризується тим, що допомога постраждалому населенню ззовні неможлива, масштаби лиха ще не оцінили, а незахищене населення проблему виживання вирішує шляхом надання само- та взаємодопомоги. 
Друга фаза (порятунку). У цю фазу проводяться рятувальні роботи загонами, що прибувають з районів, які не постраждали від лиха, розгортаються медичні формування для надання невідкладної медичної допомоги, що здійснюють сортування і зосередження постраждалих за життєвими показаннями, евакуацію. Тривалість цісї фази 10-12 днів.

Третя фаза (відновлення). Для постраждалих ця фаза починається після евакуації їх у безпечні райони, де $\epsilon$ всі умови для повноцінного обстеження, подальшого лікування і подальшої реабілітації на рівні сучасних досягнень медичної науки і практики.

Особливої уваги при організації надання допомоги потребує евакуація по-

\section{страждалих.}

Евакуація — комплекс заходів з винесення і вивозу постраждалих із зони $\mathrm{HC}$, доставка їх на медичні пункти і до лікувальних закладів для надання своєчасної та необхідної медичної допомоги та лікування. Для евакуації використовують різні санітарно-транспортні засоби та всі види громадського транспорту, а також транспорт індивідуального користування. Транспортування (евакуацію) можна розділити на невідкладну (першої черги) - для постраждалих у стані, що загрожує життю, або з пошкодженнями, які при затримці надання допомоги призводять до незворотних наслідків, і відстрочену (другої черги) - для постраждалих, затримка евакуації у яких не приведе до розладу життєво важливих функцій організму. Маршрут, за яким здійснюється вихід, винос і транспортування уражених, носить назву «шлях медичної евакуації».

Керівництво цією роботою покладається на представників територіальних комісій з надзвичайних ситуацій.

\section{9. Катастрофи на залізниці}

Основними причинами залізничних катастроф є:

- порушення вимог технічної експлуатації колійного господарства та правил безпеки при транспортуванні вантажу;

- дії зовнішніх факторів - у зонах стихійних лих, техногенних катастроф на підприємствах газової та нафтової промисловості, вибухів, пожеж тощо:

- неправильні дії (бездіяльність) локомотивних бригад та чергового персоналу станції;

- зіткнення з перешкодами (машини, люди, тварини);

- терористичні акти.

Особливу небезпеку несуть аварійні ситуації при перевезеннях РP (радіоактивних речовин) та СДОР (сильнодіючих отруйних речовин). Ці аварії можуть призвести до небезпечного опромінення людей та радіоактивного забруднення довкілля, а при впливі СДОР - до гострого отруєння людей та хімічного забруднення повітря, грунту, об’єктів колійного господарства та прилеглих населених пунктів. 
Складні обставини можуть скластися в наслідок аварії в межах залізничної станції. Як правило, до залізничних вузлів примикає міська (сільська) забудова з високою щільністю населення. На відносно малої території станції зазвичай зосереджуються велика кількість вагонів з різноманітним вантажем. На станції можуть знаходитися значні групи людей - у поїздах, на платформах, у будівлі вокзалу тощо. Це створює загрозу підчас вибуху, забрудненням повітря СДОР та іншими агресивними хімікатами.

Залізничні аварії і катастрофи класифікуються за видом рухомого складу та кількістю постраждалих.

Залежно від чисельності потерпілих катастрофи на залізничному транспорті поділяють на 5 категорій :1) - до 5 чол.; 2) - від 6-15 чол.;

3) - 16-30 чол.; 4) - 31-50 чол.; 5) - більше 50 чол.

Види уражень при залізничних катастрофах можуть бути наступні:

- механічні травми - 90,0\%;

- механічні травми плюс термічні опіки - 10,0\%;

- гострі отруєння плюс хімічні опіки;

- радіаційні ураження;

- комбіновані та поєднанні ураження.

Структура санітарних втрат за ступенем тяжкості ушкоджень може бути наступною:

- легко уражені - 35,0-40,0\%;

- уражені середнього та тяжкого ступеня - 20,0-25,0\%;

- дуже тяжко уражені - 20,0\%;

- в термінальному стані - 20,0\%.

За локалізацією при залізничних катастрофах ушкодження розподіляються наступним чином: голова $-60,0 \%$, кінцівки до $35,0 \%$, груди, живіт 3 розривом внутрішніх органів - більше 20,0\%, стегно та крупні суглоби - до 10,0-12,0\%

Характерними рисами аварій на залізниці є ймовірність травматичних ампутацій та складність вивільнення постраждалих 3 під конструкцій вагонів та локомотива.

Залізничні катастрофи часто відбуваються вночі, інколи у важкодоступних місцях, на перегонах, вдалі від населених пунктів. Ліквідація наслідків цих катастроф в значної мірі визначається оперативної інформацією диспетчерської службою проте те, що сталося.

При організації екстреної медичної допомоги (ЕМД) постраждалим під час залізничних катастроф, особливо при значному віддаленні від населених пунктів, необхідно: 3 максимальним ступенем достовірності з'ясувати розміри катастрофи i iii точні координати, інформувати найближчі лікувальні заклади. Як і при інших катастрофах, на місці залізничної катастрофи створюються пункти збору постраждалих, проводиться їх медичне сортування, надання ЕМД і евакуація до лікувального закладу. 
Як бачимо із сказаного, гуманітарний логіст у своїй діяльності взаємодіє з суміжними сферами цивільного захисту та медицину катастроф (зокрема, на стадії планування та організації транспортного забезпечення евакуації), тому повинен знати основи їх діяльності.

\subsection{0. Класифікація, причини і наслідки надзвичайних ситуацій (НС) різного походження}

Залежно від обсягів заподіяних надзвичайною ситуацією наслідків, обсягів технічних і матеріальних ресурсів, необхідних для їх ліквідації, визначаються такі рівні надзвичайних ситуацій: 1) державний; 2) регіональний; 3) місцевий; 4) об’єктовий.

Порядок класифікації надзвичайних ситуацій за їх рівнями встановлюється Кабінетом Міністрів України.

3 урахуванням положень Кодексу цивільного захисту, надзвичайні ситуації (НС) різного походження мають причини і наслідки різного виду та ступеню (табл. 4).

Таблиця 4

Причини походження та наслідки надзвичайних ситуацій різних рівнів

\begin{tabular}{|c|c|c|c|}
\hline $\begin{array}{l}\text { Причини НС } \\
\text { (походження) }\end{array}$ & Ознаки НС & Наслідки НС (ступінь) & Рівень НС \\
\hline $\begin{array}{l}\text { техногенного } \\
\text { характеру; } \\
\text { природного } \\
\text { характеру; } \\
\text { соціальні; } \\
\text { воєнні. }\end{array}$ & $\begin{array}{l}\text {...обстановка ..., } \\
\text { яка характеризу- } \\
\text { ється порушен- } \\
\text { ням нормальних } \\
\text { умов життєдіяль- } \\
\text { ності } \\
\text { населення,... }\end{array}$ & $\begin{array}{l}\text {...катастрофа, аварія, поже- } \\
\text { жа, стихійне лихо, епідемія, } \\
\text { епізоотія, епіфітотія, ... (та } \\
\text { ін.) що становить загрозу } \\
\text { життю або здоров'ю населен- } \\
\text { ня чи призводить до завдання } \\
\text { матеріальних збитків }\end{array}$ & $\begin{array}{l}\text { державний; } \\
\text { регіональ- } \\
\text { ний; } \\
\text { місцевий; } \\
\text { об'єктовий. }\end{array}$ \\
\hline
\end{tabular}

Джерело [14]; Авторське доопраџңювання

\subsection{1. Математичні моделі та оптимізаційне моделювання в гуманітарній логістиці}

Можливості застосування математичних методів розглянемо на прикладі графічного (у вигляді орієнтованого графу станів системи) та вербального (словесного), а згодом і формалізованого (математичного) опису ситуації розповсюдження захворювання COVID-19 та впливу транспортного обслуговування на параметри моделі. При цьому використаємо опубліковані результати дослідження [18]. 


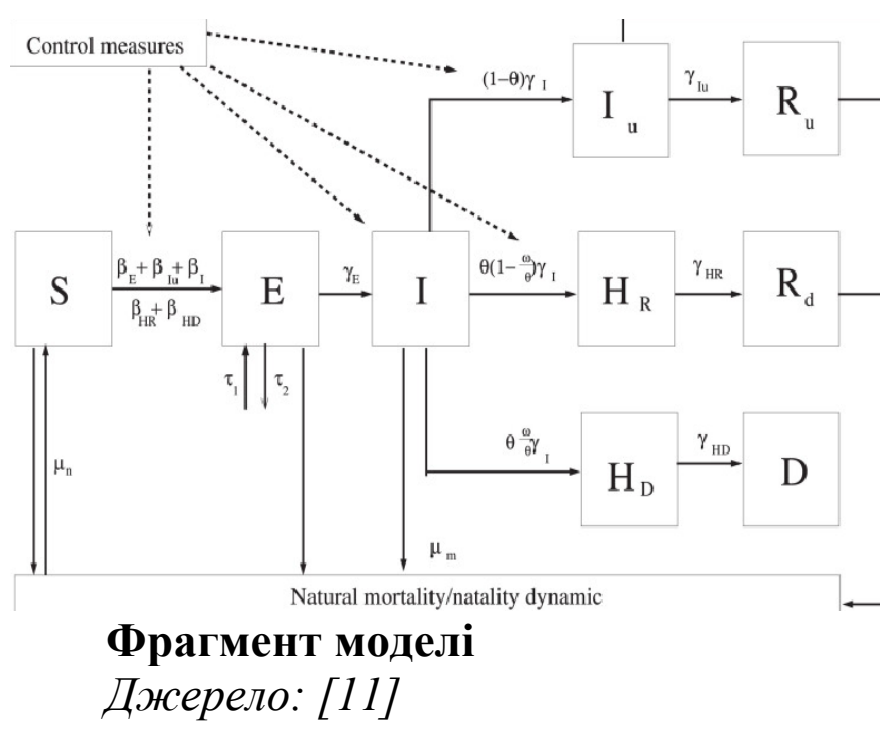

Математична модель грунтується на графічному, вербальному (словесному) та аналітичному (за допомогою формул) описі поширення інфекції як процесу переходу людини iз стану в стан 3 певними ймовірностями переходу (фрагмент рисунку зліва).

Ці стани та ймовірності позначені у квадратах великими латинськими літерами $з$ нижніми індексами та формулами. Нижче наводяться пояснення.

Швидкість розповсюдження інфекції може бути змінена за допомогою тих чи інших заходів контролю (Control measures). Стани людини, через які вона може пройти, наступні:

- Сприйнятливий (позначається S): людина не заражена збудником захворювання.

• Виявлений (позначається Е): людина перебуває в інкубаційному періоді після зараження збудником хвороби і не має видимих клінічних ознак. Індивід міг заразити інших людей, але 3 меншою ймовірністю, ніж люди в інфекційних відділеннях. Після інкубаційного періоду людина переходить в інфекційний стан I.

- Інфекційний (позначається I): Після інкубаційного періоду це перший стан інфекційного періоду, де ще ніхто не очікує його виявити. Людина закінчила інкубаційний період, може заразити інших людей і починають розвиватись клінічні ознаки. По закінченню цього періоду люди в цьому стані можуть бути або виявлені санітарними органами (і ми класифікуємо їх як госпіталізованих), або не виявлені владою і продовжуватися як інфекційні (але в іншому стані, Iu).

- Інфекційний, але не виявлений (позначається Iu): Перебуваючи у стані I, людина все ще може заражати інших людей, має клінічні ознаки, але не може бути виявлена та повідомлена органам влади. Ми припускаємо, що до цього стану можуть дійти лише люди з низькими або середніми симптомами, а не люди, які помруть. Після цього люди в цьому відділенні переходять у стан тих, що одужали Ru.

- Госпіталізований або вдома на карантині (але виявлений та повідомлений органами влади), який відновиться (позначається HR): людина перебуває в лікарні (або вдома на карантині) і все ще може заразити інших людей. Після цього стану людина переходить у стан Rd.

- Госпіталізований, який помре (позначається HD): людина госпіталізована і все ще може заразити інших людей. Після закінчення цього стану людина переходить у стан померлих.

• Померлий від COVID-19 (позначається D): людина не пережила хвороби. 
- Одужав після попереднього виявлення як інфекційний (позначається Rd): людина раніше була виявлена як інфекційна, пережила хворобу, більше не є інфекційною і виробила природний імунітет до вірусу. Коли людина потрапляє в цей стан, вона залишається в лікарні протягом періоду відновлення Со днів (в середньому).

- Вилікувався після того, як раніше був інфекційним, але не виявленим (позначається Ru): Людина раніше не була виявлена як інфекційна, пережила хворобу, більше не $\epsilon$ інфекційною і виробила природний імунітет до вірусу.

Ці стани описані для загального розуміння суті математичної моделі, а також для того, щоб дати приклад застосування математики для описання та прогнозування найрізноманітніших явищ. Математики в цитованій статті та моделі дуже багато (див. ілюстрацію на вставці нижче), і ії докладний розгляд не є зараз нашою метою.

Under those assumptions, the evolution of the compartments mentioned above is modeled by the following system of ordinary differential equations (which is simplified below):

$$
\begin{array}{cc}
\frac{\mathrm{d} S^{(i)}}{\mathrm{d} t}(t)= & -\frac{S^{(i)}(t)}{N^{(i)}}\left(m_{E}^{(i)}(t) \beta_{E}^{(i)} E^{(i)}(t)+m_{I}^{(i)}(t) \beta_{I}^{(i)} I^{(i)}(t)\right. \\
& \left.+m_{I_{\mathrm{u}}}^{(i)}(t) \beta_{I_{\mathrm{u}}}^{(i)}\left(\theta^{(i)}(t)\right) I_{\mathrm{u}}^{(i)}(t)\right)
\end{array}
$$

Фрагмент моделі. Джерело: [18]

У підсумку математична модель дає задовільне співпадіння прогнозованих теоретичних результатів 3 практичними статистичними даними (криві справа). Тобто модель адекватна, достовірно відображає реальні процеси захворюваності та смертності від COVID-19.
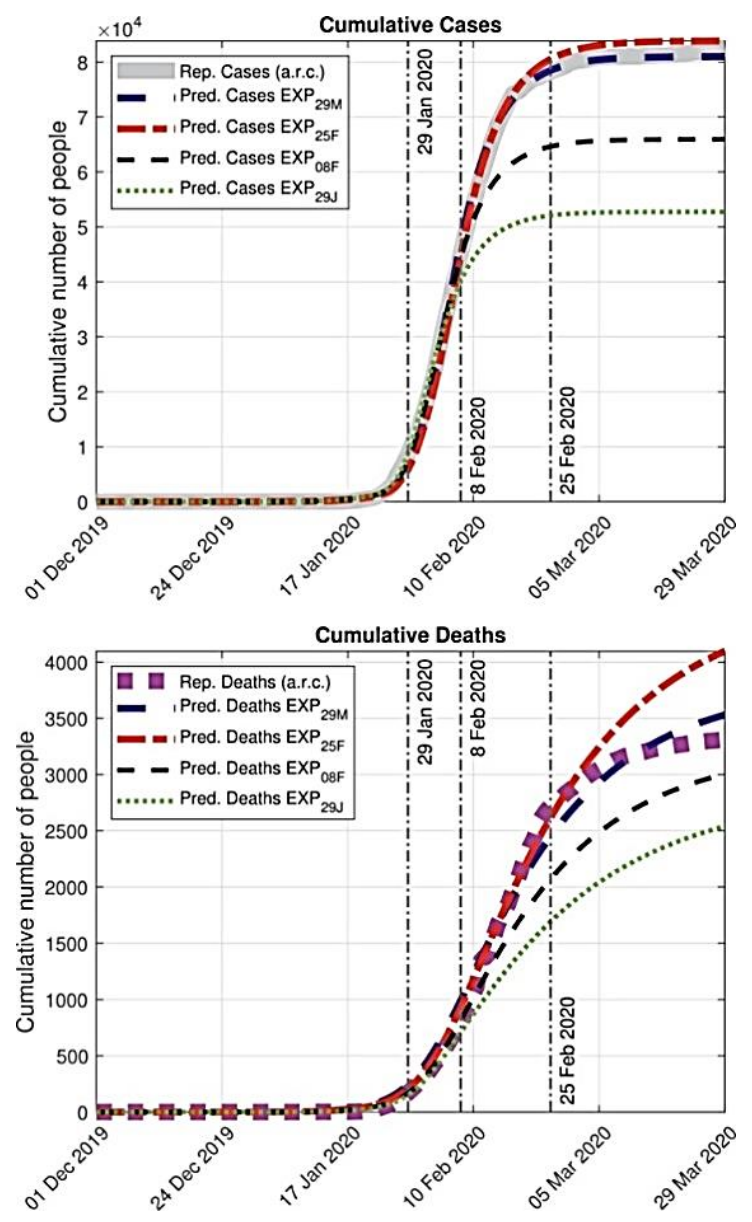

Фрагмент моделі. Джерело: [18] 
Відзначимо, що багато змінних моделі, наприклад, кількість контактів між людьми, залежать від роботи транспорту безпосередньо (наприклад, у переповненому транспортному засобі) або опосередковано (наприклад, тіснява, переохолодження чи перегрів людей на зупинках при великих інтервалах між транспортними засобами).

Слід звернути увагу на формули над та під стрілками на графі математичної моделі розповсюдження інфекції, що була розглянута вище. Ці формули використовуються для оцінки ймовірностей переходу людини із стану в стан, а 3 тексту статті видно (і з життя теж це відомо), що ці ймовірності залежать від таких чинників, представлених у формулах, як інтенсивність контактів заражених людей, кількість тих, хто виїхав за певний час 3 даної території чи прибув на неї тощо. А ці чинники, очевидно, залежать від роботи транспорту!

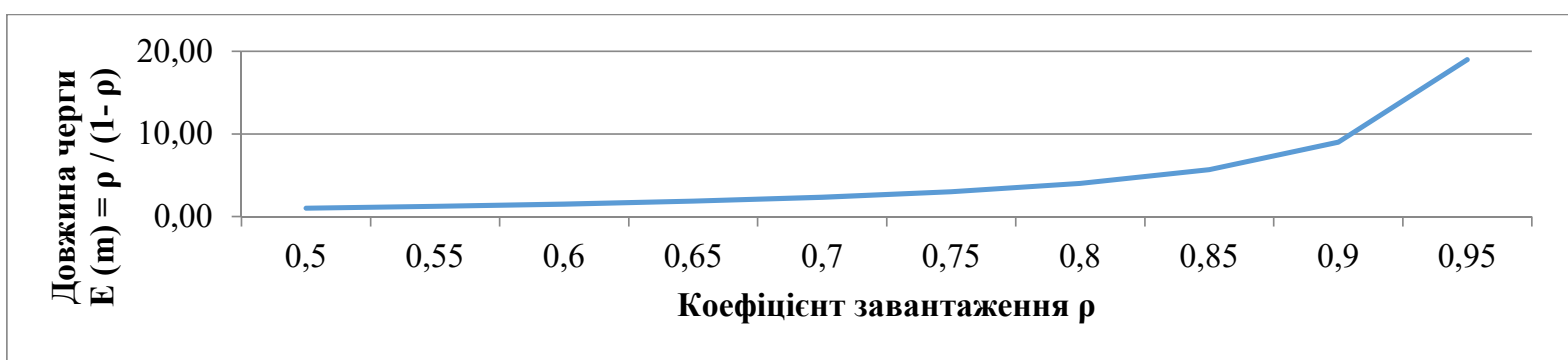

\section{Рис. 4. Середня довжина черги $\mathrm{E}(\mathrm{m})=\rho$ / $(1-\rho)$, залежно від коефіціснта завантаження $\rho$}

Авторська розробка

Коефіцієнт завантаження системи можна представити за допомогою конкретних змінних моделі, що відображають організацію транспортного обслуговування, наприклад:

$$
\begin{gathered}
\rho=\frac{\lambda}{\mu}=2\left(\frac{l_{v}}{V_{v}}+\frac{n_{p v} t_{p}}{60 \cdot 60}\right) \frac{A_{p h r}}{n_{p v} M_{v}}= \\
\frac{2\left(\frac{l_{v}}{V_{v}}+\frac{n_{p v}}{60 \cdot 60}\right) A_{p h r}}{n_{p v}\left[\frac{A_{p h r}\left(\frac{l_{v}}{V_{v}}+\frac{n_{p v} t_{p}}{60 \cdot 60}\right)}{n_{p v}} A_{p h r}+M_{v}^{r e s}\right]}=\frac{1}{2\left(\frac{l_{v}}{V_{v}}+\frac{n_{p v} t_{p}}{60 \cdot 60}\right) A_{p h r}+n_{p v} M_{v}^{r e s}}=\frac{1+\frac{M_{v}^{r e s}}{2\left(\frac{l_{v}}{n_{p v} V_{v}}+\frac{t_{p}}{60 \cdot 60}\right) A_{p h r}}}{}
\end{gathered}
$$

де $l_{v}$ - довжина маршруту руху транспортного засобу (ТЗ), км;

$V_{v}-$ середня швидкість руху Т3 на маршруті, км/год;

$n_{p v}$ - кількість пасажирів у ТЗ;

$t_{p}$ — тривалість посадки/висадки одного пасажира у Т3, с;

$A_{p h r}$ - інтенсивність пасажиропотоку, пасажирів на годину;

$M_{v}^{r e s}$ - кількість резервних ТЗ на маршруті. 


\section{3. ВИСНОВКИ}

Гуманітарна логістика як наукова дисципліна знаходиться в стадії формування, тому вона поки не має фундаментальних теоретичних основ, і навіть не має єдиного визначення.

Історія та практичні приклади із сфери сучасної гуманітарної логістики свідчать, що їі основну мету (полегшення страждань людей при надзвичайних ситуаціях та небезпечних подіях) неможливо досягти без знання основ і застосування практичних методів транспортних технологій і логістики, але з урахуванням передусім гуманітарних критеріїв та, наскільки це можливо, економічних критеріїв і технологічних обмежень.

Виконання функцій гуманітарної логістики часто неможливе без міжнародної співпраці, і Україна $є$ членом відповідних міжнародних організацій $(\mathrm{OOH}$, Червоний Хрест), взаємодіє з міжнародними партнерами.

Гуманітарна логістика — це специфічна галузь діяльності, спрямованої на надання гуманітарної допомоги людям, постраждалим внаслідок надзвичайних ситуацій техногенного чи природного характеру, суміжна 3 галузями цивільного захисту та медицини катастроф.

На відміну від транспортної логістики, де найбільш вагомими можуть бути економічні критерії транспортного обслуговування (мінімізація транспортних та інших витрат), в гуманітарній логістиці вирішальними $є$ критерії своєчасності доставки та доступу до засобів для полегшення страждань людей (засобів гуманітарної допомоги).

Для розв'язання оптимізаційних задач гуманітарної логістики широко використовуються математичні методи, математичні моделі процесів гуманітарної логістики та транспортного обслуговування в надзвичайних ситуаціях $\epsilon$ потужним засобом покращення ефективності цих процесів.

\section{ЛITЕРАТУРА}

1. Вікіпедія. [Електронний ресурс].—Режим доступу : https://uk.wikipedia.org/wiki/.

2. Sahay, B.S. Managing Humanitarian Logistics [Electronic resource] / B.S. Sahay, Sumeet Gupta, Vinod Chandra Menon (Editors) // Library of Congress Control Number.- Springer India - 2016. — Mode of access: — https://1lib.eu/book/2619022/50e95e.

3. Репіч, Т.А. Особливості використання логістичної концепції у логістиці кризових ситуацій [Електронний ресурс] / Ефективна економіка. - 2020. - № 3.- Режим доступу: https://doi.org/10.32702/2307-2105-2020.3.54.

4. Шолтисек, Я. Проблемы тождественности логистики. / Я. Шолтисек. Праці Одеського політехнічного університету. — 2011. - № 1. — С. 278-282.

5. Шолтисек, Я. Суспільна логістика - напрямки розвитку. / Я. Шолтисек, П. Колодзісйчик. Маркетинг менеджмент інновацій. — 2011. - № 1. С. 185-191.

6. Wikipedia [Electronic resource] — Mode of access: https://en.wikipedia.org/wiki/Humanitarian_Logistics. 
7. National Disaster Management Authority [Electronic resource]/ Government of India. Mode of access: - http://www.ndma.gov.in/en/policy.html.

8. Gustavsson, L. Humanitarian logistics: context and challenges [Electronic resource] / Forced Migration Review. - Mode of access: https://www.fmreview.org/logistics/gustavsson.

9. Хто ми. Принципи [Електронний ресурс] / Національний комітет Товариства Червоного Хреста України. - Режим доступу: https://redcross.org.ua/principles/.

10. УВКБ ООН доправило 92 тони гуманітарного вантажу в Луганськ [Електронний peсурс] / УВКБ ООН в Україні. — 2020. — 11 вересня. — Режим доступу: https:// www.unhcr.org/ua/25409-unhcr-B6.html.

11. Логістичний супровід гуманітарної допомоги Донбасу забезпечуватиме Червоний Хрест [Електронний ресурс] / Корреспондент.net. — 2014. - 11 вересня.— Режим доступу: https://ua.korrespondent.net/ukraine/3404484-lohistychnyi-suprovid-humanitarnoidopomohy-donbasu-zabezpechuvatyme-chervonyi-khrest.

12. Глоссарий по статистике транспорта. Четвертое издание [Електронний ресурс] / ЕЭК ООН. Межсекретариатская рабочая группа по статистике транспорта (МРГ). - Режим доступу: https://www.unece.org/fileadmin/DAM/trans/main/wp6/pdfdocs/glossru4.pdf

13. Офіційний веб-сайт Асоціації «Український логістичний альянс»/ [Електронний pecypc] — Режим доступу: https://ula-online.org/ua/.

14. Офіційний веб-портал Верховної Ради України [Електронний ресурс]. Кодекс цивільного захисту — Режим доступу: https://zakon.rada.gov.ua/laws/show/5403-17\#Text.

15. Шудренко, І. В. Цивільний захист: навч. посіб. [Електронний ресурс] / І.В. Шудренко. - Житомир: Житомирський національний агроекологічний університет, 2014. 248 с. - Режим доступу: — http://ir.znau.edu.ua/bitstream/123456789/3473/1/Tsyvilnyi_zakhyst.pdf.

16. Кузьмін, В.Ю. Медицина катастроф: основні поняття та завдання служби [Електронний ресурс] / В.Ю. Кузьмін, А.В. Терент'єва, Н.І. Іскра. - Режим доступу: https://www.researchgate.net/publication/329831141_medicina_katastrof_osnovni_ponatta_t a_zavdanna_sluzbi.

17. Офіційний веб-портал Верховної Ради України [Електронний ресурс]. Закон України «Про екстрену медичну допомогу» - Режим доступу: https://zakon.rada.gov.ua/ laws/show/5081-17\#Text.

18. Ivorra, B. Mathematical modelling of the spread of the coronavirus disease 2019 (COVID19) taking into account the undetected infections. The case of China [Electronic resource] / B. Ivorra, M.R. Ferrández, M. Vela-Pérez, and A.M. Ramos - 2020. — Mode of access: https ://www.ncbi.nlm.nih.gov/pmc/articles/PMC7190554/.

19. Відео: RailRunner Terminal Anywhere Demo 2011. [Електронний ресурс] — Режим доступу: https://www.youtube.com/watch?v=XUgi41QKmF8\&t=240s.

20. Відео: RoadRailer car counter. [Електронний ресурс] — Режим доступу: https://www.youtube.com/watch?v=YhcVsm1SOaQ.

21. Відео: Indian Frist Road Railer Trolley in Itarsi MP. [Електронний ресурс] — Режим доступу: https://www.youtube.com/watch?v=q5kjv4_snsM.

22. Відео: Efficient LOHR Railway System (timelapse). [Електронний ресурс] — Режим доступу: https://www.youtube.com/watch?v=MTvSOrTXFzw.

23. Відео: Film tourné en conditions réelles d'exploitation sur le terminal CFL de Bettembourg au Luxembourg. Rollende Landstraße am Brenner 2. [Електронний ресурс] - Режим доступу: https://www.youtube.com/watch?v=OPmq5zMKAIo. 


\title{
РОЗДІЛ 8 \\ СИСТЕМИ УПРАВЛІННЯ БЕЗПЕКОЮ ТА НАВКОЛИШНІМ СЕРЕДОВИЩЕМ У ТРАНСПОРТНИХ ПРОЦЕСАХ
}

\author{
B.M. Самсонкін ${ }^{13}$ \\ P.C. Щербина ${ }^{14}$
}

\section{1. ВСТУП}

Розділ присвячено презентації матеріалу з дисципліні «Системи управління безпекою та навколишнім середовищем у транспортних процесах».

У загальному сприйнятті кризова ситуація - це стан, що характеризується наявністю обставин, які являють собою безпосередню загрозу життю, здоров'ю та безпеці громадян. В цьому розділі розглядаються два найбільш поширені напрями виникнення кризових та надзвичайних ситуацій на транспорті. Перший напрямок пов'язаний 3 порушеннями безпеки транспортних процесів, що приводять або можуть привести до транспортних подій, які визначаються Положенням про класифікацію транспортних подій на будь якому виді транспорту. Другий - пов’язаний зі шкідливим впливом навколишнього природного середовища.

Обидва напрямки характеризуються поняттям транспортного ризику. Транспортні ризики — це ризики, які виникають в процесі перевезень вантажів різними видами транспорту. Цей вид ризиків притаманний практично всім видам і всім етапам підприємницької діяльності. Класифікація транспортних ризиків здійснюється відповідно до міжнародних стандартів, в яких мова йде про фінансові ризики та втрати, що поділяються на чотири групи за ступенем відповідальності $\mathrm{E}, \mathrm{F}, \mathrm{C}$ i D. У даному розділі мова йде про технологічні ризики, які пов'язані 3 імовірністю порушення регламентів перевізного процесу 3 нанесенням втрат здоров'ю та життю людей, технічним засобам транспорту, навколишньому середовищу та шкоди нормальному функціонуванню транспортних систем.

\section{2. ОСНОВНИЙ МАТЕРІАЛ}

\section{1. Системний підхід у керуванні безпекою на транспорті}

Цей системний підхід (надалі - MSD) побудовано на основі Методу статистичної закономірності, який розроблено Самсонкіним В.М. і Друзем В.А. і вперше повністю викладений у 2005 року [1]. MSD — це наукова методологія підтримки ефективних управлінських рішень в області безпеки руху поїздів (БР) на залізничному транспорті.

\footnotetext{
${ }^{13}$ Доктор техн. наук, професор кафедри «Транспортних технологій та управління процесами перевезень» Державного університету інфраструктури та технологій, Київ

14 Канд. техн. наук, доцент кафедри «Транспортних технологій та управління процесами перевезень» Державного університету інфраструктури та технологій, Київ
} 
Ця теорія заснована на статистичному підході до керування складними системами та включає до себе необхідні поняття та компоненти теорії управління: оцінку стану, прогнозування, керування функцією безпеки руху у масштабі реального часу на основі параметру кінцевого результату діяльності системи. Це те, що принципово відрізняє даний підхід до управління безпекою від існуючих (наприклад, $[2,3])$. Принцип керування БР поїздів представлено на рис. 1.

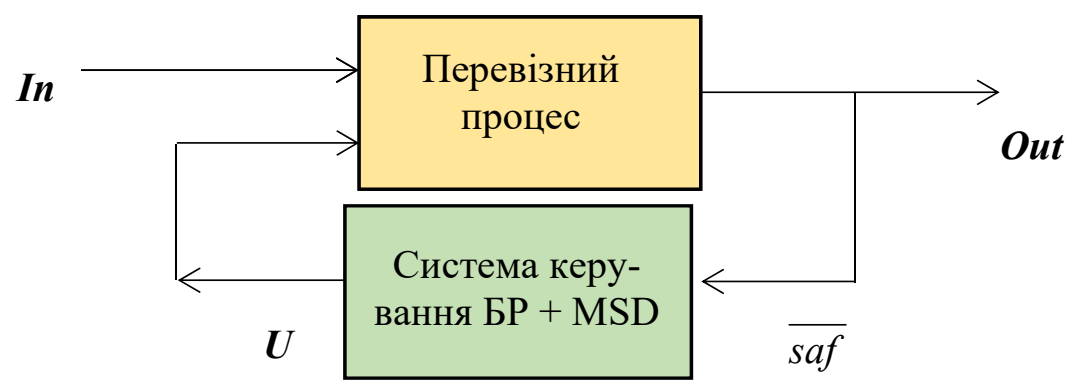

In - вхідний сигнал (завдання на перевізний процес); Out - вихідний сигнал (результати діяльності компанії: економічні, фінансові, технологічні, безпека, соціальні, ...); saf — статистика транспортних подій та порушень/збоїв регламентів перевізного процесу; $\boldsymbol{U}$ - процедури керування БР

\section{Рис. 1. Контур управління безпекою руху \\ Авторська розробка}

Метод статистичної закономірності ([1]) — це теоретичне обгрунтування керування процесом убезпечення і нагляду (або контролю) за безпечністю руху поїздів. Для тих служб залізничного транспорту, що убезпечують перевізний процес - метод указує на який саме аспект діяльності слід звернути увагу на даний час («вузькі місця»), для наглядової служби - дає вузькі місця - це спрямованість контролю, його локалізація та напрями фінансування 3 метою ефективного запобігання транспортним подіям.

Діяльність залізничного транспорту України (сигнал Out на рис. 1) в цілому характеризується більше ніж 110 параметрами. Це об'ємні, якісні, технічні, технологічні показники. Вхідною інформацією для MSD ( $\overline{s a f}$ на рис. 1) є статистика порушень БР, яка знаходиться в різних джерелах інформації (документах) та у різних місцях компанії.

Виникає питання: чому саме інформація про порушення використовується y MSD, а не показники успішної діяльності? Це пов'язано з особливостями реалій діяльності транспортних компанії та менталітету людей. Ось складові відповіді:

А. Коли все йде добре, персонал рідко замислюється про недоліки і вузьких місцях. Діють за принципом: «працює - не чіпай», «від добра не шукають добра», «дасть Боже - пронесе» і т.п.;

В. Працівників обнадіює система планово-попереджувального обслуговування інфраструктури та рухомого складу; 
С. При розслідуванні транспортних подій зазвичай всебічно вивчаються обставини, причини, дотримання технології обслуговування, дії персоналу і т.д. I тут можливе виявлення прихованих недоліків і недоробок.

D. Фахівці різних господарств залізничного транспорту навчаються за різними навчальними планами, працюють за специфічними інструкціями і наказами, часто вже не розуміючи чужі особливості. I тільки питання БР вивчаються за однаковими документами.

Е. Перший і п’ятий принципи професора Дана Петерсена [4] справедливо стверджують:

- до передумов аварій слід ставитися як до серйозних подій або джерел інформації про можливі пригоди;

- головне завдання служби безпеки - виявлення і оцінка експлуатаційних помилок, які створюють можливість виникнення аварій.

\subsection{1. Основні поняття системного підходу}

a) Система.

Під системою будемо розуміти об'єднання елементів, взаємовідномення й взаємодія яких здійснюється з метою одержання кінцевого результату, корисного для системи в изілому. Таке визначення системи відповідає теорії функціональної системи П.К.Анохіна [5]. Кінцевий результат є одночасно і метою і системоутворюючим фактором транспортної системи. Це один 3 показників діяльності системи, бажано інтегрований параметр. У цьому підході - це індикатор рівня безпеки. Складові системи називають компонентом (або елементом), підсистемою, органом. Їх вивчають неподільним цілим для розглянутого рівня узагальнення. Однак, компонента системи може бути як об'єднанням складових, так і системою більш низького рівня узагальнення.

3 погляду теорії систем залізничний транспорт у поєднанні з середовищем своєї діяльності — це складна багаторівнева багатопов'язана людино-машинна система. Головний кінщевий результат ї діяльності - безпечний перевізний процес. Безпека тут виступає як необхідна умова, бо іiі відсутність не відповідає запитам суспільства.

Системний підхід — це розгляд об'єкту дослідження (та його елементів) у взаємодї та взаємозв'язку з оточуючим середовищем як єдиної системи. При цьому параметр кінцевого результату діяльності повинен бути інтегральним, тобто враховувати внесок складових системи. Діяльність транспортної компанії як системи слід розглядати у трьохвимірному динамічному просторі «структура функиія - емерджентність» (рис. 2).

Структура АТ «Українська залізниця» характеризується:

1) вертикальною складовою (або ієрархією) за видами: 
- загальний: Правління АТ «Укрзалізниця» — регіональна філія «...Залізниця» — лінійний рівень;

- галузевий: департамент - служба - дистанція / станція / депо / дільниця / підприємство структурних та функціональних галузей;

- лінійні: піраміда окремої структурної складової.

2) горизонтальна складова - чисельні зв’язки для забезпечення кінцевого результату між елементами, які належать різним вертикалям: локомотивна бригада — диспетчер, електромеханік СЦБ - черговий по станції, департаменти, служби, ін.

Функція. У кожної транспортної компанії існує багато функцій: перевезення, виробництво, продаж, ремонт, будівництво, утримання та ін. Найважливіша функція - цє перевезення пасажирів і вантажів.

Емерджентність (або якісні характеристики, або ресурс) - властивість системи, які не притаманні іiі елементів окремо, а виникають завдяки об'єднанню цих елементів в єдину, цілісну систему. Ресурс буває людський, матеріально-технічний, фінансовий, інформаційний.

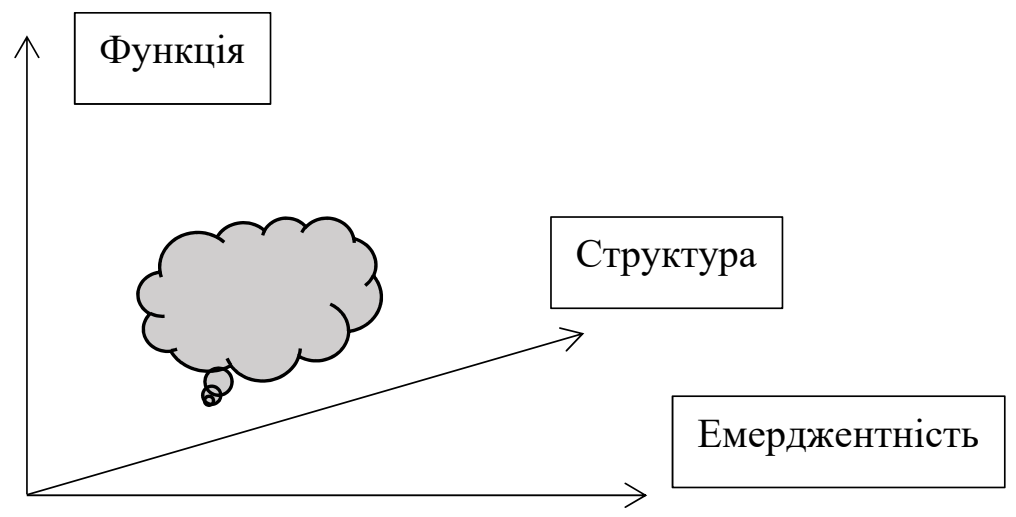

Рис. 2. Простір діяльності системи «Транспортна компанія-середовище» Авторська розробка

Синя «хмара» на рис. 2 означає область оптимальних умов діяльності транспортної системи у взаємодії з середовищем. У подальшому вона буде іменуватися зоною функціонального оптимуму або нормою функціональної діяльності системи «транспортна компанія-середовище.

б) Стан системи.

Оцінювання стану системи проводиться шляхом порівняння параметра контролю з нормою поведінки системи. Якщо параметр контролю знаходиться у межах норми, говорять про нормальний стан.

в) Толерантність.

Толерантність розуміють у значенні «нерозрізненість, неточність». Велику толерантність розуміють як широкий діапазон прояву параметра (мала точність). Мала толерантність еквівалентна високій точності й розрізненню. 
Діяльність людини пов’язана з такими поняттями як неточні розрахунки, несвоєчасність дій, недостатнє знання ситуації, недостатня компетентність, незадовільний контроль над виконуваним процесом. Усе це породжує толерантність його дій. У роботі транспортних засобів (складова «техніка») також існує певний діапазон надійного й стійкого функціонування, що задовольняє вимогам перевізного процесу та отриманню потрібного кінцевого результату. Аналогічно можна сказати й про середовище.

Все це призводить до толерантності стану системи, коли один й той же кінцевий результат може бути отриманий у різних станах. Принцип толерантності пояснює перехід до норми поведінки системи, як діапазону, що й показано на рис. 2.

г) Організація, самоорганізація.

Говорячи про відносини й зв'язки між елементами системи, використовують поняття організація. Поняття організації трактується як:

- еквівалент поняття впорядкованості здійснення конкретної функціональної діяльності;

- динамічний процес формування структурно-функціональних відносин між елементами системи.

Якщо цей процес здійснюється внутрішніми утворювальними процесами, тоді його прийнято розцінювати таким, що самоорганізується. Систему будемо називати самоорганізованою, якщо вона без специфічного втручання ззовні знаходить яку-небудь просторову, часову або функціональну структуру як реакцію на зміни внутрішнього або зовнішнього середовища. Розгляд технології перевізного процесу вимагає обов'язкового обліку того, що визначає його нормальний хід і розвиток. Це у свою чергу пов'язано з розглядом причино-наслідкових явищ, що $\epsilon$ сутністю самоорганізації. MSD використовує такі принципи самоорганізації [1]:

- єдність системи й середовища іiі існування;

- опосередкування результату функціональної діяльності системи;

- ізоморфізм систем;

- варіантність формування кінцевого результату;

- статистична організація прояву дії;

- принцип діхотомії в організації керування динамічними системами;

- найменшої дії;

- «вузького місця».

д) Класифікатор.

Класифікація - це розподіл явищ і понять на класи, розряди залежно від їх загальних ознак. Автори MSD обгрунтовують зображення причинно-наслідкових 3в'язків у вигляді ланцюжка «передумова $\rightarrow$ причина $\rightarrow$ подія $\rightarrow$ наслідки» й необхідність розроблення відповідних класифікаторів передумов, причин, подій i наслідків.

Класифікатор - систематичне наведення (перелік) явищ або понять, у якому зручно знайти опис кожного з них. 
У кожній ланці залізничної системи змістовна сторона порушень різна й вимагає складання спеціального каталогу несправностей і наслідків, які можуть виникати. Класифікатор дозволить точно контролювати й установлювати природу порушень. Сукупність класифікаторів, $є$ основою контролю й відповідальності за безпечний стан залізничної системи.

Автори Методу статистичної закономірності [1] зіштовхнулися з необхідністю надати науковий підхід до побудови класифікаторів і їх наступної адаптації до мінливих умов середовища. Було визначено два основних принципа побудови класифікаторів: «рівнева структура» та «принцип плаваючого класифікатора».

Підтримка управлінських рішень щодо убезпечення руху поїздів у даному системному підході здійснюється з використанням взаємопов'язаних класифікаторів, показаних на рис. 3 .

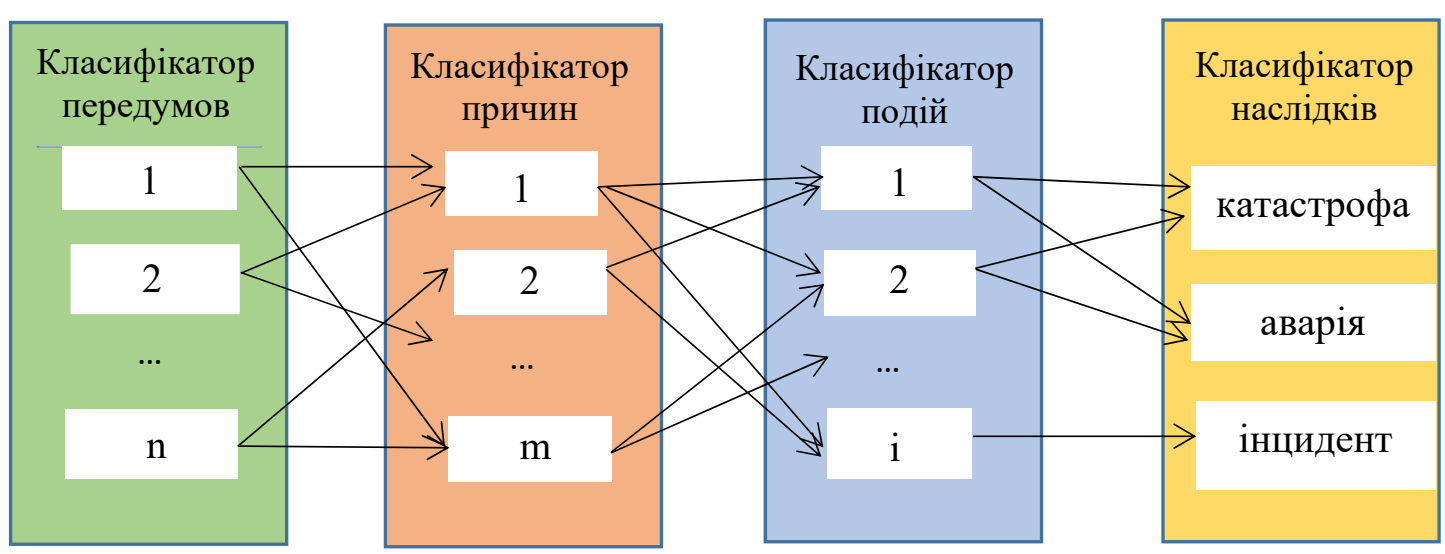

\section{Рис. 3. Класифікатори причинно-наслідкових зв'язків для аналізу транс- портних подій}

Авторська розробка

Направлені лінії означають зв'язок між елементами класифікаторів. Вага кожної лінії - це імовірність зв'язку, яка визначається експертною оцінкою.

е) Норма.

Управління безпекою руху передбачає обов'язкову наявність деякого регульованого діапазону, що визначає стійкість системи. Тривалість збереження відповідного режиму регулювання визначає надійність іiі функціонування. Режим рівноважного стану, його надійність і стійкість характеризуються показниками стану транспорту як системи. Як правило режим рівноважного стану трактується як «нормальний» або «норма».

3 іншого боку, при управлінні системою обов'язково виникає завдання ідентифікації стану. Це в свою чергу призводить до необхідності порівняння контрольованого стану з будь-якої мірою, яка характеризує ефективну діяльність системи. Що теж в техніці визначають символом «нормальний».

Все це в сукупності робить необхідним ввести визначення поняття «норма». 
Немає стандартного поняття норми. Поняття норми [1] використовується в самих різних областях людської діяльності. Однак, незважаючи на відсутність уніфікованого слововживання цього поняття у різних мовах і сферах знань, існує певна однозначність його смислового змісту.

В англійській мові «нормальний» означає звичайний, регулярний, сталий. У сучасній українській мові - це встановлення міри, розміру чогось. У перекладі 3 латинської норма відповідає поняттю правило, встановлена міра.

У біології та медицині поняття норми використовується як вимір спів-стояння здоров'я і процесу розвитку. Тому потрібні чисельні значення, які відрізняли б здорового від нездорового. Цю функцію і виконують різні норми. Насправді природа не ставить ніяких нормативів: природа безупинно «експериментує», а людина змушена постійно пристосовуватися.

В розвиток поняття норми істотний внесок внесли видатні вчені Г. Гегель, Г. Лейбніц, І. Кант, М. Брейтман, П. Анохін, А. Корольков, В. Петленко, М. Амосов, Ю. Антомонов, К. Судаков [6], В. Друзь [1], та ін.

Використання даного поняття в різних областях знань і діяльності не $\epsilon$ термінологічним збігом. У всіх випадках його застосування можна говорити про загальний змістовному характері. У різних контекстах еквівалентом терміна «норма» часто використовуються такі поняття як «звичайний», «типовий», «середній», «масовий», «правильний», «стандартний», «ідеальний» і ін. Все це говорить про загальну норму формування знакових систем.

В одному випадку норма визначається як встановлена міра, розмір чогонебудь, в іншому - як звичайний встановлений порядок, звичайний стан чогонебудь, в третьому - загальновизнане, узаконене в певному соціальному середовищі, правила поведінки людей в суспільстві.

У всьому різноманітті наведених визначень слід зазначити, що їх неоднозначність визначається тим, до якого виду систем вони мають відношення.

Введення однозначності в розуміння терміна «норма» можливо тільки при розкритті його змістовної суті, як відображення деякого стану системи. Зіставлення його трактування дозволяє тільки в загальних рисах виділити ці характеристики.

Подання норми як якогось середнього показника привело до розуміння середньостатистичної норми. Визначається середньостатистична норма величини контролю $x$ як середнє арифметичне значення цієї величини в різних об'єктах $\bar{x}=\frac{\sum_{i=1}^{n} x_{i}}{n}$.

У сучасній науці і техніці розуміння норми як середньостатистичного варіанту настільки широко поширене, що не піддається будь-яким сумнівам. Але таке розуміння норми виявляється недостатнім i, перш за все, це полягає в тому, що на невеликій кількості фактів статистична закономірність не виявляється. Крім того, середнє - це абстракція. 
Середні величини, виділені з неоднорідною сукупності, дають неправдиву кількісну характеристику щодо індивідуальної норми. Будь-яка норма, яка визначена середньо статистично, включає не тільки середнє арифметичне, а й відхилення від неї у деякому діапазоні. Часто в якості відхилення використовують середньоквадратичне відхилення (с.к.в.) $\sigma=\sqrt{\sum_{i=1}^{n}\left(x_{i}-\bar{x}^{2} / n\right.}$.

Одним 3 найбільш глибоких уявлень норми в живих системах $є$ характеристика їі як функиіонального оптимуму, що всебічно вивчалось у науковій школі академіка П. К. Анохіна. У визначеній концепції норма трактується як інтервал оптимального функціонування системи з рухомими межами. У межах інтервалу зберігається оптимальна зв'язок із середовищем і узгодження всіх функцій системи.

Кожен компонент системи, який бере участь в отриманні кінцевого ререзультату, має кінцеві межі варіації. Кількість варіантів взаємодії компонентів, що призводять до кінцевого результату, може бути надзвичайно великим. Величина меж варіації параметра кінцевого результату залежить від інтенсивності (напруженості) функціональної діяльності і може відображати статистично характер поведінки норми, тобто визначати «нормальність» стану.

Оцінку стану системи слід проводити за статистикою параметра кінцевого результату. Отримані характеристики варіації (відхилення) контрольованого параметра щодо стану можна розцінювати як адаптаційні можливості даної системи і покласти в основу оцінки норми стану. Такий підхід дозволяе ідентифікувати норму індивідуально для подібних систем. При цьому варіація параметра кінцевого результату визначає межі зони функціонального оптимуму в конкретному стані. Якщо визначити всі можливі стани, то вдасться побудувати зону функціонального оптимуму по всіх можливих станах.

Зіставляючи сутність наведених визначень норми можна виділити наступні його риси. Вона у всіх випадках включає в себе характеристику деякої основи, щодо якої в певних межах допускаються варіації взаємообумовлених зв'язків об'єкта з середовищем. У цих межах може спостерігатися певний розподіл частоти варіації або допустимі коливання відносин, що породжує деяку розмитість кордонів.

Отже, норма у всіх випадках передбачає деяку область, в якій відбуваються взаємообумовлені відносини певної природи. Сама область характеризується центром 3 межами прояви взаємообумовлених відносин, що забезпечують однаковий кінцевий результат.

\subsection{2. Найбільш вагомі концептуальні положення системного підходу}

1. Головне призначення - підтримка прийняття ефективних управлінських рішень у галузі безпеки руху.

2. Вхідна інформація - існуюча у компанії статистика транспортних подій/ збоїв/відмов. 
3. Максимально можлива передісторія. Для більш достовірних результатів слід використовувати як можна глибоку передісторію, тобто максимально можливий обсяг статистики попередніх періодів.

4. Вихідна інформачія - управлінські рімення щодо забезпечення безпеки. Визначено три рівня управлінських рішень:

- оперативні;

- поточна профілактика;

- довгострокові програми.

5. Безперервний моніторинг параметру кінцевого результату (par) з метою формування статистики або бази даних. Значення par слід фіксувати якомога частіше, наприклад кожного дня. 3 появою комп'ютерних систем для зберігання та аналізу статистики порушень це не $\epsilon$ тяжким завданням. Формується релятивна база даних, як наведено у табл. 1.

Таблиця 1

Структура бази даних порушень регламенту БР

\begin{tabular}{|c|c|c|c|c|c|c|}
\hline \multirow{2}{*}{ Рік } & \multicolumn{6}{|c|}{ День у році } \\
\cline { 2 - 7 } & $\mathbf{1}$ & $\mathbf{2}$ & $\ldots$ & $\mathbf{1 8 0}$ & $\ldots$ & $\mathbf{3 6 6}$ \\
\hline$j$ & $p a r_{1}^{j}$ & $\operatorname{par}_{2}^{j}$ & $\ldots$ & $\operatorname{par}_{180}^{j}$ & $\ldots$ & par $_{366}^{j}$ \\
\hline$j+1$ & $\operatorname{par}_{1}^{j+1}$ & $\operatorname{par}_{2}^{j+1}$ & $\ldots$ & $\operatorname{par}_{180}^{j+1}$ & $\ldots$ & par $_{366}^{j+1}$ \\
\hline$j+2$ & $p a r_{1}^{j+2}$ & $p a r_{2}^{j+2}$ & $\ldots$ & $\operatorname{par}_{180}^{j+2}$ & $\ldots$ & par $_{366}^{j+2}$ \\
\hline$\ldots$ & $\ldots$ & $\ldots$ & $\ldots$ & $\ldots$ & $\ldots$ & $\ldots$ \\
\hline
\end{tabular}

Авторська розробка

Очевидно, що par є випадковою змінною. Статистика параметру кінцевого результату буде описуватися нормальним законом розподілу щільності імовірності виду

$$
N(\text { par })=\frac{1}{\sigma \sqrt{2 \pi}} \exp \left(-\frac{(p a r-m)^{2}}{2 \sigma^{2}}\right),
$$

де $m$ - центр розподілу (математичне очікування/мода/медіана),

$\sigma$ - середне квадратичне відхилення навколо $m$.

6. Розширення формули причинно-наслідкових зв'язків транспортної подї до чотирьох пунктів: передумова, причина, подія, наслідок. Це привело до необхідності введення замість одного існуючого Класифікатора транспортних подій відповідно трьох класифікаторів: подій, причин, передумов. Новизна полягає в переході від традиційного ланцюжка причинно-наслідкових зв'язків

«ПРИЧИНА $\rightarrow$ ПОДІЯ $\rightarrow$ НАСЛІДКИ»

до

«ПЕРЕДУМОВА $\rightarrow$ ПРИЧИНА $\rightarrow$ ПОДІЯ $\rightarrow$ НАСЛІДКИ». 
Термін «передумова» означає базова причина, або «причина причин». Її необхідність пов'язана 3 тим, що причина часто виникає несподівано та випадково. Причина належить простору технології руху поїздів (технологічна причина), а передумова належить до простору забезпечення руху поїздів та включає підготовку, утримання, ремонт, огляд, матеріально-технічну базу забезпечення руху, й т.п. щодо рухомого складу та інфраструктури.

7. Визначення стану безпеки руху на основі поняття норми як функціонального оптимуму.

Вирішення питання підвищення безпечності функціонування залізничного транспорту вимагає знання його поточного стану й рівня надійності кожного 3 компонентів. Отже, розроблення методики контролю й оцінювання безпеки вимагає введення міри ризику виникнення аварії.

У даному підході діапазон можливих станів елементів залізничної системи та iï самої зображений шкалою з сім’ю градаціями, як це показано на рис. 4.

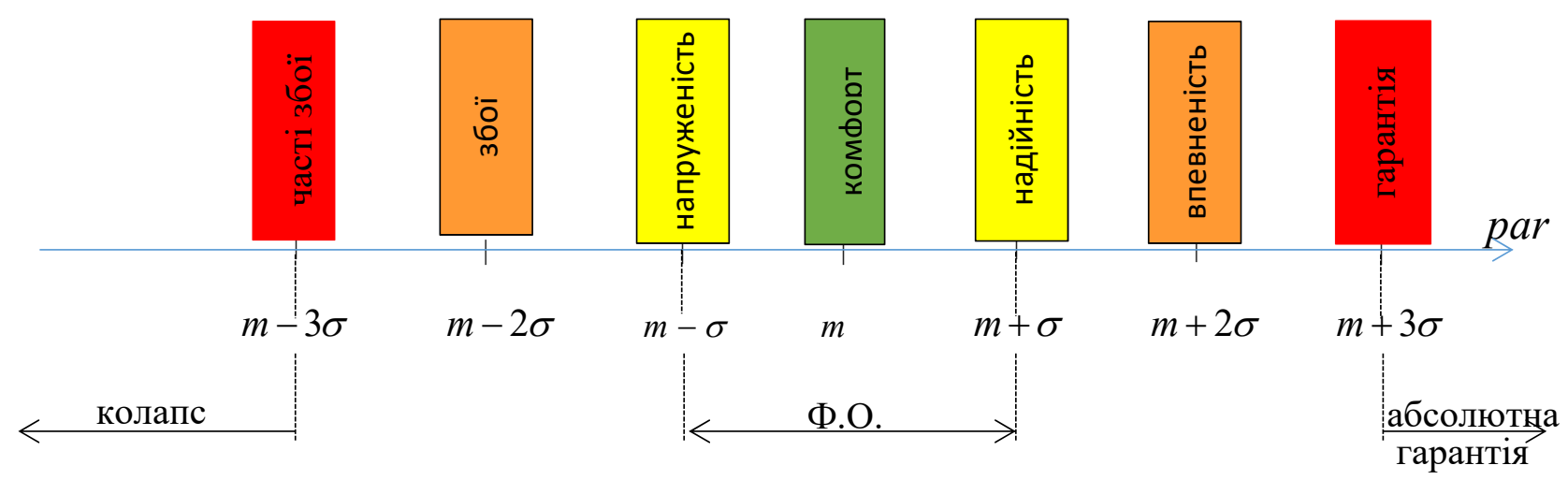

\section{Рис. 4. Шкала станів безпеки залізничної системи та її елементів}

Авторська розробка

Проаналізуємо рис. 4. Стан «комфорт» відповідає найбільш оптимальному стану системи «транспортна компанія-середовище», де вона може знаходитись скільки завгодно часу. Значення $m$ та $\sigma-3$ формули (1).

Можна вказати градацію, після якої слід приділяти особливу увагу профілактичним заходам. Таким критичним рівнем виступає стан, за якого зусилля 3 підтримання безпеки ще здатні забезпечити іiі заданий рівень. Такий стан має оцінюватися як тривожний («Напруженість» та «Надійність» на рис. 4), що вимагає вживання заходів для переходу до норми. Уведення такого роду заходів має бути загальним для будь-якої ланки залізничної системи.

Таким чином, існують дві точки, робота за межами яких стає збитковою. Відстань між цими точками $(2 \sigma)$ визначає зону функціонального оптимуму (Ф.О.) або норму поведінки системи. Наближення до цих точок з боку «комфорту» означає негативну тенденцію виходу системи 3 зони Ф.О. Це має викликати тривогу й вживання заходів для стабілізації стану транспортної компанії. Точки «напруженість» та «надійність», що визначають межі функціонального оптимуму, 
характеризують ситуацію, коли ще вдається зберегти рівність придбань і втрат. Цей факт дозволяє встановити той стан у ланках залізничної системи, за якого необхідно застосовувати заходи стабілізації положення, тобто, стан підвищеної заклопотаності. За іi межами спостерігається неузгодженість між можливостями й потребами компанії, окремої iї ланки або ділянки.

Норма поведінки транспортної системи - це:

а) процес, що визначає оптимальний режим функціонування системи у взаємодії із середовищем;

б) інтервал оптимального функціонування системи 3 плаваючими (змінними) межами, у яких зберігається оптимальний зв'язок системи із середовищем і узгоджене виконання всіх їі функцій.

Таким чином межі варіації параметра кінцевого результату можуть характеризувати норму. Зростання напруженості стану приводить до зменшення дисперсії параметра кінцевого результату навколо середнього. Нульова напруженість стану навпаки буде характеризуватися максимальною дисперсією, тому що в цьому випадку спостерігається максимальна взаємозамінність компонентів.

Може викликати питання: чому колір станів зліва та справа від «комфорту» однакові. Чим поганий стан «впевненість» або «гарантія»? Недолік цих станів у тому, що їх досягнення коштує дуже дорого (у фінансовому, фізичному, психологічному, організаційному аспектах), а підтримуватись ці стани можуть невеликий час.

Тому головне завдання ТОР-менеджменту транспортної компанії - утримувати стан компанії між градаціями «напруженість» та «надійність».

Актуалізація норми - це постійне уточнення норми поведінки в часі в міру накопичення статистичних даних про параметр контролю стану i відповідно уточнення (можливо зі зміною) норми. Необхідність актуалізації пояснюється тим, що в живих системах норма поведінки змінюється протягом життя і змінюються індивідуально. При цьому враховується вся передісторія поведінкової діяльності системи. Отже, плаваючі границі норми — це синонім змінюваних у часі величини й місця розташування центру зони Ф.О.

8. Ознаки визначення «вузьких місцьь»

Вузькі місця - це визначання найбільш проблемних або небезпечних місць у транспортному процесі. Крім того вузькі місця - це місця максимальної витрати ресурсів для збереження стійкості і безпеки системи.

Для ідентифікації вузьких місць треба визначити ознаку. Пропонується ознаку визначити по візуальним (геометричним) моделям.

Ознака 1 - «викид» - найбільші кількісні прояви подій, причин, передумов або інших параметрів стану безпеки руху за період аналізу. Для визначення викиду треба визначити його відносний рівень. Це встановлюється або експертною оцінкою, або межею (наприклад, 50\% від суми проявів всіх $n$ елементів параметру кінцевого результату). 

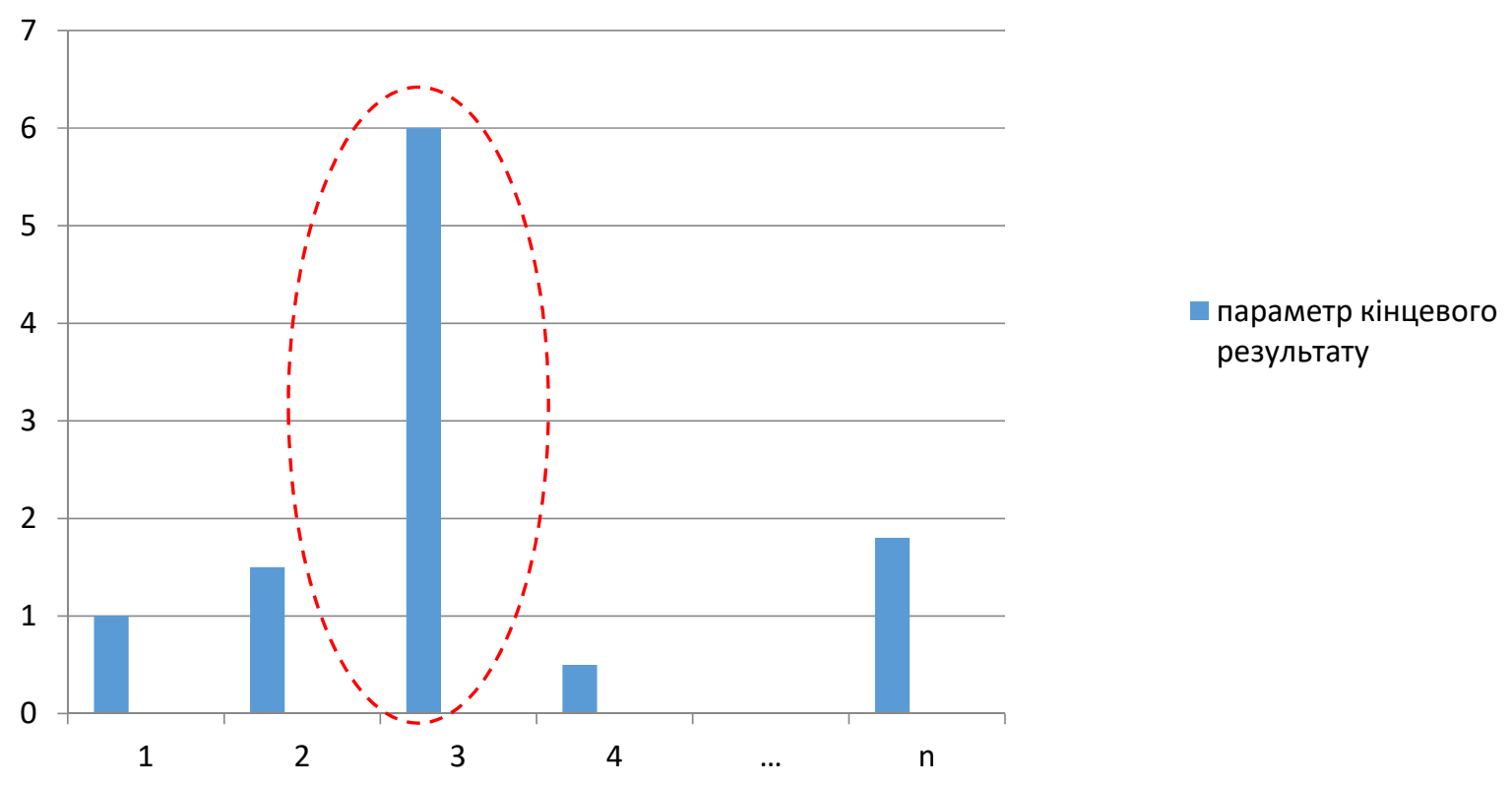

Рис. 5. Перший прояв вузького місця — «викид»

Авторська розробка

Червоним штрихом на рис. 5 позначено вузьке місце першої ознаки. Буква $n$ означає кількість елементів класифікатору параметру кінцевого результату. До речи, вузьких місць при аналізі статистичних даних може бути декілька. Якщо це має місце на фазі виявлення причин порушень, то це нормально, треба визначити рівень ідентифікації вузьких місць і розглядати всі причини. Якщо декілька вузьких місць виявлено на фазі ідентифікації передумов, то треба

Ознака 2 - «негативний тренд» динаміки (або часового ряду) зміни параметру кінцевого результату у часі.

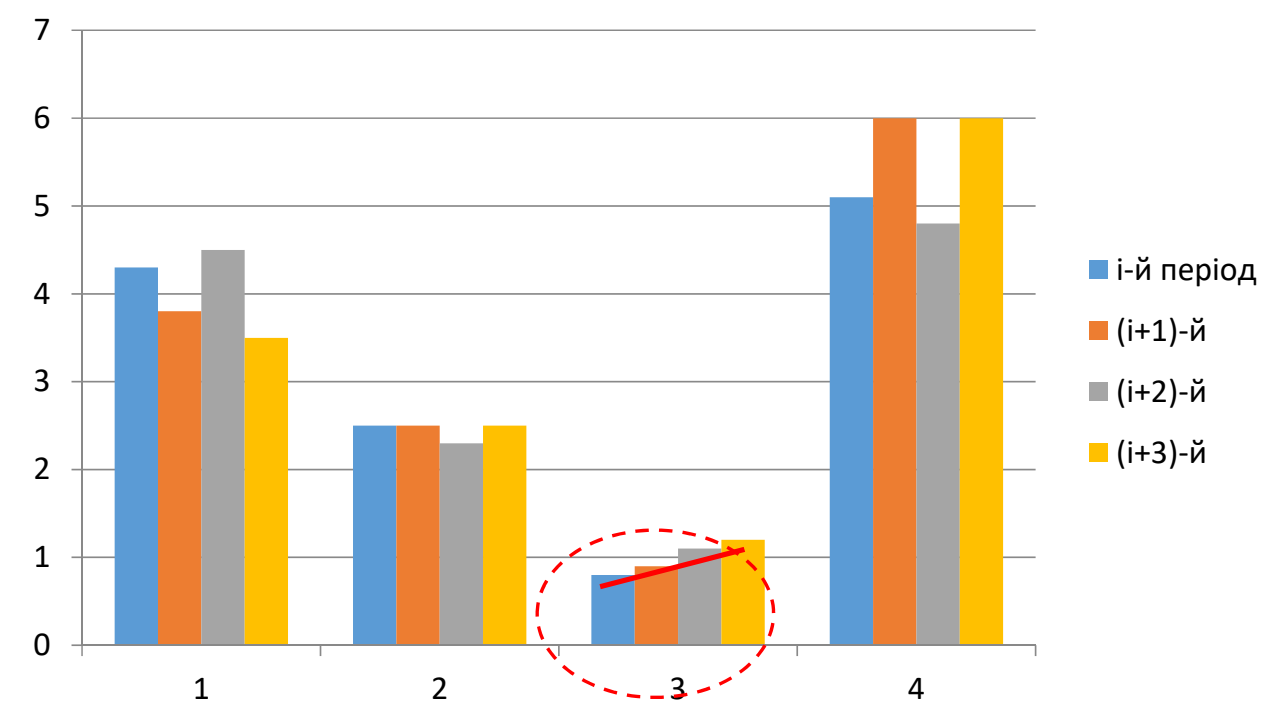

Рис. 6. Другий прояв вузького місця Авторська розробка 
Ознака 3 - якщо на підставі графічного зображення зареєстрованих параметрів спостерігається рівномірний (однаковий) прояв (тобто відсутнє виражене «вузьке місце»), то джерела поліпшення ситуації слід шукати в площині організації технологічного процесу в цілому.

9. Систематизаиія параметру кінщевого результату.

Як було сказано вище, на залізничному транспорті України багато різних джерел, в яких знаходиться інформація про порушення. Але іiі неможливо використати, бо вона представлена вербально. А це дуже корисна інформація. Для того, щоб іiі використати, в т.ч. в інформаційних системах та комп'ютерних базах даних, ця інформація повинна бути формалізована.

MSD й відповідно цей системний підхід надає спосіб формалізації статистики порушень або збоїв. Уся статистика порушень БР, тобто кожний випадок порушень систематизується (розкладається) по восьми параметрах:

1. ЩО сталося,

2. ДЕ сталося,

3. КОЛИ сталося,

4. ЯК це сталося,

5. ЧОМУ сталося,

6. НАВІЩО (умисні чи неумисні дії передували транспортній події),

7. ХТО винен

8. КОМУ нанесено збитки.

Параметр «ЩО» характеризує подію згідно 3 існуючим класифікатором транспортних подій. Відповідно існуючого Положення про транспортні події на залізничному транспорті України [7].

Оцінювання географічного місця події (підпорядкованість залізниці дирекція, станція, дільниця, перегін, блок-пост, кілометр, пікет) здійснюється параметром «ДЕ».

Параметр «КОЛИ» розкриває час, коли відбулася подія (дата, пора року, ін. часові показники).

Обставини події містяться у відповіді на запитання «ЯК» це трапилося. У ній міститься якісна характеристика події: інформація про поїзд (номер поїзда, кількість вагонів, тоннаж, кількість осей), локомотив, вагони (загальна кількість задіяних у транспортній події, з них порожніх і навантажених), погодні умови (опади, освітленість, обледеніння, природні катаклізми й ін.), стан рухомого складу (покази бортових засобів реєстрації, наземних пристроїв контролю, візуальне оцінювання очевидців, дотримання графіків ремонту й огляду), стан інфраструктури, дотримання графіка руху й ПТЕ, стан здоров'я локомотивної бригади, наявність на шляху прямування поїзда сторонніх предметів, людей і технічних засобів та ін. Головна мета аналізу інформації щодо параметру «ЯК» - визначення передумов, через які стала можлива подія.

Параметр «ЧОМУ» дає відповідь на запитання про можливу причину транспортної події, що відбулася. 
Систематизація за параметром «XTO» має містити інформацію про особистість порушника, його посаду, підпорядкованість лінійному підприємству, господарству, дирекції, залізниці, компанії або організації.

Відповідь на запитання «НАВІЩО» має пояснити навмисність або випадковість дії людини (людей) в обставинах, що призвели до транспортної події. Якщо мають місце навмисні дії, то дана подія стає предметом розслідування правоохоронних органів.

Параметр систематизації «КОМУ» має містити інформацію про наслідки нанесеної втрати постраждалому (обсяг ремонту втрата вантажу, час затримання руху й ліквідації наслідків).

10. Виявлення закономірностей здійснюється шляхом графічної побудови таких залежностей $[8,9]$ :

a) варіації окремих параметрів систематизації - ЩО, ДЕ, КОЛИ, .. - у часі;

b) варіації складових восьми параметрів у часі;

c) у просторі двох-трьох параметрів систематизації (наприклад: ЩО КОЛИ, ЩО - ДЕ, ЧОМУ - КОЛИ, ЩО - ХТО - ДЕ, ...).

11. Розробка (підтримка) управлінських рішень.

$\mathrm{C}$ підтримкою в ухваленні рішення і в загальному вигляді показано на рис. 7. Жовтим кольором показані блоки, обумовлені системним підходом, зеленим, традиційні дії структурного підходу.

Блок 1: Виявлення шкідливих закономірностей - «вузьких» місць.

Принцип «вузького місця» є одним з основних принципів MSD. У цьому блоці відбувається аналіз результатів, отриманих в 8 та 10. Існує два прояви вузького місця: «негативний тренд» і «викид», що проілюстровано у блоці 1 малюнками (б) i (a) відповідно. Вузьких місць може бути декілька.

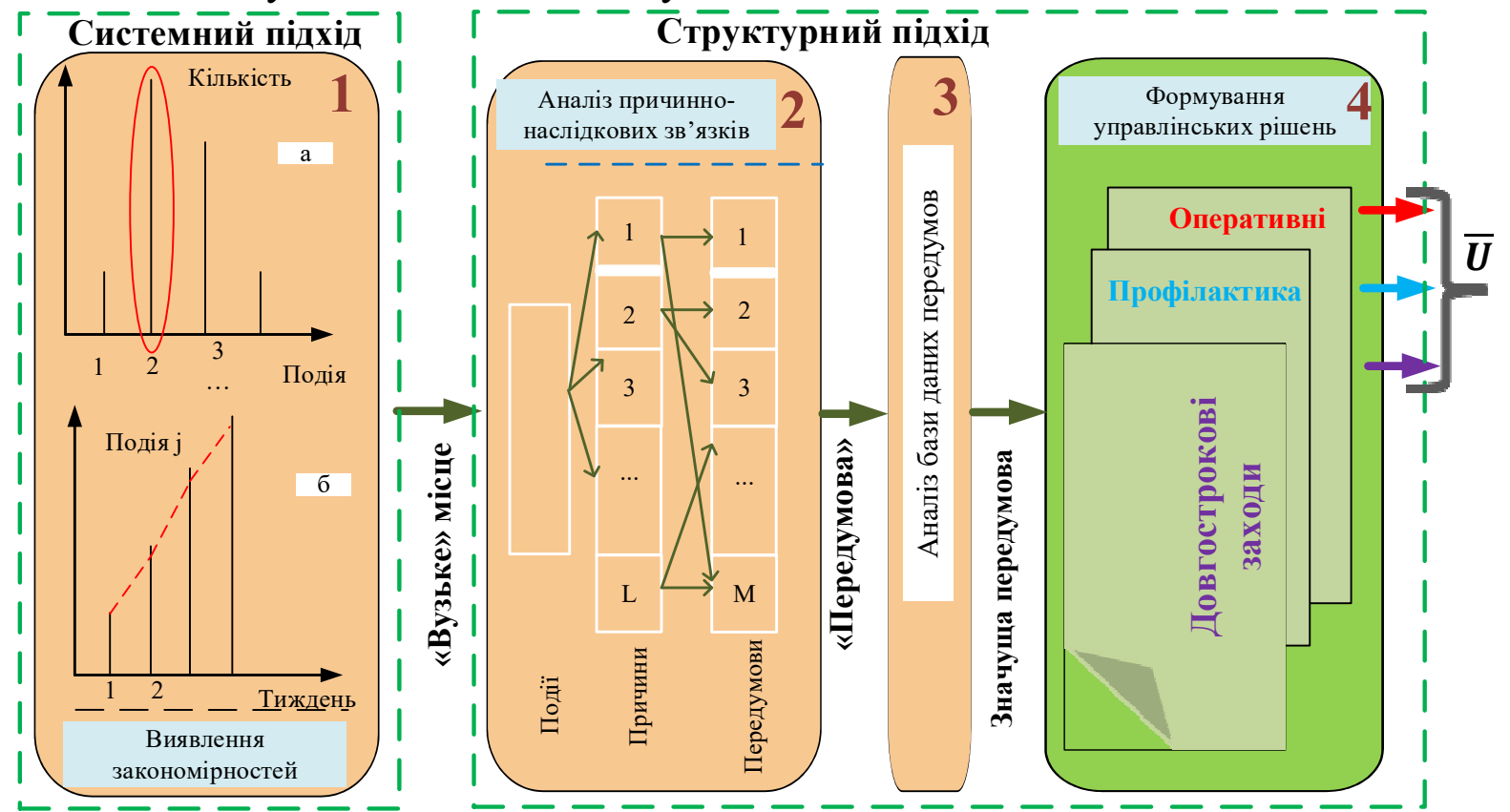

Рис. 7. Послідовність формування управлінського рішення у сфері безпеки руху Джерело: авторська розробка, надана у [10] 
Блок 2: Аналіз причинно-наслідкових зв'язків.

Кінцевий результат цього блоку — визначення передумов причин (фундаментальних причин), які призводять до транспортних подій. Це відбувається у два етапи:

1 - визначаються можливі технологічні причини порушення регламенту перевезення, що виникли в процесі руху потягу (відмова технічних засобів рухомого складу або інфраструктури, помилка машиніста або диспетчера, непередбачені катаклізми середовища);

2 - визначаються передумови можливих причин, які привели до технологічних причин. Передумови не пов'язані з процесом безпосереднього перевезення і складаються з чотирьох груп: техніка (ії зміст і діагностика), людина (кваліфікація, навчання, здатність виконувати роботу, умови роботи і відпочинку), технологія (організація робіт в структурних підрозділах, ремонт, поточна діагностика, постачання, керівництво) та середовище.

Блок 3: Аналіз передумов.

Виявлення негативних закономірностей в передумовах причин. Визначається по аналогії з блоком 1 . В результаті формуються значимі передумови «вузьких місць».

Блок 4: Зниження впливу «вузьких» місць.

Це формування управлінських рішень, які зможуть зменшити або виключити вплив значимих передумов. Існують три типи управлінських рішень: оперативне, профілактичне, перспективне. Конкретний зміст цього блоку сильно залежить від транспортної компанії.

\section{2. Врахування та регулювання взасмодії «транспорт - навколишнс середовище»}

У цьому розділі використано матеріали [11].

\subsection{1. Взаємний вплив транспорту та навколишнього середовища}

Добре відомо про взаємний вплив діяльності людської спільноти та навколишнього середовища. Представимо навколишнє середовище (НC) у вигляді біосфери, як це наведено на рис. 8.

Проблема взаємодії транспорту та довкілля є парадоксальним за своєю суттю: 3 одного боку, транспортна діяльність підтримує зростаючі вимоги до мобільності пасажирів та вантажів, а 3 іншого — транспортна діяльність пов'язана 3 негативним впливом на довкілля (рис. 9).

Екологічні умови впливають на транспортні системи з точки зору умов експлуатації та вимог до інфраструктури (будівництво та технічне обслуговування). Зростання пасажирської та вантажної мобільності розширило роль транспорту як 
джерела викидів забруднюючих речовин та багаторазового впливу на навколишне середовище. Ці наслідки поділяються на три категорії:

- Прямий вплив. Безпосередні наслідки транспортної діяльності на навколишнє середовище, де причинно-наслідкові зв'язки, як правило, чіткі та добре зрозумілі. Наприклад, як відомо, викиди шуму та чадного газу мають прямий шкідливий вплив.

- Непрямі впливи - вторинні (або третинні) ефекти впливу транспортної діяльності на біосферу. Вони часто мають вищі наслідки, ніж прямі наслідки, але їх важче встановити. Наприклад, тверді частинки, які в основному $\epsilon$ наслідком неповного згоряння в двигуні внутрішнього згоряння, опосередковано пов'язані з проблемами дихання та серцево-судинної системи, оскільки серед інших факторів вони сприяють таким станам.

- Кумулятивні впливи - адитивні, мультиплікативні або синергетичні наслідки транспортної діяльності. Це різноманітні наслідки прямого та непрямого впливу на екосистему, які часто непередбачувані. Зміна клімату зі складними причинами та наслідками є сукупним впливом декількох природних та антропогенних факторів, у яких транспорт відіграє певну роль. Частка перевезень у глобальних викидах $\mathrm{CO}_{2}$ зростає. $22 \%$ глобальних викидів $\mathrm{CO}_{2}$ припадає на транспортний сектор, а для розвинутих економік - близько $25 \%$.

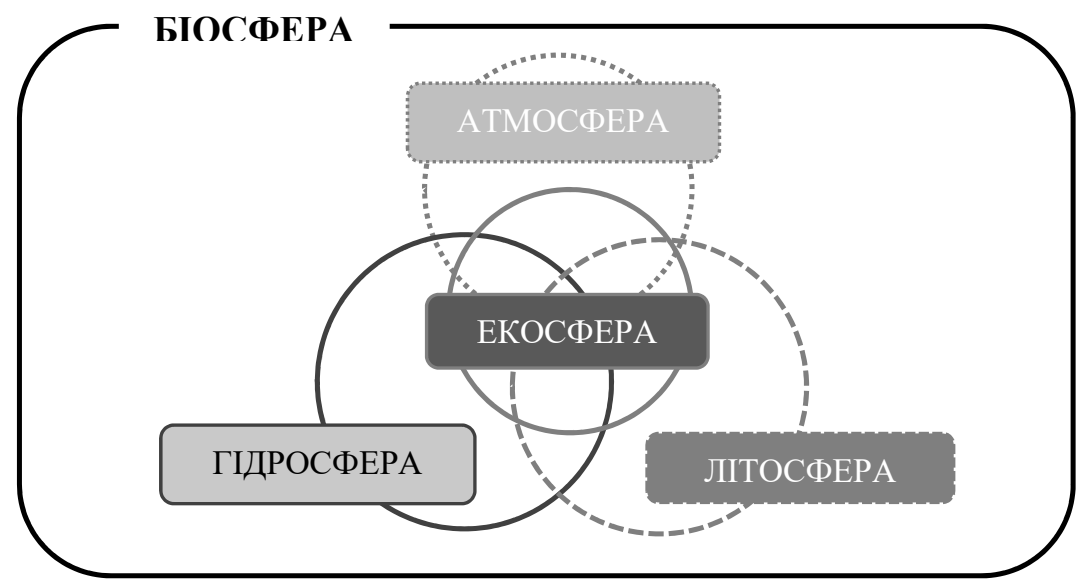

\section{Рис. 8. Екологічна система}

Джерело: [11]

Складність наслідків призвела до суперечок в екологічній політиці щодо ролі транспорту та у стратегіях пом'якшення його наслідків. Це ускладнюється тим, що пріоритети між екологічними та економічними міркуваннями змінюються в часі, що може вплинути на державну політику.

Транспортний сектор часто субсидується, особливо шляхом будівництва та обслуговування дорожньої інфраструктури. Іноді державна частка у видах транспорту, терміналах та інфраструктурі може суперечити екологічним проблемам. 
Якщо власник і регулятор однакові (різні гілки влади), тоді існує ризик того, що нормативні акти не будуть ефективно виконуватися.

CO2 Emissions by Economic Sector

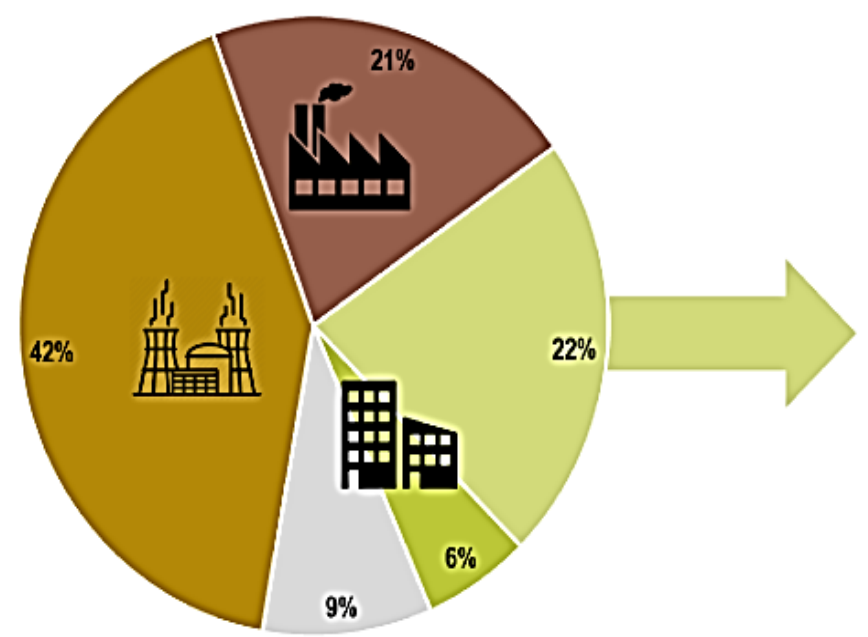

- Electricity and heat production - Manufacturing and Construction
= Transport
= Other
CO2 Emissions by the Transport Sector

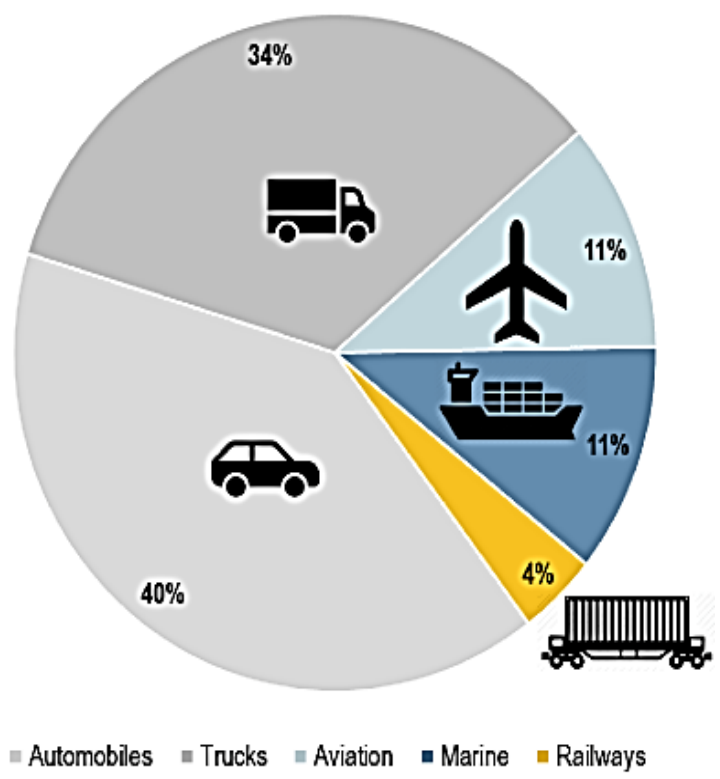

Рис. 9. Глобальні викиди парникових газів транспортним сектором Джерело: [11]

Тим не менш, задіяна складна ієрархія регулювання та відповідних витрат: внутрішніх (переважно операцій), дотримання (нормативних актів), контингенту (ризик такої події, як розлив), зовнішніх (передбачених суспільством). Наприклад, зовнішні витрати складають в середньому понад $30 \%$ від розрахункових витрат на володіння автомобілем та експлуатацію.

Якщо екологічні витрати не включаються в цю оцінку, використання автомобіля, відповідно, субсидується суспільством. Це вимагає належної уваги, оскільки кількість транспортних засобів неухильно збільшується.

\subsection{2. Законотворче регулювання взаємодісю «транспорт - навколишне середовище»}

Взаємозв'язки між транспортом і НС є багатовимірними. Деякі аспекти невідомі, а деякі нові можуть призвести до змін в екологічній політиці. Історично склалося так, що транспорт був пов'язаний з дуже незначним негативним впливом на навколишнє середовище через використовувані види транспорту та низький рівень мобільності. Наприклад, будівництво великих флотів, що складаються з вітрильних кораблів, привело до вирубки лісів у Західній Європі та Північній Америці 
у 16-19 століттях, а урбанізація та індустріалізація у 19 столітті призводять до забруднення біля портів та залізничних дворів. Але ці проблеми залишались несуттєвими та локальними.

Лише у 20 столітті виникла перспектива всебічного зв'язку між транспортом та НC, особливо з масовими викидами автомобілів та літаків. У той же час виробничі та маркетингові концепції, такі як заплановане старіння, спонукали до розробки концепції постійної заміни автомобілів та товарів що транспортуються. 60-ті та 70-ті роки були вирішальними для усвідомлення негативного впливу людської діяльності на НС та необхідності регулювання.

3 точки зору інфраструктури, перше всебічне екологічне регулювання Закон про національну екологічну політику (NEPA) - було встановлено у 1970 р. І вимагало від усіх федеральних агентств уряду США проведення оцінок впливу на навколишнє середовище. Цей закон мав значний вплив на те, як транспорт пов'язаний з екологічними проблемами.

3 точки зору експлуатації - Закон про чисте повітря (1970р.) - встановив чіткі стандарти якості повітря та очікування як стаціонарних (наприклад, електростанція), так і мобільних (наприклад, автомобільних) джерел забруднювачів повітря. Для транспортування він негайно встановив норми викидів для переліку визнаних забруднювачів, таких як вуглекислий газ, леткі органічні сполуки та оксид азоту. Результатом стало швидке зменшення викидів забруднювачів повітря транспортним сектором завдяки вдосконаленню технологій двигунів.

Закон «Про чисту воду» (1977р.) забезпечив подібне регуляторне середовище щодо забруднення води та можливості побудови інфраструктури над заболоченими землями.

90-ті роки характеризувалися реалізацією глобальних екологічних проблем, що втілюється зростаючим занепокоєнням впливу антропогенних наслідків на клімат Землі. Транспорт також став важливим виміром концепції сталості, яка стала основним напрямком, починаючи від викидів транспортних засобів і закінчуючи практикою управління зеленими ланцюгами поставок. Ці розробки потребують глибокого розуміння взаємного впливу між фізичним середовищем та транспортною інфраструктурою, проте цього розуміння часто бракує.

Основними чинниками, що враховуються у фізичному середовищі, $є$ географічне розташування, топографія, геологічна структура, клімат, гідрологія, грунт, природна рослинність та життя тварин.

Екологічні виміри транспорту пов'язані з результатами діяльності транспортних систем. Встановити зв'язок між екологічними вимірами є складним завданням. Наприклад, наскільки викиди вуглекислого газу пов'язані із моделями землекористування? Крім того, транспортування вбудовується в екологічні цикли, зокрема протягом вуглецевого циклу, де вуглець перетікає з одного елемента біосфери, як атмосфера, в інший, такий як екосфера, де він може накопичуватися (постійно тимчасово) або передаватися далі. 
Взаємозв'язок між транспортом і НС також ускладнюється двома спостереженнями:

1) рівень внеску. Транспортна діяльність, серед інших антропогенних та природних причин, безпосередньо, опосередковано та сукупно сприяє проблемам довкілля. В одних випадках вона може бути домінуючим фактором, в інших незначним і іiі важко встановити;

2) масштаб впливу. Транспортна діяльність сприяє екологічним проблемам в різних географічних масштабах, починаючи від місцевих (шум та викиди CO), континентальних / національних / регіональних проблем (смог та кислотні дощі) і закінчуючи глобальними (кліматичні зміни).

Таким чином, встановлення екологічної політики щодо транспортування повинно враховувати рівень внеску та географічний масштаб, інакше деякі держави та бізнес можуть просто перенести проблеми в інше місце. Відомим прикладом $\epsilon$ екологічна політика в країнах з розвинутою економікою, що спонукає до перенесення деяких видів діяльності з високими екологічними ефектами (наприклад, виробництво сталі) в держави, що розвиваються. Це переносить проблему з одного місця на інше. Правда, передача зазвичай передбачає нове обладнання та технології, які мають менший вплив на навколишнє середовище. Навіть якщо адміністративний підрозділ (муніципалітет, округ, штат) має адекватну політику щодо охорони навколишнього середовища, географічний масштаб впливу на навколишнє середовище (зокрема, забруднювачі повітря) виходить за межі встановлених юрисдикцій. Це стало помітним при утилізації таких відходів, як електронні товари, які передаються країнам, що розвиваються, з нижчими екологічними нормами для утилізації або переробки.

Основними факторами впливу транспорту на НС є структура транспортної мережі, способи та рівень перевезень. Мережі впливають на просторовий розподіл викидів (наприклад, централізовані та дифузні мережі), тоді як режими пов'язані з природою, трафіком та інтенсивністю цих викидів.

Крім того, слід враховувати економічні та промислові процеси, що підтримують транспортну систему. Сюди входять видобуток палива, виробництво транспортних засобів та будівельних матеріалів (деякі з яких є дуже енергоємними, наприклад, алюміній), забезпечення інфраструктури та утилізація транспортних засобів та їх складових.

Таким чином, оцінка зв’язку між транспортом та НС без урахування циклів у НС та життєвих циклів транспортних засобів дає обмежений огляд ситуації та може навіть призвести до неправильної оцінки, політики та стратегій пом'якшення наслідків. 


\subsection{3. Соціальні аспекти взаємодії транспорту та середовища}

Незважаючи на те, що транспортна діяльність підтримує зростаючі вимоги до мобільності пасажирів та вантажів, вона дедалі більше пов'язується з екологічними та соціальними проблемами.

Розглянемо основні на сьогодні напрямки регулювання взаємодією транспорту та НC.

\section{а. Зміна клімату.}

У табл. 2 надано результати впливу зміни клімату на операційну діяльність та інфраструктуру видів транспорту.

Таблиця 2

Зміна клімату та її потенційні наслідки для транспортування

\begin{tabular}{|c|c|c|}
\hline Складові зміни клімату & Операційна діяльність & Інфраструктура \\
\hline $\begin{array}{c}\text { Теплові хвилі/аномальна } \\
\text { спека }\end{array}$ & $\begin{array}{l}\text { • Вплив на підйомну силу } \\
\text { літака на коротких злітно- } \\
\text { посадкових смугах } \\
\text { • Обмеження активності у } \\
\text { будівництві }\end{array}$ & $\begin{array}{l}\text { - Температурне розширення } \\
\text { мостів } \\
\text { - пом'якшення покриття } \\
\text { тротуарів } \\
\text { - деформація залізничної колії }\end{array}$ \\
\hline Підвищення рівня моря & $\begin{array}{l}\text { Часті перебої прибережних } \\
\text { автомобільних, залізничних, } \\
\text { авіаційних сполучень 3-за } \\
\text { штормів }\end{array}$ & $\begin{array}{l}\text { - Значно частіші підтоплення, } \\
\text { а потенційно пошкодження } \\
\text { у низинах } \\
\text { • Ерозія інфраструктури }\end{array}$ \\
\hline Інтенсифікація опадів & $\begin{array}{l}\text { Збільшення затримок з-за } \\
\text { непогоди на повітряному та } \\
\text { автомобільному транспорті }\end{array}$ & $\begin{array}{l}\text { - Зміни у припортових } \\
\text { спорудах для улагодження } \\
\text { припливів та відпливів }\end{array}$ \\
\hline $\begin{array}{c}\text { Зростання частоти } \\
\text { ураганів }\end{array}$ & $\begin{array}{l}\text { - Часті перебої у повітряних } \\
\text { сервісах } \\
\text { - Часті та непередбачені } \\
\text { евакуації з прибережних зон } \\
\text { - Сміття на залізничній та } \\
\text { автомобільній інфраструктурі } \\
\end{array}$ & $\begin{array}{l}\text { - Складання умов для } \\
\text { інфраструктурних збоїв } \\
\text { • Збільшення шкоди у } \\
\text { портових спорудах }\end{array}$ \\
\hline $\begin{array}{c}\text { Зростання арктичної } \\
\text { температури }\end{array}$ & $\begin{array}{l}\text { •Зббільшення сезону } \\
\text { судноплавства } \\
\text { •Збільшення незамерзаючих } \\
\text { портів } \\
\text { •Доступність трансарктичних } \\
\text { маршрутів у судноплавстві } \\
\end{array}$ & $\begin{array}{l}\text { - Порушення інфраструктури } \\
\text { з-за відтавання вічної } \\
\text { мерзлоти } \\
\text { - Скорочення сезонів } \\
\text { льодових доріг }\end{array}$ \\
\hline
\end{tabular}

Джерело: [11]

Парниковий ефект є основною складовою регулювання глобального клімату і $є$ природним процесом, який передбачає часткове утримання тепла в земній атмосфері. Сюди входять вуглекислий газ $\left(\mathrm{CO}_{2}\right)$, метан $\left(\mathrm{CH}_{4}\right)$, закис азоту $\left(\mathrm{NO}_{2}\right)$ та галоген вуглеці - гази, які накопичуються в атмосфері досить довго, щоб досягти 
однорідного складу у всьому світі. Таким чином, незалежно від місця їх концентрація схожа.

Кількість звичайних парникових газів, що викидаються в атмосферу, значно зросла 3 часів промислової революції, особливо за останні 25 років. Їх впливи ускладнюються ще й різницею перебування цих газів у атмосфері до розпаду або поглинання біологічними або хімічними процесами. $\mathrm{CO}_{2}$, перебуває в атмосфері від 5 до 200 років, метану - близько 12 років, $\mathrm{N}_{2} \mathrm{O}-114$ років.

Діяльність транспортної галузі щороку викидає в атмосферу кілька мільйонів тонн парникових газів, що становить від $25 \%$ до $30 \%$ усіх викидів парникових газів. Триває дискусія щодо того, наскільки ці викиди пов'язані зі зміною клімату, але дискусія стосується більше ступеня цих впливів, ніж їх природи. Деякі гази, зокрема оксид азоту, також беруть участь у виснаженні шару стратосферного озону $\left(\mathrm{O}_{3}\right)$, який природним чином захищає земну поверхню від ультрафіолетового випромінювання. Зростання обсягу повітряного руху, крім викидів, збільшив кількість інверсійних слідів, які в основному являють собою кристали льоду, що утворюються в результаті конденсації навколо літаків, що летять на великій висоті. Вони можуть внести свій внесок у зміну клімату парадоксальним чином, оскільки 3 одного боку вони можуть утримувати тепло, а 3 іншого, вони також відображають сонячне випромінювання.

\section{b. Якість повітря}

Автомобільні дороги, суднові двигуни, локомотиви та літаки є джерелами забруднення у вигляді викидів газу та твердих частинок. Вони впливають на якість повітря та завдають шкоди здоров'ю людей. Найпоширеніші включають свинець $(\mathrm{Pb})$, окис вуглецю $(\mathrm{CO})$, оксиди азоту $\left(\mathrm{NO}_{x}\right)$, тетрафторид кремнію $\left(\mathrm{SF}_{6}\right)$, бензол та летючі компоненти (BTX), важкі метали (цинк, хром, мідь та кадмій) та тверді частинки (попіл, пил). Викиди свинцю значно зменшились за останні десятиліття, оскільки його використання як антидетонатора для бензину було заборонено в більшості країн світу з 1980-х років 3-за нейротоксичного впливу на людину.

Токсичні забруднювачі повітря пов'язані з онкологічними, серцево-судинними, респіраторними та неврологічними захворюваннями. Окис вуглецю $(\mathrm{CO})$ при вдиханні зменшує доступність кисню в кровоносній системі і може бути надзвичайно шкідливим і навіть смертельним при певних концентраціях. Викиди $\mathrm{NO}_{2}$ від транспортних джерел знижують функцію легенів, впливають на систему імунного захисту дихальних шляхів і збільшують ризик респіраторних проблем. Викиди діоксиду сірки $\left(\mathrm{SO}_{2}\right)$ та оксидів азоту $\left(\mathrm{NO}_{\mathrm{x}}\right)$ в атмосферу утворюють різні кислі сполуки, які при змішуванні в хмарній воді створюють кислотні дощі. Кислотні опади шкідливо впливають на навколишне середовище, знижують урожайність сільськогосподарських культур та спричиняють занепад лісу.

Смог - це суміш твердого та рідкого туману та частинок диму, що утворюються внаслідок накопичення окису вуглецю та інших хімічних забруднювачів. Зниження видимості, спричинене смогом, має ряд негативних наслідків для якості життя, привабливості туристичних об'єктів та якість повітря. Фізичні та хімічні 
властивості твердих частинок пов'язані з ризиками для здоров'я, такими як проблеми 3 диханням, подразнення шкіри, запалення очей, згортання крові та різні типи алергії. Смог часто посилюється через місцеві фізичні та метеорологічні умови, які можуть створювати періоди високої концентрації смогу та реакції громадськості на тимчасове пом'якшення їх, наприклад, обмеження використання автомобілів.

Питання якості повітря широко розглядались у країнах з розвинутою економікою, що призвело до значного зменшення викидів широкого кола забруднюючих речовин. В країнах, що розвиваються, найбільше постраждали великі міста Китаю та Індії, завдяки швидкій моторизації.

\section{с. Шум}

Шум представляє загальний вплив нерегулярних і хаотичних звуків на людей та життя тварин. В основному шум - це небажаний звук. Акустична міра інтенсивності шуму виражається в децибелах (дБ) зі шкалою від 1 дБ до 120 дБ.

Тривалий вплив рівня шуму понад 75 децибелів серйозно утруднює слух і впливає на фізичне та психологічне самопочуття людини. Шум, що виникає від руху транспортних засобів та експлуатації портів, аеропортів позначається на здоров’ї людей через збільшення ризику серцево-судинних захворювань. Навколишній шум є частим результатом автомобільних перевезень у міських районах, що є сукупним результатом усього шуму, створюваного транспортними засобами (від 45 до 65 дБ), що погіршує якість життя, а отже, і ціну майна та землі поблизу джерел гострого шуму, таких як аеропорти. Багато норм щодо шуму передбачають пом'якшення, якщо шум досягає визначеного рівня, наприклад, звукові стіни та інші звукоізоляційні методи.

\section{d. Якість води}

Паливо, хімічні речовини та інші небезпечні частинки, що викидаються 3 літаків, автомобілів, вантажних автомобілів та поїздів або від портових та аеропортових терміналів, можуть забруднювати гідрографічні системи.

Основний вплив морських транспортних операцій на якість води здебільшого виникає внаслідок днопоглиблювальних робіт, стічних вод, баластних вод та розливів нафти. Днопоглиблювальні роботи мають подвійний негативний вплив на морське середовище. Вони модифікують гідрологію, створюючи каламутність, яка може вплинути на морське біологічне різноманіття. Забруднені відклади та вода, вироблені днопоглиблювальними роботами, вимагають місць для утилізації зібраної сировини та техніки знезараження. Відходи, що утворюються внаслідок експлуатації суден у морі або в портах, спричиняють екологічні проблеми, оскільки вони можуть містити дуже високий рівень бактерій, які можуть бути небезпечними для здоров'я населення, а також морських екосистем при скиданні у води.

Крім того, різні види сміття, що містять метали та пластмаси, не легко піддаються біологічному розкладанню. Вони можуть зберігатися на морській поверхні протягом тривалого періоду часу і бути серйозною перешкодою для морського судноплавства на внутрішніх водних шляхах і в морі, а також впливати 
на причальні операції. Баластні води повинні контролювати стійкість та осадку судна та модифікувати його центр ваги стосовно вантажу. Баластні води, придбані в одному регіоні, можуть містити інвазійні водні види, які при скиді в інший регіон можуть процвітати в новому морському середовищі та порушувати природну морську екосистему. Великі розливи нафти внаслідок аварій на вантажних суднах є однією з найсерйозніших проблем забруднення внаслідок діяльності морського транспорту.

\section{е. Якість грунту}

Вплив транспорту на навколишне середовище на якість грунту особливо стосується ерозії та забруднення грунту. Прибережні транспортні споруди, такі як порти, мають значний вплив на ерозію грунту. Діяльність судноплавства змінюе масштаб та масштаби штормів, що призводять до пошкодження обмежених каналів, берегів річок. Будівництво автомобільних доріг або зменшення рівня поверхневого покриття для портових та аеропортових будівель призвели до значної втрати родючих земель. Забруднення грунтів може відбуватися через використання токсичних матеріалів транспортною галуззю. Розливи палива та масла від автотранспорту промиваються на узбіччях доріг і потрапляють у грунт. Хімічні речовини, що використовуються для збереження дерев'яних залізничних стяжок, можуть потрапляти в грунт. Небезпечні матеріали та важкі метали були виявлені в районах, прилеглих до залізниць, портів та аеропортів.

\section{f. Біорізноманіття}

Транспорт також впливає на біорізноманіття. Потреба в будівельних матеріалах та розвиток наземного транспорту призвели до вирубки лісів. Багато транспортних шляхів вимагали осушення земель, що зменшило площі заболочених територій та витіснило види водних рослин. Необхідність підтримувати перевагу дороги та залізниці або стабілізувати схил уздовж транспортних споруд призвела до обмеження росту певних рослин або спричинила зміни в рослинах із впровадженням нових видів. Багато видів тварин стають зникаючими в результаті змін їх природних середовищ існування та зменшення ареалів через фрагментацію середовища їх проживання транспортною інфраструктурою.

\section{g. Забирання землі}

Транспортні засоби впливають на міський ландшафт. Розвиток портової та аеропортової інфраструктури $є$ важливою особливістю міського та навколоміського забудованого середовища. Соціальна та економічна згуртованість може бути розірвана, коли нові транспортні засоби, такі як підвищені залізничні та дорожні споруди, прорвуться на існуючу міську громаду. Артерії або транспортні термінали можуть визначати міські кордони та створювати сегрегацію. Основні транспортні об'єкти можуть впливати на якість міського життя, створюючи фізичні бар'єри, підвищуючи рівень шуму, створюючи запахи, зменшуючи естетику міст та впливаючи на забудовану спадщину. Розширення логістичної діяльності також було непрямим фактором забирання земель у приміських та передміських районах. 


\subsection{3. Зовнішні аспекти та економічне регулювання впливу навколиш- нього середовища на транспорт}

Зовнішні ефекти — це економічне поняття, яке стосується діяльності однієї групи, що має наслідки, позитивні чи негативні, передбачувані чи ненавмисні, для інших груп. Ці наслідки, особливо якщо вони негативні, не в повному обсязі сприймаються тими, хто їх спричиняє. Тому застосовується термін зовнішні наслідки. Поширений приклад позитивного зовнішнього ефекту стосується технології, оскільки вона, очевидно, приносить користь інноваційній фірмі, а також всій економіці завдяки різному підвищенню продуктивності чи покращенню зручності. Негативні зовнішні фактори надзвичайно актуальні щодо екологічних проблем, оскільки багато негативних наслідків забруднення припускає все суспільство.

Екологічні зовнішні ефекти транспорту включають розгляд фізичних показників екологічної шкоди та оцінку пов'язаних із цим витрат для суспільства. Основна помилка, підкреслена зовнішніми ефектами, полягає в тому, що витрати, пов’язані з кількома джерелами (наприклад, користувачами автомобілів), повинні бути обтяжені багатьма (як користувачами, так і не користувачами). Знання джерел зовнішнього впливу на навколишнє середовище є відносно легким завданням, тоді як оцінка збитків та інших витрат ще не досягла порівняльних стандартів серед державних та неурядових установ. Завдання полягає у трьох питаннях:

- Відносини. Необхідно враховувати характер і ступінь взаємозв'язку між транспортом і НС. Це особливо складно, оскільки більшість екологічних відносин, як правило, непрямі і накопичувальні.

- Кількісна оцінка. Необхідно визначити кількісні відносини та оцінити їх значення для зовнішніх факторів НС. Це дуже складно, оскільки можна оцінити лише загальні цифри, що підлягають дискусіям. Отже, кількісна оцінка економічних, соціальних та екологічних витрат може суперечити. Неточні оцінки можуть призвести до перебільшення або недооцінки зовнішніх факторів навколишнього середовища, що може призвести до неправильної політики та норм.

- Пом'якшення. Рівень та ступінь коригувальних дій, які можуть бути вжиті для зменшення екологічних наслідків, пов'язаних із транспортуванням, зазвичай побудовані таким чином, що ті, хто сприяє, несуть наслідки своєї діяльності. 3 огляду на два попередні пункти, спроби регулювання, особливо якщо вони включають всеосяжну структуру (багатонаціональну та багатосекторну), не досягли значного консенсусу. Як варіант, можна досягти консенсусу щодо природи зовнішнього середовища, але не щодо його пом'якшення.

Витрати на зовнішні фактори довкілля можна розглядати 3 економічного, соціального та екологічного вимірів. Встановлення та кількісна оцінка зовнішніх факторів НС є складним завданням і знаходиться лише на попередній стадії. Багато хто використовував цей аргумент, щоб відрізняти застосування кількох екологічних політик шляхом лобіювання урядів (наприклад, кислотні дощі та кліматичні зміни). До того ж, чим ширший географічний масштаб, тим складнішою стає 
екологічна проблема, оскільки вона стосується питань різних юрисдикцій. Недавні спроби досягти консенсусу щодо зміни клімату підкреслили складність багатосторонніх екологічних угод.

Джерела викидів/забруднювачів рідко несуть відповідальність за цю діяльність. Це має кілька наслідків:

- по-перше, коли йдеться про конкретні джерела, такі як автомобільні перевезення, користувачі беруть до уваги лише прямі витрати, пов'язані з модальним володінням (транспортний засіб, паливо, страховка тощо). Власність часто стосується декількох видів транспорту. Суспільство, як правило, бере на себе роль забезпечення та обслуговування інфраструктури та інших непрямих витрат, таких як пошкодження конструкцій та інфраструктури, втрати продуктивності, очищення, медичне обслуговування та шкода екосистемам;

- по-друге, географічний поділ між джерелами та реципієнтами часто є гострим. Кислотні дощі та зміна клімату — яскраві приклади. На місцевому рівні рівень шуму на громаду може впливати значно більше, ніж ііі власний внесок (зокрема, поблизу основних магістралей), тоді як інша (наприклад, передмістя) може зазнати впливу дуже незначно, а суттєво сприяти шуму у місті під час їзди на роботу.

Існує тенденція до переходу від прямих до непрямих наслідків для зовнішніх факторів НС як загальних витрат. Наприклад, абсолютний рівень викидів забруднюючих речовин у атмосферу транспортними засобами у розвинених економіках значно впав і пряма причина забруднення повітря була вирішена. Але з'явилась нова проблема: відносна частка впливів забруднення атмосферного повітря зменшується, але не зменшується кількість транспортних засобів, що з точки зору забруднення або рівня шуму мають свої зовнішні наслідки. Зменшення відносної важливості одного виду зовнішніх факторів перенаправляє увагу на інші типи, які були менш розглянуті, але, мабуть, настільки ж важливі для загального впливу транспорту на НС.

Перерахування та збільшення витрат є дуже поширеними атрибутами зовнішніх факторів НС. Спроба зменшити економічні витрати призведе або до зменшення або до погіршення соціальних та екологічних витрат, залежно від зовнішнього впливу. В умовах обмежених ресурсів розподіл економічних, соціальних та екологічних витрат відіграє важливу роль щодо того, який вид шкоди $є$ прийнятним та в яких пропорціях. 3 минулих стратегій ясно, що кілька економічних витрат були мінімізовані, особливо для виробників та користувачів, а соціальні та екологічні наслідки не враховувались. Ця практика вже не застосовується, оскільки суспільство менш готове нести витрати та наслідки зовнішніх факторів 3 різних причин (обізнаність громадськості, міркування якості життя, високі витрати на охорону здоров'я тощо).

Таким чином, транспорт має широкий спектр зовнішніх факторів, деякі з яких можна обгрунтовано оцінити, тоді як інші $є$ переважно спекулятивними, але часто екологічними групами сприймаються як факти. 
Зовнішні явища також трапляються в різних географічних масштабах, а деякі можуть навіть перекриватися в декількох масштабах. Суть полягає в тому, що кращі транспортні практики, такі як економічні транспортні засоби, що зменшують зовнішні фактори НС, можуть мати позитивні економічні, соціальні та екологічні наслідки. Поки державний сектор заохочується вирішувати екологічні наслідки транспорту за допомогою політики та нормативних актів, приватний сектор займається дотриманням вимог та намагається впроваджувати інновації. Залишається з'ясувати, яка стратегія $є$ найвигіднішою, оскільки в усіх екологічних питаннях переважає велика доля суб'єктивності та часто ідеологія.

\section{3. ВИСНОВКИ}

1. Системний підхід до управління безпекою руху поїздів MSD, створений на основі Методу статистичної закономірності, ліквідує недоліки існуючих у залізничних компаніях світу систем управління безпекою руху поїздів в частині керування функцією безпеки у реальному часі, виявлення «вузьких місць» та короткочасного прогнозування.

2. Системний підхід дозволяє приймати обгрунтовані управлінські рішення щодо фінансування вагомих напрямків покращення стану безпеки руху транспортних засобів. Обгрунтовано реальність управління та прогнозування безпеки руху у режимі он-лайн з використанням цифрових технологій [12].

3. Вплив процесів транспортування на біосферу приводить до необхідності час від часу регулювати виникаючи проблеми. Це реалізується шляхом розробки законотворчих актів у екологічній, економічній та соціальній сферах для отримання консенсусу, рівноваги у взаємодії «транспорт-середовище» та зменшення негативного впливу на середовище, людей та тварин. В цьому й $є$ сенс регулювання. Цей процес перманентний.

\section{ЛІТЕРАТУРА}

1. Самсонкин, В.Н. Метод статистической закономерности в управлении безопасностью движения на железнодорожном транспорте: Монография / В.Н.Самсонкин, В.А.Друзь. Донецк: ДИЖТ, 2005. - 158 с.

2. The European Parliament. Directive 2004/49/EU (Railway Safety Directive). European Union: Official Journal of the European Union; 2004. - 24 p.

3. Положення про Систему управління безпекою руху поїздів у Державній адміністрації залізничного транспорту / В кн. «Збірник нормативних актів з безпеки руху га залізничному транспорті». - Київ: ДАЗТУ, 2011. - С. 32-130.

4. Petersen, D. Techniques of Safety Management: A Systems Approach / D.Petersen. - San Diego: Amer Society of Safety Engineers, 2003. - 364 pp.

5. Анохин, П.К. Узловые вопросы функциональной системы / П.К.Анохин. - М.: Наука, 1980. - $287 \mathrm{c}$. 
6. Судаков, К.В. Общая теория функциональных систем / К.В.Судаков. - М.: Медицина, 1984. - $224 \mathrm{c}$.

7. Положення про класифікацію транспортних подій на залізничному транспорті / Наказ Міністерства інфраструктури України від 03.07.2017 № 235. URL: https://zakon.rada. gov.ua/laws/show/z0904-17\#Text.

8. Самсонкин, В.Н. К вопросу эффективного управления работой дистанции сигнализации и связи / В.Н.Самсонкин, А.Б.Бойник, А.Н.Прогонный // Електромагнітна сумісність та безпека на залізничному транспорті. - 2018. - № 16. - С. 95-105.

9. Самсонкін, В. Практичне застосування визначення «вузьких місць» в убезпеченні руху на підприємствах залізничного транспорту для профілактики транспортних подій / В.Самсонкін, А.Мартишко // Залізничний транспорт України. - 2015. - №1. C. 3-10.

10. Samsonkin, V. Development of an approach for operative control over railway transport technological safety based on the identification of risks in the indicators of its operation / V.Samsonkin, O.Goretskyi, V.Matsiuk, V.Myronenko, A.Boinik, V.Merkulov // Східно-Свропейський журнал передових технологій. - 2019. - 6/3 (102). - С. 6-14.

11. Rodrigue J.P. The Geography and Transport Systems. 5-th edition. — New York: Routledge, 2020. - $456 \mathrm{pp}$.

12. Samsonkin, V., Control Technology of Railway Traffic Safety: A System Approach and Digitalization / Lecture Notes in Intelligent Transportation and Infrastructure / V.Samsonkin, O.Goretskyi. - Springer Nature Switzerland AG, 2020. — Pp .633-638. 


\title{
РОЗДІЛ 9 \\ НОВІ ВИКЛИКИ В УПРАВЛІННІ КРИЗАМИ І РИЗИКАМИ В ЛОГІСТИЧНИХ СИСТЕМАХ
}

\author{
І.В. Ніколаснко ${ }^{15}$ \\ M.B. Xapa ${ }^{16}$
}

\section{1. ВСТУП}

Розвиток культури управління ризиками та використання різноманітних методів ризик-менеджменту в логістичних системах є одним з найважливіших факторів виживання компаній та динамічного розвитку економіки окремих регіонів та країн в цілому.

Постійне розширення глобальних проблем збільшило площу впливу і величину ризиків, від зміни клімату і розвитку багатополярної економічної системи до зростання мобільності і цифровізації. Дослідження McKinsey \& Company показують, що кожен рік принаймні одна з двадцяти компаній страждає від збоїв в ланцюгу поставок, вартість яких становить не менше 100 мільйонів доларів.

Сучасні логістичні системи та ланцюги поставок впливають на необхідність формування вимог до компетенцій управлінського персоналу, що відповідають складному бізнес-середовищу, яке функціонує в умовах значної географічної віддаленості компаній, має орієнтацію на клієнтів та потребує інтенсивної підтримки ІТ-систем.

Основними завданнями дисципліни «Нові виклики в управлінні кризами і ризиками в логістичних системах», матеріалам якої присвячено цей розділ, є навчити здобувачів вищої освіти:

- виявляти джерела небезпеки і аналізувати результати впливу ризиків на функціонування логістичних систем;

- оцінювати кількісні та якісні наслідки виникнення ризиків в умовах певної логістичної системи за допомогою методик і довідкових даних наведених у фаховій літературі;

- використовувати методи попередження та зниження ризиків з врахуванням реальних умов функціонування логістичних систем.

У світлі зростаючої складності бізнесу та зростаючої загальної невизначеності, створення систематичного підходу до управління кризами та ризиками стає все більш актуальним.

\footnotetext{
${ }^{15}$ Канд. техн. наук, доцент кафедри «Технології міжнародних перевезень і логістика» ДВНЗ «Приазовський державний технічний університет», Маріуполь 16 Канд. техн. наук, доцент кафедри «Транспортні технології підприємств» ДВНЗ «Приазовський державний технічний університет», Маріуполь
} 


\section{2. ОСНОВНИЙ МАТЕРІАЛ}

\section{1. Кризи та глобальні ризики}

Поняття «криза» має багато змістових інтерпретацій та характеристик. Від давньогрецького слова крі́бı — це поворотний пункт, рішення.

В сучасних тлумачних словниках іноземних мов надаються досить різноманітні трактування слова «криза» 3 точки зору життя людини, організації та управління. Наприклад, в Кембриджському словнику написано, що криза: 1) це час великих розбіжностей, розгубленості чи страждань; 2) це надзвичайно важка або небезпечна точка в ситуації. В американському словнику Merriam-Webster слово «криза» пояснюється як нестабільний або вирішальний час, або стан справ, в якому відбувається вирішальна зміна.

Китайською слово «криза» складається із двох ієрогліфів: один означає «небезпека», а другий - «можливість». I це дає розуміння того, що криза потрібна так само, як і стабільний стан. Кризу можна сприймати як переломну подію у розвитку, що дає простір новому етапу в існуванні системи.

Згідно тлумачного словника сучасної української мови: «Криза - різка зміна звичайного стану речей, злам, загострення становища». Під кризою також розуміють процес порушення рівноваги самокерованої системи, який супроводжується втратою іiї стійкості та може закінчитись або руйнацією і цілковитим припиненням існування системи, або переходом іiї в новий стан стійкої рівноваги.

У науково-дослідних та методичних роботах вітчизняних та зарубіжних вчених проаналізовано наступні види криз:

1. Економічні кризи - це погіршення економічного стану окремих країн чи світового господарства загалом, що призводить до спаду виробництва, зростання розриву між попитом та пропозицією, затоварення, знецінення грошей $\mathrm{i}$, як наслідок, росту вартості життя, безробіття, погіршення інших макроекономічних показників.

2. Політичні кризи - стосуються втрати респектабельності й авторитету апарату управління, розкол у партіях; руйнація принципів і підвалин, моральності, тощо.

3. Соціальні кризи - виникають при загостренні протиріч чи зіткненні інтересів різних соціальних груп та утворень: працівників і роботодавців, підприємств і профспілок; персоналу і менеджерів та інш.

4. Виробничо-технологічні кризи - пов'язані з браком нових технологічних ідей в умовах явно вираженої потреби в нових технологіях. Ця криза може бути результатом невдалої виробничо-технічної політики підприємства, що виявляється в нездатності випускати конкурентоспроможну продукцію або надавати якісні послуги, та може призвести до повної зупинки виробництва.

5. Організащійні кризи - виникають у вигляді суперечностей усередині і за межами організації внаслідок: створення нових структур в системі управління; невиконання планів; збоїв комунікаційних процесів; перерозподілу функцій, тощо. 
По відношенню до логістичної системи причини виникнення криз можуть бути поділені на дві групи: зовнішні і внутрішні. Зовнішні причини пов'язані з тенденціями і стратегією макроекономічного розвитку або розвитку світової економіки, ринковою конкуренцією, політичною ситуацією в країні. Внутрішні 3 недосконалістю управління, інноваційною та інвестиційною політикою, ризикованою маркетинговою стратегією, внутрішніми конфліктами та ін.

Передбачувані або закономірні кризи настають як етап розвитку системи, вони можуть прогнозуватися, оскільки викликаються об'єктивними причинами, самою природою соціально-економічної системи.

Несподівані кризи зумовлені суб'єктивними причинами i $є$ результатом, наприклад, катастрофічних природних явищ, пандемій та ін. Пандемія COVID-19 виявила вразливості в довгих і складних ланцюгах поставок багатьох компаній, коли в одній країні або навіть на одному заводі не працювали, виробництво зупинилося через відсутність критично важливих компонентів.

Таким чином, узагальнюючи вищевказане, можна відмітити, що криза - це різке порушення існуючої рівноваги в процесах життєдіяльності людини, різноманітних бізнес-процесах, в технічних системах внаслідок різного роду економічних та політичних диспропорцій, антропогенного впливу на природу та ін. Кризу також доцільно розглядати як переломний момент у розвитку системи, що дає простір новому витку економічних змін.

Основна небезпека кризи - руйнування системи. Для попередження або усунення цього необхідно розуміти, що на економічну систему впливають екзогенні та ендогенні чинники, які й провокують кризові явища і для запобігання та нівелювання їх впливу необхідно використовувати особливий вид управління, а саме антикризове управління [1].

Важливо також усвідомлювати, що деякі кризи занадто великі, щоб їх могла вирішити будь-яка одна організація. Міцні партнерські відносини і гарне спілкування $\epsilon$ ключем до пошуку вирішення таких серйозних проблем як, наприклад, пандемія COVID-19.

Загострення проблем світової безпеки, неоднозначний вплив процесів глобалізації на розвиток різних країн, значний ріст масштабів та географії ланцюгів поставок, а також інші комплексні чинники вплинули на поширення та використання поняття «глобальний ризик».

Аналітики Всесвітнього економічного форуму дають наступне визначення: глобальний ризик - це невизначена подія або умова, яка у разі іiі виникнення може спричинити значний негативний вплив для кількох країн чи галузей протягом наступних 10 років.

Глобальні ризики поділяються на п'ять груп:

1. Економічні ризики (пузир активів у великих економіках, що лопнув; крах системно важливої галузі, що впливає на світову економіку, фінансові ринки та / або суспільство; боргові кризи у великих економіках, що призводить до масових банкрутств, дефолтів, неплатоспроможності, криз ліквідності або криз суверенного 
боргу; нездатність стабілізувати траєкторії цін; поширення незаконної господарської діяльності, яка підриває економічний прогрес і зростання: підробка, нелегальні фінансові потоки, незаконна торгівля, ухилення від сплати податків, торгівля людьми та ін.; тривала економічна стагнація; сильні товарні потрясіння).

2. Природоохоронні ризики (втрата біорізноманіття та колапс екосистеми; провал кліматичних дій, нездатність урядів та підприємств застосовувати чи інвестувати в ефективні заходи щодо адаптації та пом'якшення наслідків зміни клімату, зберігати екосистеми, захищати населення та переходити до вуглецевонейтральної економіки; екстремальні погодні явища i, як наслідок, втрата людського життя, пошкодження екосистем, знищення майна та / або фінансові втрати в глобальному масштабі - дерегуляція природоохоронних територій, виробничі аварії, розливи нафти, радіоактивне забруднення, торгівля дикими тваринами та ін.; шкода, завдана людиною навколишньому середовищу — виробничі аварії, розливи нафти, радіоактивне забруднення та ін.; великі геофізичні катастрофи внаслідок землетрусів, зсувів, геомагнітних бур, цунамі, вулканічної діяльності тощо; кризи природних ресурсів в результаті надмірної експлуатації та / або безгосподарного управління).

3. Геополітичні ризики (розпад багатосторонньої установи, створеної для вирішення економічних, екологічних, геополітичних та / або гуманітарних криз з регіональними чи глобальними наслідками: прикордонні суперечки, екологічні зобов'язання, міграційні кризи, надзвичайні ситуації зі здоров'ям, торгові суперечки тощо; перелом міждержавних відносин; геополітизація стратегічних ресурсів, що є критично важливими для людського розвитку; міждержавний конфлікт 3 глобальними наслідками: біологічні, хімічні, кібер- та / або фізичні напади, військові втручання; крах держави в результаті внутрішнього конфлікту, руйнування верховенства права та ін.; терористичні атаки, які що призвели до загибелі людей, серйозних травм та / або матеріальної шкоди; зброя масового знищення).

4. Соціальні ризики (колапс або відсутність систем соціального забезпечення; криза в сфері зайнятості та засобів до існування - безробіття, неповна зайнятість, більш низька заробітна плата, нестійкі контракти, порушення прав робітників і ін.; руйнування соціальної згуртованості негативно впливає на соціальну стабільність, індивідуальне благополуччя і економічну продуктивність; відмова громадської інфраструктури в результаті неефективного управління розростанням міст, погане планування і / або недостатнього інвестування, що негативно позначається на економічному розвитку, освіті, житло, громадській охороні здоров'я; інфекційні захворювання, що призводять до епідемії або пандемії з людськими жертвами і економічним потрясінням; масштабна вимушена міграція викликана зміною клімату, дискримінацією, відсутністю можливостей економічного розвитку, переслідуваннями, стихійними лихами або антропогенними катастрофами, насильницькими конфліктами і т.д.; повсюдна негативна реакція на науку; серйозне погіршення психічного здоров’я; поширене розчарування молоді).

5. Технологічні ризики (несприятливі наслідки технічного прогресу; порушення критичної інформаційної інфраструктури в результаті системної залежності 
від кібермереж і / або технологій: систем з інтенсивним використанням штучного інтелекту, Інтернету, портативних пристроїв, комунальних служб, супутників і т. Д.; цифрова нерівність в результаті нерівних інвестиційних можливостей, відсутності необхідних навичок у робочої сили, недостатньої купівельної спроможності, державних обмежень і / або культурних відмінностей; цифрова концентрація влади, що призводить до дискреційним механізмів ціноутворення, відсутності неупередженого нагляду, нерівного приватному і / або загальнодоступному доступу і т. д.; недотримання заходів кібербезпеки, що призводить до економічних збоїв, фінансових втрат, геополітичної напруженості і / або соціальна нестабільність; невдача в управлінні технологіями в результаті того, що різні держави або групи держав приймають несумісну цифрову інфраструктуру, протоколи та / або стандарти).

У звіті Всесвітнього економічного форуму «The Global Risks Report 2021» до числа найбільш ймовірних ризиків найближчих десяти років віднесено: екстремальні погодні умови, провал дій по боротьбі зі зміною клімату і шкоди навколишньому середовищу, викликаний діяльністю людини; а також цифрова концентрація влади, цифрова нерівність і збій кібербезпеки (табл. 1).

Таблиця 1

Вплив глобальних ризиків 2020-2021 pp.

\begin{tabular}{|c|c|c|}
\hline $\begin{array}{c}\text { Основні } \\
\text { глобальні } \\
\text { ризики }\end{array}$ & 2020 p. & 2021 p. \\
\hline $\begin{array}{l}\text { За ймовір- } \\
\text { ністю }\end{array}$ & $\begin{array}{l}\text { 1.Екстремальні погодні умови. } \\
\text { 2.Провал в боротьбі зі зміною клі- } \\
\text { мату. } \\
\text { 3. Стихійні лиха. } \\
\text { 4. Втрата біорізноманіття. } \\
\text { 5. Техногенні екологічні катастрофи. } \\
\text { 6. Шахрайство або крадіжка даних. } \\
\text { 7. Кібератаки. }\end{array}$ & $\begin{array}{l}\text { 1.Екстремальні погодні умови. } \\
\text { 2.Провал в боротьбі зі зміною клімату. } \\
\text { 3.Шкода навколишньому середо- } \\
\text { вищу від людини. } \\
\text { 4. Інфекційні захворювання. } \\
\text { 5.Втрата біорізноманіття. } \\
\text { 6.Цифрова концентрація влади. } \\
\text { 7.Цифрова нерівність. }\end{array}$ \\
\hline $\begin{array}{l}\text { За } \\
\text { впливом }\end{array}$ & $\begin{array}{l}\text { 1. Провал в боротьбі зі зміною клімату. } \\
\text { 2. Зброя масового ураження. } \\
\text { 3. Втрата біорізноманіття. } \\
\text { 4. Екстремальні погодні умови. } \\
\text { 5. Водні кризи. } \\
\text { 6. Відмова інформаційної інфра- } \\
\text { структури. } \\
\text { 7. Стихійні лиха. }\end{array}$ & $\begin{array}{l}\text { 1. Інфекційні захворювання. } \\
\text { 2. Провал в боротьбі зі зміною клімату. } \\
\text { 3.Зброя масового ураження. } \\
\text { 4. Втрата біорізноманіття. } \\
\text { 5. Кризи природних ресурсів. } \\
\text { 6. Шкода навколишньому середови- } \\
\text { щу від людини. } \\
\text { 7. Криза засобів до існування }\end{array}$ \\
\hline
\end{tabular}

Джерело: [2, 3] 
У порівнянні з 2020 роком, інфекційні хвороби знаходяться на першому місці за впливом на наступне десятиліття. За ними слідують невдачі в діях по боротьбі зі зміною клімату та інші екологічні ризики; а також зброя масового знищення, кризи засобів до існування, боргові кризи і поломки IT-інфраструктури.

Сучасний ландшафт глобальних ризиків (табл.1) значною мірою формується невпорядкованим геополітичним середовищем - таким, в якому формуються нові центри сили та впливу - під час випробування старих структур альянсу та глобальних інституцій. Геополітичний ризик, як і будь-який інший, має об'єктивно-суб'єктивну природу, оскільки зумовлюється невизначеністю міжнароднополітичного середовища та характеризується особливим типом взаємозв'язку об'єктивної ситуації світового політичного процесу й діяльності суб'єкта в ній [4].

Аналітики ВЕФ рекомендують проводити «цілісний» аналіз ризиків і інвестувати у вивчення нових форм управління ризиками, таких як державно-приватне партнерство.

\section{2. Природна небезпека та ризики стихійних лих 2.2.1. Кліматичні загрози}

Кліматична криза є системною, вона швидко розвивається, широкомасштабна і глобальна. Багато світових дослідницьких інституцій вважають зміну клімату і пластикові відходи одними 3 найбільших проблем, 3 якими стикається світ, навіть в розпал COVID-19. Незважаючи на неминучі наслідки COVID-19, питання, пов’язані з кліматом, є основними у звіті «The Global Risks Report 2021», ці ризики описуються як «екзистенційна загроза людству». Попри зниження викидів вуглецю, спричинене зменшенням активності у міжнародній торгівлі й туризмі, $\epsilon$ побоювання, що при наступному економічному відновленні викиди знову зростуть (рис. 1).

Зміна клімату вражає сильніше і швидше, ніж багато хто очікував. Останні роки є найтеплішими за всю історію спостережень, стихійні лиха стають все більш інтенсивними і частими, а в 2019 році в світі спостерігалася безпрецедентна екстремальна погода. До кінця століття глобальні температури зростуть не менше ніж на $3^{\circ} \mathrm{C}$ - удвічі більше, ніж попереджають експерти з питань клімату, - це межа, що дозволяє уникнути найбільш серйозних економічних, соціальних і екологічних наслідків. Найближчі наслідки зміни клімату посилюють планетарну надзвичайну ситуацію, яка буде включати загибель людей, соціальну і геополітичну напруженість і негативні економічні наслідки.

Індекс глобального кліматичного ризику (Climate Risk Index - CRI) вказує рівень схильності і уразливості до екстремальних погодних явищ, які країни повинні розуміти як попередження, щоб бути готовими до частіших і / або більш серйозних явищ в майбутньому (табл. 2). 


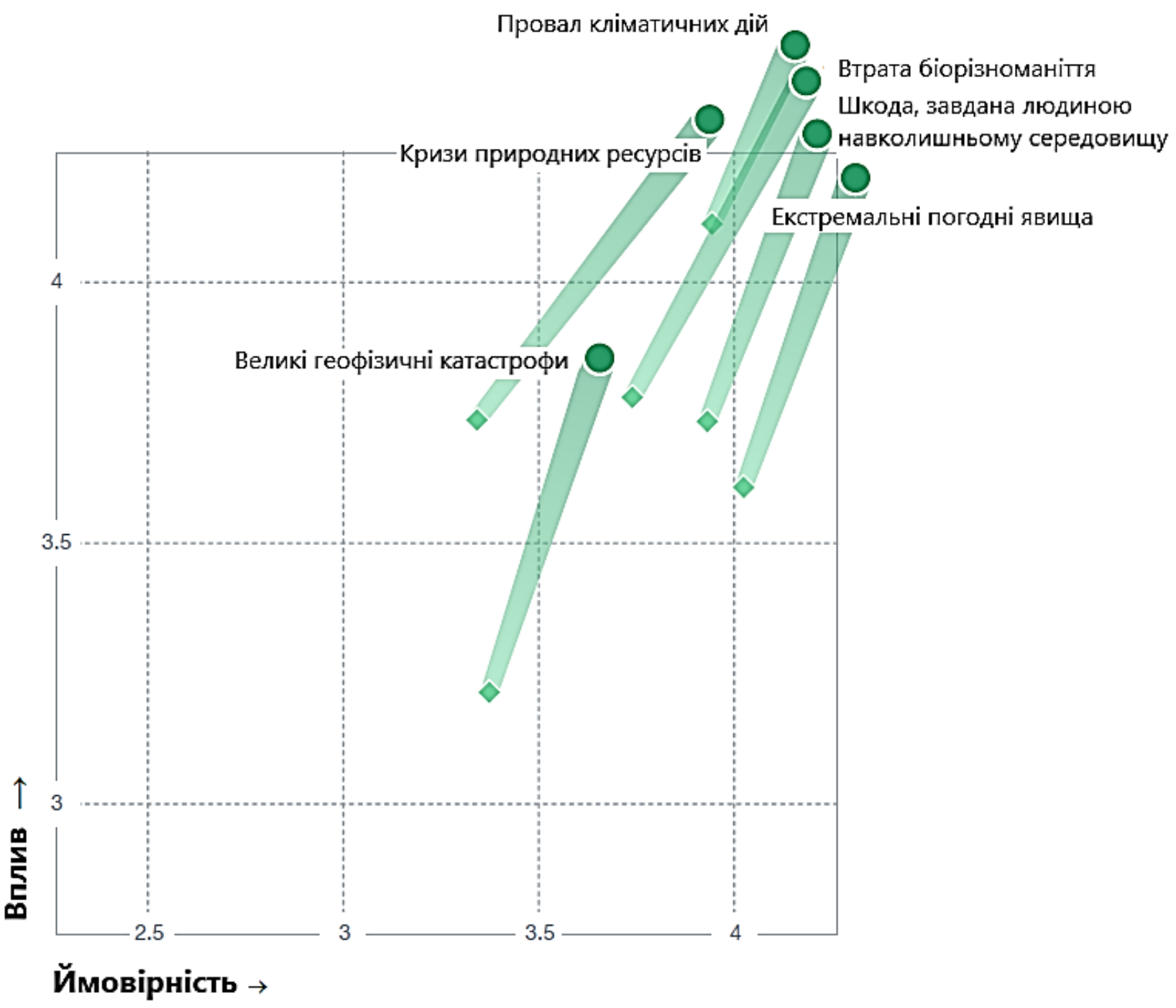

Рис. 1. Співвідношення рівня впливу та ймовірності природоохоронних ризиків

Джерело: [3]

Таблиця 2

Індекс кліматичних ризиків на 2019 рік

\begin{tabular}{|c|l|l|c|c|c|c|}
\hline $\begin{array}{c}\text { Рейтинг } \\
\text { CRI }\end{array}$ & Країна & Бали & $\begin{array}{c}\text { Смертність } \\
\text { в 2019 г. } \\
\text { (Рейтинг) }\end{array}$ & $\begin{array}{c}\text { Число загиб- } \\
\text { лих на 100 000 } \\
\text { жителів }\end{array}$ & $\begin{array}{c}\text { Втрати, } \\
\text { млн дол. } \\
\text { США }\end{array}$ & $\begin{array}{c}\text { Втрати на } \\
\text { одиницю } \\
\text { ВВП, \% }\end{array}$ \\
\hline 1 & Пуерто-Рико & 7.17 & 149.85 & 4.12 & 4149.98 & 3.66 \\
\hline 2 & М'янма & 10.00 & 7056.45 & 14.35 & 1512.11 & 0.80 \\
\hline 47 & Австрія & 56.83 & 84 & 79 & 25 & 37 \\
\hline 56 & Німеччина & 61.33 & 65 & 102 & 11 & 44 \\
\hline 85 & Україна & 76.17 & 76 & 100 & 41 & 70 \\
\hline 93 & Польща & 80.00 & 76 & 97 & 40 & 85 \\
\hline
\end{tabular}

Джерело: [5] 
У цілому за період з 2000 по 2019 рік більше 475000 чоловік загинули в результаті більш ніж 11000 екстремальних погодних явищ у всьому світі, а збитки склали близько 2,56 трильйона доларів США (за паритетом купівельної спроможності). Шторми і їх прямі наслідки - опади, повені та зсуви - були однією з основних причин втрат і збитків в 2019 році. 3 десяти найбільш постраждалих країн в 2019 році шість постраждали від тропічних циклонів. Недавні дослідження припускають, що кількість сильних тропічних циклонів буде збільшуватися з кожної десятої градуса підвищення середньої глобальної температури [5].

Потепління Землі в наступному десятилітті неминуче, і в цій новій реальності зростає ризик фізичних та економічних небезпек. Єдиний спосіб уникнути найгірших наслідків зміни клімату після 2030 року — це інтенсивно декарбонізувати економіку і повсякденне життя. Таким чином, пом'якшення наслідків зміни клімату за допомогою декарбонізації є необхідною відповіддю. Широкий спектр наукових досліджень в галузі мультимодальних перевезень сфокусований на розробці альтернативних варіантів транспортування товарів та вирішенні проблем декарбонізації в ланцюгах поставок. Цілі по викидах в Паризькій угоді свідчать, що всі сторони скоротять свій вуглецевий слід більш ніж на 50 відсотків до 2030 року і усунуть його до 2050 року.

Стихійне лихо може спровокувати різкі зміни в нормальному функціонуванні будь-яких спільнот або суспільства в цілому у вигляді несприятливих наслідків для населення, несприятливих матеріальних, економічних або екологічних наслідків. Небезпечні фізичні явища вимагають невідкладних надзвичайних заходів реагування для задоволення життєво важливих людських потреб і можуть вимагати надання зовнішньої допомоги для цілей відновлення.

Ризик стихійних лих — це імовірність протягом певного періоду часу різких змін в нормальному функціонуванні будь-яких спільнот або суспільства в цілому, викликаних небезпечними фізичними явищами і що відбуваються при наявності вразливих соціальних умов.

Екстремальний вплив на антропогенні, екологічні або фізичні системи може бути результатом окремих екстремальних метеорологічних або кліматичних явищ. Екстремальний вплив може також бути результатом неекстремальних явищ, коли схильність і вразливість бувають високими, або поєднання явищ або їх впливів. Наприклад, посуха в поєднанні з екстремальною спекою або низькою вологістю може підвищити ризик стихійної пожежі.

Адаптація в антропогенних системах — це процес пристосування до існуючого або очікуваного клімату і його впливів, з тим щоб пом'якшити шкоду або скористатися вигідними можливостями.

Управління ризиками стихійних лих включає в себе:

1. Процеси розробки, здійснення і оцінки стратегій, політики та заходів щодо поліпшення розуміння ризику стихійних лих.

2. Сприяння зменшенню і переносу (страхування) ризику стихійних лих. 
3. Сприяння постійному вдосконаленню заходів щодо забезпечення готовності до стихійних лих, реагування на них і відновленню після них, тобто заходи націлені на підвищення безпеки людей, добробуту, якості життя, опірності і забезпечення сталого розвитку.

Опірність - це здатність системи і складових ії частин своєчасно і ефективно припускати вплив небезпечних явищ, компенсувати їх, пристосовуватися до них або відновлюватися після них, в тому числі за допомогою забезпечення збереження, відновлення або вдосконалення своїх істотних базових структур і функцій. Схильність і вразливість $є$ ключовими визначальними факторами ризику стихійних лих та їх наслідків у разі виникнення ризику. Наприклад, хвиля тепла може мати дуже різні наслідки для різних груп населення в залежності від їх уразливості.

Ступінь природної небезпеки визначається видами небезпечних явищ i ïx характеристиками [6]:

1. Енергетичними, тобто розподілом по силі - зустрічальністю. Їх рівні $\epsilon$ фізичними величинами (амплітуда коливань грунту під час землетрусу, швидкість вітру під час урагану та ін.). Рівні негативних факторів (діючі навантаження) описуються параметрами i, визначальними їх негативними діями (вражає, виснажує, блокує) на об'єкти.

2. Часовими - часовим розподілом (частотою реалізації або повторюваністю небезпечних явищ, їх циклічністю і прогнозованими термінами виникнення).

3. Просторовими - просторовим розподілом (областями розвитку несприятливих явищ або можливого виникнення небезпечних явищ заданої сили і повторюваності; площами зон дії їх негативних факторів).

Управління ризиками вимагає врахування небезпечних явищ, реалізація яких малоймовірна, але наслідки великі (сильні повені, землетруси та ін.). Господарське освоєння без достатнього обгрунтування і прийняття адекватних заходів інженерного захисту територій, схильних до рідкісних, але сильних повеней, призводить рано чи пізно до знищення об'єктів інфраструктури.

Розподіл в часі

Природні процеси і явища в конкретних пунктах на деякій території в часі i просторі і описуються деякими параметрами $u$. Будемо розглядати їх як реалізацію деякого одновимірного (функція одного параметра природного процесу) квазістаціонарного ергодичного випадкового процесу $U(t / x)$. Викиди цього процесу $\epsilon$ небезпечними природними явищами, в якості критерія настання яких розглядається умова:

$$
u \geq u_{k},
$$

де $u_{k}$ - деяке критеріальне значення.

Тоді небезпечні природні явища утворюють потік випадкових подій — викидів випадкового процесу за рівень $u_{k}$. 
Негативну дію небезпечних явищ на елементи антропосфери характеризують, як правило, амплітудні значення їх параметрів. Тому в якості $u$ зазвичай розглядають амплітуди викидів $u_{\max }$ (наприклад, максимальну швидкість вітру при ураганах, максимальний підйом рівня води при повенях, максимальне прискорення грунту при землетрусах). Опис небезпечних явищ в цьому випадку має включати:

- в часі - потік небезпечних явищ;

- за силою - розподіл небезпечних явищ по амплітуді викидів. Амплітуда викидів є випадковою величиною діючої $U_{\max }$ на елементи антропосферою навантаження, що описується розподілом $F_{\max }(u)=P\left(U_{\max }<u\right)$.

Припустимо, потік небезпечних явищ має властивості ординарності (за досить малий проміжок часу відбувається не більше однієї реалізації), відсутність післядії (після чергової реалізації їх частота не змінюється, хоча, зрозуміло, заходи щодо попередження небезпечних явищ і зниження їх наслідків приймаються після кожної реалізації) і стаціонарності (частота реалізацій $\lambda(t)=$ const). При цих умовах потік реалізацій небезпечної події $\epsilon$ найпростішим пуассонівським, для якого випадкове число $\xi$ реалізацій, що відбуваються протягом часу $\Delta t$, розподілено згідно із законом Пуассона:

$$
F(n)=P(\xi \leq n)=\sum_{k=0}^{n} P(k), \quad n=1,2, \ldots,
$$

де $P(k)=\frac{1}{k !} a(\Delta t)^{k} \exp [-a(\Delta t)]$ - ймовірність $k$ реалізацій протягом інтервалу часу $\Delta t$;

$a(\Delta t)=\lambda \Delta t$ - параметр розподілу Пуассона (середнє число $a(\Delta t)=M[\xi]$ реалізацій протягом інтервалу часу $\Delta t)$;

$\lambda$ - частота реалізацій (середнє число реалізацій за одиничний і досить малий інтервал часу, (од. часу) $)^{-1}$ ), яка $є$ основним кількісним показником потоку небезпечних явищ.

Рідкісні події майже завжди розподілені в часі за законом Пуассона. Для пуассонівського потоку час $T$ між подіями підпорядковується експоненціальним законом, тобто ймовірність хоча б однієї реалізації за інтервал часу $\Delta t$ відповідно до (2) обчислюють за формулою

$$
Q(\Delta t)=1-P(0)=1-\exp (-\lambda \Delta t) .
$$

Співвідношення (2) використовують для визначення частоти настання непоправного збитку для конкретного об'єкта, наприклад, індивідуальної ймовірності смерті для людини.

Зі збільшенням $\lambda$ або $\Delta t$ зростає і число подій. Коли $a(\Delta t) \rightarrow \infty$, розподіл Пуассона наближається до нормального 3 параметрами $M[\xi]=a(\Delta t)$ та $\Delta[\xi]=$ $=a(\Delta t)$. В цьому випадку приблизно в якості (1) можна застосовувати рівняння 


$$
F(n)=\Phi\left(\frac{n-M[\xi]}{\sqrt{D[\xi]}}\right)
$$

де $\Phi(\cdot)$ — функція Лапласа.

Практично нормальним наближенням користуються при $a(\Delta t)>100$. Воно корисно для отримання гарантованих оцінок ризику методами довірчого оцінювання, оцінок точності.

Для рідкісних подій (наприклад, важких радіаційних аварій типу Чорнобильської), коли $a(\Delta t) \ll 1$ (практично при $a(\Delta t)<0,1$, наближено можна вважати, що

$$
Q(\Delta t) \approx a(\Delta t)=\lambda \Delta t .
$$

Просторовий розподіл

Просторовий розподіл (області можливого виникнення) небезпечних природних явищ на картографічній основі доцільно відображати ізолініями їх повторюваності і (або) сили. Повторюваність небезпечних природних явищ $\lambda_{0}$ (рис. 2) визначається для точок - центрів квадратів фіксованої площі $S_{0}$, яка дорівнює, наприклад, для торнадо 10000 км².

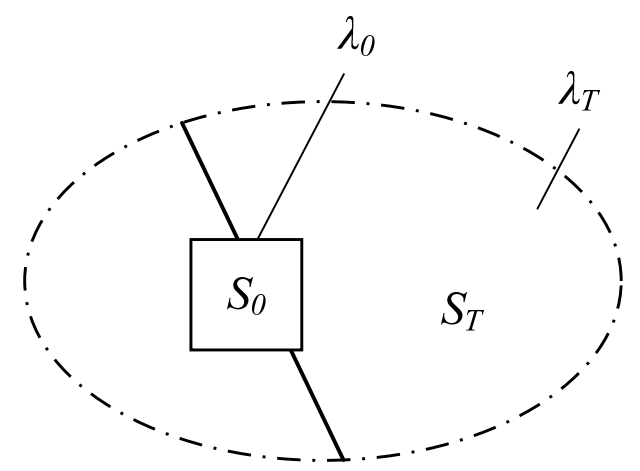

Рис. 2. Визначення повторюваності небезпечних природних явищ на території

Джерело: [6]

Величина $S_{0}$ визначається розмірами області можливого виникнення небезпечного природного явища, градієнтом зміни його повторюваності і площею зони ураження. У припущенні, що $\lambda_{0}$ для всієї території постійна, частоту $\lambda_{\mathrm{T}}$, небезпечних явищ на певній території (в адміністративно-територіальному утворенні) площею $S_{T}$, обчислюють за формулою [6]:

$$
\lambda_{\mathrm{T}}=\frac{S_{T}}{S_{0}} \lambda_{0} .
$$

Якщо територія розглянутого адміністративно-територіального утворення розміщена в зонах з різною частотою небезпечних природних явищ, то середня частота природного явища на ній складе: 


$$
\lambda_{\mathrm{T}}=\frac{1}{S_{0}} \sum_{j} \lambda_{0 \mathrm{j}} S_{T j}
$$

де $S_{T j}$ - площа частини території $\left(\sum_{j} S_{T j}=S_{T}\right)$ на якій небезпечні природні явища відбуваються з частотою $\lambda_{0 j}$.

При відображенні небезпеки на карті за основу взяті ізолінії повторюваності $\lambda_{0}=v a r$ небезпечних природних явищ 3 силою $u \geq u_{0}$. Для визначення повторюваності природних явищ 3 силою $u \geq u_{1}$, додатково розглянемо розподіл реалізацій небезпечного природного явища по силі $F(u)$. В якості критеріальних значень $u_{0}$ та $u_{1}$, може, зокрема, розглядатися розрахункова стійкість розміщених на території типів об'єктів.

Частоту реалізацій небезпечного природного явища, що перевищують певний рівень $u_{1}$, можна визначити за формулою:

$$
\lambda_{1}=\frac{1-F\left(u_{1}\right)}{1-F\left(u_{0}\right)} \lambda_{0}
$$

де $\lambda_{0}-$ відома частота реалізацій небезпечного природного явища з силою $u \geq u_{0}$.

Якщо $u$ — це параметр, що характеризує нищівну силу негативних природних стихій від деякого джерела небезпеки на об'єкт, тоді $u_{\text {кр }}$ - критичне значення, починаючи з якого об’єкт руйнується. Отже, руйнування об’єктів відбувається на відстані $r \leq R_{n}$, від джерела небезпеки (рис. 3).

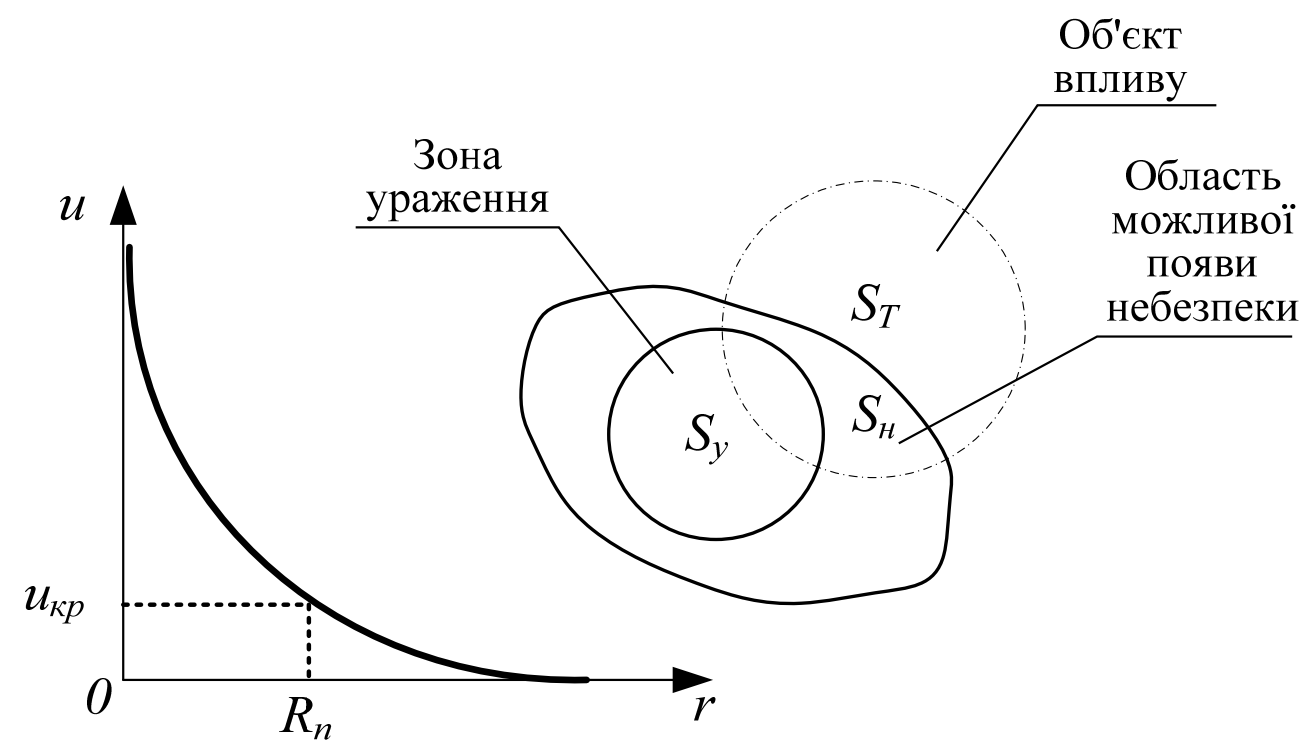

\section{Рис. 3. Відносний просторовий розподіл джерела небезпеки та об'єкта впливу \\ Джерело: [6]}


Якщо зона ураження - коло, то площа зони ураження негативними факторами розглянутого джерела небезпеки $S_{\mathrm{y}}=\pi R_{n}^{2}$. Радіус ураження $R_{n}$, визначається

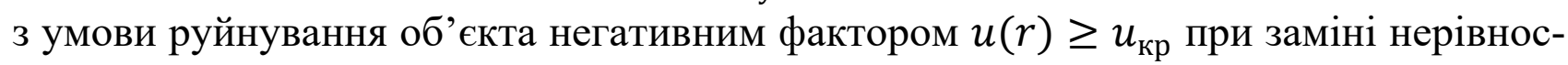
ті на рівність.

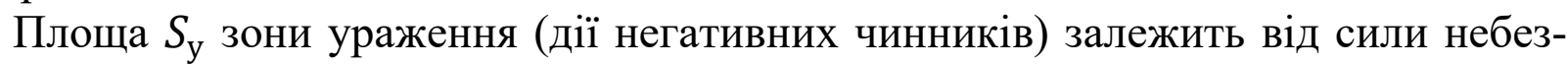
печного природного явища, стійкості забудови до впливу негативних і інших чинників. Вона оцінюється за статистичними даними або за допомогою теоретичних моделей.

Для характеристики ступеня небезпеки території використовують також поняття ураженості геологічним процесом, під якою розуміють співвідношення площі прояви (поширення) певного геологічного процесу до загальної площі розглянутої території. Кількісним показником ураженості є коефіцієнт ураженості [6]:

$$
\alpha_{\mathrm{y}}=S_{\mathrm{H}} / S_{\mathrm{T}}
$$

де $S_{\mathrm{T}}$ - загальна площа території;

$S_{\mathrm{H}}$ — площа прояви небезпечного природного явища на розглянутій території.

Загалом, природні ризики стають істотними для логістичних систем 3 трьох причин:

1. Коли бізнес прямо залежить від характеру операцій, продуктивності ланцюга поставок, вартості активів нерухомості, фізичної безпеки і безперервності бізнесу.

2. Коли прямий і непрямий вплив господарської діяльності на навколишнє середовище може викликати негативні наслідки, такі як втрата клієнтів або цілих ринків, судові позови і нормативні зміни, які впливають на фінансові результати.

3. Коли природні збитки завдають шкоди суспільству і ринкам, на яких працюють підприємства, що може проявлятися як в фізичних, так і в ринкових ризиках.

У підприємств є можливість вжити заходів щодо обмеження своїх кліматичних ризиків, наприклад, зробивши свої капітальні вкладення більш стійкими до зміни клімату або диверсифікуючи свої ланцюги поставок.

Уряди при взаємодії з приватним сектором мають можливості створювати інфраструктуру для пом'якшення наслідків повеней та інших кліматичних ризиків на території країн та регіонів, інвестувати в засоби раннього попередження і підтримувати передові можливості управління надзвичайними ситуаціями.

\subsection{2. Водна криза та шляхи її вирішення}

Водні кризи стають звичайним явищем у сучасному світі. Водосховища в Ченнаї, шостому за величиною місті Індії, зараз майже висохли. У 2018 році жителі Кейптауна, Південна Африка, ледь уникли відключення води у так званий 
день зеро («Day Zero», коли рівень запасів у водосховищі стає гранично низьким). В 2017 році Рим унормував воду для збереження мізерних ресурсів.

Причини цих криз набагато глибше, ніж посуха. Завдяки новим гідрологічним моделям Інституту водних ресурсів (World Recourse Institute - WRI) виявлено, що водозабір в світі більш ніж подвоївся з 1960-х років через зростаючий попит. I немає жодних ознак уповільнення цього процесу.

Нові дані інструментів WRI Aqueduct показують, що 17 країн, в яких проживає чверть населення світу, стикаються з «надзвичайно високим» рівнем вихідного дефіциту води, при цьому зрошуване землеробство, промисловість і муніципалітети щороку в середньому забирають більше $80 \%$ загальнодоступного запасу води (рис. 4).

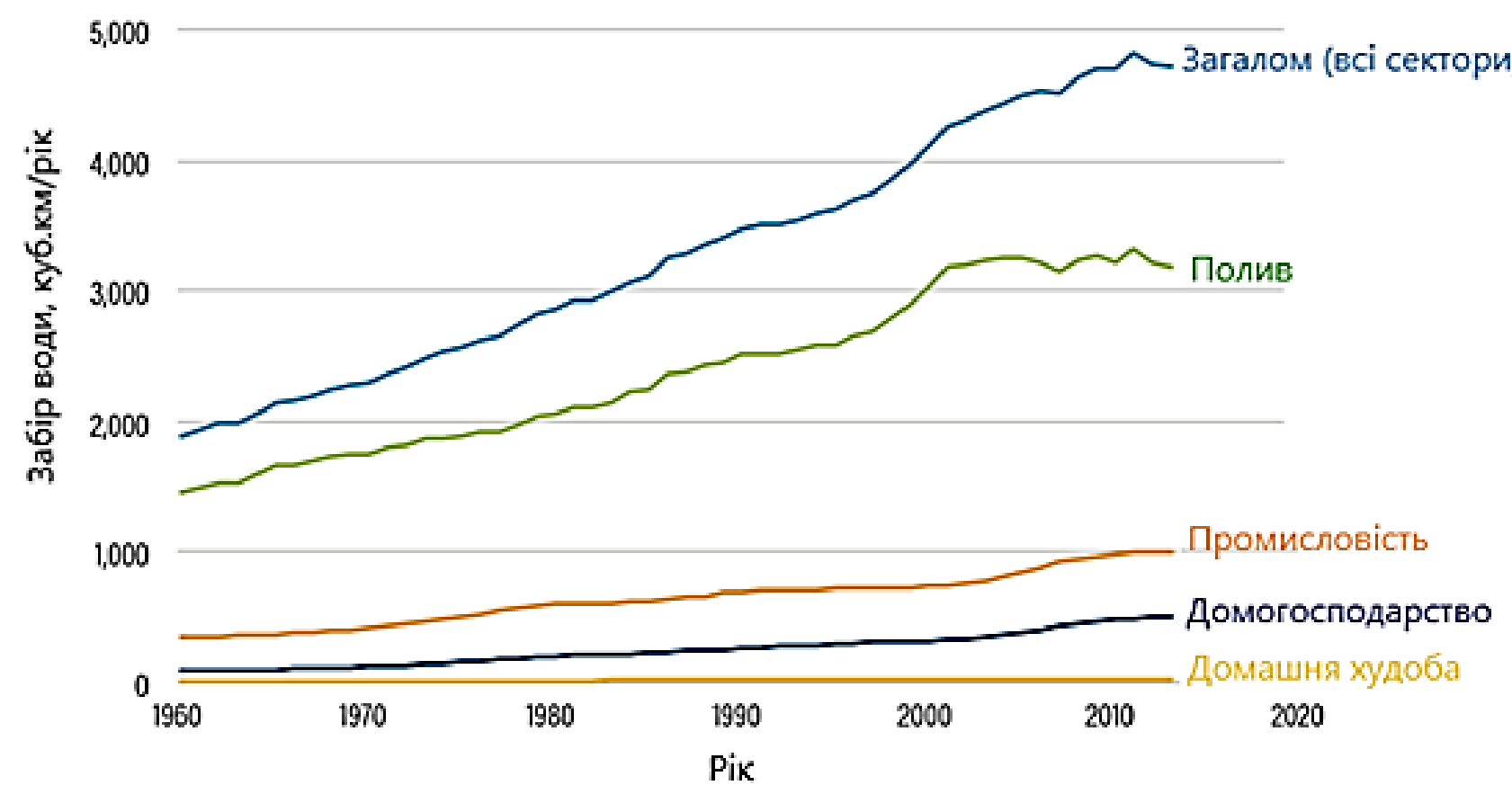

Рис. 4. Динаміка об'ємів споживання води за секторами Джерело: [7]

Сорок чотири країни, в яких проживає одна третина світу, стикаються 3 «високим» рівнем стресу, коли в середньому більше $40 \%$ доступного запасу води вилучається щороку. Такий вузький розрив між попитом і пропозицією робить країни уразливими для таких коливань, як посухи або збільшення водозабору, спостерігається все більше і більше спільнот, які зіткнулись зі своїми власними «Day Zero» та іншими кризами.

Водний стрес створює хвильовий ефект в суспільстві та економіці. Водний стрес $\epsilon$ серйозною загрозою для життя людей, засобів до існування і стабільності бізнесу. Ситуація може погіршитися, якщо країни не будуть діяти: зростання населення, соціально-економічний розвиток і урбанізація збільшують потребу у воді, в той час як зміна клімату може зробити опади і попит більш мінливими. 
Основні способи зменшення водного стресу включають наступні рішення.

По-перше, підвищення ефективності сільського господарства: світові необхідно, щоб кожна крапля води йшла далі в своїх харчових системах.

Фермери можуть використовувати насіння, яким потрібно менше води, і вдосконалювати свої методи поливу, використовуючи точний полив, а не затоплюючи свої поля. Фінансисти можуть надати капітал для інвестицій в продуктивність води, а інженери можуть розробляти технології, які підвищують ефективність у сільському господарстві. А споживачі можуть скоротити втрати продуктів харчування і відходів, які використовують чверть всієї сільськогосподарської води.

По-друге, інвестування в супутню інфраструктуру. Дослідження Інституту водних ресурсів і Світового банку показують, що побудована інфраструктура (наприклад, труби та очисні споруди) і зелена інфраструктура (наприклад, водноболотні угіддя і здорові водозбірні басейни) можуть працювати спільно для вирішення питань як водопостачання, так і якості води.

I також людство повинно припинити думати про стічні води як про відходи. Обробка і повторне використання створює «нове» джерело води. $Є$ також корисні ресурси в стічних водах, які можна збирати для зниження витрат на очищення води. Цим, наприклад, займаються заводи в Сян'яне (Китай) і Вашингтоні (округ Колумбія). Річ йде про повторне використання або продаж багатих енергією і поживними речовинами побічних продуктів, відділених під час очищення стічних вод.

Виробництво атмосферної води може допомогти стабілізувати зростаючу нестачу води в світі, але протягом багатьох років сучасні генератори атмосферної води (Atmospheric Water Generator - AWG) страждали від проблем, які перешкоджали здатності безпечно і надійно виробляти воду у великих масштабах. Наразі ця проблема вирішена. Сучасні AWG генерують воду незалежно від наявності водойм чи дощів, дозволяючи тим, хто живе в пустельному кліматі, в умовах посухи, в районах, що сильно постраждали від забруднення або іншим чином постраждали від нестачі водних ресурсів, отримати доступ до чистої питної води.

Найбільшими світовими виробниками водогенераторов 3 повітря є ізраїльська компанія Watergen, американські компанії та виробники водогенераторов TUAFI, Zero Mass Water та Eshara Water з Об'єднаних Арабських Еміратів. Генератори цих компаній здатні створювати високоякісну питну воду з вологості повітря за рахунок надефективного процесу конденсації.

На відміну від інших, технологія Watergen Genny Water Treatment дозволяе отримати питну воду високої якості навіть 3 дуже сухого і забрудненого повітря 3 мінімальними енерговитратами. Генератор вбирає повітря, очищує його, фільтрує і направляє в спеціальну систему охолодження, де відбувається процес конденсації. Пристрій не залежить від інфраструктури водопостачання і працює в зонах стихійного лиха, в пустелі і віддалених поселеннях. Для виробництва п'яти літрів води апарату потрібен всього 1 кВт енергії, що робить воду, видобуту з повітря, надзвичайно дешевою. 
Також технологія AWG є більш екологічним рішенням, оскільки усуває необхідність виготовлення та утилізації пластикових пляшок, а також усуває потребу в наповненні пляшок з перевантажених природних запасів або транспортуванні по всьому світу.

\section{3. Кібератаки та цифрові крадіжки}

Кібербезпека і кібератаки стають все більш серйозною проблемою для підприємств і організацій. І це може негативно вплинути на всі компанії, незалежно від розміру. Згідно Дев'ятому щорічному звіту про дослідження вартості кіберзлочинності, опублікованому Accenture в 2019 році, середнє число порушень безпеки з 2018 року зросла на 11 відсотків [8].

У 2019 відбулося кілька дуже серйозних, тривожних і публічних порушень інформаційної безпеки. Деякі з порушень безпеки, зареєстрованих в 2019 році, включають (представлені в порядку убування дати звіту про порушення):

1. Gekko Group, дочірня компанія Accor Hotels, в листопаді 2019 року розкрила понад 660000 записів клієнтів.

2. Quest Diagnostics в червні 2019 року, торкнулося близько 11,9 мільйона записів пацієнтів.

3. Перша американська фінансова корпорація в травні 2019 року зі близько 885 мільйонами записів про угоди з іпотекою.

4. Facebook в квітні 2019 року, через сторонні розміщені сервери з більш ніж 540 мільйонами записів.

5. Capital One в березні 2019 року зі більш ніж 106 мільйонами порушених даних клієнтів.

6. У січні 2019 року компанія Fornite, що належить Epic Games, торкнулася близько 200 мільйонів користувачів по всьому світу.

Згідно з прогнозами, до 2021 року кіберзлочинність обійдеться світовій економіці в 6 трильйонів доларів. Кібернетичні вторгнення загрожують не тільки бізнес-операціям і ланцюгам поставок, але також фінансовій та комунікаційній інфраструктурі, національній безпеці, конфіденційності, торгівлі і комерції [9].

Безпрецедентні обставини медичної і гуманітарної кризи у 2020 році спровокували інноваційний виток кіберзлочинності. Кібератаки сфокусувалися на уразливості віддалених співробітників, пропонуючи приманки і пастки, що імітують достовірні джерела. У зв'язку з цим, операційні центри безпеки компаній вважають, що їм необхідно використовувати тактичну, операційну та стратегічну інформацію про погрози для виявлення тенденцій і технологій, що загрожують безперервності бізнесу.

3 появою нових ризиків і загроз, що виникають щодня, ризики компрометації даних про клієнтів або співробітників стають все більш і більш складними для 
організацій, так як більш серйозні наслідки виникають і виконуються регулюючими органами.

Відповідно до Закону України «Про основні засади забезпечення кібербезпеки України» кіберзахист — це сукупність організаційних, правових, інженернотехнічних заходів, а також заходів криптографічного та технічного захисту інформації, спрямованих на запобігання кіберінцидентам, виявлення та захист від кібератак, ліквідацію їхніх наслідків, відновлення сталості та надійності функціонування комунікаційних, технологічних систем.

Пандемія COVID-19 спровокувала несподівану технологічну революцію як для великого, так і для малого бізнесу. Швидка цифровізація змінила соціальну і робочу взаємодію. Електронна комерція, віртуальні конференції, ігри і потокова передача - все це пережило безпрецедентне зростання. В 2020 році використання Інтернету у всьому світі збільшилося на $30 \%$, а електронна комерція виросла більш ніж на 20\%. Ця швидка цифровізація також експоненціально збільшила кібервразливість компаній і створила більш складні і потенційно менш безпечні мережі.

В Доповіді про глобальні ризики 2021 року неефективність заходів кібербезпеки розглядається як головний короткостроковий ризик. Протягом 2020 року спостерігалося зростання кібератак на державні установи і компанії по всьому світу - багато хто використовував кризу COVID-19 для проникнення в мережі. У глобальному масштабі з другої половини 2019 року до першої половини 2020 року об`єм атак збільшився вдвічі [3].

Рентабельне зниження ризиків в ланцюгу поставок вимагає, щоб організації ідентифікували ті системи і компоненти, які найбільш уразливі і вплинуть на організацію в разі компрометації. У зв'язку з цим зростає також роль національних та міжнародних дослідницьких центрів, які надають компаніям, урядовим установам та іншим організаціям набір практик для управління зростаючими ризиками кібербезпеки, пов'язаними з їх ланцюгами поставок.

Наприклад, одним 3 напрямків роботи Національного інституту стандартів і технологій США (National Institute of Standards and Technology - NIST) є розробка стандартів в галузі кібербезпеки. Розроблений фахівцями цього Інституту проєкт управління ризиками (Cyber Supply Chain Risk Management - C-SCRM), знаходиться на перетині інформаційної безпеки та управління ланцюгами поставок.

C-SCRM - це процес виявлення, оцінки та зниження ризиків, пов'язаних з розподіленим і взаємопов'язаним характером ланцюгів поставок продуктів і послуг інформаційних, комунікаційних і операційних технологій (ICT / OT). Він охоплює весь життєвий цикл системи (включаючи проектування, розробку, поширення, розгортання, придбання, обслуговування та знищення), оскільки загрози і вразливості ланцюга поставок можуть навмисно або ненавмисно поставити під загрозу продукт або послугу на будь-якому етапі.

Програми C-SCRM демонструють тісну співпрацю між функціональними та діловими напрямами. Сюди входять ради з управління ризиками в ланцюгах поставок на рівні виконавчої влади та численні робочі зустрічі на рівні персоналу. 
Співпраця між організаційними напрямками відповідальності гарантує, що використання C-SCRM сприяє прийняттю рішень 3 різних точок зору та допомагає організаціям проявляти ініціативу щодо своїх пріоритетів. Це, в свою чергу, дозволяє вчасно реагувати на потенційні проблеми та ефективніше залучати підприємства [10].

Традииійне управління ризиками ланцюга поставок здійснюється глобальною групою постачальників, що вводить відповідні заходи з питань кібербезпеки від груп інформаційної безпеки, включаючи загрози кібербезпеки, що стоять перед ланцюгом поставок, та відповідні вимоги безпеки, які потрібно використовувати при пошуку. Групи постачальників та інформаційної безпеки проводять спільні огляди після інцидентів та проводять щорічні конференції для обговорення подій у ландшафті загроз.

Централізована команда відповідає за управління ризиками у всіх групах категорій поставок. Вона функціонує як команда внутрішнього аудиту та співпрацює з групами з питань інформаційної безпеки, IT, юридичних питань та комплаєнс (група 3 контролю за узгодженнями і відповідності вимогам) для проведення оцінки ризиків усіх постачальників. Ця уніфікована практика спрощує управління постачальниками і здатна швидко вирішувати події або загрози в ланцюгу поставок без ескалації до керівництва виконавчої влади [10].

Комбінований nidxid. Централізована команда забезпечує керівництво та нагляд за C-SCRM з бізнес-підрозділами, відповідальними за відносини з постачальниками. У цьому поєднаному підході всіма або значною частиною відносин 3 постачальниками управляє централізована функція, тоді як рештою цих відносин 3 постачальниками управляють місцеві підрозділи. Загалом обов'язки розподіляються між централізованою службою та бізнес-підрозділами таким чином:

1) Централізована команда визначає ризики кіберпостачання, розробляє вимоги безпеки для постачальників та виконує ці вимоги по всій організації. Ця команда також схвалює зміни в ланцюгу поставок, включаючи нових постачальників та продовження контрактів.

2) Централізована команда працює як служба для решти бізнесу, що включає дослідження та рекомендації конкретних постачальників, коли власники бізнесу потребують певного товару чи послуги. Ця команда володіє більшістю аспектів відносин $з$ постачальниками протягом усього життєвого циклу, включаючи розробку запитів на пропозиції, переговори щодо контрактів та управління перевірками відповідності.

3) Власники бізнес-підрозділів несуть відповідальність за вибір та запит власних постачальників та виступають головним менеджером у цих відносинах [10].

Багато організацій почали активно розробляти і реалізовувати на практиці внутрішні програми безперервності ведення бізнесу. В основі таких процедур одну з визначальних ролей повинна була зіграти готовність компанії мінімізувати зовнішні і внутрішні загрози національній безпеці через правильне управління 
такими ризиками як з боку інхаузов (штатний / внутрішній фахівець), так і шляхом передачі тих чи інших сервісів на професійний аутсорсинг.

Компанії та підприємства можуть вирішувати питання кібербезпеки за допомогою декількох стратегій управління: уникнення ризику; диверсифікація (розосередження) ризику; передача ризику; зниження ризику; прийняття ризику [11].

Зниження ризику включає в себе всі дії, за допомогою яких компанія зменшує частоту і / або вплив ризикованих подій:

- покупка і використання антивірусного програмного забезпечення;

- встановлення міжмережевих екранів всередині мережі;

- посилення політик контролю доступу;

- оновлення інфраструктури ІКТ; і

- організація навчальних курсів для співробітників, щоб підвищити їх обізнаність про ризики кібербезпеки і розвинути більш обережне поводження [12].

Інвестиції в безпеку і кіберстрахування - це дві стратегії управління кіберризиками, які можна використовувати разом для оптимізації загальних витрат на безпеку. Mazzoccoli i Naldi [12] вважають, що інвестиції в безпеку і кіберстрахування не $\epsilon$ взаємовиключними альтернативами. Їх можна використовувати синергетично для боротьби 3 кіберризиками, використовуючи поєднання різних стратегій. Синергія полягає в можливості використання зниження уразливості за рахунок інвестицій в безпеку, щоб знизити розмір страхової премії. Потім можна спільно оптимізувати інвестиції в безпеку та страхування для досягнення мінімально можливих витрат на безпеку.

Ефект від інвестицій в безпеку для окремої фірми, тобто компанії з одним офісом (без філій) залежить від таких величин: інвестиції z в кібербезпеку; вразливість $\mathrm{v}$, тобто ймовірність успіху кібератаки при відсутності інвестицій; і ймовірність $\mathrm{S}$ того, що кібератака буде успішною при вкладенні z. Очікується, що інвестиція зменшить ймовірність успішної кібератаки, тобто $S<v$.

Gordon i Loeb [13] ввели наступну функцію ймовірності безпеки для опису взаємозв'язку між S, v i z:

$$
S(z, v)=v^{\propto z+1},
$$

де $\propto>0$ - коефіцієнт, що описує ефективність інвестицій (більш високі значення $\propto$ відповідають більшій ефективності інвестицій).

Коли досягається баланс між додатковими інвестиціями і скороченням граничних збитків, отримується оптимальна сума інвестицій в безпеку, оскільки не варто вкладати більше.

Якщо компанія вирішує також покладатися на страхування, при оптимізації необхідно враховувати передачу ризику, передбачену страховим полісом, і виплату страхової премії, яка, в свою чергу, залежить від очікуваних збитків. Отже, 
якщо компанія також захоче придбати страховий поліс, вона несе два типи витрат: інвестиція z; і страховий внесок Р, який визначається за формулою:

$$
P=P_{0}[1-r(1-S(z, v))]
$$

де $P_{0}$ - базова премія, що застосовується, коли є повна вразливість $(v=1), \mathrm{i}$ компанія не робить жодних інвестицій;

$r$ - ставка дисконтування, що переводить зменшення вразливості у надбавку.

Mazzoccoli i Naldi провели дослідження оптимальних стратегій для зниження втрат, пов'язаних $з$ кібербезпекою, для компанії з декількома філіями. Уразливість філій може істотно вплинути на загальні витрати на безпеку головного офісу. За умови збільшення вразливості окремих філій, головний офіс змушений менше інвестувати в безпеку (що може здатися дещо нелогічним), але більше покладатися на страхування [12].

\section{4. Ефективне дослідження та попередження ризиків 2.4.1. Культура управління ризиками}

У гіперконкурентому і турбулентному діловому середовищі підприємства та компанії стикаються з меншими вікнами прийняття рішень, посиленням спеціалізації ресурсів, фрагментованими ринками, відсутністю передбачуваних потреб в ресурсах і загальною відсутністю довгострокового контролю. В таких умовах при зростанні невизначеності та ризиків, помилкові стратегічні рішення менеджерів визначають напрямок діяльності логістичної системи.

Мінливі ситуації на швидкозростаючих ринках призводять до необхідності модифікацій і коригувань стратегічних рішень або навіть стратегічних напрямків діяльності фірм. Ініціювання та реалізація стратегічних рішень досягається за рахунок ефективного керівництва. Лідерство сприяє створенню позитивного клімату для змін і позитивному ставленню до реалізації стратегії. Розуміння зовнішнього і внутрішнього контексту свого бізнесу, прагматизм і перебування в реальності кращі критерії менеджерів усіх рівнів логістичної системи. На цьому базується працездатність прийнятих нових рішень в умовах невизначеності.

Наприклад, дослідження McKinsey показало, що середня енергетична компанія США може заощадити до 1 мільярда доларів за 20 років, інвестуючи в зміцнення інфраструктури і підвищення стійкості та адаптованості, наприклад, за рахунок використання мікромереж і акумуляторів, в порівнянні з вартістю ремонту пошкоджень після того, як аварії відбулися.

У глобальному опитуванні, проведеному міжнародною організацією Deloitte в 2019 році, взяли участь понад 500 керівників антикризового управління, забезпечення безперервності бізнесу та управління ризиками. 
Кризи часто виникають в результаті дій третіх сторін, таких як постачальники і партнери по альянсу, і одні і ті ж треті сторони часто грають важливу роль в управлінні кризами і пом'якшення їх наслідків. Визнаючи це, 59 відсотків респондентів Deloitte кажуть, що вони беруть участь в антикризових навчаннях $з$ третіми сторонами, вивчають плани третіх сторін на випадок кризи чи $\mathrm{i}$ те, $\mathrm{i}$ інше. В Свропі ця частка становить 80 відсотків.

Чим більше глобальна присутність організації, тим більша ймовірність залучення зовнішніх сторін в діяльність з управління кризами. Дослідження Deloitte показують, що сімдесят відсотків глобальних організацій (які працюють на всіх континентах), 65 відсотків міжнародних організацій (які працюють в двох-восьми країнах) і 55 відсотків компаній тільки національного масштабу врахували цей факт [14].

Культура ризиків і сумлінності відноситься до світогляду і нормам поведінки, які визначають, як організація виявляє ризики і керує ними. Сильна культура ризику $\epsilon$ критичним елементом інституційної стійкості перед обличчям будь-яких проблем.

Відправною точкою для більшості організацій, які прагнуть поліпшити свою культуру ризику, є діагностика поточного стану. Організації, які побудували сильну культуру ризику і сумлінності, прагнуть зрозуміти (а потім усунути) три взаємопідсилюючих фактори: образ мислення щодо ризику, методи управління ризиками і сприйняття поведінки.

Ризик-образ мислення можна розуміти як набір припущень про ризик, до яких схильні люди в організації; ризик-практики - це повсякденні дії, що визначають ефективність управління ризиками; сприяє поведінки включає в себе колективні дії, які формують ставлення до ризику. В ідеалі ці дії повинні бути систематичними і навмисно спрямованими на зміцнення відносини людей до ризику, при цьому бажане ризиковану поведінку має бути вбудовано в повсякденне життя.

Компаніям, що прагнуть зрозуміти культуру ризику, найкраще почати 3 вироблення конкретних, детальних визначень. Вони повинні чітко визначати конкретні елементи культури ризику, щоб визначати прагнення і вимірювати прогрес. Експерти McKinsey \& Company визначають десять показників культури ризику, що засновані на широкому спектрі досвіду роботи з компаніями у всіх основних галузях промисловості, а також на ретельному вивченні ряду реальних недоліків культури ризику (рис. 5).

Компанії з сильною культурою ризику з меншою ймовірністю постраждають від ризиків операційних помилок або репутаційних проблем, і у них буде більше залучених і задоволених клієнтів і співробітників.

Наслідки кризи залежать від ефективності антикризового управління, що може або пом'якшувати або загострювати кризу для логістичної системи.

Управління ризиками логістичної системи може включати в себе такі напрямки:

1. Формування міжфункціональної команди кризового реагування. Необхідно створити інтегровану і крос-функціональну команду кризового реагування, щоб отримати загальне уявлення про наслідки для всієї організації і координувати зусилля. Повинні бути організовані підгрупи для управління певними робочими 
потоками: зв’язок, юридичні питання, фінанси або операції. Кризова група повинна діяти в рамках чіткого мандату, наданого виконавчим керівництвом. Він повинен мати високий рівень повноважень щодо прийняття рішень, щоб можна було швидко і ефективно діяти.

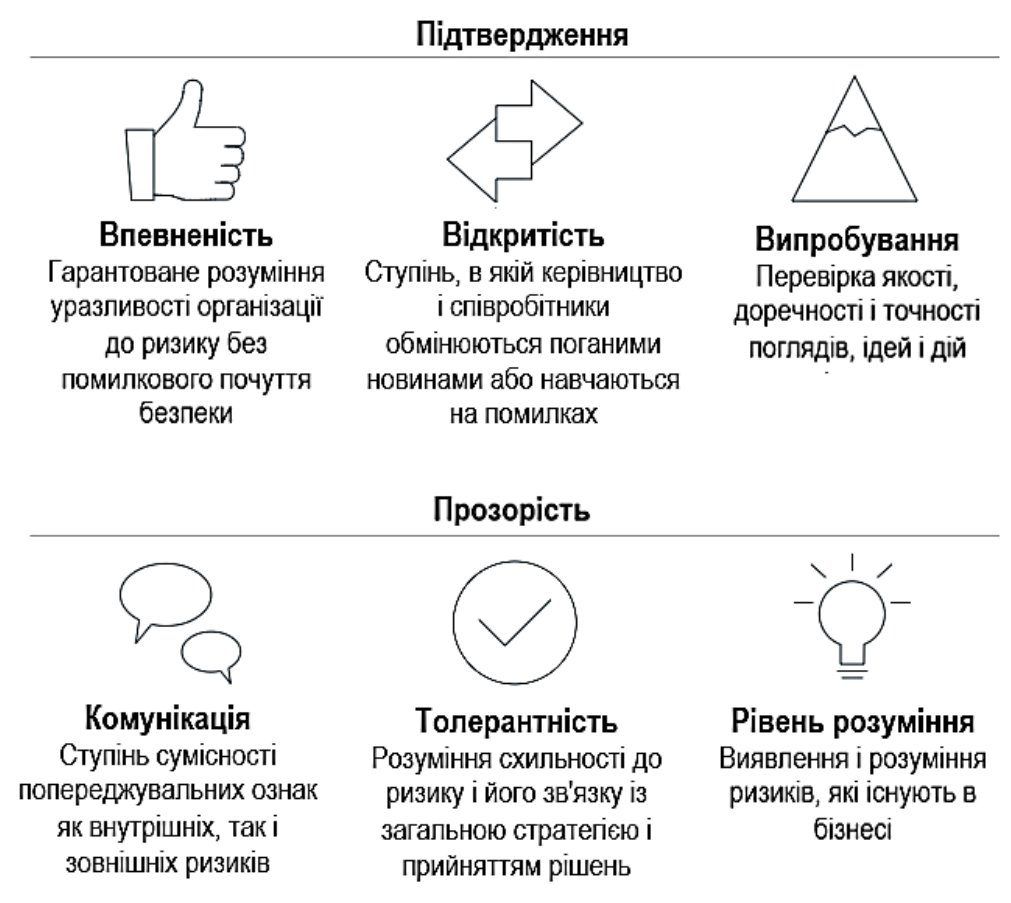

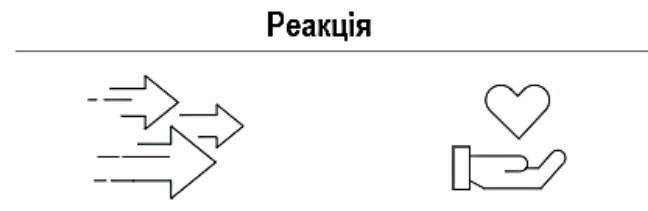

Швидкість відповіді Рівень турботи Сприйняття зовнішніх змін Обов'язок піклуватися і швидкість реакції на про результат дій і інновації або зміни рішень

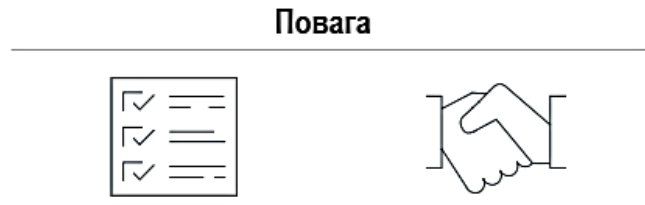

Дотримання правил

Узгорження схильності до ризику окремих осіб і організаційних наспідків і організації Співробітництво
Розгляд більш широких
організаційних наслідків і
впливу на загальну
схильність до ризику, коли яка-небудь одна команда діє або приймає рішення

\section{Рис. 5 - Чотири напрямки проблематики культури ризику} Джерело: [15]

2. Оцінка схильності організації. Якщо у компанії є ключові залежності в областях постачання, отримання доходів або аутсорсингу, необхідно зробити рішучіші дії. Проведення стратегічної оцінки впливу на бізнес для виявлення і зіставлення критично важливих сервісів і функцій з операційними залежностями, включаючи ключові системи, персонал, треті сторони і операційні центри.

3. Готовність до співмірної відповіді. Забезпечення своєчасності та відповідності планів має важливе значення для стійкості організації. Необхідно визначити значимі організаційні тригери активації і деактивації.

4. Планування сценаріїв. Організації повинні заздалегідь планувати можливі збої в роботі, викликані тривалою відсутністю співробітників, «відключенням» географічних регіонів, збоями в ланцюгу поставок і т.п. Це включає в себе плани дій в кризових ситуаціях, які необхідно активувати в залежності від певних подій.

5. Постійний контроль планів, політики та процедур. Організаційна готовність - це повторюваний процес. Плани, політики і процедури повинні бути адаптивними і гнучкими до виникнення загрози, щоб організація залишалася підготовленою і захищала своїх співробітників, репутацію, стратегію і прибуток.

$$
-274-
$$




\subsection{2. Важливість використання KRI}

Одним з найважливіших елементів ефективної стратегії управління ризиками логістичної системи є визначення відповідних ключових індикаторів ризику (Кеу Risk Indicator - KRI).

Ключовий індикатор ризику — це показник, який використовується для оцінки і вимірювання потенційного ризику, який може мати згубні наслідки для компанії або їі діяльності. Індикатори ризику можуть бути використані для попереджуючого управління негативними ситуаціями для досягнення стратегічних цілей логістичної системи (рис.6).
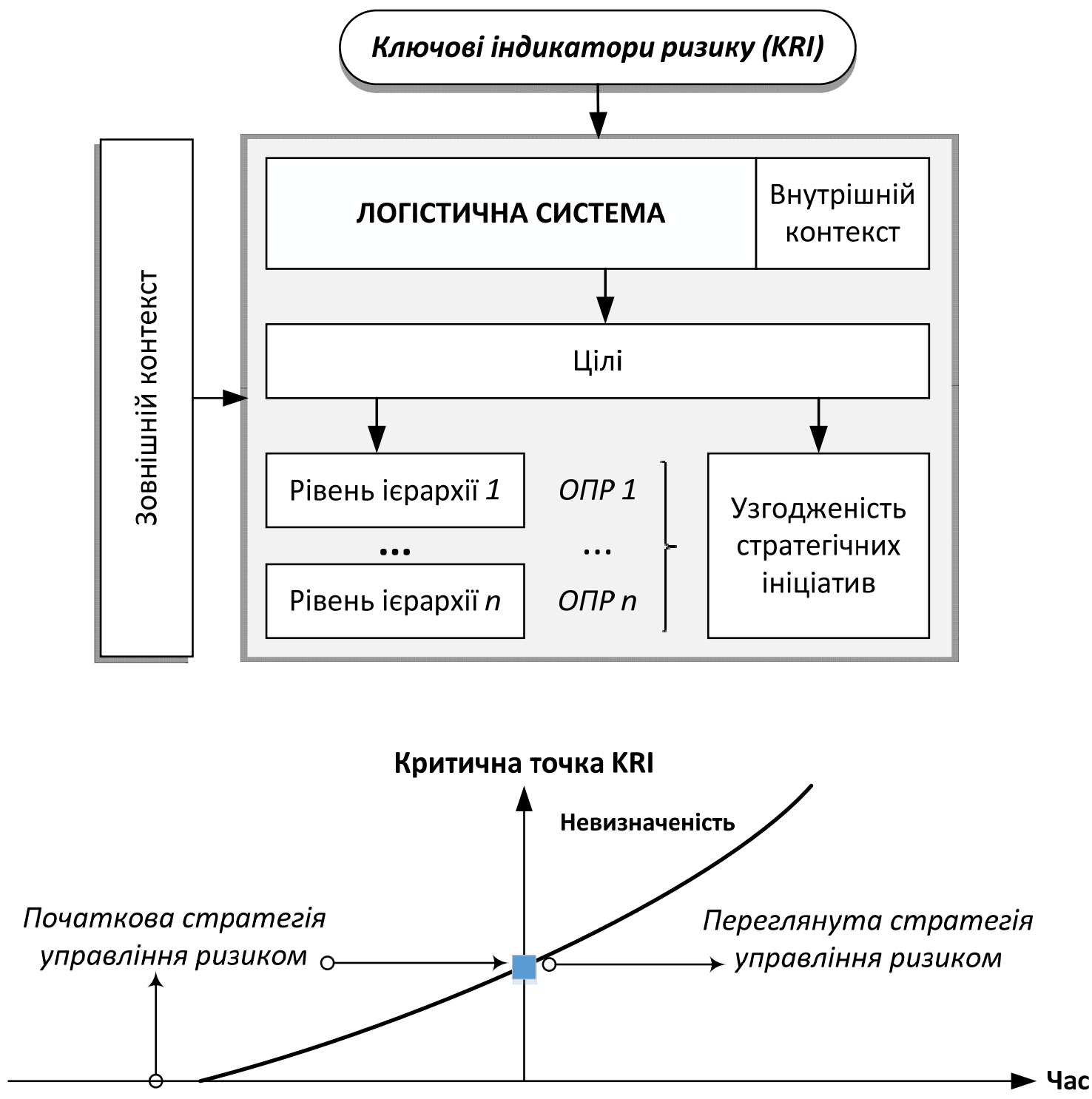

Рис. 6 - Ідентифікація та використання ключових індикаторів ризику в логістичній системі

Джерело: авторська розробка 
Ключові індикатори ризику повинні відповідати певному набору вимог:

1. Вимірність: або в абсолютних числах, або у відсотках.

2. Відстеження: KRI повинні показувати послідовну шкалу значень, що дозволяє порівнювати їх еволюцію.

3. Передбачуваність: KRI повинні давати ранні сигнали про потенційні ризики.

4. Інформативність: дає точне уявлення про статус ризику.

Мета KRI логістичної системи - попередити осіб, які приймають рішення (ОПР), про потенційне збільшення ризику, який може вплинути на цілі (випуск готової продукції, надання логістичних послуг, організація доставки товарів та ін.). Це означає, що інформацію не можна просто зібрати - iі потрібно відстежувати, аналізувати та повідомляти відповідним посадовим особам.

Процес ідентифікації KRI може отримати користь від експертів 3 питань, що знаходяться в організації, оскільки ці особи можуть бути в найкращому положенні і знати де існують точки стресу (тобто основні причини та проміжні події) в підрозділах, якими вони керують, або процесах, які вони контролюють. Їх внесок допомагає гарантувати, що ключові ризики не залишаються поза увагою і що КРI, розроблені для висвітлення цих ризиків або тенденцій, найімовірніше будуть ефективними при повідомленні про ранні вказівки на необхідні дії.

Чітке визначення ключових індикаторів ризику може принести логістичній системі значні переваги:

1. Краще розуміння динаміки ризиків: визначення та моніторинг KRI забезпечує більш глибоке розуміння основних загроз для бізнесу.

2. Більш надійні стратегії управління ризиками: з більш глибоким розумінням динаміки ризиків керівництво може визначити більш точні методи оцінки та мінімізації потенційних ризиків.

3. Рівень стійкості до окремих видів ризиків: використовуючи KRI, керівництво може визначити рівень толерантності компанії і межі ризику, які запускають коригувальні дії.

4. Краще розуміння тенденцій ризиків: періодичний і регулярний моніторинг KRI дає організації більш точне уявлення про тенденції ризиків. Їх можна використовувати для визначення того, які види діяльності або структурні підрозділи більш уразливі і потребують подальшого моніторингу, а також для визначення нових можливостей для зростання.

Наприклад, для транспортних компаній ефективне впровадження KRI повинно визначити відповідні ліміти аварій та інцидентів на транспорті і моніторинг їх порушення. Кольорові індикатори можуть бути використані для оцінки серйозності порушень 3 розмежуванням між «жовтим» рівнем, для якого потрібно більш ретельний моніторинг, і «червоним», для якого втручання вищого керівництва стає важливим. «Червоні» межі повинні становити ризик 3 дійсно високою ймовірністю (зі значними наслідками, які вимагають негайної уваги та дій), щоб 
уникнути надмірно частих сигналів тривоги - ситуації, яка має тенденцію викликати самозаспокоєність щодо майбутніх, більш серйозних порушень.

Логістична система повинна мати: ефективні комунікаційні процеси для забезпечення того, щоб потрібна інформація потрапляла на потрібний рівень управління в потрібний час після перевищення ліміту; селективну увагу, щоб уникнути ситуації, в якій вище керівництво підприємства звикає до надмірних «тривог» і починає їх ігнорувати.

Будь-яка організація не може керувати тим, що не можна виміряти. Наприклад, в логістичній системі не можна виміряти кібербезпеку, якщо не відстежуються певні ключові показники ризику.

Необхідність відстеження показників кібербезпеки важлива з таких причин:

1. Коли справа доходить до інформаційної безпеки, компанія бачить повну картину: якщо не відстежуються ключові показники ефективності (KPI) і ключові показники ризику (KRI), ризик-менеджер не зможе чітко зрозуміти, наскільки ефективними були зусилля з кібербезпеки або як вони покращилися (або зменшилися) з плином часу. Без надійних історичних даних, на які можна покластися, компанія не зможете приймати обгрунтовані рішення щодо кібербезпеки в майбутньому. Замість цього рішення будуть прийматися наосліп.

2. Спілкування із зацікавленими сторонами: без хороших показників кібербезпеки ризик-менеджер не зможе обгрунтувати свої зусилля (трудові витрати, інвестиції та бюджет) в області інформаційної безпеки у розмові з керівництвом або членами ради директорів організації.

Потрібен порівняльний аналіз кібербезпеки, який відображає ретроспективу та можливий прогноз. Обрані ключові показники ефективності повинні бути чіткими, актуальними і давати повне уявлення про кібербезпеки логістичної системи.

Отже, використання ключових індикаторів ризику необхідно, щоб дати ранній сигнал (сповіщення) про збільшення схильності до ризику в різних сферах діяльності підприємства.

\subsection{3. Ділова репутація, професіоналізм і ризики}

Кризи можуть мати руйнівні наслідки для фінансових показників компанії, морального духу співробітників, продажів і репутації. У сучасній економіці надзвичайно загострилася конкурентна боротьба між компаніями, яка ведеться не тільки на основі використання матеріальних і фінансових активів. Велике значення набувають нематеріальні активи, особливо репутаційні, які все частіше стають джерелом вагомих нематеріальних конкурентних переваг організації. У цих умовах потрібна підвищена увага до питань захисту ділової репутації та мінімізації відповідних загроз.

Недоццінка або ігнорування репутаційних ризиків здатні зруйнувати навіть найміцнішу репутацію. Відгук 8,5 млн. машин в Європі вартістю в $€ 6,7$ млрд, квартальні збитки в $€ 2,5$ млрд, рекордний штраф в \$18 млрд. і критичне падіння 
рівня репутації з 76,9 бала до 53 балів [16]. Таку ціну довелося заплатити автоконцерну Volkswagen за спробу приховування реальних обсягів забруднення навколишнього середовища, вироблених його машинами в 2015-2016 роках.

Згідно з результатами дослідження, проведеного компанією Economist Intelligence Unit y 2018 році, ризик-менеджери великих європейських організацій оцінили репутаційні загрози як найістотніші з усіх можливих, при цьому найважливішими факторами репутаційного ризику були названі швидкість поширення інформації з міжнародних комунікаційних каналів і посилення вимог регуляторів. Те, що декілька років тому було просто випадковістю і оцінювалось компанією як інцидент, тепер може стати кризою завдяки використанню соціальних мереж. Майже три 3 п'яти компаній-респондентів (57 відсотків), які повідомляють про збитки репутації, зазнали різкий стрибок скарг клієнтів.

Експерти консалтингової компанії Reputation Institute, що займає провідні позиції в області дослідження репутації компаній, галузей, регіонів і особистостей, виділяють чотири основні перешкоди на шляху до ефективного управління репутаційними кризами:

1. Недолік уваги, що приділяється проблемі. Незважаючи на розуміння більшістю компаній існуючих загроз, відсутній системний підхід до їх запобігання.

2. Складність оцінювання. Мало хто з представників великих компаній має прогресивні системи оцінювання ризиків.

3. Відсутність ефективної системи управління ризиками. Вважається, що $57 \%$ відповідальності за управління репутаційними ризиками лежить на вищому керівництві компанії, але тільки $39 \%$ справляються з цією метою.

4. Недостатня увага персоналу до питання репутаційного менеджменту. Для створення ефективної системи управління репутаційними ризиками необхідно мати чітке розуміння важливості цього процесу з боку всіх працівників компанії. Згідно $з$ дослідженнями, лише 51\% найбільших компаній змогли створити спільне розуміння даної проблеми.

Згідно $з$ дослідженням Reputation Institute 2020 Global Trends, 70,2\% репутаційних лідерів кажуть, що управління репутацією їх компанії зараз важливіше, ніж будь-коли [16].

Reputation Institute зібрав основні поточні репутаційні тенденції за допомогою інтерв'ю з більш ніж 200 репутаційними лідерами (вищі керівники, віце-президенти і директора) в 18 галузях світу, в компаніях з різними доходами:

1. Вища мета - компаніям необхідно досягти мети корпоративного бренду і прийняти культурні цінності на емоційному рівні, що виходить за рамки продуктів і послуг, які вони продають.

2. Політика приватності. Порушення цілісності електронної інформації і виток даних - повсякденна реальність і зростаюча загроза для всіх великих компаній.

3. Відповідальне інвестування - розгляд етичних та екологічних проблем до прийняття фінансових рішень.

$$
-278-
$$


4. Вплив технологій. Штучний інтелект, Інтернет речей, Big Data i дрони впливають на споживачів і бізнес.

5. Зміна клімату. Очікується, що країни, уряду і підприємства будуть захищати свій вплив на зміну навколишнього середовища і керувати ним.

6. Впливові особи. Деякі зацікавлені сторони і окремі особи можуть мати величезний вплив на громадську думку і репутацію. Це можуть бути приватні особи, політики або профільні експерти.

7. Недовіра до великих організацій — недовіра громадськості і сумнів в чесності великих організацій, таких як підприємства, уряду і ЗМІ.

8. Сталий розвиток і відповідальний вибір постачальників. Очікується, що компанії будуть відповідально підходити до вибору матеріалів і мінімізувати вплив на навколишнє середовище через свій ланцюг поставок.

9. Активність генерального директора. Керівники великих компаній все частіше займають публічну позицію щодо політичних, соціальних і ціннісних питань, а не тільки стурбовані своїми результатами.

10. Рівність, різноманітність і інклюзивність. Бізнес оцінюється на основі демографічного профілю (стать, етнічна приналежність, раса і т.п.) його робочої сили [16].

Професійний хист в управлінні ризикованими ситуаціями в антикризовому менеджменті набуває вирішального значення, адже загалом залежить не лише від об'єктивних факторів економіки, а від сприйняття ситуації менеджером, його досвіду, знань, інтуїції. Від професійного рівня посадової особи залежить вірність та швидкість прийняття відповідних рішень, що в свою чергу є запорукою зниження кількості помилок (професійних ризиків), а також підвищення загального рівня безпеки виробництва.

\section{3. ВИСНОВКИ}

1. Дослідження показують, що стійкість будь-якої логістичної системи вимагає культури обізнаності про глобальні ризики, щоб допомогти компанії створити і підтримувати сильні захисні бар'єри від невизначеності та невідомості, а також більш швидко реагувати в разі серйозної кризи або операційної загрози.

2. При аналізі потенційного впливу кризи важливо, щоб організації були активними і підготовленими, приділяючи особливу увагу виявленню ризиків і схильності організації до них, критичних залежностей від контрагентів, і розробці прагматичних і ефективних рішень для подолання криз і збереження стійкості.

3. Під час криз компанії та підприємства повинні мати не тільки здатність долати потрясіння, але і використовувати їх для створення конкурентної переваги. Наслідки кризи залежать від ефективності антикризового управління, що може або пом'якшувати або загострювати кризу. 
4. Сучасні ризик-менеджери повинні не просто розуміти ризики і приймати сміливі та відповідальні кроки по їх усуненню, але також в рівній мірі усвідомлювати небезпеку бездіяльності або занадто довгого коливання по відношенню до кризи, що виникла. Це вимагає від компаній та підприємств подолання технічних, організаційних і культурних бар'єрів, та вміння поєднати людей, процеси та інфраструктуру управління.

\section{ЛIТЕРАТУРА}

1. Тюріна Н. М. Кризи в економіці України: причини, наслідки, шляхи подолання [Електронний ресурс] / Н. М. Тюріна, Н. С. Карвацка, Т. В. Назарчук // Вісник Хмельницького національного університету. Економічні науки. — 2017. - № 2(2). - С. 12-21. Режим доступу: http://nbuv.gov.ua/UJRN/Vchnu_ekon_2017_2\%282\%29_4.

2. The Global Risks Report 2020, 15th Edition [Electronic resource] / The World Economic Forum. — 2020. - 15 January. — Mode of access: https://www.weforum.org/reports/theglobal-risks-report-2020.

3. The Global Risks Report 2021, 16th Edition [Electronic resource] / The World Economic Forum. - 2021. - 13 January. — Mode of access: https://www.weforum.org/agenda/2021/01/global-risks-report-2021.

4. Кривошеїн, В. В. Концепт «геополітичний ризик» у структурі оцінки інвестиційного клімату України / В. В. Кривошеїн // S.P.A.C.E. Society, Politics, Administration in Central Europe : електронний науково-практичний журнал / редкол.: Д. В. Яковлев (голов. ред.), К. М. Вітман (заст. голов. ред.), Д. Ю. Дворніченко (відп. секр.) [та ін.] ; НУ «ОЮА». - Одеса, 2016. - Вип. 1. - С. 85-90.

5. Eckstein, D., Künzel, V., Schäfer, L. Global Climate Risk Index 2021 [Electronic resource] / D. Eckstein, V. Künzel, L. Schäfer // Germanwatch. - January 2021. — Mode of access: https://www.germanwatch.org/en/19777.

6. Вишняков, Я.Д., Радаев, Н.Н. Общая теория рисков: учеб. пособие для студ. высш. учеб. заведений / Я.Д. Вишняков, Н.Н. Радаев. - М.: Издательский центр «Академия», 2007. - $368 \mathrm{c}$.

7. Otto, B., Schleifer, L. Domestic Water Use Grew 600\% Over the Past 50 Years [Electronic resource] / B. Otto, L. Schleifer // World Resources Institute (WRI). — 2020. — February 10. - Mode of access: https://www.wri.org/blog/2020/02/growth-domestic-water-use.

8. Bissell, K., Lasalle, R.M. Ninth annual cost of cybercrime study unlocking the value of improved cybersecurity protection [Electronic resource] / K. Bissell, R.M. Lasalle // Accenture Security \& Ponemon Institute. - 2019. - March 6. - Mode of access: https://www.accenture.com/us-en/insights/security/cost-cybercrime-study.

9. Treverton, G. F., Efandiari, P. Data: Governance and Geopolitics [Electronic resource] / G. F. Treverton, P. Esfandiari. — 2021. - January 11. - Mode of access: https://www.csis. org/analysis/data-governance-and-geopolitics.

10. Boyens, J., Paulsen, C., Bartol, N., Winkler, K., Gimbi, J. Case studies in cyber supply chain risk management. Summary of Findings and Recommendations [Electronic resource] / J. Boyens, C. Paulsen, N. Bartol, K. Winkler, J. Gimbi // National Institute of Standards and Technology. - 2020. - February 4. - Mode of access: https://doi.org/10.6028/ NIST.CSWP.02042020-1. 
11. Peterson, Kevin E. 2020. What is risk management? [Electronic resource] / Kevin E. Peterson // The Professional Protection Officer (Second Edition). - Amsterdam: Elsevier. P. 367-372. — Mode of access: https://doi.org/10.1016/B978-0-12-817748-8.00053-5.

12. Mazzoccoli, A., Naldi, M. Optimal Investment in Cyber-Security under Cyber Insurance for a Multi-Branch Firm [Electronic resource] / A. Mazzoccoli, M. Naldi // Risks. - 2021 Volume 9. — Issue 24. — Mode of access: https://doi.org/10.3390/risks9010024.

13. Gordon, L., Loeb, M. The Economics of Information Security Investment [Electronic resource] / L.A. Gordon, M.P. Loeb // ACM Transactions on Information and System Security. - 2002. - Vol. 5, No. 4. - 438-457. — Mode of access: https://dl.acm. org/doi/10.1145/581271.581274.

14. Dent, P., Woo, R., Cudworth, R. Stronger, fitter, better. Crisis management for the resilient enterprise [Electronic resource] / P. Dent, R. Woo, R. Cudworth // Deloitte, Johannesburg. 2019. - Mode of access: https://www2.deloitte.com/content/dam/Deloitte/za/Documents/risk/za_Crisis_Management_For_the_Resilient_Enterprise.pdf.

15. Strengthening institutional risk and integrity culture [Electronic resource] / Higgins, R. [et al.]. - 2020. - November 2. — Mode of access: https://www.mckinsey.com/businessfunctions/risk/our-insights/strengthening-institutional-risk-and-integrity-culture.

16. 2020 Global Trends in Reputation [Electronic resource] / The RepTrak Company. — 2020. 24 January. — Mode of access: https://www.reptrak.com/blog/reputation-risk/. 


\title{
РОЗДІЛ 10 \\ УПРАВЛІННЯ ПРОЕКТНОЮ КОМАНДОЮ I ОСОБИСТА ЕФЕКТИВНІСТЬ
}

\author{
О. М. Гненний ${ }^{17}$ \\ Н. С. Чернова ${ }^{18}$ \\ А. С. Дорош ${ }^{19}$
}

\section{1. ВСТУП}

Однією з основних проблем сучасної української економіки є дефіцит професійних менеджерів та управлінського персоналу. Дослідженнями встановлено, що для успішного керування сучасними організаціями лише професійних знань в сфері економіки, фінансів або бізнесу недостатньо. Саме тому сьогодні потрібні керівники нового типу, які вміють створити атмосферу співробітництва в колективі і повести за собою людей.

Дослідження показали, що фундаментальні теоретичні знання, навички або вміння $з$ тієї чи іншої спеціальності зовсім не гарантують персонального успіху або успіху для своєї організації. Так, Deloitte опублікувала дослідження [3], з якого стає очевидним, що близько $70 \%$ опитаних бачать причину національного економічного спаду в кризі керівництва і відсутності розвитку лідерства. На даний час успішний менеджер будь-якого рівня повинен володіти як професійними навичками (hard skills), так і суто особистісними (soft skills). При цьому дослідженнями встановлено, що лише 15\% кар'єрного успіху забезпечується рівнем професійних навичок, в той час як інші $85 \%$ — це «м'які» навички.

\section{2. ОСНОВНИЙ МАТЕРІАЛ}

\section{1. Поняття hard skills та soft skills}

Згідно з класичним означенням, навички в цілому і «м'які» навички зокрема, це навички, сформовані шляхом тривалого повторення. Їх досить важко виявляти, наочно демонструвати, перевіряти, оцінювати. Однак, якщо навичка сформована, то людина починає діяти автоматично, не замислюючись над тим, що і як потрібно робити.

Soft skills - це комплекс неспеціалізованих, пов'язаних 3 особистісними якостями навичок, які дозволяють гармонійно взаємодіяти 3 іншими людьми,

\footnotetext{
17 Доктор економ. наук, доцент, завідувач кафедри «Економіка та менеджмент» Дніпровського національного університету залізничного транспорту імені В. Лазаряна, Дніпро 18 Канд. економ. наук, доцент кафедри «Економіка та менеджмент»

Дніпровського національного університету залізничного транспорту імені В. Лазаряна, Дніпро 19 Канд. техн. наук, доцент кафедри «Транспортні вузли»

Дніпровського національного університету залізничного транспорту імені В. Лазаряна, Дніпро
} 
підвищувати ефективність роботи в своїй галузі, а також дають можливість змінювати сферу діяльності, зберігаючи при цьому свою затребуваність. Вони носять універсальний характер і не пов'язані з конкретною сферою діяльності. На практиці поряд 3 терміном soft skills, використовують ряд термінів 3 тотожним змістом: соціально-особистісні компетенції, «м'які» компетенції, «м'які» знання, «м'які» навички, «soft» знання/уміння/навички. Комплекс характеристик особистості, що входять до поняття soft skills, однаково необхідний як для повсякденного життя, так і для професійної діяльності. Однак, згідно з дослідженнями, він особливо важливий для успіху в професійній діяльності [1].

Опитування провідних вітчизняних роботодавців та дослідження ринку праці, свідчать про те, що потенційні претенденти повинні мати розвинуті soft skills, оскільки саме їх роботодавці вважають не менш важливими, ніж грунтовні професійні знання та вміння (hard skills). Крім того, вважається, що професійні вміння та навички деколи втрачають свою актуальність, а soft skills актуальні завжди.

До групи hard skills відносять професійні знання, вміння та навички, які необхідні при виконанні завдань підприємства; їх легко виміряти та вони є досить об'єктивними. До групи soft skills можна віднести значну кількість навичок, зокрема: критичне мислення, вміння планувати, чітко формулювати думки та завдання, керувати часом, чесність, ініціативність, працелюбність, здатність до навчання, творчі здібності, навички командної роботи, уміння переконувати, витривалість, здатність йти на компроміс, уміння вирішувати конфлікти тощо. Перелічені навички важко виміряти, а тому і оцінювання носить суб'єктивний характер.

\section{2. Класифікація «м'яких» навичок}

Використання soft skills передбачає уміння використовувати різні моделі поведінки [4] навіть в однакових ситуаціях, швидко розставляти пріоритети та адаптуватись відповідно до нових обставин, бути стресостійким до навантажень, уміти досягати поставленої мети та ін.

Традиційно виділяють три основні великі групи soft skills (рис. 1):

1) індивідуальні;

2) комунікативні;

3) управлінські.

4) На рис. 1 наведено розгорнуту класифікацію soft skills, разом 3 тим, ця класифікація не може бути вичерпною та враховувати абсолютно усі «м'які» навички. 


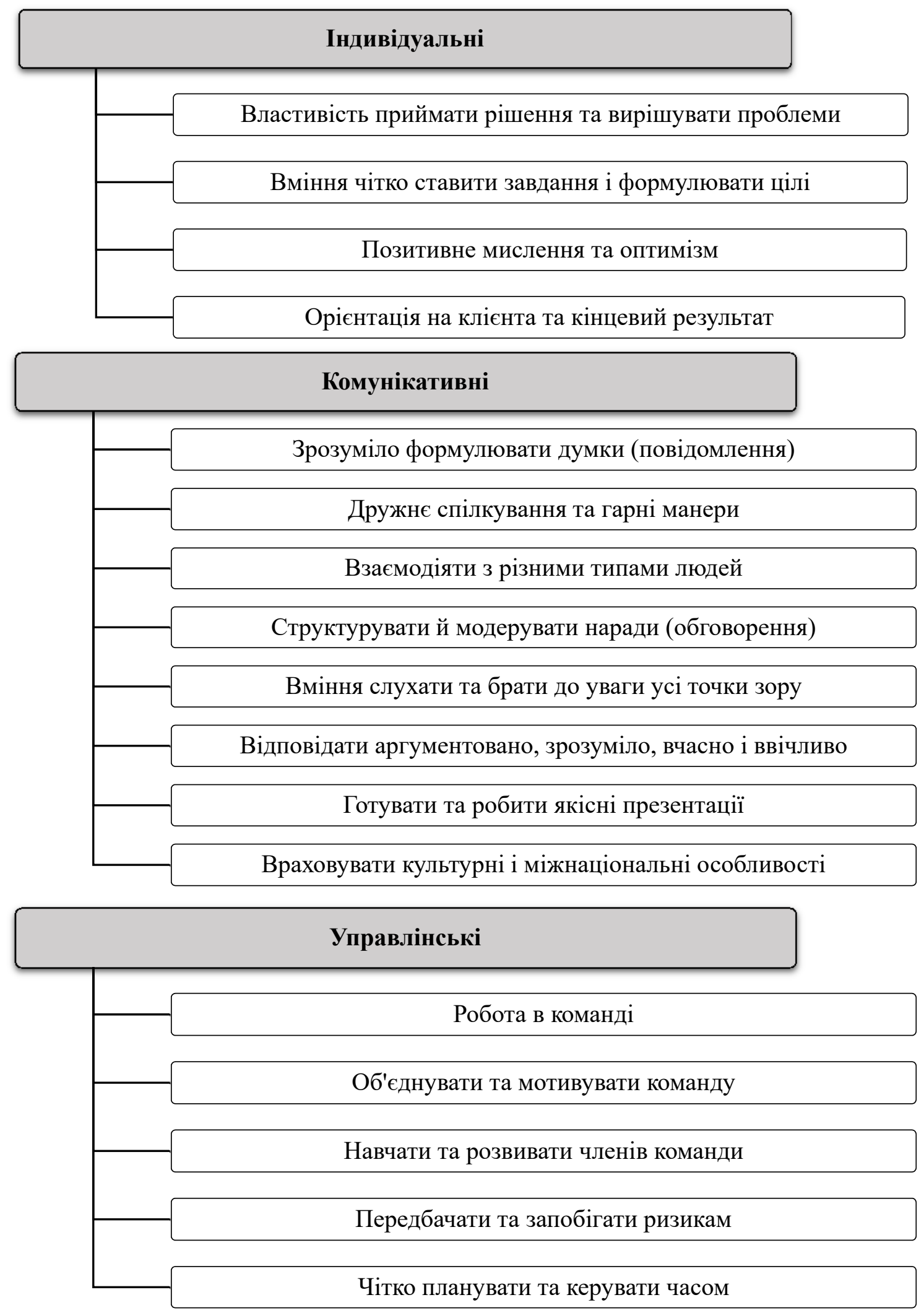

Рис. 1. Класифікація «м'яких» навичок

Авторська розробка 


\section{3. Вміння ставити цілі і їх досягати}

Вміння ставити цілі та вміння їх досягати - одна 3 базових компетенцій ефективних працівників на будь-якому рівні ієрархії підприємства, компанії, установи чи організації. На робочому місці вони регулярно отримують завдання, прагнуть їх виконати і виконують, при цьому досягаючи цілей як своїх особистих, так і цілей підрозділу чи компанії загалом.

Практика показує, що далеко не всі справи, які починаються з ентузіазмом і впевненістю, завершуються успішно. Регулярне планування, жорсткий контроль керівника, а також самоконтроль, не рятує ситуацію. Не рятує ситуацію і робота як така — неосмислене виконання функціональних обов'язків чи рутинна діяльність в особистому житті. Крім того, певні дії віддаляють успіх і роблять його неможливим.

Усвідомлені, «розумні» цілі, прийняття рішень на шляху до них, негайні та видимі результати мотивують працівників та допомагають досягнути успіху в професійному та особистому житті. Отже, життєва та професійна діяльність успішні тоді, коли чітко і правильно спрямовані, а напрям та правильність тих чи інших дій вказує мета [11].

Що таке мета?

Для того, щоб стати ефективною особистістю, дуже важливо усвідомлено ставитись до свого життя, ставити перед собою цілі, планувати своє майбутнє i досягати бажаного. Прийнято вважати, що поняття «мета» і «цілепокладання» мають відношення тільки до розвитку особистості. Однак, це помилка.

Цілепокладання - діяльність, що реалізується в будь-якій сфері, де потрібно домогтися конкретних результатів.

Термін «мета» має багато визначень в різних сферах життя та науки; перелічимо деякі з них.

Психологія. Мета - уявлення результату, який має бути досягнуто.

Соціальна психологія. Мета - це бажаний результат; щось, чого людина бажає досягти або зробити.

Менеджмент. Мета - це конкретні показники, яких прагне організація в певний період часу.

Психологія праці та управління. Мета — це ідеальний або подумки представлений результат діяльності; то, чого ще реально немає, але має бути отримано в результаті діяльності.

Всі ці визначення об’єднують такі слова, як: результат, бажання, досягнення. Тобто, мета - це формулювання бажаного майбутнього, до якого ми прагнемо і досягаємо. Процес, коли ми ставимо перед собою цілі, називається «цілепокладанням».

\section{Навіщо потрібна мета?}

Статистичними дослідженнями на Заході встановлено, що лише $1 \%$ людей можуть точно сказати, чого вони хочуть досягти в житті [13]. Бенджамін Франклін знав це напевно - його видавала працездатність і цілеспрямованість. Ще в юності 
він склав план і намагався його виконувати. Суть полягала в наступному: глобальне завдання розбивалася на більш дрібні, а ті ще на більш дрібні.

Ця система стала одним з найбільш відомих інструментів цілепокладання піраміди Бенджаміна Франкліна (рис. 2).

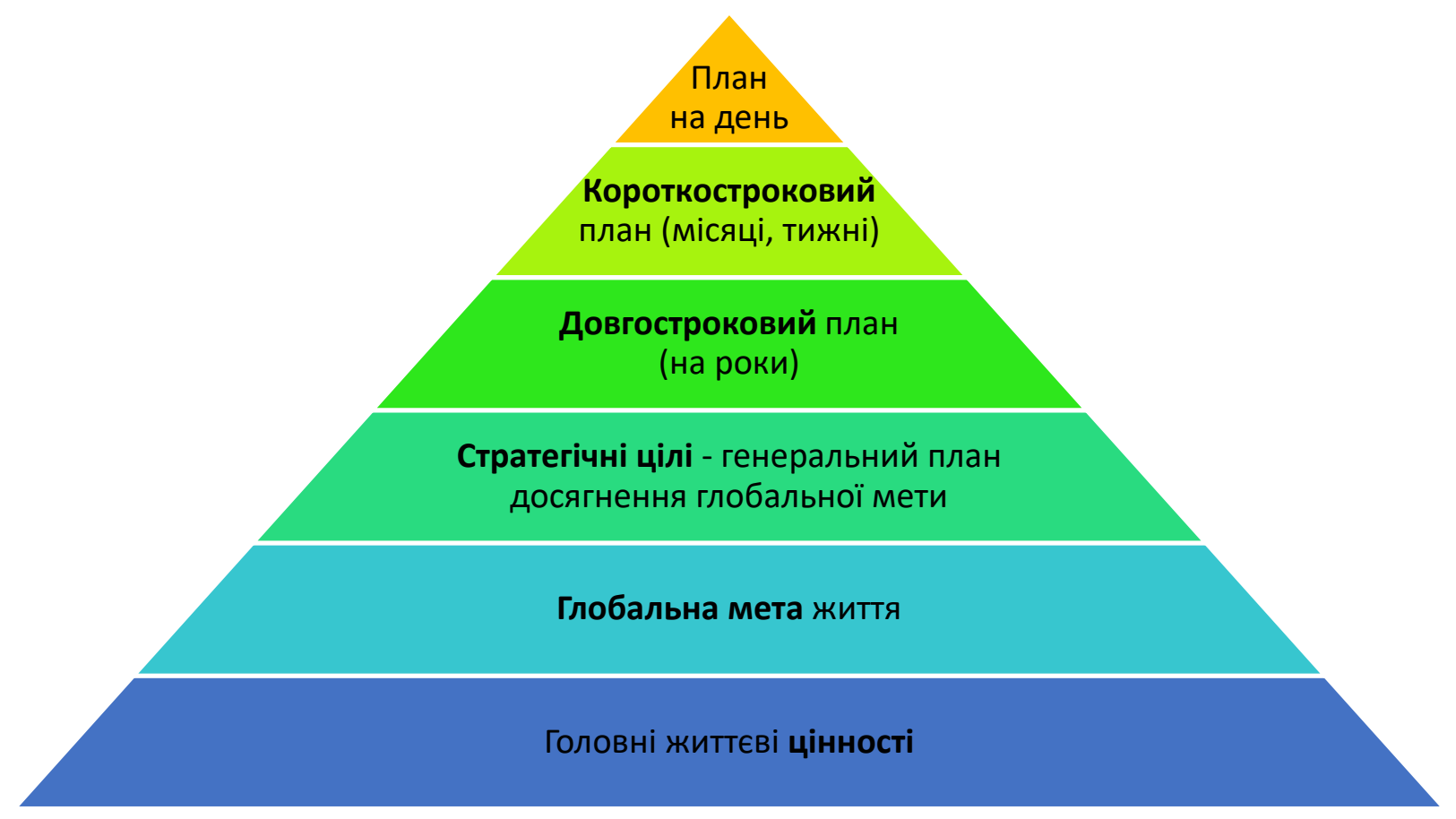

\section{Рис. 2. «Піраміда життя» Бенджаміна Франкліна}

Джерело: [13]

1. Перший блок піраміди, а, інакше кажучи, фундамент життя становлять цінності - те, що важливо, значимо, цікаво. Цінності відповідають на вічне питання «навіщо я роблю те, що роблю?».

2. Цінності визначають весь життєвий шлях і складаються в глобальну мету життя. Визначити головну мету всього життя спочатку здається абсолютно непосильним завданням. Тому Франклін конкретизував, що глобальна мета життя це максимально бажаний результат, найвища точка успіху.

3. На шляху досягнення глобальної мети життя ми вирішуємо стратегічні цілі. Це генеральний план і покрокова інструкція досягнення глобальної мети. Це досить великі цілі - на десятиліття. Наступні блоки піраміди дроблять стратегічні цілі на довгострокові (5 років), середньострокові (1 рік), короткострокові (3-6 місяців) і поточні (тиждень, день).

Таким чином, все, що Ви робите сьогодні, будете робити завтра, на цьому тижні і в цьому місяці - безпосередньо впливає на те, досягнете ваших цілей, чи будете успішним і щасливим через багато років. Піраміда життя говорить нам про те, що важливо правильно формулювати цілі, планувати шлях їх досягнення і підкріплювати бажання і мотивацію їх досягати [15].

$$
-286-
$$


Правильно поставлена мета впорядковує життя і спрощує процес прийняття рішень, що в підсумку призводить до значного зростання особистої ефективності.

Як правильно формулювати мету?

Найбільш відомим методом постановки мети є SMART, автором якої вважається Дж. Доран. Саме в його статті «There's a S.M.A.R.T. way to write management's goals and objectives» (в перекладі - Ось розумний шлях написати управлінські цілі і завдання) описано тлумачення абревіатури SMART.

Отже, цілі, які ставляться перед корпорацією, компанією, відділом повинні бути:

$\boldsymbol{S}$ (Specific) - конкретними; спрямованими на ті чи інші аспекти в одній області;

$\boldsymbol{M}$ (Measurable) - вимірними; щоб на основі їх аналізу можна було вивести показник прогресу;

$\boldsymbol{A}$ (Achievable) - досяжними; з націленістю на результат, який може бути досягнуто з урахуванням наявних ресурсів;

$\boldsymbol{R}$ (Relevant) - актуальними; виконання мети дійсно необхідного для досягнення бажаного;

$\boldsymbol{T}$ (Time-related) - певні в часі; межі досягнення мети повинні бути чітко визначені.

Однак практично відразу ці критерії стали використовувати і для особистісного розвитку. Разом з тим, не всі люди можуть відразу і з легкістю розібратися і скористатися цими критеріями. Нижче вони збудовані в тій послідовності, в якій Ви повинні перевіряти вашу мету. Так, крок за кроком, ви зможете сформулювати коректну мету, яку зможете почати реалізовувати вже сьогодні.

\section{1. Справжня мета}

Ваша мета повинна бути справжня. Справжні цілі виходять з бажань, мрій і ваших «ХОЧУ». Це природні потреби, реалізувавши які ви почнете відчувати себе повноцінним. Такі цілі досягаються легко і не доставляють особливих труднощів.

Якщо ви зараз згадали будь-яку мету, яку вам дуже важко досягти, то велика ймовірність, що вона «не ваша». Якщо мета нав'язана суспільством або близьким оточенням (приклад батьків, вплив друзів), то ви думаєте про неї з позиції «ТРЕБА» - мені треба знайти високооплачувану роботу, мені треба завести сім’ю.

\section{2. Позитивна мета}

Позитивна мотивація завжди сильніше негативної. Тому і мета повинна бути сформульована як прагнення до чогось, а не втеча від чогось.

Неправильно: звільнитися.

Правильно: знайти нову роботу, що задовольняє моїм інтересам і потребам.

\section{3. Конкретна мета}

Мета повинна бути конкретною, тобто повинна вказувати на те, що саме необхідно досягти. Не повинно бути двозначностей, невизначеностей і суперечностей. Дивлячись на мету, ви відразу повинні розуміти, який саме результат ви хочете мати.

Неправильно: 3 понеділка почну нове життя.

$$
-287-
$$


Правильно: до 16 вересня досягну системного режиму харчування: буду їсти 4 рази на день (о 9:00, о 13:00, о 17:00 та о 20:00).

\section{4. Вимірна мета}

Міра потрібна у всьому, в цілі теж. Вимірність - це те, що говорить вам, що мета досягнута. Вказівка міри дає вам розуміння, до чого необхідного прагнути. I, як наслідок, усвідомлення і задоволення в момент, коли ви цього досягнете. Міра може бути кількісною, тобто містити цифри, показники, або якісною, тобто емоційно насиченою.

Неправильно: хочу багато заробляти.

Правильно: станом на 1 травня я знайду роботу зі стартовим заробітком в 20000 грн.

\section{5. Визначена в часі}

Мета повинна мати чітко визначені межі часу іiі досягнення. Уточнення часу досягнення мети, по-перше, визначає той період часу, за який ви з метою повинні впоратися, по-друге, дозволяє перевірити іï досяжність, по-третє, прагнути до реалізації в намічені терміни.

Неправильно: закінчити університет.

Правильно: в червні 2021 року я отримаю диплом про вищу освіту.

\section{6. Досяжність}

Поставлена мета, а також механізм іï досягнення, повинна бути реальною. Щоб реалізувати мету, у вас повинно вистачати на це ресурсів - часу, сил, енергії, знань, навичок та ін. При постановці мети важливо визначити можливі ризики та перешкоди, а також способи їх подолання [12].

Неправильно: хочу схуднути на 20 кг за тиждень.

Правильно: 31 грудня я важу 50 кг, тобто за 10 днів схудла на 2 кг.

\section{7. Екологічність}

Для суспільства і світу в цілому. Якщо у Вашій меті беруть участь інші люди, суспільство або природа (спільна 3 родиною відпустка; виробництво, яке спричинить багато відходів, що не перероблюються), то необхідно подбати про те, щоб мета не шкодила іншим учасникам.

$S M A R T$-технологія не є універсальним методом постановки мети, як і всі інші способи. Вибір відповідної методики залежить від особистих переваг, розуміння суті методу і бачення бажаного.

\section{4. Активна життева позиція і проактивність}

Людська свідомість піддається впливам суспільства, культури, соціуму, колективів та інших особистостей. Цей вплив можна приймати чи не приймати. Головне - це прийняття чи неприйняття має бути свідомою дією, а не пасивним наслідком виховання та зовнішніх подій.

Суть активної життєвої позиції - усвідомлена реакція, яка позитивно впливає на долю людини:

$$
-288-
$$


- дає можливість перемогти стереотипи суспільної поведінки, які насаджені ззовні та заважають, гальмують рух до цілі;

- розширює, урізноманітнює життєві ролі;

- дає можливість брати участь у формуванні згуртованих і працездатних колективів.

Активна життєва позиція сприяє самореалізації та успіху, оскільки людина в такому випадку проявляе сміливість, ініціативність і готовність діяти [5]. Вона не чекає, щоб ій «дали» світогляд, знання, роботу, фінансові можливості тощо. Натомість - активно опрацьовує інформацію і діє відповідно до впливів зовнішніх (середовища) та внутрішніх (мотивів, бажань, почуттів). Подібний працівник цінується в сучасних ринкових умовах, оскільки він стає потужною силою, що допомагає втілити будь-яку перспективну бізнес-ідею. Йому притаманна ініціативність, активність, самостійність, принциповість.

Активна життєва позиція означає:

- орієнтацію в навколишньому середовищі та в суспільних цінностях;

- усвідомлене ставлення до інших людей;

- готовність до дії та до різних форм діяльності.

Фактори, що впливають на формування життєвої активності:

- формування власного світогляду;

- набуття соціальних та професійних навичок;

- спілкування з іншими людьми;

- трудова діяльність;

- громадсько-політична діяльність та ін.

Сфери, в яких проявляється активна життєва позиція:

- професійна сфера - одержання нових знань, навичок, досвіду з професії, зростання від стажера до кваліфікованого високооплачуваного працівника;

- соціальний напрям - організація та реалізація нових проектів, волонтерство тощо;

- особистий напрям - відвідування тренінгів та семінарів для саморозвитку тощо.

\section{Напрями і види життевої позиції}

Залежно від напрямку дій чи бездіяльності життєва позиція може мати два спрямування:

- позитивне (утвердження добра і подолання зла);

- негативне (діяльність на шкоду іншим).

Залежно від того, чи навчилась людина брати участь у вирішенні власних та суспільних проблем, розрізняють активну чи пасивну життєву позицію.

Людина з активною життєвою позицією:

- не вдоволена існуючою дійсністю;

- має уявлення про те, як виглядатиме нове, більш удосконалене буття; 
- активно діє, щоб перебудувати реальність.

Людина $з$ пасивною життєвою позицією:

- не має особистої місії, є інертність, байдужість;

- відсутня відповідальність за власні вчинки;

- якщо відбувається якась подія, завжди знаходиться причина, щоб нічого не робити;

- у всіх особистих невдачах винні всі навколо.

Проактивність - чітке усвідомлення особистих цілей та цінностей та діяльність згідно з ними, а не під впливом зовнішніх обставин. При цьому людина здобуває знання, приймає рішення, діє свідомо і сплановано, робить лише те, що допоможе досягнути цілей, i не розмінюється на дрібниці.

Проактивність в більшості випадків формується до 30-річного віку і народжується з активної життєвої позиції.

Необхідно, щоб активна життєва позиція гармонійно поєднувалася з розважливістю та мудрістю, бажанням допомогти іншим і почуттям міри. Інакше прагнення до перетворень може мати негативні наслідки різного масштабу — від власної нещасної родин до загибелі мільйонів людей.

\section{5. Аналітичне та критичне мислення}

Аналітичне мислення - це вміння аналізувати отриману інформацію логічним чином. Його можна розглядати як аналіз, синтез та оцінка даних, внаслідок чого отримані факти, проблеми і поняття доповнюються новим змістом. Замислюючись над засвоєним знанням, людина приходить до повнішого розуміння світу.

Аналітичне мислення неможливе без логіки, яка вказує правила, закони або норми, яким повинне підкорятися мислення для того, щоб бути істинним. Саме тому на аналітичному мисленні грунтується вся класична освіта. Крім того, у всіх наукових напрямках і течіях використовується принцип аналізу фактів, їх перетворення та отримання нових висновків.

Розвиток аналітичного мислення починається з раннього дитинства і триває все життя. Існує велика кількість методик і способів розвитку аналітичного мислення, більшість з яких полягає у тренуваннях на вирішенні тих чи інших задач з повсякденного життя [10]. Щоб успішно застосовувати аналітичне мислення, треба володіти достовірними фактами і механізмом формулювання висновків з наявних фактів.

Критичне мислення - це тип наукового мислення, що приводить, по-перше, до ухвалення добре обміркованих, виважених, усвідомлених рішень та, подруге, до самовдосконалення. Вважається, що саме критичне мислення є тим типом мислення, що забезпечує науково-технічний прогрес.

$$
-290-
$$


Процес критичного міркування при вирішенні задачі може бути представлений кількома етапами (рис. 3):

1 етап - породження проблеми та усвідомлення задачі;

2 етап - спроба подолати проблему за допомогою відомих способів дій та знань;

3 етап - переструктурування способів дії і знань та вироблення нового погляду, нових підходів, що завершується народженням ідеї;

4 етап - обгрунтування знайденого рішення та подання результатів розв'язання задачі.

Властивості критичного мислення: самостійність, усвідомлення, самоаналіз, цілеспрямованість, контрольованість обгрунтованість, організованість.

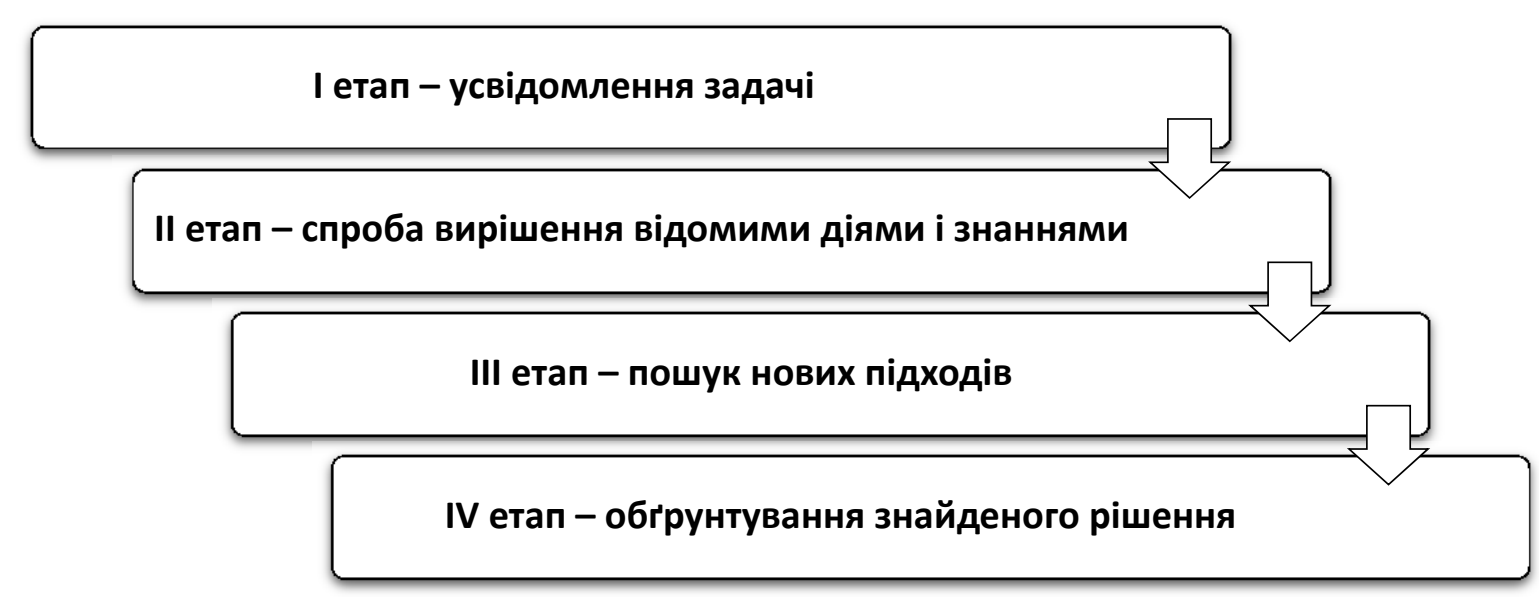

Рис. 3. Процес критичного мислення

Джерело: [5]

\section{6. Комунікативні навички}

Відповідно до класичної теорії менеджменту, комунікація - це обмін інформацією між двома і більше особами. При цьому ставиться мета забезпечити розуміння отримувачем інформації, яка $є$ предметом обміну.

Процес комунікації може набувати різних форм залежно від кількості учасників, цілей сторін-учасниць, засобів, стратегій та каналів, що використовуються. Існує велика кількість моделей комунікації.

Модель Аристотеля. Виділяються три основні елементи комунікації: оратор мова - слухач (рис. 4). Ці елементи відтворюються і в подальших моделях комунікації. Тільки з розвитком масових комунікацій через радіо, кіно, телебачення і під впливом потреби в удосконаленні методів пропаганди класична модель зазнала змін. 


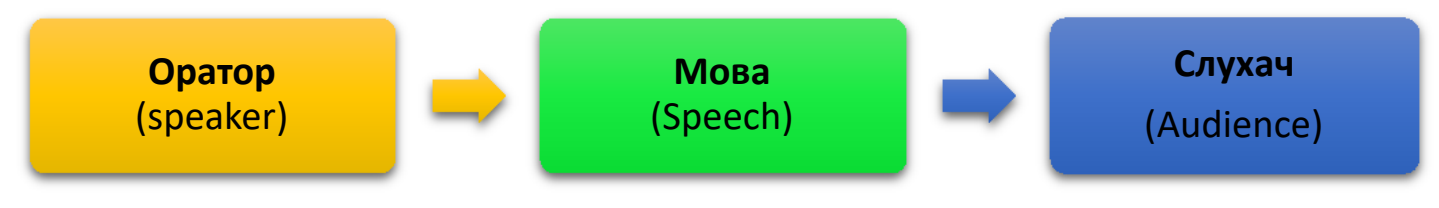

\section{Рис. 4. Модель комунікації Аристотеля}

Джерело: [2]

Модель Лассуелла розкривається під час відповідей на послідовно виникаючі питання (рис. 5): хто та 3 яким наміром комунікує? що та як говорить? в якій ситуації відбувається комунікація? яка аудиторія? який результат?
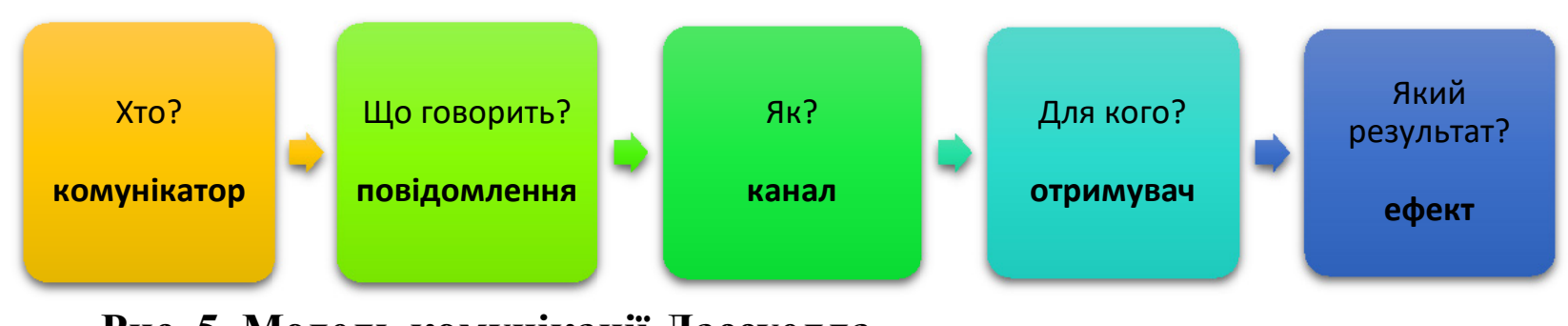

Рис. 5. Модель комунікації Лассуелла

Джерело: [2]

Комунікація складається 3 таких елементів процесу обміну інформацією (рис. 6):

- відправник (особа що генерує ідею, або збирає та опрацьовує інформацію для передачі);

- повідомлення (інформація, подана вербально чи іншим чином за допомогою символів);

- канал (засіб передачі інформації);

- отримувач (адресат, якому призначена інформація);

- зворотний зв'язок (реакція).

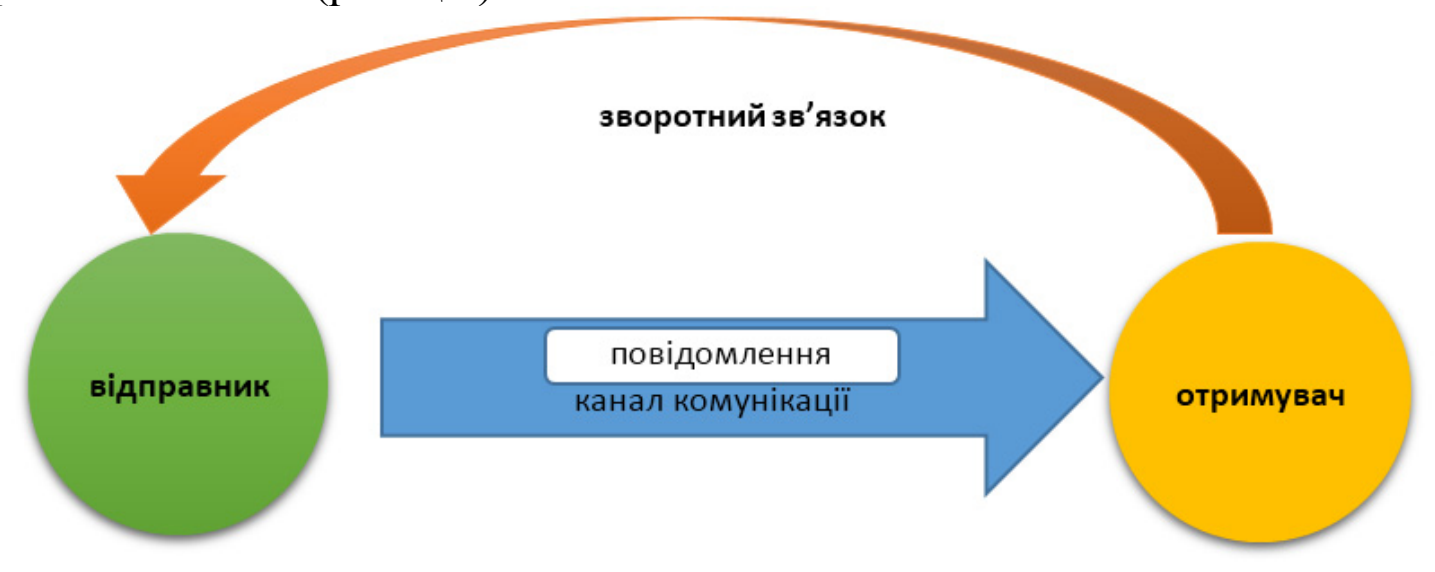

Рис. 6. Елементи процесу обміну інформацією Джерело: [2] 


\section{Комунікативні навички можна розділити на:}

- уміння формувати інформаційне повідомлення (говорити, писати чи іншим чином висловлюватись);

- уміння адекватно реагувати на повідомлення (вміння слухати, осмислена реакція, емоційна реакція);

- уміння користуватися різними каналами комунікації (усна мова, лист, повідомлення, електронна пошта, соціальні мережі).

Як свого часу сказав Наполеон Бонапарт: «Хто не вміє говорити - кар’єри на зробить». То ж вміння говорити і формулювати думку для того, аби донести свої ідеї, вимоги чи просто відчуття до інших - це один 3 основних показників розвитку комунікативних навичок. Звичайно, без цього неможливо працювати в жодному колективі чи виконувати будь-яку роботу.

\section{Рекомендації для ефективної комунікації}

Розвитку комунікативних навичок приділяють багато уваги успішні бізнесмени, політики, громадські діячі. Часто саме завдяки цим навичкам вони й досягли успіху, стали тими, ким є. Отже, якщо скористатись рекомендаціями, сформульованими на основі досвіду відомих особистостей, комунікація буде більш ефективною.

«При комунікації потрібно бути лаконічним $і$ чітко формулювати свої повідомлення" - радить Річард Бренсон, мільярдер і власник групи Virgin. При підготовці презентації чи будь-якого письмового повідомлення варто пам'ятати: усе, що перевищує «одне текстове повідомлення для пейджера» - це надто багато. Бренсон зазначає, що «все що пишу, свідомо намагаюся висловити настільки стисло, щоб воно вмістилося у формат твіта. Навіть якщо мені вдається скоротити своє послання лише до пари сотень знаків, я гадаю, що висловив свою думку більш ефективно, ніж якби воно було вдесятеро довшим» [6]. Лаконічність при комунікації - це ознака гарного тону ще й тому, що цінується час, як власний, так і своїх колег.

Уміння слухати для успішної комунікацї̈ не менш важсливо, нізс вміння говорити. Р. Бренсон рекомендує [6]: «Слухайте - так ви здаватиметесь розумними». Від того, що людина почує, а отже - сприйме, буде залежати, чи інформація отримана повною мірою. Втрати при сприйнятті будуть завжди, але потрібно намагатись, щоб вони були якомога меншими. Розвиток комунікаційних здібностей передбачає і покращення вміння сприймати інформацію. Доброю звичкою є нотатки і короткі замітки, вони можуть освіжити чи розкрити додатковий зміст в подальшому спілкуванні. Уінстон Черчилль якось сказав: «Мужність в тому, щоб встати і говорити; мужність і в тому, щоб сісти і слухати».

Комунікації $і$ коло спілкування потрібно постійно розширювати $і$ зміню$\boldsymbol{в a m u , ~ з н а и ̆ о м л я ч и с ь ~} 3$ новими людьми, підтримуючи комунікацію 3 колегами та друзями. В сучасному інформаційно-насиченому суспільстві чим ширше коло спілкування, тим успішніше реалізовуються та розвиваються комунікативні здібності особистості. Часто саме випадкові комунікації стають початком успішних проектів чи стартапів. Наприклад, Ларрі Пейдж і Сергій Брін (засновники Google) познайомились випадково за філіжанкою кави саме тому, що обом не вистачило квитків до кінотеатру. 
Для комунікативних навичок важливо і розвинуте вміння використовувати різні канали комунікації, залежно від ситуації, потреби або доцільності. Чи потрібно призначати зустріч, якщо можна вирішити питання в режимі телефонного спілкування? Чи викладати пропозицію на папері, якщо краще ії обговорити? Завдяки розвитку технологій кожен має можливість обирати серед широкого вибору каналів комунікації. Бесіди віч-на-віч, телефонна розмова, відеозв'язок, переписка в чаті чи за допомогою «месенджера» - сучасні засоби комунікації між людьми, які потребують швидкої і адекватної реакції, роблять навички комунікації вкрай необхідними і важливими.

Варто також згадати про таке поняття, як розумна цастота комунікації $\boldsymbol{i}$ взаємодіï. Регулярність комунікацій для підтримки контактів, для інформованості щодо перебігу подій, для планомірного впливу чи лобіювання тощо залежить від конкретних ситуацій і об'єктів спілкування. Як правило, такі знання кожен отримує лише завдяки власному досвіду.

\section{7. Емоційний інтелект}

Вміння розуміти емоції свої та оточуючих сприяє соціальній адаптації людини та професійній успішності.

Емоційний інтелект (з англ. Emotional intelligence, EI) - здатність керувати і використовувати емоційну складову особистості, тобто:

- усвідомлення емоцій (радість, сум, страх, гнів та ін.);

- досягнення доречного рівня та генерування емоцій, щоб сприяти мисленню;

- розпізнавання емоцій своїх та оточуючих (уміння назвати і зрозуміти, що вони означають);

- керування своїми емоціями.

Емоційний інтелект потрібен для:

- комунікації з людьми - для керівників, $h r$-менеджерів, бізнесменів, рекламних агентів, піар-менеджерів, інженерів тощо;

- розвитку в особистій та професійній сферах;

- управління стресом - стресостійкість;

- протистояння маніпуляціям - через рекламу, НЛП-технології та людейманіпуляторів (свідомих та несвідомих);

- розуміння власних пріоритетів та цілей.

Складові емоційного інтелекту: самопізнання та самоконтроль, соціальні навички (комунікація та взаємодія з оточуючими), емпатія, мотивація [7].

\section{Прийоми розвитку емоційного інтелекту:}

- стежити за власними емоційними реакціями;

- прислухатись до мови власного тіла, щоб розуміти мову тіла інших людей;

- виявляти і аналізувати зв'язок емоцій та поведінки (наприклад, гнів примушує кричати, сором - тихо говорити та ін.); 
- не піддаватись емоціям, якщо вони шкодять ситуації;

- розвивати емоційну пам'ять - аналізувати зв'язок між емоціями, вчинками та наслідками, щоб скорегувати поведінку;

- практикувати бажані емоції - наприклад, позитивне мислення;

- розвивати емпатію;

- бути емоційно чесним - не приховувати емоції.

\section{8. Емпатія}

Для успішної професійної діяльності потрібні не лише теоретичні знання та практичні навички, а й відкритість, терпимість, гнучкість, толерантність, почуття власної гідності, готовність до діалогу — все те, що так чи інакше вказує на здатність людини до емпатії [9].

Емпатія - здатність зрозуміти переживання іншої людини, уміння особливим чином спілкуватись та діяти на основі цього розуміння.

Емпатія

- сприяє зростанню: інтелекту, креативності, відповідальності; самодисципліни, самоорганізації; особистісної автономії; самоусвідомлення; самоповаги; спонтанності; свободи самореалізації;

- зменшує фізичну та словесну агресію; прояви вандалізму; порушення дисципліни.

Емпатія містить 3 компоненти:

- когнітивна - розуміння стану іншої людини без зміни власного стану;

- емоційна - розуміння стану іншої людини і зміна власного стану (співпереживання, співчуття);

- поведінкова - розуміння стану іншої людини, зміна власного стану, активна підтримка і допомога іншій людині.

Риси характеру людини, здатної до емпатії:

- терпимість до того, як виражають емоції інші люди;

- розуміння внутрішнього світу іншої людини;

- пристосування власних станів та емоцій до відповідних станів та емоцій іншої людини.

\section{Наслідки недостатнього рівня емпатії:}

- зростають проблеми у спілкуванні;

- зростає кількість конфліктів та непорозумінь;

- сповільнюється професійне зростання та ін.

Здатність до емпатії можна розвинути: навчатись самоаналізу, розвивати чутливість, навчатись емпатичному слуханню та адекватній демонстрації власних емоцій. 


\section{9. Стресостійкість}

Природна реакція організму на стрес - це реакції боротьби або втечі. В певних ситуаціях - це адекватна відповідь, особливо, якщо первісна людина бореться за життя в прадавніх джунглях. В сучасному світі подібні реакції є часто неефективними, а іноді - навіть небезпечними. Зокрема Всесвітня Організація охорони здоров'я називає стрес, що виникає на робочому місці, хворобою 21 століття.

\section{Негативні наслідки стресу:}

- хвороби;

- зниження працездатності;

- міжособистісні конфлікти.

Однак є й позитивні наслідки стресу:

- мобілізація фізичних та розумових здібностей в стресових умовах;

- переоцінка життєвих цінностей та самовдосконалення.

Стрес - реакція організму на різні подразники - стресори (табл. 1).

Фізіологічні та психологічні реакції формують певну характерну поведінку людини — «втечу» чи «боротьбу» [8]. Ці терміни проявляють себе в значенні і прямому (втеча, боротьба), і в переносному («втеча» - хвороба, уникнення певних ситуацій, приховування емоцій тощо, «боротьба» - психологічна готовність до дії, мобілізація зусиль тощо).

Стресори - фактори, впливи, ситуації, які здатні викликати стресові реакції «втечі» чи «боротьби».

Таблиця 1

\section{Реакції на стрес}

\begin{tabular}{|l|l|}
\hline \multicolumn{1}{|c|}{ Фізіологічна реакція } & Психологічна реакція \\
\hline - зростає м’язове напруження; & - страх; \\
- зростає частота серцебиття (пульс); & - гнів та агресія; \\
- зростає артеріальний тиск; & - розгубленість; \\
- зростає виділення поту; & - хвилювання та ін. \\
- зростає нервове збудження; & \\
- змінюється концентрація певних речовин (натрію, глюкози, \\
$\quad$ соляної кислоти тощо)
\end{tabular}

Джерело: [14]

Частина стресорів однакова у всіх людей, частина - унікальна для кожного (табл. 2). Наприклад, звільнення з роботи для однісї людини - катастрофа, для іншої - шанс почати нове життя.

Природні реакції на стрес в сучасному житті часто не $\epsilon$ корисними. Наприклад, на робочому місці працівник отримує завдання, яке є складним для нього. Прогул (аналог реакції «втеча») чи сварка (аналог реакції «бійка») буде некорисною реакцією - не виконується завдання, з'являються проблеми у працівників, управлінців, власників. 
Таблиця 2

Приклади стресорів, які виникають під час навчання та на робочому місці

\begin{tabular}{|l|l|}
\hline \multicolumn{1}{|c|}{ Стресори під час навчання } & \multicolumn{1}{|c|}{ Стресори на робочому місці } \\
\hline - перший рік навчання поза домом (зміна способу & - недостатня участь у прийнятті рішень; \\
життя, вибір професійної діяльності та ін.); & - рольові проблеми - нерозуміння влас- \\
- оцінки; & ної ролі на підприємстві, перевантажен- \\
- академічне перевантаження; & ня недостатність обов’язків; \\
- соціальні відносини (дружба, кохання та ін.); & незадоволеність роботою (низька зар- \\
- насильство; & плата, погані умови, загроза скорочення \\
- сором’язливість; & та ін.); \\
- невпевненість у собі та ін. & трудоголізм; \\
\hline
\end{tabular}

Джерело: [14]

3 іншого боку, напередодні екзамену студенти навчаються з більшою віддачою, а тривога щодо публічного виступу допомагає краще до нього підготуватись.

Отже, фізіологічні та психологічні реакції на стрес можна контролювати і використовувати собі на користь. Це і називається стресостійкістю.

Стресостійкість - здатність людини в стресовій ситуації не перебувати у стані стресу.

\section{Стресова ситуація складається 3 таких етапів:}

- життєва подія-стресор;

- сприйняття ситуації;

- емоційні зміни;

- фізіологічні зміни;

- наслідки ситуації.

Між сусідніми етапами стресової ситуації можна ставити певні «бар'єри»тобто свідомо втручатися в природні реакції, змінювати їх. Тоді ситуація стане менш травматичною, а дії - кориснішими, продуктивнішими [14].

Бар'єри для боротьби зі стресом:

- на етапі «подія - сприйняття» - заспокійливі засоби, вольові зусилля (наполегливість, впертість, сила волі);

- на етапі «сприйняття - емоції» — позитивне мислення;

- на етапі «емоції - фізіологічні реакції» — техніки релаксації;

- на етапі «фізіологічні реакції - наслідки» — фізична активність (заняття спортом).

Найкращий метод збільшення стресостійкості - комплексне та свідоме застосування усіх бар'єрів. Загальний алгоритм боротьби зі стресом містить три складових:

- зміна сприйняття ситуації, погляд на неї під іншим кутом зору;

- зміна власного фізіологічного стану — концентрація, відпочинок, заспокоєння;

- вирішення проблеми. 
Існує спеціальна методика Холмса-Рея для самооцінки стресового навантаження. Оцінивши його, можна спрогнозувати ймовірність проблем зі здоров'ям та знайти способи самостійного подолання стресу. Будь-хто в змозі самостійно скористатись загальновідомими важелями керування стресом і повернути життєву ситуацію собі на користь.

«Наша реакція повинна бути найкращою $з$ можливих альтернатив для вирішення проблем, підтримки добрих взаємин та збереження енергії. Це і є реакцією людини, здатної контролювати рівень стресу!».

\subsection{0. Кризовий менеджмент}

Конфлікт - це ситуація (набір обставин), при якій виникає зіткнення протилежних сторін, сил чи поглядів або має місце відсутність згоди між двома чи більше суб' єктами.

Обов'язкові складові конфліктної ситуації:

- учасники (сторони) конфлікту;

- об’єкт конфлікту (явище, причина);

- рушійна сила (інцидент) конфлікту.

Ось як описує тривалий міжособистісний конфлікт зі своїм колегою відомий банкір Девід Рокфеллер у своїх мемуарах: «Що вище ми просувались кар'єрними сходами, то гострішим і очевиднішим ставав наш особистий i професійний конфлікт. Установи працюють найкраще, коли у них сильне та об'єднане навколо однієї мети керівництво. Його небажання просувати запропонований мною план породжувало купу затримок і змарнованих нагод».

Щоб успішно розв'язати конфлікт і підібрати найкращу стратегію поведінки, потрібно знати, на якій стадії знаходиться конфлікт (табл. 3)

\section{Стадії конфлікту}

Таблиця 3

\begin{tabular}{|c|l|}
\hline Стадія конфлікту & \multicolumn{1}{c|}{ Як розв'язати конфлікт } \\
\hline Латентна & - Відновити взаєморозуміння \\
\hline \multirow{2}{*}{ Демонстративна } & - Продемонструвати готовність до нормального спілкування \\
& - Прояснити позиції сторін \\
\hline \multirow{2}{*}{ Агресивна } & - Зруйнувати образ ворога \\
& - Зменшити підозри щодо агресивності, підступності іншої сторони \\
& - Зменшити власне прагнення вчинити зло \\
\hline \multirow{2}{*}{ Батальна } & - Перемир'я \\
& - Намагання до мирного співіснування \\
& - Припинення агресивних дій \\
& - Домовленість не чинити зла \\
\hline
\end{tabular}

Джерело: [8] 


\section{Методи вирішення конфліктів}

Усталена думка, коли конфлікти порівнюються з різними неприємностями і негараздами, суперечками, ворожнечею є руйнівними i не мають позитивних ознак. Проте, крім негативної ролі, конфлікт відіграє і позитивну роль - він сприяє руху організації вперед і виносить на поверхню фактори, які заважають цьому процесу. В будь-якому разі конфлікт потребує вирішення. Існуючі методи вирішення конфліктів поділяють на структурні та міжособистісні.

Структурні методи вирішення конфлікту:

- роз'яснення вимог до змісту роботи (делегування чітких повноважень);

- принцип використання ієрархії (звернення до керівника);

- підпорядкування цілей загальній меті організації;

- вплив на поведінку через систему винагород.

Міжособистісні методи вирішення конфліктів:

1. Стиль уникання, ухилення. Людина, що дотримується цієї стратегії, прагне уникнути конфлікту. Ця стратегія може бути доречна, якщо предмет розбіжностей не представляє для людини великої цінності, якщо ситуація може розв'язатися сама собою (це рідко, але все-таки буває), якщо тепер немає умов для ефективного розв'язання конфлікту, але через деякий час вони з'являться. Стиль уникання можна запропонувати до застосування в таких ситуаціях:

- джерело розбіжностей тривіальне і несуттєве для вас порівняно з іншими важливішими завданнями, а тому ви вважаєте, що не варто витрачати на нього сили;

- Ви знаєте, що не можете або навіть не хочете розв'язати питання на свою користь;

- у вас мало влади для розв'язання проблеми бажаним для вас способом;

- хочете виграти час, щоб вивчити ситуацію й одержати додаткову інформацію, перш ніж прийняти рішення;

- намагатися розв'язати проблему негайно небезпечно, тому що розкриття і відкрите обговорення конфлікту можуть тільки погіршити ситуацію;

- підлеглі можуть самі успішно врегулювати конфлікт;

- у вас був важкий день, а розв'язання цієї проблеми може принести додаткові прикрощі.

2. Стиль згладжування. Цей стиль грунтується на тезах «Не варто розгойдувати човен», «Давайте жити дружно». «Згладжувач» прагне не випустити назовні ознаки конфлікту, конфронтації, закликаючи до солідарності. При цьому часто забувається проблема, що лежить в основі конфлікту. Внаслідок цього може тимчасово наступити спокій. Негативні емоції не проявляються, але вони нагромаджуються. Рано чи пізно залишена без уваги проблема і негативні емоції, що нагромадилися, приведуть до вибуху, наслідки якого виявляться дисфункціональними.

3. Стиль примусу. Той, хто дотримується цієї стратегії, намагається примусити прийняти свій погляд за будь-яких обставин; його не цікавить думка інших. 
Цей стиль пов'язаний з агресивною поведінкою, для впливу на інших людей тут використовують владу, засновану на примусі, і традиційну владу. Цей стиль може стати ефективним, якщо його використовують в ситуації, що загрожує існуванню організації або перешкоджає їй досягти своїх цілей. Керівник відстоює інтереси справи, інтереси організації, і деколи він просто зобов'язаний бути наполегливим. Головний недолік того, що керівник використовує цю стратегію - придушення ініціативи підлеглих і можливість повторних спалахів конфлікту.

4. Стиль компромісу. Цей стиль характеризується ухваленням погляду іншої сторони, але певною мірою. Здатність до компромісу в управлінських ситуаціях високо цінується, оскільки зменшує недоброзичливість і дозволяє відносно швидко розв'язати конфлікт. Але за деякий час можуть виявитися і дисфункціональні наслідки компромісного розв'язку, наприклад, незадоволеність «половинчастими рішеннями». Крім того, конфлікт у деякій видозміненій формі може виникнути знов, оскільки залишилася нерозв'язаною проблема, що породила його.

Такий підхід до розв'язання конфлікту можна використовувати в таких ситуаціях:

- обидві сторони мають однаково переконливі аргументи і мають однакову владу;

- задоволення вашого бажання має для вас занадто велике значення;

- вас може влаштувати тимчасове рішення, тому що немає часу для вироблення іншого, або ж інші підходи до розв'язання проблеми виявилися неефективними;

- компроміс допоможе вам хоч щось одержати, ніж усе загубити.

5. Стиль співробітництва. Грунтується на переконаності учасників конфлікту в тому, що розбіжність в поглядах — це неминучий результат того, що в розумних людей $\epsilon$ свої уявлення про те, що правильно, а що ні. За цієї стратегії учасники визнають право один одного на власну думку і готові зрозуміти один одного, що дає їм можливість проаналізувати причини розбіжностей і знайти прийнятний для всіх вихід. Той, хто спирається на співробітництво - не прагне досягти своєї мети завдяки іншим, а шукає розв'язку проблеми.

Цей стиль найважчий, тому що він вимагає тривалішої роботи. Мета його застосування - розробка довгострокового взаємовигідного рішення. Такий стиль вимагає уміння пояснити свої бажання, вислуховувати один одного, стримувати свої емоції. Відсутність одного з цих факторів робить цей стиль неефективним.

Для розв'язання конфліктів цей стиль можна використовувати в таких ситуаціях:

- треба знайти загальний розв'язок, якщо кожний із підходів до проблеми важливий і не допускає компромісних рішень;

- у вас тривалі, міцні і взаємовигідні відносини з іншою стороною;

- основною метою $є$ придбання спільного досвіду роботи;

- сторони здатні вислухати одна одну і викласти суть своїх інтересів.

Оцінюючи особливості різних стилів поведінки у конфлікті, слід виходити 3 кількох основних моментів. 
По-перше, не можна абсолютизувати жоден 3 описаних способів або говорити, що саме він «найправильніший», «ліпший за інші», оскільки кожен з учасників конфлікту у179 відповідній ситуації поводитиметься відповідно до свого індивідуального стилю поведінки, який у свою чергу залежить від темпераменту, особливостей емоційної сфери, здатності до спілкування тощо.

По-друге, кожен з учасників конфлікту найчастіше буде користуватись різними стилями поведінки залежно від контексту конфлікту, значущості тих потреб та інтересів, які реалізуються в ньому, від людей, з якими він взаємодіє, від особливостей опонента, оскільки власна поведінка в конфлікті досить часто є «віддзеркаленням» поведінки останнього.

По-третє, кожен з учасників конфлікту здатний до зміни свого стилю поведінки. А тому, враховуючи, що стиль співробітництва є найефективнішим, оскільки він дає можливість задовольнити інтереси всіх його учасників, слід якнайбільше, як це можливо в конкретній ситуації, орієнтуватися на реалізацію саме цього стилю.

Здатність вирішувати конфлікти оптимально будується на методиці вирішення конфлікту шляхом розв'язання проблеми:

а) визначити проблему, встановити причину проблеми, а не зосереджуватись на боротьбі з ії наслідками;

б) після виявлення суті проблеми розглянути варіанти ऑii вирішення, які б влаштовували всі зацікавлені сторони;

в) сконцентрувати увагу на проблемі, а не на персональних якостях опонента;

г) створити атмосферу довіри, покращивши обмін інформацією;

д) прагнути досягнення результату під час спілкування, не здавати власні позиції і враховувати конструктивні зауваження іншої сторони.

\subsection{1. Кризовий менеджмент}

Кризовий менеджмент - це мистецтво оволодіння складною ситуацією, усунення ризику і невизначеності, контроль над процесами, що приводить в результаті до успішного перебігу подій. Кризовий менеджмент на сьогодні набув настільки великого значення, що у компаніях 3'явилась спеціальна посада кризовий менеджер [16]. Кризових менеджерів поділяють за Маккобі на чотири типи: «спеціаліст», «боєць у джунглях», «людина фірми», «гравець».

Одна з найважливіших навичок кризового менеджера або просто людини, яка має вирішити конфліктну ситуацію в колективі — це уміння вести переговори та підтримувати діалог. Ці уміння є дуже цінними у критичних ситуаціях, коли конфлікт назріває або вже у розпалі.

Основна мета проведення переговорів - запропонувати свої умови і схилити всі сторони на свій бік. Вправні майстри часто в свої умови закладають пункти явно суперечливі, конфліктні і неприйнятні для іншої сторони. Згодом, під час процесу перемовин, ніби йдучи на поступки, вони знімають ці пункти. В підсумку

$$
-301-
$$


створюється враження компромісного рішення, хоча насправді спрацьовує попередньо задуманий сценарій.

Психологи та маркетологи мають різні підходи і багато рекомендацій щодо того, як краще готуватись та вести переговори, щоб вони завершились успіхом:

- має значення, в яких умовах, в якому оточенні буде відбуватись спілкування: ті, для кого це оточення є більш знайомим чи більш звичним, матимуть перевагу;

- важливо підготуватись до можливих заперечень щодо запропонованої позиції, одразу продумати аргументи, щоб на них відповідати;

- важливо бути витриманим під час переговорів - занадто багато емоцій зводять переговори до рівня суперечки чи навіть сварки;

- рівень поінформованості учасників допомагає швидким та конструктивним перемовинам — хто краще поінформований, той веде діалог в потрібному напрямку;

- однак не потрібно одразу викладати всю відому інформацію, інтрига допомагає тримати увагу;

- слід врахувати, що увага з часом слабшає, тому найпродуктивнішими в переговорах є перші півгодини;

- в конфлікті, навіть у найскладніших ситуаціях, потрібно тримати контакт між сторонами, адже поки є діалог - $є$ надія на успіх.

\subsection{2. Управління проектною командою}

У основі сучасної концепції управління персоналом в проектах лежить зростаюча роль особистості працівника, знання його мотивацій, їх здатність формувати і керувати відповідно до завдань, що стоять перед проектною командою.

Менеджмент дозволяє досягати результатів «за допомогою людей», а результати роботи багато в чому залежать від того, як керівник проекту спілкується 3 людьми і як ці люди ставляться один до одного. Ефективна організаційна система, структуроване планування і контроль, а також хороші командні відносини необхідні для успіху проекту.

Ефективне управління персоналом — основа управління проектами. Основна мета управління персоналом проекту:

- забезпечити, щоб поведінка кожного члена проектної команди сприяла досягненню цілей організації і в цілому реалізації проекту;

- створення проектної команди для реалізації проекту оптимально (за якістю, часом і вартості).

Основними напрямками управління персоналом в проектах є:

1) лідерство проектного менеджера;

2) командний розвиток і групова робота;

$$
-302-
$$


3) мотивація окремих осіб і груп;

4) управління конфліктами.

Збільшення складності проектів, використання нових технологій вимагає створення інтегрованих команд. Вони складаються з різних фахівців, які працюють один $з$ одним.

Команда проекту — це група людей, які працюють разом для досягнення спільної мети. Вони працюють безпосередньо над проектом і підзвітні керівнику проекту. Команда проекту формується на період реалізації проекту і розпускається після його завершення.

Робота у команді може об'єднувати людей, щоб вони підвищували свою продуктивність, не втрачаючи індивідуальності. Робота в команді має синергетичний ефект, коли обробляються різні пропозиції, коли одному члену команди конструктивно допомагають інші, що сприяє більш високим результатам.

Переваги спільної роботи:

1. Робота в команді - це інструмент, що забезпечує підтримку і успіх керування.

2. Командна може оновлюватись самостійно через набор людей у міру вибуття окремих членів.

3. Команда створює «банк» колективного досвіду, інформації та правил, які можна передати новим членам.

4. Багато людей більш успішно працюють в команді, ніж поодинці.

5. Командна синергія дає більше результатів, ніж сума індивідуальних вкладів.

Що дає кожній людині можливість працювати в команді:

1. Задовольняє соціальну потребу належати до чого-небудь або бути у групі.

2. Сприяє формуванню самооцінки в процесі аналізу своїх взаємин у групі.

3. Надає допомогу в досягненні мети (обмін ідеями, конструктивна критика, альтернативні пропозиції тощо).

4. Розподіляє ризик між членами команди.

5. Створює «психологічний дім».

Складність завдань управління реалізацією проекту вимагає високої технічної компетентності, великого обсягу економічних, юридичних, управлінських знань. Тому створення професійної команди проектів є необхідною умовою ефективної проектної роботи. Команда проекту має поєднувати навички у трьох категоріях:

- технічні та функціональні, тобто професійні, навички (hard skills);

- навички вирішення проблем та прийняття рішень;

- міжособистісні навички (soft skills).

Цілі створення команди проекту:

1. Поліпшити розподіл робочих місць. Поєднуйте навички, уміння, можливості та розподіляйте свої завдання серед членів відповідно до часу.

2. Управління роботою та контроль. Робота кожної групи організовується та контролюється іншими членами.

3. Вирішення проблем та прийняття рішень. Зробити це завжди легше, поєднуючи вміння, здібності, знання групи людей.

$$
-303-
$$


4. Перевірка та затвердження рішень. Перевірити реальність рішення, яке сприйняли ззовні, або затвердити таке рішення.

5. Спілкування та інформація для тих, хто повинен знати, як приймати рішення або надавати необхідну інформацію.

6. Накопичування ідей, інформації, порад.

7. Координація та зв’язок між функціональними підрозділами.

8. Підвищення відповідальність та залучення членів команди, створення сприятливого середовища для участі у плануванні та діяльності організації.

9. Переговори та вирішення конфліктів на різних рівнях управління.

10. Аналіз результатів реалізації проекту з метою покращення інформаційної бази їх оцінки.

Основні організаційні завдання створення проектної групи:

- створення професійно-стимулюючого середовища;

- здійснення грамотного управління;

- забезпечення кваліфікованим технічним персоналом;

- забезпечення підтримки керівництва та стабільно дружнього середовища.

Члени команди повинні бачити себе частиною команди проекту та розробляти спільні цінності та норми, перш ніж працювати в команді. Процес формування єдиного почуття колективу та загальної команди вимагає часу. Зазвичай команда проекту проходить п’ять етапів створення.

Етап створення команди:

1. Формування.

На етапі створення команди основні проблеми виникають 3 наступних причин:

- власні відчуття членів колективу (чи відчувають вони себе повноправними членами колективу, як до них ставляться);

- взаємовідносини всередині команди (хто з ким взаємодіє і хто має вплив);

- місце команд у організації в цілому.

Спочатку члени команди збираються разом з почуттям взаємного нерозуміння. Мотивація висока, тому що вони були обрані для реалізації проекту, але ефект від першого етапу низький, тому що члени команди не впевнені у собі.

2. Період спрацьованості учасників.

Основні питання, які виникають на цьому етапі:

- складність командної роботи (немає просування, передача відповідальності);

- прояви характерів (владолюбство, неформал, лірик, «мильні бульбашки», лінь тощо);

- обговорення питань (суперечка або абсолютна згода);

- неправильні методи звітності (недооцінка результатів, атрибуція, неякісна інформація);

- помилки управління (швидкі коливання, перепади настрою, відсутність чіткого планування, слабкий контроль);

- відносини (ворожість, відсутність підтримки і довіри, конфлікти).

$$
-304-
$$


Коли члени команди починають працювати разом, вони виявляють, що у них різні ідеї про те, як найкраще досягти цілей проекту. Вони також виявляють, що $\epsilon$ різні підходи до роботи над проектом. Ці відмінності можуть викликати конфлікти, знижуючи ефективність команди.

3. Період функціонування належним чином (у кожного своя роль і місце).

Члени команди починають погоджуватися з різних питань. Шляхом переговорів і компромісів. В результаті такої адаптації вони починають розвивати почуття єдності і певні загальні норми і цінності. Це формує основу для спільної роботи членів команди. Ефективність і мотивація починають рости до певного рівня.

4. Реорганізація (в зв'язку зі зміною обсягу і виду роботи, тимчасове професійне залучення).

Керівникам проектів необхідно підтримувати високий рівень продуктивності, досягнутий в разі вимушених змін в команді проекту.

5. Розпуск (після завершення роботи).

У міру наближення до закінчення роботи ефективність збільшується, коли члени команди зосереджуються на поточному завданні, або знижується, коли члени команди висловлюють жаль 3 приводу завершення роботи і розривів налагоджених відносин. Останнє трапляється, коли майбутнє команди не визначено.

Щоб команда працювала ефективно, керівник проекту повинен робити наступне:

- визначати організаційну структуру команди;

- розподіляти функціональні обов'язки;

- призначати керівників і відповідальних за конкретну область;

- забезпечити своєчасне планування і розподіл праці;

- ясно пояснювати цілі і завдання;

- долати перешкоди і уникати зіткнень;

- зацікавлювати, допомагати;

- створення привабливого іміджу команди.

Наступні методи використовуються для створення і розвитку команд. ності.

- Ролевий аналіз і відбір членів команди 3 точки зору психологічної придат-

- Проведення семінарів, організація курсів, ситуаційний аналіз.

Існують різні підходи до визначення можливих ролей в команді. По одному 3 них всі ролі розділені на дві групи.

- роль, яка сприяє виконанню завдання;

- роль створення необхідного мікроклімату всередині колективу.

Наприклад, всім відомий Белбін-тест допомагає визначити роль кожного виконавця в команді.

Кількісний склад команди визначається наступними факторами:

1) Кількість людей, необхідне для виконання проекту.

2) Необхідні для проекту експертизи.

3) Оптимальна кількість 3 точки зору конфліктності.

Фахівці вважають, що оптимальна кількість людей - 5-10 осіб.

$$
-305-
$$


Керівникам проектів, які сформували команду, необхідно підтримувати певний рівень ефективності роботи.

Оцінка ефективності команди заснована на наступних показниках:

- Ясне розуміння свої цілі і зосередження на кінцевому результаті.

- Чіткий поділ функцій і обов'язків.

- Наявність плану розвитку команди.

- Командна солідарність.

- Взаєморозуміння і неконфліктність;

- Відвідуваність робочих зустрічей та активна участь в рішенні проблем.

Команда доб'ється успіху, якщо:

1) Лідер має відповідний стиль управління з точки зору ефективності проекту і членів команди.

2) Щонайменше один $з$ членів команди пропонує новаторські ідеї як спосіб вирішення проблеми.

3) До команди входять люди з хорошими розумовими здібностями.

4) Команда створюються різними людьми і дає їм можливість підтримувати баланс.

Іншими словами, команда повинна бути креативною і гнучкою.

Для управління проектом потрібна постійна команда проекту. Керівник проекту та його команда єдині і повинні діяти як добре змащений механізм. Створення команди експертів для нового проекту вже відповідальність керівника проекту на перших етапах його роботи. Цей процес вимагає набору адміністративних навичок: вміння ідентифікувати та об'єднувати фахівців з різних підрозділів та організацій.

У матричній структурі з подвійним підпорядкуванням набір здійснюється керівником проекту та керівником функціонального відділу. У процесі підбору персоналу обговорюються цілі та завдання проекту, очікувані результати, витрати на ресурси, ролі та обов'язки членів команди, підзвітність, очікувані винагороди та важливість проекту для організації. Кандидати можуть увійти до команди, яка відповідає професійним вимогам і дуже зацікавлена в успіху проекту. Керівники проектів, які формують команди, по’єднують людей на основі спільних цілей.

Новизна, унікальність, ризик, швидкоплинність — це унікальні риси нового проекту. Вони викликають труднощі у формуванні команд, які ускладнюються тим, що люди, які не працювали разом, не мають спільних цінностей та норм, а їх діяльність повинна бути ефективною. Команді потрібен час, щоб рости всередині групи та встановлювати загальні норми, стандарти та цінності. Все це має відбутися до того, як команда зможе діяти на «повну потужність».

Керівники проектів повинні всіляко сприяти процесу переосмислення групи фахівців у команду. Перш за все, необхідно створити атмосферу сприятливого психологічного клімату для забезпечення адаптації учасників. Керівник проекту вирішує такі основні організаційні проблеми:

- Створення професійно стимулююче середовище.

$$
-306-
$$


- Здійснення грамотного керівництва;

- Забезпечення кваліфікованим персоналом.

- Забезпечення підтримки від керівництва та сприятливого середовища.

Керівники проекту створюють середовище, де члени команди нового проекту можуть відчувати професійне задоволення, впевненість у своєму становищі та чітке розуміння взаємозв'язку та відповідальності, взаємної довіри та взаємоповаги.

Організаційна структура команди проекту.

Незважаючи на те, що команди - це тимчасові групи, що діють всередині організації, вони мають особливу організаційну структуру, характер якої залежить від цілей, завдань та інших параметрів проекту.

У практиці управління проектами використовуються два типи структур проектних команд.

Матричний формат структури команди.

Підходить для малих та середніх проектів із життєвим циклом до 2-х років. Суть матричного формату полягає в тому, що фахівці з функціональних підрозділів організації відбираються до проектної групи на тимчасовій основі. Формат матриці має свої сильні та слабкі сторони.

Переваги:

- Гнучкість в організації та розвитку команди.

- Немає дублювання функціональних відділів.

- Наявність «впевненості у завтрашньому дні» членів команди.

Керівник проекту має можливість запросити до команди стільки професіоналів з функціонального відділу, скільки потрібно для виконання робочого навантаження на певний період часу. 3 появою нових видів робіт, коли обсяг роботи збільшується і зменшується, він знову може змінювати склад колективу за рахунок фахівців функціональних підрозділів організації.

Структура команди проекту не створює власного функціонального відділу, тому повноваження та функції окремих спеціалістів, присвячених проекту, не збігаються 3 постійними функціональними відділами організації. Після завершення проекту члени команди повернуться до функціонального відділу. Тобто їм не потрібно шукати нову роботу. Це дуже важливий позитивний фактор у матричній структурі.

Обмеження:

- Відсутність принципу управління однією особою;

- Тимчасовість команди.

- Проблеми з розподілом ресурсів у організації.

- Складність відносин в організації.

Основним недоліком матричної структури команди є те, що вона порушує принципи управління однією особою. Перетин вертикальних і горизонтальних зв'язків ускладнює формування команди та управління. Члени команди, які постійно працюють у відділах організації і тимчасово зайняті проектом, можуть не мати можливості вирішити, кому підпорядковуватись, чиї доручення виконувати. 
Постійна дилема: що важливіше? Належати до колективу функціональних підрозділів або команди проекту?

Відсутність єдиноначальності створює серйозні проблеми для керівників проектів. Важко керувати, якщо люди зосереджені на іншому лідері. Тимчасовий характер проекту турбує як керівника, так і всю команду. Членам команди потрібен час, щоб зрозуміти один одного, знайти точки дотику, зав'язати дружні відносини i «спрацюватись». Для невеликих проектів часто немає часу завершити цей процес, відносини перериваються.

Тимчасовість, подвійність позицій учасників і двовладдя створюють конфлікти всередині організації з таких важливих питань, як призначення експертів і розподіл ресурсів всередині неї. Це багато в чому залежить від взаємин між менеджером проекту і керівником організації, керівником функціонального відділу, а також від здатності створити переконливий імідж проекту.

Проектний формат структури команди.

Для управління великими проектами все частіше використовуються спеціальні проектні організаційні структури. Певна «зменшена копія» організації створюється для реалізації великого проекту всередині організації. У цій організаційної структури також $є$ свої сильні і слабкі сторони.

Переваги:

- Принцип єдиного лідерства;

- Впевненість у ситуації всередині організації.

- Командні зусилля і зосередження уваги на результатах проекту.

Команда створюється на великий термін (більше двох років), тому повністю зосереджена на проекті і його цілях. Найважливішою перевагою форми проекту є те, що всі зусилля можуть бути зосереджені на досягненні основних цілей проекту, не відволікаючи учасників на виконання інші обов'язки в функціональних відділах організації.

Постійний склад команди орієнтований на довгострокову співпрацю. Члени команди не відчувають своєї тимчасовості і займають певну позицію всередині організації. Як правило, великі проекти мають пріоритет, навіть якщо у організації наявні інші проекти. Це дає переваги для відбору фахівців та розподілу ресурсів, тому менеджери проектів 3 меншою ймовірністю будуть боротися 3 цими проблемами.

Недоліки:

- Дублювання функції всередині організації.

- Нестача гнучкості в розвитку і реорганізації команди.

- Невпевненість членів команди в працевлаштуванні після завершення проекту.

Перебування в проектній групі «філій» функціональних відділів організації призводить до дублювання функцій. Це тягне за собою додаткові витрати для організації. Перетин функцій і повноважень команди і ключових функціональних відділів організації $є$ джерелом конфлікту. В процесі розвитку або реорганізації команди керівникам проектів складно наймати фахівців і залучати нових фахівців 3 ключових відділів організації. Після завершення важливого проекту у більшості

$$
-308-
$$


учасників немає можливості повернутися до своєї колишньої роботи. Цей фактор працює двояко.

Перший варіант. Очікується нове замовлення на важливий проект, який буде передано тому самому керівнику проекту. На заключному етапі завершення проекту члени команди прагнуть бути більш продуктивними, заявляючи про необхідність приєднатися до нової проектної команді.

Другий варіант. Нових проектів не очікується. Продуктивність праці в кінці проекту різко падає, так як учасники стурбовані пошуком нових робочих місць.

У разі другого варіанту, завдання менеджера проекту — знайти нові цікаві мотиви для відновлення інтенсивної командної діяльності і зробити все можливе для забезпечення роботою колег після проекту.

Ефективні командні характеристики.

Ефективність команди можна оцінити за загальноприйнятими критеріями, прийнятим будь-якою організаційною структурою. Однак є певні особливості, характерні для проектної групи. В першу чергу, вся команда націлена на кінцевий результат, ініціативність і творчий підхід до вирішення проблеми. Висока продуктивність, орієнтація на кращі рішення і живі і зацікавлені обговорення нових питань доповнюють характеристики ефективної команди.

Підбір професійно підготовлених фахівців визначає грамотне рішення нової проблеми. Ефективна командна робота - це чітке відстеження взаємовідносин і взаємодій учасників, атмосфера довіри та участі, ентузіазму i творчості. Деструктивні конфлікти рідкісні, а конструктивні конфлікти підтримуються, щоб сприяти кращому вирішенню проблеми. Всі члени команди відчувають відповідальність за реалізацію всього проекту і виконання окремих завдань.

Щоб створити згуртовану і ефективну команду, менеджерам проектів необхідно максимально використовувати свої знання і навички, включаючи організаційні навички, професійний авторитет і знання в області взаємин.

1. Основні труднощі та бар'єри.

Керівник проекту повинен розуміти, що в процесі побудови команди його чекають різні зміни. Перш за все, він повинен уникати таких помилок:

- незрозумілі цілі або часта зміна цілей та пріоритетів;

- нестача ресурсів та фінансування;

- боротьба за владу та конфлікти в колективі;

- недостатня технічна оснащеність;

- відсутність інтересу та підтримки з боку керівництва.

2. Розподіл обов'язків та повноважень.

Керівник проекту повинен насамперед затвердити керівні посади у сферах діяльності, призначити відповідних спеціалістів, розподілити між ними функції та обов'язки та делегувати необхідні повноваження. Усі призначення повинні обговорюватися 3 кожним кандидатом окремо. Щоб створити атмосферу взаємного відбору іншого персоналу, необхідно проводити це разом з керівниками різних сфер. Тут доречні очні розмови, збори невеликих груп за вказівками, а також 
загальні збори команди. Основна увага повинна бути зосереджена на питаннях, пов'язаних 3 основною метою проекту, його значенням та значенням для всієї організації, а також участю членів команди в його реалізації.

3. Планування діяльності колективу.

Планування діяльності повинно починатися на ранніх стадіях проекту. Керівник проекту повинен об’єднати зусилля всіх функціональних секторів команди для ефективного використання та розподілу ресурсів проекту, досягнення зацікавленої та творчої участі всіх членів команди. Його завдання також залучати членів команди до обговорення питань та проблем, що виникають, аналізу та врахування їх поглядів.

4. Розвиток команди.

У полі зору керівника проекту повинні відбутися всі зміни, що відбуваються в команді, яку він очолює. Часті конфлікти, знижена інтенсивність, повторення помилок - сигнал про неприємності в колективі. Якщо керівник проекту не може самостійно визначити причини цього явища, йому слід звернутися до консультантів, які можуть запропонувати свіжі ідеї щодо встановлення нормального психологічного клімату в колективі.

Звичайно, лідери повинні прагнути уникати складних проблем, особливо психологічних. Для цього потрібен певний досвід, знання практичної психології поведінки людини. Лідер через потенційні причини деструктивних конфліктів сприяє їх уникненню.

Однак розвиток колективу пов'язаний не лише з вирішенням питань суб'єктивного характеру. Він також передбачає кількісні та якісні зміни в колективі, спричинені зміною обсягу робіт, появою нових видів робіт, залученням інших субпідрядників або підлеглих тощо.

5. Створення привабливого іміджу колективу.

Для керівника проекту надзвичайно важливо забезпечити належну підтримку команди з боку керівництва. Відносини керівника проекту з вищим керівництвом та можливість отримати його підтримку визначають довіру членів команди, а отже, популярність та імідж проекту.

\section{3. ВИСНОВКИ}

Таким чином, постійний розвиток soft skills необхідний для успішного досягнення поставлених цілей, грамотного використання навичок, знань і здібностей як в особистому житті, так і в професійній діяльності, в тому числі, i для досягнення необхідного рівня конкурентоспроможності на ринку праці. 


\section{ЛIТЕРАТУРА}

1. Brewer, Laura The top 6 skills today's employers want? [Electronic resource] / Laura Brewer. - Mode of access: http://iloblog.org/2014/04/11/the- top-6-skills-todays-employerswant/.

2. Greenberg, B. S.; Salwen, M. B. Mass communication theory and research: Concepts and models. In An integrated approach to communication theory and research. -2008 .

3. Johnson, Tim. Crisis Leadership: How to lead in times of crisis, threat and uncertainty / Tim Johnson / Bloomsbury Business, USA. - 2018. — 272 pp.

4. Абашкина, O. Soft skills: ключ к карьере / О. Абашкина // Справочник по управлению персоналом : научный журнал. - 2008. - № 9 (сентябрь). - С. 124-126.

5. Бахтияров, О. Активное сознание / Олег Бахтияров / - М. : РИПОЛ Классик, 2015. $330 \mathrm{c}$.

6. Бренсон, Р. Шлях Virgin / Річард Бренсон ; [пер. $з$ англ. Н. Лавська, А. Мішта]. — К. : Країна мрій, 2015. - 352 с.

7. Гоулман, Д.. Эмоциональный интеллект в бизнесе / Дэниел Гоулман; [пер. с англ.]. М. : Манн, Иванов и Фербер, 2013. - 512 с.

8. Джерольд С. Гринберг. Управление стрессом / Джерольд С. Гринберг. - СПб. : Питер, 2002. - 496 c.

9. Долгова В. И. Эмпатия : монография / В. И. Долгова, Е. В. Мельник. - М. : Издательство «Перо», 2014. - 185 c.

10. Едвард де Боно. Шесть шляп мышления / Едвард де Боно ; [пер. с англ. А. Захарченко]. - СПб. : Питер Паблишинг, 1997. — 256 с.

11. Исхаков, Э. Р. Как поставить цель и мотивировать себя для ее достижения / Эдуард Робертович Исхаков. - М. : Издательские решения, 2015. - 70 с.

12. Керолайн. А. Микрорешения. Проверенный путь к достижению больших целей / Керолайн Арнольд ; [пер. с англ.]. - М. : Манн, Иванов и Фарбер, 2014. — 288 с.

13. Мауэр, Р. Шаг за шагом у достижению цели. Метод Кайдзен / Роберт Мауэр ; [пер. с англ.]. - М. : Альпина паблишер, 2014. — 192 с.

14. Мельник, Ш. Стрессоустойчивость. Как сохранять спокойствие и высокую эффективность в любых ситуациях / Шэрон Мельник ; [пер. с англ.]. - М. : Манн, Иванов и Фербер, 2014. - 310 с.

15. Моран, Б. 12 недель в году. Как за 12 недель сделать больше, чем другие успевают за 12 месяцев / Брайан Моран, Майул Леннингтон ; [пер. с англ. ]. - М. : Манн, Иванов и Фарбер, 2014. - 208 с.

16. Пушкар, Р. М. Менеджмент: теорія та практика : підруч. / Р. М. Пушкар, Н. П. Тарнавська. - Тернопіль : Карт-бланш, 2003. - 490 с. 
Наукове видання

Самсонкін Валерій Миколайович

Ніколаєнко Ірина Володимирівна

Булгакова Юлія Вікторівна

Вернигора Роман Віталійович

Галан Ольга Вікторівна

Гненний Олег Миколайович

Горецький Олексій Анатолійович

Горобець Володимир Леонідович

Демченко Свген Борисович

Дорош Андрій Сергійович

Мироненко Віктор Кімович

Окороков Андрій Михайлович

Саблін Олег Ігорович

Хара Марина Володимирівна

Чернова Наталія Сергіївна

Щербина Розалія Степанівна

Юрченко Оксана Григорівна

\section{ІНЖИНІРИНГ КРИЗ ТА РИЗИКІВ ТРАНСПОРТНИХ ПОСЛУГ}

Колективна монографія

За ред. В.М. Самсонкіна та І.В. Ніколаєнко

Комп'ютерна верстка - Думанеиька С.С. Дизайн обкладинки - Бабинеиь Н.A.

Підписано до друку 01.10.2021 p.

Формат 70х100/16. УМ. друк. арк. 25,4.

Наклад 100 прим. Зам. № ...

Видавецьь і виготовлювач ТОВ «Талком».

м. Київ, вул. Львівська, 23,

тел./факс (044) 424-40-69, 424-56-26.

E-mail: ukraina.vdk@email.ua.

Свідоцчтво суб'єкта видавничої справи ДК № 4538 від 07.05.2013. 